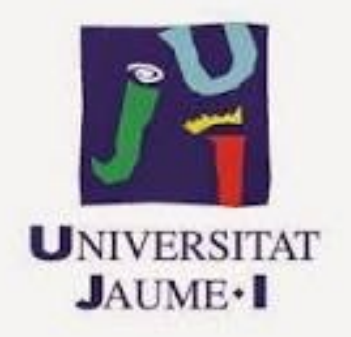

TESIS DOCTORAL

\title{
LA CONSTRUCCIÓN DE LA IDENTIDAD DE LAS MUJERES A TRAVÉS DE LA IMAGEN DE LOS ESPACIOS INTERIORES
}

INSTITUT UNIVERSITARI d'ESTUDIS FEMINISTES I DE GÈNERE "PURIFICACIÓN ESCRIBANO"

Presentada por: Zoraida Nomdedeu Calvente

Dirigida por: Joan Manuel Marín Torres

Castellón de la Plana, 2017

Febrero 2017 



\section{AGRADECIMIENTOS}

Es este un apartado complejo y delicado para cualquier doctorando.

Resulta casi imposible garantizar que no voy a cometer el error de caer en una elipsis imperdonable. Este hecho resulta paralizante frente al teclado.

Una tesis que versa sobre la incidencia de las imágenes de los espacios interiores en la construcción de la identidad de las mujeres es un trabajo que ha intensificado con mucho mi capacidad para darme cuenta. El vivir de manera consciente la percepción del proceso de construcción de la identidad me ha obligado a revisar constantemente mis orígenes y mi presente, desde una mirada casi nueva. Soy fruto de infinitos estímulos, vínculos, procesos y situaciones, pero si tengo que especificar, en función de lo que expongo en estas páginas, soy fruto sin duda de la lucha consciente de Xaro Nomdedeu Moreno por dignificar esta sociedad, luchando contra el heteropatriarcado, y cómo negarlo, del propio heteropatriarcado que ha dejado sus huellas en mi.

Gracias mamá por tu planteamiento de vida. Gracias también por tu aportación desde tu rol profesional, por tu colaboración desinteresada en el cálculo estadístico de una de las partes sustanciales de este trabajo.

Gracias a mi padre, quien a su modo contribuyó en mi infancia en mi desarrollo como persona.

Es evidente que ser arquitecta configura una parte importante de mi propia identidad. Gracias a todas las maestras y maestros que tuve en lo que entonces era EGB, Enseñanza General Básica, a todas las profesoras y profesores de mi etapa en secundaria, BUP y COU, y por supuesto en la Universidad Politécnica de Valencia en la que obtuve mi título universitario. Todas estas personas aportaron para que pudiera superar cada escalón necesario para que haya llegado a ser quien soy.

Hubo importantes momentos de flaqueza. De nuevo gracias a mi madre por no desfallecer en su apoyo constante, y gracias desde lo más profundo a $\mathrm{mi}$ querida amiga Lledó Maicas Sangüesa. Ella no solo contribuyó con su eficiencia y buen hacer desde la biblioteca del Colegio de Arquitectos de 
Castellón, y desde la Vocalia de cultura i biblioteca, facilitándome el camino desde mis primeros años de estudiante de arquitectura, sino que lo hizo desde su gran capacidad humana y la amistad que llegamos a forjar con los años.

A Lledó Maicas Sangüesa, sempre.

En mi andadura académica también, cómo no, mi agradecimiento sincero a todas las personas que constituían el cuadro docente del Màster en Investigació Aplicada en Estudis Feministes, de Gènere i Ciutadania, de la Universitat Jaume I de Castellón y a la propia UJI por los recursos puestos a mi alcance.

De aquella etapa deriva la presente investigación. Ya entonces Joan Manuel Marín Torres fue quien dirigió con destreza mi trabajo final de máster, y posteriormente quien me invitó a proseguir hasta donde ahora me encuentro. No sólo tengo que agradecer su esmero, entrega y gran acierto en todas y cada una de las sugerencias y observaciones que me ha hecho para esta investigación a lo largo de estos años, sino incluso aquella invitación a empezar mi doctorado. Ha resultado un camino, aunque laborioso, muy gratificante para mí, gracias Joan.

Tanto el fondo bibliográfico del Colegio de Arquitectos de Castellón, como el de la biblioteca de la UJI o el de la Biblioteca de Cataluña han sido una fuente necesaria para el desarrollo de este trabajo.

A Isabelle Godinau, de la Fundación Le Corbusier, quien me ha facilitado documentación muy interesante para elaborar parte del apartado 6 de este texto.

Tampoco puedo dejar de agradecer su aportación desde la Vocalia de cultura, biblioteca i formació a Javier Sorlí Gellida, quien ha continuado la tarea profesional de Lledó Maicas de manera eficiente y amigable en este último periodo del desarrollo de este trabajo.

A Vicent Ibañez Recatalá, mi compañero y padre de mis hijas. Él revisa constantemente la influencia que sobre su comportamiento tiene el heteropatriarcado, casi por osmosis. Lo hace con lo que yo siento como un profundo amor hacia mi persona y respeto por mi trabajo, además de una 
atención clara a la repercusión que los roles asumidos pueden generar en el proceso de construcción de la identidad de nuestras hijas.

A mis hijas, quienes han crecido viéndome entre papeles y revistas, con generosidad por su parte en las largas horas que he dedicado a investigar, tratar y analizar los datos.

A mi abuelita Isabel, por sus cocas de danone, sus risas y su amor incondicional, y no precisamente en este orden.

A Alejandro Calvente Nomdedeu, mi hermano mayor quien inspiró con su ejemplo mi atrevimiento con esta tarea; y me ayudó con sus ánimos en momentos de desánimo. Gracias Alejandro por miles de pasos en los que me has guiado, por la complicidad en momentos delicados de nuestras vidas, por tenderme una mano cuando lo he necesitado sin esperar ni tan siquiera mi petición. Por aquellas horas de agosto en 2011 en las que hablaste parapetado tras una sonrisa que ocultaba tu preocupación por mi. A Irene, su compañera, gracias por quererle tanto, y por enriquecer a nuestra familia con dos nuevas sobrinas.

A Leo Nomdedeu Calvente, mi hermano pequeño, que fue, desde sus cortos catorce años, y continua siendo hoy en día mi técnico informático. Siempre dispuesto a solventar accidentes del sistema, graves o leves, de día o de noche. Siempre atento a mi inseguridad en un mundo que él domina. Siempre con cariño y aderezando estos años con sabrosas comidas en familia y gratificantes sobremesas. Leo y Sanja Dabic Radisic, su excepcional compañera de viaje en esta vida, han contribuido, junto a Vicente y las abuelas, porque han asumido todas las tareas domésticas que he necesitado delegar para dejar en mi vida espacio a mi rol como mujer profesional. Gracias de corazón.

A Sanja especialmente por estos últimos días apoyándome en la maquetación de la tesis, sin ella hubiera desesperado, y por supuesto por esas sobremesas con ella también compartidas y tantas y tantas cosas, como la gestión de los breves pero necesarios descansos que en estos años me he tomado para compartir con ellos. 
A mi hermana Xaro por estar ahí, con quien compartí espacio privado, nuestro reducto, hasta que dejé nuestro hogar de origen, y a quien tanto quiero. Cómo no, también a su compañero Ramón.

A mi hermano David, por toda la ternura demostrada a mis hijas y a su compañera Bea.

A mis suegros, a María Segarra y Froi, mis cuñados que han estado cuando ha sido necesario, con voluntad y buen humor.

A todas y cada una de mis diez sobrinas y mis dos sobrinos, para quienes, junto a mis hijas, pretendo una sociedad que permita su pleno desarrollo en equilibrio e igualdad.

A cada amiga y a cada amigo que me han esperado en mis eternas horas de ausencia. 


\section{Índice}

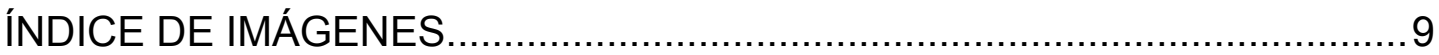

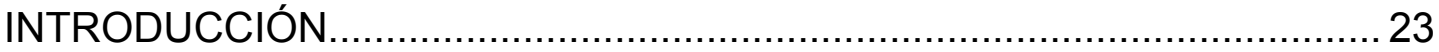

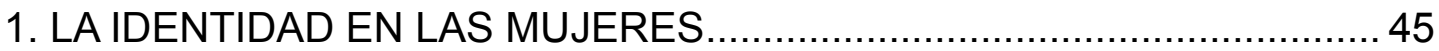

1.1. Concepto de construcción de la propia identidad..............................47

1.2. La construcción de la propia identidad desde la perspectiva de género 51

2. CRÍTICA AL DISCURSO ANDROCÉNTRICO EN ARQUITECTURA........63

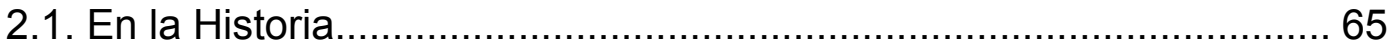

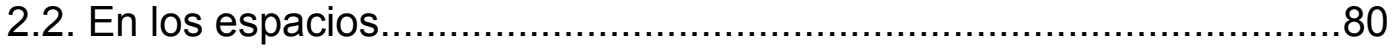

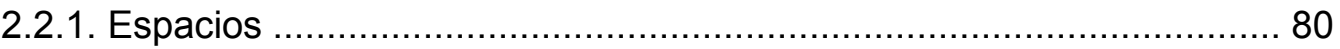

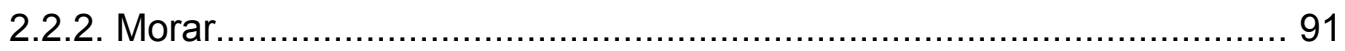

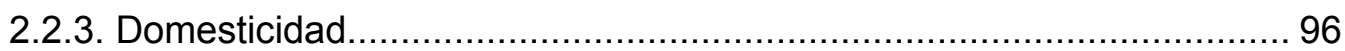

3. LOS TEXTOS Y LAS EXPERIENCIAS DE LAS PIONERAS …..............111

3.1. En torno a la Primera Guerra Mundial...............................................113

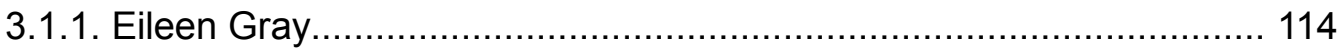

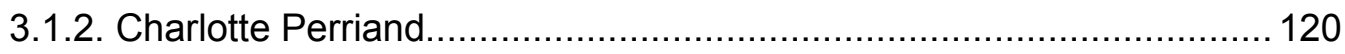

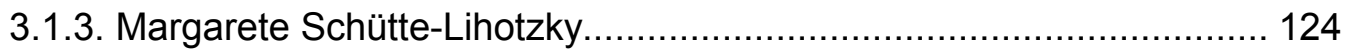

3.2. En torno a la Segunda Guerra Mundial..........................................135

3.2.1. De la Bauhaus y su influencia.......................................................... 135

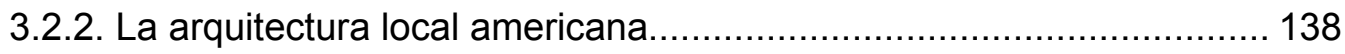

3.2.3. El Estilo Internacional.................................................................. 149

4. CONSTRUCCIÓN Y RECONSTRUCCIÓN DE LOS DISCURSOS FEMINISTAS EN ARQUITECTURA..................................................... 169

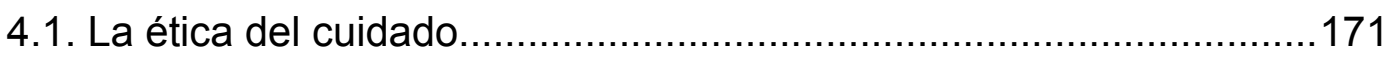

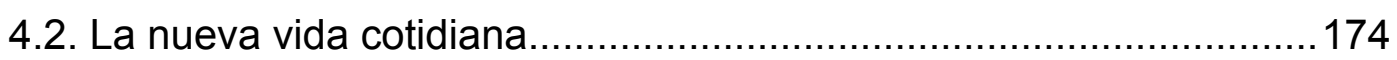

5. LA IMAGEN DE LAS MUJERES EN LOS ESPACIOS INTERIORES ....191

5.1. Los medios de difusión. Las revistas............................................194 


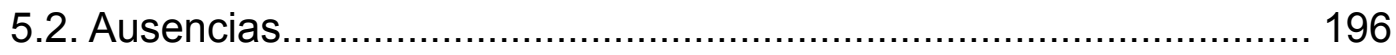

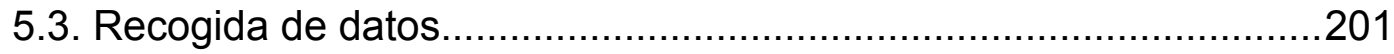

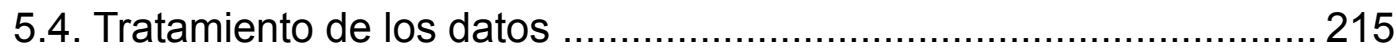

5.4.1. Criterios establecidos para el tratamiento de datos............................215

5.4.2. Gráficas derivadas del tratamiento de datos........................................226

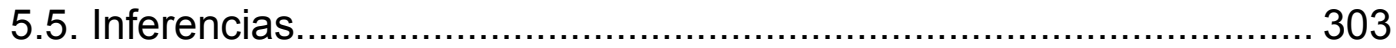

6. EVIDENCIA DEL LUGAR ASIGNADO POR EL TOPO-PODER ............307

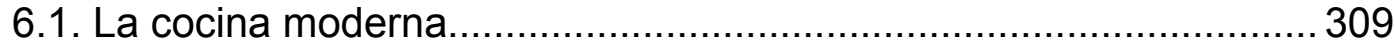

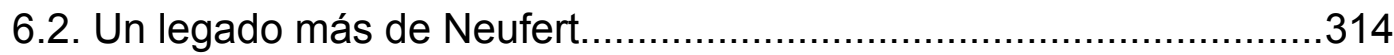

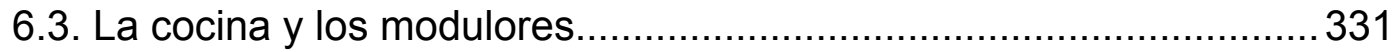

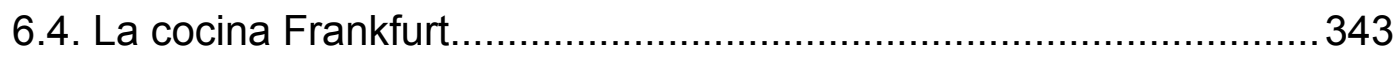

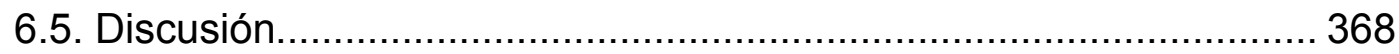

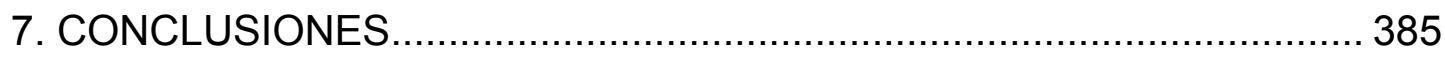

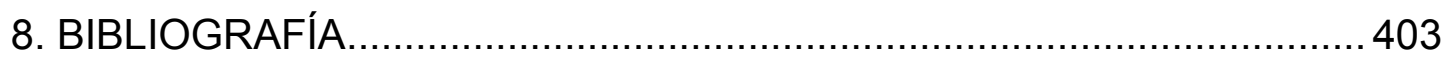

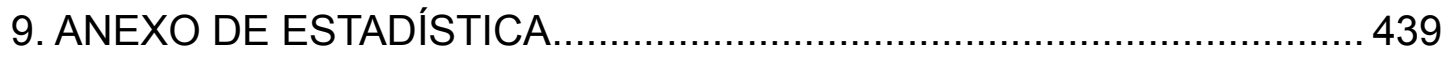




\section{ÍNDICE DE IMÁGENES}




\section{Índice de imágenes}

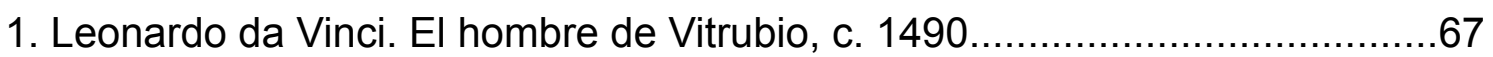

2. Ernst Neufert. Ilustraciones androcéntricas y esterotipadas en el libro El arte

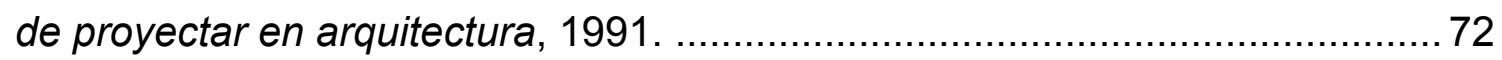

3.Hoff en La Viena Roja. Fotografía de la autora, 2015..............................75

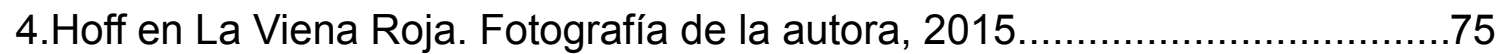

5. Hoff en La Viena Roja. Fotografía de la autora, 2015. ............................75

6. Hoff en La Viena Roja. Fotografía de la autora, 2015..............................75

7. Hoff en La Viena Roja. Fotografía de la autora, 2015..............................75

8. Exposición en el recinto de la lavandería de la Karl-Marx Hoff en La Viena

Roja. Fotografía de la autora, 2015. ...................................................... 76

9. Exposición en el recinto de la lavandería de la Karl-Marx Hoff en La Viena

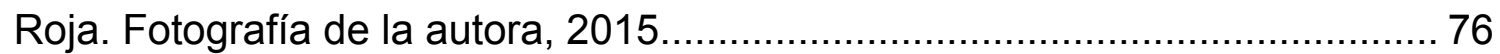

10. Exposición en el recinto de la lavandería de la Karl-Marx Hoff en La Viena

Roja. Fotografía de la autora, 2015.

11. Exposición en el recinto de la lavandería de la Karl-Marx Hoff en La Viena

Roja. Fotografía de la autora, 2015.

12. Exposición en el recinto de la lavandería de la Karl-Marx Hoff en La Viena

Roja. Fotografía de la autora, 2015.

13. Exposición en el recinto de la lavandería de la Karl-Marx Hoff en La Viena

Roja. Fotografía de la autora, 2015

14. Tabla evolución del tiempo medio en actividades domésticas. Fuente:

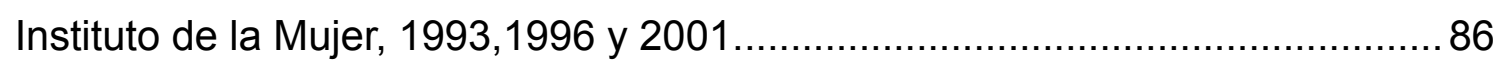

15. Horas trabajo doméstico. Fuente: El diario.es, 2015.............................86

16. Horas trabajo doméstico. Fuente: El diario.es, 2015............................... 87

17. La maison en bord de mer (E.1027) y su autora Eileen Gray, 1929. Fuente:

Matter More Than Ever de SAF, 2016 ..................................................... 115

18. Eyleen Gray: Casa E-1027, 1929. Fuente: Historia Diseño Interiores IED, 2015.

19. Charlotte Perriand. Fotografía de Pierre Jeanneret (probablemente), 1928. 
20. Baño y cocina integrados, de los archivos de Charlotte Perriand, 1937.

Fuente: Mary McLeod, 2003.

21. Cocina de la Unidad de Habitación de Marsella Tipo I, adaptada de Charlotte Perriand. Fuente: Georges Meguerditchian-Centre Pompidou, 2003.............123

22. Margarete Schütte-Lihotzky. Fuente: Promedia, 2014 124

23. Christine Frederick: racionalización de los movimientos en la cocina, 1910.

Fuente: Kaiser y de León, 2012 126

24. Margarete Shütte-Lihotzky: Frankfurter Küche (reconstrucción de 1990), MAK, Museo de Artes Aplicadas de Viena.

25. Lillian Gilbreth: triangulación del flujo de trabajo en la cocina, 1930. Fuente: Kaiser y de León, 2012

26. Estereotipos arquitectónicos. Fuente: Built environment, número

monográfico sobre género y urbanismo, 1990

27. Placas y fachada de la Otto-Haas Hof . Fotografía de la autora, 2015

28. Exposición en el recinto de la lavandería de la Karl-Marx Hoff en La Viena

Roja. Fotografía de la autora, 2015 133

29. Sylver Bullet, el modelo más antiguo data de 1934, 1935. Fuente: Catálogo de Airstream, 2015

30. Caravana Airstream moderna, 2015. Fuente: Catálogo Airstream, 2015...142

31. Gropius: House and Garden, 1939. Fuente: Ken Schwarz, 2016. 143

32. Gropius y su esposa, en la terraza, mirando hacia el interior. Fuente:

Colomina, 2006

33. Buckmister Fuller. DDU, boceto. Fuente: Colomina, 2006.

34. Buckmister Fuller. DDU, reproducción. 1945. Fuente: Cristina Rojo, 2014.

35. The Round House Project - Dymaxion Deployment Unit (D.D.U.), 1940.

Autor: Sebastiaan Kaal.

36. Advertising leaflet for the Dymaxion Deployment Unit, 1940. Autora:

Suzanne Junker.

37. U.S. pilots stand in front of a cluster of DDU, North Africa, 1944. Autor:

Alastair Gordon.

38. Matrimonio Eames. La casa de los Eames. Obsérvese en la fachada el estilo

Piet Mondrian. Pacific Palisade, California, 1949. Autor: Quintin Lake. 150 
39. Jean-Pierre Junker. A la izquierda, según miramos, espacio vacío, típico de la primera generación, a la derecha el espacio habitado destruye la propuesta arquitectónica de autor, 1990.

40. Espacio ocupado por los objetos coleccionables del matrimonio Eames, segunda generación. Fuente: Colomina. 2006.

41. Patio \& Pavillion, del matrimonio Smithson, tercera generación, ocupado por objetos fósiles y restos cerámicos simbolizando el pasado de los habitantes de Patio \& Pavillion. Fuente: Nieves Fernández Villalobos, 2013. 153

42. Marcel Breuer: La casa en el jardín. Instalada en el MOMA, 1949. 154

43. New York Times, 1959 155

44. Casa Playboy de Hugh Hefner. Fuente: Nbcdeportes, 2015. 157

45. Allison y Peter Smithson. Casa del futuro, 1956. Fuente: Nieves Fernández

Villalobos, 2013 159

46. Instalación Glimpses de USA en la URSS, 1951. Fuente: Arquitectura Viva $141,2012$. 163

47. Warren Chalck, Archigram. Casa cápsula, 1964. 165

48. Jay Swayze. Casa cueva. Fuente: El Confidencial, 2014. 166

49. Exposición en el recinto de la lavandería de la Karl-Marx Hoff en La Viena

Roja. Fotografía de la autora, 2015. 181

50. Comedor colectivo con cinta transportadora, Stroikom, 1929. Fuente: FADU UBA AID, 2002 182

51. Narkomfin apartments, 1928-1932. Autor: Robert Byron. 184

52. Le Corbusier. L'Unité d'habitation de Marseille, 1945-52. Fuente: CaViCa, 2011

53. Casa matrilineal (izquierda), casa patrilineal (derecha). Fuente: Espegel, 2008 189

54. Bandler y Grinder. Porcentajes del mensaje,1992. 200

55. Datos y cifras del sistema universitario español (2012/2013). Fuente:

Ministerio de Educación, Cultura y Deporte, 2013. .219

56. Datos y cifras del sistema universitario español (2012/2013). Fuente:

Ministerio de Educación, Cultura y Deporte, 2013. 219

57. Datos del sindicato de arquitectos. Tasa de paro. Fuente: INE EPA, 2012. 
58. Datos de la Escuela de Arquitectura de la Universidad de La Coruña.

Fuente: MAGA, 2012.

59. Datos Escuela de Arquitectura de la Universidad de La Coruña. Fuente:

MAGA, 2012.

60. Datos Escuela de Arquitectura de la Universidad de La Coruña. Fuente:

MAGA, 2012

222

61. Proporción de matrícula en Diseño de Interiores según sexos en la EASD de Castellón en 2015-16, imagen superior CFGS, imagen inferior ESEAS. G.E.P., 2016. 223

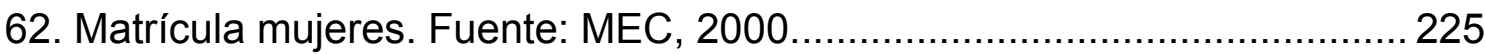

63. Presencia. Fuente: Casabella 844, 2014 ..............................................226

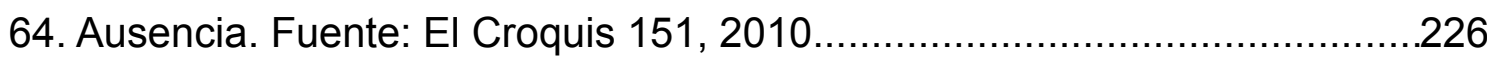

65. Presencia de figura humana en las revistas de arquitectura y diseño. G.E.P., 2016.

66. Presencia de figura humana global en las revistas de arquitectura y diseño.

G.E.P., 2016 228

67. Imagen de figura humana mixta. Fuente: Diseño Interior 262, 2014_.......230

68. Imagen de figura humana mixta. Fuente: On Diseño 350, 2015..............230

69. Imagen de figura humana mixta. Fuente: On Diseño 350, 2015. 231

70. Presencia de figura humana distribuída por sexos en revistas de arquitectura y diseño, G.E.P., 2016. 232

71. Presencia de figura humana distribuída por sexos global en revistas de arquitectura y diseño. Fuente: G.E.P., 2016. 233

72. Mujer en rol doméstico. Fuente: Arquitectura Viva 169, 2014 .234

73. Mujer en anuncio. Fuente: El Croquis 161, 2012 …............................234

74. Mujer diseñadora. Fuente: Diseño Interior 237, 2012 ..........................235

75. Presencia de figura humana distribuída por roles de mujeres en revistas de

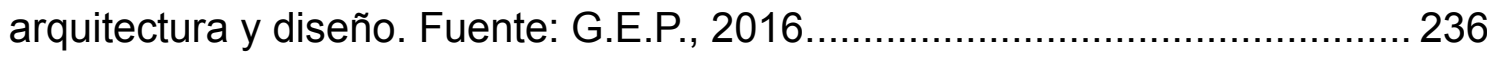
76. Presencia de figura humana distribuída por roles de mujeres global en revistas de arquitectura y diseño. Fuente: G.E.P., 2016 ..............................237

77. Varón en rol doméstico. Fuente: Domus 990, 2015...............................238

78. Varón en anuncio. Fuente: Diseño Interior 214, 2010 ............................239

79. Varón arquitecto. Fuente: El Croquis 151, 2010......................................240 
80. Presencia de figura humana distribuída por roles de varones en revistas de arquitectura y diseño. Fuente: G.E.P., 2016.

81. Presencia de figura humana distribuída por roles de varones global en revistas de arquitectura y diseño. Fuente: G.E.P., 2016

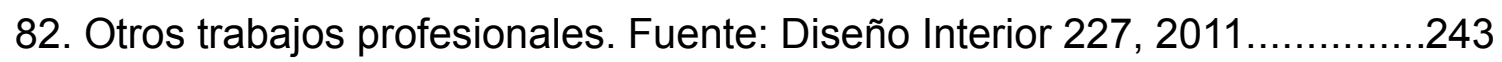

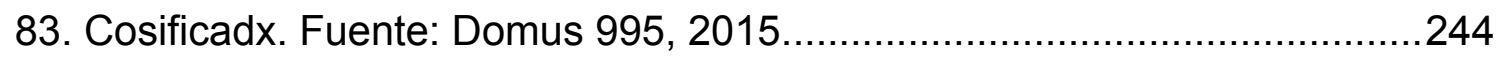

84. Mujer «usuaria». Fuente: On Diseño 332, 2013.....................................244

85. Presencia de figura humana distribuída por funciones en revistas de arquitectura y diseño Fuente: G.E.P., 2016 .......................................... 245

86. Presencia de figura humana distribuída por funciones global en revistas de arquitectura y diseño. Fuente: G.E.P., 2016 .......................................... 248

87. Anuncio Varón. Fuente: Arquitectura Viva 163, 2014_.............................249

88. Anuncio Mujer. Fuente: Diseño Interior 201, 2009...................................250

89. Presencia de figura humana distribuída por roles publicitarios en revistas de arquitectura y diseño. Fuente: G.E.P., 2016 ............................................ 251

90. Presencia de figura humana distribuída según modelos publicitarios por sexos global en revistas de arquitectura y diseño. Fuente: G.E.P., 2016_.......254 91. Mujer arquitecta. Fuente: Arquitectura Viva 167, 2014_..........................254

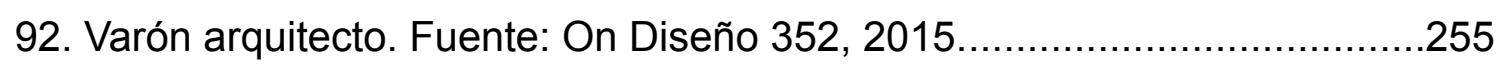

93. Mujer diseñadora de interiores. Fuente: Diseño Interior 227, 2011_...........255

94. Varones arquitectos. Fuente: El Croquis 161, 2012 .............................256

95. Presencia de figura humana que se dedica a la arquitectura o al diseño de interiores distribuída por sexo en revistas de arquitectura y diseño. Fuente:

G.E.P., 2016.

96. Número de arquitectas y arquitectos colegiad@s en Galicia. Fuente: MAGA, 2011 258

97. Presencia de figura humana distribuída por sexo global en revistas de arquitectura y diseño. Fuente: G.E.P., 2016 ............................................... 259

98. Varón profesional. Fuente: On Diseño 338, 2013..................................260

99. Mujer profesional. Fuente: On Diseño 356, 2015................................. 260

100. Presencia de figura humana distribuída por otros trabajos según sexo en revistas de arquitectura y diseño. Fuente: G.E.P., 2016. 
101. Tabla de inserción laboral. Datos y cifras del sistema universitario español Curso 2012-2013. Fuente: Ministerio de Educación, Cultura y Deporte, 20122013.

102. Encuesta de población activa, $4^{a}$ trimestre 2015. Fuente: INE, 2016.....263 103. Presencia de figura humana distribuída por sexo en otros trabajos global en revistas de arquitectura y diseño, Fuente: G.E.P., 2016 .......................264 104. Mujer en rol doméstico. Fuente: Diseño Interior 224, 2011...................265 105. Varón en rol doméstico. Fuente: Diseño Interior 224, 2011.................265 106. Presencia de figura humana distribuída por roles domésticos en revistas de arquitectura y diseño, Fuente: G.E.P., 2016 266

107. Gráfica del trabajo no remunerado, datos Encuesta CSIC sobre Uso del Tiempo en España en 2013, Fuente: G.E.P., 2016. 269 108. Presencia de figura humana distribuída por roles domésticos global en revistas de arquitectura y diseño, Fuente: G.E.P., 2016. 270 109. Varón trabajo remunerado. Fuente: El Croquis 170, 2014...................270 110. Varón trabajo remunerado. Fuente: On Diseño 326, 2012....................271 111. Mujer trabajo remunerado. Fuente: Arquitectura Viva 142, 2012 ...........271 112. Mujer trabajo no remunerado. Fuente: Domus 932, 2010....................272 113. Varón trabajo no remunerado. Fuente: Domus 932, 2010...................272 114. Presencia de figura humana distribuída por remuneración en revistas de arquitectura y diseño, Fuente: G.E.P., 2016 273 115. Presencia de figura humana distribuída por remuneración global en revistas de arquitectura y diseño. Fuente: G.E.P., 2016 ....................................... 275 116. Mujer cosificada. Fuente: On Diseño 314-315, 2010 ............................276 117. Varón cosificado. Fuente: On Diseño 352, 2015...............................276 118. Imagen mixta, anuncio. Fuente: Diseño Interior 206, 2009...................277 119. Presencia de figura humana distribuída por cosificación en revistas de arquitectura y diseño. Fuente: G.E.P., 2016 278 120. Presencia de figura humana distribuída por cosificación global en revistas de arquitectura y diseño. Fuente: G.E.P., 2016 ......................................... 279 121. Espacio anuncio. Fuente: Diseño Interior 247, 2013 ...........................280 122. Espacio real. Fuente: On Diseño 314-315, 2010...............................281

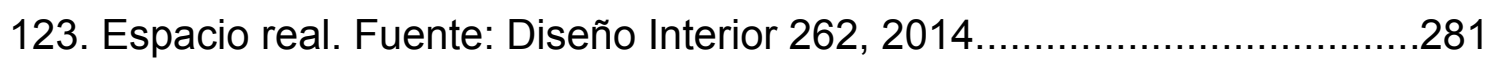


124. Presencia de figura humana distribuída en anuncios en revistas de arquitectura y diseño. Fuente: G.E.P., 2016.

125. Proporción de espacios virtuales frente a reales global en revistas de

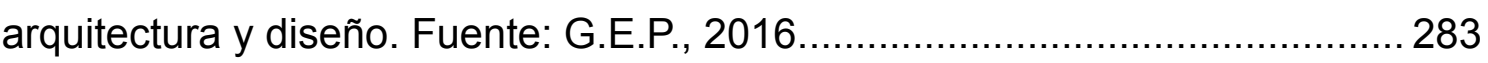

126. Espacio interior doméstico. Fuente: Diseño Interior 237, 2012 ..............284

127. Espacio interior privado. Fuente: Arquitectura Viva 146, 2012 ..............285

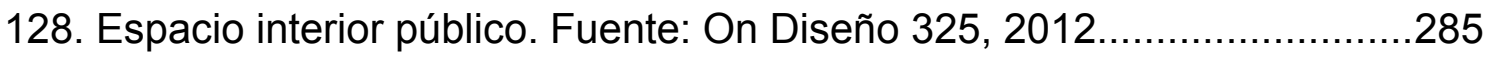

129. Presencia de figura humana distribuída por tipos de espacios interiores en revistas de arquitectura y diseño. Fuente: G.E.P., 2016 .............................28 130. Presencia de figura humana distribuída por tipos de espacios interiores global en revistas de arquitectura y diseño. Fuente: G.E.P., 2016 ................287 131. Varón profesional. Fuente: On Diseño 323, 2011 ...................................28

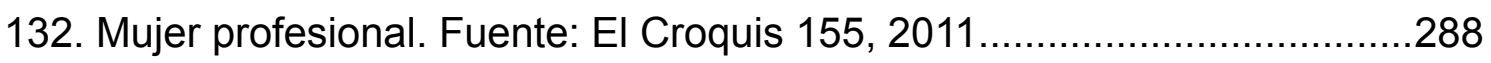

133. Varón rol doméstico. Fuente: On Diseño 351, 2015.............................28

134. Mujer rol doméstico. Fuente: El Croquis 155, 2011 .............................288

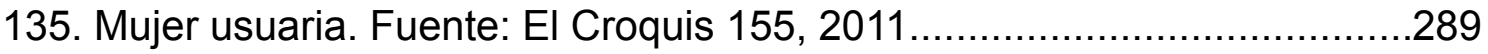

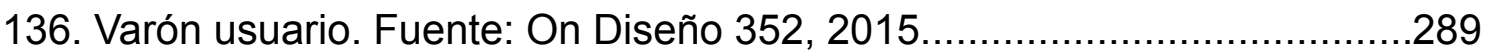

137. Presencia de figura humana distribuída en el interior doméstico en revistas de arquitectura y diseño. Fuente: G.E.P., 2016 ...................................... 290 138. Visualización de la causa de los 0\% en Casabella. Fuente: G.E.P., 2016.

139. Presencia de figura humana distribuída en el interior doméstico global en revistas de arquitectura y diseño. Fuente: G.E.P., 2016 .............................292 140. Varón profesional. Fuente: Casabella 820, 2012 ................................293 141. Mujer profesional. Fuente: On Diseño 352, 2015 ............................... 293 142. Varón en rol doméstico. Fuente: Casabella 839-840, 2014....................294 143. Mujer en rol doméstico. Fuente: On Diseño 352, 2015.........................294 144. Varón en rol usuario. Fuente: Casabella 838, 2014............................294 145. Mujer en rol usuaria. Fuente: Diseño Interior 277, 2015 ......................294 146. Presencia de figura humana distribuída en el interior privado en revistas de arquitectura y diseño. Fuente: G.E.P., 2016. 295 147. Presencia de figura humana distribuída en el interior privado global en revistas de arquitectura y diseño. Fuente: G.E.P., 2016. 


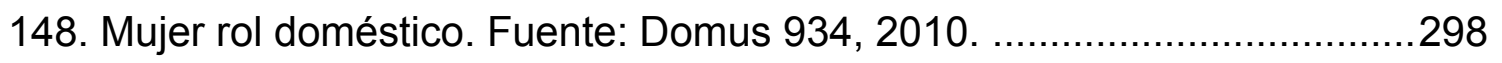

149. Varón rol doméstico. Fuente: On Diseño 352, 2015 ...............................298

150. Varón en rol profesional. Fuente: Domus 943, 2011 ….........................298

151. Mujer en rol profesional. Fuente: Casabella 848, 2015...........................298

152. Mujer en rol usuaria. Fuente: On Diseño 348, 2014..............................298

153. Varón en rol usuario. Fuente: Domus 938, 2010 ................................... 298

154. Presencia de figura humana distribuída en el interior público en revistas de

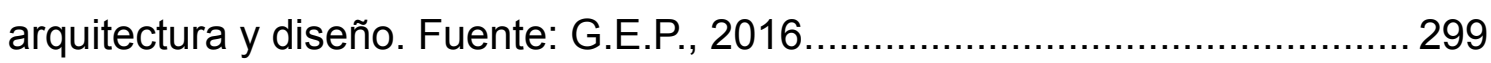

155. Presencia de figura humana en interior público global en revistas de arquitectura y diseño. Fuente: G.E.P., 2016 ............................................. 300

156. Presencia de figura humana estudio comparativo en revistas de arquitectura y diseño. Fuente: G.E.P., 2016.

157. Presencia de figura humana estudio comparativo global en revistas de arquitectura y diseño. Fuente: G.E.P., 2016. 302 158. Esquemas de funcionamiento de los ascensores y de la cocina del bloque Highpoint II de Bertold Lubetkin. Fuente: Montays y Fuertes, 2001. 313 159. Ernst Neufert. Ejemplos de usos y medidas de cocinas estándarizadas, 1942. 315

160. Mueble de cocinar en la Frankfurt Küche. Fotografía de la autora, 2015.315 161. Ernst Neufert. El arte de proyectar en la arquitectura. Edición $12^{\mathrm{a}}$ española, $21^{\mathrm{a}}$ alemana, 1964 316

162. Ernst Neufert. Ejemplos de usos y medidas de cocinas estándarizadas.

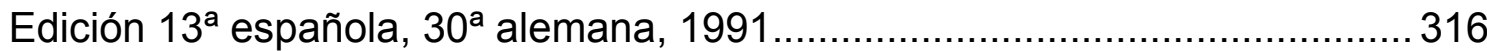

163. Ernst Neufert. Altura de la bancada en la $13^{a}$ edición española, 1991 ...317

164. Ernst Neufert. Altura fogones y mesa de trabajo según $13^{\mathrm{a}}$ edición española, 1991

165. Ernst Neufert. Ejemplos de usos y medidas de muebles cocina estándarizadas, página 212 de la $33^{\mathrm{a}}$ edición en alemán, $14^{\mathrm{a}}$ en castellano, 1995.

166. Las medidas de los muebles de la cocina. Fuente: Kansei, 2016...........324

167. Medidas estándar de los módulos de cocinas. Fuente: Hermanos Pérez, 2012. 325

168. Consejos de ergonomía. Fuente: Kansei, 2016 326 
169. Detalle de la figura 112. Consejos de ergonomía. Fuente: Kansei, 2016.

170. Altura encimera cocina. Fuente: Valcucine, 2016.

171. Erns Neufert. Estereotipo de género en las tareas domésticas. Página 205

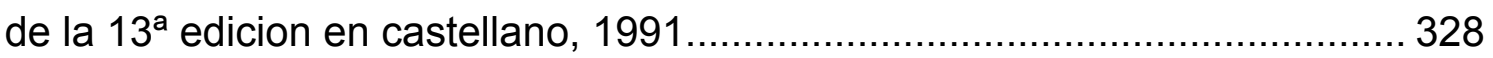

172. Tallas mujeres y hombres. Fuente: EUROSTAT-INE, 2001...................329

173. El mapa mundial de la estatura. Fuente: El País, 2016 .........................330

174. El mapa mundial de la estatura. Fuente: El País, 2016 ........................330

175. Noor Makkiya. Recopilación de escalas humanas de arquitectos famosos.

Fuente: Plataforma de arquitectura, 2016

176. Noor Makkiya. Recopilación de escalas humanas de arquitectos famosos.

Fuente: Plataforma de arquitectura, 2016.

177. Pentagrama místico pitagórico, con la palabra «úyıદía», Hugieia, es decir,

«salud». Fuente: Cátedra de Cultura Científica, 2013.

178. Segmento áureo de un segmento. Fuente: G.E.P., 2016 …....................333

179. Construcción de la sección áurea. Fuente: Piziadas, 2016.....................334

180. Construcción de la sección áurea. Fuente: G.E.P., 2016........................334

181. Leonardo da Vinci. Cuadrado y pentágono en el hombre de Vitrubio.

Fuente: Berman Araya Lara, 2013

182. Triángulo áureo y construcción del pentágono regular del hombre de

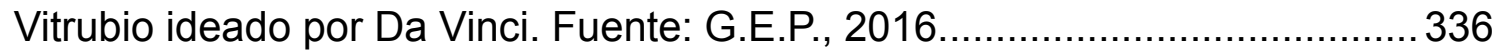

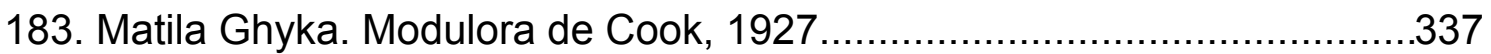

184. Ernst Neufert. Historia de las proporciones del cuerpo humano,1950.....338

185. El Modulor de Le Corbusier en El arte de proyectar en arquitectura.

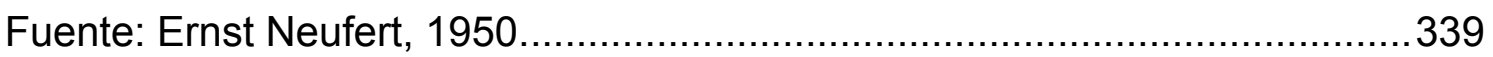

186. Le Corbusier. Izquierda Modulor I a) Derecha Modulor II b) , 1950 ........339

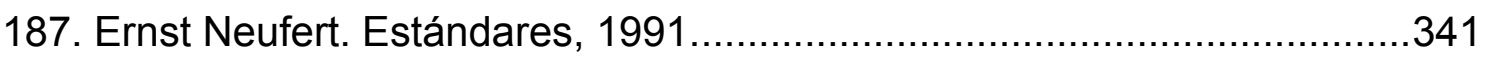

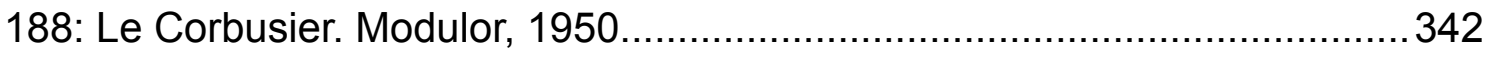

189. Le Corbusier. Modelo de ergonomia del Modulor I b, 1953....................343

190. Benita Otte y Erns Gebhardt. Cocina de la Haus am Horn de Benita Otte

Weimar, 1923. Fuente: Juan Bravo, 2011...................................................346

191. Gerge Muche. Planimetría de la Haus am Horm de Meyer y Otte de la exposición Bauhaus, Weimar, 1923. Fuente: Juan Bravo, 2011....................347 
192. J. P. Oud. Cocina Weissenhof, Sttutgard, 1927. Fuente: Pinterest, 2016.348 193. Ernst Neufert. Séptima edición portuguesa adaptada de la $21^{\text {a }}$ de El arte

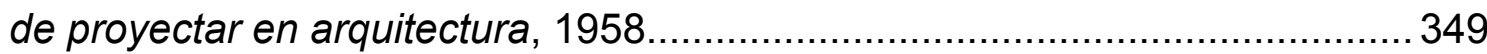

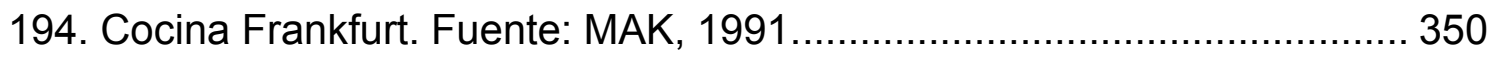

195. Conjunto de fotografías que muestran la toma de datos de los elementos de la cocina Frankfurt en el museo del diseño de Viena. Fotografías de la autora, 2015

196. Croquis de la distribución de la cocina Frankfurt de Schütte-Lihotzky

expuesta en el MAK. Fuente: G.E.P., 2015.

197. Croquis acotado del prototipo de la cocina Frankfurt de Schütte-Lihotzky expuesta en el MAK. Fuente: G.E.P., 2015.

198. Ernst Neufert. La cocina Frankfurt como ejemplo en la duodécima edición alemana de El arte de proyectar en arquitectura, 1949.

199. Ernst Neufert. La cocina Frankfurt como ejemplo en la décimo segunda edición española, vigésimo sexta de El arte de proyectar en arquitectura, 1977.

200. Ernst Neufert. Bancada de $85 \mathrm{~cm}$ en la vigésimo primera edición de $E /$ arte de proyectar en arquitectura, 1960.

201. Ernst Neufert. Cocina Frankfurt en la $12^{\mathrm{a}}$ edición alemana de El arte de proyectar en arquitectura, 1949. 356

202. Ernst Neufert. Cocina Frankfurt en la $12^{\mathrm{a}}$ edición alemana de $\mathrm{El}$ arte de proyectar en arquitectura, 1950

203. La mujer «usuaria» de la cocina sirviendo la comida a los usuarios. Fuente: Roger Griffit, 2015.

204. La mujer «usuaria» de la cocina de Charlote Perriand, cocinando. Fuente:

Roger Griffit, 2015 357

205. Charlotte Perriand. Planimetría de la cocina de Charlotte Perriand, 1948.

206. Charlotte Perriand. Planimetria de la cocina prototipo de Perriand, 1948.

207. Charlotte Perriand. Bocetos del mueble bar de Perriand, 1948. 360

208. Cocina de LHM con el mueble-bar de Charlotte Perriand que la integra en la dinámica social de la casa. Fuente: MOMA, 2014. 361 
209. Un boceto de la cocina de l'UHM adaptación del prototipo de Charlotte

Perriand. Fuente: Jacques Sbriglio, 1992.

210. Planimetría de la cocina de L'Unité habitationel de Marsella. Fuente:

Centro Pompidou, 2016

211. Primera edición en lengua castellana del Modulor I de 1953. Fuente:

Gustavo Gili, 1961. .364

212.Le Corbusier. Series roja y azul del Modulor Ib, 1961 365

213.Ernst Neufert. Detalle de la lámina sobre cocinas de El arte de proyectar en arquitectura, 1936 369

214. Ernst Neufert. Modelo de cocina sueca $7^{\mathrm{a}}$ ed. portuguesa, $21^{\mathrm{a}}$ alemana en El arte de proyectar en arquitectura, 1958.

215. No cabe duda alguna de que se destina al propietario de un cuerpo masculino. Fuente: Lenombredor, 2016. 375 216. Planimetría de la casa Rietveld-Scröder. Fuente: Utrech Central Museum, 1995 376

217. Casa Rietveld-Schröder. Fotografía de la autora, 1995 377 218. Cocina de la casa Rietveld-Schröder en exposición IVAM. Fotografía de la autora, 2016. 377 


\section{INTRODUCCIÓN}




\section{INTRODUCCIÓN}

\section{Justificación}

Existe abundante literatura sobre la relación entre la historia de los espacios urbanísticos y su personalidad, su identidad. También existen muchas publicaciones que tratan de expresar la necesidad de conocer la personalidad de las futuras personas moradoras, para proyectar un espacio interior que responda a sus necesidades, que se mimetice con ellas. Sin embargo, no hay tanto interés en descubrir, recíprocamente, cómo influye ese espacio interior en la construcción de la personalidad de sus habitantes, en particular en la construcción de la identidad de cada mujer.

En esta investigación trataré de dilucidar cómo el habitar un determinado espacio interior no sólo contribuye sino que condiciona -de manera muchas veces casi inevitable - el constructo que cada mujer acaba haciendo de su propia percepción del yo.

Espero, tras el análisis global de todo el trabajo que conlleva la presente propuesta de investigación, llegar a conclusiones que permitan apuntar algunas posibilidades de intervención arquitectónica capaces de contribuir a cambios en la autoconciencia de las mujeres que repercutan en el cambio social. Un cambio que permita revertir el proceso de opresión y explotación en el que está inmersa hoy en día cada mujer, no sólo desde el exterior, un exterior que no piensa en ella, sino también desde su interior, pues como afirma Fina Sanz, entre otros y otras estudiosas de las clases subalternas:

[...] es frecuente que la gente colonizada pierda sus referencias de identidad y suscriba los valores ético-morales de la colonización como un recurso de valoración personal o de supervivencia física o psíquica. Algo similar ocurre en el mundo occidental. Los términos de normalidad, las normas, etc., vienen impuestas por la sociedad patriarcal. Se desconoce el mundo de la mujer, ese mundo que se ha ido creando a partir de esa diferenciación sexual, y que incluso las 
propias mujeres pueden desconocer, buscando su identidad en un paralelismo con la del varón. (Sanz, 1990: 37-38)

Hasta tal punto puede interiorizar los valores patriarcales que con frecuencia se convierte en cooperadora necesaria del patriarcado que la oprime.

Para conjurar esta ominosa sumisión mental y abrir cauces de pensamiento empoderante a las mujeres, tengo la intención de sopesar la presencia de las mujeres en los estudios tradicionales: pretendo visibilizar a algunas arquitectas pioneras, aportaciones feministas al corpus teórico de la arquitectura; y denunciar hostilidades patriarcales de la praxis y androcentrismos de la teoría arquitectónica clásica. Al mismo tiempo, tendré presentes los rasgos que Sandra Harding reconoce en las mejores investigaciones feministas, para no desviarme y así procurar que la unión de todo ello dé un resultado superior a su suma. Algunos de esos rasgos son: tomar en cuenta las experiencias de las mujeres, como nuevos recursos empíricos y teóricos; mantenerse a favor de las mujeres, en orden a su empoderamiento y cambios sociales de justicia de género; y situarse, como investigadoras, en el mismo plano crítico que el objeto explícito de estudio. (Harding, 1987: 15-26)

Parto de mi propia experiencia como mujer occidental, blanca, de 45 años, arquitecta y madre de tres hijas, las mayores adolescentes. Lo cual me hace consciente de la problemática que el patriarcado genera respecto a la construcción libre de la identidad femenina. También de las dificultades que una arquitecta de mi condición experimenta para desarrollar su profesión. Convencida de la necesidad de revertir la situación, en beneficio de las mujeres arquitectas y habitantes, dispuesta a no renunciar al conocimiento que aportan las experiencias hasta ahora derivadas del rol de las mujeres en general y de las arquitectas en particular, desde las mías propias. También conviene revertir la situación, desde mi punto de vista, a los varones, pues la actual mutila para ellos partes esenciales del mundo de las emociones, renuncian al conocimiento derivado del rol de las mujeres y por tanto se encuentran con menos posibilidades de alcanzar una vida plena.

Desde ese lugar, mi lugar, observo que las conductas que produce el espacio habitado condicionan de modo insoslayable la construcción de la imagen de las 
mujeres adolescentes. Lo hace de un modo triplemente perverso que acaba por anularlas bajo un modelo patriarcal que desea troquelarlas a todas bajo el molde de «la mujer ideal»:

Mujer ideal que no existe, que no es más que el constructo de La Mujer del patriarcado

[...] la demanda patriarcal de que la «Mujer» es una categoría natural y atemporal, definida por ciertas características biológicas innatas. Pero hablar de la Mujer, no obstante, no es, en absoluto, lo mismo que hablar acerca de las mujeres. "La Mujer Eterna» es una invención de la imaginación patriarcal. Las construcciones de los teóricos clásicos del contrato, sin duda, están influenciados por esta figura de la Mujer y mucho han dicho sobre sus capacidades naturales. (Pateman, 1995: 30)

No sólo el patriarcado arcaico o el clásico, como acabamos de ver en la cita de Pateman, también el moderno pretende el engaño de considerar sinónimas las expresiones «La Mujer»y «las mujeres».

Continuamente estamos articulando frases en donde, en la mayoría de las ocasiones, nos referimos como sinónimos a la mujer o a las mujeres; así, decimos «¿Por qué las mujeres no ocupan puestos de dirección en los organismos de poder de las empresas?» o «¿cuál es el problema más acuciante, hoy, que tiene la mujer? En la propia universidad, las profesoras que vienen impulsando los Estudios de género en España, se han planteado, y todavía lo hacen, cuestiones semánticas acerca de las dos palabras. Largos fueron los debates para elegir designaciones del tipo «Centro de Estudios de la Mujer» o «Centro de Estudios de las Mujeres»; sin mencionar la posición política que entraña elegir el nombre de un Seminario o Instituto y nombrarle «Instituto de Investigaciones Feministas». Desde la necesaria posición de reconceptualización que hemos adoptado, ¿es lo mismo hablar de mujer que de mujeres? ¿Es lo mismo hablar desde la perspectiva de la mujer que desde la perspectiva feminista o de género? ¿Es lo mismo cuestionarse el lugar en que la sociedad patriarcal ha colocado a las mujeres o sufrirlo, en el marco de la ignorancia, sin posibilidad de superación del dolor? 
[...] En nuestro país sigue siendo necesario recurrir a la investigación cuantitativa de los medios para hacer significar la diferencia que existe entre la actividad política, laboral, representativa de las mujeres, y la construcción que los medios siguen elaborando de «la mujer». (López Díez, 2007: 8, 13)

La casa ideal, lugar de la mujer ideal, modelizada en los juegos infantiles de casitas y muñecas y en las imágenes de los escenarios de interiores de las películas juveniles, especialmente diseñados y decorados para acoger determinado modelo de adolescente, como describe en su tesis doctoral María Elisa França Rocha:

Los decorados de la serie aportan información visual, especialmente por sus elementos simbólicos y de referencia. Los escenarios colaboran en la construcción de los significados ideológicos del discurso de la serie y los diversos ambientes enseñan al espectador cómo son sus personajes, cómo viven, de qué sustrato económico proceden o qué modo de vida practican. (França, 2001: 149)

Interiores mimetizados por las fans de las protagonistas en sus propios espacios. Interiores reforzados por la publicidad y la prensa amarilla, mimetizados en toda la casa. La casa que, por lo general, no muestra su uso y decoración definitivos en los proyectos arquitectónicos modernos de interiores ni en las revistas de decoración que se pretenden neutras, como neutro se pretende el orden social actual por el mero hecho de su sometimiento superficial a la norma de lo «políticamente correcto». Ainhoa Anaut razona del siguiente modo:

Y en la medida en que los principios de visión y división de las normas sociales que propone el orden mundial están objetivamente ajustados a las divisiones preexistentes y consagra el orden establecido, llevándolo a la existencia conocida y reconocida, la oficial, la mujer seguirá sujeta a la esfera privada. Así, la visión androcéntrica se impone como neutra y no siente la necesidad de enunciarse en unos discursos para legitimarla. (Anaut, 2013: 21) 
En esta línea de reflexión, Begoña San José afirma:

Todas estas prohibiciones y coerciones se han acompañado de un discurso, una ideología legitimadora de la igualdad, destinada sobre todo a ser aceptada por las propias mujeres, para disuadirnos de la subversión, en lo privado y en lo público, del orden establecido. (San José, 2004: 2)

En esta investigación pretendo desentrañar hasta qué punto es paradójica esta situación, en la que parecen haber desaparecido los estereotipos en las revistas de arquitectura, de interiorismo y decoración con pretensiones de neutralidad.

¿Será consecuencia de que la psicopublicidad sabe que los roles, estereotipos y valores se internalizan en los primeros años de la infancia? ¿y que las elipsis en los diseños serán rellenadas inconscientemente por el cerebro de nuestras adolescentes con aquellos valores, estereotipos y roles aprendidos durante la primera etapa de crecimiento?

Tal vez la investigación de la neurocientífica Susana Martínez-Conde pueda aclarar esta aparente paradoja que anuncia en la primera página de su libro con las siguientes palabras:

Las ilusiones visuales constituyen una muestra especialmente
palpable de la producción sistemática de ilusiones que ocurre en
nuestro cerebro en todo momento y a todos los niveles de
percepción, consciencia y pensamiento. (Martínez-Conde, 2013: 1)

En una reciente entrevista, Martínez-Conde apunta a que no sólo la vista sino cualquier percepción, sufre esta trampa ilusionista y la memoria no escapa a sus efectos.

La vista y la memoria nos engañan, pero, dadas las circunstancias, esa distorsión de la realidad es beneficiosa [...] le llega en general al cerebro porque toma muestras de la parte que puede tener mayor información y después rellena los huecos. Pero a veces se rellena de una manera que es incorrecta. (Martínez-Conde, 2014: 1) 
Cuando es incorrecta ¿es siempre beneficiosa? ¿siempre rellena huecos? ¿no añade supuestos implícitos? ¿Qué papel juegan los estereotipos en esa tarea de rellenar huecos o suponer implícitos?

Los proyectos que hoy publican las revistas de interiores, si bien evitan aludir a los usos estereotipados que luego reciben los espacios -explícitos en $\mathrm{El}$ arte de proyectar en arquitectura, de Ernst Neufert, libro de referencia de la industria de la construcción- tampoco sugieren evitarlos. La estrategia es la omisión, la ocultación, la invisibilización, la negación de la evidencia de la vida cotidiana.

En esa elipsis de la figura humana puede residir el núcleo de una investigación que pretende desvelar la desigualdad oculta, como paso previo a la apertura del camino a nuevos diseños de interiores, provocadores de nuevos usos no estereotipados. Investigación que pretende, más concretamente, averiguar hasta qué punto la difusión que del diseño de interiores se hace, en las revistas especializadas, contribuye a que las mujeres vayan hacia la servidumbre y la autocosificación. Así como la corresponsabilidad atribuible al propio diseño de esos interiores en ese camino de construcción de identidades subyugadas. Extremo éste que quisiera comprobar mediante el análisis de una muestra de revistas de interiorismo, con la que espero desvelar la contribución de estas revistas al modelo patriarcal, por sutilmente que se presenten los diseños seleccionados, tan neutros formalmente, tan limpios de figura humana, como si la ausencia de esas figuras humanas fuera suficiente para borrar toda la carga patriarcal que encierran los espacios, las mentes y la sociedad.

\section{Objetivos}

La intención de este trabajo es encontrar algunas formas de ayudar a las mujeres a construir su identidad, libres de los mandatos patriarcales implícitos en la ordenación del espacio doméstico que habitan.

Para ello analizaré las relaciones entre distribución, diseño de interiores y roles de sus habitantes; las posibilidades de elección de los entornos domésticos en los que van a vivir las mujeres y las contradicciones entre sus deseos genuinos 
y las elecciones que hacen, especialmente en lo referente a la injusticia que se deriva del sistema patriarcal.

El diseño de los espacios interiores, como hemos visto antes, forma parte del decorado de fondo de los productos audiovisuales y condiciona el locus asignado por los medios a mujeres y varones, en el proceso de transmisión de valores que realizan subliminalmente. Es necesaria la crítica previa para conseguir que después se potencien los contenidos positivos, orientando a las nuevas generaciones de mujeres lejos de la domesticidad, de la cosificación y de criterios de superficialidad.

Mi investigación pretende aportar elementos que contrasten esta hipótesis para dar un salto y mostrar la necesidad de un cambio de sistema económico, político, social y cultural.

Me planteo en estas páginas los siguientes objetivos:

1. Analizar la dificultad de construir una identidad femenina independiente.

2. Indagar la posibilidad de que se den aspectos androcéntricos en la historiografía y la teoría de la arquitectura.

3. Rastrear, en la teoría arquitectónica, las estrategias del topo-poder, destinadas a asignar a las mujeres al espacio doméstico, y cómo la historia androcéntrica de la antropometría ha dejado su huella como prueba de lo antedicho.

4. Analizar los logros y dificultades que las mujeres arquitectas han afrontado y afrontan para ejercer su profesión.

5. Investigar el nivel de neutralidad de las revistas especializadas en el diseño de interiores en la selección y publicación de sus imágenes.

6. Investigar la posibilidad de que exista o no una asignación patriarcal de locus desde la arquitectura. 
7. Realizar un estudio comparativo entre la cocina Frankfurt de Margarete Schütte-Lihotzky y las cocinas estandarizadas actuales con los modulores de Le Corbusier.

\section{Metodología:}

La metodología de las ciencias sociales incluye las técnicas y procedimientos para recabar información, la manera de analizar los datos recopilados y el punto de vista de la persona investigadora sobre el mundo y su manera de acercarse a él.

Sandra Harding, en su artículo «¿Existe un método feminista?», siente la necesidad de clarificar los conceptos método, metodología y epistemología, pues considera que se entrecruzan en la literatura general y esto afecta a la comprensión del propio título de su artículo. Considero pertinente traer aquí una síntesis de su discusión, en tanto en cuanto, bajo el título del epígrafe metodología, me veré impelida a introducir mi punto de vista sobre estos conceptos, en lo concerniente a la investigación en curso.

Para Harding, un método de investigación es una técnica o una manera de proceder para recabar información. Los clasifica en tres grupos: escuchar a las personas informantes, observar el comportamiento, y examinar vestigios y registros históricos, que son los empleados por cualquier investigación tradicional. Lo que hará la diferencia en una investigación feminista no será cuál de ellos se utilice, pueden utilizarse los tres, sino la manera de aplicarlos:

Las investigadoras feministas escuchan muy atentamente lo que las mujeres informantes piensan acerca de sus propias vidas y de las de los hombres, y mantienen posiciones críticas frente a las concepciones de los científicos sociales tradicionales sobre las vidas de hombres y mujeres. [...] En el caso de la historia, buscan patrones de organización de los datos históricos no reconocidos con anterioridad. (Harding, 1987: 11)

En cuanto al procedimiento para el análisis de los datos, Harding expone la existencia de discusiones feministas acerca del enfoque fenomenológico, el 
marxista, y sus limitaciones. Discusiones que tienen por objetivo mejorar el análisis de la problemática de género y de las mujeres, limitado por el punto de vista androcéntrico de los investigadores tradicionales.

Harding refuerza la importancia del punto de vista cuando trata la confusión que oscurece el concepto de epistemología:

Los sociólogos del conocimiento consideran que las epistemologías son estrategias diseñadas para justificar creencias. Ejemplos muy comunes de estrategias de justificación serían la apelación a la autoridad divina, a la costumbre y a la tradición, al «sentido común», a la observación, a la razón y a la autoridad masculina. [...] la voz de la ciencia es masculina y que la historia se ha escrito desde el punto de vista de los hombres. (Harding, 1987: 13-14)

Ese punto de vista influye, no sólo en el modo de aplicar el método, el análisis o de interpretar los resultados. Influye también en la elección del objeto de estudio y en ese sentido tres son las mujeres que han influido en mi elección del contexto del objeto de mi investigación: La pintora colombiana Doris Salcedo, la fotógrafa canadiense Lynne Cohen y la neurofisióloga española Susana Martínez-Conde.

La primera de ellas, Doris Salcedo, ha hecho presentes a las personas ausentes con su obra, al estilo de la materialización del silencio en la música, la poesía o el cine, según Kosme Barañano:

Este ensayo trata el concepto de silencio en la música y en la poesía del siglo XX y cómo se manifiesta este concepto en la llamada pintura del silencio (Julius Bissier, Zoran Music, Mark Tobey) o en la escultura abstracta (Eduardo Chillida, James Turrell). Esta materialidad del silencio escultórico, la fuerza constructiva del vacío, se da en los silencios de la música, y en lo no dicho de la poesía mística, como en lo no contado del cine o en la ausencia de presencia en la pintura. (Barañano, 2011: 1)

La segunda, Lynne Cohen, se niega a fotografiar personas, pues afirma que su presencia, incluso su identidad, se desprende del contexto de sus fotografías. 
Al hilo de la cita de Barañano podríamos incluir a la fotografía entre las disciplinas que trabajan el silencio.

La tercera, Martínez-Conde, va más allá y afirma que la operación de «rellenar» ausencias es habitual en nuestro cerebro.

No es posible tener una representación fidedigna de la realidad con los recursos neurales que tenemos. El cerebro tiene un tamaño que es bastante reducido, y se ve forzado a tener, en el caso del sistema visual, solo el millón de fibras, que son los axones, que componen el nervio óptico. Eso sería el equivalente a un millón de pixels. Esto, que sería muy poco en una cámara, le llega en general al cerebro porque toma muestras de la parte que puede tener mayor información y después rellena los huecos. Pero a veces se rellena de una manera que es incorrecta. (Martínez-Conde, 2014: 1)

Es un trabajo inverso al de estudiar el espacio interior a través de retratos de mujeres a lo largo de la historia, para desvelar los roles que se les asignaban. Es también un trabajo de descubrimiento necesario pues, como dice Marcuse «Lo ausente debe hacerse presente porque la mayor parte de la verdad reside en lo que está ausente». (cit. en Cevedio, 2003: 27-31)

De estos trabajos puedo aprovechar sus enfoques y, una vez conocida la relación entre mujer y espacio interior que nos proporciona Cevedio, extraer el tipo de mujer y sus roles, que está latente en las imágenes donde la presencia de la mujer es pura ausencia.

Seguiré la estrategia de Betty Friedan y Daniela Arias, consistente en el estudio de revistas que, en mi caso, serán de interiorismo y proyectos de arquitectura actuales. También, imitando las pesquisas arqueológicas, el estilo de Lynne Cohen y el de Doris Salcedo, investigaré cuánto preocupa lo políticamente correcto y cuán poco han cambiado las expectativas sociales respecto al rol social de mujeres y varones.

La metodología adoptada en esta investigación, será la propia de las ciencias humanas y sociales, antes citada, teniendo un cuidado especial con la obtención de los datos, la contextualización social de la información y su adecuada interpretación hermenéutica, bajo el punto de vista de la 
investigadora, situada al mismo nivel de las mujeres investigadas, tal como se ha expuesto en el epígrafe «justificación».

En cuanto al método para recopilar datos que voy a seguir en mi investigación, tres fases lo caracterizan: Investigación bibliográfica, investigación de campo 1 e investigación de campo 2.

Investigación bibliográfica:

En el apartado de «Bibliografía» puede verse el material bibliográfico trabajado en esta investigación, pero destacaré algunos de ellos por su especial incidencia en la estructura o descubrimientos de esta investigación.

En lo referente a la identidad femenina, me apoyaré en la lectura de diversos textos sobre la identidad y en particular los de Cristina Molina y Almudena Hernando, que serán la fuente en la que trataré de basarme para estructurar el concepto de identidad femenina y la línea de la categoría de género con que quiero trabajar.

Utilizaré la lectura crítica de los tratados originales de los arquitectos clásicos y modernos para indagar el posible androcentrismo en la teoría y la historia de la arquitectura. Vitrubio, Filarete, Le Corbusier o Neufert, son algunos de los más señalados.

En la lectura de textos originales de mujeres arquitectas buscaré sus logros y las dificultades que atravesaron para conseguirlos, es el caso de Eileen Gray o Margarete Schütte-Lihotzky. Los textos de las arquitectas pioneras no son fáciles de encontrar, a veces he tenido que beber de fuentes secundarias como Carmen Espegel o Beatriz Colomina.

Investigación de campo 1:

El estudio de las imágenes de revistas de interiorismo y arquitectura me permitirá investigar el nivel de neutralidad de estas publicaciones. Las revistas a analizar serán On diseño, Arquitectura Viva, El Croquis, Diseño Interior, Domus y Casabella. 
Un volcado y un tratamiento estadístico de los datos obtenidos de las imágenes de dichas revistas especializadas en diseño de interiores y en arquitectura, permitirá clarificar las relaciones entre las variables presentes en las imágenes.

Esta fase de la investigación constituye, junto a la que a continuación se detalla, el grueso de la aportación genuina con la que pretendo una contribución en el camino de la construcción de una nueva sociedad, más equilibrada y saludable, en la que pueda darse el libre desarrollo de las personas en igualdad. El apartado de investigación bibliográfica es el marco necesario en el que inscribir las investigaciones de campo que planteo. Es necesario contextualizar el estudio que propongo, para lo cual la revisión desde el punto de vista de mi hipótesis de partida de aspectos históricos resulta condición sine qua non para desarrollar este estudio.

Investigación de campo 2:

Por otra parte realizaré un rastreo para tomar conciencia de la moda en las cocinas estándar con la idea de confirmar la vigencia de las propuestas de Ernst Neufert en lo que a adjudicación de estereotipos domésticos se refiere y en lo que atañe a la pervivencia de las medidas del Modulor y sus precedentes.

Considero que la cocina es un espacio especialmente revelador, expresión de estructuras sociales. Sobre ella realizaré un rastreo específico en proyectos, revistas, publicidad y exposiciones, para dilucidar el manejo que de ella hace el patriarcado en orden a mantener el statu quo.

Kate Millet y otras autoras nos recuerdan que la habitación y la cocina son sitios de lucha política en la misma medida en la que pueden serlo el tribunal o la casilla de votación. (Harding, 1987: 23)

Un viaje a Viena, con el objetivo principal de contrastar y completar los datos sobre la cocina Frankfurt obtenidos de fuentes bibliográficas, ha sido una buena herramienta para explorar in situ tanto el contexto histórico y geográfico de alguno de los escasos proyectos ejecutados en Viena por una de las pioneras, como el estudio detallado de su cocina Frankfurt, expuesta en el museo de arte y diseño (MAK) de dicha ciudad. Estoy hablando, por supuesto, de Margarete Schütte-Lihotzky. 
También he establecido contacto, en el transcurso de mi investigación, con las personas responsables de las fundaciones y exposiciones donde se encuentran los modelos de las primeras cocinas integradas, así por ejemplo la Fundación Le Corbusier o el Centro Pompidou en París.

Los pasos que he ido dando hasta aquí me han permitido realizar un estudio comparado de la cocina Franckfurt de Margarete, con la cocina de Charlotte Perriand, en la Unité Habitacionalle de Marseille (UM) de Le Corbusier, y con las cocinas estandarizadas actuales, así como con los modulores de Le Corbusier, incluidos en ediciones tempranas del libro El arte de proyectar en arquitectura, que es una referencia habitual en los estudios de arquitectura, escrito por Ernst Neufert. Otro análisis que he llevado adelante trata sobre la fidelidad de las cocinas estándar modernas con las propuestas de las distintas actualizaciones del Neufert.

En este apartado me he apoyado en algunos cálculos matemáticos para establecer relaciones que dan consistencia al estudio comparado de las cocinas.

La comparación de las imágenes con figura humana en las cocinas modernas estándar y las ilustraciones del Neufert he podido utilizarlas para reforzar los roles que derivan de la investigación de campo 1.

Visitar la Biblioteca de Cataluña, lugar en el que la editorial Gustavo Gili decidió dejar en depósito los ejemplares de ediciones tempranas del libro El arte de proyectar en arquitectura de Ernst Neufert me permite un análisis del hilo de transferencia de datos entre las distintas ediciones que se han publicado desde el año 1936, en tanto en cuanto a las dimensiones en planta y especialmente en sección se refiere respecto a las cocinas.

\section{Estructura}

He dividido el texto en tres partes, la primera de ellas versa sobre la identidad de las mujeres. En la segunda se revisa la producción androcéntrica de la arquitectura y su praxis patriarcal; $y$ en la tercera me centro en la imagen de las mujeres en los espacios interiores. 
En un primer epígrafe abordo el concepto de identidad y su evolución a lo largo del tiempo. Me centro en la interpretación de la identidad según las teorías narrativas. Planteo, de la mano de Almudena Hernando, la insuficiencia de dicha interpretación para abarcar las experiencias de un sujeto femenino al que sólo se le reconoce por su alteridad. La autora desvela dos tipos de identidad, la individuante, que coincide con la narrativa; y la relacional, sin la cual la otra no se sostiene. En la dicotomía y la convivencia contradictoria de estas dos identidades se sitúa la identidad femenina fuerte, autónoma, no dependiente, frente a la identidad individuante masculina, dependiente del trabajo relacional que la mujer no ha abandonado nunca y el varón moderno abandonó al construirse una identidad individual burguesa.

La identidad fuerte que Almudena Hernando descubre en la mujer moderna es la que puede integrar la lucha por el propio empoderamiento con la lucha contra el heteropatriarcado para liberar a todas las mujeres de la opresión, sumisión, subordinación e invisibilización. Pues la tarea de empoderamiento que requiere, según Cristina Molina, la posesión previa de alguna cota de poder (Molina, 2003: 126), no es suficiente. Como dice Celia Amorós, la lucha debe transformar al que mira en mirado, al que discursea en discurseado, para que la liberación abarque a esa gran mayoría silenciosa de mujeres no pensadas que no tienen poder de partida para iniciar ese empoderamiento. Celia Amorós, en su artículo «Notas para una teoría nominalista del patriarcado» acuña una frase que, interpretada desde el concepto de Hanna Arendt de la «banalidad del mal», explica la gran expansión de los micromachismos que se filtran en una sociedad autoevaluada como políticamente correcta.

Únicamente la pura y simple irreflexión -que en modo alguno podemos equiparar a la estupidez- fue lo que le predispuso a convertirse en el mayor criminal de su tiempo. $Y$ si bien esto merece ser clasificado como «banalidad». (Arendt, 2003: 171)

La irreflexión, el no pensar en la otra persona, en los efectos que sufrirá por las acciones que se autojustifican en la obediencia a una orden, una norma, una costumbre, una tradición, nos sitúa en la posibilidad de ejercer un mal banal, un mal no pensado, no intencionado, no decidido tras una reflexión. La frase de 
Amorós antes anunciada es: «En este sentido, la ideología patriarcal es precisamente el no-pensamiento acerca de la mujer» (Amorós, 1992: 49). De ese no pensamiento se derivarían los males que se infligen a la mujer sin intención, sin mala idea, sin querer... sin querer evitarlo, diría yo.

Amorós encabeza su artículo dejando clara cuál es la lucha necesaria contra este mal banal del machismo patriarcal:

El presente artículo se inscribe en la tarea de hacer del «patriarcado» el objeto de la mirada analítica feminista. Tarea teórica y prácticamente inseparable del proyecto del feminismo de constituir a las mujeres en sujeto emergente -proyecto que, a su vez, es en buena medida deudor de un proceso social que es condición de posibilidad del propio feminismo-. Una constitución tal tiene su punto de partida en una situación del colectivo femenino que Jean Paul Sartre denominó «nosotras-objeto», es decir, el correlato de la mirada totalizadora de quienes han estado en la posición del sujeto, del que mira y nombra. Y el paso del «nosotras-objeto» al «nosotras-sujeto» requiere, entre otras prácticas y otras mediaciones, que el «nosotrasobjeto» se instituya en mirada crítica que defina a quienes han constituido a las mujeres como "lo femenino» mediante sus discursos, sus prácticas y sus definiciones. «La asunción del nosotros en ciertos casos fuertemente estructurados [...] implica el proyecto, no ya de liberarse del nos por una recuperación individual de ipseidad, sino de liberar al nosotros íntegro por la objetividad, transformándolo en nosotros-sujeto. Se trata, en el fondo, de una variante del proyecto $[\ldots]$ de transformar al que mira en mirado [...] La clase oprimida, en efecto -y las palabras de Sartre valen para los genéricos hombre y mujer en lo que concierne a esta dinámica- no puede afirmarse como un nosotros-sujeto sino con relación a la clase opresora y a expensas de ésta, es decir, transformándola a su vez en «ellos objeto». En suma, se trata de definir a los definidores. Porque no creemos que haya alternativa posible al poder de la definición, del poner en discurso y del análisis. Así, en lugar de hacer que la definición deje de tener poder, para lo cual no hay expediente voluntarista posible, proponemos que el feminismo se arme del poder 
de la definición, poder que, de suyo, no es intrínsecamente masculino, lo es, sencillamente, de quien lo ejerce. (Amorós, 1992: 41)

En la segunda parte, reviso la producción androcéntrica de la arquitectura y su praxis patriarcal; visibilizo la presencia en la historia y la teoría de la arquitectura de mujeres arquitectas y expongo algunas de las aportaciones de los discursos feministas en arquitectura. Con esta investigación pretendo contribuir a la construcción de esos nuevos discursos.

Me ocupo por un lado, tanto del análisis de la identidad de la mujer arquitecta, como por otro de la identidad de la mujer usuaria de arquitectura, de la construcción de su propia identidad derivada de las imágenes de los espacios interiores, así como del uso de estos espacios.

En los capítulos segundo, tercero y cuarto abordo de manera sucinta 1) el androcentrismo de la teoría y la historia arquitectónica, 2) las biografías de las primeras mujeres que la historia recoge como arquitectas, las pioneras; $y$, por último, 3) reflexiones sobre arquitectura y género que se han producido en los últimos años por influencia de los avances feministas en otras materias como antropología, filosofía, sociología o psicología.

Con todo doy así una visión del estado de la cuestión en las tres líneas de actuación que desarrollo en el capítulo primero como generalización del análisis de Sonia Reverter en filosofía, que circunscribo aquí al ámbito de la arquitectura. Líneas necesarias para discernir la identidad de las mujeres en relación a la arquitectura, para comprender sus narrativas biográficas:

1. Revisión de la producción teórica de los hombres a lo largo de la historia en la arquitectura.

2. Búsqueda de los textos y de las experiencias de las mujeres pioneras en arquitectura.

3. Construcción y reconstrucción de los discursos feministas en arquitectura.

En el capítulo segundo, el androcentrismo, en arquitectura, no se revela sólo a lo largo de la historia sino también en los espacios. Una clasificación de los 
espacios se hace necesaria para distinguir conceptos como el morar y la domesticidad; y también para el posterior análisis de los datos que desarrollo en el capítulo quinto.

El estudio de los textos y de las experiencias de las pioneras, que se aborda en el capítulo tercero, se estructura en dos secciones:

En el subcapítulo 3.1, en torno a la Primera Guerra Mundial, se expone el trabajo de las pioneras en el periodo del Movimiento Moderno. Destaca aquí la emergencia de los proyectos de vivienda popular posibilitados por los siguientes factores: la demanda, desde finales del siglo XIX, de vivienda obrera como consecuencia del desplazamiento masivo de mano de obra del campo a las industrias de las ciudades; las condiciones de escasez de vivienda generada por la guerra, que significaron no sólo mayor demanda sino también la oportunidad de proyectar sobre suelo libre de edificaciones; la situación socio-político-económica favorable; la producción industrial de nuevos materiales; el interés de las arquitectas y arquitectos del Movimiento Moderno en el uso de esos nuevos materiales para ejecutar la nueva arquitectura y su adhesión a los procedimientos de producción en serie de la industria (armamentística primordialmente).

En el subcapítulo 3.2, en torno a la Segunda Guerra mundial, se aborda el Estilo Local Americano y el Estilo Internacional. Se reflexiona sobre las mujeres que destacaron en la arquitectura de esta época así como sobre las mujeres usuarias, que pasaron de ser ángeles del hogar en una economía de producción a ser modelos acordes a la nueva arquitectura y la novedosísima industria cinematográfica y de electrodomésticos, en una economía de consumo.

En el capítulo cuarto se estudia la construcción y reconstrucción de los discursos feministas en arquitectura. Tras el análisis de la ausencia casi total de mujeres en la arquitectura pública y en el urbanismo, así como de la desconsideración de las necesidades y experiencias habitacionales de las mujeres en la arquitectura doméstica, tanto en lo concerniente a la vivienda suburbana burguesa como en lo que atañe a la vivienda mínima popular, voy a rastrear las aportaciones que se han hecho para corregir este estado de cosas, 
tanto por arquitectas feministas como por arquitectos concienciados o por otros y otras profesionales.

El capítulo quinto de esta investigación se centra en la imagen de las mujeres en los espacios interiores.

Desde los tiempos del Movimiento Moderno, las revistas de arquitectura e interiorismo constituyen un órgano privilegiado de difusión. Quien no publica en las revistas prestigiosas del ramo, no existe como profesional. Muchas de las obras arquitectónicas famosas y que han hecho famosos a sus creadores sólo han alcanzado la existencia en el papel de una revista de arquitectura. Así ocurrió con parte de la obra de Le Corbusier, como también lo comprendieron Ray y Charles Eames; y así lo aprovechó Hug Hefner.

Si una obra ha de marcar tendencia, lo hará a través de su presencia en esta institución: la revista de arquitectura o de diseño. Si un estilo de vida ha de imponerse, las revistas de arquitectura, desde su autoridad, lo harán realidad a través de las construcciones y diseños que lo configuran. Es por eso que, si queremos probar la invisibilidad de la mujer en arquitectura, bastará que la comprobemos en las revistas especializadas de esta disciplina. Y un paso más allá, si no están, pero sabemos que existen ¿dónde están?, ¿qué hacen? Veremos que no están pero que es evidente el lugar que el topo-poder les asigna. Para verlo he procedido a la recopilación de datos referentes a diversas variables, de las revistas citadas en el apartado de metodología. El volcado de estos datos en una serie de hojas de cálculo me ha permitido hacer recuentos y establecer relaciones entre las variables, así como aplicarles un tratamiento gráfico que haga emerger las situaciones ocultas tras las formas aparentemente neutras de las revistas.

Una vez evidenciados los roles que realmente asigna la arquitectura actual a las mujeres, paso a centrarme, en un nuevo nivel de profundización, en el estudio de una de las dependencias fundamentales de cualquier vivienda, la cocina, para detectar el lugar asignado a las mujeres por el topo-poder y la desconsideración con que lo ha hecho. 
Para ello comparo las medidas de las encimeras de las cocinas actuales estandarizadas con las alturas medias de las mujeres en la actualidad según estadísticas oficiales, con las propuestas por Neufert, y con las alturas tipo de los modulores. Todo este trabajo se apoya en los datos obtenidos de las cocinas compactas de las pioneras y tras estas comparativas se establece una discusión que si no aclara las causas de las contradicciones actuales, al menos las pone en evidencia. 
1. LA IDENTIDAD EN LAS MUJERES 


\subsection{Concepto de construcción de la propia identidad}

El título de esta investigación contiene términos que conviene clarificar para establecer el camino a seguir en ella. Uno de ellos es el concepto de identidad. Según el Diccionario de la Real Academia Española (DRAE), identidad es la conciencia que una persona tiene de ser ella misma y distinta de las demás. Tiene que ver con la propia imagen y con lo que cualquiera cree o piensa que es. Pero el concepto de identidad ha sufrido importantes metamorfosis a lo largo de la historia, por ejemplo para Hume es un verdadero laberinto en el que se entrecruza con otros conceptos como sujeto, individuo y subjetividad. Esquemáticamente: la puerta de entrada a ese laberinto, es el sentido, el sentido de la vida; al sentido lo construye la identidad; a la identidad la construye el sujeto; la subjetivación es el proceso de construcción del sujeto a partir del individuo biológico; y la subjetividad es el punto de vista particular del sujeto, de lo que se derivan términos como subjetivo -u opuesto a objetivo- y subjetivamente -o manera de conocer de modo subjetivo-.

En la actualidad distintas escuelas le adjudican significados diferentes. Por ello es necesario centrar desde un principio cual será el significado que manejaré en esta investigación. En primer lugar debo aclarar que mi planteamiento será occidental, tanto en lo que concierne al tema de la identidad como al de la arquitectura; tanto por lo concerniente a mis propios orígenes, como por los materiales a mi alcance.

En principio haré un somero repaso de la evolución del concepto de identidad a lo largo del tiempo, luego expondré esquemáticamente las distintas líneas de investigación que se siguen en la actualidad; y por último me centraré en una de ellas bajo un punto de vista crítico a la luz de la categoría de género.

La identidad humana, en las sociedades arcaicas, es fundada por los seres míticos. Cada miembro del grupo se identifica con el ser mitológico que da sentido al grupo y, si por alguna causa pierde la conexión con ese ser y con el grupo, se le aplicarán exorcismos, ritos específicos, para recuperar la identidad 
perdida. Según Almudena Hernando (2015: 86-90) la identidad primitiva es relacional para todos los individuos del grupo, esto es, cada individuo se reconoce como parte del grupo y no tiene conciencia de existir individualmente. De hecho, es constante la existencia de distintivos de grupo que lucen todos sus componentes. El grupo se cohesiona por la red de afectos y el sentimiento de pertenencia que dan seguridad a cada uno de sus individuos

En las sociedades tradicionales son los mitos de origen y las tradiciones religiosas las que configuran la identidad grupal -relacional según Hernandoque absorbe las identidades individuales. Es con la emergencia de la modernidad cuando surge el sujeto burgués (masculino).

En esta línea de reflexión, afirma Juan Oleza:

Es el sujeto dueño de la razón y centro del universo que comenzará a elaborar el Renacimiento, que llegó a su madurez teórica con la llustración y que desplegó su hegemonía histórica tras las revoluciones burguesas, en las sociedades capitalistas y liberales del siglo XIX, en la poesía romántica y en la novela realista, en la filosofía idealista y en el positivismo europeo, en las modernas ciencias de la naturaleza, en los procesos de racionalización del estado y del derecho o de la economía, en las utopías del progreso y de la historia.

(Oleza, 1996: 6,7)

Es Descartes quien inaugura la modernidad desde su concepción racionalista e individualista del sujeto-mente, que piensa y se construye destruyendo los prejuicios (Descartes, 1984: 48). Puede considerarse que con él comienza el proceso emancipatorio, incluso de las mujeres pues, como dijo su discípulo Poulain de la Barre los prejuicios sobre la inferioridad de las mujeres (que siguen identificándose relacionalmente) son los prejuicios más profundos y sólo cuando sean superados éstos, se podrá pensar que la humanidad se ha librado de todos (Poulain, 1679: 5). Para el cartesianismo la identidad es la conciencia, la toma de conciencia. Simultáneamente nace la ciencia moderna con Galileo y su método según el cual el sujeto es lo cognoscente y el objeto lo cognoscible; el conocimiento científico debe ser objetivo, debe desprenderse de toda subjetividad, el sujeto y el objeto se divorcian, el sentido comienza a caminar 
hacia la verdad científica como instrumento del progreso histórico. Más tarde Locke centra la identidad en la memoria y se constituye así en precursor de las actuales teorías narrativas; así como Kant, a las puertas de la Revolución Francesa, inicia el camino hacia la teoría crítica, sin que por ello abandonen el solipsismo de la identidad del sujeto.

[...] los síntomas de la crisis de este modelo de hombre que fue el sujeto de la filosofía occidental entre el Renacimiento y las Vanguardias, se acumularon en el fin de siglo y la crisis misma fue elaborada teóricamente a través, al menos, de tres vías: el vitalismo e irracionalismo nietzscheanos, de un lado, el marxismo, de otro, y el psicoanálisis de un tercero. (Oleza,1996: s/c)

El vitalismo e irracionalismo nietzscheano concibe al individuo como la objetivación de la voluntad de poder sin ningún sentido más allá de sí mismo; el marxismo, de Marx a Altusser y de Luckas a Bajtin, concibe el sujeto y el estilo individuales en función de instancias sociológicas e ideológicas que los trascienden; y el psicoanálisis contempla un sujeto descentrado que es un punto de encuentro de fuerzas psíquicas y sociales más bien que señor de ellas.

Tras las dos grandes guerras, a mediados del siglo pasado, T. W. Adorno, en su libro Dialéctica de la llustración, nos decía que la autonomía real es imposible para la conciencia burguesa ya que no reconoce la posibilidad de una relación dialéctica entre el sujeto y el objeto (Adorno, 2008: 137)

Vemos que habla claramente de una crítica a un tipo concreto de sujeto, el burgués. Como dice Habermans, discípulo de Adorno, en su «Discurso filosófico de la modernidad», ésta encuentra uno de sus principios determinantes en la razón centrada por el sujeto, en una razón objetivante, homogeneizadora, totalizadora, controladora y disciplinadora (Habermas, 1985: 321).

Curiosamente, sin embargo, ahora que el término sujeto, que fue creado por la filosofía, goza de una aceptación y utilización que la trasciende a ella e incluso al campo del pensamiento teórico, existe otra vertiente de la producción filosófica contemporánea que lo 
rechaza, acumulando sobre él todo tipo de acusaciones. Las así llamadas «teorías de la postmodernidad» impugnan la categoría de sujeto, identificando este instrumento conceptual con el pensamiento totalitario y con prácticas políticas represivas y uniformizadoras. (Acanda, 2008:1)

Ello ha llevado a esa corriente llamada posmoderna a enunciar la muerte del sujeto, sustituido por el individuo subjetivado. Esta corriente sigue sólo a una de las dos pulsiones de la modernidad que ciertamente nos llevó a esa razón objetivante, pero también a la concepción del sujeto como individuo con capacidad de conformar consciente y autónomamente su vida. Es decir, aunque todo individuo tiene subjetividad, no todo individuo es un sujeto, para serlo necesita esa capacidad de consciencia y autonomía, que no significa independencia respecto a los otros ya que:

En el contexto de la construcción de un mundo constituido por una relación de seres culturales, el sujeto y su subjetividad se resignifican en torno a la constitución de nuevas identidades colectivas. En este sentido, las posiciones subjetivas salen del encierro de su individualismo para proyectarse hacia la construcción de los nuevos actores sociales en la construcción de un mundo nuevo, libre, igualitario, sustentable. (Leff y Elizalde; 2010: 2)

Las nuevas identidades colectivas hacen retornar al sujeto que nunca se había marchado, que solamente había muerto en el sentido de su concepción burguesa, individualista, ensimismada, esencialista, cerrada y paradójicamente alienada.

El retorno del sujeto viene de la mano de las nuevas identidades sociales, identidades que el sujeto, como nudo de relaciones objetuales e intersubjetivas, construye por diferenciación, identificación y memorización de su historia personal: «el individuo se ve a sí mismo y es reconocido como perteneciendo a una serie de colectivos, como siendo una serie de atributos y como cargando con un pasado biográfico» (Giménez; 1997: 13). Y es desde ahí desde donde da sentido a su vida, donde encuentra la motivación para sus acciones, donde surge el impulso emancipatorio. 
La subjetivación es la posibilidad de que un indivíduo biológico se conforme como sujeto, sujeto deseante que puede darle sentido a su vida de manera singular. (Ribeiro; 2010: 1). Ahora bien, esta definición sería válida para el sujeto burgués, que los análisis posmodernos muestran que ha muerto. El nuevo sujeto construye su identidad confrontándola con los otros, es más, la identidad colectiva es un prerrequisito de la identidad individual, ello supone que el sujeto construye su identidad mientras construye la alteridad de esos otros.

\subsection{La construcción de la propia identidad desde la perspectiva de género}

Como dice Sonia Reverter:

«La identidad de la propia subjetividad necesita de la categoría del «otro» [...] la mujer se convierte en alteridad absoluta cuando se construyen las leyes contra ella; leyes que buscan proteger los intereses económicos, políticos, morales y ontológicos del sujeto que las crea: el varón ». (Reverter, 2004: 121)

Es decir, el patriarcado ha relegado a la mujer a la alteridad absoluta, por eso las teorías feministas (de la segunda ola del feminismo) reflexionan sobre la construcción del otro/otra como sujeto dominado. En cambio, las teorías feministas de la igualdad afirman que la mujer no existe, cada mujer insiste por existir, por reconocerse y ser reconocida como sujeto que puede dirigir su vida de modo consciente, libre y autónomo. Dichas teorías son herederas de los movimientos emancipatorios ilustrados del siglo XVIII (entre ellos, las vindicaciones sobre la igualdad de las mujeres, que se sintieron excluidas del proyecto ilustrado) y de las revoluciones sociales del XIX (incluidos los movimientos sufragistas llamados primera ola del feminismo) y polemizan con las teorías feministas de la diferencia que constatan la insuficiencia de los logros en igualdad y defienden la libre expresión del deseo femenino genuino vinculándolo a tres movimientos: toma de conciencia, deseo de ser libre y voluntad de existir. También polemizan con aquellas que beben de las teorías posmodernas y que afirman la muerte del sujeto, incluso del concepto sujeto, 
como es el caso de las teorías postfeministas. Respecto al tema que nos concierne es fundamental la aportación de Judith Butler.

\section{Como nos recuerda Sonia Reverter:}

[...] para las feministas de la diferencia la igualdad anula la subjetividad femenina pues calza a las mujeres con el modelo de subjetividad masculina; para las feministas de la igualdad precisamente el feminismo debe luchar porque las mujeres puedan constituirse una nueva subjetividad que no sea la de la dominación o exclusión, ni la del varón. ¿Cómo encontramos la liberación de los sujetos, que es en definitiva la búsqueda común de ambos feminismos? ¿Dónde hallar ese punto de encuentro? [...] Uno de los frentes en los que se trabaja es la búsqueda de un concepto de igualdad que a su vez sea sensitivo a las diferencias. (Reverter, 2003: 44-45)

Todas las corrientes feministas comparten el objetivo de transformar cultural y simbólicamente la sociedad para evitar la dominación sobre las mujeres y permitirles libertad y subjetividad plena.

Puesto que los feminismos comparten los problemas a resolver, el objeto de reflexión y el objetivo social, sólo se diferencian en el modo de conseguirlo. Por ello Sonia Reverter se pregunta:

¿Si no hay un «sujeto mujer», ¿cuáles son las posibilidades de las mujeres por luchar por sus derechos sin perderse en un relativismo que sólo beneficia a aquellos que no necesitan de un discurso universalista porque ya lo tienen todo? ¿Qué es «lo femenino» sin las mujeres?, como ha apuntado acertadamente Françoise Collin. En contrapartida, como responden las feministas de la diferencia, ¿no es el «sujeto mujer» el sujeto que está construido a la vez que dominado? ¿No será mejor por tanto descentrar los conceptos de «mujer» y «hombre», ya que son sólo los posicionamientos identitarios que sirven como base para el reparto de poder y de exclusión? (Reverter, 2003: 43-44)

Actualmente, la teoría crítica propone frente a los fallos del racionalismo moderno, más racionalismo, frente a los fallos de la ilustración, más ilustración, 
frente al nihilismo de la muerte del sujeto, de los sujetos alienados, el retorno del sujeto, de un sujeto social que implica la construcción de identidades abiertas, intersubjetivas y el retorno del sentido.

Tal vez es el momento de la construcción de identidades no excluyentes. Tal vez es hora de rescatar y poner en valor algunos aspectos de la primitiva identidad grupal, aquellos que la caracterizan por ser relacional y afectiva. Estos son los aspectos de la identidad grupal que han permanecido a lo largo de la historia preservados en la única identidad permitida a las mujeres y que permiten el sostén de la identidad individualizada del sujeto varón moderno. El sujeto varón moderno, con los afectos y las relaciones sociales bien atendidas por sus mujeres, puede dedicarse, sintiéndose seguro, a la cosa pública. En suma la atención y mantenimiento de los vínculos afectivos y relacionales por parte de las mujeres hacen posible la supervivencia de los varones como ciudadanos de pleno derecho. Es más, la atención a los vínculos citados se hace necesaria para aglutinar los fragmentos de la sociedad individualizada que ellos, los varones-ciudadanos, construyen mientras hacen dejación en las mujeres de los aspectos afectivos y relacionales. Estos aspectos afectivos y relacionales dan cohesión a la sociedad y la estructura así establecida permite a los varones ensimismarse en su yo. Esas necesidades que cubre la mujer para que el sujeto varón independiente pueda funcionar, hacen de este último un sujeto dependiente.

Sin embargo, las mujeres como nuevos sujetos modernos que no renuncian a los afectos pero defienden sus derechos, desde la identidad racional que las acompaña, hace de ellas mismas sujetos independientes, por mucho que ello las sitúe frecuentemente en situaciones contradictorias, paradójicas.

Ésta es la concepción que contemplaremos en esta investigación. Identidad individual y relacional en el sentido expresado por Almudena Hernando, por tanto identidad independiente.

Esta es una individualidad en construcción pues, como indica Hernando:

Creo que estamos en un momento de crisis de identidades: de crisis de la identidad relacional de las mujeres, pues la sociedad moderna 
no ha podido seguir evitando, al profundizar en la lógica democrática consustancial al nacimiento del sujeto, dotarnos de los instrumentos de representación metafórica de la realidad, con todas las implicaciones estructurales que ello tiene y el surgimiento de la individualidad que implica; y de crisis de la identidad individualizada de aquellos hombres (no muchos aún, desgraciadamente) que entienden el alcance de esa lógica y la justicia de su aplicación, y desean seguir el camino de su individualización extendiendo a todos los miembros del grupo social los principios que hasta ahora regían sólo para ellos. (Hernando, 2002: 201)

Giménez interviene en el actual debate sobre identidades, aportando, desde el punto de vista sociológico una visión historicista global, pero compatible con el análisis de Hernando, donde la identidad débil de Giménez se aproxima a la identidad relacional de Hernando; y la concepción fuerte se refiere al mismo sujeto burgués con su individualidad cerrada y, en consecuencia, dependiente de otras individualidades para sustentar su pertenencia al grupo:

De este modo el debate sobre la identidad se entabla entre una concepción "fuerte" que deja pocos espacios a la libertad del sujeto, y una concepción "débil" que le atribuye libertad casi total. El desafío consiste en superar este dilema manteniendo la libertad (siempre relativa) del sujeto, pero sin diluir la consistencia y el espesor de su identidad. La inscripción obligada de la identidad en la sociedad global nos permite formular preguntas sobre cómo afectan a la constitución de la identidad los diferentes tipos de sociedad. En efecto, podemos suponer con fundamento que las identidades no se configuran de igual manera en las sociedades arcaicas (donde hay seres míticos que fundan la identidad humana y prácticas rituales que exorcizan el riesgo de su pérdida), en las sociedades tradicionales (donde la identidad étnica grupal, fundada en mitos de origen y en una tradición religiosa, tiende a absorber las identidades individuales), y en las sociedades modernas caracterizadas por la diferenciación. (Giménez, 1992: 197) 
Parece que partiendo cada uno de uno de los extremos entre las diversas concepciones sobre la identidad, Hernando y Giménez llegan a una zona de aproximación:

\begin{abstract}
Ubicada de este modo en la subjetividad emergente de una intersubjetividad, la identidad puede ser analizada en términos de lo que la escuela europea de psicología social denomina representaciones sociales: en efecto, la identidad tiene que ver con la organización, por parte del sujeto, de las representaciones que tiene de sí mismo y de los grupos a los cuales pertenece, así como también de los "otros" y de sus respectivos grupos. (Giménez, 1992: 188)
\end{abstract}

Esta organización de la identidad individual se realiza en torno a una serie de elementos constituyentes:

1) la pertenencia a una pluralidad de colectivos (categorías, grupos, redes y grandes colectividades),

2) la presencia de un conjunto de atributos idiosincrásicos o relacionales;

3) una narrativa biográfica que recoge la historia de vida y la trayectoria social de la persona considerada. (Giménez, 1997: 5)

Teniendo en cuenta que las representaciones sociales del individuo proceden básicamente de la experiencia vivida, de las matrices culturales de los grupos en que se ha inscrito y de las ideologías hegemónicas en cada época y lugar, cabe preguntarse qué representaciones sociales puede hacerse un individuo perteneciente a la categoría mujer, categoría determinante de roles y estereotipos, mujer cuya experiencia se ha desarrollado sin excepciones bajo una ideología patriarcal, que la define como alteridad, no como identidad. ¿Qué representaciones tendrá la mujer sobre sí misma que le permitan ser reconocida a través de ellas por el Sujeto que la necesita como alteridad absoluta en la construcción de su propia identidad?. Y, como colectivo ¿qué biografía/historia le confiere unidad temporal?

El patriarcado impone los roles de género y el androcentrismo. La historia es androcéntrica: no ha sido silenciada sólo la presencia de las mujeres sino 
también su experiencia y sus aportaciones, tomando la parte (del varón) por el todo (la humanidad).

La intersubjetividad no existe porque la Mujer (término con el que el simbólico patriarcal engloba a todas las mujeres) ha sido relegada al lugar de alteridad absoluta. La voz de las mujeres no cuenta, no se les da voz para expresar sus experiencias. El texto Los ecos del Banquete no escrito, de Nieves Muñoz, ilustra esta situación con brillantez.

Creo que hablan del mundo que se fabrican como si lo ajeno a su poderío, a sus ideas y a su bienestar privado no existiera, porque realmente no existimos para los hombres; nuestra humanidad se tambalea cuando las acciones que realizamos son movidas por extraños hilos cuya procedencia ignoramos. (Muñoz, 2010: 47)

Pero la seguridad que confiere la identidad relacional es necesaria y el sujeto masculino se aprovecha de las mujeres que le garantizan los vínculos emocionales a través de su identidad relacional. El varón niega la importancia de esa identidad pero la necesita, la considera «atrasada», primitiva. Identidad que no es reconocida pero que no ha desaparecido. La identidad relacional es hoy denominada identidad de género femenina.

Las mujeres han desarrollado una identidad mucho más basada en la relación que en la individualidad a lo largo de la historia, pero la modernidad, al desarrollar la lógica individualista inherente a una percepción de la realidad basada en las categorías Sujeto/Razón, empezó a introducir una contradicción cuyos efectos definen la identidad femenina actual y generan temor en unos hombres acostumbrados históricamente a ser los únicos sujetos de deseo y acción. Durante todo el desarrollo de la llustración (y aún hoy en muchos casos, desgraciadamente) se pretendió aplicar dichas categorías de identidad y percepción del mundo sólo a los hombres, alegando que las mujeres no podían decidir sus destinos, pues su naturaleza ya les había marcado el único destino posible para ellas: ser madres y esposas, «ángeles del hogar» (sin deseos, ni siquiera sexual -ya se sabe cómo son los ángeles-, ya que la conciencia de un deseo abriría la puerta de los demás y, por tanto, a la conciencia de 
individualidad. Su destino era atender sólo el deseo de los demás). Es decir, se pretendía que las implicaciones identitarias de la modernidad sólo correspondían a los hombres, mientras que las mujeres estaban destinadas, por naturaleza, a mantener una identidad colectiva, relacional o adscriptiva. $Y$, de hecho, los rasgos de la identidad de muchas mujeres de la sociedad actual siguen reproduciendo la estructura de la identidad relacional, en la que basan su orientación en el mundo los grupos que no tienen dominio sobre las circunstancias que les rodean: construyen su identidad más a través de las relaciones que establecen (con el marido, los hijos...), que de la discriminación y satisfacción de sus propios deseos. Necesitan ser «deseadas» para sentir que tienen valor, porque su seguridad en la vida no deriva de su iniciativa y la satisfacción de sus deseos, sino del hecho de haber sido «elegidas» por una instancia superior que ofrece protección $y$, sobre todo, genera sentido. (Hernando, 2002: 187-188)

Resulta relevante la diferencia entre las categorías de género débil y fuerte, tal como la señala Cristina Molina: la diferencia entre categoría débil de género (limitada a los roles, las representaciones de un guión) y categoría fuerte (no en el sentido esencialista sino que tiene en cuenta las relaciones de poder; de poder escribir ese guión y reescribirlo para actualizarlo constantemente) implica diferencias fundamentales a la hora de decantar el peso de las transformaciones sólo en el terreno de lo individual o tener en cuenta también la acción colectiva, destinada a derrocar el poder del patriarcado.

En su dimensión histórica el patriarcado va cambiando y, aunque atento siempre a sus intereses, va adaptándose a las condiciones sociales del momento. Así, pueden cambiar igualmente los lugares y los nombres de «lo femenino» aunque (y para que) se sigan manteniendo las jerarquías. Desde la situación de las mujeres occidentales de países avanzados, el poder patriarcal ya no se define tanto, en palabras de A. Jonasdóttir (1993), por situaciones de desigualdad formal ni de opresión en la asignación de espacios prácticos de discriminación, cuanto por el poder del amor, donde el patriarcado extrae una importante plusvalía de la capacidad de amor 
y cuidado de las mujeres con el fin de habilitar a los hombres como personas completas y autorizadas. El patriarcado desplaza su poder hacia el campo del deseo en su interés de siempre de apartar a las mujeres de los espacios de poder. (Molina, 2003: 126-127)

Me interesa el enfoque desde esta última posición, es decir, desde el concepto de patriarcado como generador de una sociedad asimétrica en cuanto a la distribución del poder por sexos:

El patriarcado, como poder de los hombres sobre las mujeres, daría cuenta del género y, en su dimensión histórica, en la historia de sus complicidades para mantener sus intereses de dominio daría cuenta igualmente del entrecruzamiento del género con otras variables. (Molina, 2003: 124)

Aparte de constituir una dimensión fundamental del patriarcado, junto al androcentrismo, entre otras, la categoría género ha proporcionado una herramienta de análisis del androcentrismo y los silencios de esa historia, de esas praxis patriarcales. Estos análisis, desde los años 70 , vienen iluminando tres líneas de actuación que, como ya he adelantado, parafraseando a Sonia Reverter (2003: 35), puedo adaptar a este trabajo como:

1. Revisión crítica de la producción teórica de los hombres a lo largo de la historia en los distintos sectores del conocimiento. En este texto, revisión y crítica de la producción teórica de los arquitectos varones a lo largo de la historia.

2. Búsqueda de los textos y las experiencias de las mujeres en cada sector del conocimiento. En particular, para el tema que nos ocupa en arquitectura.

3. Construcción y reconstrucción de discursos feministas en cada sector del conocimiento. Tomar la palabra. Discursear. Discursear-los. (Cristina Molina, 2003: 144)

Pero, como dice Cristina Molina, no basta con disponer de una categoría analítica como la de género para incidir realmente en el núcleo del problema y así remover las estructuras que impiden su solución. 
[...] caben dos caminos que han transitado las feministas definiendo desde ellos las estrategias posibles [...]

- O bien se actúa en [...] «la base material» del género, la estructura de macropoder (llámese desigualdad económica, posesión de recursos, trabajo familiar o explotación emocional) y en la, digamos, «superestructura» implícita: ideologías, imágenes y modelos de lo femenino que remiten al «poder de nombrar».

- O bien se actúa en el aspecto «identitario-subjetivo» de las prácticas que nos han «generizado», y constantemente nos «generizan», en una suerte de terapia comportamental, que va desde la resistencia a aceptar las identidades genéricas hasta las contraprácticas genéricas [...] no se busca tanto -o nada- destruir la estructura de poder, sino desestabilizar el género a partir de prácticas contradictorias con la normativa de género. (Molina, 2003: 146)

El primer camino es el defendido por Celia Amorós que busca una sociedad en la que no se produzca la marca de género. Para ello, es necesaria la construcción de un sujeto-agente fuerte y colectivo, capaz de desmarcarse individualmente de las identidades genéricas adscriptas y de articular estrategias de lucha colectiva.

El segundo camino es el elegido por Judith Butler y no busca la supresión de los géneros, sino la del binarismo. Su estrategia consiste en desplazar lo real por el simulacro, la máscara, el carnaval, el teatro.

Almudena Hernando (2002: 212), coincide con Celia Amorós en la necesidad de construir una sujeto femenino fuerte y colectivo. Para ello propone la construcción de una identidad individualizada, que da poder, sin desmarcarse de la identidad relacional, lo cual daría lugar a una identidad individual independiente, frente a la identidad individual dependiente propia del sujeto varón burgués, dependiente del soporte femenino para satisfacer, aunque no reconocer, la necesidad de la identidad relacional, que preserva los vínculos afectivos de los que dependen las tareas del cuidado. Y superaría la construcción de la identidad postfeminista falsamente liberada, falsamente exitosa, falsamente empoderada que, tras esos falsos atributos responde a la 
sumisión al modelo masculino Playboy, puesto que no se siente completa si su éxito y empoderamiento no se acompañan de una liberación sexual que no está orientada a satisfacer sus propios deseos sino a satisfacer los deseos de ese varón Playboy que menciona Beatriz Preciado en su obra Pornotopía. Arquitectura y sexualidad en Playboy. Modelo deudor de las arquitecturas que contienen y configuran las nuevas identidades de género patriarcales.

Este ensayo nos adentra en el archipiélago Playboy: un Disneyland para adultos hecho de mansiones, camas redondas, grutas tropicales, habitaciones temáticas, circuitos de vigilancia, piscinas transparentes, residencias de conejitas, aviones equipados con pista de baile y termas romanas...Este complejo, inspirado en las utopías sexuales revolucionarias de Sade y Ledoux, funciona como el primer burdel multimedia de la historia. Una pornotopía moderna instalada en la cultura de los medios de comunicación de masas y en la arquitectura del espectáculo. El archipiélago Playboy sirve de laboratorio para estudiar las mutaciones que van desde la guerra fría hasta un capitalismo caliente cuyos medios de producción son el sexo, las drogas y la información, y donde la arquitectura funciona como un escenario en el que se teatraliza la identidad masculina. (Preciado, 2010: 413)

La supuesta liberación sexual de la mujer dará lugar, como consecuencia del abandono y descrédito del feminismo y la irrupción del neoliberalismo global, a una identidad femenina que se considera liberada sexualmente, pero que no es más que la nueva identidad sumisa, cuyo deseo genuino no existe, sino que su deseo es ser deseada. No nace de su rebelión sino de la adaptación al nuevo modelo de masculinidad impuesto por Hug Hefner. Ahora ya no le basta, para ser elegida, su identidad relacional, ahora además ha de competir con las sex simbol de los medios de comunicación que han descubierto el gran negocio que supone explotar la imagen femenina como objeto de deseo sexual. Hablo del concepto de colaboración necesaria. Ellas han descubierto el gran negocio que supone explotar la imagen femenina como objeto sexual. Creen haber descubierto, pues no es más que otra trampa del sistema capitalista y el heteropatriarcado. Se ha modelado el deseo de ser, ellas quieren ser deseadas. 
Ese deseo se ve colmado cuando, en un sistema capitalista, se le pone valor económico al objeto a consumir. Son ellas, se sienten plenas de manera fugaz cuando el sistema invierte económicamente en difundir sus imágenes, ya sea en directo o a través de los medios de comunicación. Digo de manera fugaz porque uno de los valores es la juventud, y no dura demasiado según los cánones de belleza actuales.

El neoliberalismo nacido a finales del siglo pasado ha supuesto un retroceso en todas las luchas sociales, también en el feminismo. Por ello, los frutos del feminismo teórico y práctico están lejos de haber madurado particularmente en arquitectura. Las identidades construidas por los productos arquitectónicos han sufrido especialmente este frenazo. Baste recordar la afirmación de Beatriz Preciado quien escribe «mientras Hefner se esfuerza por adoptar los códigos visuales de representación de la masculinidad del arquitecto, los arquitectos empiezan a desear ser representados como playboys». (Preciado, 2010: 23) 


\section{CRÍTICA AL DISCURSO ANDROCÉNTRICO EN ARQUITECTURA}




\subsection{En la Historia}

Como apuntábamos en el capítulo anterior, la arquitectura va a la zaga de otras áreas del conocimiento y de la actividad humana, en lo referente al tratamiento igualitario de la mujer, bien sea arquitecta o usuaria, por lo que la historia de la arquitectura desde el Renacimiento hasta el Movimiento Moderno, casi carece de referentes femeninos.

Vitrubio es autor de la obra De Arquitectura, en 10 tomos, que constituye una compilación de los saberes arquitectónicos grecorromanos, escrita en el siglo I antes de nuestra era y que fue utilizada a lo largo de toda la Edad Media por ser el único texto de arquitectura clásica superviviente, aunque incompleto.

Entre la revalorización renacentista de la obra de Vitrubio, y finales del siglo XVIII, encontramos antivitrubianos y vitrubianos corifeos del arquitecto romano, por lo que la teoría de la arquitectura europea en ese periodo puede resumirse desde la exégesis y la crítica a su obra.

Cuando la Grecia clásica y el Renacimiento ponen al hombre en el centro de todas las cosas, no se refieren al hombre como representante del género humano, sino al hombre como varón. Así se desprende de los textos que nos han llegado. Es el caso de Vitrubio, quien en el capítulo primero de su tercer libro, expone las proporciones de los órdenes dórico, jónico y corintio; y según la edición de 1997 dice: «[...] una, de aspecto viril y sin ninguna clase de adorno (dórica) y la otra imitando los adornos femeninos (jónica)» (1997: 98)

Un párrafo más arriba afirma: «De esta manera, la columna dórica era una respuesta a la proporción del cuerpo humano». (1997: 98)

La lectura de estos dos párrafos evidencia el salto semántico bajo el que se agazapa el androcentrismo que planea en todo el libro. Texto que será referente en estas cuestiones para toda la arquitectura posterior, como veremos en el próximo capítulo, pues, el antivitrubianismo no se centró precisamente en el análisis androcéntrico del texto. Todavía Loos, a finales del siglo XIX, mantiene la idea de Vitrubio respecto a que la casa debe ser construida teniendo en cuenta el rango y profesión del varón que va a ser su propietario y morador. Y 
en pleno siglo XXI, Galmés hace un recorrido del morar a través de doce moradores, varones, salvo dos casos, el matrimonio Eames y el matrimonio Smithson. Son fieles seguidores del androcentrismo de Vitrubio:

Por tanto, quien posea un escaso patrimonio no precisa de vestíbulos suntuosos, ni de recibidores, ni de atrios magníficos, ya que son ellos los que se ven obligados a visitar a otras personas y nadie acude a visitarlos. Los que viven de los productos del campo deben disponer sus establos y sus tiendas en los vestíbulos, y en el interior de la vivienda se situarán las bodegas, graneros y despensas, cuya finalidad es guardar los productos, más que ofrecer un aspecto elegante. Los prestamistas y arrendadores dispondrán de casas más cómodas, más amplias y protegidas frente a posibles manejos ocultos. Los abogados e intelectuales habitarán casas más elegantes y espaciosas, con el fin de celebrar sus reuniones cómodamente; los ciudadanos nobles y quienes ostentan la responsabilidad de atender a los ciudadanos por ejercer cargos políticos o magistraturas, deben disponer de vestíbulos regios, atrios distinguidos, peristilos con gran capacidad, jardines y paseos adecuadamente amplios, en consonancia con el prestigio y la dignidad de sus moradores; y además bibliotecas y basílicas que guarden una digna correlación con la magnificencia de los edificios públicos, dado que en sus propios domicilios se celebran decisiones de carácter público. (Vitrubio, 1997: 165)

Es obvio que Vitrubio está preocupado por construir la casa adecuada a cada varón, adecuada a su profesión y su estatus social. Es la casa del pater familias. Vivienda y familia son así conceptos que refuerzan la estructura patriarcal (Cevedio, 2010: 71).

Desde un principio, el deseo de Vitrubio de compilar todo el saber arquitectónico grecorromano hasta la época de Augusto tuvo críticos que echaron en falta la coherencia entre ese deseo cerrado, dogmático uniformador y la realidad misma que se mostraba pertinazmente variada. Hasta el siglo XVIII sus seguidores defendían que la falta de coherencia con las ruinas romanas posteriores a Vitrubio era comprensible pues presentaban las variaciones que él mismo 
autorizaba para adaptar la construcción a la cultura, el clima y los materiales de cada lugar. Además, decían, Vitrubio era helenista, por eso su obra parece ceñirse más a las construcciones griegas. Pero a finales del siglo XVIII la arqueología dio un gran salto y las ruinas griegas fueron descubiertas ¡tampoco había coherencia con ellas!. Pero volvamos al texto de Vitrubio. Su influencia sobre los estudiosos del libro, empeñados en realizar los dibujos supuestamente perdidos es indiscutible. Más bien que escribir sus propios textos, estaban empeñados en limpiar el libro de Vitrubio de sus faltas, carencias y pérdidas, en particular los dibujos supuestamente perdidos y supuestamente necesarios para sacarlo del oscurantismo de su jerga técnica y griega.

Uno de esos dibujos es el llamado «hombre de Vitrubio» realizado por el propio Leonardo da Vinci que lo dibujó en torno a 1490.

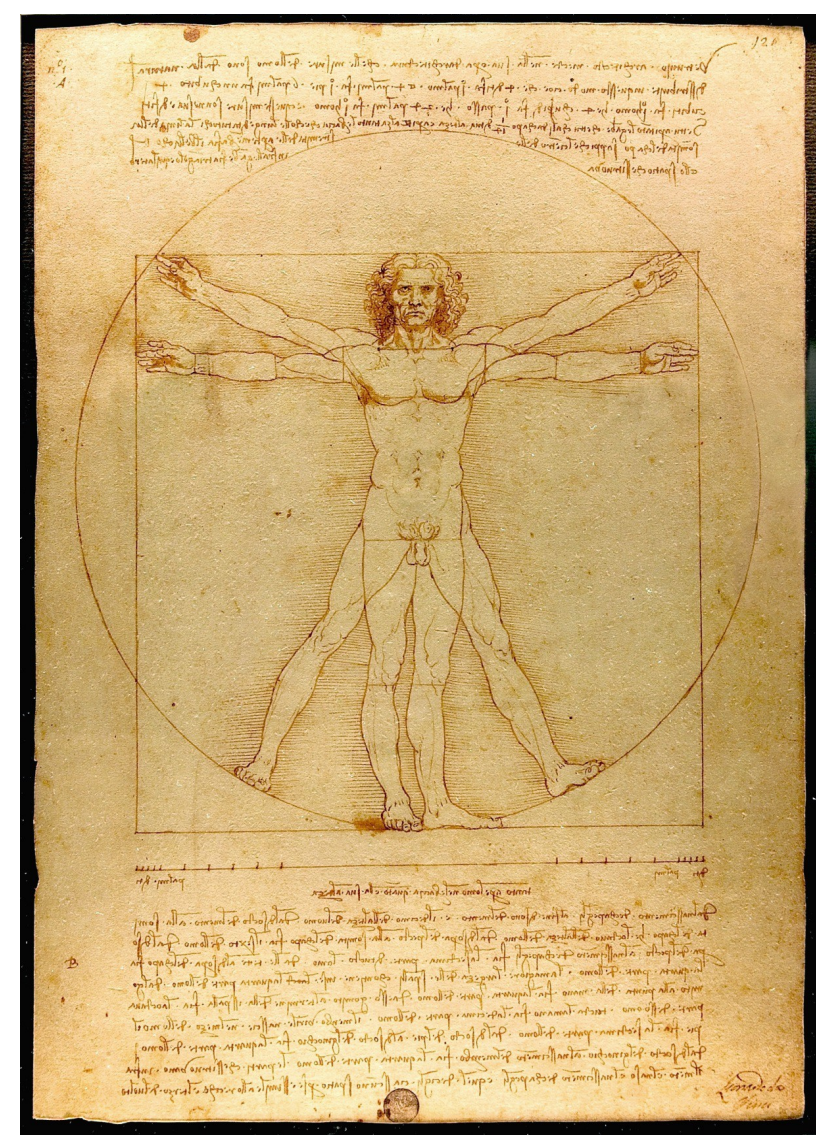

1. Leonardo da Vinci. El hombre de Vitrubio, c. 1490. 
Este dibujo sintetiza y confirma la influencia de la idea vitrubiana según la cual, el centro, el modelo de simetría y proporción y la medida de todas las cosas, el módulo, es para ambos, el arquitecto clásico y el moderno, el ser humano, tomado como el hombre varón, tal y como veremos con más detalle en el próximo capítulo.

En los siglos posteriores, no sólo el módulo será el varón, también las funciones de los objetos arquitectónicos toman como modelo al varón. Escuchemos la voz de Filarete en el siguiente párrafo:

The building is conceived in this manner. Since no one can conceive himself without a woman, by another simile, the building cannot be conceived by one man alone. As it cannot be done without woman, so he who wishes to build needs an architect. He conceives it with him and then the architect carries it. When the architect has given birth he becomes the mother of the building. Before the architect gives birth, he should dream about his conception, think about it, and turn it over in his mind in many ways for seven to nine months, just as a woman carries her child in her body for seven or nine months. He should also make various drawings of this conception that he has made with the patron, according to his own desires. As the woman can do nothing without the man, so the architect is the mother to carry this conception. When he has pondered and considered and thought [about it] in many ways, he ought to choose [according to his own desires], what seems most suitable and most beautiful to him according to the terms of the patron. When this birth is accomplished, that is when he has made, in wood, a small relief-design of its final form, measured and proportioned to the finished building, then he shows it to the father. (Filarete, 1965: 15) ${ }^{1}$

\footnotetext{
1. El edificio se concibe de esta manera. Ya que nadie puede ser concebido sin una mujer, haciendo otro símil, el edificio no puede ser concebido por un solo hombre. Como no se puede hacer sin la mujer, también quien desea construir necesita un arquitecto. Él concibe con el arquitecto y luego el arquitecto lo gesta. Cuando el arquitecto ha dado a luz se convierte en la madre de la construcción. Antes de que el arquitecto dé a luz, debe soñar con su concepción, pensar en ello, y darle la vuelta en su mente de muchas maneras durante siete a nueve meses, al igual que una mujer lleva a su hijo en su cuerpo durante siete o nueve meses. También debe hacer varios dibujos de esta concepción que él ha hecho con el patrón, de acuerdo con sus propios deseos. Así como la mujer no puede hacer nada sin el hombre, el arquitecto es la madre para llevar adelante esta concepción. Cuando él ha meditado y considerado y pensado [al respecto] de muchas maneras, debe elegir [de acuerdo con sus propios deseos], lo que le parece más adecuado y más hermoso, de acuerdo a los términos del patrón. Cuando se logra este alumbramiento, que es cuando ha hecho, en madera, un pequeño diseño de su forma final, medido y proporcionado al futuro edificio terminado, entonces lo muestra al padre. (Traducción propia)
} 
Pero no sólo impone su cuerpo como modelo en la construcción de los edificios nobles y se travestiza en madre generadora y paridora de su obra arquitectónica, sino que, tanto el interior como el exterior de los edificios, debe estar al servicio de las necesidades del hombre, del usuario, del padre de la obra: el varón, tal como podemos leer en el siguiente párrafo de Francesco di Giorgio:

In prima adunque è da sapere ce la Piazza principale debba nel centro della terra, o più propinqua a quello che si puo, essere locata, come il bellico del l'uomo, la quale alla comodità deba essere seconda. E la ragione della similitudine può essere questa: perchè siocome per un bellico nel principio la natura umana piglia nutrimento e perfexione, così per questo luogo comune gli altri proprii sono sovvenuti. Ma la ragione naturale è in pronto, perchè tutte le cose comuni debbano alle proprie essere indifferenti ${ }^{2}$. (Di Giorgio, 1841: 73)

Si tenemos en cuenta que la ciudad es para Di Giorgio, como una casa pero a gran escala, podemos deducir qué piensa sobre las funciones de una casa y por tanto en beneficio de quién hay que adaptar la construcción.

En la época de la llustración, poco cambian las cosas. Para las edificaciones del pueblo todo sigue igual, pero éstas no figuran en los tratados de arquitectura. En las altas esferas, se dirime la lucha por el poder entre la nobleza y la burguesía. La Revolución Francesa alienta, dirige al pueblo con sus eslóganes de Libertad, Igualdad y Fraternidad, pero cuando Olympe de Gouges pide la igualdad entre mujeres y hombres, es guillotinada. El pueblo cambia de amos pero no de posición. Los grandes edificios son construidos ahora por la burguesía y los arquitectos siguen las normas, las pautas que escribiera por primera vez Vitruvio y desarrollaran más tarde los renacentistas. Habrá que esperar a que las revoluciones sociales de mediados del siglo XIX posibilitaran a principios del siglo XX nuevas visiones a las pioneras que vamos

2. Por lo tanto, decir que en primer lugar, la plaza principal se debe colocar en el centro de la ciudad o lo más cerca posible, al igual que el ombligo en el cuerpo del hombre, la utilidad debería ir en primer lugar. La razón de esta similitud podría ser la siguiente; al igual que es a través del ombligo que la naturaleza humana obtiene la nutrición y la perfección en sus inicios, de la misma manera desde la plaza principal, común, se sirven otros lugares particulares. (Traducción propia) 
a encontrar en el próximo capítulo. El pueblo llano sigue autoconstruyendo sus viviendas u ocupando las infraviviendas de colonias fabriles, o viviendo de alquiler en las casas construidas en serie por la oligarquía burguesa, al estilo del resto de la producción industrial.

Ninguna mujer arquitecta, ninguna consideración a las experiencias, los deseos o necesidades de las mujeres, ningún reconocimiento a sus derechos, sólo invisibilización en el mejor de los casos o la usurpación de su identidad en casos como en la cita de Filarete en la que la capacidad de concebir se traspasa al hombre arquitecto varón.

Las excepciones a esta omnipresencia de varones arquitectos, existieron ya en el cartesiano siglo XVII: Plautilla Bricci, que ejerció y se la recuerda como hermana del arquitecto romano Basilio. Esta vinculación y el hecho de estar a la sombra de los hombres de su entorno familiar serán constantes entre las excepciones mencionadas de mujeres arquitectas hasta bien entrado el siglo XX. Tras este caso de Plautilla Bricci no volveremos a encontrar nombres de mujeres en la historiografía de la arquitectura hasta finales del siglo XIX. Algunas pasarán a la historia por su relevancia como interioristas, otras por ser las primeras en acceder a las instituciones educativas. Su mérito será ensombrecido casi siempre por el brillo de su padre, hermano o esposo arquitecto, entre cuyos méritos no es el menor el de disfrutar de privilegios sociales debidos a su clase social y a su sexo, como en los inicios de la Antigüedad Clásica, como en el Renacimiento, como en las primeras vanguardias, como hoy en el star system.

Pero sigamos con esa historia androcéntrica, vacía de mujeres. La revolución industrial favorece la emergencia de una arquitectura en hierro, cristal y hormigón, como el Cristal Palace de Londres que albergó la primera exposición universal de diseño industrial (1887), la Torre Eiffel construida en París para la exposición universal de 1889 o la de Tatlin (1919) destinada a sede de la Internacional Comunista en Moscú. El modernismo intentará romper con ese estilo lineal y frío aportando su estilo naturalista orgánico, aunque aprovechando los nuevos materiales, que mezclará casi artesanalmente con los materiales nobles tradicionales. El arquitecto controlará todo el proceso, desde el diseño de 
los objetos y muebles, pasando por el diseño de interiores hasta el proyecto propiamente arquitectónico, coherente con el resto del trabajo en el interior. Ya hemos visto antes que no será un trabajo tan en solitario, pues esos interiores serán responsabilidad en muchas ocasiones de esas primeras mujeres, a las que sólo se les dejará ese espacio profesional en su intento de aproximarse a la arquitectura (Novas, 2014: 20-23).

Pero la transición modernista durará poco, el funcionalismo del Movimiento Moderno romperá con todos los estilos, historicistas o innovadores, aunque mantendrá los cánones de las proporciones.

Tras la Primera Guerra mundial, confluyeron varios factores: la necesidad de reconvertir la industria armamentística -y los avances tecnológicos acaecidos como consecuencia de la guerra- en una industria para los tiempos de paz, por ejemplo en industria de la construcción; la conveniencia de utilizar los nuevos materiales descubiertos entre el final del siglo XIX y principios del XX -hierro fundido, cristal y hormigón armado- la antigua necesidad de viviendas populares, exacerbada ahora y la disponibilidad de suelo edificable, como consecuencia de la destrucción ocasionada por la guerra. Esta confluencia de factores llevó a arquitectos como Mies Van der Rohe, Gropius y Le Corbusier a divorciarse de la tradición clásica de los órdenes arquitectónicos y a crear una nueva arquitectura: el Movimiento Moderno, la Nueva Construcción, el funcionalismo, más allá del mero racionalismo.

Por otro lado, mientras los hombres estuvieron en el frente, las mujeres ocuparon sus lugares en fábricas, talleres y estudios. También en arquitectura. Así se incorporaron las pioneras al Movimiento Moderno. Una nueva arquitectura cuyo referente principal fue la Bauhaus, fundada en el año 1919 por Gropius quien, a pesar de abrir las puertas de la escuela a las mujeres, se las cerró a los talleres de arquitectura; fue así como la mayoría de ellas se inscribieron en talleres de diseño como el textil.

Ante una Europa arrasada, ése era el espíritu con que varios arquitectos, y como veremos, también arquitectas, ven la oportunidad y abordan la tarea de construir muchas viviendas en poco tiempo y con poco gasto para dar alojamiento a las gentes que llevan décadas viviendo en las cassernes y que, 
además, ahora han quedado desahuciadas por tanta devastación, erigiéndose así en continuadores de los proyectos de vivienda popular preexistentes en América, Europa central y Europa del este. También ven la oportunidad de dar un aprovechamiento de posguerra a la industria armamentística. Así surge el proyecto de la producción de viviendas en serie de Le Corbusier, ligado a la industria de aeronaves. En su obra Hacia una arquitectura escribió:

[...] se han producido en las fábricas tantos cañones, aviones, camiones y vagones, uno se dice ¿No se podrían fabricar casas? [...] la casa ya no será esa cosa pesada y que pretende desafiar los siglos, el objeto opulento por el cual se manifiesta la riqueza, será una herramienta, como lo es el auto. (Le Corbusier, 1923: 197)

Esta frase que condensa la idea corbuseriana de la casa como una máquina para vivir, parece un faro que guiará los experimentos arquitectónicos durante todo el siglo XX y los comienzos de este siglo.

El sesgo de género de la producción teórica y práctica de esta arquitectura se verá a lo largo de este texto. Baste decir ahora que un discípulo de Gropius en la Bauhaus, Ernst Neufert - un mitlaufer (adepto colaborador o simpatizante) que permaneció al servicio del Tercer Reich, ocupando cargos relevantes en la Escuela de Arquitectura de Weimar durante la guerra- es el autor de El arte de proyectar en arquitectura, un libro eminentemente visual que se ha convertido en una especie de enciclopedia técnica para todos los estamentos relacionados con la industria de la construcción, y cuyo androcentrismo queda patente en imágenes como la número 2 de este texto.

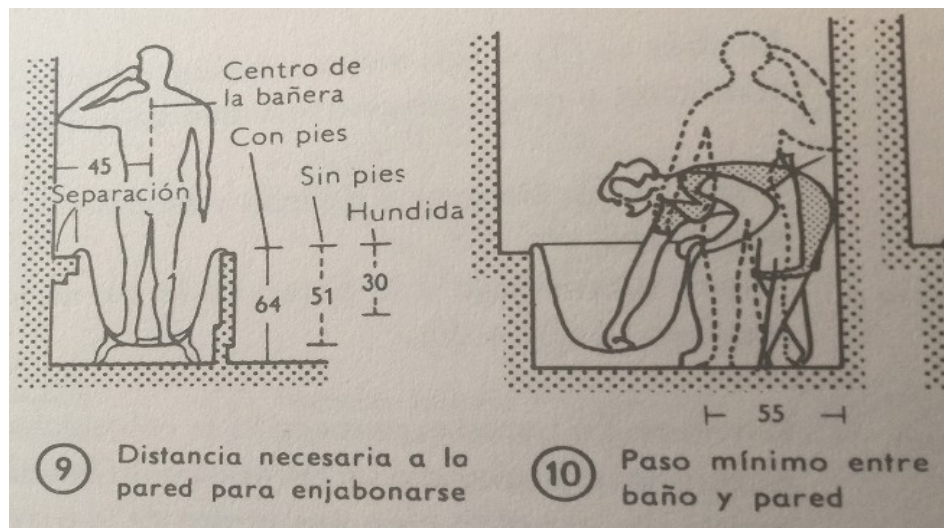

2. Ernst Neufert. Ilustraciones androcéntricas y esterotipadas en el libro El arte de proyectar en arquitectura, 1991. 
La producción de viviendas en serie abría la esperanza de resolver el problema de habitación a las clases populares pero era necesaria una voluntad política para financiarla. Por eso, aunque se hicieron intentos en casi todos los países europeos, sólo cabe remarcar algunos logros como el proyecto de la Nueva Frankfurt (1925-1930) en Alemania, el de vivienda popular en Austria durante el periodo de la Viena Roja (1923-1933) y el proyecto colectivista Narkomfin (1928-1932) en Rusia.

Del artículo «La vivienda popular en el movimiento Moderno» escrito por Auke van der Wonde, extraeremos algunas ideas al respecto. Desde 1875, dos procesos se dieron simultáneamente: la revolución industrial en el sector de la construcción y el aumento de la demanda de vivienda. Estas circunstancias impulsaron a los arquitectos modernos a reorientar su trabajo profesional. En 1927, en Sttutgart, se celebró una exposición con dos ejes directores: una nueva forma de construir y una nueva forma de vivir, pero la realización de dicho proyecto tuvo lugar en Franckfurt: donde Ernst May y un equipo de arquitectos entre los que se encontraba Grete Schutte-Lihotzky, construyeron 25 colonias bajo la estandarización más radical. Las 11-12000 viviendas así construidas surgieron de 13 tipos y 8 variantes. La vivienda mínima tenía $37 \mathrm{~m}^{2}$, en alguas viviendas había muebles empotrados, incluso una cocina estándar, diseñada por Grete, pensada para aliviar el trabajo doméstico del ama de casa. Eran viviendas populares, contemplaban un igualitarismo para la clase obrera, pero no para los géneros. Sólo cuando la crisis del 29 hizo emigrar a los arquitectos alemanes a Rusia, que se hallaba en pleno desarrollo de sus planes quinquenales, se diseñaron viviendas colectivas en las que cocina, comedor, lavandería o guardería, eran comunitarias, tal como anunció Alexandra Kollontai:

En la Rusia Soviética, la vida de la mujer trabajadora debe estar rodeada de las mismas comodidades, la misma limpieza, la misma higiene, la misma belleza, que hasta ahora constituía el ambiente de las mujeres pertenecientes a las clases adineradas. En una Sociedad Comunista la mujer trabajadora no tendrá que pasar sus escasas horas de descanso en la cocina, porque en la Sociedad Comunista 
existirán restaurantes públicos y cocinas centrales en los que podrá ir a comer todo el mundo.

Estos establecimientos han ido en aumento en todos los países, incluso dentro del régimen capitalista. En realidad, se puede decir que desde hace medio siglo aumentan de día en día en todas las ciudades de Europa; crecen como las setas después de la lluvia otoñal. Pero mientras en un sistema capitalista sólo gentes con bolsas bien repletas pueden permitirse el gusto de comer en los restaurantes, en una ciudad comunista estarán al alcance de todo el mundo.

Lo mismo se puede decir del lavado de la ropa y demás trabajos caseros. La mujer trabajadora no tendrá que ahogarse en un océano de porquería ni estropearse la vista remendando y cosiendo la ropa por las noches. No tendrá más que llevarla cada semana a los lavaderos centrales para ir a buscarla después lavada y planchada. De este modo tendrá la mujer trabajadora una preocupación menos.

La organización de talleres especiales para repasar y remendar la ropa ofrecerán a la mujer trabajadora la oportunidad de dedicarse por las noches a lecturas instructivas, a distracciones saludables, en vez de pasarlas como hasta ahora en tareas agotadoras.

Por tanto, vemos que las cuatro últimas tareas domésticas que todavía pesan sobre la mujer de nuestros tiempos desaparecerán con el triunfo del régimen comunista.

No tendrá de qué quejarse la mujer obrera, porque la Sociedad Comunista habrá terminado con el yugo doméstico de la mujer para hacer su vida más alegre, más rica, más libre y más completa. (Kollontai, 1918: 10).

Un $25 \%$ de viviendas fueron construidas según este modelo. Pero las arquitectas alemanas progresistas y sus compañeros arquitectos tuvieron poco respiro, si en 1930 fueron expulsados de Alemania bajo la acusación de bolcheviques, en 1932 tuvieron que abandonar Rusia bajo la acusación de funcionalistas capitalistas. (Van der Wonde, 1999: 5-18). Durante la misma década fueron construidas las viviendas sociales de la Viena Roja: 


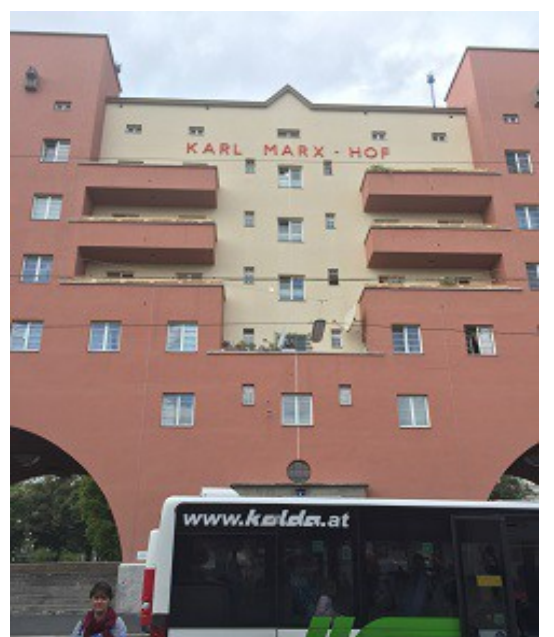

3.Hoff en La Viena Roja. Fotografía de la autora, 2015.

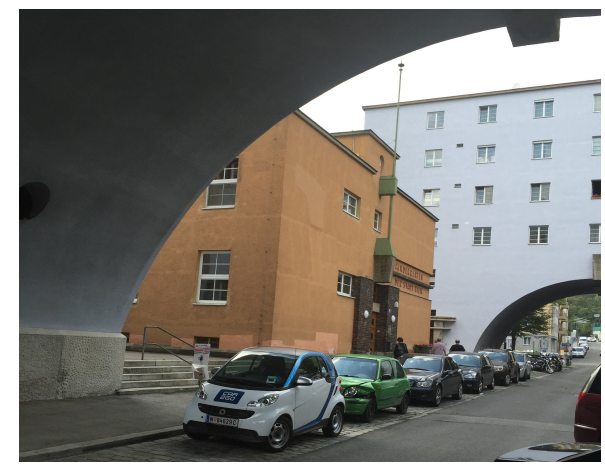

6. Hoff en La Viena Roja. Fotografía de la autora, 2015.

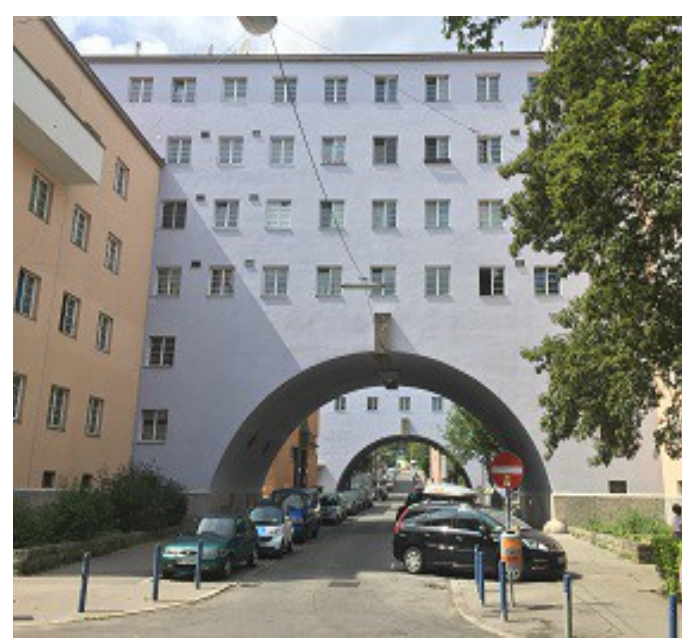

4. Hoff en La Viena Roja. Fotografía de la autora, 2015.

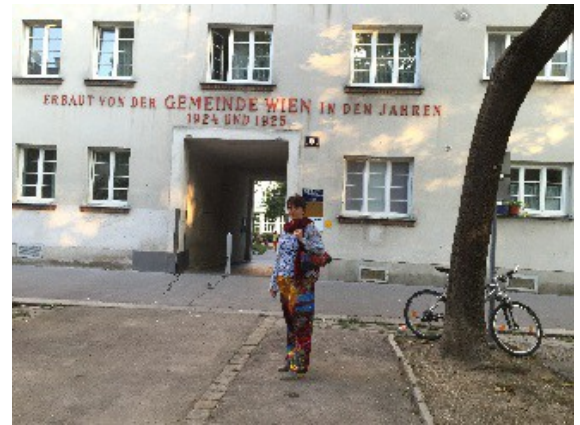

5. Hoff en La Viena Roja. Fotografía de la autora, 2015.

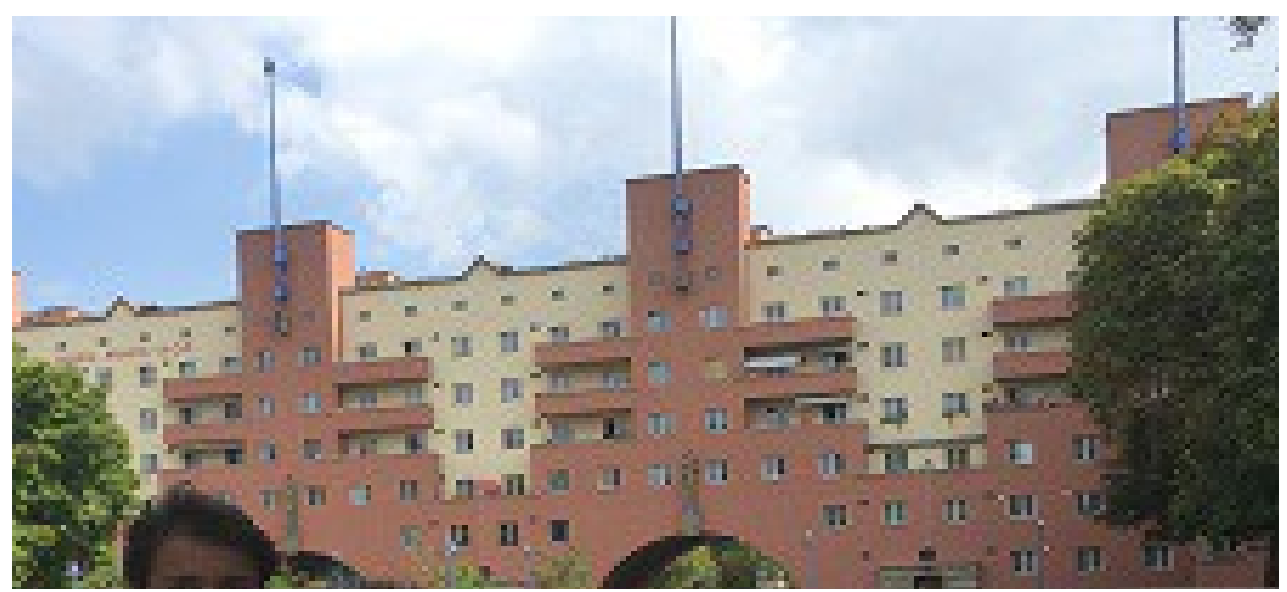

7. Hoff en La Viena Roja. Fotografía de la autora, 2015. 


\section{En las que destacan sus servicios colectivos:}

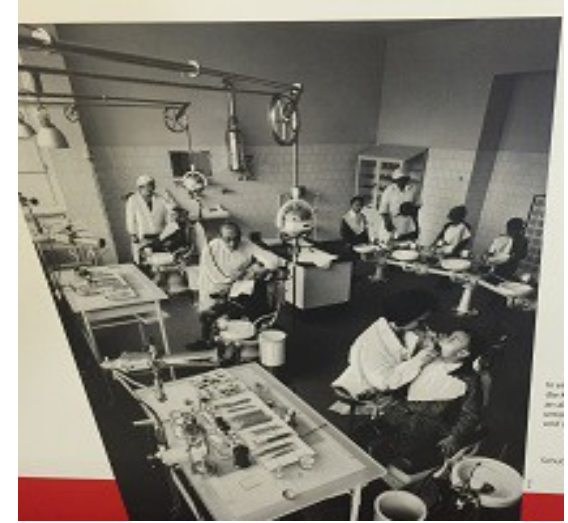

8. Exposición en el recinto de la lavandería de la Karl-Marx Hoff en La Viena Roja. Fotografía de la autora, 2015.

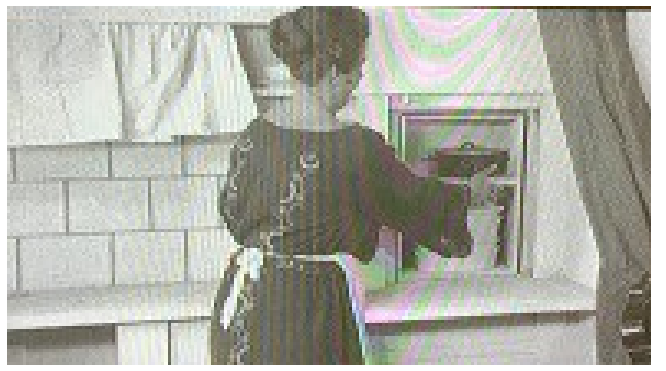

11. Exposición en el recinto de la lavandería de la Karl-Marx Hoff en La Viena Roja. Fotografía de la autora, 2015

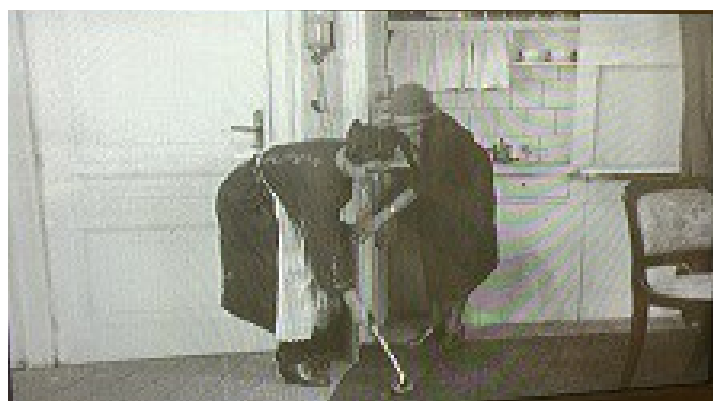

13. Exposición en el recinto de la lavandería de la Karl-Marx Hoff en La Viena Roja. Fotografía de la autora, 2015.

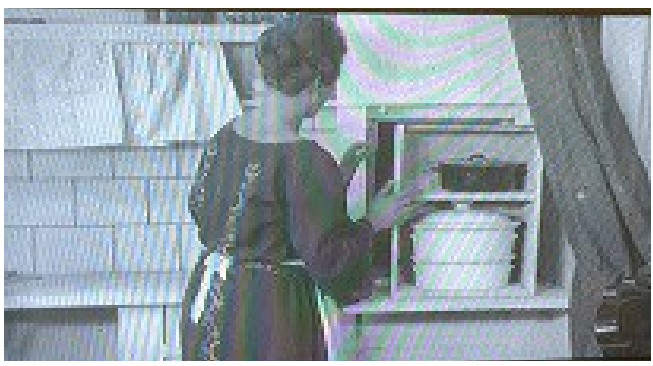

9. Exposición en el recinto de la lavandería de la Karl-Marx Hoff en La Viena Roja. Fotografía de la autora, 2015.

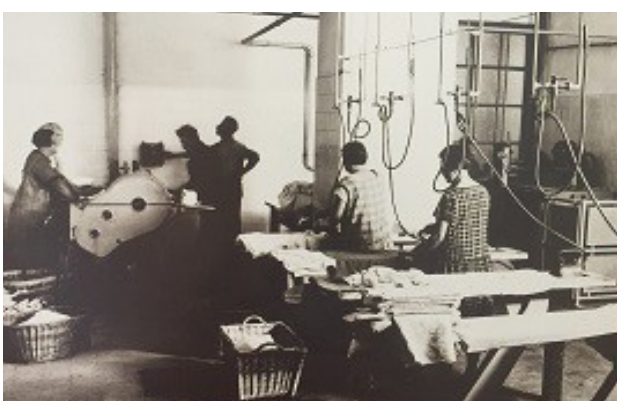

10. Exposición en el recinto de la lavandería de la Karl-Marx Hoff en La Viena Roja. Fotografía de la autora, 2015.

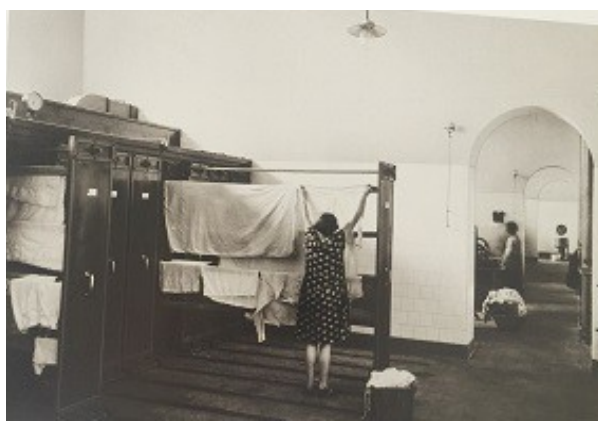

12. Exposición en el recinto de la lavandería de la Karl-Marx Hoff en La Viena Roja. Fotografía de la autora, 2015. 
Las clases trabajadoras seguirán concentradas en las viviendas sociales, hasta que la irrupción del neoliberalismo las dispersará. El modelo colectivista de la Viena Roja simbolizará el deseo de proporcionar a la mujer de la clase obrera no sólo una vivienda mínima sino una vida digna. Más de cinco décadas después de la proyección, ejecución y declive de estos proyectos vieneses de vivienda popular con servicios comunitarios, las arquitectas feministas occidentales, retomaron el modelo colectivista.

Posteriormente la guerra fría enfrentaba el modelo colectivista ruso con el consumista americano. Multitud de experimentos se desarrollan en Estados Unidos, a donde han ido a parar los arquitectos emigrantes. Desde la casa como un coche al coche habitable se llega a la vivienda en movimiento a través de múltiples proyectos, la mayoría de los cuales no alcanzarán la fase de ejecución, salvo la caravana y la autocaravana que conocerán una gran expansión, primero como objeto de lujo de las clases medias más acomodadas y luego como vivienda de sectores nómadas de la población. Otros experimentos serán la casa cápsula, la casa electrodoméstico o la casa traje, todos paralizados en la fase experimental, aunque cada uno de ellos ha abierto nuevos caminos para resolver los problemas de la nueva vivienda en una sociedad consumista cuyo estilo de vida es el de usar y tirar, el del movimiento, el de lo efímero, el cambio permanente, la moda.

Incluso en estas casas experimentales hipermodernas, podemos encontrar tics patriarcales que filtran subrepticiamente el papel de subalterna de la mujer, a través del máximo representante de la Moderna Arquitectura, Le Corbusier:

Nuestras necesidades son necesidades de hombres [...] Si somos quince en el pequeño salón de la pequeña casa, que han venido decididos a no hacer nada, el ama de casa ha sacado de dentro del armario empotrado los quince taburetes, encajados uno en otro. (Le Corbusier, 1999: 142)

Hoy la mayoría de las mujeres del mundo occidental acomodado conducen, sin embargo, una estadística sencilla nos muestra que las caravanas y autocaravanas, como los vehículos pesados, son conducidas por varones. Según el censo de la Dirección General de tráfico, en 2013 obtuvieron el carnet 
$\mathrm{B}, \mathrm{B}+\mathrm{E}, \mathrm{A}$ ○ $\mathrm{A} 24.825$ mujeres, frente a 391.350 varones. La caravana es una máquina, como lo es el coche y ellos tienen asignado socialmente el rol de «mecánicos» del hogar. Si el propio hogar es una máquina pesada, las tareas domésticas quedan asignadas por exclusión, ellos son quienes pueden conducirla por su tamaño, quienes entienden su mecánica, quienes la utilizan como signo de riqueza. Ellas se ocuparán de las tareas domésticas, en cocinas diminutas, dormitorios incómodos, aseos con limitadas condiciones de higiene, todo soportable cuando su uso es vacacional, pero absolutamente precario cuando la casa rodante se ha convertido en vivienda habitual. Esta cuestión queda clarificada si se usa el concepto de escenario de género inscrito en los objetos, en el sentido de la interacción entre género y objeto.

La notion de scénario (de genre) souligne l'existence de deux procesus en jeu dans le façonement réciproque du genre et des objects technologiques. Tout d'abord, un object peut devenir sexué si ses créateurs anticipent les préférences, les motivations, les goûts et les compétences des utilisateurs potenciels, ainsi que les normes culturelles de la société dans son ensemble. De telles anticipations se matérialisent ensuite dans la conception technologique du nouveau produit. En second lieu, les objects dotés d'un scénario de genre peuvent façoner et définir les actions des femmes et des hommes. En raison des normes et des valeurs inscrites dans un object technique, le dit object peut atribuer et conférer des rôles, des actions et des responsabilités spécifiques à leurs uilisateurs. ${ }^{3}$ (Oudshoorn, 2009: 306)

Los datos de la DGT nos hablan claramente de cual es el escenario de género de un tipo particular de objetos tecnológicos, los vehículos a motor. Muchos otros objetos tecnológicos serán producidos en esta época con distintas adscripciones de género, los electrodomésticos en particular. Las autoras de la

3. El concepto de escenario (de género) subraya la existencia de dos procesos en juego en la configuración mutua del género y los objetos tecnológicos. En primer lugar, un objeto puede convertirse en sexuado si sus creadores anticipan preferencias, motivaciones, gustos y habilidades de las personas usuarias potenciales, así como las normas culturales de la sociedad en su conjunto. Tales expectativas se materializan más adelante en el diseño tecnológico del nuevo producto. En segundo lugar, los objetos tienen inscrito un escenario de género que puede crear la ventaja competitiva y definir las acciones de las mujeres y los hombres. Debido a las normas y valores consagrados en un objeto técnico, dicho objeto puede atribuir y conferir funciones, acciones y responsabilidades específicas a sus usuarios. (Traducción propia) 
cita anterior, analizan la exposición Objects $\mathrm{f} / \mathrm{m}$. Le design sexué des objects de la vie quotidienne, que tuvo lugar en la Universidad de Twente en 1996 y en el museo New Metropolis de Amsterdam en 1997, y, por un lado, confrontan los diseños de un microondas con una cadena hi-fi; y, por otro, dos modelos de rasuradora, la Ladyshave y la Philishave, para mujer y hombre respectivamente. Sobre la segunda de las comparaciones observan:

Tout d'abord, d'enormes differences de représentation des utilissateurs masculins et féminins sont inscrites dans ces objects. La femme est représentée comme un utilisateur qui préfère les couleurs pastel et les formes arrondies, en cherche pas à tripoter des objects technologiques, en s'interesse pas aux gadgets et préfère rester chez elle. Par opposition, l'homme est représenté comme un utilisateur qui préfère les couleurs sombres et les formes anguleuses, aime jouer avec des objects technologiques, adore les gadgets et mène une vie nomade. ${ }^{4}$ (Oudshoorn, 2009: 306)

Los visitantes de la exposición, en la que también había bicicletas, ordenadores, videojuegos, perfumes, rellenaron un cuestionario y la mayoría de ellos concluyó que los objetos expuestos poseen, de una forma determinada, un género.

Las casas experimento, fueron, ellas mismas, objetos tecnológicos y, como veremos, mantienen inscritos escenarios de género. En cuanto a las mujeres que intervinieron en estos experimentos, fueron captadas desde el mundo del diseño y el interiorismo y sus nombres van acompañados por el de sus maridos con el único apellido de éstos que, por las leyes de familia vigentes, es el que sustituye al propio en la mayor parte de países del Norte. Es decir, fueron eclipsadas en lo civil y en lo profesional.

Mientras tanto, en las casas experimentales seguían copiando los procedimientos constructivos de la industria de guerra e iban a ser destinadas a

4. En primer lugar, en estos objetos están inscritas las enormes diferencias en la representación de usuarios masculinos y femeninos. Las mujeres están representadas como usuarias que prefieren los colores pastel y las formas redondeadas, que no buscan relacionarse con los objetos tecnológicos, no les interesan los aparatos y prefieren quedarse en casa. Por el contrario, el hombre es representado como un usuario que prefiere los colores oscuros y formas angulares, le gusta jugar con objetos tecnológicos, ama los aparatos y lleva una vida nómada. (Traducción propia) 
configurar la identidad de las nuevas familias consumidoras. Casi a un tiempo se expandió el modelo arquitectónico-mediático Playboy que configuró la identidad del nuevo varón consumidor de placeres y su contraparte, la mujer sexi, al estilo Marilyn, según la investigación que desarrolla Beatriz Preciado en su libro Pornotopía: arquitectura y sexualidad en Playboy durante la guerra fría.

En plena guerra fría, el joven Hug Hefner crea la que pronto se convertirá en la revista para adultos más vendida del mundo: Playboy. Lo que el público desconoce es su pionera labor como artífice de las casas del placer. Playboy no era simplemente una revista de chicas con o sin bikini, sino un vasto proyecto arquitectónico-mediático que tenía como objetivo desplazar la casa heterosexual como núcleo de consumo y reproducción proponiendo frente a ésta nuevos espacios destinados a la producción de placer y capital. Ésta podría ser la divisa de Playboy: si quieres cambiar a un hombre, modifica su apartamento. De la misma manera que la sociedad ilustrada creyó que la celda individual podía ser el enclave de reconstrucción del alma criminal, Playboy confió a la mansión de soltero la fabricación del nuevo hombre moderno. (Preciado, 2010, 413)

Esto son claros ejemplos de que el espacio habitado sí define, según nuestra sociedad, el proceso de construcción de la propia identidad.

\subsection{En los espacios}

\subsubsection{Espacios}

Para ser fieles al título de este trabajo, es necesario hablar de espacios, de espacios interiores y relacionarlos con la construcción de las identidades de las mujeres que los habitan.

Antes de construir el espacio está el vacío. El vacío es ordenado por los espacios que construimos y nos construyen. Nuestras existencias están ligadas a nuestros espacios dinámicos. Todo lo que hacemos, experimentamos o soportamos ocurre en algún momento en algún lugar. Construimos nuestros espacios según nuestro concepto del mundo, según el sentido que en cada momento tiene nuestra vida y, así, quedan ligados nuestro tiempo y nuestros espacios, nuestra historia que nos da identidad. 
La arquitectura y el urbanismo son los responsables de la ordenación de esos espacios, interior y exterior respectiva y solidariamente, pues el exterior, competencia del urbanismo, queda definido cuando se construyen los edificios que albergarán los interiores, competencia de la arquitectura que, a su vez, se ha dividido tradicionalmente en arquitectura pública, monumental, institucional o estrictamente arquitectura a secas para algunos autores- $y$ arquitectura de la casa privada o doméstica que tiene dos ejes de actuación: la construcción de casas unifamiliares propias de las clases altas y la construcción de viviendas populares.

Así como la línea divisoria entre interior y exterior no es nítida, la aparente antítesis entre privado y público es interpretada desde distintos enfoques, se complica al interferir con ella otras dualidades $y$, además, se mueve continuamente en el tiempo dificultando la fijación de los dos términos. Según Teyssot no se trata de dos tesis simétricas y opuestas:

Público contra privado. Una oposición nunca es la confrontación de dos términos, sino la institución de una jerarquía que establece un orden de subordinación. Así queda bien claro que en el pensamiento político de la llustración el segundo término de las oposiciones [...] derivada de toda la metaforología que opone lo inteligible a lo sensible, se obtienen las sucesivas: intelecto/sentimiento, juicio/imaginación, unidad/variedad, utilidad/deleite $y$, finalmente severidad/elegancia, gravedad y ligereza, [...] la estética inglesa le añadirá la oposición entre lo sublime y lo pintoresco. Si en la lista que hemos apuntado se intenta separar el segundo término de cada una de las oposiciones, se obtendrán las cualidades más o menos características de la «arquitectura privada» [...] Las oposiciones entre los dos términos se complican cuando interfieren con otras antítesis, como las de lo colectivo y lo individual, o lo espectacular y lo íntimo. En efecto, una casa individual y privada se puede organizar de un modo espectacular para quedar abierta a la representación social (un palacio principesco, por ejemplo); o bien colocarse en una estructura residencial colectiva (un apartamento en régimen de propiedad horizontal) o en una estructura individual (una casita en la periferia). (Teyssot, 1988: 9) 
Si en el texto de Teyssot se analiza la relación entre público y privado, Murillo incluye en su análisis el concepto doméstico desde el punto de vista de género, analiza los conceptos de público, privado y doméstico a lo largo de determinados procesos históricos. Volviendo al análisis previo a los planteamientos de género, reconociendo que los conceptos público y privado han ido cambiando de sentido según el contexto histórico. En los siglos $X V$ y $\mathrm{XVI}$, anteriores a la llustración, según el Diccionario Oxford, entendían que private derivado del latín privare (quitar a alguien algo, despojar) era la forma de aludir a «quien no ocupa ni un cargo público ni un puesto oficial».

A este respecto, la reflexión de Georges Bataille sobre la esencia originariamente pública de la arquitectura nos ofrece un buen ejemplo de deconstrucción y de cambio de las categorías. En la voz «arquitectura» del Dictionnaire critique, escribe: «La arquitectura es la expresión del ser mismo de la sociedad, al igual que la fisonomía humana es la expresión del ser de los individuos. Sin embargo, dicho parangón debe relacionarse sobre todo con fisonomías de personajes oficiales (prelados, magistrados, almirantes, etc.). En efecto, sólo el ser social ideal, ese que ordena y prohíbe con autoridad, es el que se expresa en las composiciones arquitectónicas propiamente dichas». [...] Parece entonces que el espacio geométrico de los urbanistas y de los arquitectos funciona como el sentido estricto, construido por los gramáticos y por los lingüistas con el objeto de disponer de un nivel normal y normativo al que referir las desviaciones del sentido figurado. (Teyssot, 1988: 10)

Los siglos XVII y XVIII trajeron importantes cambios en lo referente al espacio público que influyeron en la aparición de un nuevo sentido de espacio privado:

[...] la descomposición del orden feudal a favor de la participación en la soberanía popular. Demasiadas tensiones, como para no contar con un espacio donde guarecerse: el espacio privado. Ambos espacios serán pensados para un sujeto masculino exento de atributos naturales (ingrediente básico del ámbito doméstico). Inmerso en un mundo complejo y azaroso, observaremos a un individuo que, una vez replegado en su privacidad, podrá volver a la escena política como un sujeto con plenos derechos. (Murillo, 1996: 1) 
En el siglo XIX se produjo la devaluación de lo doméstico, lo no retribuido.

Nuestro viaje proseguirá, en orden cronológico, en el siglo XIX: aquí el acontecimiento se inscribe en territorio inglés, donde la Revolución Industrial será testigo de la separación de la producción doméstica y la esfera mercantil. En virtud de esta frontera se gestará un poderoso concepto: actividad-inactividad. El trabajo sólo será vinculado a la producción, y así la retribución monetaria es el único signo de valor: sólo es trabajo aquello que se retribuye. (Murillo, 1996: 1)

Tras el análisis histórico, Soledad Murillo, en su obra El mito de la vida privada. De la entrega del tiempo propio, confronta la dicotomía público/privado que se ha asignado históricamente a masculino/femenino con el término doméstico. Desdobla el concepto de privacidad en dos acepciones con significados muy diferentes: una de ellas -la comúnmente aceptada por la literatura- habla de la apropiación de sí mismo, la retirada voluntaria y puntual de un espacio público, para beneficiarse de un tiempo propio, lo cual requiere no sólo de un tiempo sino también de un espacio propio; la otra acepción de privacidad-expresada por las mujeres de su investigación como experiencia vivida- es la de privación (de sí) y se identifica con el ámbito doméstico traducido en una presencia continuada y atenta a los asuntos de los otros, lo cual requiere ausencia de tiempo y espacio propios, aunque su presencia esté directa o indirectamente en todos los espacios y tiempos de los otros.

La «vida privada» ha registrado dos tratamientos muy divergentes en función de la privacidad de la que se hable. El primero, desde una perspectiva masculina, se refiere al que tiene que ver con el recogimiento del varón en la vida familiar, pero al margen de obligaciones y prestaciones públicas. Un segundo tratamiento se desarrolla en el hogar, con la familia y las necesidades que ésta genere. Aquí se carece del sentido positivo de lo propio y el sujeto se especializa en la cobertura de lo ajeno.[...]

En la primera concepción, la privacidad es un valor positivo, una forma de distanciamiento del afuera para conquistar el bienestar que procura el privilegio de la reserva. En cambio, el término privado -en femenino- carece de este valor [...] se convierte en un conjunto de 
prácticas que tienden al desprendimiento de sí, más próximas al dominio de la domesticidad. Privado-doméstico, de compartir alguna similitud sería el aislamiento con respecto a la mirada ajena, al vigilante espacio público. Aunque en la primera instancia siempre medie la voluntad, mientras que, en la segunda acepción, la reclusión del exterior está más emparentada con el mantenimiento de la virtud que con el descanso de la norma. (Murillo, 1996: XVII)

En plena globalización, aparece una nueva imagen de lo privado, los intereses privados campan como la idea más propicia para asegurar el orden social. Incluso podemos leer cómo la oposición puede considerarse disuelta por ocupación de lo privado por lo público:

Es probable, por tanto, que el bastión de lo privado, lo íntimo y lo doméstico, no sea ya una zona de refugio y de protección que se alza para defendernos de la esfera pública (¿lo ha sido alguna vez, salvo en la mente y en los interiores Biedermeier de algunos burgueses un poco kitsch?), sino que haya sido fagocitado por la mirada voraz de los numerosos expertos que, desde la segunda mitad del siglo XIX, comienzan a querer proyectar la casa de todos: médicos, higienistas, criminólogos, reformadores, ingenieros, arquitectos, decoradores, mueblistas, jueces, asistentes sociales, economistas, sociólogos, psicólogos, psiquiatras, etc. Toda una comparsa repleta de portadores de saberes $-\mathrm{y}$, por tanto, de poderes- que asaltan con armas $y$ equipos el umbral de la vivienda, y que destilan los humores privados al fuego de un centenar de ciencias. (Teyssot, 1988: 11)

A pesar de todo ello y de las metamorfosis sufridas a lo largo de la historia, se puede constatar que hoy el interior-privado, cuando existe, sigue siendo propio del varón, según los cambiantes cánones patriarcales, es su lugar de reposo y de atención a sus asuntos particulares. La mujer, en el interior no tiene espacio privado, lo habita pero no se lo apropia, lo cuida, pero no para ella. Otros espacios interiores privados podemos encontrarlos en los edificios públicos como restaurantes, clubes -en los que se hace posible una privacidad distinta, una privacidad grupal-, iglesia -donde las mujeres han encontrado frecuentemente su lugar de reposo-, etc. 
Para proseguir con esta «redefinición» de los términos, paso a enunciar los cuatro nuevos modos de citar el espacio que voy a seguir: interior-doméstico, interior-público, exterior-público y exterior-doméstico.

El interior-doméstico es el espacio propio de la mujer definida por el patriarcado, de diversos modos y en diferentes momentos de la historia, como el ama de casa, cuidadora, madre y femenina esposa, indisolublemente unida a su hogar, bien fuera la granja modelo de Jefferson a finales de la década de 1780 , bien fuera la casa suburbana de Catharine Beecher de 1869, en la que la mujer americana era descrita como «ministra del hogar», o la vivienda digna de Veiller y Nolan de finales de la I Guerra Mundial. Después de la II Guerra Mundial la vivienda digna se convirtió en la casa de ensueño que

[...] sustituyó a la ciudad ideal como representación espacial de las esperanzas americanas acerca de la vida feliz. No sólo triunfó sobre la ciudad modelo, sino que prevaleció sobre otros dos tipos de viviendas: uno basado en el ideal del aprovechamiento eficaz de los recursos escasos; y otro inspirado en el ideal de la barriada modelo. (Hayden, 1988: 37)

Al sustituir la ciudad ideal por la casa de ensueño, el modelo social propuesto a las mujeres las invitaba a imaginar una vida feliz. Pero en realidad, en esa casa de ensueño, la mujer que la habita prestando sus servicios, es la doméstica, la sirvienta para todo y para toda la vida, según la sociedad bien pensante, tal como se desprende de la siguiente tabla del Instituto de la Mujer, anterior a la crisis de 2008 y, por tanto, menos sesgada de lo que cabe esperar en la actualidad. 


\begin{tabular}{lcccc}
\hline $\begin{array}{l}\text { Tabla 2. Evolución del tiempo medio dedicado a actividades } \\
\text { domésticas por la población según el sexo (h y min diarios) } \\
\text { (España, 1993, 1996 y 2001) }\end{array}$ \\
\hline Actividades & Año de estudio & Hombres & Mujeres & Total \\
\hline Trabajo de casa & 1993 & 0,28 & 4,46 & 2,42 \\
& 1996 & 0,37 & 4,24 & 2,34 \\
Cuidado de hijos & 2001 & 0,44 & 3,58 & 2,23 \\
& 1993 & 0,35 & 1,32 & 1,05 \\
Cuidado de adultos & 1996 & 0,46 & 1,23 & 1,05 \\
& 2001 & 0,43 & 1,33 & 1,08 \\
Mantenimiento y gestión & 1993 & 0,07 & 0,10 & 0,08 \\
de servicios & 1996 & 0,07 & 0,16 & 0,11 \\
& 2001 & 0,08 & 0,19 & 0,13 \\
Compras & 1993 & 0,59 & 0,43 & 0,50 \\
& 1996 & 1,08 & 0,41 & 0,55 \\
& 2001 & 1,08 & 0,40 & 0,54 \\
Total trabajo doméstico & 1993 & 0,14 & 0,39 & 0,26 \\
& 1996 & 0,22 & 0,33 & 0,27 \\
& 2001 & 0,19 & 0,46 & 0,31 \\
& 1993 & 2,30 & 7,56 & 5,20 \\
& 1996 & 3,05 & 7,35 & 5,25 \\
& 2001 & 3,10 & 7,22 & 5,18 \\
\hline
\end{tabular}

Fuente: Instituto de la Mujer ${ }^{8}$.

14. Tabla evolución del tiempo medio en actividades domésticas. Fuente: Instituto de la Mujer, 1993,1996 y 2001.

No menos clarificadores resultan los gráficos publicados por el periódico digital eldiario.es el 12 de enero de 2015 para los que utilizaron una muestra de parejas heterosexuales con hijos de 0-18 años. Encuesta española de uso del tiempo (2003-2010).

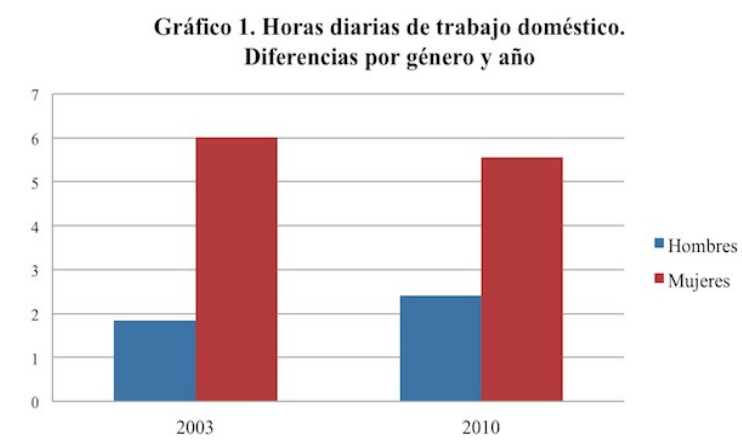

15. Horas trabajo doméstico. Fuente: El diario.es, 2015. 
Gráfico 2. Horas diarias de trabajo doméstico.

Diferencias por género y modelo laboral de pareja

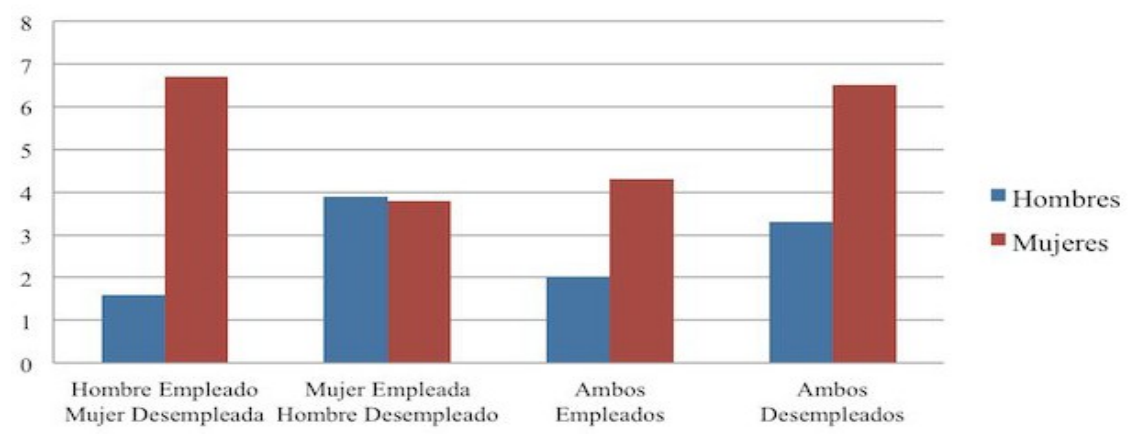

16. Horas trabajo doméstico. Fuente: El diario.es, 2015.

El interior-público es el interior de los edificios donde se realizan las tareas económicas, laborales, políticas, administrativas, y aquel interior-privado, ubicado en la morada, que cede su privacidad a tareas laborales de promoción, formación o prolongación de la jornada laboral.

En el caso de los varones, y por ejercer un dominio sobre su tiempo libre, la lógica laboral establece una relación de contigüidad con el espacio privado, lo rentabiliza como lugar de formación y reciclaje [...] A pesar de este «vampirismo», el varón obtendrá mayor solidez en el mercado de trabajo. (Murillo, 1996: XIX)

El exterior-público, es el espacio donde se ubican los interiores públicos antes mencionados y donde tienen lugar actividades y eventos colectivos.

Y el exterior-doméstico es ese espacio exterior que necesariamente se utiliza para desarrollar las tareas domésticas relacionadas con el exterior: resolución de asuntos burocráticos, asistencia a centros médicos, centros educativos o de servicios sociales y que tiene asignadas socialmente la mujer.

Así pues interior y privado o exterior y público no son acotaciones que agoten las funciones estereotipadas asignadas a ambos géneros.

Virginia Woolf, en su novela Una habitación propia reclama para la mujer un interior privado donde pueda reflexionar, pensar, crear -con lo que reconoce que el espacio doméstico no es su espacio privado- y las modernas urbanistas 
reclaman en sus proyectos criterios para facilitar la vivencia de los espacios exteriores urbanos a las mujeres en sus tareas domésticas.

El espacio doméstico trasciende el interior de la casa como nos han hecho ver las modernas urbanistas y la naturaleza de la domesticidad trasciende el espacio doméstico. El mandato de género femenino ordena hacerse cargo de las necesidades y deseos ajenos, por encima de los deseos e incluso necesidades de la propia mujer. $\mathrm{Y}$ cuando digo necesidades y deseos ajenos, no me refiero sólo al ámbito de la propia familia nuclear o extensa. Es tan potente y profundo el mandato, moralizante donde los haya, que propicia que las virtudes domésticas sean exigibles por cualquiera, a cualquier mujer que desee ser aceptada socialmente como tal. No se trata únicamente del perfil de mujer casada. Si es soltera, si es una niña o una anciana, si está en su casa o en la ajena, incluso en los lugares públicos, ese mandato es exigente, se les impone y las atrapa.

Otros términos que conviene aclarar son «morar» y «habitar», pues con la acción que indican estos verbos es como el espacio se convierte en morada, en habitación, lo convertimos mientras moramos en él, de igual modo que él es nuestra principal referencia dinámica en la biografía de nuestra identidad, es el marco que la contiene.

El hombre busca la posibilidad de una situación, de un punto fijo al que volver, un espacio de referencia a partir del cual comprender el mundo, un lugar en el que enraizarse, veremos cómo hasta en los fenómenos del habitar nómada se busca este arraigo. (Galmés, 2014: 24)

Pero las dimensiones, la organización de los espacios interiores y exteriores, su decoración, no se relacionan igual con cada uno de sus habitantes.

Sabemos del poder de las convenciones, no se trata de ignorar la precisión modeladora de los comportamientos, pero desde la sociología, menos comprometida en esclarecer los procesos de construcción individual, es oportuno desvelar la fuerza de los mecanismos cotidianos que, inscritos en todo orden social, son 
capaces de proveer de distintos horizontes y formas de ver el mundo a uno y otro género. (Murillo, 1996: XXI)

Las moradas no le devuelven la misma imagen a quien ocupa las estancias privilegiadas y tiene el derecho a exigirlas en perfecto orden e higiene para el disfrute de su privacidad, que la que le devuelven a quien transita todas las estancias para controlar su higiene y su orden y tiene como núcleo emisor de su actividad la zona de servicios de la vivienda: la cocina, el lavadero, el fregadero y el almacén.

Para la mujer del patriarcado, el espacio de la vivienda, de la casa donde vive, no tiene espacios que le sean propios, por lo que no tiene espacio privado, aunque lo habite, aunque entero sea su espacio doméstico, porque lo es en el sentido de prestar o facilitar el servicio doméstico a los moradores de la casa, que, como ella, también la habitan.

Carecer de vida privada no es sólo un matiz, incide en un desigual reparto de oportunidades personales, además de construir identidades con profundas deficiencias para los dos géneros. [...] Bajo estas reglas del juego, la ausencia de privacidad dificulta poderosamente la construcción de la individualidad (añadiré que de autoestima) y provoca una deficitaria posición en el espacio público. (Murillo, 1996: XX)

Así pues, si arquitectos, arquitectas y élites culturales diversas, tienen el poder de construir sus moradas, de morar en ellas y construir sus identidades a un mismo tiempo, ello presupone un plus de poder que permite espejos referenciales poderosos con los que construir las identidades, dialógicas si queremos, pero identidades, no alteridades, un plus de poder del que habla Cristina Molina y sin el cual no es posible descentrar el género. En estos casos se desarrolla una estrategia de segundo nivel, una mascarada, que no responde a la exigencia de un reparto de poder equitativo, sólo escenifica cómo es posible escapar a la marca de género cuando se tiene el poder de hacerlo. Se trata de un pensamiento débil que no resuelve ni pretende resolver el desequilibrio de poder, porque cada cual ya disfruta del suyo gracias a la pertenencia a una clase económica y cultural alta. 
Personalmente, no quisiera limitarme a la estrategia de segundo nivel, prefiero luchar por la de primer nivel, para que cada quien nazca y viva sin marca de género, para que cada cual pueda construir su espacio mientras construye su identidad, para que las alteridades desaparezcan y con ellas los espacios de clausura que habitan y no les son propios, que cuidan y no se les reconoce, en los que invierten su tiempo, todo su tiempo en implementar la buena vida de los demás y ya no les queda tiempo ni tienen espacio para su vida, evidentemente lejana de una buena vida.

En el primer nivel se parte de que el género es un sistema social de poder que se impone como una jerarquía de un sexo sobre otro. Se busca destruir la jerarquía y, consiguientemente, el género. El fin sería una sociedad de individuos sin adscripciones genéricas en los que no se produzca la «marca» de género. Los referentes serían individualizados. Es el ideal de un feminismo nominalista como el que propone Celia Amorós. Para ello se necesita un sujeto-agente fuerte, capaz de articular estrategias de lucha contra el sistema exterior, un sujeto colectivo que se construya, al menos estratégicamente, con miras a las necesidades de lucha y capaz de desmarcarse, consecuentemente, de sus identidades genéricas adscriptas.

En el segundo nivel se parte de que el género es un aparato discursivo que construye prácticas de exclusión, una normativa que marca comportamientos y construye así las identidades genéricas. Aquí el género no tendría más valor que una máscara.

Se busca entonces romper la normativa para lograr la inclusión a través de microprácticas que traspasen las fronteras de lo permitido en cada género. [...] el problema estriba en que en esta búsqueda de la identidad necesitan un orden simbólico que tienen que inventarse de la nada o recurriendo a mitos. Pero la simbólica no es independiente de las relaciones de poder: no simboliza quien quiere sino quien puede. [...] Mientras el horizonte normativo de Celia Amorós, por ejemplo, en sus propuestas sobre la conquista de la individualidad, sería la justicia por medio de la igualdad, el de Butler si pudiera hablarse de normativa sería la libertad a través de las deconstrucciones del deseo. Por eso Butler promueve la transgresión, 
mientras que Celia es partidaria de la vindicación. La una habla en clave estética, la otra en clave ética. (Molina, 2003: 148)

\subsubsection{Morar}

Las pioneras fueron silenciadas pero su concepto de la casa como la concha del caracol, que construye la casa mientras se construye a sí mismo quedó como herencia irrenunciable.

Lo que hemos visto en el punto anterior, es hoy comúnmente aceptado en la teoría y en la práctica arquitectónica: la casa no queda construida hasta que se la apropia quien la habita, con lo que estas personas también se construyen en ese mismo proceso de habitación-construcción de la casa, ya que las representaciones que de sí mismas construyan, no se producen en el vacío, sino insertas en los espacios que habitan.

También hemos visto que esta perspectiva nos ha servido un debate, a saber: ¿son todas las formas de habitar equivalentes? Ya hemos visto en el capítulo anterior que no, que varían según el sexo, la clase y el momento histórico.

Con seguridad, este modelo de casa -la casa modelo- es el propio de las intimidades burguesas. Un modelo que desgrana sus variantes de innumerables pormenores desde el Londres victoriano a la Viena de fines de siglo e incluso, más al este, hasta el corazón de Berlin y de San Petersburgo. Cabe la hipótesis de una relativa unidad del modo de vida burgués del siglo XIX y de las formas de habitar [...] No obstante cuántos matices, ¡cuántas disparidades engendradas por las culturas nacionales, religiosas o políticas, en las relaciones sociales, en las familiares, en los roles sexuales y, por consiguiente, en las estructuras y los usos de la casa que nos expresan! (Perrot, 1988: 15)

Me he preguntado antes si son equivalentes las formas de habitar en el sentido de tener la libertad de ir construyendo la habitación mientras se habita y me he respondido que no. Para construir la identidad propia, primero habrá que tener una habitación privada, no en el sentido económico, no como propiedad privada, ni como privación, sino en el sentido de «para sí» definido por Murillo y Woolf, como la concha del caracol, como lugar de recogimiento e intimidad 
donde ir escribiendo la propia biografía y a salvo de intrusiones no deseadas. ¿Qué ocurre cuando la respuesta es negativa? Como en las casas mencionadas en el capítulo anterior: la granja, el retiro suburbano o la casa de ensueño, que encarcelan a sus moradores, de ambos géneros, cada cual en su rol: el uno viendo atrapada su privacidad por lo público; la otra, por lo doméstico. A este respecto resulta interesante reflexionar sobre algunos textos de Álvaro Galmés extraídos de su obra Morar, arte y experiencia de la condición doméstica. Mi intención es establecer un potente contraste entre estos moradores elitistas (claros herederos del morar burgués antes citado) y las moradoras del siguiente capítulo.

Ya el título llama poderosamente la atención, pues en nuestro contexto no suena igual morar que habitar, ni suena con igual significado la palabra doméstica.

Habitar es más que estar en un lugar, es la relación misma del hombre con el mundo: «la manera según la cual los hombres somos en la tierra», decía Heidegger en Dramstat, ante un auditorio plagado de arquitectos» [...] Entendemos por habitar la instalación y el desarrollo del ser humano en un ámbito concreto $y$, por ese principio activo y dinámico, la acción de estar construyendo constantemente un entorno adecuado. El carácter incesante de esta construcción será una de las ideas a través de las cuales interpretaremos la condición doméstica. [...] pero sí queremos defender el habitar poético en la vida: creemos que el habitar que postula Hölderlin se puede desarrollar en el día a día de los hombres y que es posible una existencia ordinaria y noble, un habitar poético de la vida cotidiana. (Galmés, 2014: 20-27)

Para desarrollar este punto de vista, el de su creencia en la posibilidad de un habitar poético en la vida cotidiana, Álvaro Galmés escribe un texto incuestionablemente poético, una utopía del habitar, tejida con el habitar en doce hábitats selectos, construidos por la flor y nata del estrellato arquitectónico del siglo XX: Le Corbusier, Melnikov, Barragán, Alvar Aalto, Neutra, Utzon, Prouvé, Smithson, Eames. 
Hábitats habitados por ellos mismos (salvo el primer caso, las casas Pessac proyectadas por Le Corbusier y profundamente transformadas por sus habitantes) o por sus selectos clientes y partícipes del proyecto como Malaparte y Warhol.

Casi todos, arquitectos-habitantes y habitantes-partícipes del proyecto, sin cargas familiares (entre todos suman 3 hijos); y las esposas, cuando las hay (el $50 \%$ aproximadamente no están casados), o son arquitectas (en los casos de Aalto, Smithson y Eames) o hijas de arquitecto (en el caso de Melnikov y Neutra).

Son moradas de la élite, para la élite. Veamos un fragmento que retrata al morador, Curzio Malaparte, en relación a la biblioteca, que Galmés define como sigue:

La biblioteca doméstica es el lugar donde una mente ilustrada se proyecta en el espacio. Muchos intelectuales utilizan su biblioteca como un exocerebro; en ella ordenan los materiales que se revuelven en su cabeza, proyectan una jerarquía de temas o de autores, resaltan algunas ideas contenidas en los libros y relegan otras a rincones inaccesibles. La biblioteca es el dispositivo externo imprescindible para el pensamiento del hombre culto. Va más allá del puro almacenamiento de la información, ya que los libros son objetos que nos vinculan a los hechos concretos. No sólo está en ella la enseñanza del pasado, sino también el objeto que reaviva las circunstancias en las que se originó dicho conocimiento. Además es un esquema mental: en la biblioteca encontramos organizados espacialmente los diferentes temas que nos interesan, hay un escalafón en cuanto a la ubicación de los libros: su relevancia cualitativa, y el volumen del espacio ocupado, es la proyección de nuestra sabiduría en el espacio doméstico. (Galmés, 2014: 98)

No cabe duda de que el material escogido es altamente poético. Y poética es la estructura del libro, dividido en tres partes, tituladas pertenencia, permanencia y hospitalidad. Cada una de estas partes desarrolla acciones esenciales del habitar como: transformar, superponer, proyectar y desdoblar, en la primera; 
converger, armonizar, preservar y aligerar en la segunda; y, por último, celebrar, acompañar ofrecer y entrelazar, en la tercera.

La prosa utilizada es sumamente lírica, los conceptos filosóficos se entrelazan con los literarios y la obra final es un verdadero poema al habitar. Un fragmento como muestra:

Desde otra escala estos dispositivos poseen la misma intención: ser una transición entre la fascinación del horizonte y la intimidad del hogar. Porque el mar también provoca inseguridad y su imagen es demasiado intensa como para no resquebrajar la estabilidad de la morada. Es por esto que se necesita de una transición, un intervalo que se interponga en el tiempo y que traslade una imagen cercana en el espacio a una distancia intemporal: es el mar el que se ve, el que se impone, pero no en el que se pueda uno bañar; es el mar de otro tiempo, con el que no se puede establecer contacto corporal. La función de los abocinamientos es mantener el horizonte accesible a nuestra mirada pero a través de un túnel que suspende la lógica del tiempo; en otras palabras, el pequeño espacio de las ventanas reconstruye un Mediterráneo intemporal. (Galmés, 2014: 196)

Este párrafo recuerda enormemente otro, escrito por Soledad Murillo en los noventa, para comenzar la introducción del libro El mito de la vida privada:

Si acompañamos a un noble del siglo XVII en uno de sus paseos y le seguimos hasta sus aposentos, veremos cómo después de despojarse de aquellos abalorios más pesados, se sumerge en el silencio de su biblioteca para leer o meditar a solas. En este preciso instante asistimos al mudo acontecimiento de la privacidad, que consiste en plegarse sobre uno mismo y disfrutar del privilegio de la reserva. (Murillo, 1996: XVI)

No encontramos rastros de las variables de clase social y género en este bello libro. Es más, la interpretación de la condición doméstica, a la que el autor hace referencia repetidamente, es legítima pero distante de la que hemos apuntado en el capítulo anterior y desgranaremos en el siguiente.

Pero hay otras facetas no menos importantes. Ante todo, la oposición entre la ciudad y el campo, fractura profunda de las intimidades, sin 
olvidar que en los confines del siglo XX la mayor parte de la población europea sigue siendo rural. El campo no ignora ni la intimidad ni el secreto, pero éstos son consustanciales al espacio abierto. [...] El exterior -el granero, las breñas, la zanja en los prados cercados con setos, el bosquecillo en medio de los campos rasos en que se resguardan las pastoras, las orillas umbrosas del río-; todos esos parajes son, por encima de la habitación común, los sitios propicios para los juegos del amor y los cuidados del cuerpo; en la casa todo el mundo se halla bajo las miradas de los demás. (Perrot, 1988: 16)

Y ¿al alcance de quién está esa forma poética de habitar la vida cotidiana que expone Galmés? Porque cotidiana no es sinónimo de vulgar, defiende el autor, pero tampoco cualquier vida cotidiana tiene recursos para convertirse en una obra de arte. La vida cotidiana de las clases populares necesita de ayuda para alcanzar esos niveles que la vanguardia clásica y la contemporánea exhiben, porque, como llevamos visto, «El orden de los ritos y los lugares apropiados compartimenta el espacio y el tiempo» (Perrot, 1988: 15) y construye diferentes identidades, a veces, alteridades.

Apretujadas en infectos cuchitriles, las clases populares urbanas desarrollan de manera diferente su intimidad, Las promiscuidades de las que parecen gustar incluso en sus placeres -para el mismo Zola, el baile popular es pura excitación sexual- son a los ojos de las clases altas el signo de una sexualidad primitiva y de una condición salvaje. [...] conviene desde luego señalar su ceguera obsesiva con respecto a las formas de vida cotidiana de las clases populares. Forzadas a «vivir en la calle», éstas se las ingenian para sacar partido de las posibilidades de los inmuebles colectivos y del barrio, del espacio intermedio, de esa zona de ayuda mutua y comunicación. [...] La noción de "vivienda mínima» con normas de comodidad y de cubicación del aire, empieza a perfilarse a finales del siglo XIX. EI mismo movimiento obrero, durante mucho tiempo relativamente insensible a esta problemática «de la vivienda», empieza a reivindicar a comienzos del siglo «aire puro» y «salubridad». (Perrot, 1988: 16) 


\subsubsection{Domesticidad}

\subsubsection{En el exterior, urbanismo}

A lo largo de la historia han existido alternativamente dos corrientes habitacionales en relación a las soluciones de los problemas sociales: la utopía urbana y la casa modelo. Dolores Hayden, autora de La gran revolución doméstica expone, en su artículo "La felicidad entre cuatro paredes», la alternancia americana de los dos modelos:

Durante cientos de años, cuando alguien pensaba poner fin a los problemas sociales, diseñaba ciudades modelos, no casas modelo, para expresar estos deseos. De hecho, el ideal de una buena ciudad fue en su momento tan importante para la vida americana como el ideal de una buena casa. Analizar cómo y cuándo abandonaron los americanos la ciudad modelo en favor de la casa de ensueño es comenzar a entender los miedos, esperanzas, y errores de cálculo que han generado la actual crisis de vivienda. [...] Algunos de los mejores escritores, activistas y diseñadores americanos esperaban cambios en la ciudad industrial en lugar de una huida a las casas modelo. Frente a la granja familiar idealizada por Jefferson y a la devota casa suburbana de Beecher, aparecieron varias visiones alternativas de interés sobre el espacio urbano público. Desde finales de 1840 hasta 1870, los activistas del movimiento abolicionista y las del feminista unieron sus fuerzas para reclamar sus derechos en cuestiones de política y espacio social. [...] Olmsted pronunció una valiente conferencia en la que sostenía que la ciudad americana se debía volver a planificar para fomentar asociaciones fraternales entre sus ciudadanos, ricos y pobres, hombres y mujeres, jóvenes y viejos, ya provinieran de los cenáculos de la alta sociedad o fueran inmigrantes de tercera clase. [...] Olmsted con sus parques públicos, Peirce con su ideal de barriadas modelos y Williard y Addams con sus proyectos de servicios sociales urbanos, concibieron una ciudad americana ideal donde la arquitectura paisajística, las viviendas y la planificación social y física estuvieran entrelazadas. Estos activistas no separaron la vida pública de la privada, los programas domésticos de los públicos, las iniciativas privadas de las sociales, ni los 
conocimientos de las posturas éticas de dichos conocimientos.

(Hayden, 1988: 34, 35)

Entre las propuestas de la utopía urbana norteamericana, figuran la socialización de las tareas domésticas y la creación de guarderías; y entre sus experiencias, la creación de cooperativas de amas de casa y la construcción de casas sin cocina, junto a la construcción de cocinas colectivas y comedores comunitarios. No olvidemos que esto ocurría a finales del siglo XIX, mucho antes de las primeras experiencias europeas del mismo calado, al tiempo que se planteaba el problema habitacional en las ciudades y se comenzaba a abordar el de la vivienda mínima, tanto en América como en Europa. Sin embargo, tanto en Europa como en América, «La casa de ensueño sustituyó a la ciudad ideal como representación espacial de las esperanzas americanas acerca de la vida feliz». (Hayden, 1988: 34)

Un siglo más tarde, desde principios de los años 70, varias geógrafas feministas y culturales iniciaron trabajos de investigación tendentes a visibilizar la experiencia y las necesidades de las mujeres en los espacios públicos y mostraron la diversidad de estas experiencias según la edad, clase social, el origen étnico y el cultural. Experiencias radicalmente distintas de aquellas de la mayoría de los urbanistas varones, de clase media, blancos y occidentales que por aquel entonces y aún hoy, dominaban el panorama de la proyección urbanística, siendo responsables de la actual sectorización de las ciudades que pretende ordenarlas según las falsas necesidades del sujeto que falsamente presuponen como usuario del espacio público: el varón con las características recién mencionadas. Digo falsamente porque existen estudios que demuestran que la extensión de las tareas domésticas que el patriarcado asigna a las mujeres, las hace las máximas usuarias de los espacios públicos: comerciales, de juegos, sanitarios, educativos, etc.

Según Pascuala Campos de Michelena:

El espacio nos envuelve como un todo. Nos contiene, nos limita y nos da forma. Nos da estructura mental y afectiva. La política, cuando marca directrices en la manipulación del espacio, suele no tener la capacidad de prever las consecuencias espaciales de una decisión 
abstracta normativa. Decisiones que suelen destrozar tejidos complejos, elaborados en el tiempo, con importantes contenidos referenciales. El romper señas de identidad espaciales pienso que genera sentimientos de impotencia y confusión, y que fomenta actitudes de acatamiento. (Campos de Michelena, 1999: 18)

En la Bienal de Venecia 2014, Andrés Jaque, en su proyecto SALES ODDITY: Milano 2 y la Política del Urbanismo Direct-to-Home TV, muestra que la política, cuando marca directrices en la manipulación del espacio, no es tan inocente e incapaz como supone Michelena. En el suplemento «Babelia» del periódico El País, Jaque resumía su proyecto de investigación, premiado con el León de Plata; y hacía referencia al origen del poder de Silvio Berlusconi, con las siguientes palabras:

[...] -cuestionado magnate italiano y ex Primer Ministro italiano en tres ocasiones- realmente se forjó en sus proyectos de urbanización en los años setenta, formulando un «urbanismo radical, diseñado para aislar a la población en sectores homogéneos y para eliminar la política de las relaciones entre consumo y producción». (Jaque, 2014: 1)

En la sección que el portal «Plataforma de Arquitectura» dedica a la Bienal de Venecia de 2014, se explica este fenómeno:

En la década de los 70 , dos dinámicas fueron dando forma a una nueva realidad urbana en Italia: por un lado, la televisión estaba influyendo fuertemente en la sociedad italiana, convirtiéndose en parte intrínseca de la vida cotidiana; por el otro, la tensión social resultante de las protestas estudiantiles y la inmigración acelerada habían comenzado a impactar las ciudades de manera caótica. Estas dinámicas fueron pavimentando el camino para Milano 2, una nueva ciudad en las afueras de Milán, que prometió un nuevo e idílico tipo de urbanismo.

El complejo promovido como la «ciudad de los número 1», parecía un barrio a primera vista tradicional, sin embargo logró poner en práctica conceptos modernos. Sus 2.600 departamentos contaban con acceso a servicios de educación y entretenimiento, organizados en torno a un 
jardín y lago artificial, y se conectaban a través de circulaciones peatonales elevadas. Debajo de la tierra, el complejo albergó los estudios de la primera cadena de televisión privada en Italia, un hecho que en cierto modo dio forma a la vida de los habitantes de Milano Due y, trascendiendo finalmente a toda la sociedad italiana. (Mora, 2014: 1)

Una reciente visita a Milán en abril de 2016 me ha permitido conversar con un habitante de Milano 3, Pier. Mi propósito era visitar el citado Milano 2, hecho que llamó su atención, contó que él vivía en Milano 3 y que el primer Milano era conocido como Milano Viscontea. Dedicado a orientar a turistas constantemente en su estancia en la ciudad, le pareció llamativo el destino que me planteaba. La información sobre la experiencia de haber crecido en Milano 3 , complejo residencial que repite el prototipo de Milano Due fue más provechosa para mi de lo que Pier pueda llegar a imaginar. Su respuesta inmediata fue transmitirme que Milano 3 es un lugar tan alejado de la realidad que, y cito textualmente, «creces como si tuvieras complejo de Peter Pan». Aun así, quiso que me quedara muy clara la superioridad de Milano 3 sobre Milano 2. "A nosotros nos han dado los bancos» comentaba respecto a mi charla acerca de la ubicación de la televisión de Berlusconi en el subsuelo del complejo residencial por el que le preguntaba. «Si quieres verlo, ¡mejor Milano 3!». También hizo referencia a que incluso la policía necesita de los guardias de seguridad privados del complejo residencial para localizar a posibles delincuentes de guante blanco si ha tenido que ir a detenerles. Se trata de un gueto, con características que producirían temor a cualquier persona en otro contexto. Un gueto que aísla a su población, que se hace cargo gustosamente del alto coste que este aislamiento supone, a cambio de una inducida necesidad de pertenencia a una élite económica. Un aislamiento que es pretendido, que tenía un origen político, insistiendo en la cita de Michelena, «El espacio nos envuelve como un todo. Nos contiene, nos limita y nos da forma.». La intención de desactivar a la sociedad es un objetivo cumplido, Pier reflexionaba «crecer fuera de la ciudad y en este tipo de complejo residencial te hace crecer fuera de la realidad». En cualquier campaña contra la violencia de género alertan sobre los primeros signos que anuncian que una relación es 
insana. Resulta llamativo el hecho de que, tal y como previenen tantas y tantas campañas de concienciación en este sentido, sabiendo que el control y la evidencia de llevar a una mujer hacia el aislamiento son ya un signo de maltrato, cuando se aísla a una comunidad entera, pase desapercibido. A pesar de que el principio de actuación es el mismo. Se desvincula a toda la población de esa urbanización del resto de barriadas de la ciudad y así se desactiva su capacidad de protesta. Protestas estudiantiles sofocadas antes de que se produzcan, perverso.

\subsubsection{En el interior, arquitectura doméstica y arquitectura pública}

No sólo el urbanismo invisibiliza a las mujeres y a otros colectivos excluidos de la toma de decisiones sobre la organización del espacio, también en el interior de las construcciones prevalece el criterio uniformador y sexista de los arquitectos en ejercicio, varones en su mayoría, que con sus distribuciones y medidas fuerzan los estereotipos sexistas facilitando la distribución de roles según los cuales las tareas domésticas y de cuidados se realizan con distribuciones que invisibilizan el desarrollo de estas tareas al tiempo que separan a las mujeres de los espacios de socialización familiar y evitan a los varones la visión de las tareas desagradables pero necesarias en el proceso de acondicionamiento de la vivienda, la comida y el cuidado de niños, enfermos y personas mayores. Como dice Pilar de Bustos:

Al igual que las relaciones humanas, el espacio construido es la consecuencia de estructuras sociales, económicas, culturales, psicológicas y afectivas. (Bustos y Lasaosa, 1999: 18)

La lectura de "Arquitectura y género. Una reflexión teórica» de María Novas, evidencia la transversalidad teórica del género en la arquitectura tanto a nivel teórico como de diseño y de praxis. Ello me ha conducido a buscar esa transversalidad a lo largo de la historia, haciendo un esfuerzo por incluir a las mujeres en esa historia que necesariamente considero que debe ser reescrita; y a preguntarme ¿dónde podremos hallar los deseos de las mujeres con mayor probabilidad, en las primitivas autoconstrucciones bárbaras o en las sofisticadas construcciones que las eluden? He elegido la historia, la antropología y la etnografía para bucear en las raíces de la relación entre las mujeres y los 
espacios construidos, porque, como dice Jane Rendell en la introducción de la segunda parte de Gender Space Architecture:

The study of gender and space is an interdisciplinary one. Currently, those looking at gender in architecture have started to take their inspiration from the work of feminists in other fields: namely, geography, anthropology, cultural studies, film theory and art history, psychoanalysis, identity politics and philosophy. Such fields are those concerned with space, the representation of space and spatial metaphors. This is not space as it has traditionally been defined by architecture- the space of architect-designed buildings-but rather space as it is found, as it is used, occupied and transformed through everyday activities. ${ }^{5}$ (Rendell, 2000: 101)

Las mujeres, probablemente, no han sido ajenas a la arquitectura jamás. Ésta es una hipótesis que refuerzan antropólogos como Schoenauer que ha «analizado numerosos ejemplos de refugios construidos por mujeres en distintos tipos de asentamientos preurbanos, de sociedades nómadas, seminómadas o sedentarias, en todo el mundo.» (Espegel, 2008: 19)

Ángela Davis, cuenta en su texto Mujeres raza y clase:

En 1973, realicé un viaje en jeep a través de las llanuras de Masai, en el que se puso de manifiesto la centralidad de las tareas domésticas de las mujeres en las culturas precapitalistas. En un solitario camino de tierra en Tanzania me fijé en seis mujeres masai que enigmáticamente hacían equilibrios con una enorme madera que portaban sobre sus cabezas. Según me explicaron mis amigos de Tanzania, probablemente estas mujeres estaban transportando el tejado de una casa a una aldea nueva que estarían construyendo. Entonces, supe que, entre los masai, las mujeres son .responsables de todas las actividades domésticas $y$, por lo tanto, también de la construcción de las casas que su pueblo nómada cambia frecuentemente de lugar. Para las mujeres masai, el trabajo doméstico no sólo conlleva co-

\footnotetext{
5. El estudio de género y espacio es interdisciplinar. En la actualidad, quienes estudian cuestiones de género en arquitectura han comenzado a tomar su inspiración del trabajo de feministas de otros campos: a saber, la geografía, la antropología, los estudios culturales, la teoría del cine y la historia del arte, el psicoanálisis, la política de la identidad y la filosofía. Tales campos son los relacionados con el espacio, la representación del espacio y metáforas espaciales. Este no es el espacio como tradicionalmente ha sido definido por la arquitectura -el espacio de edificios diseñados por arquitectos- sino más bien el espacio tal como se encuentra, tal como se utiliz a, ocupado y transformado a través de las actividades diarias. (Traducción propia).
} 
cinar, limpiar, criar a los niños, coser, etc., sino que también implica la construcción de las viviendas. A pesar de la importancia que puedan tener las funciones relativas a la cría de ganado que realizan los hombres de su pueblo, el «trabajo doméstico de las mujeres no es ni menos productivo ni menos esencial que las contribuciones económicas de los hombres masai.

Dentro de la economía nómada y precapitalista de los masai, el trabajo doméstico de las mujeres es tan esencial para la economía como los trabajos de cría de ganado realizados por los hombres. En calidad de productoras, ellas disfrutan de un status social investido de una importancia equivalente a la de ellos. En las sociedades del capitalismo avanzado, la dimensión servil de la función de las amas de casa, que pocas veces pueden producir pruebas palpables de su trabajo, menoscaba el status social de las mujeres en general. En resumen, según la ideología burguesa, el ama de casa no es más que la sirvienta vitalicia de su marido. (Davis, 2005: 223)

En los primeros momentos del patriarcado, la nueva sociedad jerarquizada se estructura en tres clases: la clase de los jefes militares que acumulan riquezas y poder; la clase de la burocracia que controla recursos alimenticios, metalúrgicos y bélicos; y en tercer lugar la clase a la que pertenecen siervos y/o esclavos.

La estructura de los poblados ya se pone al servicio de la jerarquía que es explícita en el tipo de urbanismo de poblados en colinas, con varias series de murallas defensivas, arriba la última, la más fuerte, la más alta, la más protegida por las anteriores, dentro el jefe del poblado y su familia. Ello obligaba a las mujeres, a las siervas, a transitar por calles empinadas que deterioraban sus articulaciones en las piernas, como se comprueba en los restos óseos hallados en las excavaciones arqueológicas y prueba la temprana desafección del patriarcado respecto a las condiciones de vida de las mujeres. Los siervos trabajaban en los campos, abajo, en el llano, los hombres que accedían a la zona más protegida lo hacían a caballo. Las siervas no tenían ninguna capacidad para influir en los criterios urbanísticos de sus poblados.

Se tienen datos de que durante el imperio romano, se daba una cierta intervención de mujeres en el espacio a través de una actividad conocida como el matronazgo, mecenazgo de las mujeres acomodadas, que, con su 
contribución económica aportaban la elección de qué construcciones iban a recibir su apoyo.

Esto se perdió con la caída del imperio y la entrada en la Edad Media en la que las grandes construcciones se redujeron a palacios, castillos y monasterios, sufragados por las instituciones feudales y construidas por los maestros canteros. Las mujeres ya han sido excluidas, como ocurre siempre que un oficio comienza a ser económicamente jugoso. Jane Rendell se pregunta el por qué:

in Part 2: 'Gender, Space' addresses the gendering of space from another perspective-through use. Specific places may be 'sexed' according to the biological sex of the people who occupy them, or gendered according to the 'gender' associated with the different kinds of activities which occur in them. For example, toilets (rest rooms in the US) are 'sexed' male or female because they are occupied by men or women, while the domestic kitchen is gendered feminine because the activity of cooking is something that is socially connected with women. However, how do we consider the kitchen of the public restaurant where the cooking is done by the chef who is usually male? ${ }^{6}$ (Rendell; 2000: 101)

En la Edad Media sólo algunas abadesas tuvieron algo que aportar. En cuanto a la edificación habitada por los siervos, el modelo poco difería del modelo neolítico o del modelo de casa del campesino humilde del siglo pasado que aún podemos contemplar hoy día. En éstas viviendas humildes, encontramos elementos constructivos que fueron redescubiertos por las pioneras, dígase por ejemplo la pieza recibidor - estar -cocina-comedor típica de las casas de labranza, heredera del habitáculo único de las civilizaciones primitivas neolíticas, lugar de relación, concepto éste presente en las viviendas de las culturas matrilineales y de las arquitectas vanguardistas pioneras de principios del siglo pasado.

\footnotetext{
6. en la parte 2 : «Género, Espacio» se refiere al estudio según el género del espacio desde otra perspectiva, el uso. Lugares específicos se pueden asignar a un «sexo» de acuerdo con el sexo biológico de las personas que los ocupan, o por el género de acuerdo con el "género» asociado con los diferentes tipos de actividades que tienen lugar en ellos. Por ejemplo, los aseos (salas de descanso en los EE.UU.) son considerados de hombres o mujeres «sexuado» porque están ocupados por hombres o mujeres, mientras que la cocina doméstica tiene género femenino porque la actividad de la cocina es algo que está socialmente conectado con las mujeres. Sin embargo, ¿cómo se considera la cocina del restaurante público donde la función de cocinar se realiza por el chef que es generalmente de sexo masculino? (Rendell, 2000: 101).
} 
Tras los castillos y monasterios medievales, la vivienda acomodada evolucionó hacia los palacios renacentistas y luego hacia las casas de la alta burguesía que encerró más, si cabe, a las mujeres de esa clase social en el recinto del hogar, lugar de la privacidad del otro. El otro, varón, al cuidado de ella que carece de privacidad, de intimidad y de espacio y tiempo propio. Sólo al final comienza a aparecer algún boudoir como recinto anejo al dormitorio, lugar donde refugiarse o esconderse en los momentos de los malos humores adjudicados a ciertos días del ciclo vital de las mujeres.

Mostrando la evidente condescendencia masculina hacia la mujer en esta época, y en base a que el término Boudoir, procede del verbo bouder, cuya traducción sería manifestar el mal humor, el Boudoir, desde el punto de vista del hombre del S.XIX, sería utilizado para ocultar el descontento, haciendo referencia a un lugar donde pasar los asiduos pequeños enfados, lo que ahora llamamos la tensión premenstrual, eso era lo que suponían algunos escritores del momento, aludiendo de forma eufemística a la supuesta «inestabilidad» propia del carácter de las mujeres. (Vélez, 2016: 3)

Los primeros intentos de modificación de los interiores domésticos vinieron de la mano de la necesidad de una vivienda mínima para alojar a la creciente clase obrera, necesidad incrementada por la devastación de las guerras y, en Europa y EEUU, por la necesidad de la reconversión de la industria de guerra en industria de producción. No obstante, el Movimiento Moderno presentó pronto dos líneas nítidamente diferenciadas: la estetizante al servicio de la burguesía, de las élites culturales y económicas y de la mayor gloria del arquitecto estrella; y la línea apoyada por gobiernos socialistas y socialdemócratas que, allá donde pudieron gobernar, destinaron fondos para financiar proyectos de vivienda popular, que fueron diseñados por arquitectos y arquitectas con inquietudes sociales.

Dos textos muestran con contundencia estas dos líneas de desarrollo del Movimiento Moderno en la Arquitectura: Morar. Arte y experiencia de la condición doméstica de Álvaro Galmés Cerezo, comentado en el capítulo anterior, que a pesar de reconocer en la página 34 el problema de la falta de vivienda digna, desarrolla todo el discurso del libro sobre el morar de la élite 
cultural y económica. $Y$ «La vivienda popular en el Movimiento Moderno» de Auke Van der Woude, que pone el acento en el fracaso del Movimiento Moderno como fuente de soluciones para la vivienda popular. Como afirma Rafael García, traductor al español del texto de Van der Woude:

[...] no es verdad que el funcionalismo jugara un papel significativo en la construcción masiva de vivienda en los años 20 y 30 . En Inglaterra, Alemania y Francia se construyeron entre 1924 y 1936 alrededor de 7,5 u 8 millones de nuevas viviendas, mientras que los funcionalistas, como es aparente en el siguiente artículo, produjeron no más de 35.000 viviendas en dichos países, es decir, menos del $0,5 \%$ del total. $\mathrm{Si}$ se incluye el resto de Europa, la contribución sería proporcionalmente incluso más insignificante. (García, 2010: 4)

No sólo diverge Van der Woude respecto a la eficacia del Movimiento Moderno para resolver el antiguo problema de la vivienda para las clases populares, Dolores Hayden explica cómo, cuándo y para qué se inició la estrategia de la vivienda en propiedad:

Tras la II Guerra Mundial, se hizo realidad la estrategia de la casa en propiedad para trabajadores blancos iniciada más de veinte años antes. Como en los años que siguieron a la I Guerra Mundial, muchas empresas de armamento quisieron dar los trabajos de las mujeres a los veteranos y transformar algunas industrias para la producción de bienes de consumo. $Y$ esta vez los programas nacionales de seguros hipotecarios y el sistema bancario norteamericano estaban preparados, y la red de autopistas organizada, por lo que los especuladores de la construcción pudieron tomar las riendas. [...] Alojar a los americanos fue, como había predicho Hoover, un magnífico negocio y los intereses bancarios, inmobiliarios y de transporte se vieron estrechamente implicados en él. (Hayden, 1988: 34)

El problema perdura hasta nuestros días de manera hipertrofiada, hasta llegar a la obscenidad de la brecha social. Por un lado, el star system arquitectónico continua proyectando los edificios que las élites políticas y económicas demandan desde su megalomanía. Por el otro, la necesidad provocada de poseer una vivienda en propiedad hace caer a las clases desfavorecidas en las trampas financieras tendidas por el capital. Se da la situación de encontrar hoy, 
a esa franja social desfavorecida, no sólo sin viviendas mínimas, de las que han sido desalojadas familias enteras, sino atrapada en una deuda impagable por causa de leyes que impiden la dación en pago en nuestro país.

En cada una de las líneas divergentes, existen a su vez luchas de género, entre arquitectos y arquitectas, entre moradores y moradoras, entre la conceptualización de lo doméstico por unos y otras. Y esto es una realidad por mucho que se pretendan ocultar con eufemismos lingüísticos dichas luchas, negando la actualidad de la clase obrera o reduciendo la lucha de géneros a la violencia doméstica y una ley insuficiente e injusta como solución.

También los estudios de arquitectura y género siguen vertientes separadas en el sentido de analizar las injusticias de género que sufren por un lado las mujeres de las clases media y alta, como moradoras y como profesionales, en particular como arquitectas. Este es el caso del texto Arquitectura y Género de Mónica Cevedio, que reconoce que su investigación está centrada en la búsqueda de la mujer-sujeto-arquitecta (2003: 19) o los de Beatriz Colomina y Carmen Espegel, que rescatan y reivindican el papel de las pioneras en arquitectura, pertenecientes en su totalidad a las clases privilegiadas económicamente. Incluso Una habitación propia de Virginia Woolf, es una reivindicación de género, pero burguesa.

Por otro lado, para encontrar reivindicaciones de género para las clases populares, tenemos que remitirnos a la obra de Alexandra Kollontai que, desde su cargo como Comisaria del Pueblo para la Asistencia Pública, defendió la política de construcción de viviendas con servicios colectivos superadoras de las corralas y precedidas por las propuestas americanas de finales del XIX. Sus propuestas fueron replicadas en la URSS y en algunos países del norte de Europa, pero, tras la Segunda Guerra Mundial decayeron. Los servicios mínimos en la vivienda popular se trasladaron al interior; y los módulos prefabricados de la cocina Franckfurt de Margarete Schütte-Lihotzky y el baño integrado de Charlotte Perriand, como veremos más adelante, tomaron el protagonismo. Las viviendas sociales actuales son sus herederas y en ellas buscaremos los rastros del androcentrismo arquitectónico agazapados en la antropometría. 
Pilar de Bustos García-Salmones y $\mathrm{M}^{\mathrm{a}}$ José Lasaosa Castellanos reflexionan:

[...] nos planteamos a menudo, en el ejercicio de nuestra actividad profesional, cuál puede ser el método para aproximar mejor el diseño de las viviendas a las necesidades reales de sus habitantes [...] nos preocupa proyectar edificios anónimos para futuros habitantes de los que no sabemos nada. (Bustos y Lasaosa, 1999: 54)

Aunque sí sabemos que esas viviendas serán el espacio de lo privado que se rige por criterios, costumbres, normas y leyes dictadas generalmente por hombres.

Porque, como ya hemos reiterado, el espacio privado es el espacio de la recuperación. Pero alguien, en la mayoría de casos mujeres, se encarga de esa recuperación, tanto en las granjas de Jefferson de finales del XVIII como en el prototipo de Beecher de mediados del XIX o, a mediados del siglo XX, en la mayoría de las casas americanas, basadas en el modelo Levitt de hogar como refugio de la familia del trabajador: "Se supone que cada familia está formada por el hombre -sostén de la misma- el ama de casa y sus hijos» (Hayden, 1988: 34)
Beecher denominó a su prototipo de 1869 «la casa de la mujer americana», y esta casa era, sobre todo, un espacio para el trabajo doméstico de la mujer al servicio de los hombres y los niños. Beecher intentaba fundamentalmente actualizar el ideal de Jefferson. [...] Su objetivo primordial era dar a la mujer el control del espacio doméstico para equipararlo con la participación del hombre en la producción agrícola e industrial. (Hayden, 1988: 34)

La mayoría de las casas americanas siguen el modelo Levitt y las europeas replican la ordenación y jerarquía de las burguesas, pero sin servicio doméstico. Así pues, las mujeres, en general, se encargan de la recuperación de los demás y eso implica atención y tiempo incondicionales; y la suspensión del propio proyecto vital, si existe, salvo que el cuidado de los otros constituya conscientemente un proyecto propio, declarado como tal por la mayoría de mujeres que no han tenido ni tiempo, ni espacio, ni oportunidad de descubrir sus deseos genuinos; mujeres a las que adaptarse al rol social les garantiza la 
aceptación que tanto necesita su baja autoestima, porque el topo-poder del patriarcado les asigna el espacio doméstico y las desprestigia si no acatan el lugar asignado -el topo-poder no sólo nombra y asigna lugares, también los valora-. Acatar el lugar asignado tiene sus gratificaciones: establece la dialéctica hegeliana entre víctima y verdugo, entre amo y esclavo, de la que es importante considerar que surgen relaciones de poder que mantienen el equilibrio. De no considerarlo, corremos el peligro de ignorar esa dimensión y caer en la esencialización victoriana de lo femenino como lo dulce, lo virtuoso y... lo impotente y devaluado -caricaturizado por Margaret Atwood en su distopía La criada.

Impotentes -o no tanto- y prisioneras en el locus doméstico. Autovigiladas por su propia creencia en el sistema patriarcal, incuestionado, y satisfechas por las lisonjas, adulaciones y reconocimientos que dicho sistema les ofrece. El título de ángel del hogar parece ser su máxima aspiración. Vivir inmóviles en el escaso espacio de un altar es el premio a su sometimiento y a su función de primera línea de ataque contra aquellas otras que osan cuestionar esas creencias, pues las críticas más aceradas que reciben las mujeres que renuncian a ese lugar vienen habitualmente de las sumisas al sistema. No se dan cuenta de que esa dedicación absoluta al cuidado de las condiciones necesarias para que los demás puedan descansar en su tiempo y espacio privados, las priva a ellas mismas de tiempo propio y espacio privado. Virginia Woolf lo expresó con claridad en su obra Una habitación propia en la que afirma que a la mujer sin unos recursos económicos propios y mínimos -en 500 libras cifraba la cantidad necesaria- se la ha privado no sólo de gran parte de su vida y de su tiempo, sino de todo su espacio -nos hace notar que las grandes escritoras que la precedieron, tuvieron que escribir en la salita de estar, de estar toda la familia, claro.

La discusión sobre el espacio doméstico, el privado y el público es inseparable de la discusión sobre los tiempos dedicados a las actividades domésticas, privadas o públicas y éstos están determinados por la división sexual del trabajo que, a su vez, está en la base de la organización social del patriarcado. 
Dicha discusión ha sido abordada por Soledad Murillo, inspiradora de la ley contra la violencia de género, en Espacio doméstico. El uso del tiempo. En ella encontraremos un matiz de lo doméstico muy distinto al que utiliza Álvaro Galmés en Morar. Arte y experiencia de la condición doméstica. Para Murillo, doméstico, pertenece a la familia semántica de lo domesticado, de la domesticidad, de la sirvienta como sinónimo de doméstica. En el libro de Galmés el varón morador es el domesticador de los espacios, el que se los apropia, el que transforma la casa en morada, imprimiéndole sus costumbres (mors-moris).

Ese matiz que diferencia el uso del término doméstico en Murillo y Galmés será uno de los ejes de mi investigación. Rastrearé en la teoría arquitectónica las estrategias del topo-poder, destinadas a asignar a las mujeres al espacio doméstico en el sentido en el que lo utiliza Murillo, y cómo la historia androcéntrica de la antropometría ha dejado su huella como prueba de lo antedicho. 
3. LOS TEXTOS Y LAS EXPERIENCIAS DE LAS PIONERAS 
Mirar ahora, hacia lo que ciertas mujeres del pasado lograron, no es simple nostalgia retrógrada, ni radical feminismo reivindicativo, sino una verdadera necesidad histórica de búsqueda de otros modelos que sirvan para otorgar mayor dignidad a cualquier ser humano. (Espegel, 2013: 18)

\subsection{En torno a la Primera Guerra Mundial}

Las arquitectas pioneras, procedentes de las clases acomodadas como todas las pioneras, se propusieron tener en cuenta a las personas que iban a habitar las viviendas y ello marcó la diferencia en sus proyectos por su punto de vista y por los obstáculos que encontraron para el ejercicio de su profesión y sobre todo para el reconocimiento de su labor creativa.

Fue el espíritu del tiempo, el mismo que inspiró a Woolf para reivindicar una habitación propia, el que inspiró ese punto de vista diferente de las arquitectas pioneras. Opuesto a la estetizante arquitectura de autor, varón. Una arquitectura poco interesada en los deseos y peculiaridades de las personas que tendrán que habitar las casas construidas por ellos.

Es en este periodo cuando comienzan a abrirse camino algunas arquitectas, enmarcadas en el movimiento de la Nueva Construcción. Algunas de ellas, como Aino Marsio Aalto y las polacas Helena Syrcus y Bárbara Brukalscy, iniciaron la saga de pioneras minimizadas por la sombra de sus esposos, arquitectos que concentraron la fama de un trabajo realizado en equipo. Esta saga continuó en los países anglosajones en la etapa de la postguerra de la segunda conflagración mundial, por ejemplo con el matrimonio estadounidense Eames, o el británico Smithson, de los que hablaré en el subcapítulo 3.2.

Del periodo de entreguerras, las tres arquitectas elegidas son Eileen Gray, Margarete Schütte-Lihotzky y Charlotte Perriand.

Eileen, arquitecta, interiorista y diseñadora de mobiliario, fue una de las primeras mujeres reconocidas a nivel internacional. Le Corbusier fue ferviente e irreverente admirador de su obra. 
Entre muchas otras, estas tres mujeres y su obra me resultaban interesantes en primer lugar por sus vínculos con grandes maestros del Movimiento Moderno. Vínculos que permiten una explícita comparativa del tratamiento que la historia ha hecho de su obra en contraposición a la de ellos.

Eileen Grey, tuvo una más que especial relación con uno de los grandes del Movimiento Moderno, Le Corbusier, de quien 17 obras acaban de ser reconocidas por la Unesco como patrimonio de la humanidad, pero que, como veremos, tuvo serios problemas para reconocer la grandeza de la obra de Eileen. Le Corbusier no solo tuvo problemas con Eileen Grey, también tuvo luces y sombras en su relación con Charlotte Perriand.

Por su parte Grete y Charlotte han sido elegidas por su significación en el Movimiento Moderno y, en particular, porque desarrollan un trabajo vinculado a la producción industrializada que será muy relevante en el diseño de espacios interiores posteriores. Producción que está muy vinculada a la investigación respecto a los cánones de medidas que me he planteado en esta tesis. Sus diseños de cocinas se analizan en el capítulo 6 , de manera más extendida

\subsubsection{Eileen Gray}

El arte de Eileen Gray pretende ser una prolongación de la vida. Desde esa máxima proyectó y construyó, entre 1926 y 1929, la Maison en bord de mer (E. 1027) para su pareja, Badovici. Marco Antonio Orsini nos permite un recorrido virtual por la casa de una arquitecta que, como dice Sarasota Architectural Fundation (SAF), interesa hoy más que nunca. La casa fue construida junto al mar en Roquebrune-Cap-Martin, en el Departamento de los Alpes Marítimos. Eyleen compró el terreno en el lugar exacto, construyó la casa con la orientación perfecta y todo fue pensado y diseñado por ella con la misma precisión con que diseñó los muebles y los objetos del interior pues, para ella, diseñar era una actividad genérica que abarcaba tanto la arquitectura como el diseño de interiores, la única diferencia que ella veía entre ambas actividades era de escala. 
Jean Badovici, para quien Gray diseñó la casa E. 1027 -la E de Eileen, el 10 porque la $\mathrm{J}$ de Jean es la décima del abecedario, $\mathrm{y}$, análogamente, el dos por Badovici y el siete por Gray-, fue el creador y único director de la prestigiosa revista L'Architecture Vivante, en la que publicaron sus proyectos los arquitectos más famosos del Movimiento Moderno, en especial Le Corbusier.

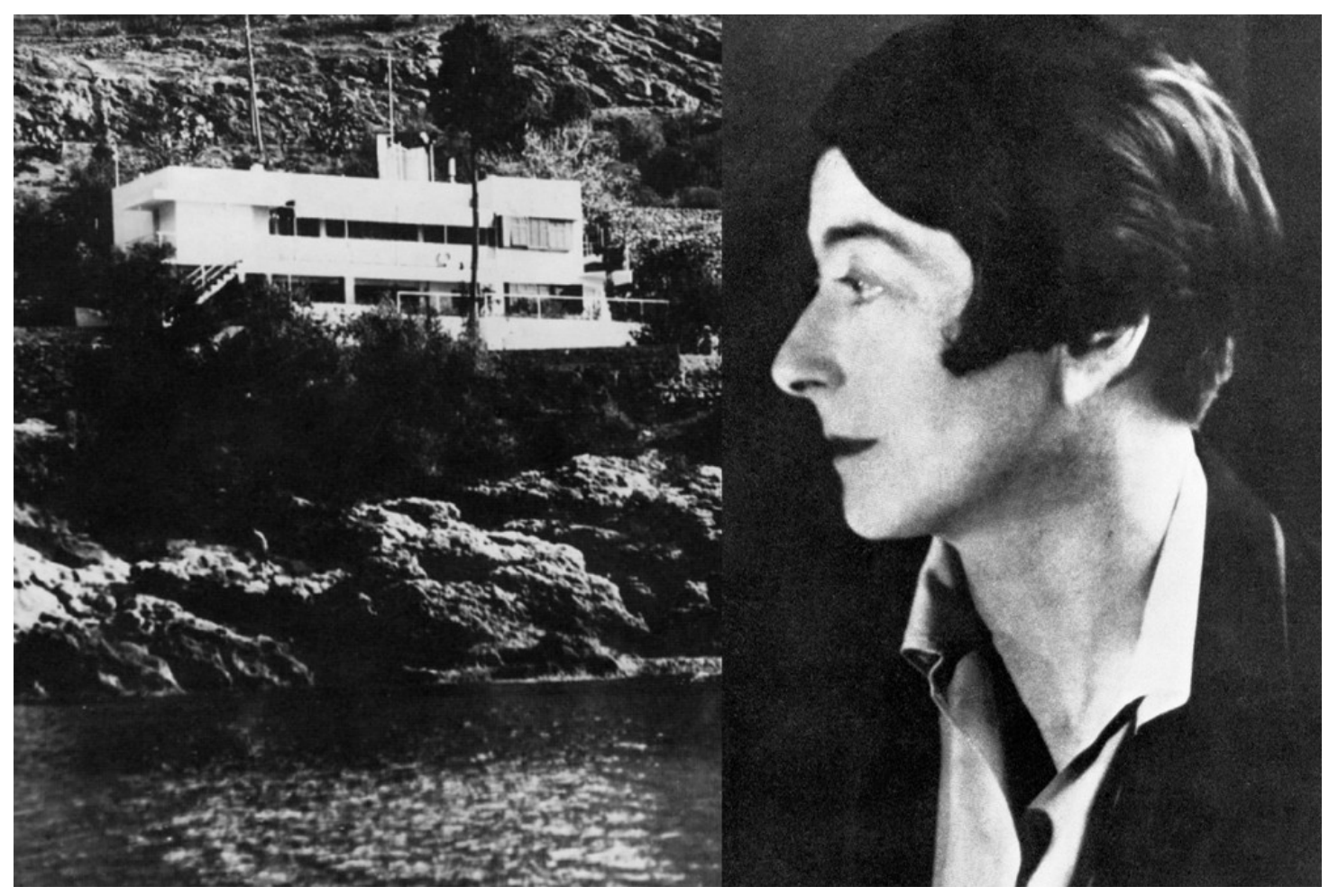

17. La maison en bord de mer (E.1027) y su autora Eileen Gray, 1929. Fuente: Matter More Than Ever de SAF, 2016.

No es posible desligar la vida y la obra de la arquitecta de esta singular edificación. La admiración que despertó en Le Corbusier, hasta el límite de la envidia, fue causa del distanciamiento entre ambos. Un análisis detallado de la historia de amor/odio, soberbia/envidia que tiñó de miseria la relación de Le Corbusier con Eileen, Badovici y su casa, podemos leerla en el artículo de Carlos Luís Marcos, «Crítica de Género. E. 1027: Eileen Gray VS. Le Corbusier en Cap Martin» (Marcos: 2011).

La E. 1027 se convirtió en una obsesión para el arquitecto suizo a lo largo de toda su vida. Obsesión que le llevó a perpetrar sucesivas y múltiples manipulaciones de la casa, su entorno y sus referencias en las revistas de arquitectura, en un desesperado intento por borrar de la historia la obra de 
Eileen Gray que, aun siguiendo aparentemente el canon corbuseriano constituía en sí misma un compendio de sutiles críticas a éste, superándolo con sencillez y elegancia. Hasta tal punto era acertada esa crítica, que Carlos L. Marcos comenta:

Buena parte de la crítica que se ha hecho al Estilo Internacional tiene que ver con su inestabilidad para con el lugar -sobre todo en el caso de las propuestas urbanísticas- El ejemplo de Le Corbusier resulta paradigmático en este sentido, pero incluso su visión idealizada de una arquitectura modélica también tenía cierto sentido de desapego respecto del lugar sobre el que se actuaba. La E. 1027 se acomoda y hace suyo el lugar de muchas maneras, la casa no podría estar en otro lugar distinto del que está. (Marcos, 2011: 293)

Y Carmen Espegel dice que

La Maison en bord de Mer consigue su identidad insertándose en la tradición (no formal) mediterránea, bebiendo de ella sus logros esenciales, y en cierta manera reinventándola, pero es auténtica en la fidelidad que guarda consigo misma y con su tiempo. (Movimiento Moderno, hormigón armado, planta libre, imagen marítima) [...] El proyecto se utiliza como arma de distinción y de resistencia contra la uniformidad cartesiana moderna que niega toda tradición. (cit. en Marcos, 2011: 293)

A continuación, veamos sucintamente las manipulaciones a las que sometió Le Corbusier a esta villa para colonizarla, anular a su creadora, invisibilizarla, borrar la expresión genuina de Eileen con la imposición de su ego: la pintura de los murales, de estilo incoherente con la casa, uno de ellos pintado sobre el original de la propia Gray que, lógicamente, sí era coherente con la limpia geometría del conjunto; intervenciones arquitectónicas desafortunadas; intentos de intervenir los interiores, rompiendo el cuidadoso paseo proyectado por Eileen; modificación de los exteriores con un proyecto de construcción de viviendas en serie, no llevado a término; construcción del cabanon a 20 metros de la E.1027, con multitud de errores de bulto e incoherencias con su propia doctrina y con el entorno; intento de compra de la casa, finalmente adquirida de modo poco transparente por Mdm. Schelbert, amiga de Le Corbusier; ocupación 
de la casa durante los últimos años de su vida; publicaciones en las que no reseñó el nombre de Eileen como autora, otras en las que se atribuyó el diseño a sí mismo; y la miserable ocultación de la verdad durante años a $\mathrm{Mdm}$. Schelbert, su amiga y anfitriona, que vivió en la casa convencida de que todo allí había sido diseñado por el «maestro».

Beatriz Colomina relata algunos de estos episodios en Privacidad y Publicidad. La Arquitectura Moderna como Medio de Comunicación de Masas.

[...] casi ocupación del lugar cuando, tras la Segunda Guerra Mundial, construyó el Cabanon, una pequeña cabaña de madera que situó en el límite mismo de la propiedad adyacente, justo detrás de la casa de Eileen Gray. Le Corbusier ocupó y controló el lugar desde esta cabaña que era poco más que una plataforma de observación. La violencia de esta ocupación ya se había manifestado cuando Le Corbusier pintó los murales -había un total de ocho- en la casa sin el permiso de Eileen Gray [...] Ella consideró aquello un acto de vandalismo, de hecho, tal y como Peter Adán ha apuntado, «fue una violación». Cuando Le Corbusier publicó los murales en L'Architecture d'Aujourd'hui (1948), se refirió a la casa E. 1027 como una casa de Cap Martin, sin mencionar nunca el nombre de Eileen Gray. (Colomina, 2010: 81)

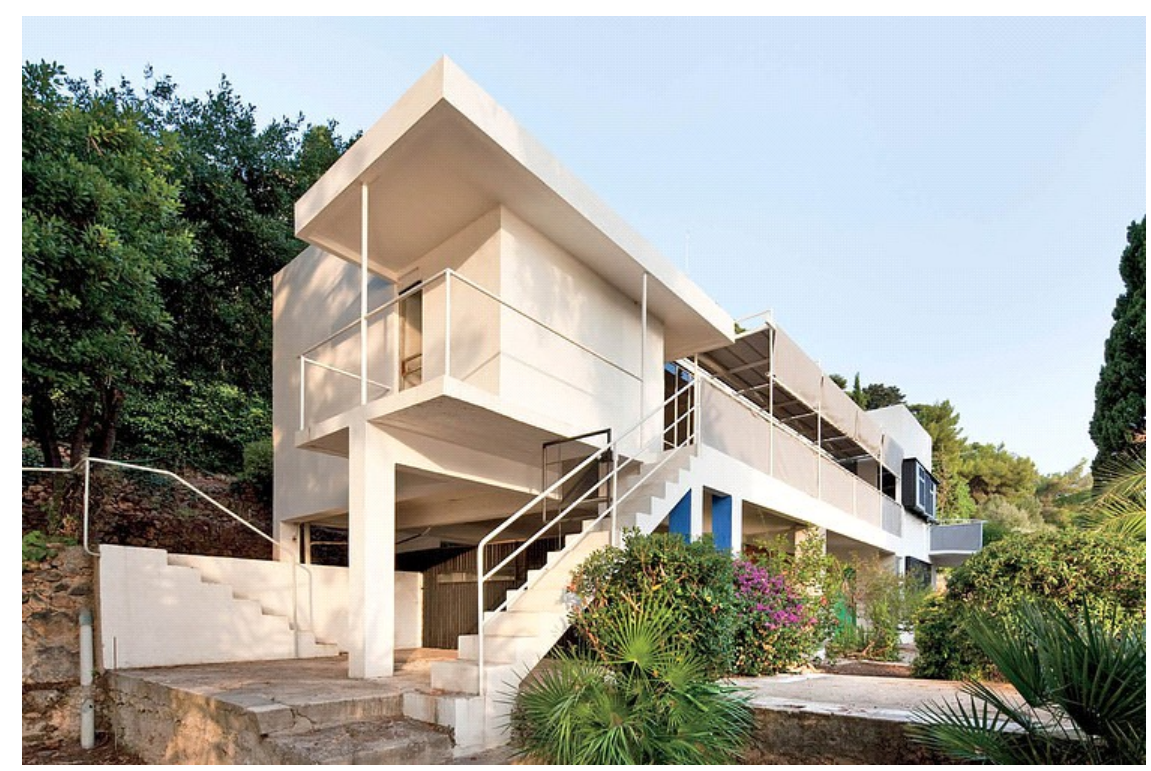

18. Eyleen Gray: Casa E-1027, 1929. Fuente: Historia Diseño Interiores IED, 2015. 
Sobre el artículo conjunto de Gray y Badovici, de 1929, "De l'eclectisme au doute», publicado en la revista dirigida por éste último, L'Architecture Vivante, comenta Carmen Espegel:

El artículo profundiza, de manera general, en todos los interrogantes teóricos que en ese momento se están planteando sobre la arquitectura, el papel del arquitecto, la poética, las vanguardias, el maquinismo, el higienismo. Podríamos resumir que Badovici, en cierto sentido, aparece como el portavoz de la ideología de la línea racional y objetivista de la modernidad mientras que Gray lo es de la línea ecléctica «expresionista» y vitalista de dicha modernidad.

Gray considera a «las duras leyes del mecanicismo moderno» como una transición necesaria aunque demasiado teórica, intelectual y fría. Ella exige la vuelta de la emoción, del pathos, de los sentimientos y de la emotividad en la arquitectura, pero purificados por el conocimiento; contrapone la sencillez a la simplificación grosera; propone añadir la «vida», lo vital (espíritu más corazón) a las fórmulas racionalistas del Movimiento Moderno, enriqueciéndolas, haciendo «penetrar lo real en la abstracción», negando el rígido dogmatismo del sector más conspícuo de dicho movimiento. (Espegel, 2008: 125)

En efecto, las propias palabras de Eileen son claras al respecto:

- Ne crains tu pas que ce retor aux éléments, que cette simplification systématique dont on semble faire une loi à l'art moderne no finissent par fixer cet art en général, et l'architecture plus particulierement, dans une recherche purement théorique et trop intellectuelle pour satisfaire à la fois aux exigencies de notre esprit et a celles de notre corps? L'homme n'est pas un pur esprit. Et quand on voit ces grandes constructions aux lignes unies et surtout ces intérieurs ou tout semble répondre à un strict et froid calcul, on se demande si l'homme pourrait se satisfaire d'y demeurer.

\section{$[\ldots]$}

-Ainsi tu preconizes un retour aux sentiments, à l'émotivité!

-Oui, mais encore une fois, à une émotivité purifiée para la connaissance; enrichie par l'idée, et qui n'exclut point la connaissance 
et l'appréciation des acquisitions scientifiques. II ne faut demander aux artistes que d'être de leur temps. ${ }^{7}$ (Gray y Badovici, 1929: 17)

A pesar de todos los intentos del star system por eliminarla, recordaremos a Gray porque fue origenial, como diría el padre del movimiento moderno en la música, Erik Satie. La arquitectura de Eileen respetaba lo esencial, lo arquetípico, vestido con lo mejor de la historia de la arquitectura. Eclecticismo le llamaron despectivamente aquellos que pretendieron presentarse a sí mismos como originales, en el sentido divino de creadores, ignorantes de que nada se crea de la nada, todo es recombinación nueva de lo preexistente. Como decía Parménides Ex nihilo nihil fit. En la misma línea Virginia Woolf desarrolla esta idea para explicar a las mujeres lo necesario que es que se pongan a la tarea:

[...] las obras maestras no son logros aislados y solitarios, son el resultado de muchos años de pensamiento en común, del pensamiento colectivo de muchas personas, de tal suerte que, tras esta voz individual, se encuentra la experiencia de la masa. (Woolf, 2012: 89)

Woolf exhortaba de este modo a las mujeres a pensar, a crear, a valorar, a acumular pensamiento y experiencia de las mujeres que ella no veía reflejados en las creaciones de los varones.

Una escena que transcurre en un campo de batalla es más importante que una que transcurre en una tienda. En todos los terrenos y con mucha más sutileza persiste la diferencia de valores. Por tanto, toda la estructura de las novelas de principios del siglo diecinueve escritas por mujeres la trazó una mente algo apartada de la línea recta, una mente que tuvo que alterar su clara visión en deferencia a una autoridad externa. Basta hojear aquellas viejas novelas olvidadas y escuchar el tono de voz en que están escritas

\footnotetext{
7. ¿No temes que esta vuelta a los elementos, que esta simplificación sistemática que parece hacerse ley en el arte moderno no acabe por fijar este arte en general, y la arquitectura más particularmente, en una investigación puramente teórica y demasiado intelectual para satisfacer a la vez a las exigencias de nuestro espíritu y a las de nuestro cuerpo?, El hombre no es puro espíritu. Y cuando se ven esas grandes construcciones de líneas continuas y sobre todo esos interiores donde todo parece responder a un estricto y frío cálculo, se pregunta uno si el hombre podría sentir satisfacción de permanecer en ellas.

[...]

- Entonces preconizas una vuelta a los sentimientos, ja la emotividad!

- Sí, pero insisto, a una emotividad purificada por el conocimiento; enriquecida por la idea, y que no excluye en absoluto el conocimiento y el aprecio de los logros científicos. No hay que pedirles a los artistas más que que sean de su tiempo.(Traducción propia)
} 
para adivinar que el autor era objeto de críticas; decía tal cosa con fines agresivos, tal otra con fines conciliadores. Admitía que era «sólo una mujer» o protestaba que "valía tanto como un hombre». Según su temperamento, reaccionaba ante la crítica con docilidad y modestia o con cólera y énfasis. No importa cuál; estaba pensando en algo que no era la obra en sí. Desciende su libro sobre nuestras cabezas. En su centro hay un defecto. $Y$ pensé en todas las novelas escritas por mujeres que se hallaban desparramadas, como manzanas picadas en un vergel, por las librerías de lance londinenses. Las había podrido este defecto que tenían en el centro. Su autora había alterado sus valores en deferencia a la opinión ajena. (Woolf, 2012: 99)

Sus detractores quisieron encasillar el trabajo de Gray en la falsa acusación de la copia, pero la E.1027 sobrevivió a su creadora y a sus difamadores para colocar a cada cual en su lugar. El profundo sentido de integración de entorno, construcción, interiores y mobiliarios, tomando lo esencialmente adecuado de cada estilo caracterizan el trabajo de esta arquitecta pionera.

\subsubsection{Charlotte Perriand}

Charlotte Perriand vivió una larga y buena vida, nació en 1903 y murió a los 96 años en 1999.

Al tiempo que se proyectaba y construía la villa E.1027, se incorporó al taller de Le Corbusier una joven de la alta sociedad, enamorada de la moda, de los nuevos materiales y de los fascinantes productos de la industria.

Ella trasformó los interiores descuidados que hasta ese momento utilizaba el taller, centrado exclusivamente en las construcciones de la nueva arquitectura que permitían esos nuevos materiales y la industria. Ella introdujo en el taller el principio de armonización de exterior, construcción, interior y mobiliario que tan bien modelizaba la E.1027 y que el monográfico antes citado de L'Architecture vivante había difundido en todo el mundillo de la profesión. Charlotte Perriand sigue por tanto el camino iniciado en esta disciplina por Eileen Gray y lo lleva al despacho de Le Corbusier quien capitalizará el mérito de ambas mujeres arquitectas e interioristas. 


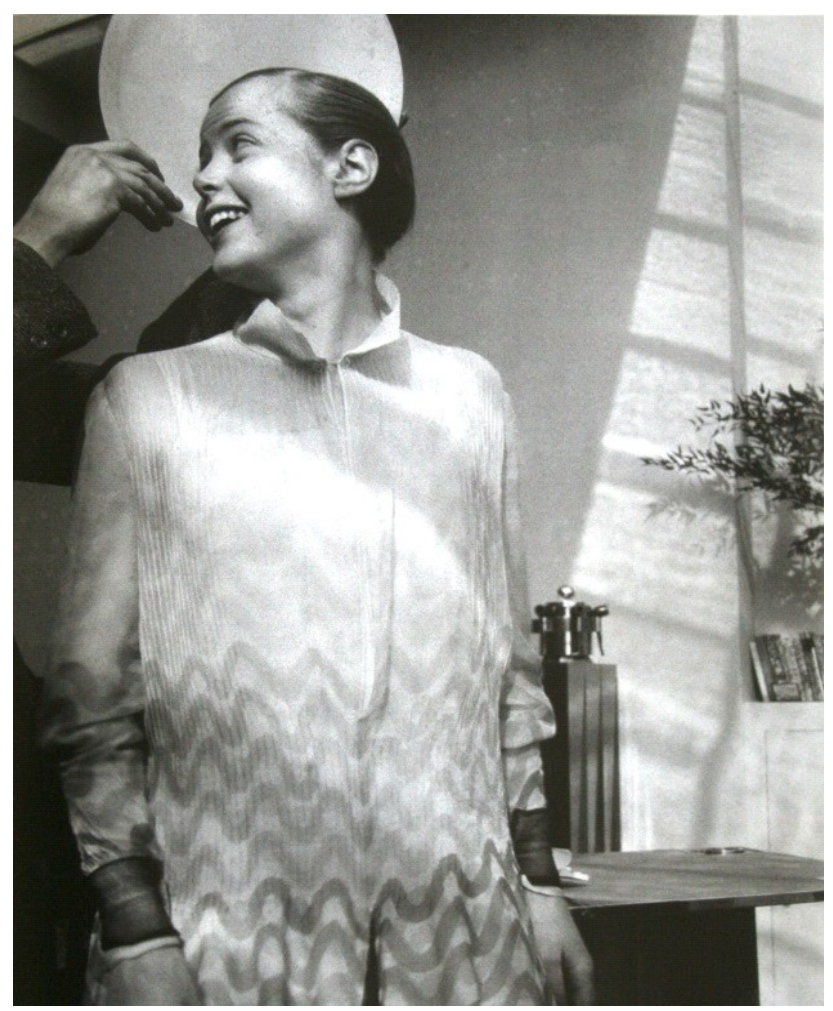

19. Charlotte Perriand. Fotografía de Pierre Jeanneret (probablemente), 1928.

El ático de Charlotte en París, reformado en 1970, es el reflejo de una personalidad marcada desde la cuna y labrada durante los diez años en que formó equipo con Le Corbusier y Pierre Jeanneret. Desarrollada y pulida a lo largo de una dilatada existencia en la que trabajó en su estudio independiente en París o en Japón, absorbiendo todo aquello que diera soluciones modernas, sencillas, claras. Así es su ático, claro, sencillo, y sereno. A pesar de su fascinación por la modernidad, supo trascenderla:

La meta que Perriand se propuso a lo largo de su carrera queda resumida en el título de la exposición retrospectiva que se preparó en 1985 en el Musée des Arts Décoratifs de París, Un Art de vivre. Ella creía que habíamos sido sobrepasados por la evolución de la máquina y que las cuestiones sobre arquitectura se planteaban frecuentemente "en términos de forma y no de necesidades», Sus interiores reflejan, utilizando palabras con las que Hegel describe la pintura holandesa, el «domingo de la vida». (Espegel, 2006: 232) 

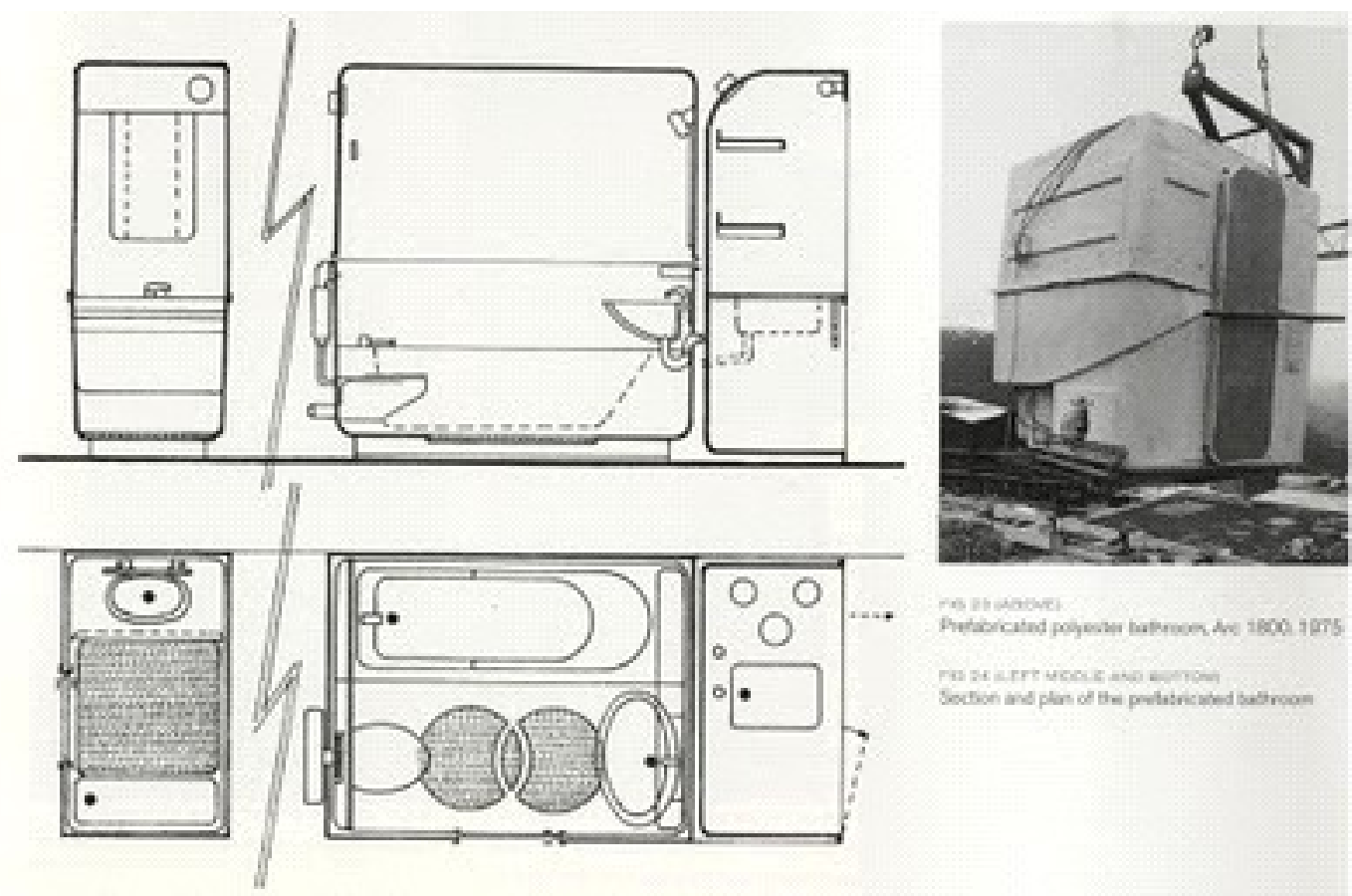

20. Baño y cocina integrados, de los archivos de Charlotte Perriand, 1937. Fuente: Mary McLeod, 2003.

Perriand, fiel a su máxima, propia de los felices años veinte, se dedicó al diseño de espacios de ocio. Estos necesitaban habitáculos mínimos puesto que la actividad primordial se desarrollaba al aire libre. Para minimizar esos habitáculos, diseñó varios modelos de bloques húmedos en poliéster. Una cabina lavabo-ducha, un cuarto de baño completo, es decir, lavabo, inodoro y bañera y una diminuta cocina, fabricados de una pieza en poliéster. Este diseño es de 1937, por tanto contemporáneo a las primeras caravanas -la caravana Silver Bullet de Airstreem diseñada por Hawley Bowlus es de 1934-. La cabinalavabo-ducha de Perriand estaba destinada a espacios de ocio, a complejos deportivos de montaña. Las habitaciones para dormir o los salones para estar y comer, no eran necesarias porque el evento duraba unas horas o estaban en el edificio central del complejo. A la cabina sólo le faltan las ruedas y el dormitoriosalón transformables para poder prescindir del edificio central y multiplicar sus posibles aplicaciones en espacios diversos, no necesariamente ligados a los eventos deportivos. Esa transformación hubiera convertido a la cabina de Perriand en una caravana. 
El cuarto de baño completo era una cáscara continua de poliéster modelado, de modo que sus relieves daban lugar al inodoro, bañera y lavabo; y las instalaciones de éstos iban por la parte externa del cubículo -el matrimonio Smithson retomará esta técnica en su casa del futuro-. Este diseño fue fabricado por una industria inglesa que producía las unidades sanitarias para la armada francesa. En una mañana se sacaba adelante 7 baños completos para el complejo Les Arcs.

Así como Margarete Schütte-Lihotzky trabajó siempre con la idea de estandarizar los módulos para aprovechar las potencialidades de la industria y ofrecer con ello mejores viviendas dignas a un mayor número de personas trabajadoras y con características que facilitaran a las mujeres el trabajo doméstico, Perriand llegó a soluciones mínimas desde el lugar opuesto. En su obra cumbre, el complejo invernal Les Arcs en Savoie, tres estaciones de esquí a 1600,1800 y $2000 \mathrm{~m}$ de altitud que podían alojar a 1800 personas, es donde pudo hacer realidad su sueño de la célula mínima estandarizada y prefabricada. Sus experiencias al respecto se originaron en los años de colaboración con Le Corbusier y tuvieron éxito con la cocina integrada para la Unité d'Habitation de Marsella. Hoy habitada por clases medias altas, la Unité d'Habitation fue diseñada en el taller de Le Corbusier cuando Charlotte ya se había independizado.

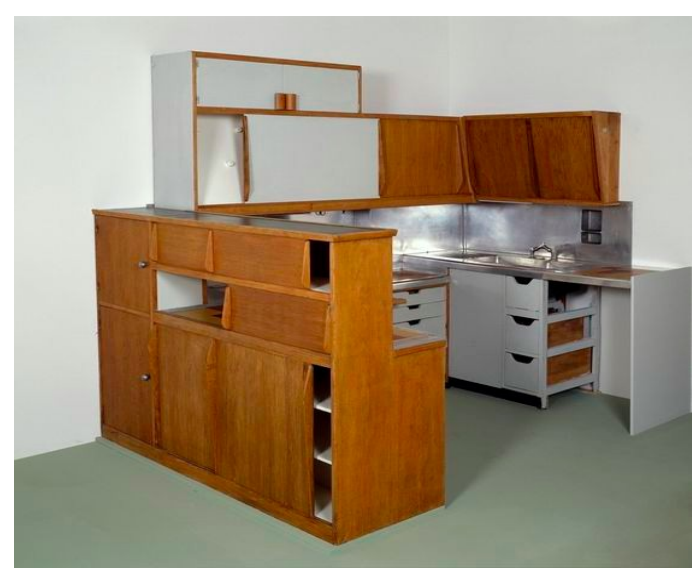

21. Cocina de la Unidad de Habitación de Marsella Tipo I, adaptada de Charlotte Perriand. Fuente: Georges Meguerditchian-Centre Pompidou, 2003. 
Otros trabajos de Perriand estuvieron también relacionados con la construcción de unidades mínimas para estancias temporales de ocio en la montaña. Su motor era la fascinación que le producían los nuevos materiales y los métodos industriales. Su pensamiento era el de una bonne vivante. Su origen era alto burgués. Su vocación, la moda, el pelo a lo garçon, el charlestón, los muebles en acero cromado y en caucho. Se declaraba amante de la naturaleza pero desde el derecho a su disfrute, marcando diferencia con los campesinos, a quienes decía respetar por ser quienes más cerca de la tierra estaban, pero lo hacía desde el cielo.

\subsubsection{Margarete Schütte-Lihotzky}

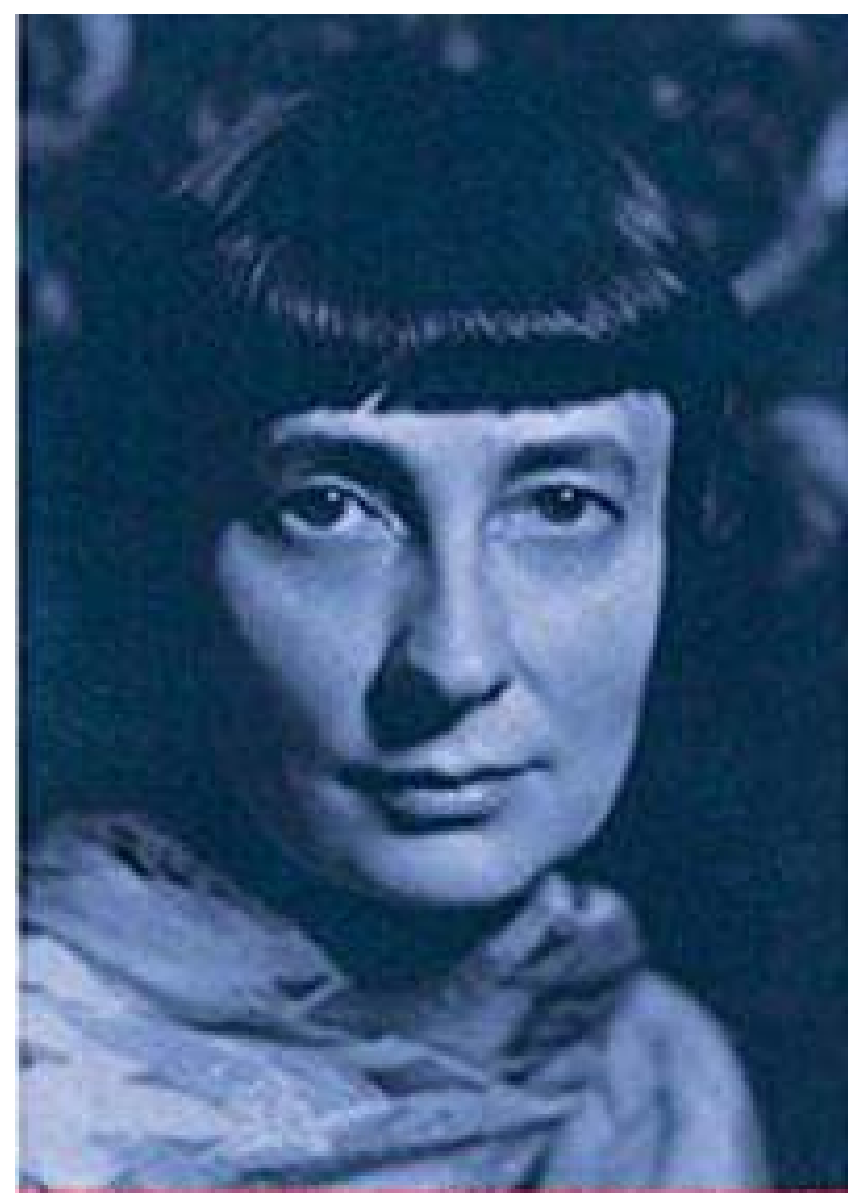

22. Margarete Schütte-Lihotzky. Fuente: Promedia, 2014.

Margarete Schütte-Lihotzky nació en Viena el 23 de enero de 1897 y desarrolló su labor profesional entre Viena y Frankfurt durante los gobiernos 
socialdemócratas de la república de Weimar y de Austria. Tras el ascenso de gobiernos fascistas se exilió a Moscú en la URSS, donde pudo desarrollar sus ideas colectivistas respecto al trabajo doméstico. También de la URSS tuvo que emigrar, ahora acusada de derechista. Tras este episodio de su vida, trabajó en Londres, París y Estambul, antes de volver a su Viena natal afiliada al partido comunista y decidida a luchar en la resistencia antifascista, lo cual la llevó a la cárcel, detenida por la Gestapo en 1941. Las tropas aliadas la liberaron en 1945. Este periodo lo cuenta en sus memorias Erinnerungen aus dem Widertand, publicadas en versión digital por Promedia (Schütte-Lihotzky, 2014). El manuscrito se guarda en el Museo de Artes Aplicadas de Viena, el MAK, donde también hay expuesta una reproducción de su Frankfurter Küche, que hizo posible ella misma, como advierte uno de los paneles que completan la exposición, titulado The Mother of the Fitted Kitchen:

The Frankfurt Kitchen by Margarete Shütte-Lihotzky is regarded as the prototype of today's industrially-made fitted kitchens. This replica was created in 1990 for a retrospective exhibition of Viennese architect's work in the MAK.

As Austra's «first female architect,» Shütte-Lihotzky was involved in «Red Vienna's» construction projects in the 1920s. In 1926 she went to Frankfurt on the Main and further developed planning approches that she had been working on in Vienna: improving the quality of life and the quality of living conditions by rationalizing residential buildings and furnishings.

In exhibitions and magazines she presented variations of practical, inexpensive, and visually appealing working kitchen. Tasks and work steps were reduced to a minimum, meaning that the working woman --according to the ideas of the time-- slightly relieved of the burden of housework. Occasionaly her design has been accused even more tightly to the kitchen, a criticism Shütte-Lihotzky has taken to heart. 
The Frankfurt Kitchen displayed here is not a copy, but rather an ideal reconstruction of the design. It was the architect herself who enabled this replica thanks to her memory of the details. It clearly shows how successful the Frankfurt Kitchen was at harmonizing rationalized housekeeping according to the newest technical opportunities from 1926 with homely, architectural details.

The radical nature of the design is difficult to comprehend today, in an era when the successors of the Frankfurt Kitchen stand in nearly all homes. Its architecture neverthless appeals to us even now, and hence it remains a milestone in kitchen developement. ${ }^{8}$ (MAK, 1990)

Las ideas de la época a que se refiere el texto del panel del MAK, son las vinculadas al taylorismo que imperaba en la época, referentes a la mejora de la productividad industrial, entre las que cabe destacar el estudio científico de los movimientos del trabajador para rentabilizar el tiempo productivo.

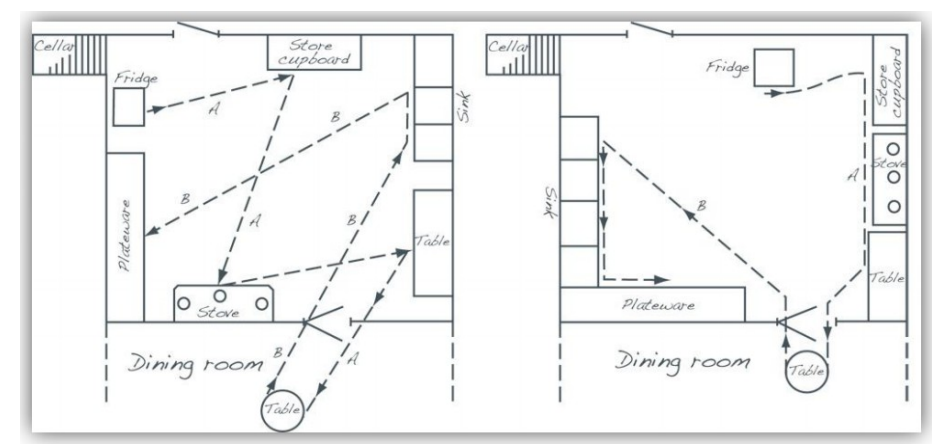

23. Christine Frederick: racionalización de los movimientos en la cocina, 1910. Fuente: Kaiser y de León, 2012.

8. La cocina de Frankfurt de Margarete Shutte-Lihotzky es considerada como el prototipo del que nacen las cocinas equipadas hechas industrialmente en la actualidad. Esta réplica fue creada en 1990 para una exposición retrospectiva de la obra de la arquitecta vienesa en el MAK.

Como «primera arquitecta austriaca», Shütte-Lihotzky estuvo involucrada en los proyectos de construcción de la Viena Roja en la década de 1920. En 1926 se fue a Frankfurt con el objetivo principal de desarrollar un planeamiento con un nuevo enfoque en Viena: la mejora de la calidad de vida y la calidad de las condiciones de vida mediante la racionalización de edificios residenciales y el amueblamiento.

En exposiciones y revistas presenta variaciones de cocina baratas, prácticas y atractivas a la vista. Tareas y pasos de trabajo se redujeron al mínimo, lo que significa que la mujer trabajadora -según las ideas del tiempo- se ve ligeramente aliviada de la carga de las tareas domésticas. Ocasionalmente su diseño fue atacado, incluso aún más fuertemente el de la cocina, una crítica que Shütte-Lihotzky se tomó en serio.

La cocina Frankfurt que se muestra aquí no es una copia, sino más bien una reconstrucción ideal del diseño. Fue la arquitecta misma quien permitió esta réplica gracias a su memoria respecto a los detalles. Muestra claramente la eficiencia de la cocina Frankfurt en cuanto a la armonización del trabajo racionalizado de limpieza de acuerdo a las nuevas oportunidades técnicas a partir de 1926, con detalles arquitectónicos para el hogar.

La naturaleza radical del diseño es difícil de comprender hoy, en una época en que las sucesoras de la cocina Frankfurt están en casi todos los hogares. Su arquitectura sin embargo nos atrae incluso ahora, y por lo tanto sigue siendo un hito en el desarrollo de la cocina. (MAK, 1990) 
Una acérrima defensora de estas ideas fue Christine Frederick, una americana experta en economía doméstica que en los primeros años del siglo XX hizo un estudio de los movimientos del ama de casa en la cocina. Se preocupó también por la adecuación de las alturas de las mesas de trabajo pues, en las cocinas antiguas, no estandarizadas, estas alturas se ajustaban a la altura de la mujer, "usuaria» indiscutible de la cocina tradicional. Pero la fabricación en serie exigía estandarizar las medidas y en consecuencia sacrificar la ergonomía. Christine Frederick aconsejaba cortar las patas de las mesas de trabajo 0 utilizar tarimas para elevar la posición, pues reconocía, implícitamente, que las alturas estándar eran excesivas para la mujer de talla media.

Christine está considerada como una de las madres de lo que conocemos hoy como la obsolescencia programada. En su afán por contribuir al buen funcionamiento de un sistema de consumo basado en la creencia de que los recursos eran ilimitados, plantea una serie de artículos, en los que el objetivo es enseñar al ama de casa, convertir al ama de casa en consumidora habitual para mantener el sistema.

En ese proceso de transformación del perfil del ama de casa de finales del siglo XIX y principios del XX Ellen Richards, en 1900, escribía:

Es la tendencia inconfundible del progreso económico e industrial moderno el apartar de la casa todos los procesos de fabricación. Se retirará una cosa tras otra hasta que queden solo el cocinar y el limpiar y ninguno de estos dos procesos [...] deja tras de sí resultados para recompensar al trabajador como lo hacían [...] el hilar, tejer, y fabricar jabón. Lo que se cocina en un momento se come en el siguiente; la limpieza de un día se debe repetir al día siguiente, y la desesperación de todo esto ha penetrado profundamente en el alma de las mujeres. (Richards, 1900: 203)

El estudio de los movimientos en la cocina, desarrollado por Christine Frederich es de 1910 y llega a las arquitectas del Movimiento Moderno en un momento histórico en el que se plantean concursos para generar prototipos de cocinas. 
Erna Meyer incluyó este estudio en las bases del concurso Weissenhof de 1927 en Stuttgart.

En las intervenciones de construcción masiva de vivienda para la clase obrera como las del programa del planeamiento del Nuevo Frankfurt esta filosofía sobre el espacio de la cocina y los criterios de movimiento queda asumida.

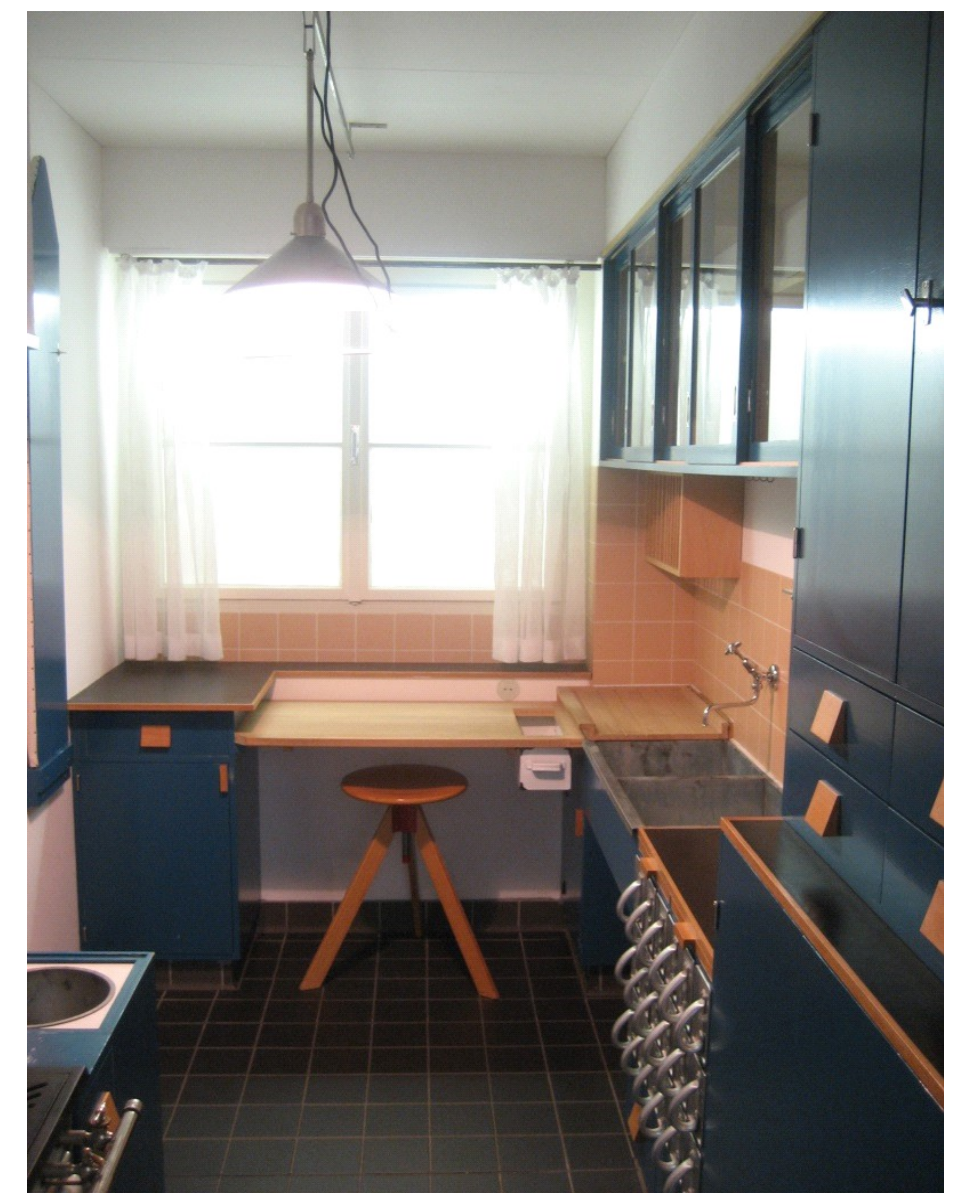

24. Margarete Shütte-Lihotzky: Frankfurter Küche (reconstrucción de 1990), MAK, Museo de Artes Aplicadas de Viena.

En 1930 Lillian Gilbreth realizó un estudio estadístico de los movimientos en la cocina y estableció el modelo de la triangulación de las áreas principales de trabajo, según el cual se optimizaba el tiempo de producción del ama de casa en la más pura línea taylorista. 


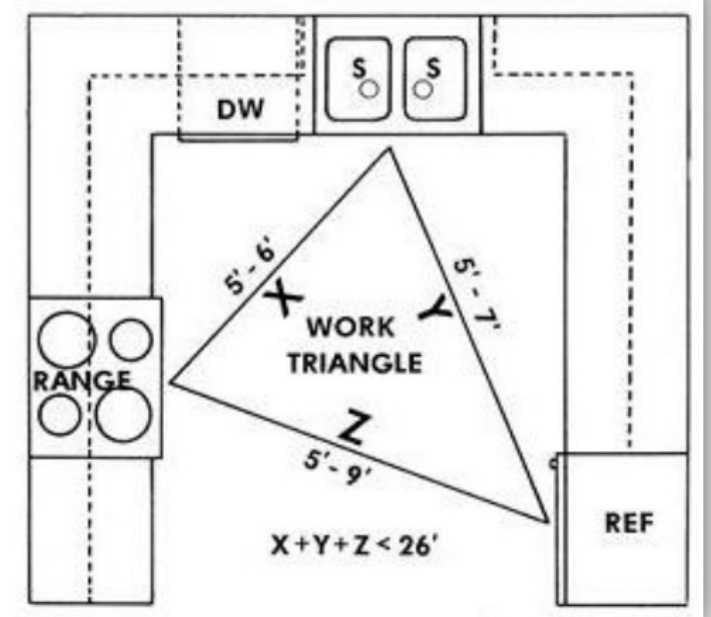

25. Lillian Gilbreth: triangulación del flujo de trabajo en la cocina, 1930. Fuente: Kaiser y de León, 2012.

Como vemos aquí y se profundiza en el capítulo 6, en la tarea de proyectar cocinas es evidente la afirmación de Virginia Woolf sobre la construcción acumulativa del conocimiento. Frederick y Gilbreth fueron importantes eslabones de la cadena de proyectos sobre la cocina moderna.

En todos sus proyectos, Margarete Schütte-Lihotzky destacó por la racionalización, funcionalidad, precisión y austeridad de sus resultados. Ella misma definió la parte fundamental de su método de trabajo: «sólo cuando la función se haya solucionado el proyecto puede comenzar» (cit. en Espegel, 2008: 165). No son sólo palabras, sus proyectos así lo atestiguan, el resultado evidencia la prioridad que concede a la función y cómo ésta determina la configuración del proyecto.

Tras su periodo de aprendizaje y una etapa profesional en Viena donde manifestó su vocación por la construcción de colonias en la llamada Viena Roja, comenzó a trabajar en Frankfurt donde su ejercicio profesional más reconocido fue la colaboración que durante los años veinte llevó a cabo con el arquitecto y urbanista Ernst May para el planeamiento del «Nuevo Frankfurt», donde: 
[...] construyeron alrededor de 15000 viviendas, que representaron el $90 \%$ de las edificadas en esta ciudad en todo ese periodo. Los estándares mínimos de May, gracias a los cuales se pudieron producir tal cantidad de alojamientos, dependieron en gran medida del uso de ciertos dispositivos de almacenaje, tales como camas plegables, y sobre todo de la eficiente cocina que Schütte-Lihotzky diseñó, la Frankfurter Küche, símbolo de la vida moderna. Este primer ejemplo de cocina estándar, realizada con piezas prefabricadas y criterios estrictamente funcionales, tenía $6,50 \mathrm{~m}^{2}$ y fue producida por el Ayuntamiento de Frankfurt con precios más baratos que los de la industria privada. La cocina se diseñó para facilitar y racionalizar las labores domésticas del ama de casa, con el objetivo de mejorar así la posición social de la mujer. (Espegel, 2008: 165)

El plan municipal de Frankfurt (1925-1930) fue el referente en toda la Europa de la postguerra para los planes, generalmente llevados a cabo por gobiernos socialdemócratas o por cooperativas, para la construcción de viviendas mínimas destinadas a alojar en régimen de alquiler a las clases populares pobres, en particular a la clase obrera. También lo fue en la URSS; un país que contó con las arquitectas y arquitectos que abandonaron Alemania con el ascenso del nazismo. La propia Grete y su jefe, Ernst May, hicieron allí una importante labor, palidecida sólo por la escasez de materiales cuyo uso prioritario iba destinado a la industria así como por la precariedad de mano de obra que además contaba con escasa formación.

La estandarización de módulos y medidas había comenzado su andadura exitosa en el nuevo mundo industrializado y destinado al consumismo. La cocina Frankfurt fue el modelo para Aino Aalto, arquitecta que diseñó la conocida como cocina mínima en 1930, cuatro años después de que viera la luz el diseño de la Frankfurter Küsche. La cocina mínima de Aino Aalto aporta sobre el diseño de Grete una reordenación de sus elementos. A partir de la versión que Aino realizó de la cocina Frankfurt, este modelo comenzó a extenderse en todo el mundo industrializado. Ha sido conocido desde entonces como «cocina sueca», aunque afamados industriales como Bulthaup, siguen reconociendo el origen de la cocina moderna en la cocina de Margaret Schütte-Lihotzky. 
En la exposición de CaixaForum que estuvo en Madrid hasta el 10 de enero de 2016, titulada Alvar Aalto, 1898-1976. Arquitectura orgánica, arte y diseño, desde el primer cartel en el interior de la exposición se podía leer sobre la figura de Aino y la gran relevancia de su trabajo en colaboración con el arquitecto finés, sin embargo, el título de la exposición habla por sí mismo. El reconocimiento sigue decantado. A pesar de que toda la obra realizada por el matrimonio finés fue firmada siempre por Alvar y Aino Aalto; y de que la segunda esposa, Elissa Aalto, participó en el diseño y dirección de los proyectos de la compañía Aalto incluso después de la muerte de Alvar, el reconocimiento de Aino y Elissa, esposas, colaboradoras, arquitectas y diseñadoras, con aportaciones originales como la cocina mínima que ha colonizado el mundo, quedaron a la sombra del nombre del varón.

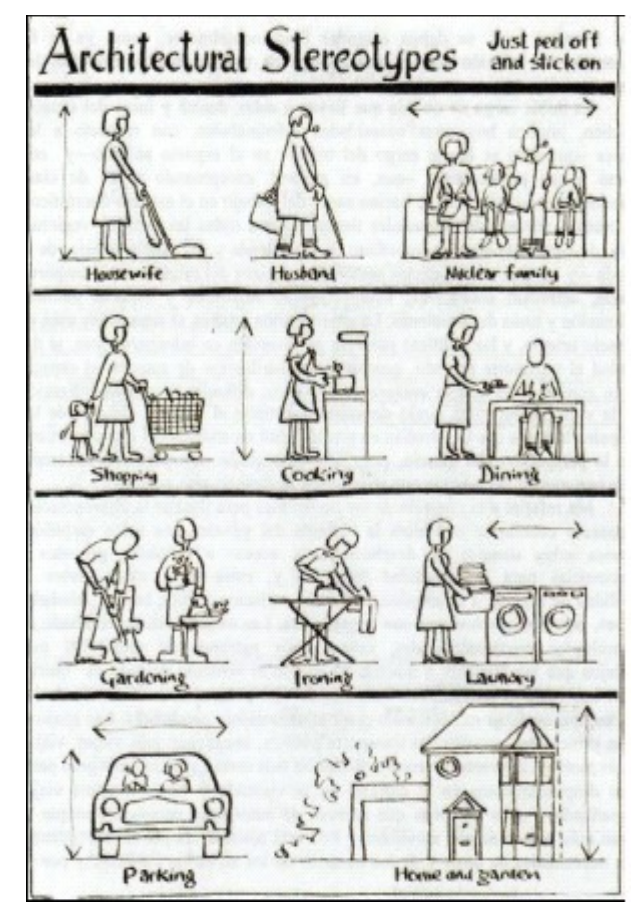

26. Estereotipos arquitectónicos. Fuente: Built environment, número monográfico sobre género $\mathrm{y}$ urbanismo, 1990.

Siempre pensando en el bienestar de las mujeres, sin cinismo alguno, Grete pensó que aquellas viviendas mínimas para familias trabajadoras, necesitaban 
cocinas comunitarias, jardines y guarderías, que facilitaran la colectivización del trabajo doméstico ganando tiempo para la vida de la mujer obrera. Pero tanto esta propuesta como la de espacios de viviendas luminosos y aireados, higiénicos en suma, fracasaron porque no les eran rentables a quienes decidían las inversiones en el mundo de la construcción.

Sólo cuando se trasladó a la URSS, tras la caída de la República de Weimar, después de la crisis del 29, tuvo la oportunidad de continuar la línea iniciada en la Viena Roja, la de los servicios comunitarios tan defendidos por ella y por la líder feminista socialista Alexandra Kollontai. Aunque estos proyectos tenían como objetivo político prioritario la destrucción del modelo burgués de familia y la construcción de identidades socialistas, los servicios comunitarios permitían cumplir con el objetivo feminista de la política Kollontai y de la arquitecta Schütte-Lihotzky: liberar a la mujer de la carga doméstica para que pudiera disponer de tiempo propio que podría dedicar a su privacidad o a su profesión según su criterio, aunque el gobierno comunista, lo que pretendía era facilitar la incorporación de toda la mano de obra femenina al gran proyecto de los planes quinquenales.

Margarete Shütte-Lihotzky ideó también un modelo de guardería que se puede visitar en la Viena roja, en la Otto-Haas Hof de Loos, construida en 1924 con la colaboración Karl Dimhuber y Franz Schuster. Poco después, tras la caída del gobierno socialdemócrata en Austria y el ascenso fascista al poder, como consecuencia de la crisis del 29, Grete emigró a los países socialistas y exportó el modelo a lugares como la URSS, Japón y Turquía, siempre con la idea de facilitar tiempo libre para que las mujeres pudieran disponer de él en privado.

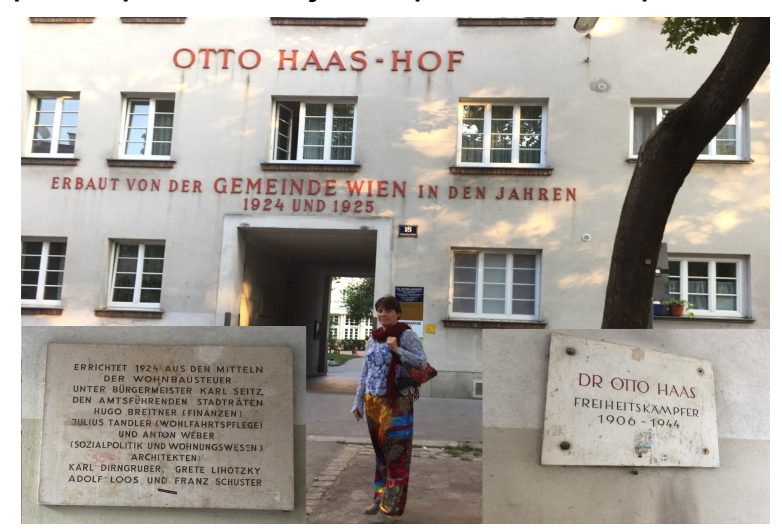

27. Placas y fachada de la Otto-Haas Hof . Fotografía de la autora, 2015. 


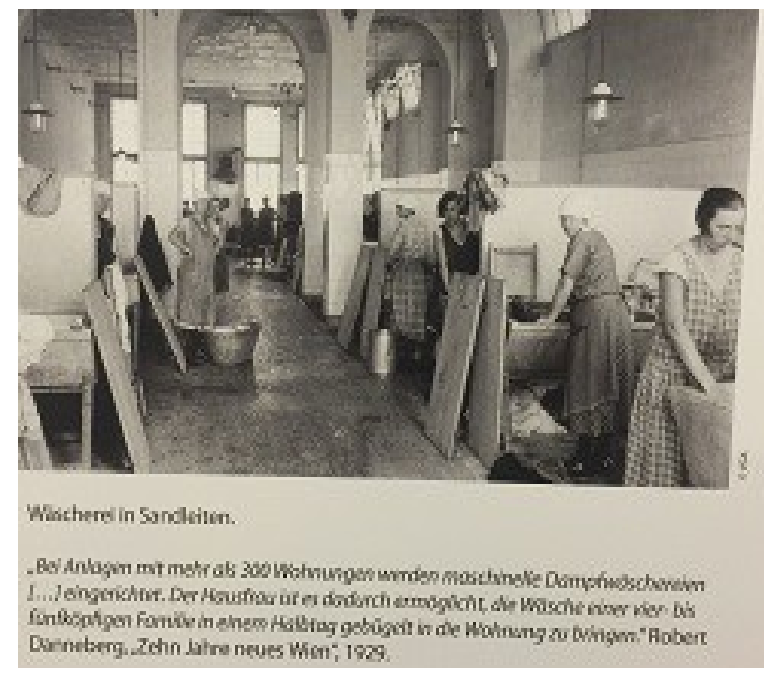

28. Exposición en el recinto de la lavandería de la Karl-Marx Hoff en La Viena Roja. Fotografía de la autora, 2015.

Estos ejemplos de arquitectas parecen justificar las siguientes palabras de Carmen Espegel:

Podría afirmarse que la casa es la arquitectura arquetípica de la mujer. Del mismo modo que Gramsci aserta que no tanto hay «filósofos» como que todos somos filósofos, postulamos que no hay «mujeres arquitectos», aunque todas ellas contienen arquitecto y arquitectura como algo endógeno. Desde una antropología básica, la casa posee un carácter uterino y se manifiesta como un símbolo femenino relacionado con la tumba, el regazo, la matriz, el cobijo y, por tradición, ha devenido el reducto y el territorio de la mujer. (Espegel, 2008: 15)

Quisiera comentar brevemente que esta cita pertenece al libro Heroinas del espacio: mujeres arquitectos en el Movimiento Moderno. No solo el empleo del 
genérico masculino aparece en el cuerpo del texto, sino incluso en el título. Se trata de un libro evidentemente vinculado a la idea de transformación social desde una perspectiva de género, sin embargo, arrastramos la losa del androcentrismo incluso cuando estamos en el camino para librarnos de ella.

Sólo me he adentrado sucintamente en el trabajo de tres de las arquitectas europeas pioneras del siglo pasado, que comenzaron su andadura en el periodo de entreguerras. Pero fueron más y todas, o casi todas, fueron invisibilizadas.

Kim Trogal, en su "Feminine tactics in architecture», dedica un capítulo a la exclusión de las mujeres arquitectas de la historiografía y dice:

Even if a woman is «designated architect» it doesn't necessarily mean that she is part of the historical record. Women have been omitted from architectural history and part of the feminist project must involve recovering this «lost» work. But through examining and questioning the ways in which women have been treated in the architectural profession, something is revealed about the role architects have made for themselves. I have chosen three examples, Eileen Gray, Denise Scott-Brown and Louis Sullivan because they demonstrate several things. Firstly the examples of Eileen Gray and Denise Scott Brown show two of ways in which women in the $20^{\text {th }}$ century have not been valued as architects, they shows that the role of the architect has been invent by men with a specific agenda, and secondly all three examples highlight the desire that exist within the profession for the architect to be understood as sole author or creator of a project, and that this position is a heroic or «masterful» one. The role of the architect as traditionally conceived does not allow women to invent their identity as creators and whitin the profession they are not acknowledged as creators. Nor does the traditional role of the architect allow for collaboration, or collective authoring. Both these things must be key to 
«femininie» practices in architecture and in terms of «feminine» tactics

these precedents must be challenged. (Trogal, 2003: 16) ${ }^{9}$

\subsection{En torno a la Segunda Guerra Mundial}

\subsubsection{De la Bauhaus y su influencia}

En pocos años cambió radicalmente el panorama de la arquitectura en Europa. Los gloriosos años veinte acabaron con la crisis del 29 y el subsiguiente ascenso del fascismo. Estos sucesos influyeron definitivamente en el proceso y en la ruta de modernización de la arquitectura que había florecido en distintas ciudades europeas -París que acogió a Eileen Gray y a Charlotte Perriand; Viena y Frankfurt donde trabajó Margarete Schütte-Lihotzky; y Weimar y Dessau donde las mujeres tuvieron la oportunidad, por primera vez, de ingresar en igualdad de condiciones «formales» en la Escuela de la Bauhaus (19191933), en Alemania, donde tuvo lugar la transformación más profunda.

Los tres directores de la Bauhaus -Walter Adolph Georg Gropius, Hans Emil Meyer y Ludwig Mies van der Rohe- imprimieron su estilo no sólo en la escuela durante su mandato sino también en los lugares a donde se dirigieron una vez la abandonaron. El primero de ellos, Gropius, recibió, en 1922 -mientras Eileen Gray diseñaba en Francia su casa E.1027-, el encargo de la república de Weimar de organizar la primera exposición de la Bauhaus como demostración y símbolo de modernización y progreso del país. Entre los criterios de modernización de la escuela, figuraba la inclusión de las mujeres en la vida social en condiciones de igualdad con los varones. Gropius abrió la escuela a las mujeres, pero restringió sus actividades, sobre todo en lo referente a la arquitectura. Las mujeres se refugiaron en el taller de textiles en su gran mayoría. La preocupación de Gropius fue la fusión de arte y artesanía, de

9. Incluso si una mujer es «designada arquitecta» no significa necesariamente que ella es parte del registro histórico. Las mujeres han sido omitidas de la historia de la arquitectura y parte del proyecto feminista debe implicar la recuperación de esta obra «perdida». Pero tras examinar y cuestionar las formas en que las mujeres han sido tratadas en la profesión de arquitecta, algo se revela acerca del rol que los arquitectos han establecido para sí mismos. He elegido tres ejemplos, Eileen Gray, Denise Scott-Brown y Louis Sullivan porque demuestran varias cosas. En primer lugar los ejemplos de Eileen Gray y Denise Scott Brown muestran dos de las formas en que las mujeres en el siglo XX no han sido valoradas como arquitectas, muestra que el papel del arquitecto ha sido inventado por los hombres con una agenda específica, y en segundo lugar los tres ejemplos ponen de relieve el deseo que existe dentro de la profesión de arquitecto de entenderse como un único autor o creador de un proyecto, y que esta posición es entendida como heroica o «magistral». El papel del arquitecto como tradicionalmente está concebido no permite que las mujeres construyan su identidad como creadoras y dentro de la profesión no son reconocidas como creadoras. Tampoco el papel tradicional del arquitecto permite la colaboración, o la autoría colectiva. Ambas cosas deben ser la clave para «feminizar» prácticas en la arquitectura y en términos de tácticas «femeninas» estos antecedentes deben ser impugnados. (Traducción propia). 
arquitectura e industria. Los talleres de la escuela supusieron un empuje importante para el diseño industrial moderno:

Todos los talleres a partir de ese momento se orientan hacia una mente ingenieril en lugar de medievalista romántica. Todo el alumnado se debe convertir en una estructura mecanizada pero con alma, deben proporcionar modelos para la industria [...]. (Hervás, 2015: 86)

Gropius en 1925 trasladó la escuela a Dessau, al nuevo edificio proyectado por él mismo y por colaboradores como Neufert con los principios de la Bauhaus:

\begin{abstract}
Para su construcción reuní a todo el cuerpo de profesores y estudiantes en un verdadero trabajo en equipo. La dura tarea de coordinar las múltiples facetas del diseño en la construcción real de un edificio fue un éxito rotundo y ninguno de los colaboradores se sintió herido en su amor propio. Por el contrario, el hecho de convertir la escuela en una obra de construcción aumentó la moral del alumnado, que se sentía directamente responsable del trabajo que realizaba. El equipo con el que había soñado, formado con personas inspiradas por una misma voluntad y propósito común, se había convertido en una realidad. (Gropius, cit. en Hervás, 2015: 88)
\end{abstract}

Cuando llegó al poder el gobierno socialdemócrata, Gropius, que había diseñado su proyecto para la escuela con la condición de ser neutral políticamente, buscó a Meyer, reconocido marxista, para que ocupara el cargo de director. Primero lo había intentado con Mies van der Rohe que declinó la invitación. Era el año 1928, mientras Perriand trabajaba en el taller parisino de Le Corbusier, Meyer, en Dessau, abrió la Bauhaus verdaderamente a las mujeres y potenció el departamento de arquitectura en el que impuso el criterio de una arquitectura social para resolver los problemas de la población. Cuando el gobierno cambió de color, Meyer fue destituido y Mies fue nombrado director. Purgó y expulsó a cuantos estudiantes y profesores fueran sospechosos de simpatizar con el comunismo. A pesar de ello, la escuela de Dessau fue clausurada por el gobierno local en 1932. En un intento desesperado por salvar a la escuela del cierre definitivo, Mies la trasladó a Berlín como escuela privada pero, al final, el gobierno nazi la cerró en 1933. Durante la dirección de Mies, Lilly Reich, su compañera en la vida privada y de profesión, fue profesora en la 
Escuela incluso cuando Mies trasladó la Bauhaus a Berlín. El cierre definitivo supuso el final de la Bauhaus y de la relación entre Lilly y Mies quien, en 1938 emigró a EEUU, Gropius lo había hecho 4 años antes. Allí fueron recibidos con admiración y el Movimiento Moderno adquirió con ellos un lugar eminente en la arquitectura del país. En 1932 había tenido lugar, en el MOMA de Nueva York, la exposición The Internatinal Style: Architecture from 1922, presentada por Henry Russel Hitchcock y Philip Johnson, en la que expusieron fotos y maquetas de sus obras Gropius, Mies y Le Corbusier, entre otros. El nombre de la exposición fue adoptado, después de la Segunda Guerra Mundial, para la versión americana del Movimiento Moderno.

Lilly se quedó en Alemania y siguió trabajando hasta su muerte en 1947. La Bauhaus cerró pero Neufert -uno de los primeros alumnos de Gropius desde 1919 y colaborador suyo desde 1921- rompió con el lenguaje de la escuela. Ernst Neufert rentabilizó extraordinariamente sus enseñanzas técnicas. Muy próximo al Führer, de hecho aparece en las Ilamadas Führerlistes, colaboró con el Tercer Reich haciéndose cargo en 1934 de la jefatura de las industrias del vidrio unificadas (VLG), en 1943 como directivo en la Organización Tod (O.T.), en la que proporcionó trabajo a Lilly Reich. La O.T. estaba dirigida por Speer, arquitecto personal de Hitler. Era una organización militar dedicada a la construcción de infraestructuras civiles o militares, como búnkers, líneas defensivas, barracones de los campos de concentración, reparación de infraestructuras dañadas por el bombardeo enemigo -estaciones de ferrocarril, puentes, carreteras, centrales hidroeléctricas-. El arte de proyectar en arquitectura, 1936 -la obra magna de Neufert, de la que no falta un ejemplar en cada estudio de arquitectura del mundo actual y va ya por la 41 edición alemana- fue la guía de construcción del tercer Reich en plena guerra. Gracias a la fama que le otorgó el libro y a su afinidad con el régimen nazi, Neufert, en 1938 es nombrado por Speer comisario para la tipificación, normalización y racionalización de la vivienda en Berlin y a partir de 1939, año en que el Tercer Reich inicia la Segunda Guerra Mundial, se convierte en el representante de la estandarización de la arquitectura industrial alemana. 
Cuando en Alemania comenzó la persecución de los comunistas, Meyer y otros representantes de la otra línea de la Bauhaus, no tuvieron más salida profesional que emigrar hacia países socialistas. En la URSS pudieron desarrollar sus ideas colectivistas dentro de los planes quinquenales del gobierno soviético.

Así, vemos que la Bauhaus, uno de los centros neurálgicos del Movimiento Moderno, durante los años anteriores y posteriores a la Segunda Guerra Mundial y durante su desarrollo, proyectó su estilo en los EEUU y en la URSS.

\subsubsection{La arquitectura local americana}

En lo que concierne al renacimiento del Movimiento Moderno en EEUU, tras la segunda Guerra Mundial, recibió su impulso gracias, a la necesidad de rentabilizar la industria armamentística, reconvirtiéndola en industria de electrodomésticos. Las mujeres arquitectas no faltaron a esta cita, casi todas ellas formando pareja con sus maridos arquitectos y por tanto bajo el apellido de ellos.

Este periodo se caracterizó por la proliferación de proyectos de casas experimentales, diseñadas a propuesta de empresas comerciales deseosas de publicitar sus productos domésticos. Para los promotores, el interés primordial de estas casas no era arquitectónico sino que se trataba de utilizarlas como plataformas publicitarias. Por parte de los arquitectos y arquitectas que las diseñaron, sin perder el punto de vista de quien promovía, fueron concebidas con una mirada integradora de la arquitectura europea que habían desarrollado los maestros inmigrados al país y la arquitectura local.

La función publicitaria perseguida por las empresas comerciales fue ampliamente cumplimentada por las revistas de arquitectura y las exposiciones de los prototipos que se realizaron en museos como el MOMA. La promoción de los concursos, publicación de las revistas y construcción de los prototipos, corrió a cargo de la industria que andaba reconvirtiendo su producción bélica en producción doméstica. La publicidad de un hogar maravilloso lleno de los últimos inventos tecnológicos tenía al menos dos objetivos: hacer atractiva a las mujeres la vuelta a la domesticidad, tras haberse incorporado exitosamente al 
trabajo profesional durante la guerra, y el convertir la unidad familiar en unidad de consumo, tras una larga historia funcionando como unidad de producción.

La publicidad consiguió el propósito de las grandes empresas de la construcción, cada mujer soñaba con una casa moderna y bien pertrechada con todos los nuevos inventos. Se suponía que iban a liberar a la mujer de la esclavitud de las tareas domésticas, pero las nuevas casas y sus sofisticados electrodomésticos multiplicaron las exigencias a las nuevas amas de casa. Pronto surgieron problemas que afectaron a su salud. Las consultas de los médicos se llenaron de mujeres que se encontraban mal y no sabían por qué. El síndrome que apareció fue estudiado por Betty Friedan, «el malestar sin nombre» le llamó; y a su causa la nombró La mística de la femineidad, que da título a un profundo trabajo de investigación, publicado en 1963.

Las arquitectas pioneras que trabajaron en torno a la Primera Guerra Mundial, quisieron facilitar el trabajo doméstico a las mujeres $y$, desde luego, bajo la premisa de que el trabajo doméstico lo iban a desarrollar ellas, diseñaron viviendas que les hacían más cómodo hacerlo. Inconsciente e involuntariamente consolidaron el lugar subalterno de la mujer en la cocina. Pero al menos tenían un cometido importante, eran las expertas en las tareas domésticas. La situación cambió a peor para las mujeres tras la Segunda Guerra Mundial y elPrimera Guerra cambio de la economía de producción por la economía de consumo, a la que la arquitectura no negó su colaboración.

El malestar sin nombre se desarrolló en el interior de los nuevos tipos de vivienda, que se promocionaban como el modelo de un mundo feliz para las mujeres. Casas de ensueño repletas de electrodomésticos que inducían a pensar que ya no tenían que hacerse cargo de las tareas del hogar, pues los aparatos las harían más rápidamente y mejor. Los nuevos modelos de vivienda, diseñados por la arquitectura escaparate, las encerraba en las viviendas como maniquíes sin control sobre sus vidas. De ahí las neurosis, depresiones y malestares varios que no encontraban explicación, pues estas mujeres tenían todo lo que «deseaban» o les habían inducido a desear.

El análisis que realizo a continuación de algunos de los prototipos más famosos de esas viviendas experimentales de ensueño, pretende descubrir elementos 
ocultos en estas casas de vanguardia futurista. Casas de vanguardia que sin embargo mantienen bien sea una estructura, una distribución de espacios y una asignación de funciones que fijan ese rol doméstico de subalternas para las mujeres.

Con el objetivo de estructurar de una manera clara el recorrido que propongo a través de algunas de las casas experimentales o pabellones expositivos de más relevancia del siglo $\mathrm{XX}$, he recogido en la tabla que sigue el itinerario que propongo a través de las viviendas seleccionadas:

\begin{tabular}{|l|l|l|l|}
\hline Año & Título & Proyecto & Autor \\
\hline 1934 & Sylver Bullet & $\begin{array}{l}\text { casa nómada } \\
\text { (caravana) }\end{array}$ & $\begin{array}{l}\text { Hawley Bowlus } \\
\text { Airstream }\end{array}$ \\
\hline 1939 & Casa Gropius & Casa unifamiliar & Gropius \\
\hline 1945 & $\begin{array}{l}\text { Dimaxion Deployement } \\
\text { Unit (DDU) }\end{array}$ & Casa silo & $\begin{array}{l}\text { Buckmister } \\
\text { Fuller }\end{array}$ \\
\hline $1945-49$ & Case Study, House n $^{\circ} 8$ & $\begin{array}{l}\text { Concurso The Case } \\
\text { Study House Program }\end{array}$ & $\begin{array}{l}\text { Charles y Ray } \\
\text { Eames }\end{array}$ \\
\hline 1948 & Casa en el jardin & Moma & Breuer \\
\hline $1954-59$ & Casa Playboy & Revista Playboy & Hugh Hefner \\
\hline 1956 & Apliance Houses & Casas de usar y tirar & $\begin{array}{l}\text { matrimonio } \\
\text { Smithson }\end{array}$ \\
\hline 1959 & Glimpses & Pabellón en Moscú & Nixon \\
\hline 1964 & Casa cápsula & Cápsula de Archigram & Warren Chalk \\
\hline 1964 & Casa búnker & $\begin{array}{l}\text { Feria mundial de Nueva } \\
\text { York }\end{array}$ & Jay Swayze \\
\hline
\end{tabular}


La primera casa nómada o caravana como la llamamos hoy en día surge tras catorce años de prototipado de remolques. Desde 1920 Wally Byam, quien construyó la primera vivienda móvil en 1934, se plantea la construcción de remolques. La casa nómada de 1934 es una vivienda móvil, conocida como Sylver Bullet, fabricada por Airstream y diseñada por Hawley Bowlus.

Es también en esos años, recordemos, en 1937, cuando Charlotte Perriand desarrolla su módulo de baño.

Airstream construyó caravanas durante los años treinta sin aparentemente resentirse por la crisis económica. Al llegar la Segunda Guerra Mundial el negocio sí se verá afectado por la decisión de Estados Unidos de dedicar el aluminio a la fabricación de armas.

De la construcción de casas al estilo de automóviles, sugerida por Le Corbusier, y propiciada por la asociación de la necesidad de casa y automóvil, se pasó a la construcción de caravanas, -casas como automóviles o electrodomésticos transportables y desplegables- y, por último, al automóvil-casa o autocaravana.

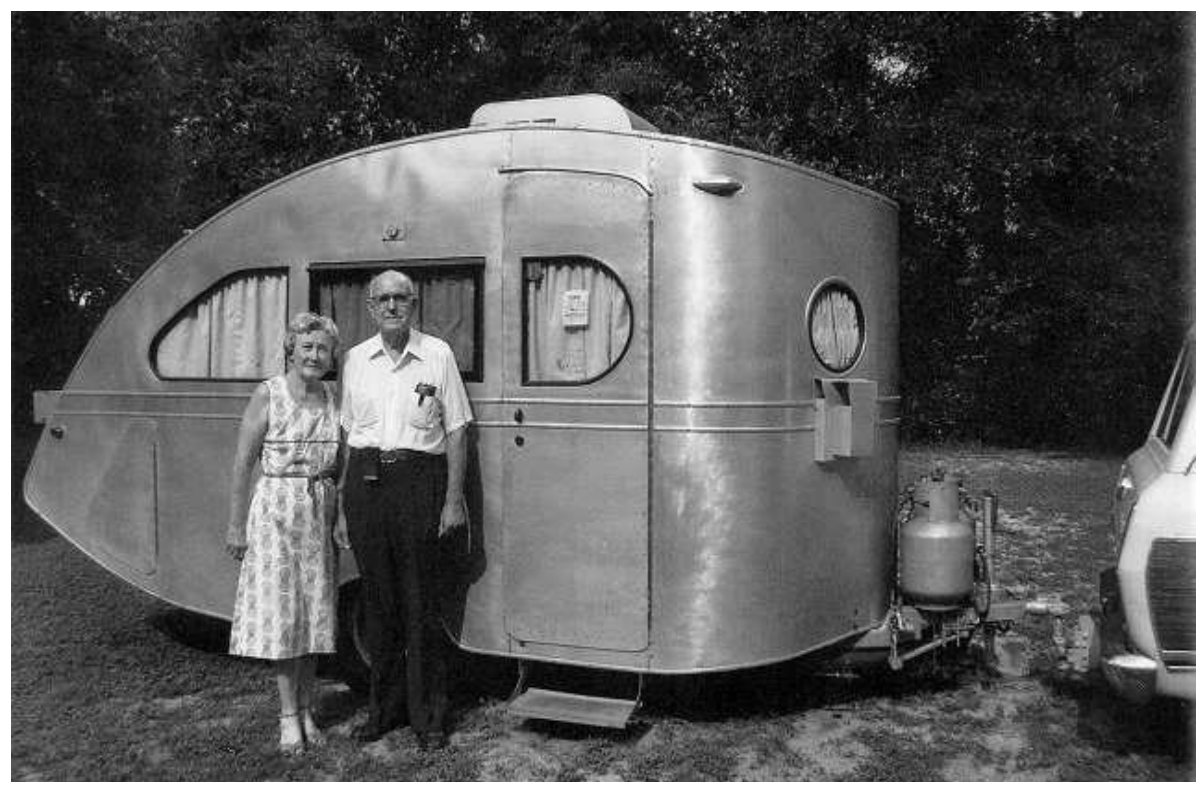

29. Sylver Bullet, el modelo más antiguo data de 1934, 1935. Fuente: Catálogo de Airstream, 2015.

El diseño y la arquitectura consolidaban su unión, pronto sería una fusión y más tarde la arquitectura sería pura imagen, como lo demostró la Feria Internacional de 1964, celebrada en New York. 
En la autocaravana, los roles de género hoy se viven intensamente. Tiene dos asientos principales jerarquizados, piloto y copiloto, se suponen para una pareja heterosexual. Los lugares de poder, la conducción, instalación y mantenimiento del motor son asumidos mayoritariamente por el varón de la pareja recordemos los datos de la DGT-. Lo mismo ocurre con las caravanas que arrastran los coches.

Las tareas domésticas, en un espacio reducidísimo, las asume la mujer, con la alusión, en muchos casos, al hecho de que su tamaño se lo permite con mayor comodidad. Basta la visita de una muestra aleatoria a varios campings actuales para verificarlo, ellas son quienes hacen uso de las mini-cocinas integradas. Podemos encontrar a algún varón asumiendo el rol de cocinero, pero no suponen un porcentaje significativo sobre el total y suelen cocinar en los espacios abiertos preparados para hacer paellas o para las brasas más que en las reducidas cocinas de los remolques vivienda. Si esto es así en la actualidad en el mundo occidental, no es arriesgado conjeturar que así era hace casi un siglo, en el inicio de este tipo de casa.

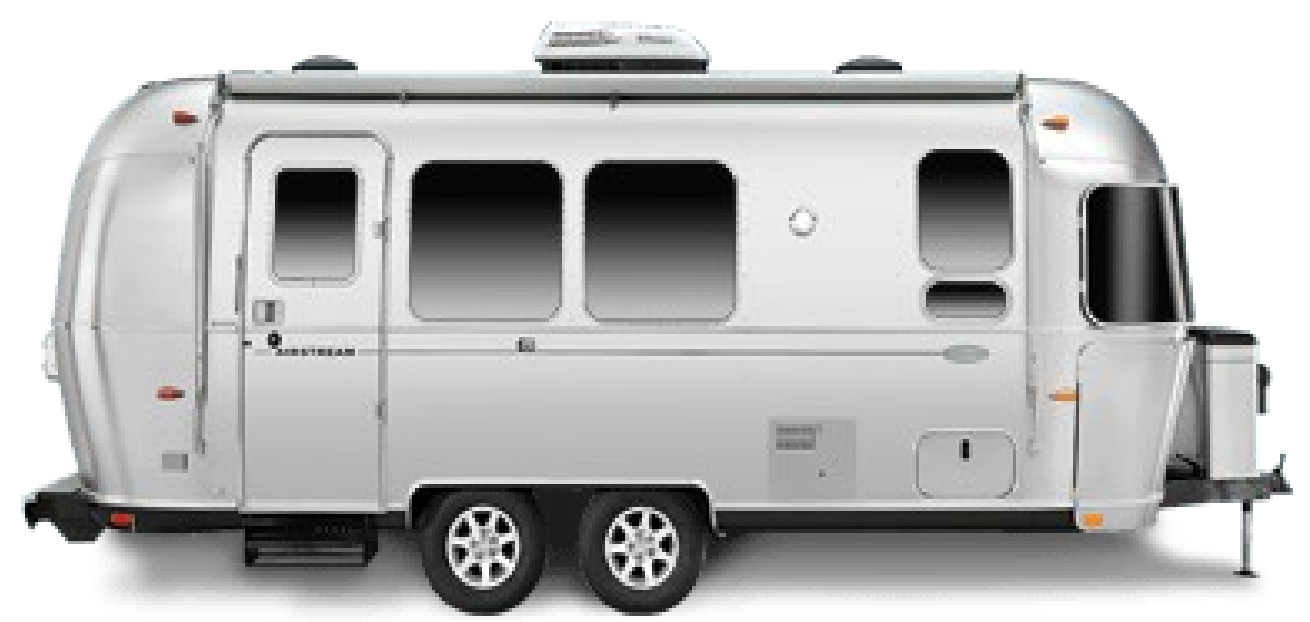

30. Caravana Airstream moderna, 2015. Fuente: Catálogo Airstream, 2015. 
El 1 de septiembre de 1939 estalló la Segunda Guerra Mundial. Gropius se había exiliado a EEUU en 1937. Walter Gropius suponía una buena adquisición para un país que en 1932 se había adherido oficialmente al Movimiento Moderno con la exposición International Style organizada por el MOMA de New York.

El Movimiento Moderno, como ya hemos visto, se desarrolló en Europa en torno a los años de la Primera Guerra Mundial. El año 1923 fue clave para éste. Entre otros acontecimientos, se publicó Vers une Architecture de Le Corbusier y se realizó la primera exposición de la Bauhaus. Las técnicas, los materiales y los métodos de la industria de guerra se tomaron prestados. Gropius llevaba ese equipaje en su viaje a América y lo casó con la tradición del país de acogida.

Tras la decisión de establecerse con su familia en Lincoln, Walter Gropius proyecta su propia casa unifamiliar en colaboración con Marcel Breuer. El propio Gropius explicó que la casa fue diseñada en 1939, teniendo en cuenta la tradición de Nueva Inglaterra y los estándares que se habían planteado en la Bauhaus, así como el clima de Lincoln y el paisaje. Todo ello le llevó a proyectar una casa donde la luz era el elemento primordial. Cabe destacar la utilización de la diagonal en la planta de acceso y especialmente en este texto merece mención la cocina.

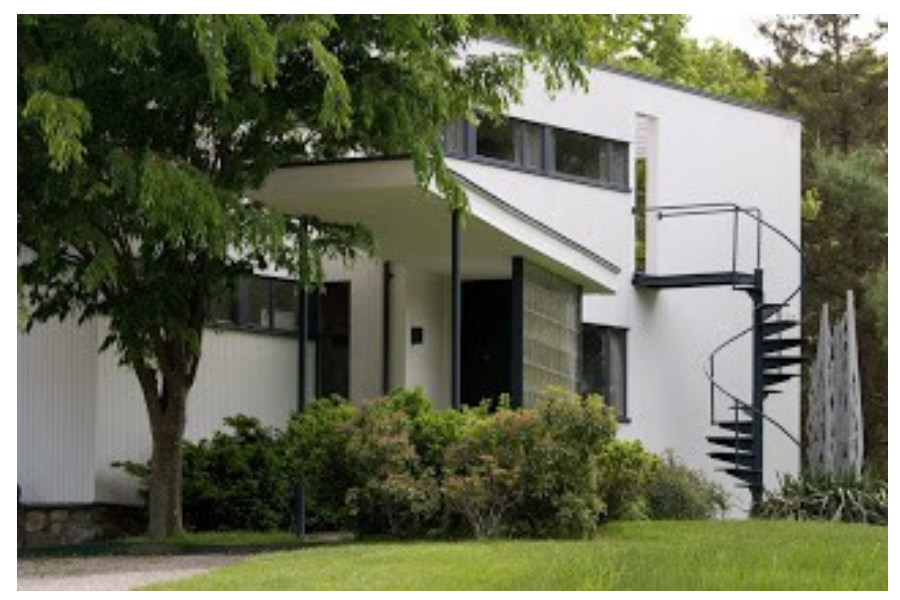

31. Gropius: House and Garden, 1939. Fuente: Ken Schwarz, 2016. 
La cocina de la casa Gropius presta atención a aspectos muy concretos de eficiencia y funcionalidad. Los colores empleados en esta cocina son un claro reflejo de la procedencia de Gropius. Utiliza el negro, el blanco y el gris, aplicando rojo únicamente en los detalles. La Bauhaus latía en él.

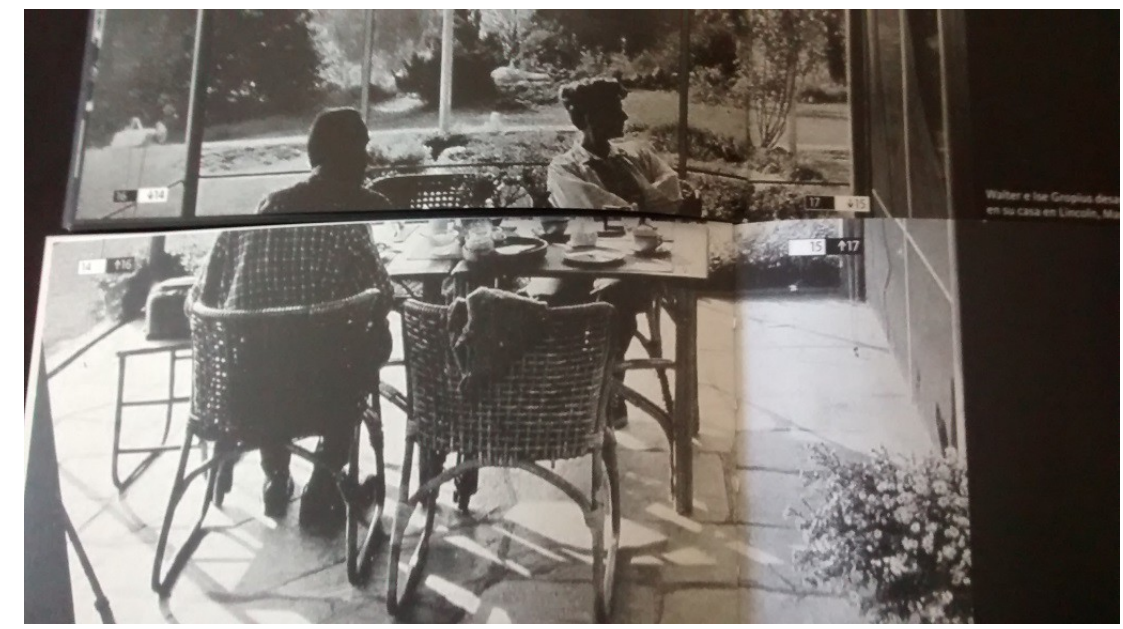

32. Gropius y su esposa, en la terraza, mirando hacia el interior. Fuente:

Colomina, 2006.

Es importante notar que las aberturas que iluminaban la casa no tenían como objetivo dirigir la mirada hacia el exterior. En los proyectos de Le Corbusier o August Perret dirigir la mirada de un modo determinado hacia el afuera formaba parte de lo pretendido. Perret concebía las ventanas como marcos a escala humana que encuadraban la perspectiva del paisaje. Le Corbusier cambió el estilo de las ventanas verticales, defendidas por su maestro, por las ventanas horizontales, como pantallas de cine, para contemplar el paisaje al deambular por las estancias como en un travelling. (Colomina, 1988: 636).

Los acristalamientos de Gropius pretendían llevar la luz al interior, era una propuesta de cambio de estilo de vida. El deseo se dirige hacia el interior, allí está la felicidad, el hogar dulce hogar, el estilo Good Life. El propio arquitecto es sujeto de ese estilo de vida. Ya no aparece fotografiado seriamente junto a su obra como un profesional, ahora vende la imagen de una vida idílica en compañía de su esposa Isa, disfrutando de su preciosa casa burguesa.

Walter Gropius es profesor de arquitectura en la prestigiosa universidad de Harvard. Es uno de los líderes del Movimiento Moderno europeo. La exposición a la luz pública de su estilo de vida es una invitación a profesionales y a 
clientes, a las mujeres americanas de clase media en particular. Con el estallido de la Segunda Guerra Mundial el centro de gravedad de la arquitectura moderna se desplaza a América. El Estilo Internacional será contemplado desde Europa como antes América contemplaba al Movimiento Moderno.

Europa está sumida en el conflicto bélico. En Estados Unidos entre 1941 y 1945 Buckminster Fuller desarrolla la Dymaxion Deployment Unit (DDU). Tras seis años y un día, el dos de septiembre de 1945 acaba la Segunda Guerra Mundial. El mundo se enfrenta al inicio de la Guerra Fría. La DDU es vista como solución habitacional tanto en el periodo de guerra como tras él.

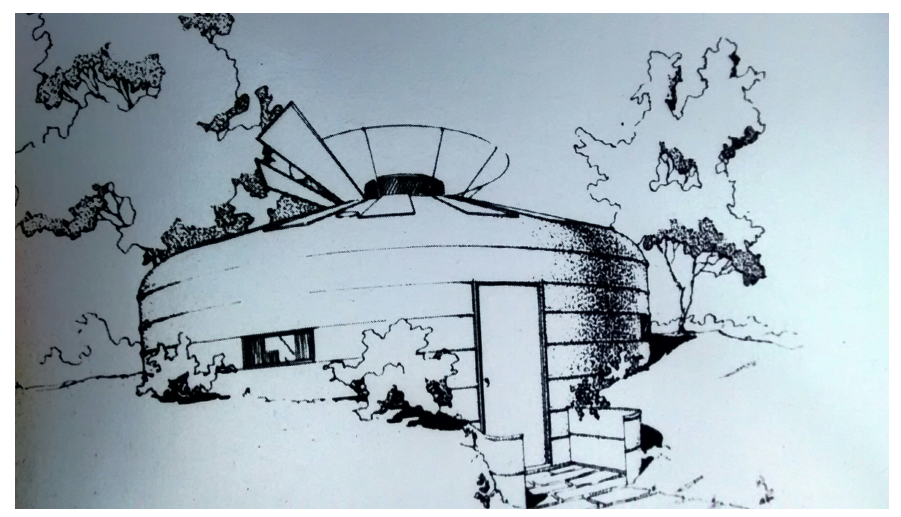

33. Buckmister Fuller. DDU, boceto. Fuente: Colomina, 2006.

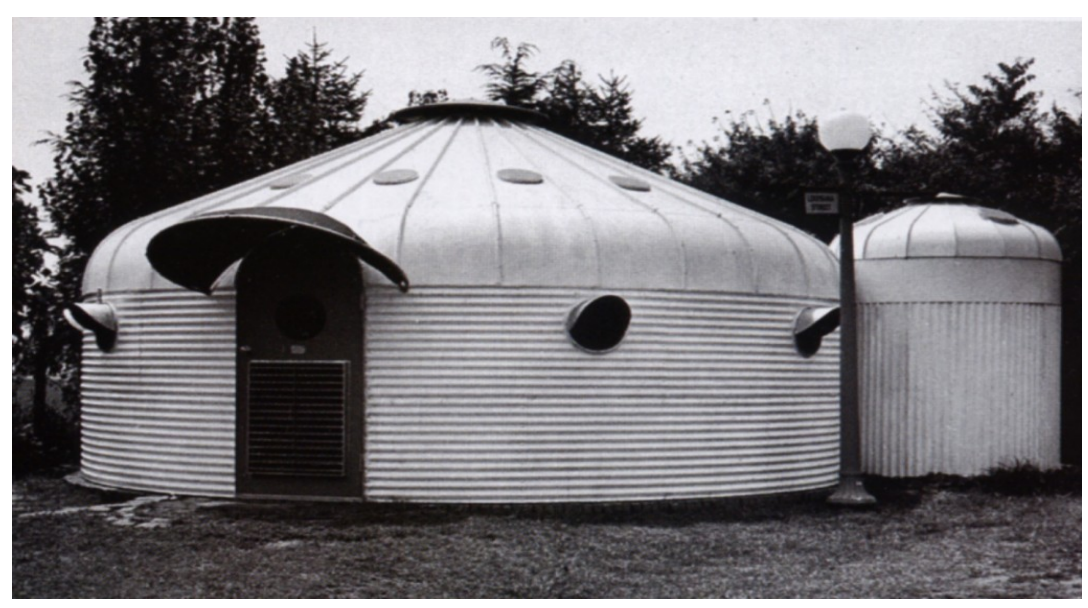

34. Buckmister Fuller. DDU, reproducción. 1945. Fuente: Cristina Rojo, 2014. 
Sobre la anécdota que inspiró a Fuller la DDU, cuenta Cristina Rojo:

[...] recorría el medio oeste americano con su amigo novelista Christopher Morley. Era noviembre de 1940 y ambos quemaban kilómetros en busca de ciertas cartas perdidas de su admirado Edgar Allan Poe. De si encontraron las cartas o no, no hay constancia, pero lo que sí ha trascendido hasta hoy es que, durante aquel viaje, Fuller quedó impresionado por los contenedores de grano metálicos que se alineaban a ambos lados de las carreteras de Illinois

En cualquier caso, Fuller averiguó el nombre de los fabricantes de los contenedores de grano y, en pocos meses, convirtió una de las estructuras de acero de Butler Manufacturing Company («A prueba de fuego, climatología y desperdicios») en un prototipo de vivienda de emergencia. Su ligereza y precio económico (cada una de ellas estaba valorada en 1.250 dólares) hacían de estos espacios un remedio que podría enviarse a cualquier lugar del mundo y servir como refugio en un bombardeo. Poco tiempo después, el Ministerio de Defensa norteamericano y Fuller firmaron un acuerdo para desarrollar 200 de estas viviendas en el menor tiempo posible. (Rojo, 2014: 1)

La DDU es un ejemplo paradigmático de las posibilidades de reconversión de una industria. En un principio fueron silos, bidones herméticos para salvaguardar el grano de roedores e incendios. Buckminster Fuller entendió las posibilidades que ofrecían para convertirlos en unidades habitacionales domésticas, al estilo del Movimiento Moderno, fabricadas en serie, fáciles de transportar, muy baratas y seguras. Se publicitaron como refugios, convertibles en tiempos de paz en casa para invitados en el jardín o casa de verano en la playa, pero las ilustraciones hablan de su aptitud para un uso cotidiano de familias trabajadoras. El primer prototipo se instaló fuera de la misma fábrica Butler. 


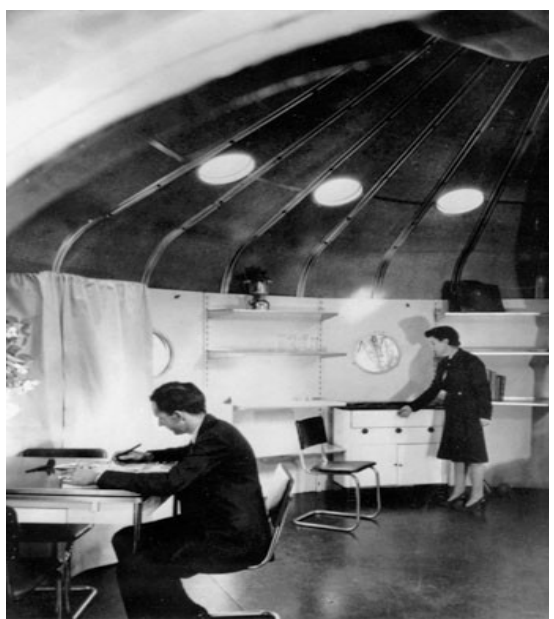

35. The Round House Project -

Dymaxion Deployment Unit (D.D.U.),

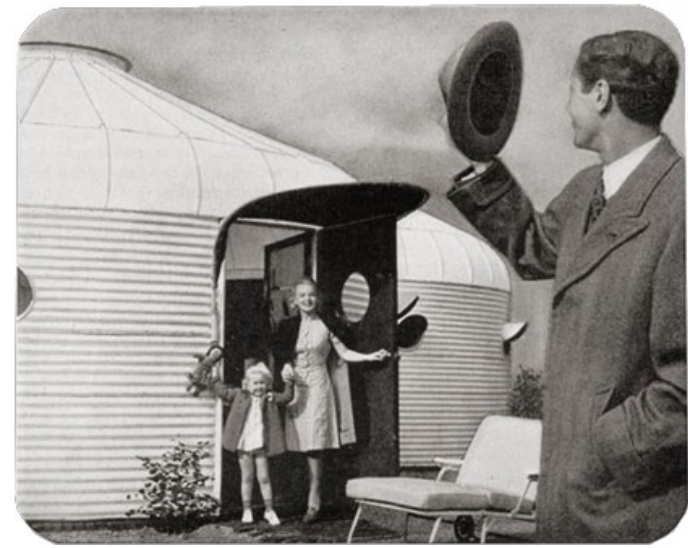

36. Advertising leaflet for the Dymaxion Deployment Unit, 1940. Autora: Suzanne Junker.

En los folletos de propaganda de la factoría Butler, el uso estereotipado de la DDU, bajo el punto de vista de género, queda más que patente. La DDU no recogía sólo la idea corbuseriana de fabricar casas como objetos industriales, también mostraba la vuelta al hogar de las mujeres que habían ocupado los puestos de trabajo de los hombres durante la guerra. Y las devolvía a su lugar, al lugar de la domesticidad, de la subalternidad. Además, en un hogar tan reducido era impensable alojar en él a la familia extensa. Se vendía así, a la clase popular, el modelo de familia nuclear generado en el siglo XIX por la burguesía, creando una grave contradicción. En este modelo la mujer no trabaja fuera pues es el varón quien debe mantener a la familia, ni dentro, pues el poderío económico del varón burgués alcanza a pagar el servicio doméstico. Pero ese modelo es inalcanzable para la clase obrera porque un jornal no alcanza para el sustento y la mujer tiene que aportar su salario. Sin embargo, el secreto está en que se les hizo creer que podían aspirar a ese modelo burgués de familia nuclear, con un ángel del hogar dedicado exclusivamente a velar por la casa y la familia. Se les hizo creer y la aspiración llevó a una evolución que suponía la aceptación de la doble jornada. La jornada laboral asalariada y la de las tareas domésticas, menos reconocidas desde ese momento si cabe de lo que lo habían estado. Las tareas domésticas son ignoradas, se hacen solas, las máquinas lo resuelven. 
No se pudieron construir en serie estas viviendas porque la Segunda Guerra Mundial había comenzado en Europa pocos meses antes y el acero de EEUU era consumido por las fábricas que suministraban el armamento a los aliados.

Sin embargo dentro de la política industrial de abastecimiento a los ejércitos aliados, la DDU encontró una posibilidad: el ejército británico hizo un pedido para utilizarlas como barracones para sus tropas.

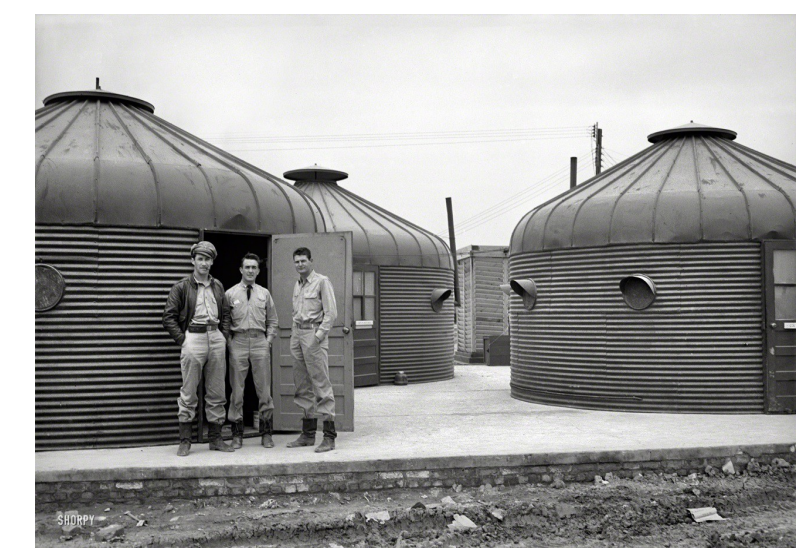

37. U.S. pilots stand in front of a cluster of $D D U$, North Africa,

1944. Autor: Alastair Gordon.

Como los Ready Mades, las casas silo no tenían pretensiones estéticas, puesto que se trataba de un rudo objeto industrial sin más pretensión que su utilidad. Se adaptaba así, a los planteamientos utilitaristas que Fuller defendió siempre como su objetivo expreso en todas sus investigaciones arquitectónicas, desde la DDU a las cúpulas geodésicas cuyo esqueleto es semejante a las costuras de un balón de fúbol, permitiendo construir una superficie casi esférica a partir de elementos rectilíneos y planos.

En noviembre de 1941, la DDU se convierte en un verdadero Ready Made. EI último requisito del «test de autentificación de un Ready Made» según Duchamp, se cumplió al ser expuesta en un museo, el Museo de Arte Moderno de New York. La DDU se instaló en el patio del MOMA. Los otros requisitos los cumplió desde un principio: El rendez vous del objeto con el artista fue el primer requisito del «test», ya que Fuller no eligió al objeto, el objeto le eligió a él en aquel viaje de 1940 por Missouri, justo un año después de que la Metro estrenara $\mathrm{El}$ mago de Oz. Los brillantes bidones asentados entre los campos de cereales le asemejaban a Fuller, por asociación, naves espaciales a punto de 
volar, como la casa del Mago de Oz. Por otra parte los silos para guardar el grano también cumplían con la condición de ser un objeto cotidiano. Tan cotidiano como el urinario de Duchamp. También cumplían el requisito de estar producidos en serie, pues la casa Butler fabricaba en serie los silos y por ello el encargo de las DDU se le hizo a la misma empresa. Y por último, el 21 de marzo de 1941, Fuller solicita la patente y se materializa el acto de inscripción exigido por el test de Duchamp.

En diciembre de 1941, se produjo el ataque a Pearl Harbor. El proyecto de construcción de barracones para el ejército británico fue abortado. EEUU entraba en guerra. Ahora todo, absolutamente todo el acero disponible iba a ser destinado a las fábricas de armamento para el uso de su propio ejército.

\subsubsection{El Estilo Internacional}

1945-49. Acabada la Segunda Guerra Mundial, se repitió en EEUU el proceso de reconversión de la industria que ya había tenido lugar en Europa al finalizar la primera gran guerra. El mercado iba a inundarse de nuevos productos de consumo. Tanto en el Este como en el Oeste, surgieron propuestas de la industria para la construcción de casas que publicitarán esos nuevos productos. En el Oeste, la revista Ars\&Architecture convocó el concurso Case Study, apoyada por los fabricantes de los más novedosos enseres domésticos. Los arquitectos y arquitectas ganadoras verían ejecutada su obra, con cargo a las empresas productoras de los objetos, electrodomésticos y materiales expuestos en los diseños.

El matrimonio Eames proyectó la House $n^{\circ} 8$ del Case Study. La casa debía ser fácil de producir en serie, barata, ligera de transportar y rápida de montar. Además flexible para readaptarla a los distintos usos de su historia.

El objetivo no fue cubierto, pues no se llevó a cabo su producción en serie, pero la casa y el trabajo de los Eames se convirtieron en un referente casi universal. La imagen de la casa escaparate sí que fue reproducida en serie y utilizada por famosas revistas de moda como Life y Vogue. Ellos mismos se fotografiaron 
infinidad de veces en la casa durante su construcción y luego durante las sucesivas transformaciones. Las revistas de arquitectura la difundieron por todo el mundo y llegó a Europa como un regalo que recogieron Alison y Peter Smithson, entre otros.

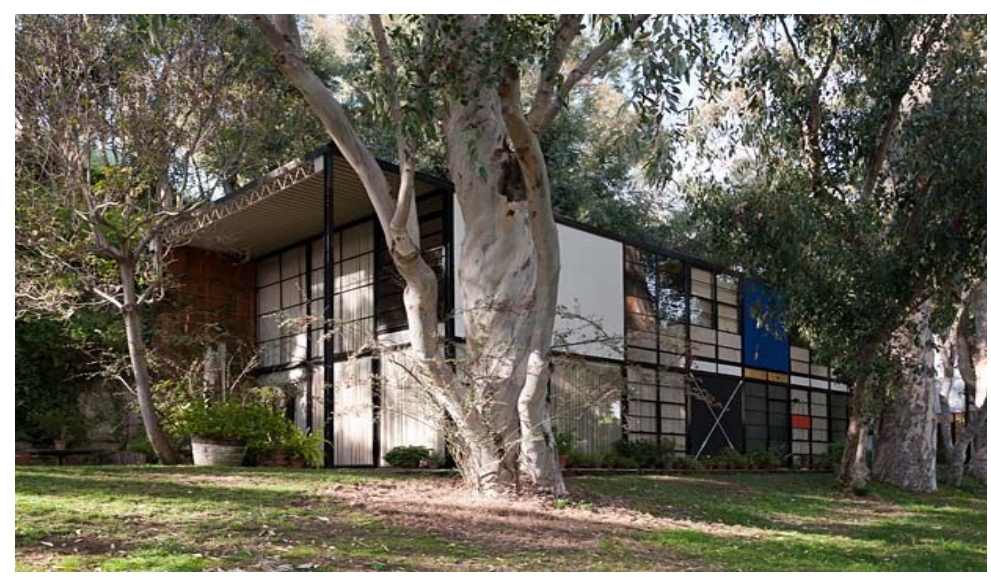

38. Matrimonio Eames. La casa de los Eames. Obsérvese en la fachada el estilo Piet Mondrian. Pacific Palisade, California, 1949. Autor: Quintin Lake.

Era como un viaje de ida y vuelta en el que las propuestas de la primera generación del Movimiento Moderno eran recogidas y transformadas por la segunda generación, protagonista del Estilo Internacional y difundida hasta llegar a manos de la tercera generación de arquitectos modernos. Estos últimos, a su vez, modificaron los proyectos de la primera y la segunda generación, planteando sustanciales diferencias, como veremos a continuación.

La casa de los Eames es una casa de esqueleto y piel, como defendía Mies Van der Rohe, pero no respetaba la pureza del estilo moderno, pues ellos llenaron la casa de objetos e imágenes que consideraban parte fundamental de su proyecto arquitectónico, desobedeciendo así el principio minimalista de Mies «menos es más». Para los Eames, los objetos eran el lenguaje en que se escribía la biografía de la casa y de sus habitantes y su disposición era importante, formaba parte de la composición pictórico-escultórico-arquitectónica. La arquitectura era para ellos un proceso. La estructura y la piel eran el contenedor de la vida que se iba a desarrollar en su interior y que iba a continuar construyendo la casa. 
Ray era pintora, creadora de la piel de la casa, y Charles arquitecto, responsable del esqueleto, siempre trabajaron juntos, sus diseños eran conjuntos; y el concepto clave que les permitía unificar sus proyectos arquitectónicos era el juego de composiciones. Juego de composiciones bien de los elementos prefabricados de la propia estructura de su casa o los paneles que cubrían el esqueleto metálico a lo Mondrian, bien los objetos, muebles y cuadros en su interior o los elementos de una mesa de desayuno.

Inglaterra, en la segunda postguerra está arrasada. La propaganda que llega de EEUU a través de las revistas, permite soñar en un mundo de feliz abundancia, brillante, colorista, lúdico, tal como lo expusieron los Eames. Ya que la realidad es paupérrima, la colección de bellas imágenes produce la fantasía de estar cerca de ese mundo feliz.

En ese camino de ida y vuelta, antes aludido, la primera generación de profesionales de la arquitectura, defensores de los espacios vacíos, Le Corbusier a la cabeza, llevaron el Movimiento Moderno a EEUU. En este país, los receptores del Movimiento lo internacionalizan y mantienen el criterio de construir espacios vacíos, pero para llenarlos con objetos que forman parte de la composición arquitectónica. El matrimonio Eames será el referente. En la Gran Bretaña de postguerra, las revistas que llegan de EEUU son el alimento para la tercera generación, que también defenderá los espacios vacíos, con lo que ello conlleva estructuralmente, pero para permitir que ese espacio lo llenen los objetos que construirán las biografías de sus habitantes. El matrimonio Smithson lo ejemplificó en su muestra Patio \& Pavillion. 


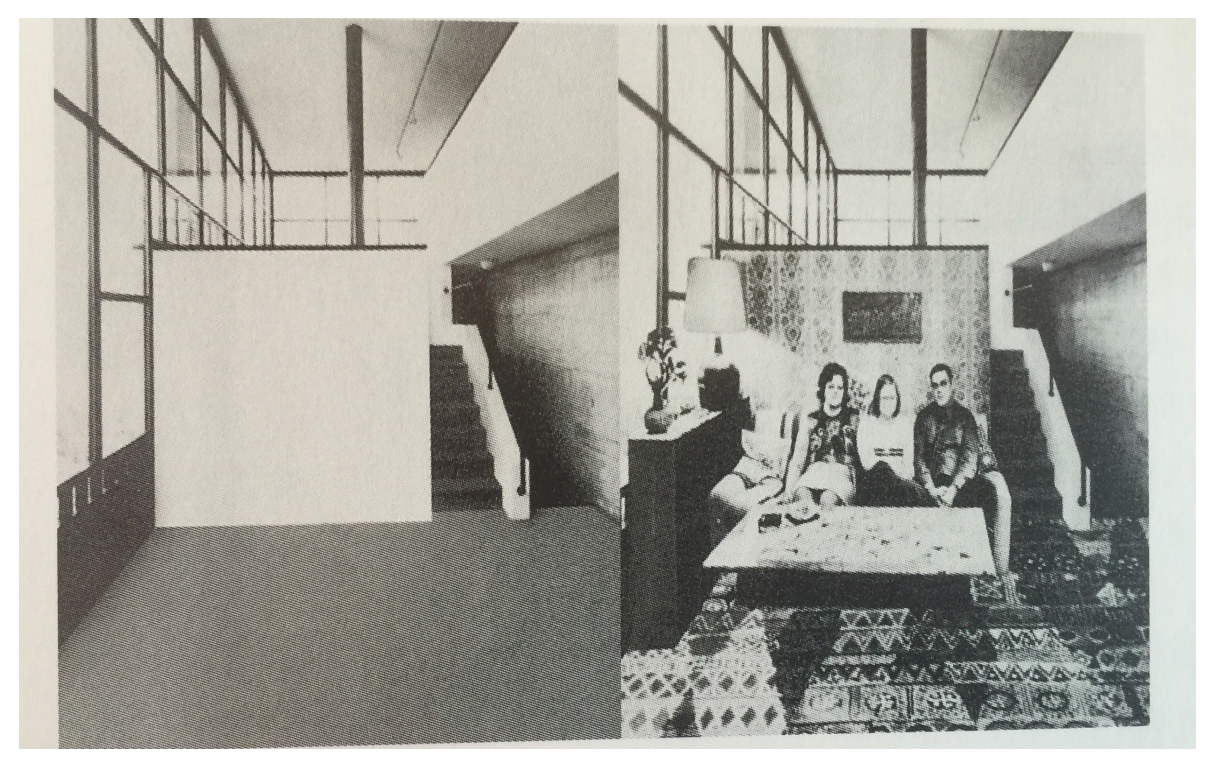

39. Jean-Pierre Junker. A la izquierda, según miramos, espacio vacío, típico de la primera generación, a la derecha el espacio habitado destruye la propuesta arquitectónica de autor, 1990.

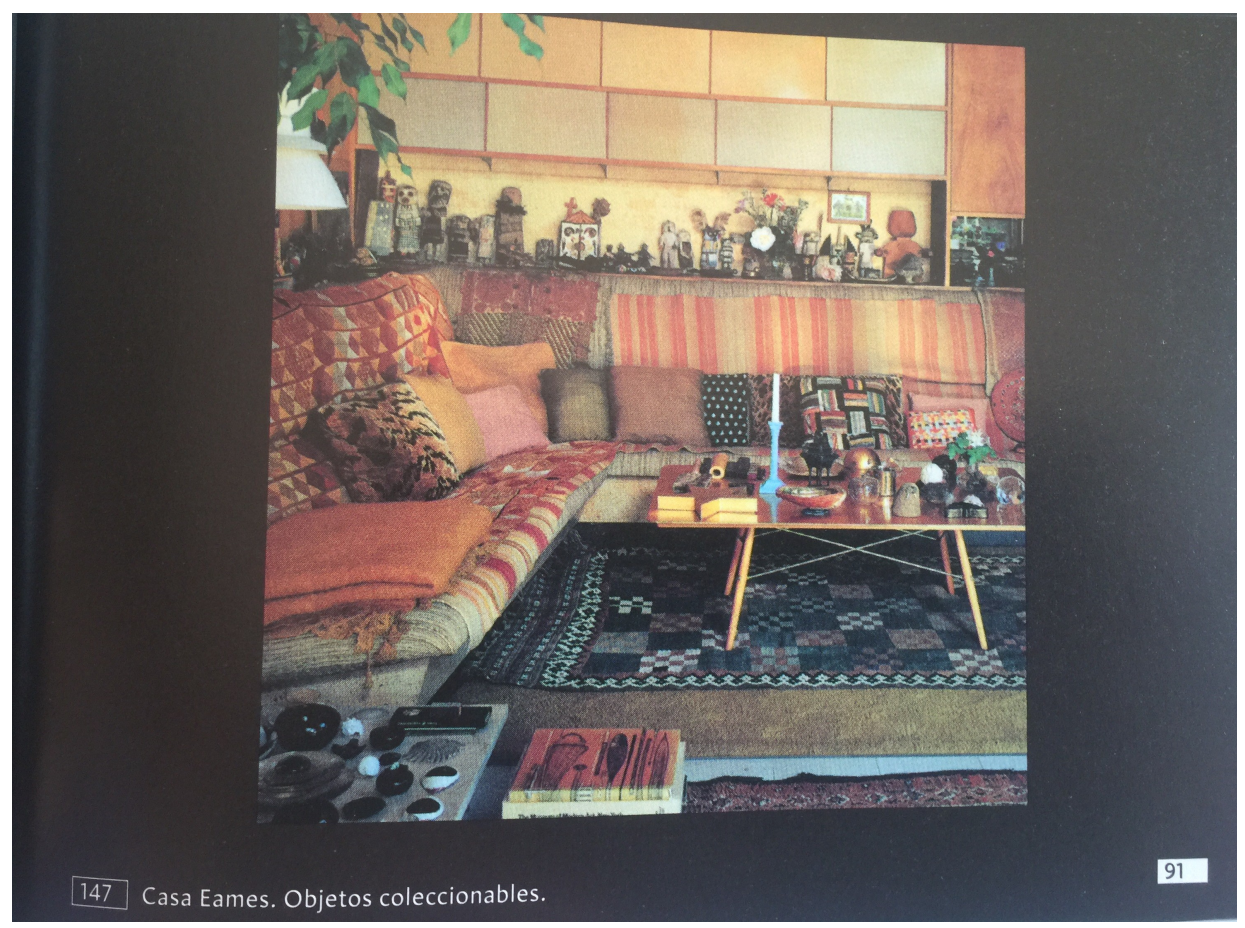

40. Espacio ocupado por los objetos coleccionables del matrimonio Eames, segunda generación. Fuente: Colomina. 2006. 


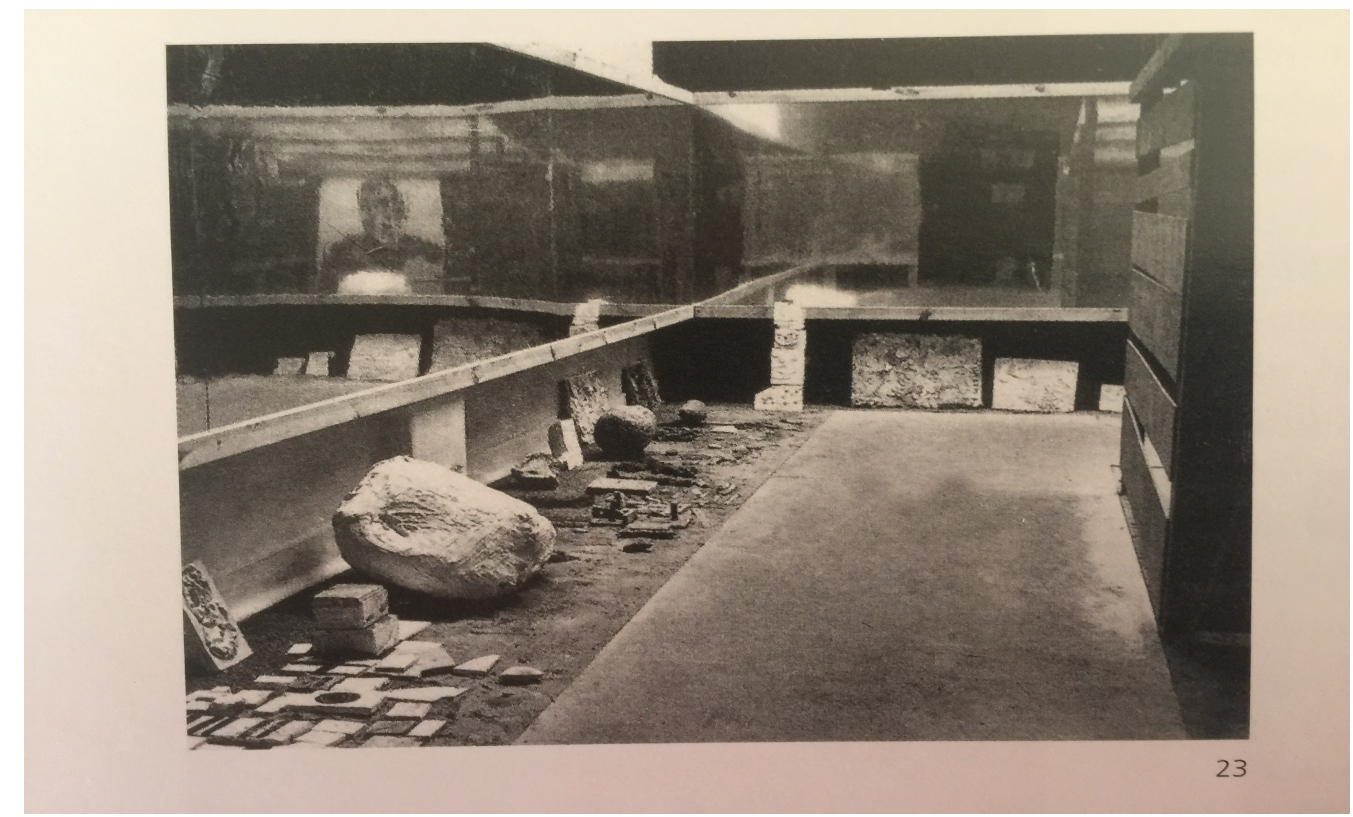

41. Patio \& Pavillion, del matrimonio Smithson, tercera generación, ocupado por objetos fósiles y restos cerámicos simbolizando el pasado de los habitantes de Patio \& Pavillion. Fuente: Nieves Fernández Villalobos, 2013.

El MOMA, colaboró activamente en la poliédrica tarea propagandística de vender artilugios, imponer un estilo de vida y asignar roles convenientes al momento sociopolítico y económico.

La casa de Breuer, instalada en el jardín del MOMA, era más un artefacto propagandístico que se apropiaba de la fama del propio MOMA, que una obra de arte en un museo, como bien lo expone Colomina en su obra La domesticidad en guerra:

La casa estaba dentro del Museo pero al mismo tiempo separada de él, poniendo así en cuestión su estatus como objeto de arte. Esta disposición refleja la nueva comprensión de la arquitectura como un entorno de good life, un tipo de vitrina de exposición para objetos de consumo más que una forma de arte. [...] Los planos de la casa se pusieron a disposición del público. La casa no era un objeto de arte único. Era un prototipo. [...] al convertirse las casas modelo en inseparables del conjunto de productos que exhibían, la arquitectura doméstica quedó absorbida por un flujo de imágenes, y una nueva 
forma de domesticidad surgió de las imágenes mismas. [...] lo radical de la casa no es la forma sino el contexto: la idea misma de exposición en el jardín del museo, diseñada para un commuter más que para un coleccionista de arte (el cliente tradicional de la arquitectura moderna), según una lógica militarizada de producción en serie, destinada a los suburbios anónimos de clase media-alta. (Colomina, 2010: 8, 40-41, 47)

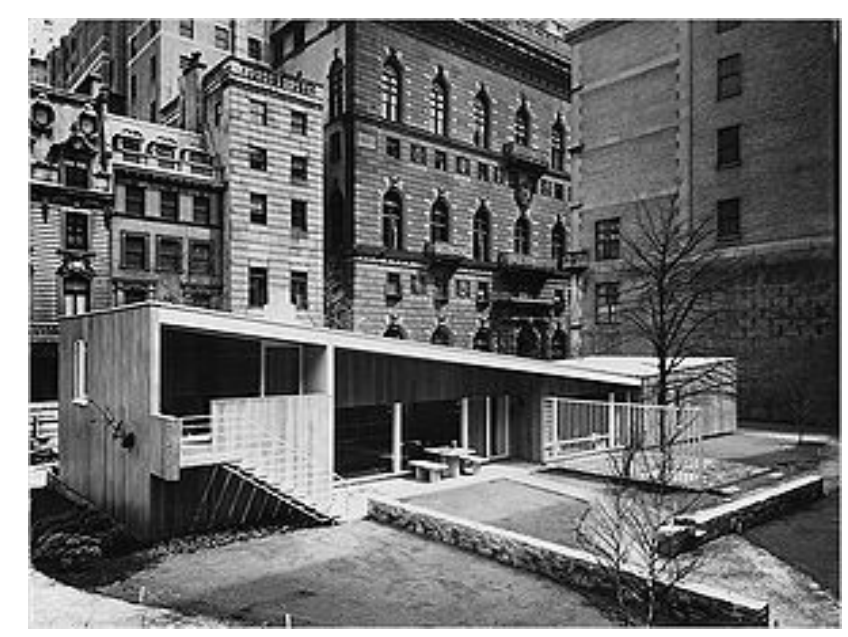

42. Marcel Breuer: La casa en el jardín. Instalada en el MOMA, 1949.

Como afirma Beatriz Colomina «El giro desde la producción en masa hasta el consumo de masas no lo llevan a cabo sólo los Eames» (Colomina, 2010: 40). En el este de EEUU, el escaparate de las casas que iban a publicitar los nuevos artefactos domésticos, artefactos y escaparates ellas mismas, fue el MOMA, en colaboración con fabricantes, almacenes y revistas en general. Las empresas que fabricaban dichos artículos utilizaron las fotografías de la casa en el jardín del MOMA para sus folletos publicitarios y su publicidad en los mass media. De hecho Bloomingdale's dobló las ventas de varios artículos de cocina, expuestos en las casas en el jardín del MOMA.

La casa en el jardín de Breuer, cuyo primer proyecto en esta línea realizó conjuntamente con Gropius, estaba concebida como vivienda para una familia nuclear de clase media que vive en una casa ajardinada unifamiliar, situada en las proximidades de la ciudad, la residencia en las afueras, la vivienda suburbana. En suma, era el modelo propuesto para la emergente clase media americana, creada como arma en la guerra fría contra los países socialistas, 
pues, esa nueva clase estaba destinada a opacar la lucha de clases. Nixon abogó por el modelo americano, ante Khrushchev, en el seno de «Los Debates de la Cocina» que tuvieron lugar con motivo de la Exposición Internacional Americana en Moscú en 1959:

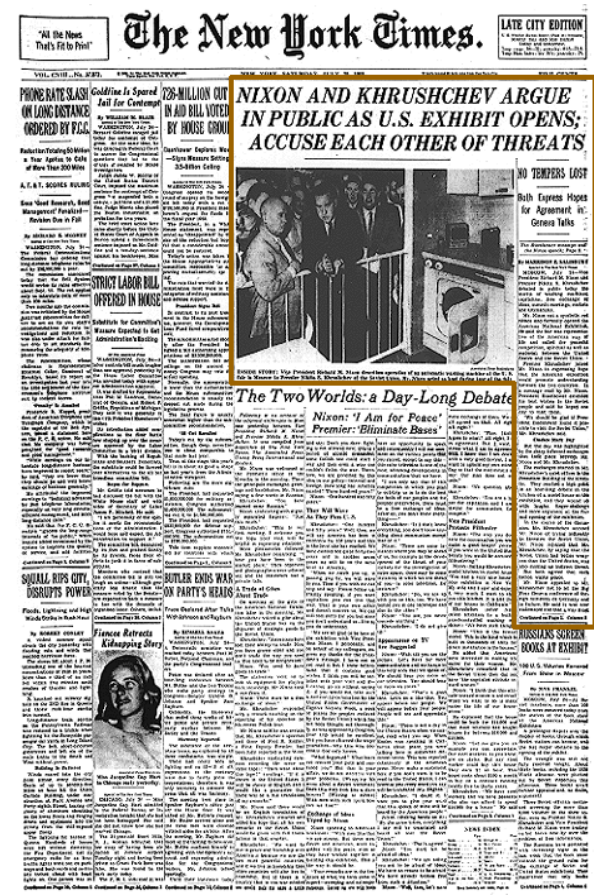

43. New York Times, 1959.

En el New York Times de 1959, se podía leer:

[...] I want to show you this kitchen. It is like those of our houses in California.»

Khrushchev (after Nixon called attention to a built-in panel-controlled washing machine): «We have shuch things.»

Nixon: «This is the newest model. This is the kind which is built in thousands of units for direct installation in the houses»

He added that Americans were intersted in making life easier for their women. Mr. Khrushchev remarked that in the Soviet Union they did not have «the capitalist attitude toward women ${ }^{10} .(N Y T, 1959: 1)$

10. Nixon: Quiero mostrarle esta cocina. Es como las de nuestras casas en California. (Nixon señalaba la lavadora de platos).

Khrushchev (después de que Nixon le señalara una lavadora en uno de los paneles): También nosotros tenemos esas cosas.

Nixon: Pero este es nuestro modelo más reciente. Del que ahora se construyen miles de unidades para las instalaciones directas de las casas. Añadió que los americanos están interesados en hacer la vida más fácil a sus mujeres... 
Donileen R. Loseke, en su obra Methodological thinking. Basic Principles of Research, detalla el párrafo en el que Nixon habla de cuidar al ama de casa americana, a colación de las lavadoras:

To us, diversity, the right to choose $\ldots$ is the most important thing ... We have many different manufacturers and many different kinds of washing machines so that the housewives have a choice ... What we want to do is make easier the life of our housewives. («The Two Wordls,» 1959), (cit. en Loseke, 2013: 164) ${ }^{11}$

Estas cuatro líneas de la cita de Losenke constituyen una síntesis de la cooperación entre el capitalismo y el patriarcado: el industrial, varón, vende lavadoras y el político patriarcal asigna la responsabilidad del lavado a la mujer que ubica en el rol de ama de casa. El supuesto cuidado consiste en que el ama de casa puede escoger la lavadora. Yo me pregunto ¿puede realmente escoger? ¿Es libre su deseo, bombardeado por la publicidad a gran escala? Y ¿puede escoger ser o no ama de casa? ¿Acaso no la bombardea la misma publicidad que le impone el rol? No sólo es secuestrado su deseo por la luminosa y colorida publicidad, sino que esa publicidad la convierte a ella misma en objeto, en objeto de deseo del otro, del que puede elegir y elige, porque puede nombrar y valorar, y lo hace, y puede ocupar, y ocupa, todos los espacios, el centro y la periferia, lo público y lo privado, porque es él quien los nombra, los crea, los define y los asigna dinámicamente, según sus deseos.

También los varones fueron objeto de esta manipulación. Hubo alguien que sí valoró la revolución arquitectónico-lúdico-mediática de los Eames, Hugh Hefner lo hizo:

Kruschev remarcó que en la Unión Soviética «No tenemos esa actitud capitalista hacia las mujeres.» (Traducción propia).

11. Para nosotros, la diversidad, el derecho a elegir, es lo más importante [...] No hay un gobierno oficial que decida por nosotros [...] Hay muchos fabricantes diferentes y muchos tipos distintos de lavadoras, de modo que el ama de casa puede escoger. (Traducción propia). 
Mientras las revistas locales como Ladies Home Journal o House Beautiful habían emprendido durante la posguerra una cruzada contra la arquitectura de Mies van der Rohe o Le Corbusier, considerándola ajena a las tradiciones autóctonas americanas, Playboy publicaba elogiosos artículos sobre Mies van der Rohe, Walter Gropius, Philip Jonson, Frank Lloyd Wright o Wallace K. Harrison, y utilizaba sus páginas como soporte de diseños simples, funcionales y modernos de los Eames, Saarinen, George Nelson, Harry Bertoia o Knoll y otros diseñadores y arquitectos para entonces vinculados directa 0 indirectamente con el «International Style». Durante la guerra fría, Playboy se había convertido en una plataforma de difusión de la arquitectura y el diseño como bienes centrales de consumo de la nueva cultura popular americana. (Preciado, 2010: 16)

Si los Eames fueron los pioneros en la producción de imágenes que colonizarían las mentes de todo el planeta, Hefner fue su amplificador y distribuidor: en seis años consiguió pasar de los 250.000 ejemplares distribuidos en su primer número (1953) a seis millones en 1959 que se difundieron por toda Norteamérica. Su revista se encargó de difundir los deseos diseñados para el género masculino y en ese diseño, la mujer hecha objeto de deseo era el cebo más preciado y la arquitectura de la casa del «nuevo hombre» el decorado de fondo.

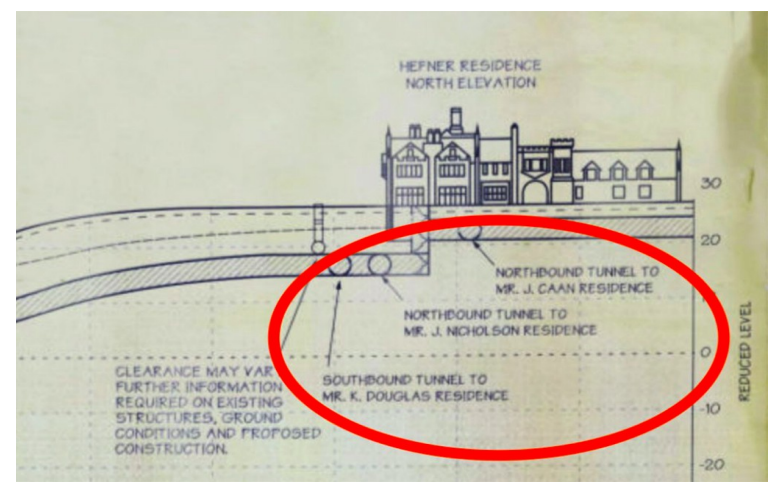

44. Casa Playboy de Hugh Hefner. Fuente: Nbcdeportes, 2015

La casa Playboy ha jugado con la fantasía de quienes han oído hablar mucho de ella pero nunca han tenido acceso. Es una mansión que ha aparecido en 
videoclips, películas y series. Ha transmitido el rol de mujer objeto a niveles que podrían calificarse de indecentes:

El análisis de la composición demográfica de la pornotopía en 2010 (reflejado en las fotos del abuelo Hefner en la Mansión West acompañado de un grupo de siempre jóvenes y rubias conejitas) arroja resultados sorprendentes. Lo que a juzgar por la diferencia de edad (sesenta años separan a Hefner de las Bunnies) y de número (en una ratio 1 hombre/n+1 mujeres) podría desde otro sistema moral ser caracterizado como gerontofilia o poligamia, es ya la tendencia más definitiva que Playboy ha logrado imprimir en los hábitos culturales del siglo XXI. (Preciado, 2010: 205)

La mansión fue edificada en 1927 por Louis D. Statham, ingeniero de profesión. En 1971 Hugh Hefner la adquiere y reforma. Las dimensiones y el diseño de la vivienda son una ostentación de poder. Genera un modelo de varón que posee, posee a la mujer, a la más sexy. La vivienda cuenta con dos piscinas, un zoológico privado, una cocina de proporciones y dotación similares a las de algunos restaurantes de lujo. Los túneles subterráneos que la comunican con otras residencias del entorno manteniendo a salvo de la mirada curiosa a sus invitados redundan en la construcción de las identidades citadas. En la casa Playboy hay consumibles, ellas, sin salvaguarda de su intimidad a ningún nivel, y consumidores con derecho al máximo de privacidad.

Hemos visto al analizar el trabajo del matrimonio Eames como el juego de composiciones era el concepto clave para permitir unir a Ray y Charles Eames sus propuestas. El juego como base. Todo era un juego, una fiesta, un regalo, como reconoció Allison Smithson:

La belleza de nuestras vidas la atribuyo hoy a Ray incluso más que a Charles; no compraríamos corbatas con dibujos de flores si no fuera por el juego de naipes de los Eames... Me gusta pensar que debemos a Ray y Charles Eames la extravagancia de la nueva adquisición. El pito, los adornos navideños y los juguetes de plástico de Woolworth, los juguetes de metal prensado alemán y los robots que andan: efímeros objetos, frescos, bonitos, multicolores. (Smithson, 1966: 447) 


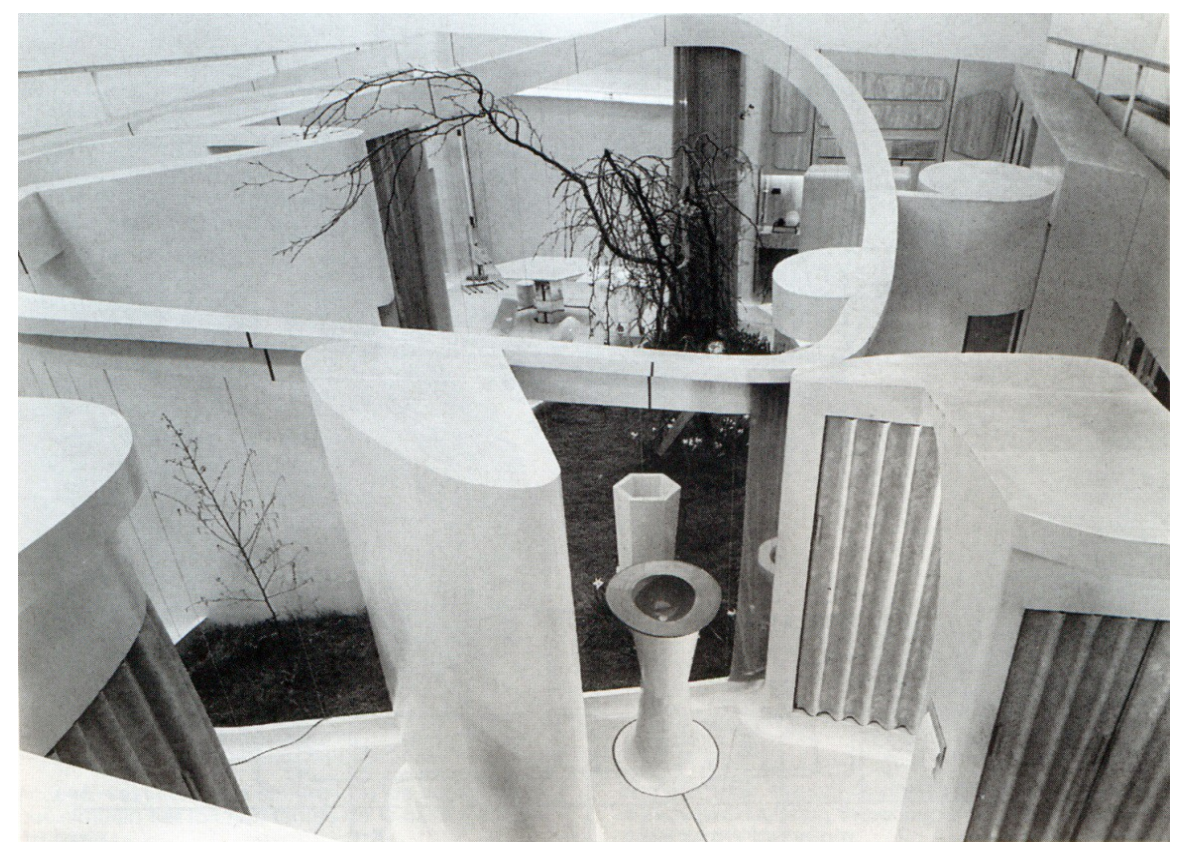

45. Allison y Peter Smithson. Casa del futuro, 1956. Fuente: Nieves Fernández Villalobos, 2013.

En 1956, Allison y Peter Smithson, enamorados de los Eames, crean en Inglaterra la casa del futuro -solo muchos años después de la muerte de Allison, reconoció Peter que el desarrollo de la vivienda de la casa del futuro era totalmente de Allison y que él sólo diseñó la caja exterior. (Fernández Villalobos, 2012: 63)-, una casa que reúne casi todas las características antes indicadas. Era casi una casa electrodoméstico como sus Appliance Houses que proyectarán más tarde. Se trataba de una casa hecha para ser fabricada como una unidad de producción industrial, como un coche; de plástico de colores que recuerdan la piel y la sangre- con formas continuas y sinuosas entre cavidades.

Los electrodomésticos evolucionaban a gran velocidad y se convertían por ello en objetos de usar y tirar. La casa del futuro era ella misma un electrodoméstico y por ello también un objeto de usar y tirar. Esta casa superaba la necesidad de flexibilidad que permitía la recomposición en la casa Eames, si quedaba obsoleta había que sustituirla por el nuevo modelo, como la lavadora, el coche o la televisión.

Indirectamente, este prototipo contribuía a hacer deseable la nueva situación de posguerra. Las fábricas de armamento han disminuido su producción bélica y 
ahora producen electrodomésticos, necesitan convertir a las amas de casa en consumidoras. Christine Friederich, escribió Selling Mrs Consumer, libro en el que propugnaba una temprana defensa de la obsolescencia programada, además de escribir, junto a su marido, una serie de artículos titulados New Housekeeping en Ladies' Journal para explicar el taylorismo a las mujeres de clase media. Resulta evidente la voluntad de modificar el comportamiento del grupo a quien va dirigido su texto en beneficio de un modelo de economía de consumo.

Aunque los Smithson insistieron en que su intención no era publicitar el consumo de electrodomésticos, ya que los mantenían ocultos en los cubículos, la realidad es que el propio espíritu de la casa como objeto enchufable de usar y tirar era un reclamo en ese sentido. Tampoco se reconocían defensores de la cultura del consumo de masas, de la cultura pop, pero la producción en serie, la contemplación de la obsolescencia de la casa y el concepto de usar y tirar está en la base de la casa y de la cultura del consumo. La casa del futuro de los Smithson miraba a un futuro de superabundancia. Se suponía que los yacimientos petrolíferos eran inagotables y por tanto que el plástico sería un material abundante y barato. También se suponía que la economía iba a permitir la adquisición masiva de estas unidades de vivienda. La realidad demostró que Gropius tenía razón:

[...] Incluso la casa más pequeña tiene una estructura exterior demasiado grande para poder ser transportada en un solo bloque por las carreteras actuales; el cuerpo debe ser subdividido, a menos que en el futuro puedan desarrollarse grandes helicópteros que las transporten por el aire [...] Tan sólo cuando se puedan fabricar en grandes cantidades -éste es un impedimento económico serio-, las casas electrodoméstico podrán ser lo suficientemente baratas. En consecuencia, sólo podrían ofrecerse en un número muy reducido de tipos, con lo que la limitación sería demasiado rígida para planificar las plantas. En realidad, los diferentes requerimientos individuales de las familias (el tamaño, la profesión, las aficiones, los gustos, etc.) pueden ser satisfechos únicamente con mayores posibilidades de flexibilidad, 
no solo de las casas Electrodoméstico, sino también de los propios espacios de estar... (Gropius, cit. en Fernández Villalobos, 2012: 174)

El prototipo expuesto sólo era adecuado para una pareja sin hijos, o a lo sumo uno muy pequeño, lo cual obligaba a sustituir más pronto que tarde ese modelo por el modelo siguiente, al estilo del cambio de coche según las necesidades familiares. Necesidades familiares que los Smithson piensan estereotipadas. Estas fueron las instrucciones que dieron a los actores que debían interpretar el papel de habitantes de la casa del futuro en la exposición Ideal Home Exhibition, patrocinada por el Daily Mail londinense:

Habrá siempre un hombre y una mujer en la casa haciendo las demostraciones: debemos asumir que es un periodo típicamente de ocio, aunque la «esposa» hará una demostración de la limpieza con la aspiradora-pulidora, del funcionamiento del lavado, el uso del equipamiento de la cocina, la preparación de la comida y el desecho de los restos. A la vez que recorre la casa, la mujer hará todo tipo de movimientos, desde sentarse en las sillas bajas hasta deslizar las puertas correderas. (Smithson, cit. en Fernández Villalobos: 2012)

El enfoque estereotipado de las tareas domésticas que se observan en la casa del futuro, y la condición de máquina, de casa enchufable, casi como un coche, como una caravana, refuerza la idea vista al comienzo de esta sección, avalada por los datos de la DGT, de que las tareas de mantenimiento de la máquina eran asumidas por el varón y, por tanto, la posibilidad de control mecánico de la casa, rompiendo la supuesta preeminencia de la mujer en el hogar.

Paradójicamente, la omnipresencia de electrodomésticos que suponían la liberación de las mujeres que los podían adquirir, las alienaron con el trabajo doméstico que seguían teniendo asignado y las enclaustraron más. El tiempo que ahorraban por un lado lo multiplicaban por otro: limpieza y mantenimiento de los aparatos, nuevas actividades escaparate como la organización de fiestas y atención, con menús más sofisticados, más coladas, más exigencia en el orden e higiene en el hogar. 
En todo este contexto de reubicación de la producción de la industria armamentística como industria de producción de bienes para el supuesto bienestar y de imágenes generadas para promover un estilo de vida determinado, la relación de los Eames con la industria cinematográfica pudo ser el caldo de cultivo para su faire play. Ellos jugando con los escenarios, con los decorados y las máscaras del teatro, Judith Butler con los personajes, con los conceptos de identidades como máscaras, en un juego que sólo le estaba permitido a sectores de la población con un estatus y poder suficientes para salirse de los roles asignados socialmente. Es más, estaban en posición de remover viejos papeles y crear otros nuevos:

La arquitectura de posguerra no fue simplemente la arquitectura luminosa que vino después de los años oscuros de la guerra. Fue también la arquitectura agresivamente feliz que surgía de la guerra, una guerra que de todos modos continuaba como guerra fría. La nueva forma de domesticidad resultó ser un arma potente. Imágenes del paraíso doméstico, virtuosamente diseñadas, eran lanzadas al mundo entero como parte de una campaña de propaganda cuidadosamente orquestada. (Colomina, 2010: 12)

Los Eames fueron pioneros en la producción de este tipo de imágenes colonizadoras. Ese fue el objetivo del pabellón Glimpses of the USA en la exposición internacional celebrada en Moscú en 1959 donde el soporte para las imágenes propagandísticas fueron siete pantallas suspendidas de la cúpula geodésica de Fuller:

Dos mil doscientas imágenes fijas y móviles presentaban el tema «Un día en la vida de Estados Unidos». Fuller señaló que nadie lo había hecho antes y predijo que publicistas y cineastas seguirían pronto esa misma vía. (Colomina, 2010: 103-4) 


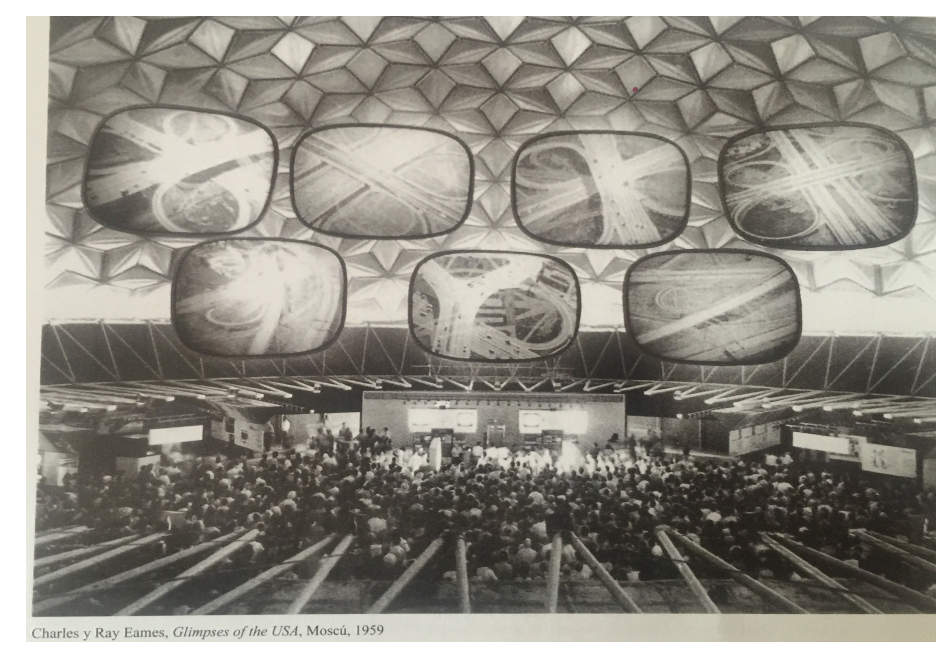

46. Instalación Glimpses de USA en la URSS, 1951. Fuente: Arquitectura Viva 141, 2012.

Hoy sabemos que la predicción de Fuller era certera pero en aquel momento no lo vio tan claro todo el mundo. Por ejemplo Philip Johnson, antiguo colaborador de Mies y autor de la Casa de Cristal, odiaba las fotografías, la televisión, las películas. Consideraba que rompían la función de la arquitectura que para él era la contención del espacio. Claramente él, como Mies, pertenecía a la primera generación de los arquitectos modernos.

Para los Eames, la esencia de la arquitectura era la composición, hasta tal punto que abandonaron los proyectos constructivos de viviendas para dedicarse a la producción de imágenes. Imágenes que eran consumidas a través de los medios de comunicación e influían en las mentes de las masas consumidoras cumpliéndose así el objetivo de esa «campaña cuidadosamente orquestada» de que nos habla Colomina, unas líneas más arriba.

Y es cierto que existía esa campaña cuidadosamente orquestada. Su cerebro fue Edward Bernays, sobrino de Freud, que aprovechó las investigaciones de su tío, sobre las pulsiones de la naturaleza humana, para controlar a las masas y dirigirlas a los objetivos económicos, políticos y sociales que los poderes respectivos iban estableciendo. En plena era de la democracia, se hurtaba la libertad de decisión a la población mediante la manipulación emocional, llevada a cabo en los medios de comunicación por la propaganda científicamente diseñada, para que, con apariencia de respeto a las libertades, las gentes se 
vieran impelidas inconscientemente a tomar decisiones en contra de sus principios, deseos e intereses verdaderos. Quienes tienen el poder crean el mensaje y lo difunden, quienes no lo tienen asumen el lugar que se les asigna (Bernays, 1928: 8, 11).

La vuelta a casa impuesta por el regreso de los varones a sus puestos de trabajo fue vendida como la ilusión de vivir en una casa de ensueño, el rol de ángel del hogar que la nueva situación sociopolítica exigía fue publicitado como el sueño de un hogar en el que las máquinas lo harían todo. El deseo compulsivo de consumir esas máquinas, esos objetos luminosos y coloristas que aparecían en las revistas, el cine y la televisión no fueron impulsos individuales independientes.

Esta fue la forma con la que el patriarcado, junto a su aliado -el capital- ejerció su poder para asignar espacios. Un claro ejemplo de cómo funciona esa operación: cuando comienza la guerra la industria necesita mano de obra, los varones están en el frente, las mujeres son llamadas a ocupar sus puestos de trabajo. Se desempeñan bien. Cuando acaba la guerra los hombres reclaman los puestos de trabajo de nuevo. Las mujeres vuelven al hogar. Como afirma Carol Pateman «el patriarcado moderno es fraternal, contractual y estructura la sociedad civil capitalista» (Pateman, 2004: 39).

Cabría preguntarse ahora por qué no tuvo éxito el proyecto de producción en serie de la casa Eames.

Tal vez las industrias que promocionaron el proyecto Case Study sólo la necesitaban como escaparate de sus productos y como señuelo del estilo de vida doméstico consumista y eso sí que lo consiguieron. El sistema de financiación a plazos posibilitó la apertura del consumo a grandes capas de la población que vivieron la ilusión de haber alcanzado el modelo de vida burgués. Se estableció la economía del consumo que era necesaria para la demanda creciente de beneficios de la economía de producción y de la economía financiera. La clase obrera vendía su fuerza de trabajo para cubrir sus necesidades básicas. Nuevas necesidades provocadas por la publicidad y los intereses de las deudas contraídas para su adquisición. Las mujeres de la clase obrera tuvieron que mantener su trabajo remunerado para la industria (dentro o 
fuera del hogar) y el trabajo doméstico que les asignaba el discurso de imágenes publicitarias. Fueron víctimas de la doble jornada. Tampoco sus congéneres de las clases acomodadas lo llevaron precisamente bien. La mujer burguesa moderna, equipada con los últimos inventos devenía ella misma, parte del moderno equipo de enseres de la casa, como el coche o la televisión.

A partir de los años sesenta se multiplican los proyectos de casas experimento, entreveradas entre la arquitectura y el diseño, con el objetivo de convertirlas en artefactos industriales a gran escala.

En 1957, la URSS puso en órbita el primer satélite espacial, el Sputnik. Ello desencadenó en el seno de la guerra fría una escalada tecnológica por ver quien ganaba la carrera espacial. Los nuevos inventos, en la era espacial, como siempre, iban siendo transformados en artefactos para el consumo masivo. La estética del espacio, el pop art, la fusión de arquitectura y diseño, la filmografía futurista se impusieron. Entre 1957-67 se diseñaron casas como cápsulas espaciales.

Buscamos una idea, un nuevo idioma vernáculo, algo que nos aproxime a las cápsulas espaciales, a los ordenadores y a los envases desechables de esta era atómico electrónica. (Warren Chalk, cit. en Fernández Villalobos, 2012: 195)

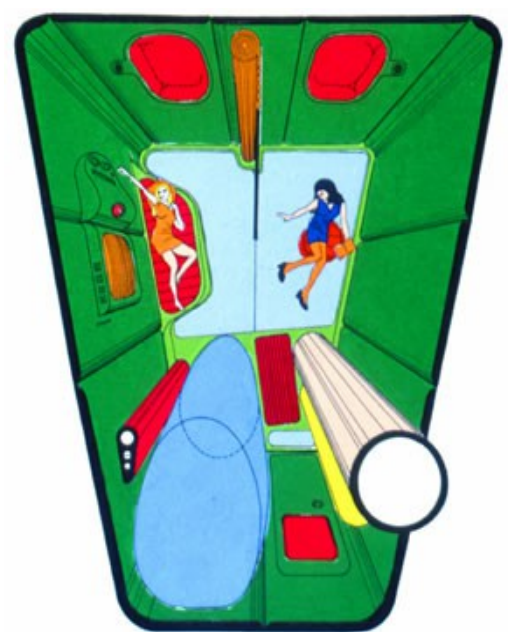

47. Warren Chalck, Archigram. Casa cápsula, 1964. 
Y en 1964 se proyectó y construyó la casa búnquer. Se trataba de un pabellón de los ciento cuarenta que ofrecía la feria mundial de Nueva York. Una feria planteada para conmemorar que la ciudad cumplía tres siglos. Cada país exhibía su cultura y forma de vida así como el nivel tecnológico alcanzado. Como en todas las ferias de estas características la pretensión era impresionar. Las características técnicas de la casa cápsula, totalmente aislada del espacio exterior, posibilitaron el nacimiento de la casa subterránea.

Era una cueva excavada artificialmente, equipada con todos los adelantos de la era espacial en lo concerniente al aislamiento, ventilación, termorregulación, iluminación, paisaje virtual.

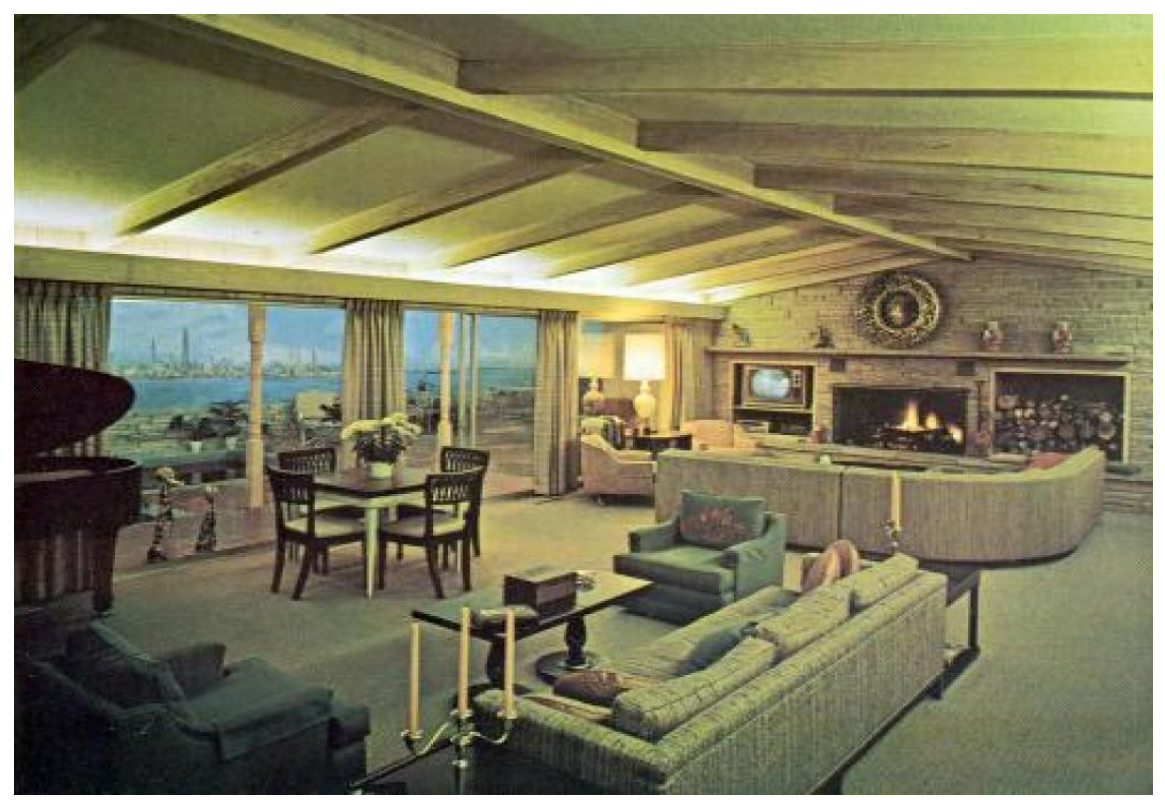

48. Jay Swayze. Casa cueva. Fuente: El Confidencial, 2014.

Al revés que en la casa de cristal, en la que la casa casi deja de percibirse, y el exterior se convierte, al deambular por ella, en una secuencia de imágenes a modo de una televisión, la casa búnker tiene sus ventanas sustituidas por pantallas televisivas de modo que se vive dentro de la propia televisión.

La casa búnker, por su absoluta interioridad sin ventanas y su inserción en el subsuelo, nos devuelve a la casa cueva, el modelo más básico de vivienda según Vitrubio (1997: 6). 
El Underground World Home planteaba todas las comodidades para vivir bajo tierra. Este diseño no era inocente. Mostrar un búnker de lujo en plena Guerra Fría tenía un significado que trascendía a la propia construcción para la sociedad norteamericana:

Unos pocos centímetros bajo tierra pueden dar a un hombre una isla para sí mismo, un lugar donde controlar su mundo, un mundo de total facilidad y control, de seguridad y sobre todo de privacidad. (Benavente, 2014: 1)

En principio todos los pabellones fueron desmontados al concluir la feria pero, Lori Walters (cit. in Hirson 2012: s/c), profesora de historia en la Universidad Central de Florida se plantea si las estancias de ese búnker siguen bajo el suelo de Nueva York. Walters pretende hacer un escaneado de la zona de Queens en busca de los restos del proyecto de Jay Swayze que no sólo lo proyectó y diseñó, sino que llevó adelante este prototipo de casa enterrada. Lori Walters defiende la hipótesis de que, una vez terminada la feria, Swayze retiró el equipamiento y dejó la estructura intacta para evitarse costes de demolición cubriéndolo todo con tierra. Puede que bajo uno de los parques de Queens siga la estructura que contenía aquella moderna vivienda de los años sesenta. Un prototipo dotado con el equipamiento técnico más avanzado. Su creador defendía incluso que reducía el esfuerzo de mantenimiento ya que no tenía ventanas que limpiar o exterior que reparar.

Casa cueva, cápsula espacial, burbuja, útero: futurismo y primitivismo como extremos que se tocan. 


\section{CONSTRUCCIÓN Y RECONSTRUCCIÓN DE LOS DISCURSOS FEMINISTAS EN ARQUITECTURA}




\subsection{La ética del cuidado}

El mundo de la imagen le toma la delantera al mundo material. La imagen se convertirá en la máxima preocupación de las gentes de finales del siglo XX y principios del XXI. La identidad se construirá sobre esas imágenes. Los centros emisores de las imágenes tendrán el poder de configurar las identidades según sus intereses. La distopía 1984 de George Orwell se hará realidad. La propia arquitectura será una arquitectura de imágenes.

Casas futuristas impensables sin las nuevas tecnologías de la información, la informática, la cibernética, la domótica, las comunicaciones inalámbricas, internet. Todo ello vuelve a presentarnos una paradoja, pues la facilidad de las comunicaciones en el mundo virtual produce una adicción que impide la comunicación en el mundo real. El enclaustramiento alcanza sus mayores cotas, la falta de comunicación en el mundo real, en el interior de casas donde se ha colado el mundo exterior, produce la soledad en compañía que agrava el malestar sin nombre. Sin interlocución es imposible la construcción de las representaciones que configuran la identidad de las mujeres habitantes de estos páramos comunicacionales $\mathrm{y}$, más imposible, adquirir el poder para escribir el propio guión o al menos realizar su montaje. Es necesaria, como dicen Celia Amorós y Cristina Molina, la reivindicación de un reparto equitativo del poder de nombrar y valorar, y del poder de asignar espacios, de lo contrario sólo las mujeres que ya han conquistado alguna cota de poder, podrán evadirse de las cadenas del género, disolviendo el concepto como propone Judith Butler. Hoy, abandonada la idea de la colectivización, se aboga por el reparto equitativo de responsabilidades domésticas pero sin conseguir hacerlo realidad. La división del trabajo por sexos está grabada a fuego en las mentalidades y mantiene a los hombres fuera del hogar jornadas larguísimas, al tiempo que las mujeres son incapaces de liberarse de las responsabilidades domésticas como algo propio, a pesar de haber salido al mundo laboral en el que siguen luchando por superar los obstáculos que en él encuentran para ser tratadas en igualdad: diferencia de salarios, techo de cristal. 
El problema que subyace es el de la necesidad de elevar el rango de la ética del cuidado al mismo nivel de la ética de la justicia, para que sea posible el diálogo entre ellas y hacer intercambiables los deseos.

Digo elevar el rango de la ética del cuidado porque:

En la historia de la filosofía política occidental, abundan los teóricos que distinguieron las tendencias particularistas intuitivamente emocionales de las mujeres -requeridas para la esfera doméstica y las relaciones privadas-, del pensamiento desapasionado e imparcialmente racional de los hombres, requerido por la vida pública. Hombres y mujeres fueron asociados a proyectos morales radicalmente distintos: las normas, valores y virtudes masculinas se estructuraron en torno a la justicia y los derechos, mientras las femeninas se nuclearon en el cuidado y la responsabilidad. Además de diferentes, ambas perspectivas se concibieron en conflicto, y la perspectiva particularista y emocional de las mujeres se vio como peligrosa para la vida social pública, justificando así la exclusión social de la mujer de esta esfera. (Fascioli, 2012: 41)

Este planteamiento esencialista ya fue denunciado por las primeras teóricas feministas, recordemos la famosa frase de Simone de Beauvoir «la mujer no nace, se hace» con la que daba la vuelta al argumentario establecido: no debían ser excluidas porque sólo eran capaces de una perspectiva particularista e intuitiva, sino que debían ser incluidas para que pudieran desarrollar también sus capacidades racionales y generalistas. El feminismo del siglo $\mathrm{XX}$ no ha dudado en clasificar como mito cultural el planteamiento dicotómico y antagónico de las dos moralidades, supuestamente femenina una, la del cuidado, y masculina la otra, la de la justicia.

En este sentido es fundamental la aportación de Caroll Gilligan que analiza no la femineidad de la ética del cuidado, que considera producto de la socialización, sino la carencia de esta ética en las teorías éticas modernas, centradas exclusivamente en la ética de la justicia. Su propuesta teórica es la de una ética de la justicia complementada por la ética del cuidado que constituya una ética general sin distinción de sexos. Dicha propuesta parte del análisis de las teorías del desarrollo moral de Freud, Piaget y Kolberg, análisis que la llevó a poner de 
manifiesto que estos autores habían incurrido en el habitual salto semántico patriarcal: hablar de los asuntos de los varones, como asuntos de los hombres y a continuación considerar que habían hablado de la humanidad.

Para Gilligan «los individuos de la ética de la justicia son formalmente iguales, han de ser tratados de modo igualitario, los de la ética del cuidado son diferentes e irreductibles y no deben ser dañados». (Gilligan, cit. en Fascioli, 2012: 51)

Sheyla Benhabib considera que el objetivo de Gilligan es ampliar la actual teoría moral al igual que Kohlberg, pero va más lejos: inspirándose en ella, considera que no es posible hacer un juicio moral según las modernas propuestas liberales como la de Rawls, defendida por Kolberg, pues:

De acuerdo a Kohlberg y Rawls, la reciprocidad moral involucra la capacidad de tomar el punto de vista del otro, ponerse uno imaginativamente en el lugar del otro, pero bajo condiciones de «velo de ignorancia», el otro, como diferente del yo, desaparece. (Benhabib, cit. en Fascioli, 2010: 49)

Es evidente que el velo de ignorancia supone una ignorancia más radical de la que pretende Rawls, pues impide ponerse en el lugar de otro invisible, inalcanzable y por lo tanto hace imposible un juicio moral coherente e informado.

Sheyla Benhabib propone integrar la perspectiva del otro concreto a la perspectiva del otro generalizado para alcanzar su propósito de una nueva teoría moral:

Mi propósito es desarrollar una teoría moral universalista que define el punto de vista moral a la luz de la reversibilidad de las perspectivas y una mentalidad ampliada. Tal teoría moral nos permite reconocer la dignidad del otro generalizado a través de un reconocimiento de la identidad moral del otro concreto. (Benhabib, cit. en Fascioli, 2012:

Caroll Gilligan superó la propuesta de Kolhberg, y Sheyla Benhabib superó a Gilligan, pero, aún con la claridad y contundencia de sus propuestas teóricas, no se supera la dificultad para abrirse paso en la práctica. 
Necesitamos que este pensamiento se convierta en hegemónico, es decir, que se convierta en el pensamiento generalizado. No basta con el trabajo de crecimiento personal, ni con el trabajo interpersonal en pequeños grupos. Es necesaria una labor colectiva y pedagógica que sitúe los cuidados en el rango superior de las tareas de prestigio, que sitúe la ética del cuidado no sólo en el mismo nivel que la ética de la justicia sino en el mismo lugar de imprescindibilidad en la construcción de juicios morales que guíen las voluntades y las acciones.

En particular las voluntades y las acciones de quienes toman las decisiones sobre qué tipo de vivienda debe ser construida.

\subsection{La nueva vida cotidiana}

Las viviendas de la clase media actual en el mundo occidental, son, si cabe, más escaparates que aquellas experimentales que se diseñaron como tales por encargo de la industria en la era naciente del consumo. Las viviendas diseñadas arquitectónicamente se han convertido hoy en objetos de consumo, transmutando a las arquitectas y arquitectos en publicistas de dichos objetos de consumo, en personajes publicitarios en los medios de comunicación, producen por su cuenta, material publicitario. Existen incluso programas televisivos dedicados en exclusiva a mostrar a la población las viviendas de ensueño, al alcance sólo de una pequeña parte de la sociedad, a alimentar los sueños y las ansiedades de la mayoría.

Dentro de la fantasía publicitaria, podría aducirse que hoy, las mujeres, al menos las occidentales de clase media, no están atrapadas por la cárcel dorada de la domesticidad, ya que las modernas arquitecturas que se nos muestran, ofrecen espacios para un reparto paritario del trabajo doméstico y de las tareas del cuidado, pero, como veremos próximamente, existen componentes invisibles $\mathrm{u}$ ocultas en los proyectos y las instituciones de la arquitectura que opacan la mano insidiosa del patriarcado.

Tanto la historia como la teoría y la práctica arquitectónica y urbanística invisibilizan a las mujeres profesionales y estereotipan a las mujeres usuarias, lo cual sucede en cualquiera de las clases sociales. Vamos a continuación a hacer 
un recorrido por algunos de los trabajos que se han realizado para enmendar la situación.

Prácticamente hasta mediados del siglo XX, la arquitectura estuvo al servicio de los grandes poderes, únicos en disposición de adquirir, costear u ordenar la construcción de obras de arte de la envergadura de una edificación. La arquitectura de vanguardia del Movimiento Moderno, de principios del siglo XX iba destinada a coleccionistas de arte con buena posición económica o a proyectos de reconstrucción de las ciudades destruidas durante la guerra. Proyectos encargados por las instituciones de gobierno, como el Nuevo Franckfurt, equipado con la cocina de Margarete Schütte-Lihotzky que se convirtió en el referente universal de cocina en la nueva construcción de viviendas populares del mundo industrializado de Occidente.

A partir de mediados de ese siglo, se pone en marcha en USA la experimentación en construcciones destinadas a las clases medias o clases populares hipotecadas.

El paso de la sociedad de producción en masa a la sociedad del consumo de masas, abre en Occidente dos líneas de actuación entre profesionales de la arquitectura: la producción industrial de viviendas destinadas a la habitación de las masas, a la población consumista; y la construcción de edificios singulares, encargados por las instituciones políticas a famosas estrellas del ámbito de la arquitectura.

Esta situación lleva, a su vez, a dos líneas de investigación feminista en el seno de la arquitectura. A saber: ¿qué pasa con las mujeres arquitectas? y ¿qué pasa con las mujeres que habitan los espacios arquitectónicos?

La primera pregunta ha sido debatida ampliamente en los foros de arquitectura del mundo occidental.

La segunda fue centro de atención para las arquitectas feministas de finales del siglo XIX en América y a principios del XX por políticas feministas socialistas, como Alexandra Kollontai en la URSS o arquitectas como Margarete SchütteLihotzky en Europa. 
En esta segunda pregunta se centra la última parte de este trabajo, en la que me ocupo de la evidente presencia de la mujer del patriarcado en las revistas de arquitectura, a pesar de que omiten la figura de mujeres en los espacios fotografiados. Espacios a los que sin embargo están asignadas. ¿Cómo hacerlas visibles si están en ellos? ¿En qué espacios las descubrimos? ¿Cómo sacarlas de esos espacios?

Como expone claramente María Novas en su texto Arquitectura y género. Una reflexión teórica, el colectivo de profesionales de la arquitectura capitalista ejerce una praxis patriarcal, produce una teoría androcéntrica y se identifica con la historia androcéntrica de esta teoría. Basta observar sus resultados: arquitectura monumental sólo al alcance de los arquitectos económica, política y socialmente bien situados -en masculino porque mayoritariamente son ellos y no ellas quienes están en esa situación de privilegio- casas suburbanas como cárceles del ángel del hogar; y viviendas populares ideadas para fijar a la población obrera y desactivarla en favor de quienes promueven el modelo, a saber, industriales y gentes de la política con una idea conservadora de la familia y la casa, incluso a pesar de tener ideas progresistas en otros ámbitos.

Por otra parte, la crítica posmoderna a la legitimidad de los saberes, produce un efecto paradójico en arquitectura. Al negar la validación del saber por la autoridad del antiguo patriarcado, es decir, por los mitos y la religión; y al desautorizar los grandes relatos filosóficos y científicos, es la utilidad la que valida la verdad. Pero la utilidad se materializa gracias a la técnica. Su implementación exige inversiones económicas que sólo están al alcance de las figuras de la arquitectura más afamadas, quienes han devenido en estrellas, quienes reciben encargos megalómanos de los poderes económicos y políticos, son los arquitectos y algunas arquitectas del llamado star system.

El efecto de esta situación es que la huida de la historia, o dicho de otro modo, superar los efectos perversos del androcentrismo en arquitectura, desde el humanismo con Vitrubio al Movimiento Moderno con Le Corbusier, con sus arquitectos varones burgueses y adinerados sólo podrían realizarla los arquitectos y arquitectas capaces de romper con los poderes tradicionales, pero el patriarcado moderno se acomoda a las demandas del gran capital y a su 
servicio. Cerrando un círculo vicioso están esos arquitectos, adinerados, casi siempre varones, y burgueses.

Las propias revistas de arquitectura reflejan esta situación. Sus contenidos son imágenes de las obras singulares de los mencionados arquitectos estrella; y, como descubre Daniela Arias Lauriño, en un estudio realizado sobre las revistas de arquitectura más prestigiosas del mundo (Architectural Design, L'Architecture d'Aujourd hui, Lotus International, SUMA+ y The Architectural Review) publicadas entre los años 2008-2012, la incidencia de los movimientos emancipatorios es mínima. En particular el movimiento feminista, en la arquitectura actual, es inexistente:

El tema de género es el gran ausente en todas las publicaciones [...] El debate en las revistas aquí mencionadas sobre los roles en la profesión que tradicionalmente ha relegado a las mujeres a campos de acción distintos dentro de la disciplina, apenas consta en un par de artículos. En cuanto a la inclusión de la perspectiva de género como variable para la planificación urbanística y de proyectos urbanos es nula y sorprende cuando son reiterados conceptos como la inclusión y el derecho a la ciudad. [...] Es posible afirmar a este respecto que la revista, como tantos otros actores sociales de influencia, reproduce y reafirma el modelo dominante que históricamente ha marcado a las sociedades, a las ciudades y a la disciplina. (Arias, 2008: 76)

Es decir, ni existe la igualdad, ni parece que el colectivo haya reparado en ello. Es más, ni tan siquiera Daniela Arias, la autora de esta crítica, se plantea la situación, más allá de la existente en los espacios exteriores, los del urbanismo. En la arquitectura doméstica no existe ni tan siquiera debate, a pesar de que el Movimiento Moderno, que rompió con los modelos antiguos de la arquitectura, en cuanto a la distribución y orden de los interiores domésticos no alteró el modelo. Su novedoso tratamiento de las proporciones fue novedoso técnicamente, pero no abandonó el referente masculino, permaneciendo así larvado el androcentrismo, también en este aspecto, con las profundas repercusiones que ello ha supuesto. 
Respecto a la primera crítica que encierra la cita de Daniela Arias, Carlos Hernández Pezzi, en La ciudad compartida. El género de la arquitectura, ya advirtió de este déficit de igualdad:

Igualdad y diferencia son discutidos hoy como parte de una teoría del poder, de la democracia en la vida. Importantes teóricas del movimiento feminista, filósofos y mujeres han trabajado sobre un problema que se percibe muy relevante en el mundo actual. Mujeres y hombres han aflorado las contradicciones escondidas bajo esos conceptos ricos en sugerencias para la ciencia y la filosofía, tanto como para la política o la sociología. En arquitectura es más complicado el pronunciamiento sobre la diferencia, porque el aformalismo, la deconstrucción y, en general, la supremacía de ciertas componentes irracionales, está creando un nuevo código frente al racionalismo antes dominante, que es una nueva forma de dominio del pensamiento arquitectónico en poder de las élites. (Hernández Pezzi, 1998: 12)

La Bienal de Venecia de 2014 tuvo como objetivo precisamente denunciar la perversión y la inflación del star system en arquitectura y centró su interés en la historia de los elementos arquitectónicos básicos, Fundamentals fue su título y el premio Pritzer 2000, Koolhass, su comisario.

[...] después de varias bienales dedicadas a la celebración de lo contemporáneo, Fundamentals se centrará en la historia -en los elementos inevitables en toda arquitectura utilizados por cualquier arquitecto, en cualquier lugar y en cualquier momento (la puerta, el piso, el techo, etc.) y sobre la evolución de las arquitecturas nacionales en los últimos 100 años. [...] (Koolhass, 2013: 12)

De nuevo Hernández Pezzi, en su artículo «Arquitecturas y mujeres en busca de nombres. Las arquitectas en contra de la doble ocultación» (2014), dice que la ocultación de las mujeres es producida por las condiciones específicas del star system y por la jerarquización propia del sistema de producción capitalista. La primera impide que las mujeres arquitectas accedan a la construcción de edificios singulares; la segunda, las coloca en lugares subalternos dentro de la 
industria de la construcción. Salvo casos aislados como por ejemplo Zaha Hadid.

Las condiciones necesarias para pertenecer al star system son señaladas por Pezzi en su artículo de modo claro y contundente: fama, estudio grande y contacto con la política. Son pocas las arquitectas famosas, pocas las propietarias de un estudio grande y pocas las que tienen contactos con el poder político. Menos son las que cumplen los tres requisitos. Dice Pezzi que esto es así a nivel global y que no hay casi crítica ni denuncia por parte de las arquitectas. (Hernández Pezzi, 2014: 76-78).

En cuanto a la situación como subalternas en la industria de la construcción es común a todas las profesiones en el actual mundo, globalizado por el neoliberalismo, en complicidad con el patriarcado. En suma, la doble ocultación de las mujeres arquitectas es la consecuencia de la asignación de locus por el topo-poder patriarcal, el mismo que asigna los roles en la vida doméstica.

El Consejo Superior de los Colegios de Arquitectos de España, encargó a Carlos Hernández Pezzi y a María Ángeles Durán, la realización de un trabajo que lleva el título de La Ciudad Compartida. El encargo se materializó en dos volúmenes, uno a cargo de Ángeles Durán, titulado La Ciudad compartida. Conocimiento, afecto y uso. El volumen escrito por Hernández Pezzi fue La Ciudad compartida. El género de la arquitectura. En su texto, Hernández Pezzi reclama la intervención en la práctica arquitectónica del feminismo de la diferencia en la arquitectura moderna y lamenta que pocos arquitectos hayan trascendido los cánones del Movimiento Moderno, uniformizador y jerarquizado (Hernández, 1998: 42), como lo han hecho los posmodernos Ghery o Zaha Hadid, que cultivan la diferencia, aunque no el feminismo, a pesar de que ésta última manifestaba las dificultades que ha tenido que salvar por ser árabe y mujer.

¿Qué ha tenido que pagar más caro? El hecho de ser mujer, inmigrante, querer ser pionera, ser rica... Todo eso. La combinación entre una mujer inmigrante, árabe, autosuficiente y que hacía cosas raras no me facilitó nada las cosas. Pero estar tan marcada me ha favorecido. Me dejaban ser y hacer lo que quisiera. Pero a la vez me 
bloqueaban la entrada a ciertos encargos y terrenos profesionales. Empecé a trabajar en uno de los momentos más carcas del siglo $X X$, cuando la arquitectura estaba sumida en la recuperación de valores históricos muy conservadores. Aquello pasó. $Y$ cuando se necesitó cambiar, las cosas fueron más fáciles para alguien como yo, que siempre había apostado por el cambio. A pesar de todo, seguimos teniendo mucha resistencia [...]¿Qué ha tenido que sacrificar para llegar a dónde está? Pues todo. Mi vida personal. No es que pensara en casarme y tener una familia. No es exactamente eso. Pero elegí una vida que no admite compaginarla con ningún otro deseo. No tengo tiempo para nada más que para lo que hago. Es fantástico el mundo abierto en el que vivimos. Podemos trabajar en cualquier sitio. Pero vivimos también en una gran trampa. En la era de las estrellas, la gente quiere verte. Si no apareces, se enfadan y te vas metiendo en una espiral de aviones que va consumiendo tu vida. (Hadid, 2008:

7)

Zaha Hadid lo ha pagado caro pero ha transgredido la barrera de género, claro que lo ha hecho sola y porque partía de una situación de poder que se lo permitía. Recordemos que el feminismo posmoderno sólo aspira a eso, no resuelve el problema de las mujeres, es sólo un juego, una mascarada, que disuelve los límites del género porque puede desde una autoridad ya adquirida. Tal vez por eso las arquitectas no hacen crítica al sistema patriarcal y se quedan en una desestabilización del género, como lo hace Hernández Pezzi, porque desde la autoridad que les confiere su profesión, tienen la expectativa de alcanzar una posición de mayor poder y no fijan su atención en la barrera estructural que supone el poder escondido tras el género, tras el género masculino, como nos lo ha mostrado Cristina Molina (2003: 139).

En los países con gobiernos socialistas o socialdemócratas de principios del siglo XX sí que se tomó en cuenta la cuestión de ¿qué pasa con las mujeres que habitan los espacios arquitectónicos? La variable género que Daniela Arias echa de menos en los planes y proyectos urbanísticos, también fue notada a faltar en la arquitectura doméstica por las arquitectas socialistas y, como consecuencia, la incluyeron en sus proyectos. Así ocurrió en Rusia, donde la 
necesidad de vivienda para las grandes masas que afluían a las ciudades desde el campo fue extraordinaria. Se desplazaban a las ciudades para trabajar en las nuevas industrias, retrasadas 70 años respecto al resto de Europa. La propia ideología del sistema comunista que abolió la propiedad privada y liberó enormes cantidades de edificaciones señoriales, se unió a la necesidad de viviendas para trabajadoras y trabajadores y a la pretensión de hacer pedagogía de las bondades del comunismo y sus políticas de colectivización. Precisamente, colectivizando la vida cotidiana y gracias al impulso de camaradas feministas como Alexandra Kollontai, se desarrollaron modelos de habitación que priorizaban la distribución comunal de las tareas domésticas. Según las camaradas feministas se trataba de liberar a la mujer del yugo al que había estado sometida, era la forma de facilitarle la participación en la construcción de la nueva sociedad; según el ideario del partido, lo que se pretendía era reducir la vida privada considerada un signo de familia burguesa y socializar a la población en la vida comunitaria. Mucho antes, en Europa, concretamente en Austria, país natal de Margarete Schütte-Lihotzky, en 1920, una cooperativa inmobiliaria sin ánimo de lucro, ya diseñó el proyecto de viviendas con cocina, comedor, guardería, lavandería y otros servicios comunitarios que permitían a las mujeres conciliar la vida familiar con la laboral. Tanto Kollontai como Schütte-Lihotzky pretendían que la mujer obrera disfrutara de algunos de los privilegios de las mujeres acomodadas.

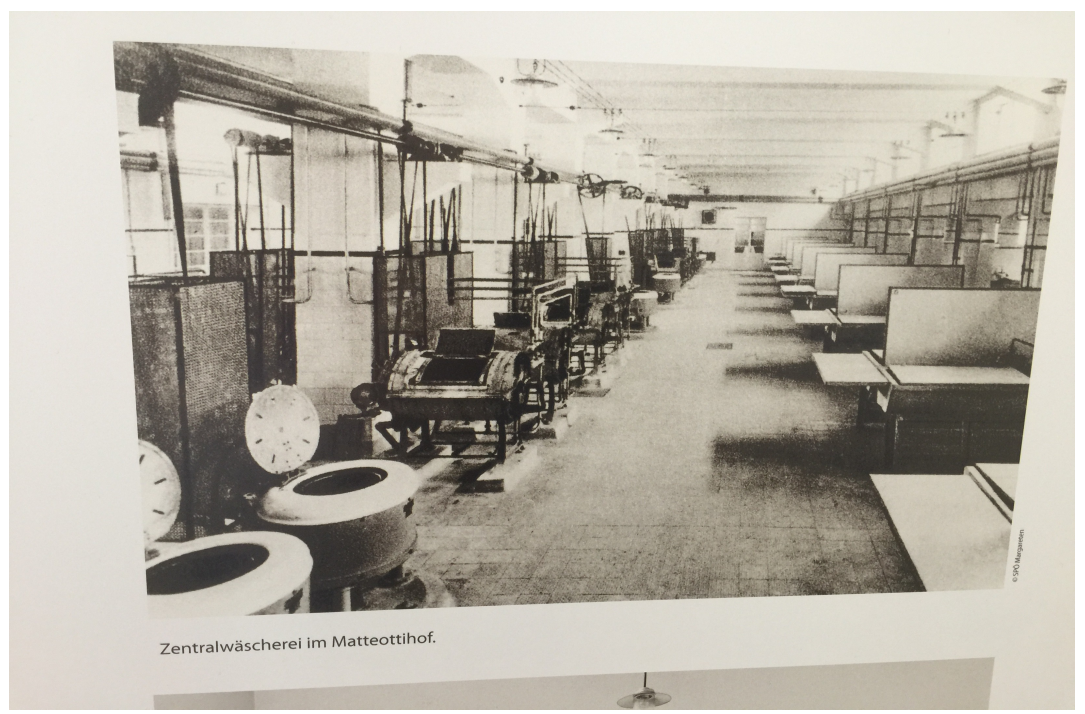

49. Exposición en el recinto de la lavandería de la Karl-Marx Hoff en La Viena Roja. Fotografía de la autora, 2015. 
La propia Margarete Schütte-Lihotzky sentía que su cocina Frankfurt era un mal menor para la mujer obrera, y el modelo colectivista rondaba siempre sus proyectos. En Viena pudo proyectar según este modelo. Aún hoy pueden visitarse las Hof en la Viena Roja. El gobierno de Viena era una isla socialdemócrata surgida de las ruinas de la debacle del imperio austrohúngaro. Ese gobierno vienés quebró con la crisis del 29. El movimiento nazi creció a su alrededor y el proyecto fue abandonado por falta de financiación y de voluntad de los gobiernos conservadores que tomaron el relevo.

En Alemania, los arquitectos y arquitectas del Movimiento Moderno, con inquietudes sociales fueron expulsados de su país por el ascenso del nazismo y emigraron hacia una Rusia que reclamaba sus conocimientos y compartía sus inquietudes. El Stroikom, Comité para la construcción de la República Federal del Soviet de Rusia, elaboró en 1928 modelos de proyectos de vivienda mínima entre 27 y $54 \mathrm{~m}^{2}$, de 6 tipologías distintas de la A a la $F$, con una superficie por persona de 9 a $6 \mathrm{~m}^{2}$. Estos proyectos incluyeron en sus diseños servicios comunes de cocina, salón-comedor, lavandería, guardería y zonas recreativas.

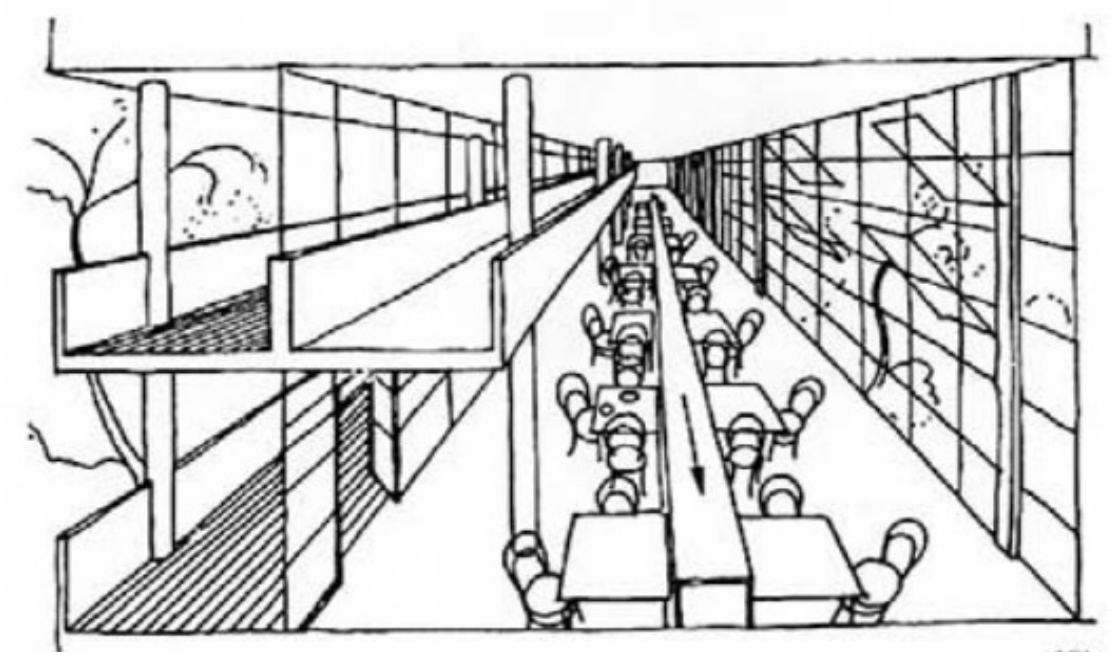

50. Comedor colectivo con cinta transportadora, Stroikom, 1929. Fuente: FADU UBA AID, 2002.

Bajo este espíritu de la Nueva Construcción, del Movimiento Moderno, se construyó entre 1928 y 1932, proyectado por Ginzburg, el Narkomfin que, a su vez, influyó en l'Unité d'habitation de Le Corbusier, en Marsella. 
L.C. n'est pas seul parmi les architectes du Movement modern, a chercher une solution nouvelle à la question du logement collectif. Au cours de l'entre-deux guerres les operations expérimentales se multiplient en Europe. Quelques-unes d'entre elles devéloppent des thèmes de recherche qui croisent sur un certain nombre de points les travaux de L.C. pour son Unité d'habitation. Parmi ceux-ci il faut citer la socialisation de l'espace du logement, la question de la densité, l'industrialisation du bâtiment et l'équipement domestique.

Sur la socialisation de l'espace du logement, un des exemples les plus significatifs est celui de la Dom Komuny, la maison commune telle qu'elle apparaît en Union soviétique au débout des années trente, Ces maison comunes qui associent logements et équipements ont pour bout de promovoir une nouvelle forme de vie collective. C'est dans cet ésprit que Moïse Ginzburg construit le Narkomfin, dont les appartements en dúplex sont deservis par un systéme de rues intérieures.

Au cours de ses voyages en l'Union soviètique, L.C. a eu de nombreux contacts avec l'avant-garde architectural de ce pays pour discuter de ces travaux. (Sbriglio, 1992: 22) $)^{12}$

Es evidente la relación entre ambos edificios al observar juntas sus imágenes, tal y como muestran en las imágenes siguientes:

\footnotetext{
12. L.C. no es el único entre los arquitectos del Movimiento moderno, que buscaba una solución novedosa para el problema del alojamiento colectivo. Durante el periodo entre las dos guerras las operaciones experimentales se multiplicaron en Europa. Algunas de ellas desarrollan temas de investigación que se cruzan en varios puntos con los trabajos de L.C. para su Unidad habitacional. Entre estos hay que citar la socialización del espacio de alojamiento, la cuestión de la densidad, la industrialización de la construcción y el equipamiento doméstico.

Sobre la socialización del espacio de alojamiento, uno de los ejemplos más significativos es el de la Dom Komuny, la casa comuna tal como aparece en la Unión Soviética al principio de los años treinta. Estas casas comuna que asocian alojamiento y equipamiento tienen por objetivo promover una nueva forma de vida colectiva. Es dentro de este espíritu que Moïse Ginzburg construyó el Narkomfin, cuyos apartamentos en dúplex se comunican por un sistema de calles interiores.

A lo largo de sus viajes por la Union soviética, L.C. tuvo numerosos contactos con la vanguardia arquitectónica de este país para discutir estos trabajos. (Sbriglio, 1992: 22). (Traducción propia).
} 

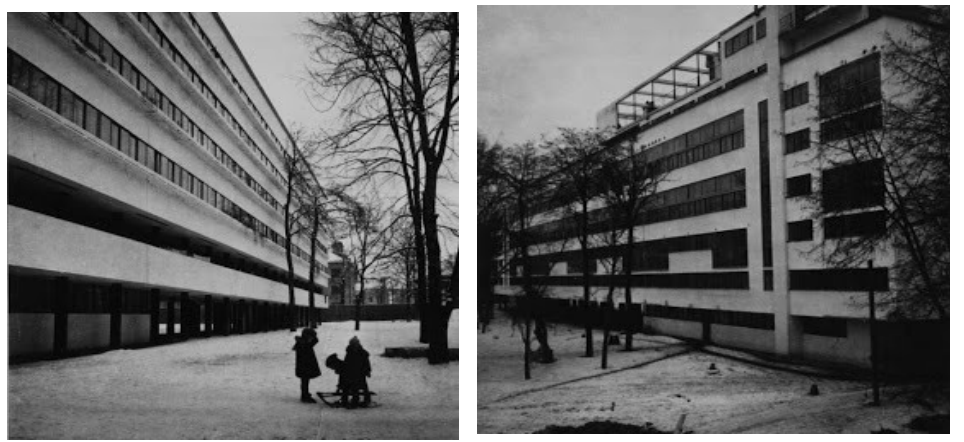

51. Narkomfin apartments, 1928-1932. Autor: Robert Byron.

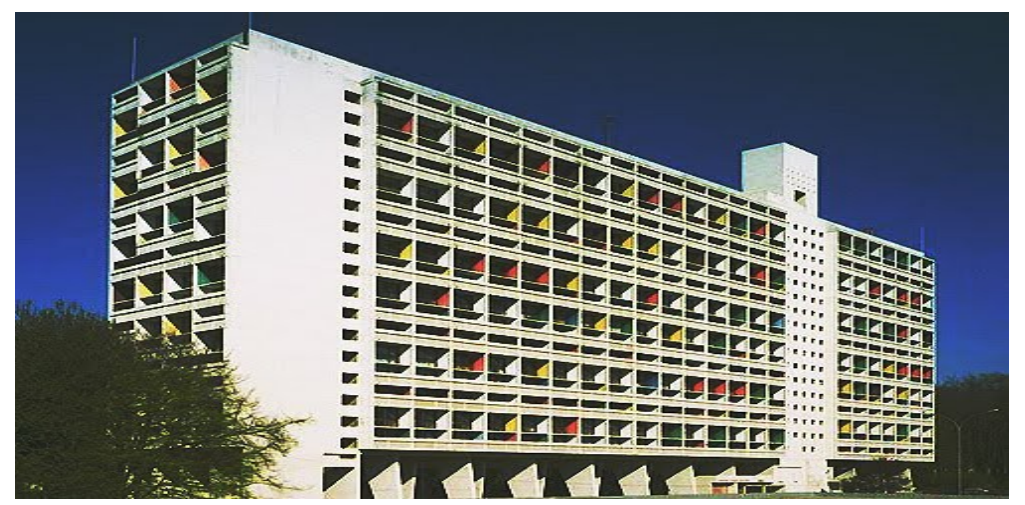

52. Le Corbusier. L'Unité d'habitation de Marseille, 1945-52. Fuente: CaViCa, 2011.

«Narkomfin» es la abreviatura de Comisariado del Pueblo para las finanzas. Fue concebido por un grupo de profesionales de la arquitectura y la ingeniería de la Asociación de Arquitectos Contemporáneos (OSA), grupo considerado pionero del constructivismo y dirigido por Mosei Ginzburg e Ignaty Milinis en Moscú. No escondían que los apartamentos eran una intervención en la vida cotidiana de sus ocupantes, con el objetivo de que llevaran una vida más acorde con el ideario socialista. Pretendían estimular ese estilo de vida colectiva, el estilo de la comuna, con poco espacio para la vida privada y doméstica, y con espacios comunes para instalaciones en las que se desarrollaban las tareas domésticas para toda la comunidad.

El feminismo luchaba por hacerse presente desde el principio de la revolución. En este tipo de proyectos, el hecho de que las cocinas y lavaderos estuvieran fuera de las viviendas, o contar con guarderías en el edificio, facilitaba, en 
principio, liberar a las mujeres del yugo de las tareas domésticas y permitía a las mujeres tener una vida más libre, ofreciéndoles la posibilidad de escapar de sus roles tradicionales ocupando nuevos puestos en la sociedad. Esta distribución de los espacios interiores de las viviendas y de las instalaciones comunitarias estaban pensadas en función de la construcción de la identidad según las teorías socialistas. Aun cuando no fuera el objetivo directo del proyecto, desde los postulados feministas pensaban que también influiría en la construcción de una nueva identidad de las mujeres. Incluso reconociendo que esos trabajos seguirian siendo desempeñados por mujeres, el avance cualitativo consistía en que recibían el reconocimiento de trabajos, habría que designarlos para poder asignar personal que los desempeñase, saldrían así del espacio de invisibilización en el que estaban.

Sin embargo, pronto Stalin impuso el llamado realismo socialista, que unido a la hipertrofia y corrupción de su burocracia, acabó con estos proyectos y expulsó de nuevo a las arquitectas y arquitectos extranjeros. Entre ellos se encontraba Margarete Schütte-Lihotzky.

Durante la guerra fría, EEUU y URSS compitieron salvajemente por la primacía científica y tecnológica en la carrera de armamento y su derivación, la carrera espacial. La propaganda fue el lenguaje para vender los respectivos proyectos políticos, los respectivos modelos de vida cotidiana. Con la caída de los países socialistas, se impuso la globalización y en el ínterin, emergieron los movimientos feministas de la segunda ola que en los 70 afectaron a todas las áreas de la cultura. También a la arquitectura y al urbanismo, sobre todo a éste último, aunque en pequeñísima medida como hemos visto en el estudio de Daniela Arias Lauriño. Pero desde esa pequeña "grieta hemorrágica», como la Ilama Cristina Molina (2003: 143), las mujeres arquitectas han recuperado los espacios comunales en sus proyectos de vivienda social y reivindican los espacios exteriores para las mujeres, en jornadas, congresos, concursos, exposiciones, artículos y textos de arquitectura que van construyendo un discurso desde la perspectiva que la mujer experimenta y tiene de los espacios urbanísticos y arquitectónicos. 


\section{Mónica Cevedio propone:}

Si bien reivindico "un lugar propio» al que todas las personas tienen derecho, sí podemos «abrir» esa idea de privacidad con algunos lugares comunes, como servicios y equipamientos colectivos, lo que supondría socializar las «tareas domésticas». [...] por ejemplo: salas de estar (para romper con el aislamiento de muchas personas), salas de lectura, salas de ordenadores, salas de estudios para los niños (para las que se podrían contratar profesores, educadores o pedagogos); comedores (en los que se podrían solicitar comidas preparadas), o cocinas, lavaderos... en los que se podría contratar personal especializado para realizar esas tareas consideradas «improductivas» (las domésticas) para que pasasen a considerarse de esta forma trabajos, con un salario, y otorgarles así un valor de productivas. Esto supondría un primer paso para romper la división del trabajo entre los sexos. (Cevedio, 2010: 99-100)

Aunque se trata de un texto escrito desde la perspectiva de género, personalmente, no puedo evitar sentir desazón al leer la cita de Mónica Cevedio, en el que el genérico masculino me resulta incómodo. Si se contrata a personas para enseñar, educar, atender a niños y niñas, la probabilidad de que se elija a mujeres es elevadísima, como puede verse en las estadísticas de la profesión, pero el genérico masculino es insistente e invisibilizador.

De los debates planteados en los 80 en Estados Unidos y Europa, surge una compilación de artículos bajo la dirección de Jane Rendell, registrados en 1988 y publicados en 2000 bajo el título Gender Space Architecture, que centraron su trabajo en una revisión de la teoría, la historia y la praxis de la arquitectura bajo el filtro de la categoría género y centrándose en la problemática de la mujer arquitecta en su vertiente profesional sobre todo.

No obstante, existen intentos de superación de ese análisis débil de género que alcanzan a movilizar los poderes y que hacen vislumbrar los frutos de la lucha contra el poder patriarcal, en un terreno tan firmemente arraigado en el patriarcado como lo es la arquitectura. 
Quiero comentar a continuación, brevemente, un proyecto vienés, el FrauenWerk-Stadt, llamado hoy Margarete Schütte-Lihotzky en honor a la pionera vienesa. Proyecto que fue posible gracias al trabajo desarrollado por la red EuroFEM, entre 1996-1998, con la ayuda financiera del IV Plan de la UE y del departamento de la mujer del ayuntamiento socialdemócrata de aquel momento, en Viena.

He elegido este proyecto por el interés del proceso, de sus contenidos, de sus logros teóricos, su repercusión en la investigación y su éxito político que permitió la ejecución de 350 viviendas por parte de la arquitecta Franciska Ullman, con bastantes de las características que más arriba demanda Mónica Cevedio.

Viena poseía antecedentes revolucionarios sobre vivienda social, tanto por sus proyectos, el «Heimhoff», como por sus pioneras, Margarete Schütte-Lihotzky. Eran revolucionarios en tanto en cuanto la vivienda actual en Viena, como en todo el mundo occidental, sigue el modelo aristócrata de la alta burguesía dieciochesca. Ana Bofill nos desvela que en cada categoría y nivel social, la vivienda mimetiza el modelo de la alta sociedad, donde la jerarquía patriarcal está perfectamente reflejada: el dormitorio de matrimonio es el de mayor tamaño, las habitaciones de los niños y niñas son las más pequeñas, la cocina está apartada de las zonas de socialización, el salón para recibir es amplio, el baño está próximo al dormitorio principal. Las diferencias de clase social no se manifiestan en esta ordenación sino en el tamaño de la vivienda, de sus estancias y por el número de ellas. En estas viviendas tenía y tiene que desarrollarse la vida cotidiana. (Bofill, 2006: 43)

El concepto feminista de vida cotidiana, o para ser más exactas, «la nueva vida cotidiana», surgió en 1979 cuando un grupo de mujeres escandinavas estableció una visión común de una vida futura más unida (NORD, 1991), a partir de una serie de valores centrales que abarcaban desde la racionalidad tecnocrática hasta una racionalidad de responsabilidad (Horelli, 2000). De forma explícita, se planteaba la creación de una sociedad que redefiniera el trabajo -remunerado o no remunerado- de forma igualitaria y que organizara y distribuyera todas las tareas de un modo distinto, sin el recurso a los estereotipos 
sexuales. Esta visión valora la labor de atención y crianza llevada a cabo por los cuidadores, que tradicionalmente son mujeres. (Booth, 2002: 6)

Pero la vida cotidiana en Europa no ha seguido las pautas que las feministas escandinavas propusieron porque:

Inevitablemente, la vida cotidiana se encuentra limitada por una gran variedad de convenciones que generan una gama de estrategias de imitación creadas por individuos y unidades familiares (Mingione, 1991, Healey, 1997, cit. en Booth, 2002: 2)

A mediados de los noventa, las mujeres arquitectas sensibles a la problemática habitacional de las mujeres, comenzaron a sentir que todo iba muy lento, que de la discusión sobre las desventajas de la mujer en un mundo de hombres, había que pasar a proponer una visión alternativa.

El proyecto-modelo Frauen-Werk-Stadt ofrece un ejemplo positivo de respuesta y comprensión de dicha problemática por parte de los responsables políticos. Este proyecto demuestra que los principios de la vida cotidiana se han insertado en el proceso de urbanismo y diseño para producir un desarrollo arquitectónico sensible a la cuestión de las diferencias entre hombres y mujeres. (Booth, 2002: 2)

Jane Jacobs también extiende esa necesidad ética de respeto a las personas habitantes de los espacios construidos, al espacio urbano al que reconoce como espacio habitado por mujeres, como recordando las características de las edificaciones matrilineales, que analiza Carmen Espegel en Heroínas del espacio, que reflejan una vida comunitaria donde lo esencial es la relación, en ese patio o plaza, espacio colectivo generador de la casa, contra el pensamiento patriarcal establecido, donde lo urbano es lo público, el supuesto espacio del varón, el lugar desde donde se ejerce la dominación, simbolizado en el árbol situado fuera del espacio doméstico. 

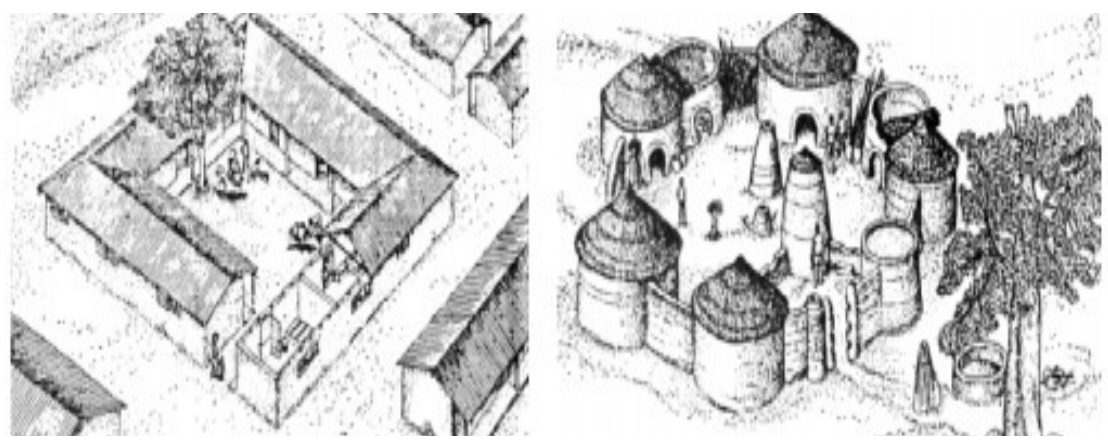

53. Casa matrilineal (izquierda), casa patrilineal (derecha). Fuente: Espegel, 2008.

Aparentemente, la morada matrilineal resulta más rígida por su estructura mecánica mientras que la patrilineal refleja, en apariencia, una mayor libertad por su geometría orgánica. La matrilineal es artificio frente a la naturaleza: es racional, abstracta, culta y social. Se instala en un sitio transformándolo en lugar. Produce una jerarquía espacial, un ámbito «urbano» y conecta gradualmente el interior con el exterior. Por el contrario, la patrilineal es mimética con la naturaleza; resulta instintiva, zoológica, realista, naturalista y encierra un sitio sin llegar a transformarlo en lugar pues no produce nuevas relaciones espaciales del entorno con ella misma. Aísla al territorio, naturalizándolo. Su carácter defensivo no genera tejido urbano, no construye «ciudad». Limita el espacio en el doble sentido de la palabra. (Espegel, 2008: 26)

Isabel Segura Soriano comenta las ideas de Jane Jacobs, coherentes con la casa matrilineal primitiva, con las siguientes palabras:

Jane Jacobs situa en el centre el que, definit com a escala domèstica, no és altra cosa que optar per una ciutat en la qual el domèstic, dit en altres paraules, la vida quotidiana, sigui l'eix prioritari per analitzar, projectar i dissenyar les polítiques urbanes, ja siguin polítiques públiques, econòmiques o socials. ${ }^{13}$ (Segura, 2012: 89)

Es en el urbanismo donde más se ha incidido desde los lugares de innovación feminista. En este trabajo intento aportar visibilidad a otras problemáticas que se encuentran en el interior, no interiores privados, no interiores íntimos, sino

13. Jane Jacobs sitúa en el centro lo que, definido como a escala doméstica, no es otra cosa que optar por una ciudad en la que lo doméstico, dicho con otras palabras, la vida cotidiana, sea el eje prioritario para analizar, proyectar y diseñar las políticas urbanas, ya sean políticas públicas, económicas o sociales. (Traducción propia). 
interiores de ocultación que lo que ayudan a construir es la alteridad de las mujeres que no los poseen como espacios privados sino como lugares de trabajo y sumisión. Las mujeres no poseen esos espacios, no son sus espacios privados, no pueden construir en ellos su identidad, pues no están en ellos para descansar, meditar, reflexionar, dialogar consigo mismas, sino para facilitar la privacidad del otro. Las mujeres habitan esos espacios como el alter ego de aquellos que sí los poseen para su privacidad y los habitan y van construyéndolos mientras construyen su identidad desde decisiones tomadas con libertad.

Nieves Muñoz, en Los ecos del banquete no escrito, describe vívidamente la alienación de las mujeres en este espacio tan fundamental en el hogar, gracias al artificio de suponerlas conscientes de ella. Hablan en la cocina, mientras preparan afanosamente las viandas que complacerán a los hombres, reunidos para hablar de Eros, el dios del amor, en el famoso Banquete de Platón.

A nosotras no nos dejan espacio para recrearnos con aquello que de hermoso pudiéramos encontrar en la vida. Creo que hablan del mundo que se fabrican como si lo ajeno a su poderío, a sus ideas y a su bienestar privado no existiera, porque realmente no existimos para los hombres; nuestra humanidad se tambalea cuando las acciones que realizamos son movidas por extraños hilos cuya procedencia ignoramos. Tras las paredes que les rodean, ellos sólo sienten el vacío, no existe nada más, ni siquiera están sus mujeres cuando, rígidas como estatuas, les acompañan en sus reuniones, tampoco ellas son. (Muñoz, 2010: 47) 
5. LA IMAGEN DE LAS MUJERES EN LOS ESPACIOS INTERIORES 
«La historia de la arquitectura no es simplemente la historia de los edificios sino también la historia de lo que pensamos de ellos: las teorías que construimos sobre ellos, las fotografías que de ellos tomamos, las conversaciones que provocan. Las buenas instituciones (publicaciones, museos, escuelas, etc.) son aquellas que no sólo registran esas conversaciones o enseñan principios ya establecidos, sino más bien las que estimulan nuevas conversaciones. La buena arquitectura es siempre una provocación»

(Beatriz Colomina, 2010: 27) 


\subsection{Los medios de difusión. Las revistas}

Una de las líneas de esta investigación pasa por acercar nuestra mirada a una serie de revistas de arquitectura y diseño de interiores. El objetivo es analizar el discurso que las revistas seleccionadas ofrecen a las personas que recurren a ellas en busca de información. Desentrañar al menos uno de los hilos argumentales de estas publicaciones, implícito, incluso explícito si nos detenemos a observar con la atención puesta en el parámetro género.

Las revistas tienen perfiles que van desde lo más técnico arquitectónico, hasta aquellas que, sin abandonar el ámbito arquitectónico, pretenden alcanzar a un público más heterogéneo con un carácter ciertamente divulgativo también.

Tal y como hemos analizado en el capítulo 3.2.3, en el Estilo Internacional, al hablar, entre otras, de la casa Eames, existía ya la necesidad de aparecer en las revistas para ser en el mundo del diseño o de la arquitectura. Cabe volverse hacia estos espacios de difusión sobre papel, con un espíritu crítico que nos permita detectar los posibles mensajes ocultos que transmiten a nuestra sociedad. Cada imagen es imagen de un objeto y cada objeto lleva inscrito un escenario de género. En ese mismo capítulo aludíamos también, según cita de Colomina, a la propaganda sobre la domesticidad, fruto de la Guerra Fría.

La Doctora Susana Martínez-Conde, cuyo trabajo ha sido referido ya en la introducción de esta investigación, doctorada por la Universidad de Santiago de Compostela, y responsable del laboratorio de Neurociencia Visual en el Barrow Neurological Instituteen Phoenix (Arizona), dedica parte de su investigación a explorar las bases neurales de la atención y de la consciencia. Martínez-Conde habla de la diferencia entre aquello que vemos con los ojos y nuestra percepción de la realidad, percepción construida por nuestro cerebro de manera subyacente a la experiencia consciente. La percepción que tenemos de la realidad se ve afectada, según esta investigadora, por aspectos tales como nuestra educación, los prejuicos que podamos tener o nuestras ideas preconcebidas. Así mismo, tanto los gustos como los intereses personales afectan a cómo percibimos la realidad. Esto implica dos interpretaciones que, pudiendo parecer contrapuestas resultan compatibles. Por una parte, frente a 
una misma escena, un grupo de personas hará una descripción con similitudes, cuando comparemos sus descripciones, habrá consenso respecto a una serie de detalles o aspectos de la misma. Por otra nos encontraremos también con que esas descripciones presentan diferencias individuales, es decir, hay partes que resultan llamativas para todo el mundo y otras que se detectarán en función más bien de cada persona en particular. Existen partes que todo el mundo va a mirar, que están presentes a nivel consciente, y otras que son inconscientes y que puede que las observe una persona pero no otra:

Necesitaríamos un cerebro del tamaño de un edificio para percibir fielmente la realidad. La cámara de un móvil tiene mayor resolución que el ojo humano, pero el cerebro recurre a trucos para lograr una imagen más nítida y detallada, aunque menos fiel. [...] La mayor parte de lo que percibimos es una ilusión, trucos del cerebro para hacer frente a sus limitaciones «técnicas». (Martínez-Conde; 2014: 1)

Lynne Cohen, fotógrafa canadiense, también ya citada, contribuye a dar sentido al análisis de las ausencias que vamos a realizar a continuación. Su obra relata la presencia humana en espacios interiores de lo más variado, desde salas de estar, pasando por aulas o clubes privados hasta lugares cuyo acceso no está al alcance de toda la población como puede ser una instalación militar; y en todos estos casos, Lynne Cohen relata la presencia humana sin fotografiar personas. Cohen trabaja sus relatos desde la ausencia.

Ausencia. Ausencia es una palabra que nos liga a la obra de Doris Salcedo, colombiana nacida en Bogotá en 1958. Esta artista implica, en sus instalaciones y esculturas, a cada persona observadora en el vacío que denuncia un hecho terrorífico que ha derivado en ausencia.

Doris Salcedo prepara una instalación que será visitable entre octubre de 2017 y marzo de 2018 en el Palacio de Cristal del museo Reina Sofía madrileño. En ella la ausencia será presencia. Una instalación de arena en la que la huella de los nombres esculpidos en agua traerá hasta nosotras a tantas y tantas otras personas, como quienes visitemos dicha instalación, ahogadas en el Estrecho de Gibraltar. 
En otro ámbito, con diferente resultado, pero desde el convencimiento de que la ausencia constituye presencia, tal y como acabamos de perfilar, cabe el acercamiento a las revistas analizadas en la investigación que nos ocupa.

\subsection{Ausencias}

"Cuando en un mosaico falta una pieza, la reconocemos por el hueco que deja, lo que de ella vemos es su ausencia; su modo de estar presente es faltar, por tanto es estar ausente» Ortega y Gasset

Que las mujeres están ausentes en arquitectura lo ilustra la siguiente cita de Daniela Arias. Arias desarrolla en su tesis una revisión sobre aspectos sociales en las revistas de arquitectura. Detecta que en ellas hay muy poca aportación sobre aspectos sociales, y entre la poca que hay, la mayoría está vinculada a temas de ecoconstrucción. Denuncia la reducida presencia de artículos que versen sobre cuestiones de género, uno de entre todos los temas sociales sobre los que investiga. Desde ese pequeño hilo de su tesis enlaza de algún modo con la mía, centrada completamente en cuestiones de género y en la que el vaciado de imágenes de revistas de arquitectura constituye un aspecto esencial:

Merece la pena esbozar brevemente como se presenta la publicidad en las revistas analizadas. Si los medios de comunicación en términos generales forjan nuestro pensamiento, la publicidad es su gran aliada. Las revistas de arquitectura no son la excepción, el rol que juega el anuncio publicitario en la introducción de nuevos productos de mercado para el mundo de la arquitectura forma parte de los contenidos de cada publicación de la misma forma que los artículos de opinión, la noticia, la crítica o la fotografía. La 
divulgación de un acontecer aparentemente cotidiano hace referencia a dos variables: el rol del sujeto como ser social y la recreación de un escenario donde se desarrolla como lugar de acción. La propaganda de carácter sexista se caracteriza por polarizar a los sujetos, las imágenes masculinas y femeninas a las cuales se les asigna roles y espacios concretos contribuyen a consolidar los estereotipos. La mujer sigue relacionada a todos aquellos productos vinculados al hogar y ámbito de lo doméstico con el añadido de la importancia que se le da al cuerpo como objeto sexuado. (Arias: 2013: 59)

Por mucho que la búsqueda de materiales gráficos de interiores con imágenes de mujeres resulte casi infructuosa, aún en su ausencia, como indica la cita de entrada, podemos encontrarlas, están presentes.

Si queremos rastrear el rol de las mujeres a través del material gráfico sobre arquitecturas de espacios interiores actuales, tendremos que intuirlas «buscando los indicios de su presencia» como dice la fotógrafa canadiense Lynne Cohen (1944-2014), interesada en fotografiar espacios interiores domésticos o institucionales, siempre sin figuras humanas:

La fotógrafa Lynne Cohen (Racine, Wisconsin, 1944) considera que para contar la vida de las personas no hace falta retratarlas. Basta con conocer los indicios de su presencia.

Su intención ha sido siempre conseguir que los materiales y los objetos hablen por sí mismos. Las cosas ya parecen suficientemente extrañas por sí mismas. Hay que oír su historia. La sala de espera de una peluquería de señoras, la consulta de un dentista, las aguas en reposo de un espá o los enchufes desordenados de un rincón de un laboratorio, pueden narrar más historias que las personas que hacen uso diario de todo ello.

[...] En uno de los textos que acompaña el catálogo de la exposición, explica que en sus paisajes de interiores, no hay personas porque no sabría qué hacer con ellas ni dónde ponerlas. En realidad, viene a decir, no aportan nada. Cada espectador puede imaginar perfectamente cuales serían las acciones posibles dentro de esos desasosegantes interiores. (García, 2014: 2) 
Beatriz Preciado aporta su punto de vista desde la arquitectura: «no se accede a la subjetividad a través de la narración psicológica, sino a través de la representación arquitectónica» (Preciado, 2010: 84).

Peter y Alison Smithson nos ofrecen una opinión semejante a la de Preciado, y relacionada con el juego ausencia-presencia, en su exposición Patio \& Pavillion, (Smithson, 2012: 43).

En toda la exposición el «principio de identidad» cobra una gran relevancia y es transmitido al visitante mediante dos elementos. El primero de ellos es la identificación con un trozo de terreno protegido, el cual es «ofrecido» por los arquitectos, y se convierte en escenario para el segundo elemento, «los signos de ocupación» proporcionados por los artistas en su papel de «habitantes genéricos». Así como Patio \& Pavillion resume el sueño de habitar tipológicamente (un trozo de mundo, por una parte, y un espacio cerrado, por otra), y simbólicamente (con los signos de ocupación). La instalación se ve poblada de objetos cotidianos, portadores de afectos y memoria, testigos de la verdadera identidad del sujeto y narradores de la historia de la casa. (Smithson, 2012: 48)

Como la fotógrafa Lynne Cohen, Peter y Alison en Patio \& Pavillion beben del método arqueológico: en los yacimientos no sólo falta la gente sino algunos edificios. Desde las ruinas y los objetos hallados, la arqueología reconstruye la vida y la cultura de sus habitantes, y las causas de la destrucción. Si damos un breve paseo por la arquitectura del siglo pasado, nos llevaremos la sorpresa de que, lejos de ser un fenómeno arcaico, está muy presente en todas las épocas y con mayor intensidad en la época contemporánea y actual, como nos hace ver Beatriz Colomina en su obra La domesticidad en guerra (2010).

La arquitectura europea y americana de la primera mitad del siglo XX está vinculada a las guerras que asolaron Europa. Tanto las ruinas que dejaron como las nuevas construcciones que se edificaron sobre parte de ellas, hablan de esas vidas y esas culturas antes y después de esas guerras. La postguerra de la guerra del 14 vio crecer sobre las ruinas de la vieja Europa, las construcciones del Movimiento Moderno; y, en América, tras la Segunda Guerra Mundial, se proyectaron multitud de casas experimento, expresión de las 
distintas necesidades que se iban generando. Todas ellas son representaciones arquitectónicas que construyeron la identidad de las gentes de esos periodos históricos. La distribución masiva de los prototipos de casas experimentales, a través de los medios de comunicación, multiplicaron su efecto, en particular a través de las revistas de arquitectura, que, desde comienzos del siglo pasado se convirtieron en institución autorizada por el estamento arquitectónico.

La ausencia, tanto de mujeres arquitectas en las revistas de arquitectura como de mujeres usuarias desempeñando las labores que el topo-poder les asigna, es un modo de violencia, como resume Rosalía Torrent Esclapés, cuyas líneas de investigación se sitúan en torno al arte feminista y al arte y el diseño contemporáneos. En su artículo «El silencio como forma de violencia. Historia del arte y las mujeres», afirma:

La violencia contra las mujeres se manifiesta de múltiples maneras. Para este artículo hemos elegido reflexionar sobre esa forma de violencia que consiste en silenciar o minimizar sus hallazgos, en este caso en la esfera creativa. Contra este silencio, las mujeres han respondido individualmente con la ironía y colectivamente con la sonoridad. No existían muchas más formas de enfrentarse a este tipo de violencia basada en su anulación como personas. A partir del desarrollo del arte feminista también se respondió levantando la voz. En cualquier caso, hemos elegido, dentro de las creaciones vinculadas al feminismo, aquellas donde el silencio se quiebra también con el silencio. (Torrent, 2012: 200)

Coincidiendo con Rosalía Torrent en la opinión de que hay silencios que rompen el silencio, Manolo Dos, profesor de la asignatura «Mujer y silencio: la ciudadanía silenciosa» dentro del Máster de Investigación Aplicada en Estudios Feministas, de Género y de Ciudadanía, en la Universitat Jaume I, en su artículo «Mujer y Cine. Voces emergentes y otros silencios» nos desmenuza los silencios del director de cine japonés Kaurismäki en La chica de la fábrica de cerillas:

La emoción que nos produce la historia de Iris no nace de lo que se nos cuenta en sí, sino del terrible contraste entre la despiadada realidad mostrada por las imágenes y sus constantes silencios. Nunca sale una queja de los labios de Iris, en cambio Kaurismäki nos ofrece su rostro 
callado para que sea el espectador quien otorgue dimensión a su tragedia. Se trata de dar forma a una emoción, a un sentimiento, a través de su ausencia. (Dos, 2012: 22)

Recuerda la expresividad, la magia del cine mudo y la queja de Chaplin, a la entrada del cine sonoro, pues consideraba que se perdería calidad expresiva, que el esfuerzo por conseguir la comunicación con la mímica se vería resentido al hacer dejación de la comunicación en la palabra. Según Bandler y Grinder, la palabra sólo aporta un $7 \%$ del mensaje cuando es coherente con la expresión corporal y el tono de voz. Sin coherencia entre dichos tres factores, la palabra por sí misma, no resulta convincente.

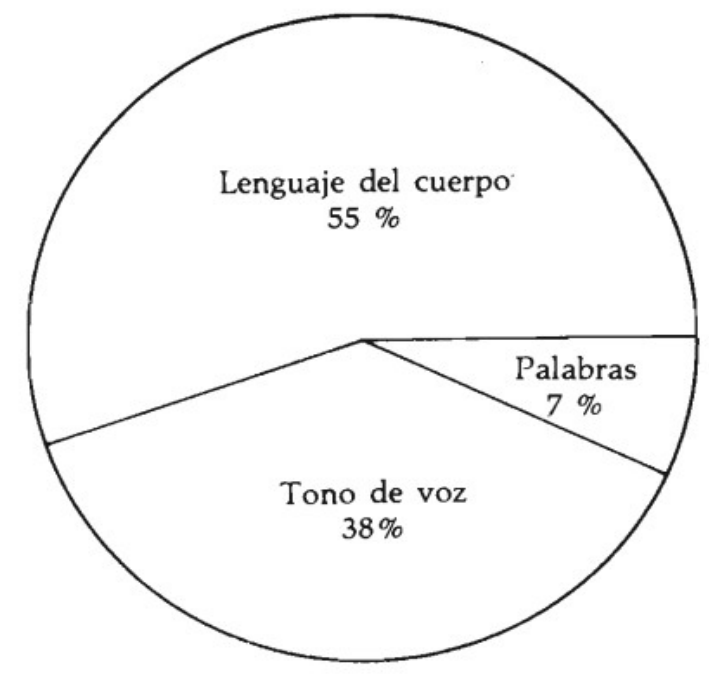

54. Bandler y Grinder. Porcentajes del mensaje,1992.

En Tiempos Modernos Chaplin se adelantó a Kaurismäki. Los únicos sonidos que se oyen son los de las máquinas y algún diálogo con el jefe, que contrastan con las expresiones del protagonista y su mujer. Expresiones de una angustia creciente hasta que deciden alejarse de ese mundo inhumano, despersonalizado, explotador del taylorismo y el fordismo industrial. 
Tiempos Modernos, un espejo pulcramente brillante donde es posible encontrar aquellos lugares comunes, interpretaciones, códigos, gestos, apropiaciones y objetos culturales que tuvo una sociedad completa durante su turno histórico. (Araya, 2010: 4)

No sólo la fotografía o el cine, otras artes como la música, la poesía, la pintura y la escultura han optado por hablar con los silencios. Así lo explica Kosme de Barañano en la cita que podemos consultar en la página treinta y tres de la presente tesis, cuando trata, en su libro Materialidad del silencio, sobre la fuerza constructiva del vacío y trae a colación la obra pictórica abstracta de Julius Bissier, Zoran Music, Mark Tobey, o la obra escultórica abstracta de personas como Eduardo Chillida y James Turrell.

La potencia del silencio activo en las artes, la denuncia que desde ellas se hace del poder del silencio, debilita la utilización de lo no dicho, de las ausencias no computadas. La escasa presencia de imágenes de personas en las revistas de arquitectura constatada en este trabajo, como veremos en el análisis de las gráficas que presento seguidamente, es lo no dicho. De ese silencio voy a hablar en este capítulo. Lo haré siguiendo la pauta de Ortega, de Lynne Cohen, del matrimonio Smithson y de la arqueología para hacer presentes las ausencias. Tal vez luego sea posible la arquitectura del silencio en el sentido aludido por Rosalía Torrent, Manolo Dos y Kosme de Barañano.

\subsection{Recogida de datos}

Actualmente existen numerosas publicaciones dedicadas a la difusión de imágenes de espacios interiores. Muchas de ellas tienen un carácter básicamente divulgativo y están destinadas a un público objetivo que dista del ámbito del diseño, ya sea del diseño de interiores o del mundo de la arquitectura. Por la dirección establecida en esta investigación, el trabajo de campo desarrollado a partir de varias publicaciones ha sido realizado descartando dicho perfil divulgativo. Las revistas escogidas para seleccionar la muestra de ejemplares que nos permita desarrollar la investigación han sido aquellas que permiten un análisis que se vincula específicamente con el mundo profesional del diseño. Las publicaciones escogidas como base para este estudio son: Arquitectura Viva, Casabella, Diseño Interior, Domus, El Croquis y 
On Diseño. En todos los casos el periodo elegido para el escrutinio ha sido de seis años. Seis años revisados de manera retrospectiva. En cinco de ellas la franja temporal analizada discurre retrospectivamente desde las publicaciones del año 2015 hasta el año 2010, y en Arquitectura Viva el período analizado comprende los seis años que van, retrospectivamente hablando, desde 2014 hasta 2009. Se trata de seis años de publicaciones generando imágenes y que no solo narran sino construyen un determinado tipo de sociedad y no otro.

Las revistas seleccionadas son publicaciones de reconocido prestigio y calado tanto internacional como nacional.

Arquitectura Viva trata en sus páginas lo más destacado de un arquitecto o arquitecta, una región o un movimiento. Presenta novedades nacionales e internacionales y saca periódicamente un anuario con los mejores proyectos en España así como una recopilación de las mejores obras terminadas en los cinco continentes.

Casabella también desarrolla en sus páginas artículos de difusión especializados en arquitectura y construcción, seleccionados a nivel internacional.

Diseño Interior es una publicación que incide, como su propio nombre indica, en el diseño. Publica proyectos que considera relevantes, diseños innovadores y de calidad conceptual, todo ello a nivel internacional.

El equipo de redacción de Domus se dirige a un público especializado y de clase alta. El contenido que aparece en sus páginas genera información sobre arquitectura y diseño con temas escogidos en el ámbito internacional.

El Croquis publica monográficos sobre arquitectos y arquitectas de todo el mundo y está considerada como una revista de carácter muy profesional.

Escogí On Diseño para completar la visión que esta selección de fuentes de información podía aportar. Es un referente de la cultura del diseño español en los últimos treinta años. Básicamente se dedica a temas proyectados y desarrollados por profesionales de nuestro país. 
Se trata, por tanto, de una amplia selección de medios de difusión que abarcan la transmisión de contenidos de interés para esta investigación desde diferentes puntos de vista. En el ámbito internacional lo más destacado de un arquitecto o arquitecta, región o movimiento; artículos especializados en arquitectura y construcción; proyectos considerados relevantes, con diseños innovadores y de calidad conceptual; contenidos escogidos para público especializado y de clase alta; y monográficos sobre arquitectos y arquitectas de todo el mundo. En el ámbito nacional, para el estudio en estas páginas planteado sobre nuestro entorno más cercano, las revistas seleccionadas constituyen un referente sobre la cultura del diseño español producida por profesionales españoles en nuestro territorio.

Esta selección presenta por tanto un abanico que permite plantear, a priori, que la información difundida desde las páginas analizadas va a trasladar un reflejo fidedigno desde un punto de vista profesional vinculado a la arquitectura y a los espacios interiores, que son los que nos ocupan, y los seis años escrutados ofrecen una lectura con perspectiva.

Con el fin de ofrecer una descripción lo más ajustada posible al criterio con el que cada una de estas publicaciones sale al mercado, me puse en contacto con sus equipos editoriales. El objetivo era, en primer lugar, informar a estos equipos de la decisión que había tomado de incluir sus publicaciones en el desarrollo de mi investigación, y en segundo lugar, obtener la explicación de sus criterios editoriales desde la fuente, obviando interpretaciones de terceros. Transcribo, a continuación, las palabras con que las propias revistas definen sus contenidos.

Tras realizar consulta por correo electrónico al equipo de Arquitectura Viva, el siete de junio de 2016 me trasladan los aspectos que, según el equipo de esta publicación, son de mayor relevancia:

Fundada en 1988, Arquitectura Viva es una publicación que, número tras número, da cuenta de las novedades nacionales e internacionales relacionadas con el mundo de la arquitectura y con disciplinas técnicas y artísticas afines. En ella se combinan el rigor 
monográfico con el desarrollo exhaustivo de un tema de portada y la amplitud de miras de una revista de actualidad con secciones de noticias breves, reseñas de libros, exposiciones, e innovación tecnológica. Arquitectura Viva es enteramente bilingüe español e inglés.

La respuesta del equipo de Casabella a mi requerimiento me reconduce hacia un número concreto de la revista, el 632, de marzo de 1996, así como al libro C. Baglione Casabella 1928-2008, Electa Milano 2008 donde puedo encontrar aquello que consideran de especial relevancia:

La proposta formativa comprende: viaggi dedicati alla visita di opere, siti e città particolarmente rilevanti per quanti interessati all'architettura; visite a cantieri, siti produttivi, mostre; lezioni; incontri con i protagonisti della professione e del mondo delle costruzioni.

«Casabella» è una delle più aggiornate e autorevoli riviste internazionali di architettura. II primo numero di «Casabella» venne pubblicato nel 1928. Sino al 1940 "Casabella» è stata una delle voci più ascoltate durante gli «anni eroici» dell'architettura moderna. Dopo il 1945 ha accompagnato la ricostruzione dell'Europa distrutta dalla guerra. "Casabella» è ora disponibile sia nella tradizionale versione cartacea sia in edizione digitale ed è pubblicata in italiano e in inglese. Dal 2007 la rivista è pubblicata in edizione giapponese con la testata «Casabella Japan».

L'iniziativa culturale ProVeViaggi nasce nel 1995 grazie all'energia di un gruppo di studenti dello IUAV (Università di Architettura di Venezia), con l'obiettivo di conoscere l'architettura attraverso la visita dei principali progetti e delle grandi trasformazioni urbane. Dopo oltre un decennio di «ProVe» di Viaggi, l'iniziativa cambia nome specializzandosi nella Progettazione di Viaggi di Studio e da qui il nome: ProViaggiArchitettura. Avvalendosi di uno staff di collaboratori presso le sedi di Siena e di Castel Bolognese ed una ricca rete di collaboratori attiva nelle più importanti città italiane e d'Europa, ProViaggiArchitettura, diretta da Roberto Bosi, collabora con le maggiori Università di Architettura d'Italia e con diversi Ordini degli 
Architetti di varie province nell'organizzazione di Viaggi di Studio e Seminari di Aggiornamento Professionale attraverso itinerari di architettura contemporanea. Di ultima sperimentazione sono i Viaggi Tirocinio/Workshop e i Viaggi d'Autore. Dal 2014 è stato riconosciuto dal Consiglio Nazionale degli Architetti - CNAPPC come Ente Terzo accreditato per la Formazione Professionale Continua per gli Architetti. ${ }^{14}$

En las mismas fechas, consultado el equipo de Diseño Interior, el día seis de junio de 2016 me remite lo que conviene en llamar el Media Kit de presentación de la revista, enfocado según me participa dicho equipo al departamento comercial, y que paso a transcribir:

Los creadores de proyectos relevantes, diseños innovadores, tendencias, están en cada edición de Diseño Interior.

La calidad conceptual, la vanguardia, pueden hoy surgir en cualquier punto del planeta. Los expertos internacionales que colaboran con nuestra revista saben detectar lo excepcional en Nueva York, Ámsterdam, Tokio y, naturalmente, en nuestro mundo próximo. Sería muy difícil encontrar un creador notable que no haya mostrado y explicado su obra en Diseño Interior en los últimos 25 años desde 1991.

La misión editorial de Diseño Interior es descubrir aquellas tendencias que superan el análisis crítico. Lo nuevo es importante si

\footnotetext{
14. La propuesta formativa incluye: viajes dedicados a visita de obras, los sitios y ciudades son particularmente relevantes para los interesados en arquitectura; visitas a sitios, lugares de fabricación, exposiciones; lecciones; encuentros con los protagonistas de la profesión y la industria de la construcción.

«Casabella» es uno de las revistas internacionales más actuales y con autoridad de arquitectura. El primer número de "Casabella», fue publicado en 1928. Hasta 1940, "Casabella» era una de las voces principales durante los años heroicos «de la arquitectura moderna». Después de 1945 acompañó la reconstrucción de la Europa desgarrada por la guerra. "Casabella» está disponible tanto en la versión tradicional de papel como en edición digital y se publica en italiano y en Inglés. Desde el año 2007 la revista se publica en la edición japonesa de la revista "Casabella Japón».

La iniciativa cultural ProVeViaggi nacida en 1995 gracias a la energía de un grupo de estudiantes de la IUAV (Universidad de Arquitectura de Venecia), con el objetivo de conocer la arquitectura a través de la visita de los grandes proyectos y grandes transformaciones urbanas. Después de más de una década de «pruebas» del viaje, la iniciativa cambió su nombre que se especializa en el estudio de la planificación de viajes y de ahí el nombre: ProViaggiArchitettura. Con una plantilla de empleados en las instalaciones de Siena y Castel Bolognese y una rica red de socios activos en las más importantes ciudades italianas y europeas, ProViaggiArchitettura, dirigida por Roberto Bosi, colabora con las principales universidades de Italia y Arquitectura con diferentes despachos de Arquitectos de varias provincias en la organización de viajes de estudio y actualización de seminarios profesionales a través de itinerarios de arquitectura contemporánea. Los últimos ensayos son los viajes de prácticas/taller y el Travel d'Autor. En 2014 fue reconocida por el Consejo Nacional de Arquitectos - CNAPPC como tercer organismo acreditado para la formación profesional continua para arquitectos.
} 
antes es solvente. Solo un criterio formado en muchos años, con expertos analistas, es capaz de rastrear lo mejor por todo el mundo y sacar a la luz cada mes proyectos imprescindibles para los profesionales de la arquitectura y el interiorismo.

Es un trabajo duro convencer a lectores profesionales que, a su vez, son creadores con obra muy importante. Lo hacemos desde 1991 y ahora también en inglés.

25 años avanzando el futuro

Nuestros contenidos responden a los intereses que nuestros lectores han definido a través de las encuestas que Diseño Interior hace regularmente:

Lo que va a ocurrir: agenda de eventos, exposiciones, ferias, presentación de novedades.

Qué acaba de ocurrir: Qué ha sido relevante en las ferias internacionales, inauguración de showrooms, exhibiciones. ZOOM: el análisis preciso, rápido, de las creaciones con valores que hay que mostrar ya.

Los grandes proyectos: la gran selección de aquellos diseños de proyección internacional que deben ser analizadas con el mayor detalle de sus cualidades.

Las nuevas soluciones: todos los componentes constructivos del interiorismo son tratados anualmente con revisiones monográficas: novedades, gamas que permanecen, las empresas que producen en el sector.

En todas las encuestas que Diseño Interior realiza desde 1991, el porcentaje de arquitectos $\mathrm{e}$ interioristas que conoce $\mathrm{o}$ lee ocasionalmente la revista supone el $94 \%$ del total del colectivo profesional.

32.000 profesionales españoles -de la arquitectura, diseño, interiorismo, y áreas afines- leen cada número.

2.100 suscriptores, de los que el $42 \%$ son estudios profesionales, reciben la revista cada mes. 
Difusión internacional desde que comenzó la comercialización en apple Store y Google Play Diseño Interior ha aumentado su difusión internacional un $18 \%$.

87.000 lectores en España y otros países

Perfil del lector:

$85 \%$ arquitectos, interioristas y profesionales de la decoración.

$15 \%$ amantes del diseño, las artes y de la estética de vanguardia.

$52 \%$ con formación universitaria.

42,5 de media de edad.

$61 \%$ hombres. $39 \%$ mujeres

Tanto en el caso de Domus, como El Croquis, ni las gestiones realizadas a título personal, ni a través de la Vocalia de cultura, biblioteca i formació del Colegio de Arquitectos de Castellón, COACS, por Javier Sorlí dan fruto, por tanto debo recurrir al formato digital en el que anuncian sus páginas:

La revista de arquitectura Domus fue fundada en 1928 por Gio Ponti.

Es una publicación sobre arquitectura, diseño, arte e información con gran repercusión internacional. Dirigida a un público especializado y de clase alta, Domus se ha convertido en un valioso instrumento de trabajo y de referencia para los profesionales del sector, no sólo en Italia sino en los 89 países donde se distribuyen sus ejemplares.

Domus destaca a lo largo de su historia por la publicación de las principales obras y proyectos de arquitectura del momento, por sus ilustraciones y por las colaboraciones de teóricos como Gio Ponti, Ernesto N. Rogers, Alberto Moravia, Vittorio Magnano Lampugnani, Stefano Boeri, entre otros.

Con sede editorial en Milán y fundada en 1928 por el arquitecto y diseñador Gio Ponti, la revista Domus se mantiene hasta la fecha como una de las publicaciones de referencia internacional sobre arquitectura y diseño. Con más de setenta y cinco años de trayectoria, su vigencia sigue siendo incuestionable: Domus es uno de los medios donde los principales estudios de arquitectura y de diseño presentan y someten a opinión crítica sus nuevos proyectos; 
contempla reportajes de análisis riguroso acerca de temáticas enfocadas desde perspectivas muy alejadas de las aproximaciones planteadas por revistas obsesionadas por las tendencias de moda 0 aferradas al purismo académico.

Setenta y cinco años de edición ininterrumpida equivalen a afirmar que por las páginas de Domus ha discurrido, en tiempo real, la historia de la arquitectura, el diseño y el arte del siglo XX: el Art Decó, el desarrollo del Movimiento Moderno, pasando por el Funcionalismo, el Pop, la Post-Modernidad han sido ilustrados y comentados en la revista desde una mirada absolutamente coetánea. Un artículo comentando un edificio en Viena proyectado, entre otros, por Adolf Loos con texto y fotografías de 1932; la noticia acerca de un proyecto de Carlo Mollino presentado en una exposición de diseño en Nueva York en 1950; la serie de platos con variaciones sobre un rostro diseñados por Pietro Fornaretti en 1955; fotografías de la construcción del World Trade Center en Nueva York en 1973; proyectos de todos los arquitectos clave del siglo. En síntesis, imágenes y textos sobre la encarnación del espíritu de la centuria en su dimensión conceptual y en su dimensión estética.

Nuestra relación con el siglo XX bascula actualmente entre la ambivalencia que supone comenzar a percibir una cierta distancia mental respecto a él y la sensación de intensa pervivencia de algunas de las constantes que lo definieron. Esto se percibe ante el compendio con carácter de enciclopedia, con cuya realización Taschen ha señalado un punto y aparte en la línea cronológica viva de Domus, imbuyendo de naturaleza de documento histórico a todo ese material que mensualmente se publicaba como reflejo de la actualidad de la arquitectura y del diseño. Permitiendo contemplar hoy esa historia como cuando era presente.

El Croquis, en las líneas que definen sus objetivos editoriales, plantea méritos y criterios establecidos para su edición:

El Croquis es una de las revistas de arquitectura más reconocidas y prestigiosas a nivel internacional. Editada y dirigida desde El Escorial (Madrid) por Fernando Márquez Cecilia y Richard Levene, dedica el 
espacio de sus páginas a extensas monografías sobre los mejores arquitectos del mundo y recoge los procesos del proyecto arquitectónico y detalles exhaustivos sobre su construcción. Álvaro Siza, Sean Godsell, Smiljan Radic o Glenn Murcutt son algunos de los arquitectos a los que se han dedicado los últimos números. Se publica con periodicidad bimestral en castellano e inglés y ha recibido la Medalla FAD en 2004.

Los primeros números de la revista El Croquis incluían habitualmente entre sus páginas una sección dedicada al Diseño Industrial, cuya presencia se justificaba al ser una disciplina tan cercana al oficio de la Arquitectura. Posteriormente la editorial tomó la decisión de crear una revista especializada en temas relacionados con el Diseño Industrial, el Diseño Gráfico y el Interiorismo, paralela a la trayectoria específica de El Croquis y que tomó el nombre programático de De Diseño. Los indudables puntos de confluencia entre ambas publicaciones, llevaron a editarlas conjuntamente en volúmenes dobles bajo el nombre de El Croquis Edición Especial. No obstante estas ediciones especiales (El Croquis + De Diseño) junto al giro que tomó la revista De Diseño al abandonar su sede en Barcelona y trasladarse a la redacción de "El Croquis" en Madrid, se traduciría en una nueva fusión de ambas, abandonando la fórmula de la edición especial por la de revista única, con una estructura de revista bimestral, bajo el nombre de El Croquis, De Arquitectura y De Diseño (1988).

En el caso de On Diseño, aunque no recibo respuesta directa, llega a Javier Sorlí, en la biblioteca del COACS, en junio de 2016, el link en el que vuelcan el criterio de su línea editorial, y del que obtengo las líneas que a continuación aparecen:

EI $n^{\circ} 0$ de la revista ON DISEÑO vió la luz el 31 de diciembre de 1978. 
Tres son los principios básicos que inspiraron la creación de $O N$ DISEÑO y que la han convertido en el referente de la cultura del diseño español de los últimos treinta años.

Su independencia crítica.

Su dedicación casi exclusiva a proyectos de nuestro país.

Su voluntad de analizar de forma global e integradora el conjunto de actuaciones que configuran el modo de vida de las personas, desde la arquitectura, el interiorismo, el diseño objetual y gráfico y que determinan la cultura contemporánea del entorno a la que llamamos diseño.

On Diseño nace en 1978, promovida por un grupo de profesionales de criterio independiente, totalmente desvinculados de los grupos de presión tan habituales, tanto en el mundo editorial como en el ámbito de la arquitectura. Su propósito: llenar el vacío existente en nuestro país en publicaciones dedicadas a la arquitectura y el diseño.

Tres son los principios básicos que inspiran la creación de On Diseño y que han marcado más de veinticinco años de historia.

En primer término, la voluntad de analizar de forma global e integradora toda la amplia problemática que gira en torno al «diseño del entorno», entendido como aquel conjunto de actuaciones que tienden a configurar y sistematizar el entorno cotidiano de las personas. En este sentido, On Diseño no excluye la consideración de ninguno de los campos disciplinares de la proyectación -arquitectura, interiorismo, diseño objetual y gráfica- puesto que, en opinión de sus editores, esta clasificación responde a motivos meramente metodológicos y no a la verdadera y real dimensión del proyecto del entorno. En cierta manera, podría afirmarse que On Diseño defiende la cultura del proyecto entendida en su magnitud total: la cultura contemporánea del entorno a la que llamamos Diseño.

En segundo lugar, On Diseño se ha caracterizado por una dedicación casi exclusiva a los temas proyectados y desarrollados por profesionales de nuestro país. Aunque resulta sumamente tentador, desde el punto de vista editorial, la publicación de materiales 
producidos en el extranjero, los editores de On Diseño han considerado imprescindible dedicar una atención prioritaria a la actividad desarrollada en el país, entendiendo que los proyectistas extranjeros disponían ya de sus propios canales editoriales. Ello no ha supuesto, desde un punto de vista esencialmente pragmático, ningún obstáculo a la publicación de temas producidos fuera de nuestro ámbito territorial, cuando ello respondía al criterio de informar mejor a sus lectores o contribuir a una cierta difusión "pedagógica» del diseño, como ocurre con las novedades de productos de diseñadores internacionalmente reconocidos.

En último término es precisa la referencia al dato sin duda más característico de On Diseño: su independencia crítica. En ningún momento la publicación ha cedido a las presiones de grupos de profesionales, intereses de empresas o cualquier otro intento de presión del exterior. En un momento como el presente en que determinadas publicaciones, tanto de nuestro país como del extranjero, se convierten en meros portavoces de determinadas capillas o tendencias, On Diseño puede proclamar su total y más absoluta libertad de opinión. Esta circunstancia ha permitido dedicar la atención de la revista a aquellas realizaciones que, por encontrarse fuera de las coordenadas de la «cultura arquitectónica oficial», apenas encontraban eco en la prensa especializada.

Para poder procesar los datos extraídos de estos ejemplares y aportar la información que en concreto hace referencia a esta tesis de un modo lo más expresivo y claro posible he creado una hoja Excel con la información extraída. Las hojas Excel aparecen en el Anexo de datos de la edición digital de esta tesis. He necesitado definir aquellos aspectos que iban a ser valorados en la investigación para poder establecer las variables a computar en los gráficos que derivan de ellos: imágenes humanas, género mujer/varón, funciones desarrolladas por las personas que aparecen en las imágenes, tales como persona desarrollando una tarea propia de la arquitectura, persona protagonizando un anuncio, profesión modelo, trabajo remunerado frente a trabajo no remunerado, usuario o usuaria y por último tipos de espacios 
considerados según las siguientes categorías: espacio interior, interior doméstico, interior privado, interior público.

Otro aspecto crucial ha consistido en establecer la muestra necesaria para esta parte de mi investigación. La muestra sobre la que se ha desarrollado esta investigación, en el apartado de campo 1, supera con creces la requerida según los criterios de la estadística, calculada sobre el número de páginas anuales publicadas por cada una de las publicaciones analizadas.

Para calcular el tamaño de la muestra suele utilizarse la siguiente fórmula:

$$
n=\frac{N \sigma^{2} Z^{2}}{(N-1) e^{2}+\sigma^{2} Z^{2}}
$$

Donde:

$\mathrm{n}=$ el tamaño de la muestra.

$\mathrm{N}=$ tamaño de la población.

$\sigma=$ Desviación estándar de la población que, generalmente cuando no se tiene su valor, suele utilizarse un valor constante de 0,5.

$Z$ = Valor obtenido mediante niveles de confianza. Es un valor constante del que, si no se tiene su valor, se toma o en relación al $95 \%$ de confianza, equivale a 1,96 (como más usual) o en relación al 99\% de confianza, que equivale 2,58, valor que queda a criterio de la persona investigadora. En este trabajo utilizo el $95 \%$.

e = Límite aceptable de error muestral. Generalmente cuando no se tiene su valor, suele utilizarse un valor que varía entre el $1 \%(0,01)$ y $9 \%(0,09)$, valor que queda a criterio de quien realiza la encuesta. En este trabajo utilizo el valor 0,05 . 


\begin{tabular}{|c|c|c|c|c|c|c|}
\hline revista & Total pág. & $\begin{array}{l}\text { Muestra } \\
\text { en pág. }\end{array}$ & $\begin{array}{l}\text { mín. } \\
\text { istas }\end{array}$ & $\begin{array}{l}\text { Total revistas } \\
\text { en } 6 \text { años }\end{array}$ & \multicolumn{2}{|c|}{ páginas/periodicidad } \\
\hline El Croquis & 6858 & 363,83 & 1 & 27 & $254 / 127$ & 6/año \\
\hline On Diseño & 6720 & 363,44 & 2 & 42 & 160 & $10+2 \mathrm{mon}$ \\
\hline $\begin{array}{l}\text { Arquitectura } \\
\text { Viva }\end{array}$ & 7930 & 366,45 & 3 & 61 & 130 & mensual \\
\hline $\begin{array}{l}\text { Diseño } \\
\text { Interior }\end{array}$ & 9360 & 369,05 & 3 & 72 & 130 & mensual \\
\hline Casabella & 7700 & 365,95 & 3 & 70 & 110 & mensual \\
\hline Domus & 9425 & 369,15 & 3 & 65 & 145 & mensual \\
\hline
\end{tabular}

Una vez aplicada la fórmula que determina el número de individuos, en este caso páginas, sobre los que realizar el escrutinio en función de la población total, en ningún caso era necesario revisar más de dos ejemplares, en el caso más desfavorable tres números en total, de los seis años estudiados de cada revista analizada. No obstante, con la voluntad de dotar de una homogeneidad temporal a la muestra, las revistas revisadas han sido seleccionadas también según el criterio de preservar, en la medida en que cada publicación contase con ejemplares suficientes, una franja temporal equilibrada entre las diferentes publicaciones.

Cabe comentar, por ejemplo, que si hacemos referencia a Arquitectura Viva, la propia publicación ofrece seis ejemplares anuales en los años 2010, 2011 y 2012 frente a los once que pasarán a publicar anualmente a partir del año 2013, es decir, la propia publicación presenta un salto en el ritmo de publicación establecido.

Aunque los tamaños por páginas implicarían un muestreo aleatorio también por páginas, como he optado por un tamaño de muestra mucho mayor y he querido homogeneizar los tramos temporales, he optado por analizar las siguientes revistas completas: 


\begin{tabular}{|c|c|c|}
\hline Revista & Año & Números \\
\hline \multirow[t]{6}{*}{ El Croquis } & 2010 & $149 ; 150 ; 151 ; 152-153$ \\
\hline & 2011 & $154 ; 155 ; 156 ; 158$ \\
\hline & 2012 & $159 ; 161 ; 163-164$ \\
\hline & 2013 & $165 ; 166 ; 167 ; 168-169$ \\
\hline & 2014 & $170 ; 171 ; 172 ; 173 ; 174-175$ \\
\hline & 2015 & $177-178 ; 179-180$ \\
\hline \multirow[t]{6}{*}{ Domus } & 2010 & $932 ; 938$ \\
\hline & 2011 & $943 ; 949$ \\
\hline & 2012 & $954 ; 960$ \\
\hline & 2013 & $965 ; 971$ \\
\hline & 2014 & $976 ; 982$ \\
\hline & 2015 & 990; 991 \\
\hline \multirow[t]{6}{*}{ Casabella } & 2010 & $785 ; 791$ \\
\hline & 2011 & $797 ; 803$ \\
\hline & 2012 & $815-816 ; 820$ \\
\hline & 2013 & $827-828 ; 832$ \\
\hline & 2014 & 839-840; 844 \\
\hline & 2015 & $847 ; 848$ \\
\hline \multirow[t]{3}{*}{ On Diseño } & 2010 & $308 ; 313 ; 318 ; 314-315$ \\
\hline & 2011 & $319 ; 323 ; 324$ \\
\hline & 2012 & $325 ; 326 ; 327-328 ; 329$ \\
\hline
\end{tabular}




\begin{tabular}{|c|c|c|}
\hline & 2013 & $331 ; 332 ; 334 ; 337 ; 338$ \\
\hline & 2014 & $342 ; 343 ; 344-345 ; 346 ; 348$ \\
\hline & 2015 & $349 ; 350 ; 351 ; 352 ; 356$ \\
\hline \multirow[t]{6}{*}{ Arquitectura Viva } & 2010 & $129 ; 130 ; 131 ; 132 ; 133 ; 134$ \\
\hline & 2011 & $138 ; 139$ \\
\hline & 2012 & $141 ; 142 ; 143 ; 144 ; 145 ; 146$ \\
\hline & 2013 & $150 ; 151 ; 152 ; 153 ; 155 ; 156 ; 158$ \\
\hline & 2014 & $159 ; 160 ; 162 ; 163 ; 164 ; 165 ; 166 ; 167 ; 168 ; 169$ \\
\hline & 2015 & $180 ; 174 ; 173 ; 172 ; 171 ; 170$ \\
\hline \multirow[t]{6}{*}{ Diseño Interior } & 2009 & $\begin{array}{l}209 ; 208 ; 207 ; 206 ; 205 ; 204 ; 203 ; 202 ; 201 ; 200 ; \\
199 ; 198\end{array}$ \\
\hline & 2010 & $\begin{array}{l}221 ; 220 ; 219 ; 218 ; 217 ; 216 ; 215 ; 214 ; 213 ; 212 ; \\
211 ; 210\end{array}$ \\
\hline & 2011 & $\begin{array}{l}233 ; 232 ; 231 ; 230 ; 229 ; 228 ; 227 ; 226 ; 224 ; 223 ; \\
222\end{array}$ \\
\hline & 2012 & $237 ; 236 ; 234$ \\
\hline & 2013 & $257 ; 256 ; 255 ; 254 ; 253 ; 252 ; 251 ; 250 ; 247$ \\
\hline & 2014 & $275 ; 266 ; 264 ; 262 ; 260 ; 259 ; 258$ \\
\hline
\end{tabular}

\subsection{Tratamiento de los datos}

\subsubsection{Criterios establecidos para el tratamiento de datos}

Del vaciado de datos de los ejemplares seleccionados puedo inferir diferentes conclusiones, por un lado la observación en términos globales de cada dato analizado de manera independiente, para lo cual he calculado los totales de cada variable. Por otra parte la interrelación entre los datos obtenidos permite otro tipo de conclusiones que complementan a las primeras y para cuya 
comparativa he calculado los porcentajes de unas variables en relación a otras. De estas relaciones porcentuales nacen los gráficos de sectores que presento en este capítulo. Establecer las combinaciones de variables óptimas para el proceso que me ocupa ha sido uno de los pasos necesarios para llegar a discernir la información conveniente para el estudio de las hipótesis establecidas. Las combinaciones de variables planteadas con el objetivo de poder construir los gráficos son aquellas con las que:

a) Por un lado presento el resultado que refleja el análisis de distribución de imágenes humanas en función de si son mujeres o varones en cada revista particular, además de aportar también este dato a nivel global, es decir, en el conjunto de todas las revistas.

b) Del total de figuras que aparecen de un sexo y de otro analizo, mediante gráficos, los roles en los que cada revista estudiada nos presenta a unos y a otras. Los resultados globales referentes a estos roles también los expreso mediante su gráfico correspondiente.

c) El siguiente ítem a valorar, derivado de la información obtenida de los ejemplares de distintas revistas, es la distribución de funciones que ofrecen en cuanto al total de figuras humanas reflejadas en ellas. Es decir, de todas las figuras humanas que aparecen en dichas revistas, qué proporción hace referencia a funciones de un corte profesional determinado y qué proporción del total a otras funciones como el trabajo doméstico.

d) Vamos a encontrar también un gráfico comparativo, según sexos, vinculado específicamente a la aparición de figuras humanas como modelos publicitarios. De la misma manera comparo la proporción de mujeres y varones que aparecen mostrando una dedicación profesional.

e) Otra gráfica relevante para el objeto de la presente investigación reflejará la proporción de imágenes, según sexo, vinculadas a roles domésticos. Una parte de las denuncias desarrolladas en el capítulo anterior del presente trabajo hace alusión a la diferenciación establecida por Soledad Murillo (1996: 57) respecto al trabajo, y según la cual, 
únicamente el trabajo remunerado pasa a ser considerado socialmente trabajo.

f) Del trabajo remunerado, reflejado según los datos obtenidos en estas revistas, desarrollado por mujeres, ¿qué proporción pertenece al ámbito de la publicidad y cuál no? Esta misma pregunta me la planteo también respecto a los varones.

g) En esta investigación una cuestión a valorar es la proporción de imágenes de figuras humanas que aparecen visibilizando roles en espacios públicos, en espacios privados, así como en lo que he convenido en llamar espacios interiores domésticos. Convendrá desgranar desde aquí, en esos interiores, cuál es la proporción de imágenes que representan a mujeres y varones según los roles de profesional, usuario o «usuaria».

Establezco el término «usuaria» con una diferenciación clara del de usuario en tanto en cuanto el rol de «usuaria» refleja no tanto a una mujer haciendo uso de un espacio para sí misma, como un uso de prestación de servicio doméstico para los demás. Pues, como dice Soledad Murillo en El tiempo de trabajo y el tiempo personal: un conflicto de intereses:

«[...] lo doméstico no es tanto un lugar, como una actitud relativa a especializarse en procurar tiempo a los demás, delegando el propio uso del tiempo a las demandas de los otros. De tal forma, que una mujer que viva sola, sin responsabilidades familiares puede ser reclamada desde todos los sistemas familiares, para iniciar tareas de cuidado». (Murillo, 2007: 13)

Carol Pateman, política y feminista británica autora de El contrato sexual, ya nos habla de la esfera privada de lo doméstico: «Un ama de casa permanece en la esfera privada doméstica pero las relaciones de la vida doméstica son naturalmente desiguales y de modo que no pueden desvirtuar la igualdad universal del mundo público.» (Pateman; 1995: 164). Y en esa expresión ya nos desvela que hay dos esferas privadas, la de lo doméstico y la del descanso en el hogar. Recogiendo las 
palabras de Murillo, podemos decir que no son dos espacios, pues ambas esferas ocupan el espacio del hogar, son dos actitudes. La del derecho al descanso, el cuidado, la intimidad y el recogimiento sobre sí y la del servicio, la del servicio doméstico y del cuidado de los otros. Realmente la diferencia no está en el lugar que ocupan sino en el tiempo que utilizan y cómo lo utilizan. La primera utiliza el tiempo propio, el tiempo que le dejan libre sus responsabilidades laborales, políticas o sociales -civiles, como diría Pateman- para sí. La segunda utiliza el tiempo propio para los demás. Es por eso que no considero los términos usuario y usuaria meramente como los genéricos gramaticales de un mismo concepto, son conceptos distintos y por eso he añadido unas comillas que aluden a la especificidad del uso que el ama de casa hace del espacio doméstico. Es como el uso que se hace del lugar de trabajo, pues es su lugar de trabajo, un trabajo a tiempo completo que no le deja apenas huecos para sí misma.

h) Concluyo el capítulo destinado a los gráficos de cada una de las revistas estudiadas con una gráfica comparativa cuyo objetivo es clarificar los roles difundidos por estas revistas en función del tipo de espacios interiores y según sexos.

Los gráficos obtenidos comparan unos totales con otros, lo cual permite inferir algunas conclusiones que, en la mayor parte de ocasiones confirman aquello que la observación detenida nos sugiere, sin dejar espacio para contra argumentaciones del estilo «hoy en día las mujeres arquitectas están equiparadas a los hombres», «en el mundo occidental actual no existe la desigualdad» o "actualmente los anuncios publicitarios son igualitarios, porque también hay hombres modelo».

i) Entiendo como un dato interesante para la presente tesis los gráficos que desvelan la proporción, según sexos, de personas dedicadas específicamente a la arquitectura y el diseño, objeto profesional específico de las revistas estudiadas y el gráfico que da esta información de manera global. El resultado que refleja este gráfico 
contrasta llamativamente con la proporción de mujeres y varones en las aulas de las escuelas en las que se imparten las citadas disciplinas.

Me ha resultado realmente difícil extraer datos concretos del sistema universitario español respecto a estudiantes y personas que obtienen la titulación de Arquitectura Superior. Los datos del INE o diferentes fuentes consultadas vinculan arquitectura con ingeniería en sus gráficas, como si de un mismo tipo de estudios se tratase. Esto no me ha permitido hacer una comparativa fiable.

Nota media del expediente académico de los egresados de Grado y $1^{\mathrm{er}}$ y $\mathbf{2}^{\circ}$ ciclo por sexo.

Curso 2010-11

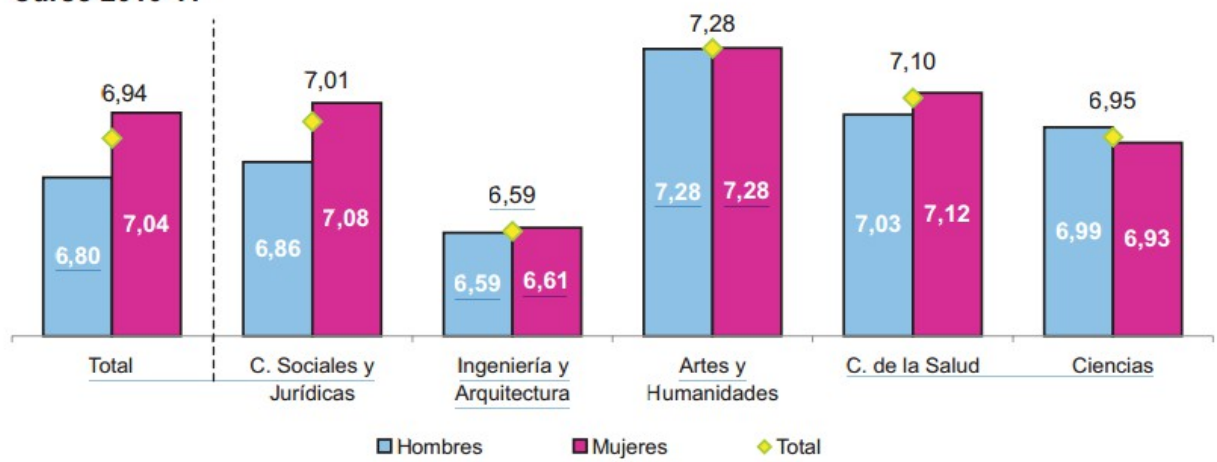

55. Datos y cifras del sistema universitario español (2012/2013). Fuente: Ministerio de Educación, Cultura y Deporte, 2013.

Distribución de los estudiantes de Máster por rama de enseñanza y sexo. Curso 2011-12 ${ }^{(1)}$
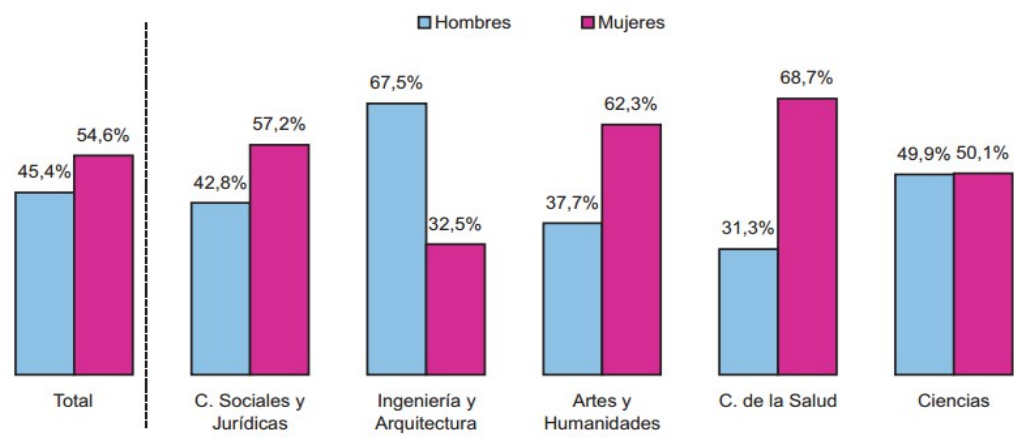

56. Datos y cifras del sistema universitario español (2012/2013). Fuente: Ministerio de Educación, Cultura y Deporte, 2013. 
En lo referente a datos de empleabilidad o paro tampoco aparece arquitectura, sino arquitectura y construcción en el mismo ítem. Volvemos a un dato que enmascara resultados de interés :

\begin{tabular}{|c|c|c|c|}
\hline \multirow[t]{2}{*}{ Porcentaje } & \multicolumn{3}{|l|}{2012} \\
\hline & Ambos sexos & Varones & $\overline{\text { Mujeres }}$ \\
\hline Total & 25,03 & 24,73 & 25,38 \\
\hline 64 Veterinaria & & & \\
\hline 46 Matemáticas y estadistica & 8,09 & 9,33 & 6.73 \\
\hline 09 Desarrollo personal & & & \\
\hline 42 Ciencias de la vida & 10,63 & 9.35 & 11.42 \\
\hline 38 Derecho & 10,64 & 6.87 & 13.90 \\
\hline 86 Servicios de seguridad & & H & \\
\hline 31 Ciencias sociales y del comportamiento & 13,90 & 11,01 & 15,43 \\
\hline 72 Salud & 14,11 & 9,38 & 15,66 \\
\hline 14 Formación de personal docente y ciencias de & & & \\
\hline la educación & 14.23 & 13,42 & 14,46 \\
\hline 22 Humanidades & 14,36 & 13,31 & 14,90 \\
\hline 44 Ciencias fisicas, quimicas y geológicas & 15,25 & 13,99 & 16,72 \\
\hline 84 Servicios de transporte & & & \\
\hline 76 Servicios sociales & 16,97 & 13,30 & 17,73 \\
\hline 52 Mecánica, electrónica y otra formación técnica & 17,32 & 17,04 & 22.07 \\
\hline 54 Industria manufacturera y producción & 17,96 & 17.12 & 21,40 \\
\hline 48 Informática & 19.57 & 18,50 & 23.49 \\
\hline 34 Enseñanza comercial y administración & 19,64 & 16,32 & 21.46 \\
\hline 32 Periodismo e información & 20,83 & 18,40 & 22,68 \\
\hline 21 Artes & 22,39 & 23,89 & 20.87 \\
\hline 85 Proteccion del medio ambiente & & & \\
\hline $\begin{array}{l}62 \text { Agricultura, ganaderia y pesca } \\
\text { 81 Senicios natzonales }\end{array}$ & 23,78 & 20,00 & 34,29 \\
\hline 58 Arquitectura y construcción & 24,90 & 23,74 & 28.40 \\
\hline 01 Programas de formación basica & 30,99 & 30,38 & 31.85 \\
\hline $\begin{array}{l}9 \text { Sectores desconocidos, no especificadios o no } \\
\text { aplicable. }\end{array}$ & 44.24 & 41,15 & 47,58 \\
\hline
\end{tabular}

57. Datos del sindicato de arquitectos. Tasa de paro. Fuente: INE EPA, 2012.

Las cifras de paro para los formados en Arquitectura y construcción están sólo por encima de Programas de formación básica. Es de destacar la gran diferencia en porcentaje (casi un 5\%) entre géneros: a nuestro modo de ver esto es debido a lo extendido de la figura del FALSO AUTÓNOMO y la baja protección social que implica para las arquitectas que deciden ser madres. (INE EPA, 2012: 1)

Frente a la dificultad de referir datos de interés concernientes, en este punto, de ámbito nacional o autonómico de la Comunidad Valenciana, sí son claros y concisos los que reflejan el estudio realizado en la Comunidad de Galicia. Las conclusiones del libro de actas de la segunda conferencia internacional sobre género y comunicación, celebrada los 
días 1, 2 y 3 de abril de 2014 en Sevilla, recogen textualmente los resultados que podemos observar en los gráficos adjuntos al texto y que incluyo en este trabajo porque sus mismos editores reconocen su validez para extrapolarlos a otras zonas del territorio español, aunque nazcan en la comunidad autónoma de Galicia:

Como conclusiones a este estudio sobre la evolución de la presencia de la mujer en la Escuela de Arquitectura, partiendo de su incorporación a la vida universitaria como alumna hasta su paso a formar parte del cuerpo docente y por último su progreso en los cargos de gestión, es posible extraer una serie de datos relevantes y no aislados pues son coincidentes con otros estudios realizados dentro del sistema universitario español.

--Podemos considerar el entorno del año 2006-2007 como el que delimita el equilibrio inicial y posterior inversión en el número de alumnas que acceden a la carrera de Arquitectura en relación al de alumnos. Sin embargo, con respecto al número de tituladas este hecho se adelanta al año 2000-2001, fecha a partir de la cual se invierte la gráfica superando las mujeres que terminan sus estudios al de sus compañeros varones. (MAGA, 2014: s/c)

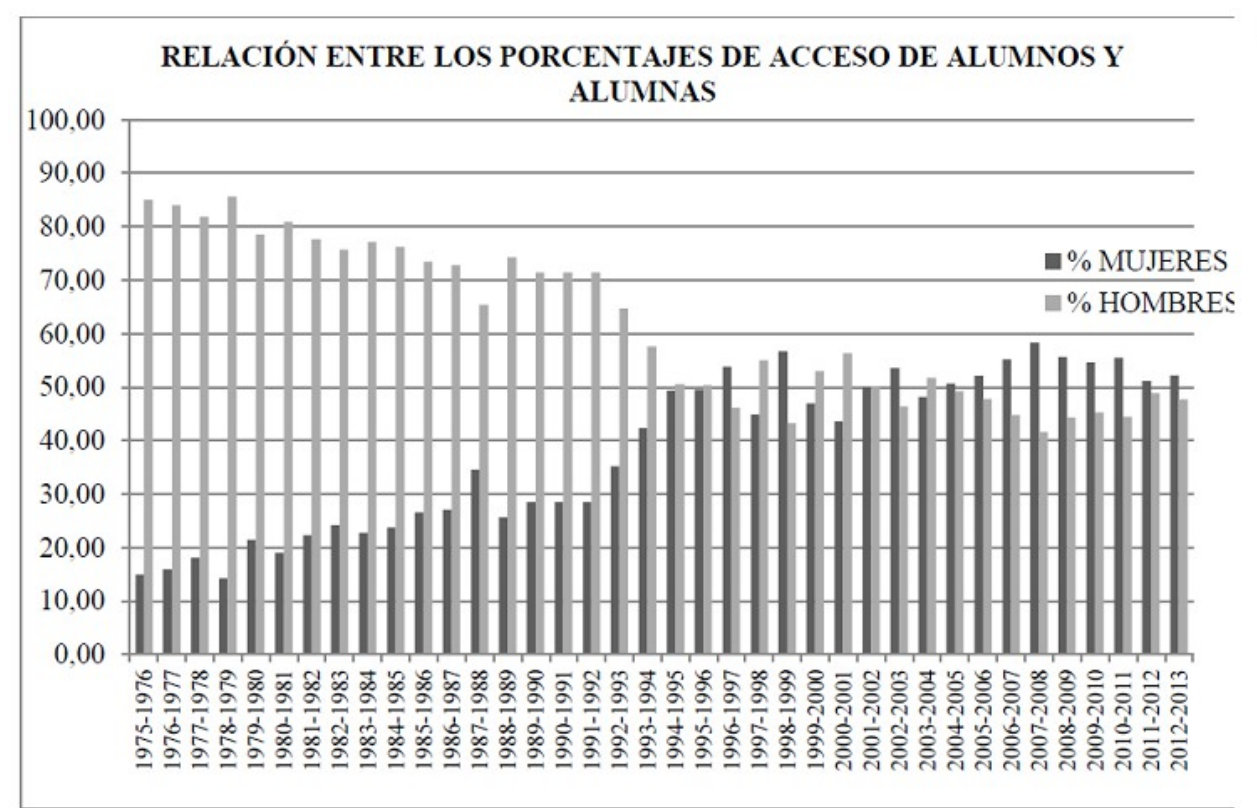

58. Datos de la Escuela de Arquitectura de la Universidad de La Coruña. Fuente: MAGA, 2012. 


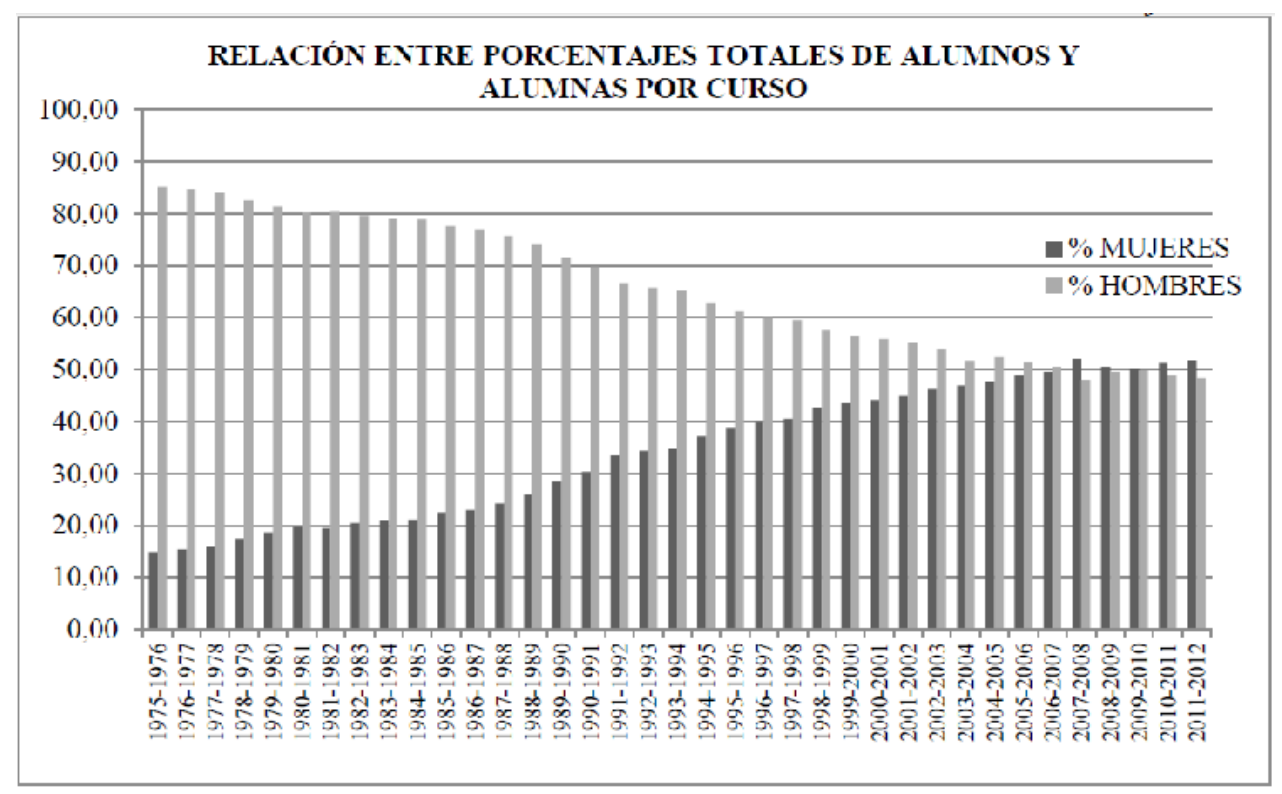

59. Datos Escuela de Arquitectura de la Universidad de La Coruña. Fuente: MAGA, 2012.

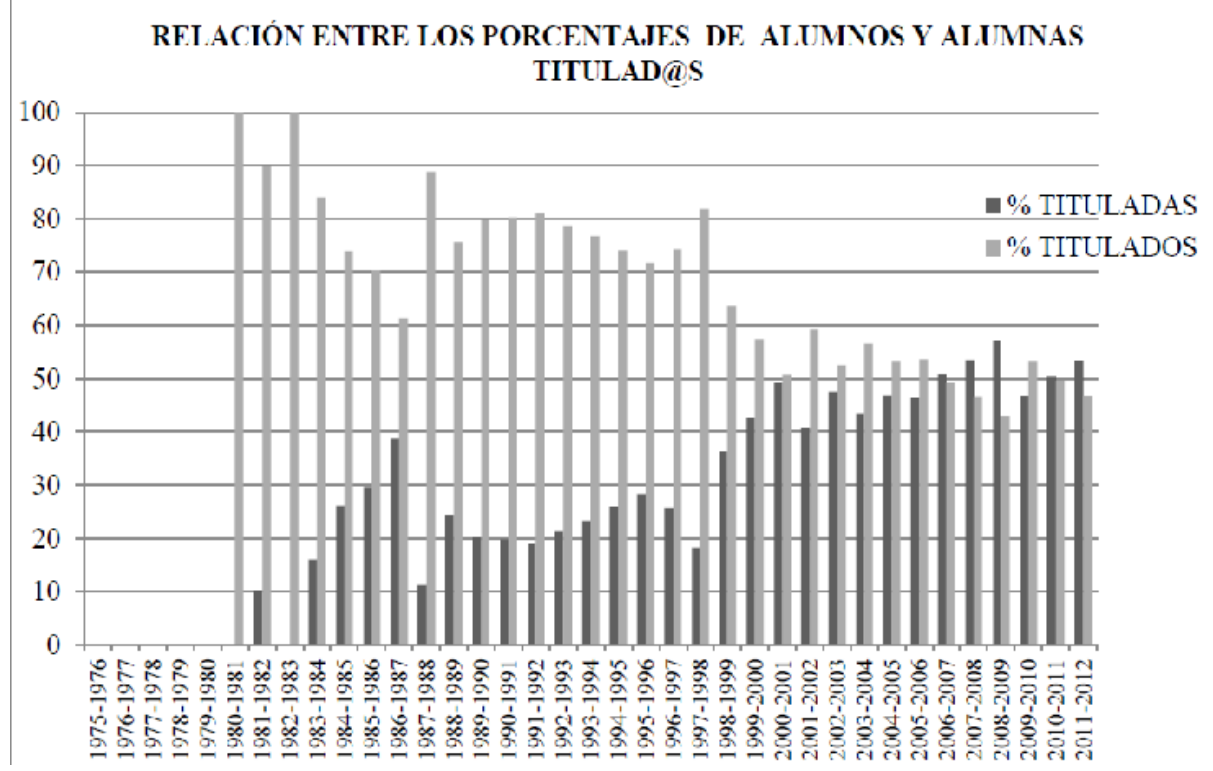

60. Datos Escuela de Arquitectura de la Universidad de La Coruña. Fuente: MAGA, 2012. 
Por otra parte, en las escuelas de Diseño de Interiores basta con asomarse a cualquier aula por lo llamativo de la superioridad de mujeres que las ocupan, hecho que deriva, inevitablemente, en que sean también más mujeres las tituladas en estas disciplinas que varones.

En concreto, los datos de la Escuela de Arte y Superior de Diseño de Castellón en sus estudios de Diseño de Interiores, en los dos niveles educativos impartidos en dicho centro, arrojan los siguientes datos:

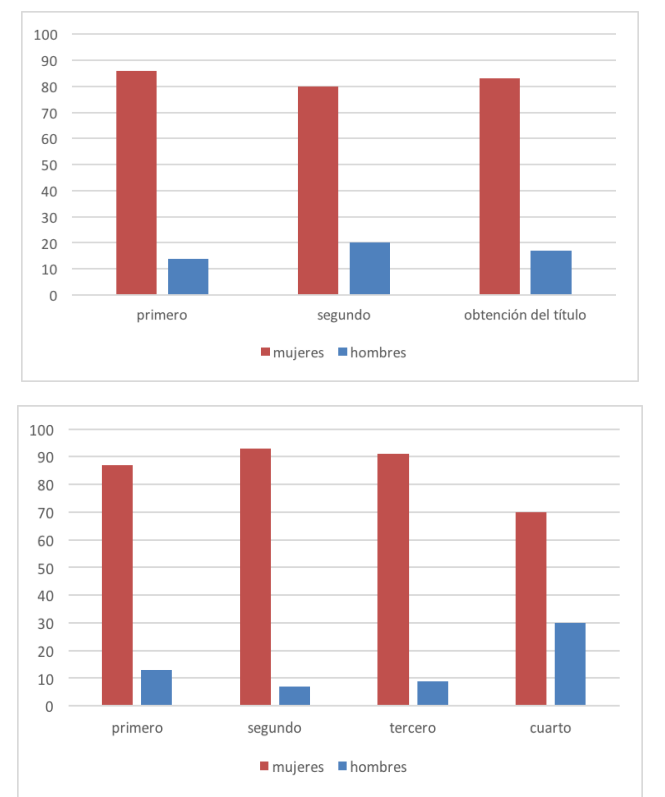

61. Proporción de matrícula en Diseño de Interiores según sexos en la EASD de Castellón en 2015-16, imagen superior CFGS, imagen inferior ESEAS. G.E.P., 2016.

En el caso de los estudios de Ciclo Formativo de Grado Superior (CFGS) de Proyectos de Decoración y Dirección de Obras (PyDOD) en los últimos tres cursos los datos de matriculación indican, para el curso 2013-2014, que las mujeres matriculadas en primero suponían un $86 \%$ del total de personas matriculadas, así como en segundo alcanzaban en ese curso académico el $81 \%$. Se matricularon del proyecto final un $83 \%$ de mujeres respecto al total; y de las personas que consiguieron la titulación de CFGS de PyDOD un 83\% eran mujeres.

Durante el curso 2014-2015 la tasa de matriculación de mujeres en primer curso ascendía al $69 \%$, en segundo curso suponían el $87 \%$. 
Sobre el total de personas matriculadas para la obtención del proyecto final el $78 \%$ eran mujeres, siendo un $83 \%$ de quienes consiguieron la obtención de dicho título también mujeres.

En el curso académico 2015-2016 las tasas de matriculación por género no difieren sustancialmente de las de los dos cursos anteriores, en primero hemos contado con un $86 \%$ de alumnado femenino así como con un $80 \%$ en segundo. El $82 \%$ de las personas matriculadas en el proyecto final eran mujeres, y de quienes han obtenido el título un $83 \%$ son mujeres.

En lo referente a ESEAS, Estudios Superiores de Enseñanzas Artísticas, el otro nivel académico referido que se imparte en la EASD de Castellón, los datos porcentuales son los que a continuación paso a describir. En el curso académico 2013-2014, en primero de estudios superiores de interiores, ESEAS Interiorismo, el 93\% de la matrícula era femenina, en segundo las mujeres suponían un $74 \%$ de las personas matriculadas, en tercero de aquel curso académico el $70 \%$ eran alumnas y en cuarto curso las alumnas suponían un $92 \%$ del total. El $100 \%$ de las personas que obtuvieron esa titulación superior fueron mujeres.

En el curso 2014-2015 las tasas porcentuales de matriculación según cursos de estudios superiores fueron de un $88 \%$ de mujeres en primero; un $87 \%$ de mujeres en segundo; un $75 \%$ de alumnas en tercero; y un $71 \%$ en cuarto. Las mujeres sobre el total de personas que obtuvieron el título supusieron un $78 \%$.

Ya en el curso $2015-2016$ los datos de alumnado suponen un $87 \%$ de mujeres en primero; un $93 \%$ en segundo curso; un $91 \%$ de alumnas en tercero y un $70 \%$ de mujeres en cuarto. Los datos porcentuales de personas tituladas no están disponibles en este momento, pero no cabe esperar diferencias significativas respecto a los que derivan de los cursos anteriores.

En la tabla que sigue a continuación generada por el MEC podemos observar como en el curso académico 1999-2000 la presencia de 
mujeres en las Escuelas de Artes Plásticas y Diseño, en concreto en la disciplina de diseño de interiores suponía un $70^{\prime} 37 \%$ de las personas matriculadas. Este dato, en el curso académico 2009-2010 ha pasado a un $74{ }^{\prime} 12 \%$ del total de personas matriculadas en esta especialidad.

\begin{tabular}{|c|c|c|c|c|c|c|}
\hline \multirow[t]{3}{*}{ Familias Profesionales ${ }^{9}$} & \multicolumn{5}{|c|}{$\%$} & \multirow{3}{*}{$\begin{array}{l}\% \\
\text { Mujeres }\end{array}$} \\
\hline & Total & Mujeres & & Total & Mujeres & \\
\hline & & & Mujeres & & & \\
\hline $\begin{array}{l}\text { Artes Aplicadas De La } \\
\text { Escultura }\end{array}$ & 978 & 527 & 53,89 & 15.936 & 9.898 & 62,11 \\
\hline $\begin{array}{l}\text { Artes Aplicadas a la } \\
\text { Indumentaria }\end{array}$ & 435 & 382 & 87,82 & 874 & 721 & 82,49 \\
\hline Artes Aplicadas al Libro & 260 & 164 & 63,08 & 292 & 200 & 68,49 \\
\hline Artes Aplicadas al Muro & 229 & 149 & 65,07 & 385 & 260 & 67,53 \\
\hline Cerámica Artística & 605 & 470 & 77,69 & 660 & 482 & 73,03 \\
\hline Diseño Gráfico & 4.091 & 2.156 & 52,70 & 7.799 & 4.204 & 53,90 \\
\hline Diseño Industrial & 368 & 164 & 44,57 & 550 & 236 & 42,91 \\
\hline Diseno de interiores & 2.582 & 1.817 & 70,51 & 3.470 & 2.572 & 74,12 \\
\hline Esmaltes Artísticos & 12 & 12 & 100,00 & 49 & 40 & 81,63 \\
\hline Joyería del Arte & 197 & 132 & 67,01 & 578 & 482 & 83,39 \\
\hline Vidrio Artístico & 31 & 23 & 74,19 & 53 & 42 & 79,25 \\
\hline Textiles Artísticos & 73 & 60 & 82,19 & 135 & 126 & 93,33 \\
\hline Arte Floral & - & - & - & 63 & 45 & 71,43 \\
\hline Promedio & & & 61,19 & & & 62,11 \\
\hline
\end{tabular}

FUENTE: Estadísticas MEC. Enseñanzas no universitarias.

Resultados detallados, curso 1999-2000.

A modo de síntesis se presenta el siguiente cuadro de resultados:

Cuadro 2.1.4: Porcentaje de matrícula femenina en distintas

titulaciones oficiales vinculadas a la adquisición de competencias

62. Matrícula mujeres. Fuente: MEC, 2000. 
Todos los datos traídos a colación respecto a las mujeres matriculadas o egresadas en estudios superiores de diseño de interiores o arquitectura superior, han sido referidos con la finalidad de poder contextualizar el ámbito académico y profesional del que cada equipo editorial elige qué proyectos y de quienes va a difundir desde sus páginas.

De alguna manera es necesario aclarar si esa selección podría ofrecer realmente una radiografía diferente de la que nos muestra o se trata de una selección sin opciones alternativas. Resulta evidente, tras este breve recorrido entre los datos de escuelas de diseño y universidades, que hay opciones. Los equipos editoriales de las revistas podrían optar, sin dificultad, por difundir proyectos aplicando el criterio de paridad respecto a la autoría de los mismos.

\subsubsection{Gráficas derivadas del tratamiento de datos}

Tal y como demuestran las gráficas de elaboración propia (G.E.P.) que siguen, referentes a los porcentajes de figura humana que aparece en los espacios interiores mostrados en los ejemplares de las revistas estudiados, dichos espacios interiores aparecen mayoritariamente plagados de ausencia.

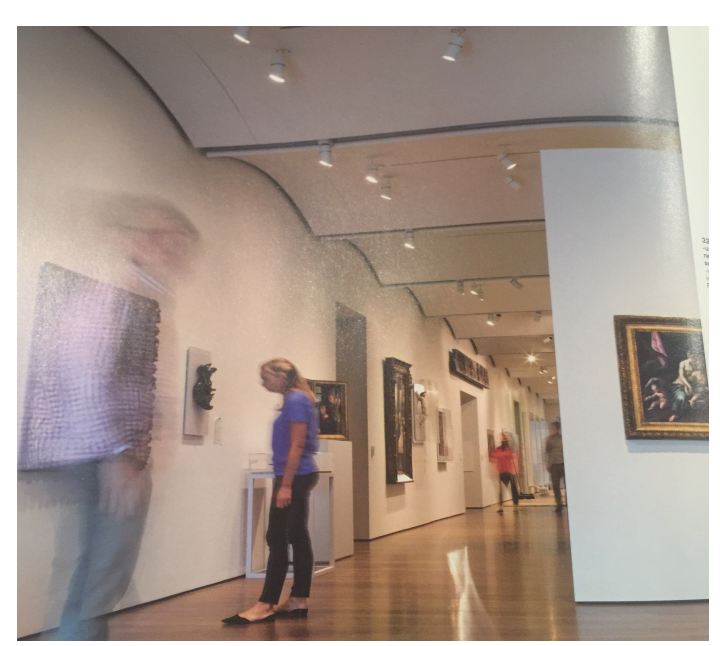

63. Presencia. Fuente: Casabella 844, 2014.

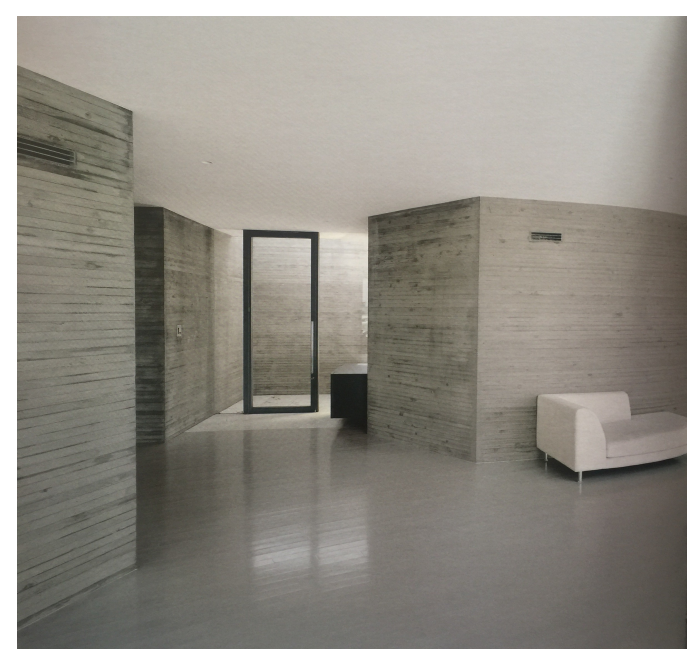

64. Ausencia. Fuente: El Croquis 151, 2010. 


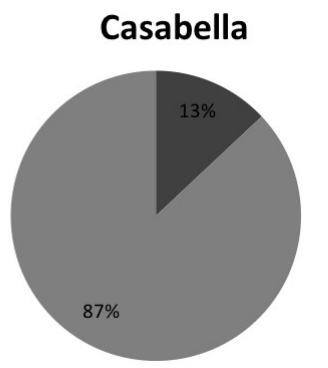

Arquitectura Viva

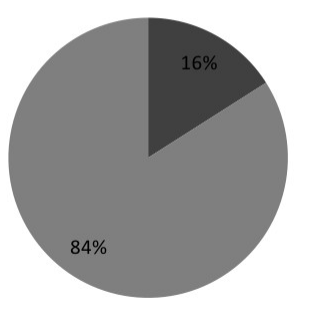

Diseño Interior

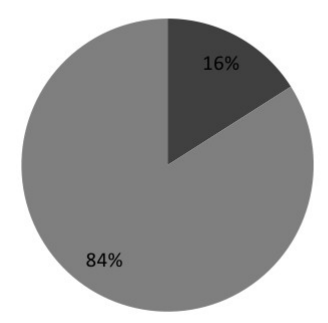

El Croquis

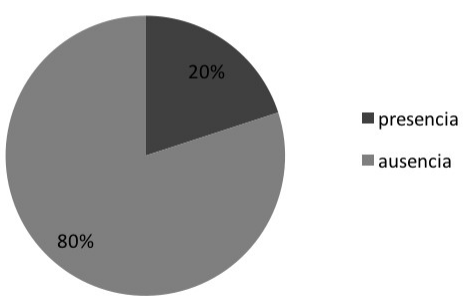

Domus

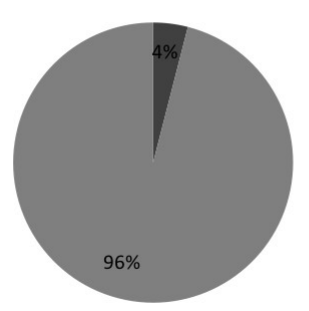

ON Diseño

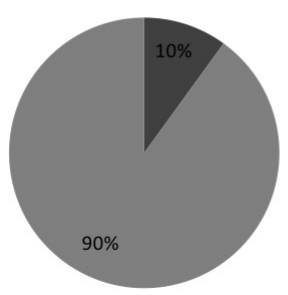

65. Presencia de figura humana en las revistas de arquitectura y diseño. G.E.P., 2016.

Entre el $80 \%$ y el $96 \%$ de las imágenes ofrecidas en estas publicaciones suponen espacios vacíos de presencia humana, lugares en los que podemos deducir qué ocurre según los criterios de la arqueología. Las personas ocupan el espacio diseñado para ellas de un modo minoritario en estos medios de difusión, contra toda lógica si esto reflejara realmente la realidad, pues están diseñados para ser ocupados.

Concretamente los ejemplares escrutados de la revista Diseño Interior (DI) ofrecen tan solo un $16 \%$ de imágenes con presencia humana. En el caso de On Diseño $(O D)$, el porcentaje de figuras humanas que podemos encontrar en las imágenes de los interiores que nos muestra en sus ejemplares oscila alrededor 
de un $10 \%$, es llamativo que el $90 \%$ de los espacios aparezcan aquí libres de presencia. Al analizar los mismos seis años de la revista Arquitectura Viva (AV) los resultados obtenidos no son muy diferentes, la proporción de imágenes de espacios interiores en las que aparecen personas ronda el $16 \%$ del total; y similar resulta también la cantidad de imágenes con personas respecto al total de imágenes de espacios interiores que nos muestran los ejemplares de El Croquis (EC) en ese mismo periodo de tiempo, un $20 \%$. Quizá resulta incluso más escandaloso el dato obtenido en el caso de la revista Domus (DO), revista que tras ser analizada deja un escaso $4 \%$ de espacios con referencia humana y por último, Casabella (CB) cuyo $13 \%$ se aproxima fielmente a la media de espacios ocupados que obtenemos al observar toda la muestra de manera global.

\section{Presencia humana global}

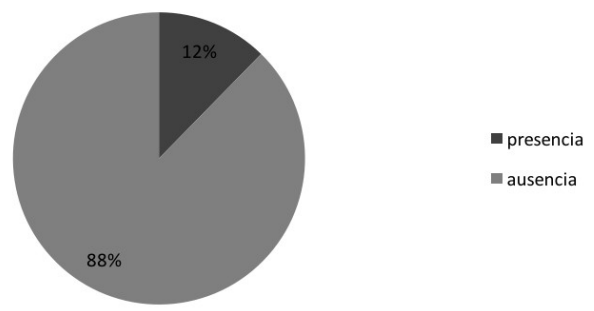

66. Presencia de figura humana global en las revistas de arquitectura y diseño. G.E.P., 2016.

De esos pequeños porcentajes, que oscilan entre el $4 \%$ y el $20 \%$, nunca superiores a la quinta parte, las gráficas que muestro a continuación reflejan la comparativa de la distribución por sexos, en la que los espacios ocupados por grupos de personas mixtos se representa en verde. Observando aquellos espacios en los que detectamos únicamente mujeres o varones puede parecer que tiende a estar equilibrada la presencia de ambos, no tanto en el caso concreto de Domus, Arquitectura Viva o El Croquis, revistas en las que el porcentaje de presencia masculina es significativamente mayor que el de la femenina, pero sí en las restantes publicaciones estudiadas. En gráficas posteriores, en las que las variables introducidas son otras, se evidencia lo 
perverso de esta suposición. Además, el cómputo global muestra ya una diferencia a razón de una mujer por prácticamente cada dos varones.

Ernst Neufert, en su Arte de proyectar en arquitectura, también resalta la carencia de imágenes en las revistas de arquitectura desde principios del siglo XX, aunque su preocupación es distinta de la mía. Él observa que la carencia de imágenes suprime el referente antropométrico que tan necesario le parece para que profesionales y personas usuarias se hagan cargo de las dimensiones de los edificios.

Cuando al lado de un objeto vemos una persona, ya sea en un dibujo o en la realidad, en seguida nos hacemos una idea correcta de su tamaño. Es una característica de nuestra época mostrar sin personas los edificios y espacios interiores en las fotografías de las revistas especializadas.

A menudo, a partir de estas fotografías nos hacemos una idea equivocada del tamaño de estos edificios, y nos asombramos de lo diferentes que son en realidad, generalmente más pequeños. Éste creo que es el motivo de la usual falta de relación entre los edificios, ya que los proyectistas parten de escalas diferentes y arbitrarias y no toman en consideración la única correcta, el hombre.(Neufert, 1991: 22)

Mi preocupación, aun coincidiendo con Neufert en este aspecto, es otra. Mi preocupación es el constante silenciamiento de la presencia de las mujeres en los lugares que el heteropatriarcado les asigna. Y la constatación de ese silencio es el objetivo de este capítulo.

Para interpretar qué están reflejando las gráficas que acabamos de observar, de las pocas imágenes con representación humana que presentan en total cada una de las revistas, he contabilizado las imágenes que presentan sólo mujeres o sólo varones, pues las representaciones mixtas he considerado que son neutras a efectos de este análisis. Esta simplificación, no solo no desequilibra la lectura de los datos, sino que en algunos casos como los que muestran las imágenes 67,68 y 69, los suaviza. Si atendemos a la 
responsabilidad que de las imágenes analizadas se deduce, pensando en las oportunidades generadas en tanto en cuanto a la construcción de la identidad de las mujeres se refiere, los roles que en estas imágenes aparecen refuerzan los desequilibrios que se detectan en las gráficas:

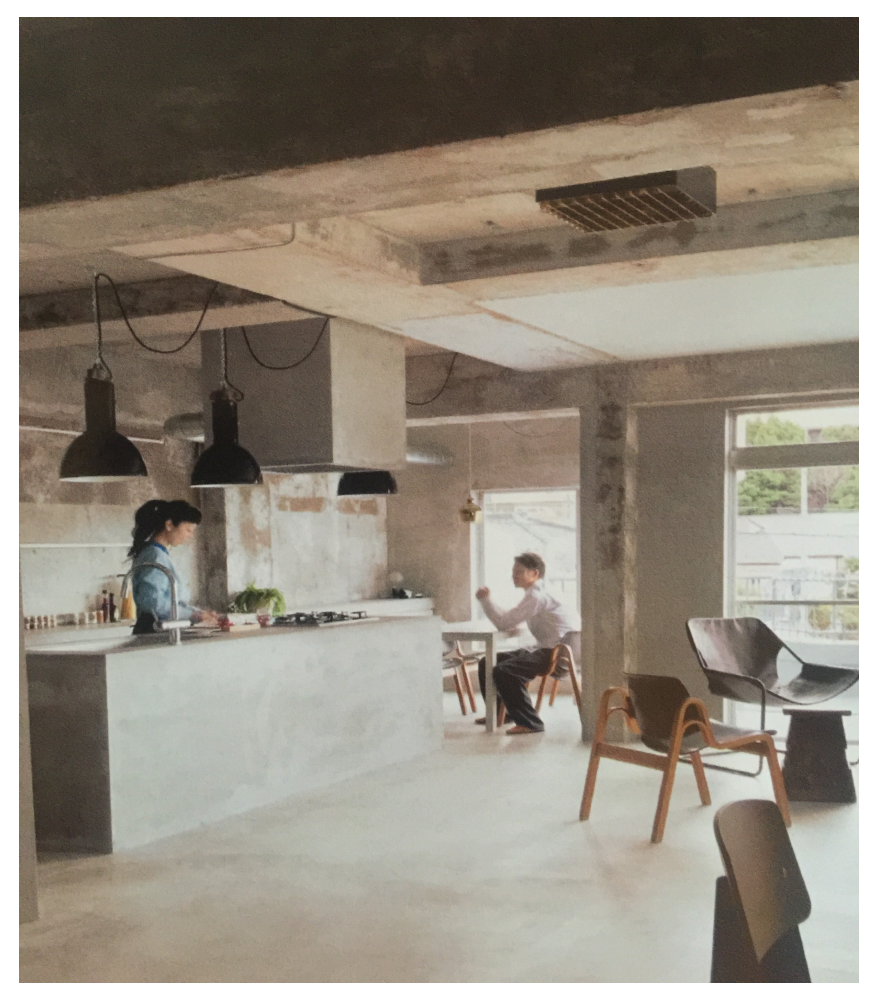

67. Imagen de figura humana mixta. Fuente: Diseño Interior 262, 2014.

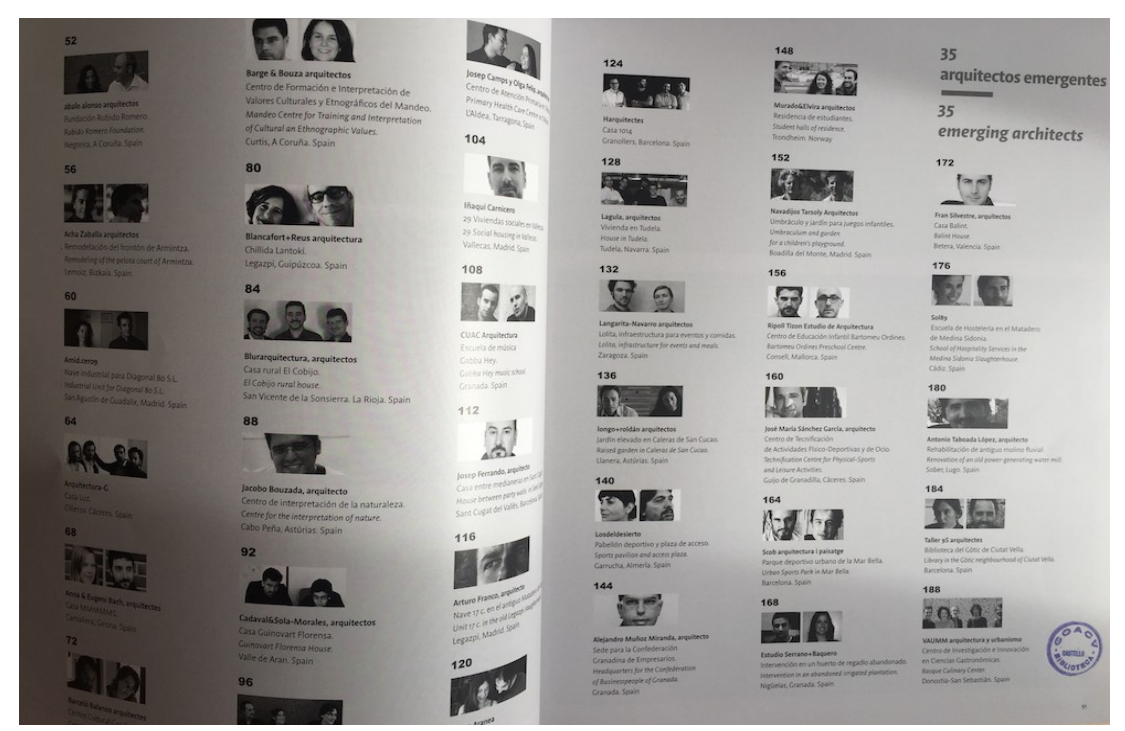

68. Imagen de figura humana mixta. Fuente: On Diseño 350, 2015. 


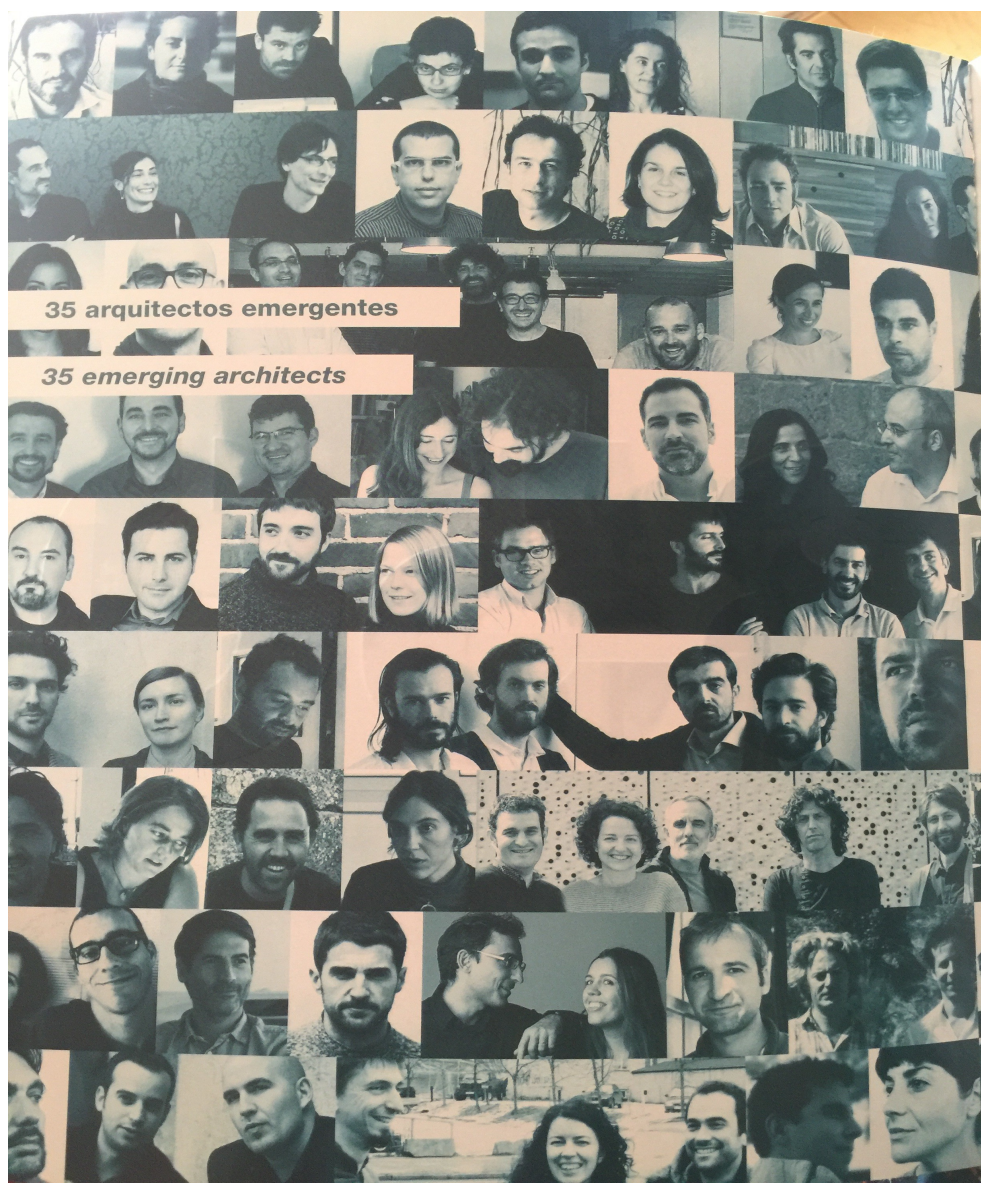

69. Imagen de figura humana mixta. Fuente: On Diseño 350, 2015.

Cabe reseñar que en el caso de las imagenes 68 y 69, aunque estemos ante presencia mixta, no aparece ninguna mujer en solitario ni ningún grupo de mujeres entre los 35 seleccionados. Estamos ante una selección de 18 equipos mixtos, el $50 \%$, y el otro $50 \%$ son 17 equipos configurados únicamente por varones o son varones en solitario. 35 arquitectos emergentes. ¿Para cuándo una sociedad igualitaria en derechos y oportunidades? ¿Para cuándo referentes que potencien las capacidades de las niñas con la misma intensidad con la que se ven potenciadas las capacidades de los niños? Sobre el total, en estas imágenes, estamos frente a un porcentaje de mujeres que no llega al $23 \%$ y que confronta al $77 \%$ de representación masculina. Una imagen que bien sirve, en el argumentario actual, para plantear niveles de igualdad que no están cerca de darse, y que en este caso, arquitectos emergentes, poco puede apoyarse en el número de personas tituladas de uno y otro sexo, según hemos visto en el subapartado 5.4.1. Criterios establecidos para el tratamiento de datos, al analizar las tasas de matrícula y egresión en estudios de diseño y arquitectura. 


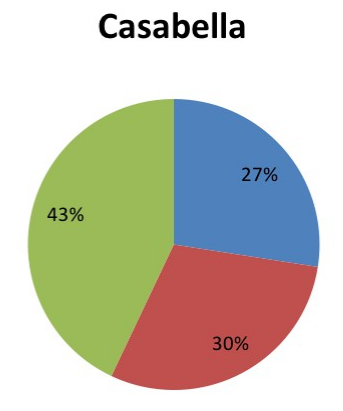

Arquitectura Viva

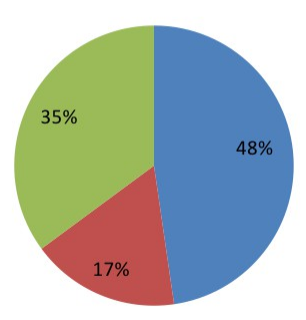

Diseño Interior

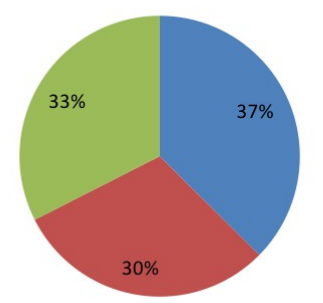

El Croquis

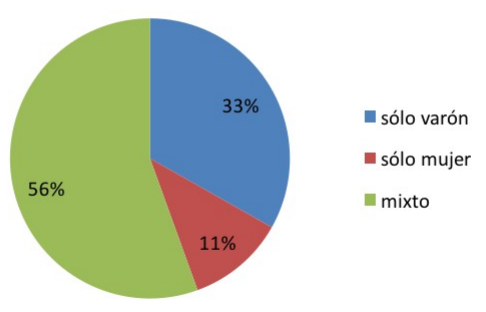

Domus

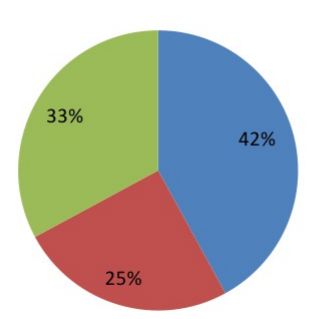

On Diseño

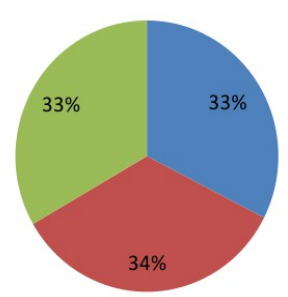

70. Presencia de figura humana distribuída por sexos en revistas de arquitectura y diseño, G.E.P., 2016.

En Diseño Interior: La representación de mujeres es algo inferior a la de varones, en concreto, del $30 \%$ de figuras de mujeres frente al $37 \%$ que ofrecen varones.

En la revista On Diseño: La representación de mujeres es similar a la de varones. En principio, la distribución no levanta ninguna alerta.

Al analizar la gráfica correspondiente a Arquitectura Viva: La representación de mujeres es poco más de la tercera parte que la de varones. Un $17 \%$ de presencia femenina frente a un $48 \%$ de presencia masculina. 
En el caso de la publicación El Croquis: La representación de mujeres es la tercera parte que la de varones. La desproporción de presencia resulta evidente en sí misma, sin necesidad de entrar en el análisis de variables posteriores.

No podemos argumentar de manera diferente en el caso de Domus, revista en la que la representación de mujeres asciende a un $25 \%$ frente al $42 \%$ de representación de varones, 17 puntos de distancia.

Al analizar la revista Casabella encontramos que la representación de mujeres es similar a la de varones, con una distancia porcentual de tan solo tres puntos. Vemos, pues, que de la escasa representación humana en las revistas analizadas, la representación de la mujer, en Diseño Interior, Arquitectura Viva, Domus y El Croquis es aún más escasa que la de los varones. En On Diseño y Casabella son similares.

\section{Distribución por sexos global}

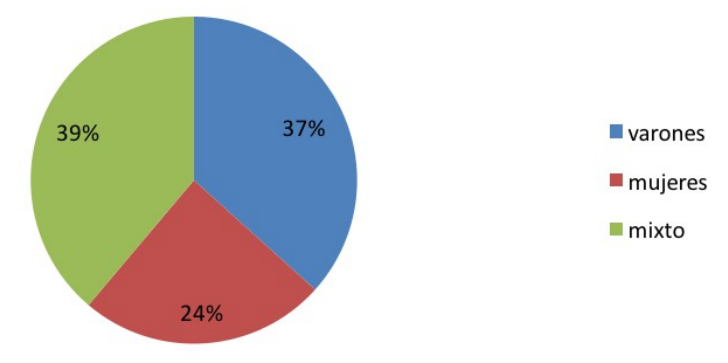

71. Presencia de figura humana distribuída por sexos global en revistas de arquitectura y diseño. Fuente: G.E.P., 2016.

A continuación paso a expresar gráficamente los roles que he encontrado en las imágenes analizadas desempeñados por mujeres. Establezco una categorización de los mismos según la cual distingo entre mujer en rol 
doméstico, mujer anuncio, y mujer bien sea diseñadora o arquitecta en la misma categoría de la clasificación.

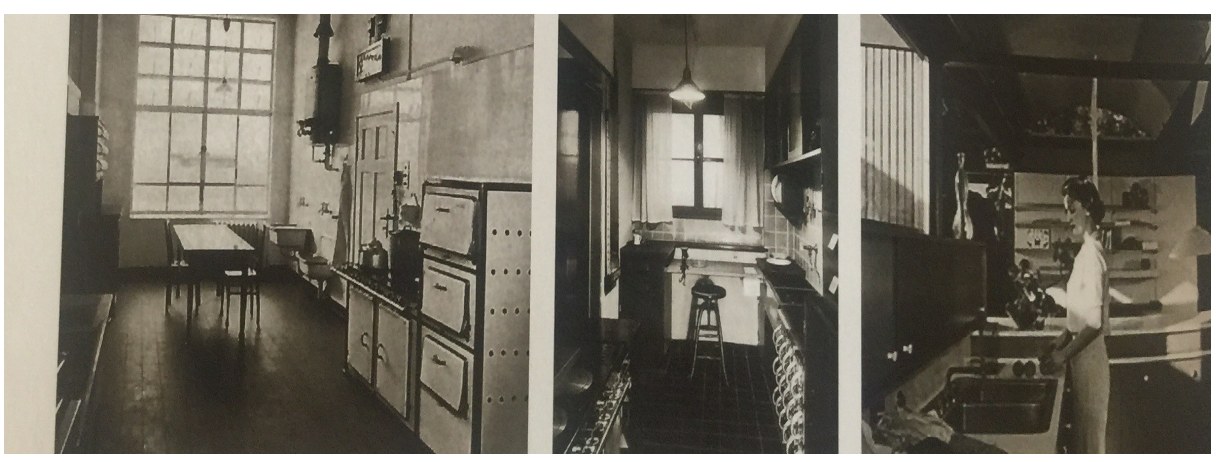

72. Mujer en rol doméstico. Fuente: Arquitectura Viva 169, 2014.

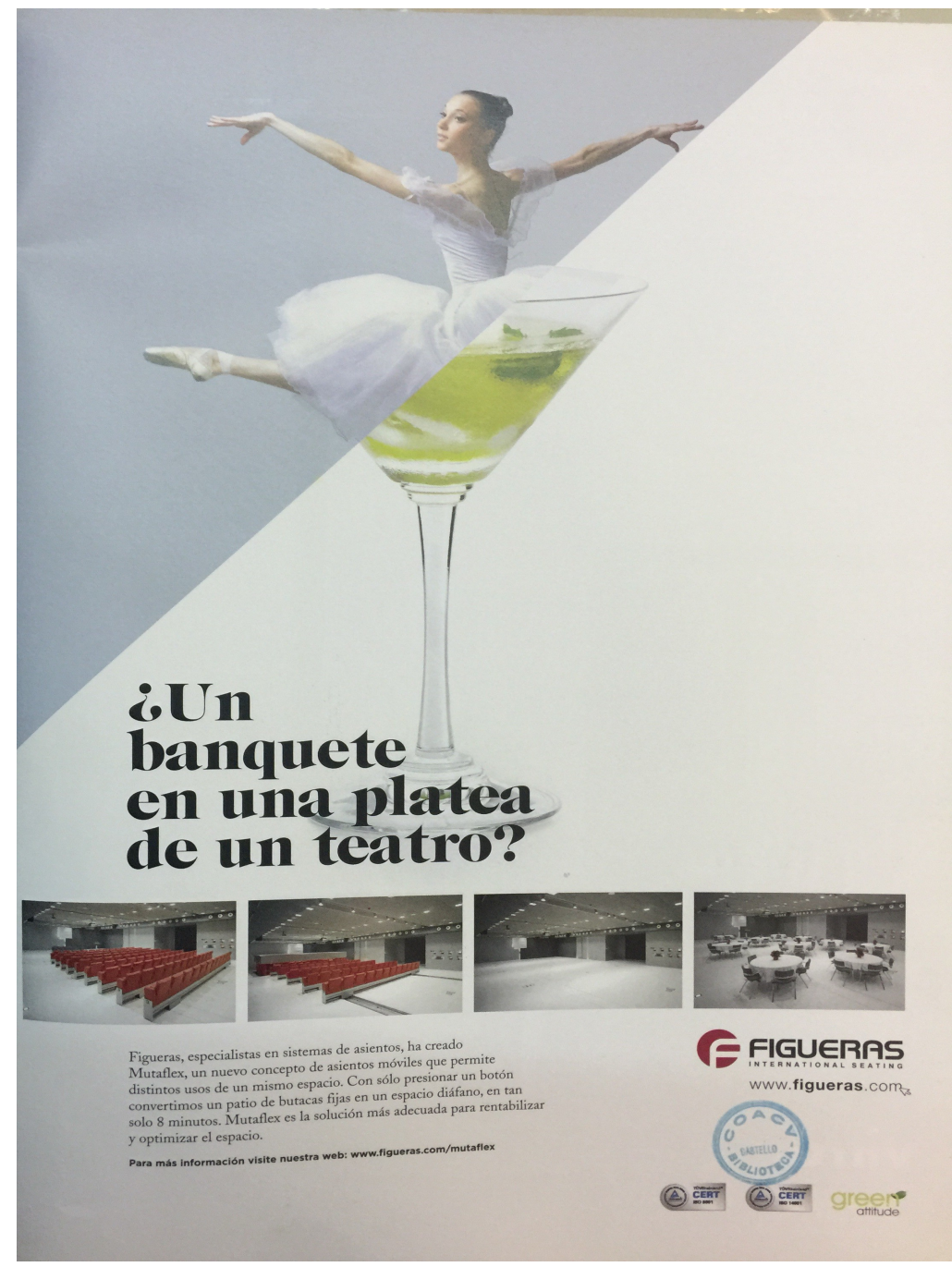

73. Mujer en anuncio. Fuente: El Croquis 161, 2012. 


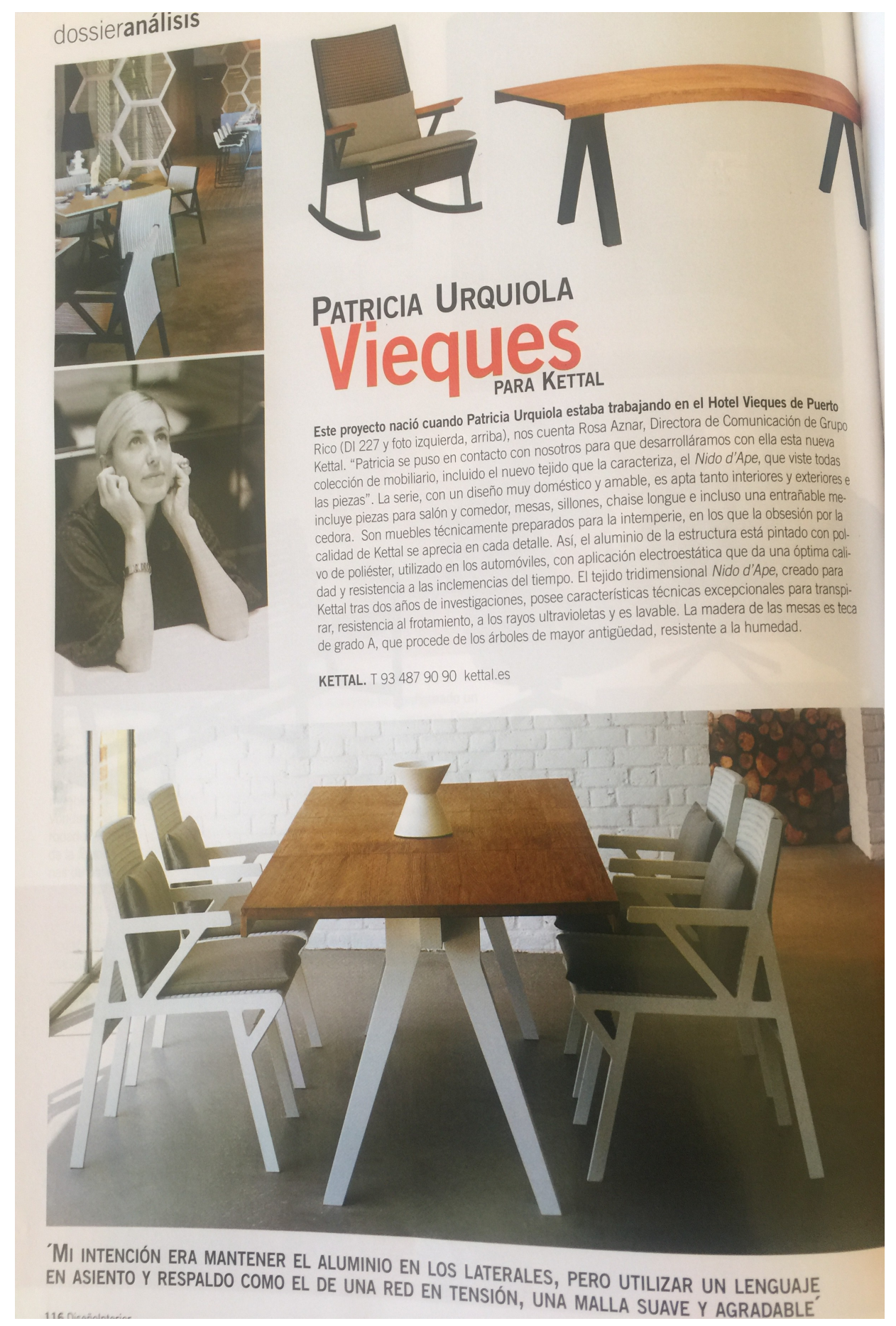

74. Mujer diseñadora. Fuente: Diseño Interior 237, 2012. 


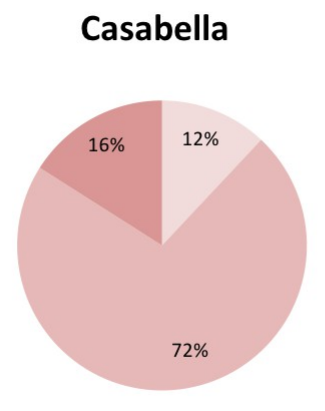

Arquitectura Viva

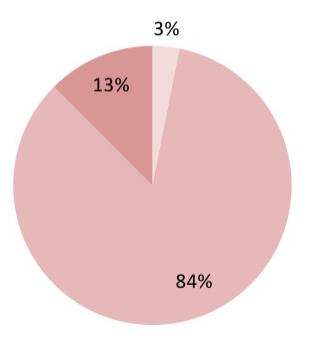

Diseño Interior

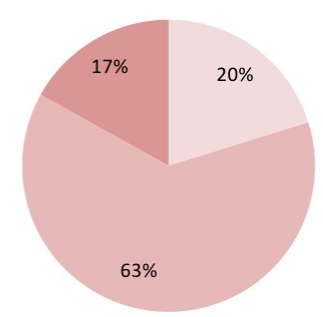

El Croquis

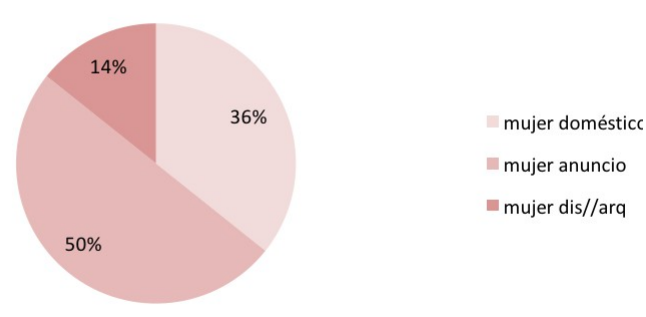

Domus

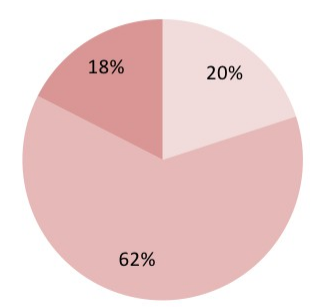

ON Diseño

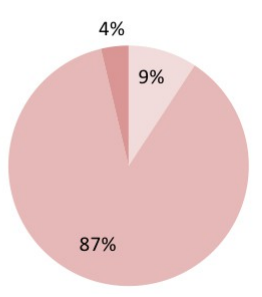

75. Presencia de figura humana distribuída por roles de mujeres en revistas de arquitectura y diseño. Fuente: G.E.P., 2016.

Una variable interesante para el objeto de estudio que nos ocupa es la proporción de mujeres diseñadoras o arquitectas que aparecen en estas publicaciones. Los porcentajes de mujeres diseñadoras o arquitectas obtenidas en las distintas revistas son: Diseño Interior: 17\%; On Diseño: 4\%; Arquitectura Viva: 13\%; El Croquis: 14\%; Domus: 18\%; Casa Bella: $16 \%$.

Entre un $4 \%$ y un $18 \%$ de esas mujeres que apenas existen en las revistas estudiadas, son profesionales de la arquitectura o el diseño de interiores. Antes de la era Marilín, el resto hubieran sido mujeres con rol doméstico. En el gráfico podemos ver la evolución que el patriarcado les ha impuesto a las mujeres modernas. Ahora son más esclavas de su cuerpo, el triple que del hogar. Hasta 
la era Marilín el mandato social era exigente en aquello que a las tareas domésticas se refería, tras este punto de inflexión, la exigencia viene a concentrarse en dos focos, el ya consolidado rol doméstico, y el nuevo criterio de eterna juventud, de belleza exuberante y en permanente disposición para el otro, para el varón. Éste último foco planea sobre las mujeres con una ferocidad despiadada, las somete sin dejar margen. Entre los dos roles, el de ángel del hogar y el de cuerpo sexi se llevan entre un $96 \%$ y un $82 \%$ de la escasa presencia con que cuentan, como hemos visto, en las revistas. La masiva presencia de modelos, nos indica la insoportable presión que reciben las mujeres que desean sentirse ángeles del hogar pero que, para no ser desbancadas por las mujeres sexi, se ven forzadas a competir con ellas y ofrecer en casa la satisfacción del deseo masculino actual que las modelos encarnan. La mujer en rol doméstico ocupa un espacio porcentual claramente inferior al ocupado por las mujeres que protagonizan anuncios, su representación ha sido absorbida por el uso creciente de su imagen corporal para la publicidad. La violencia de la invisibilización resulta estridente al observar unas gráficas tan rotundas. La representación de las mujeres, como profesionales del diseño y la arquitectura, sumada a su representación en rol doméstico es claramente inferior a su papel como modelo publicitaria en los anuncios. On Diseño va ganando la partida en el reino de la pornotopía que ocupa entre el $50 \%$ en El Croquis y el $87 \%$ en esta revista. No debemos olvidar que estos porcentajes se calculan sobre la escasísima cantidad de mujeres que aparecen dentro de la escasa presencia de imágenes humanas, por lo tanto sólo dan idea del reparto de la escasez.

\section{Roles de mujeres global}

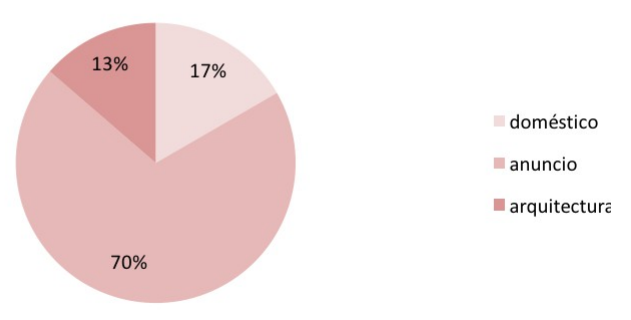

76. Presencia de figura humana distribuída por roles de mujeres global en revistas de arquitectura y diseño. Fuente: G.E.P., 2016. 
El análisis derivado de la observación de los gráficos anteriores no estaría completo sin la posibilidad de enfrentar gráfico a gráfico, revista a revista, los mismos datos pero extraídos respecto a las figuras de varones que aparecen en los números que han servido de muestra para este trabajo.

Seguidamente podemos leer la representación de los mismos roles del último cuadrante de gráficos. Es decir, rol doméstico, varón en anuncio y diseñador o arquitecto.

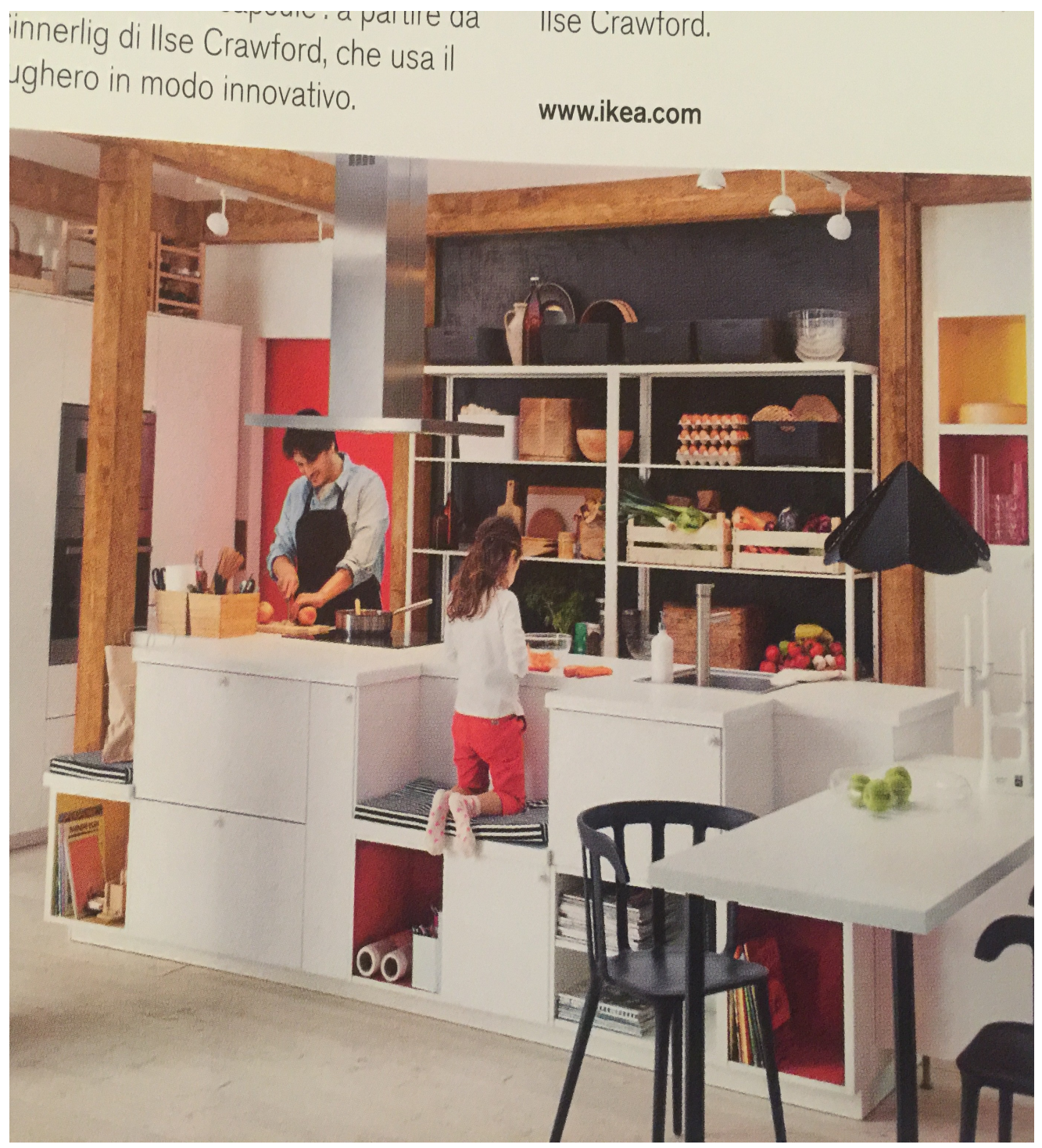

77. Varón en rol doméstico. Fuente: Domus 990, 2015. 


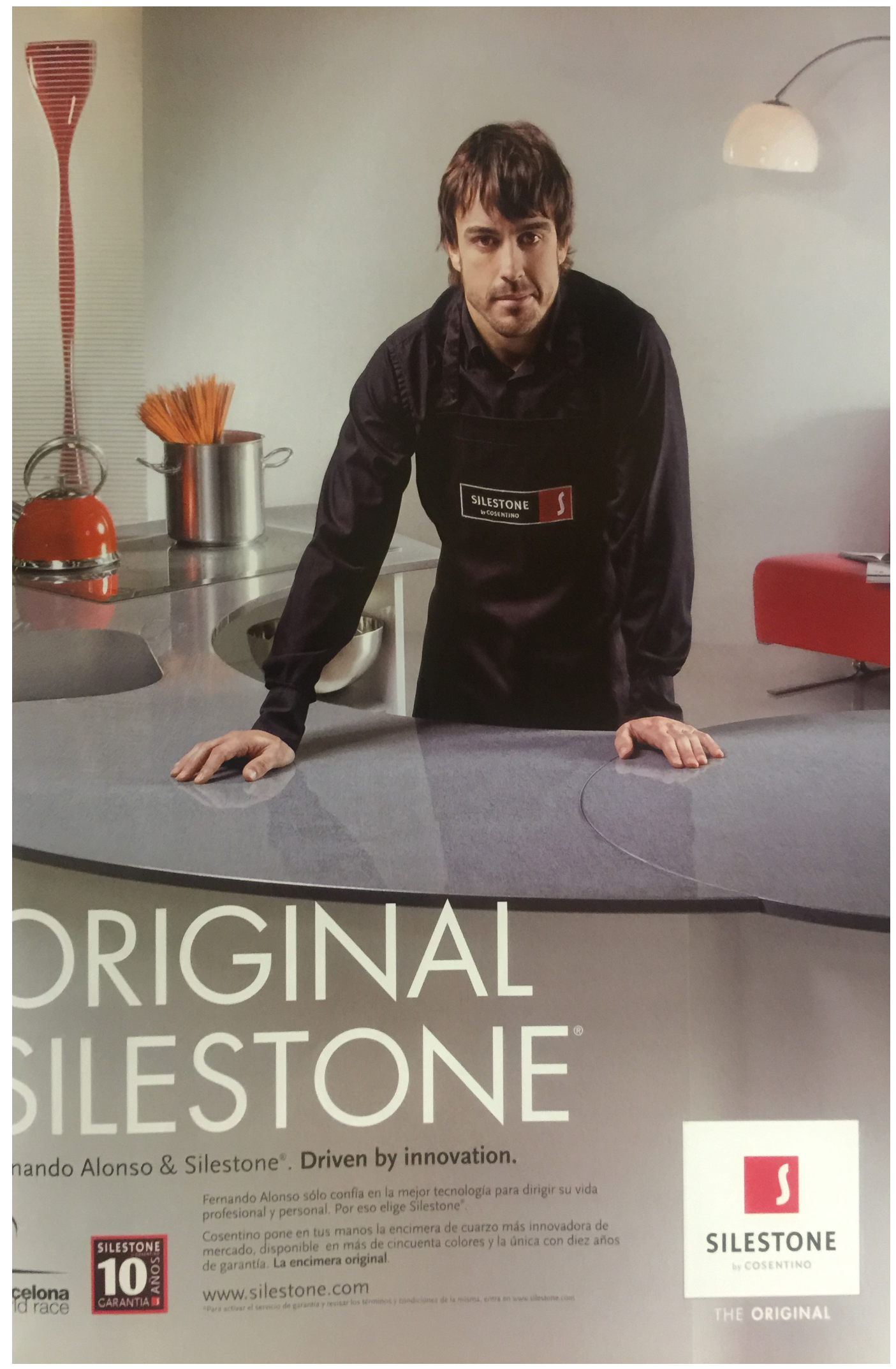

78. Varón en anuncio. Fuente: Diseño Interior 214, 2010. 


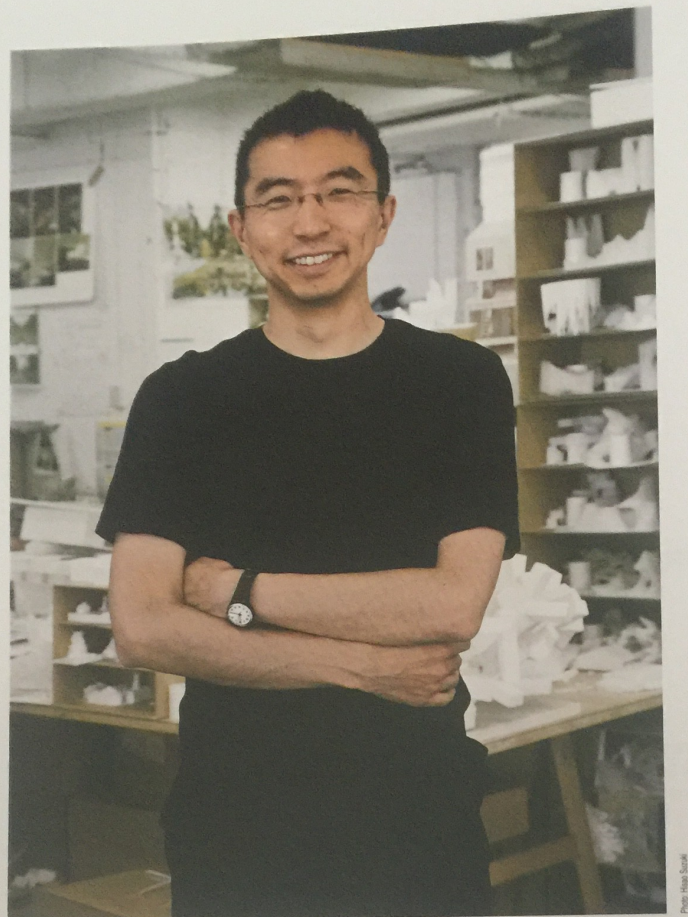

SOU FUJIMOTO

Nace en 1971. Graduado en 1994 en el Departamento de Arquitectura, Facultad de Ingenieria, Cor the reve

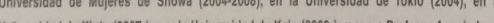
Universidad de Kioto (2007-1 y en la Universidad de Keio (2009)-; y como Protesor Asociado en a Universidad de Tokio (2009-1.

\section{PAEMIOS Y DISTINCIONES}

2009 Premios de Diseño Wallpaper - Mlejor Vivienda Privada (Casa de Madera Definitiva) Wal - Premio Categoria Vivienda Privad de Madera Definitiva

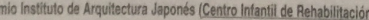
Psiquistrice

2007 Premio de Arquitectura Kenneth F. Brown - Mención Honorficica (Centro Intantili de Rehobilitación Priquiatitica)

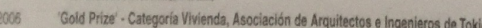

2004 Premio sla New Face

19r Premio Concurso para el Foro de Arte Ambientas para Annaka

Mención Honorilica en el Concurso para el Ayuntamiento de Ora.

2 Promilo Concurso para el Iusseo de Arte de la Preftecturn de Aomori
Born in 1971 . Graduated trom the Universty of Tohyo. Faculty of Engineering, Department of

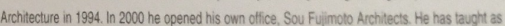
Adjunct Lecturer a t the Tokyo University of Science (2001-), at Showa Women's University (2004-2008) at the University of Tokyo (2004), at Kyoto University (2007). and at Keil University (2009); and as Associate Protessor at the Universty of Tokyo (2009-)

\section{AWARDS AND PPIZES}

Walpaper Design Awards - Best New Private House IFnel Wooden Houser World Architectural Festival - Private House Category Wimer IEnal Wooden House

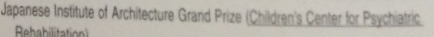
Betabititition

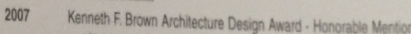
Chilorens Center to Pyschiatic Rehabitation)

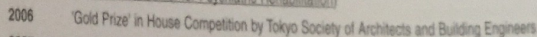
Is Prize in Wooden House Compertion in Kunarate JA New Face Award

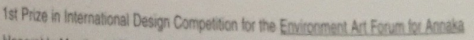
Honcrable Mention in Design Competilion for the Dea Tom Hall

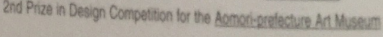

79. Varón arquitecto. Fuente: El Croquis 151, 2010. 
Casabella

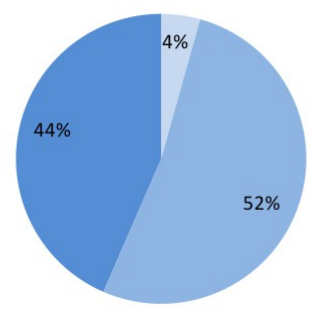

Arquitectura Viva

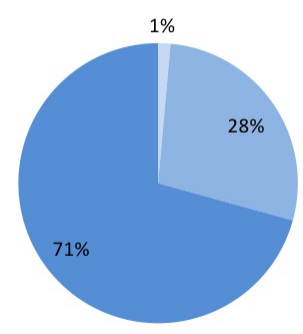

Diseño Interior

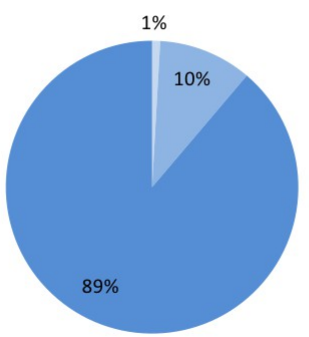

El Croquis

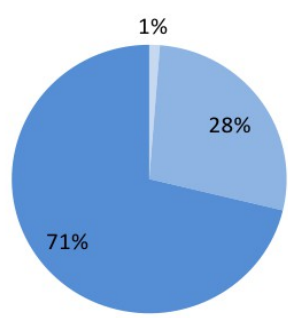

varón doméstico

घvarón anuncio

" varón dis//arq
Domus

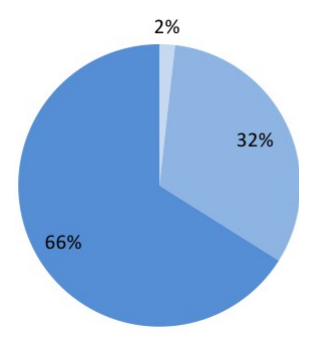

ON Diseño

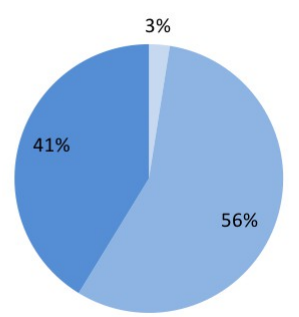

80. Presencia de figura humana distribuída por roles de varones en revistas de arquitectura y diseño. Fuente: G.E.P., 2016.

La expresión correlativa de estos cuadrantes simplifica la comparativa. Es irrebatible. No cabe el argumento del equilibrio entre géneros.

Un sólo golpe de vista sobre la distribución de roles en las gráficas estudiadas para los varones deja claro cómo el rol doméstico aparece en este caso en niveles porcentuales que podrían llegar a considerarse despreciables, no alcanzando el valor del $5 \%$ o superior en ningún caso. En On Diseño hablamos de un $3 \%$, El Croquis, Arquitectura Viva o Diseño Interior plasman un $1 \%$ de representación del rol doméstico por parte de varones. En el caso de Domus detectamos, sobre la ya comentada escasa proporción de imágenes con figuras humanas, como respecto a aquellas que se corresponden con varones, un $2 \%$ 
representan a varones en rol doméstico, y muy cerca Casabella alcanza tan solo el 4\%. Es decir, ninguna de las publicaciones analizadas presenta el rol doméstico en el caso de los varones de un modo normalizado, cuando aparece, es una excepción.

Me planteo si el hecho de que, aunque en una proporción ínfima como supone un $1 \%$ o incluso un $4 \%$ de las figuras de personas traídas a sus páginas, la proporción de varones que desempeñan ese rol doméstico deriva de un intento consciente de potenciar nuevos modelos sociales o no. De ser así, ¿ese $2 \%$ sería suficiente para una acción de tal calado? No puedo dejar de plantearme que quizá estamos ante una invisibilización de la realidad social y no ante una propuesta nueva.

Respecto a los otros dos roles que dan pie a estas gráficas, cabe comentar, cómo en Diseño Interior, El Croquis, Arquitectura Viva y Domus diseñadores y arquitectos ocupan un lugar en las páginas de la publicación de una manera más que significativa, superior al $50 \%$, alcanzando por ejemplo en el caso de Diseño Interior el $89 \%$. On Diseño con un $41 \%$ y Casabella con un $44 \%$ tampoco puede decirse que infrarrepresenten este rol masculino.

Hemos visto, al analizar los roles femeninos referidos en estas revistas, cómo, en On Diseño, el $87 \%$ de las mujeres aparecían desempeñando el rol de mujer anuncio. Vemos ahora cómo, en cuanto a varones se refiere, suponen un $56 \%$. Es decir, aunque en la gráfica de roles desempeñados por varones, el de hombre anuncio expresa el incremento de presión a este respecto que sufre esta parte de la población, la comparativa entre géneros sigue en valores de desequilibrio patente. Sería deseable suprimir este desequilibrio, no por el aumento de presión mediática a la que se están viendo sometidos los varones, sino por la desactivación de ésta sobre las mujeres.

En Casabella, comparar este gráfico con el anterior es clarificador. El incremento de varones en los anuncios es de notar, llegan a un $52 \%$. No obstante el rol dentro del anuncio es sustancialmente distinto, doméstica u objeto sexual en el caso de las mujeres, profesional en cuanto a los hombres. 
Roles de varones global

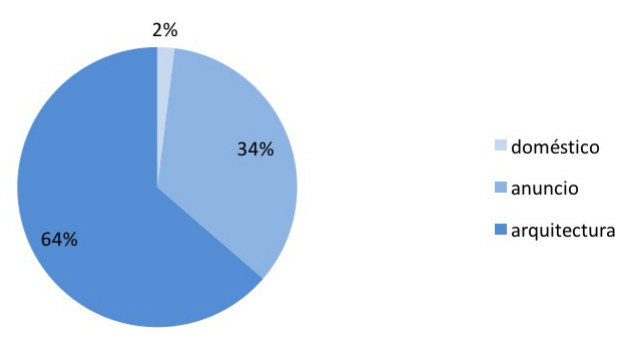

81. Presencia de figura humana distribuída por roles de varones global en revistas de arquitectura y diseño. Fuente: G.E.P., 2016.

La siguiente tabla que podemos encontrar organiza los datos según la distribución por funciones. ¿Qué actividades desempeñan las personas que encontramos entre las páginas de las revistas de arquitectura y diseño?:

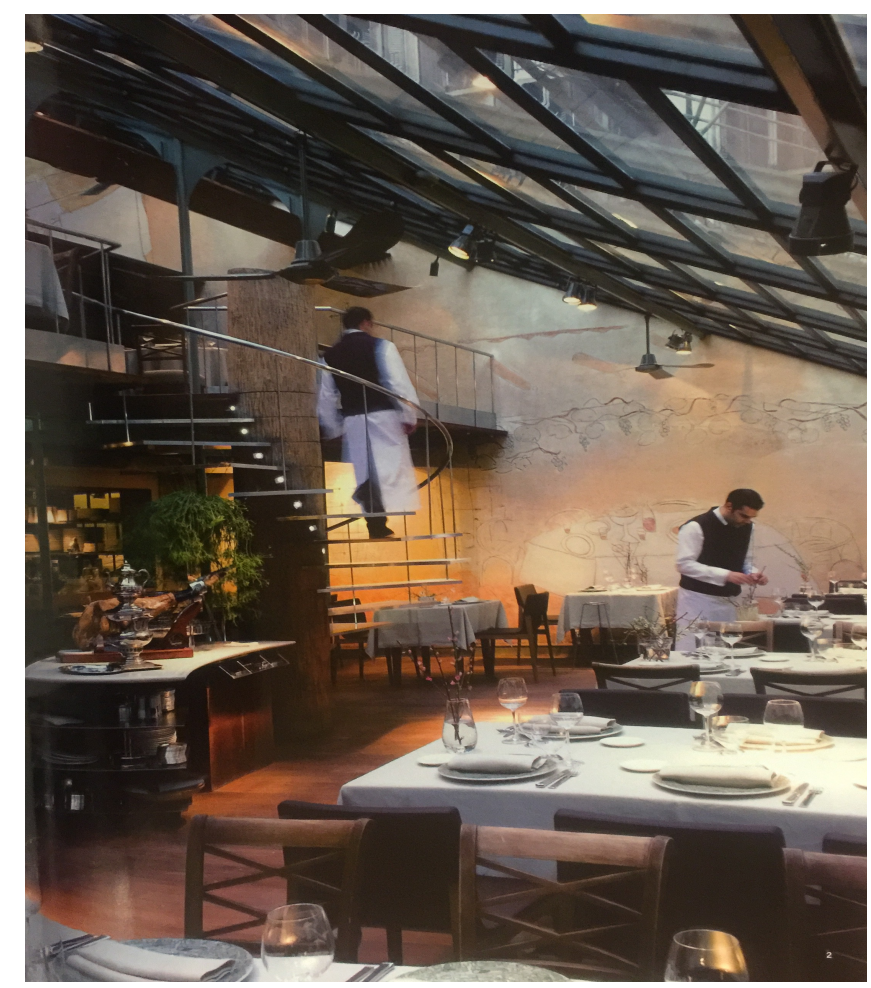

82. Otros trabajos profesionales. Fuente: Diseño Interior 227, 2011. 


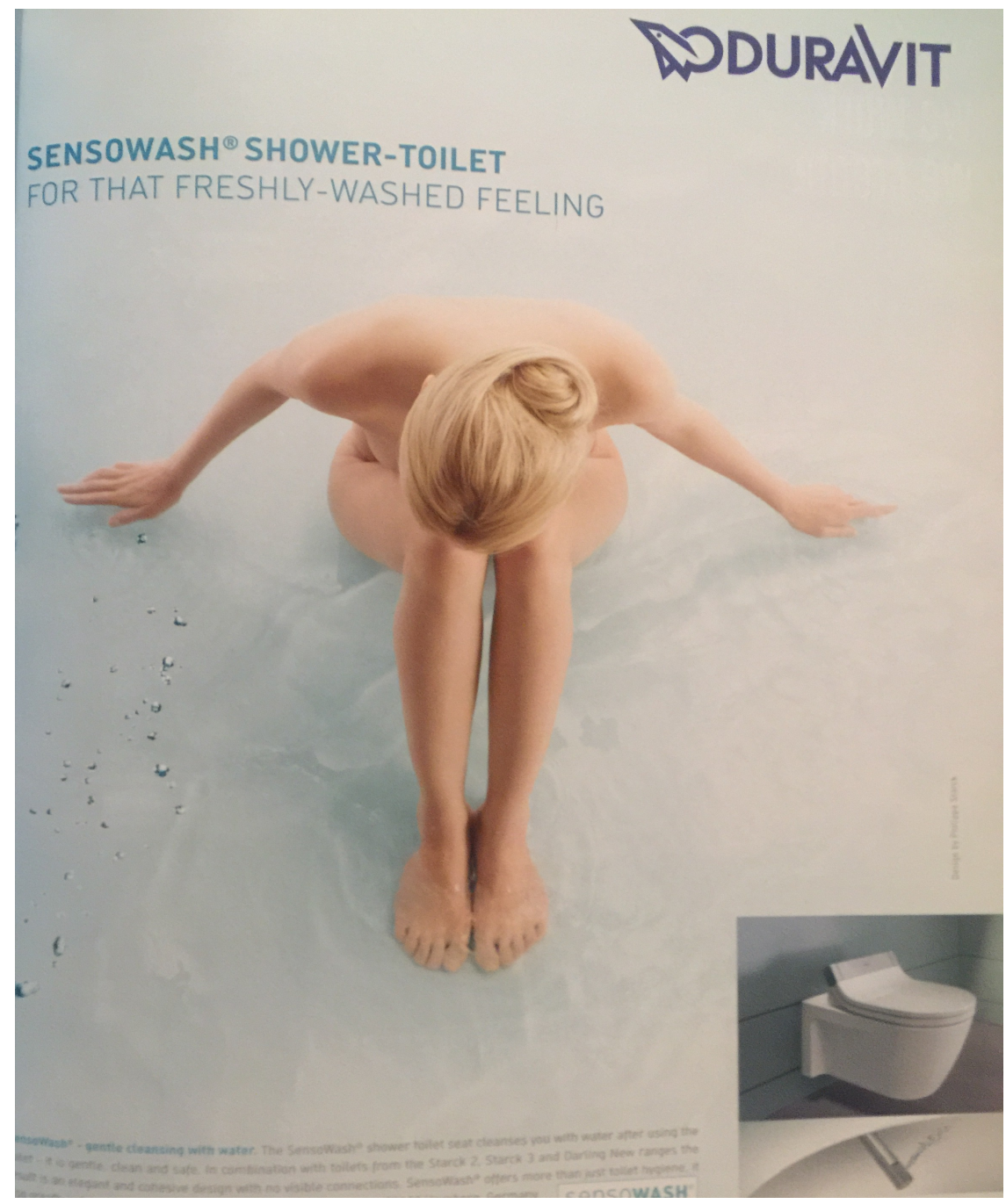

83. Cosificadx. Fuente: Domus 995, 2015.

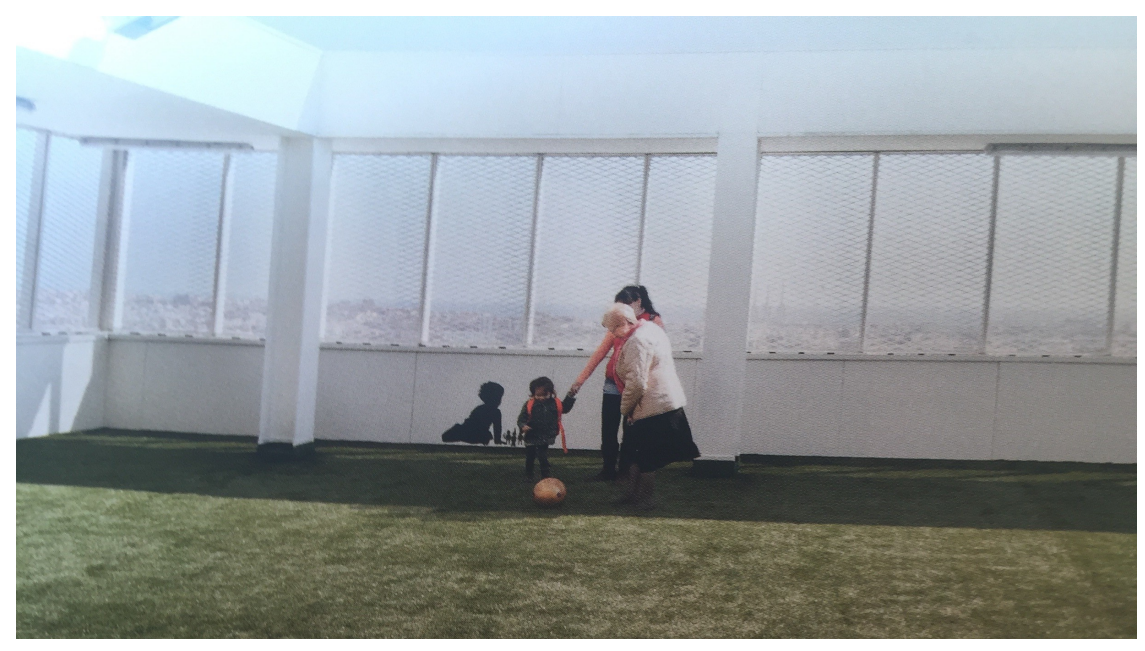

84. Mujer «usuaria». Fuente: On Diseño 332, 2013. 


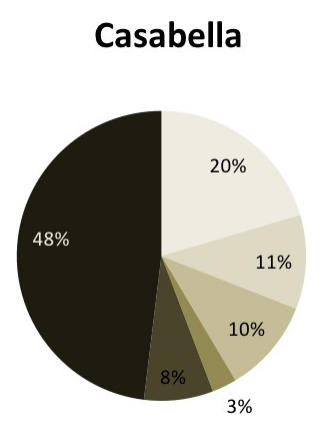

Arquitectura Viva

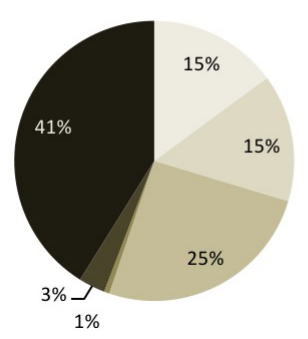

Diseño Interior

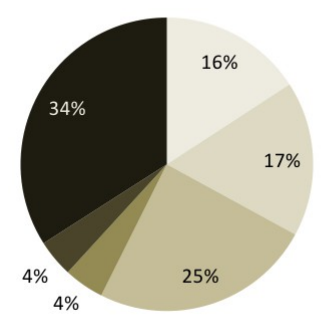

El Croquis

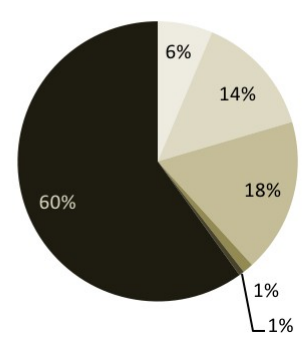

Domus

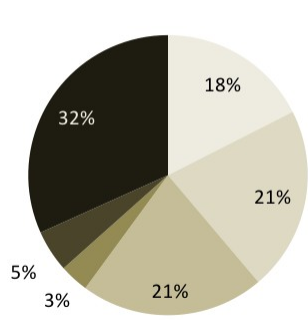

ON Diseño

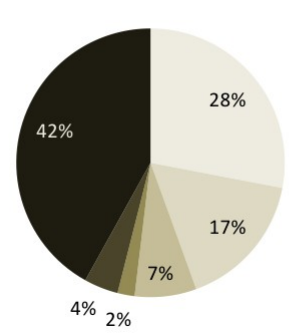

85. Presencia de figura humana distribuída por funciones en revistas de arquitectura y diseño Fuente: G.E.P., 2016.

La observación de los datos que nos proporciona el vaciado de revistas requiere, como ya he comentado anteriormente, poner el foco en diferentes variables para poder desarrollar un discurso que se corresponda con el mensaje subyacente. Al revisar los ítems observados, el aglutinarlos por funciones nos proporcionará una información relevante, en sí misma y por la posterior comparativa que me va a permitir.

Las funciones globales, sin la variable que diferencia por sexos tenida en cuenta para la reflexión que sigue, aportan los siguientes datos: 


\section{Diseño Interior:}

Ante este gráfico, podemos pensar que las revistas de arquitectura y diseño son coherentes: la mayor parte (34\%) de personas que aparecen en Diseño Interior son personas usuarias de los espacios interiores publicados, son las destinatarias de esos espacios y de la revista misma, objeto de difusión y propaganda a su vez; y el siguiente grupo a la cabeza, con un $25 \%$, profesionales de la arquitectura y del diseño; el tercer grupo es el de otros trabajos, que analizaremos más adelante; con un 17\%; en cuarto lugar aparecen quienes ocupan las páginas de los anuncios, con un porcentaje de representación casi igual al anterior (16\%); tras el cual quedan dos grupos, el de aquellas imágenes en las que desde los anuncios las personas resultan cosificadas (4\%); y por último la representación de tareas domésticas que supone un $(4 \%)$ del total.

\section{On Diseño:}

El primer grupo está representado por las personas que aparecen como usuarias (42\%); el (28\%) de figuras humanas que aparecen to hacen en anuncios; los restantes grupos tienen representaciones que oscilan entre el $2 \%$, para el trabajo doméstico; el $4 \%$ son personas cosificadas; el $7 \%$ para profesionales del diseño y la arquitectura; y el $17 \%$ son otras profesiones.

Arquitectura Viva:

El grupo más numeroso, tras el de personas usuarias (41\%), representa a las personas profesionales de la arquitectura y el diseño (25\%); cerca el de quienes aparecen en los anuncios publicitarios (15\%); los restantes grupos tienen representaciones que suponen entre el $1 \%$, para el trabajo doméstico, y el $15 \%$ para otros trabajos.

\section{El Croquis:}

El sumatorio de figuras humanas usuarias $(60 \%)$ y profesionales del diseño y la arquitectura (18\%) cubre el $78 \%$ de las personas que aparecen en las páginas de El Croquis. Los restantes grupos tienen representaciones tales que dejan un balance de entre el $1 \%$, para la cosificación y el trabajo doméstico, el $6 \%$ para los anuncios, y el $14 \%$ para otros trabajos. 


\section{Domus:}

Lo dicho en las revistas anteriores es válido en el caso de Domus.

Pocas variaciones en la contribución de unas revistas y otras a las posibilidades de generar referentes para las adolescentes al hojear sus páginas.

\section{Casabella:}

Entre usuarios $(48 \%)$, anuncios $(20 \%)$ y trabajos profesionales $(11+10=21 \%)$ los restantes grupos tienen representaciones que oscilan entre el 3\%, para el trabajo doméstico, y el $8 \%$ que supone la aparición de personas cosificadas en sus páginas.

A nivel global, en el conjunto de las seis revistas analizadas, los cuatro porcentajes más elevados y a sensible distancia de los dos restantes grupos sitúan en cabeza a las personas usuarias, seguido de la alternancia entre los anuncios - importantes para costear los presupuestos de las revistas-, las profesiones relacionadas con el diseño y la arquitectura, y otros trabajos profesionales.

En las publicaciones analizadas descubrimos un escasísimo porcentaje de cosificación y llama especialmente la atención el aún más escaso porcentaje de imágenes en espacios interiores que den testimonio del trabajo doméstico. ¿Significa que no existen estas funciones en la realidad o que las ocultan las revistas analizadas? Ese irrisorio porcentaje nos habla del hombre champiñón que aparece, en su importante lugar de trabajo, limpio, alimentado, sano y bien vestido, como si de la noche a la mañana se hubiera producido la transformación sin un trabajo previo.

El modelo prototípico de resolución de los cuidados en el capitalismo fordista se basaba a nivel macrosocial en la división sexual del trabajo clásica que adscribía a las mujeres a los trabajos de cuidados no remunerados y a los hombres al trabajo asalariado, $y$, a nivel microsocial, en la imposición de la familia nuclear (radioactiva) «hombre ganador del pan/mujer ama de casa» como la norma social. Estos dos ejes atravesaban la estructura del mercado laboral, que imponía como modelo de trabajador estándar al caricaturizado como 
«trabajador champiñón» (aquel que brota todos los días plenamente disponible para el mercado, sin necesidades de cuidados propias ni responsabilidades sobre cuidados ajenos, y desaparece una vez fuera de la empresa); el estado del bienestar, que se sustentaba en este modelo al definir el sujeto de las prestaciones (la familia nuclear a través de su «cabeza visible», la vía de acceso (el trabajo asalariado), y el contenido (quedando fuera todos los cuidados a situaciones de dependencia); y la construcción de las identidades, que suponían que la realización de las mujeres se colmaba a través de su rol de cuidadoras (madre y esposa abnegada) mientras que los hombres se hacían tal por la dedicación a su profesión. En este modelo, la responsabilidad de sostener cotidianamente la vida se remite a las mujeres, a través del trabajo de cuidados no remunerado en los hogares. Es este trabajo, oculto en el ámbito de lo doméstico, el que absorbe en gran medida las tensiones estructurales de un sistema en el que la reproducción y regeneración de la vida no son prioridad. Asumir esta responsabilidad posicionaba a las mujeres en una situación de vulnerabilidad específica e intensificada. (Orozco, 2013:

7)

Es obvio que la respuesta a la pregunta anterior - ¿Significa que no existen estas funciones en la realidad o que las ocultan las revistas analizadas?- es que las ocultan; pero aun ocultándolas, veremos en los apartados siguientes lo que se escapa por esas pequeñas fisuras.

\section{Distribución por funciones global}

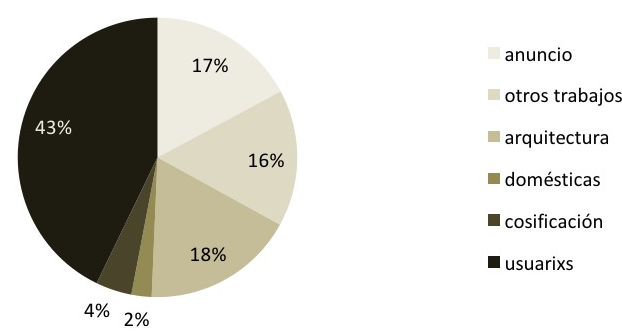

86. Presencia de figura humana distribuída por funciones global en revistas de arquitectura y diseño. Fuente: G.E.P., 2016. 
En la tarea de extraer datos para generar las gráficas hasta el momento analizadas, se me plantea la necesidad de expresar de manera cuantitativa la proporción de mujeres que aparecen en los anuncios frente a los varones que, aunque con matices de calado, también lo hacen.

Deteniéndonos en la comparativa entre mujeres en anuncios y varones en los anuncios por revistas, encontramos algunos aspectos a destacar.

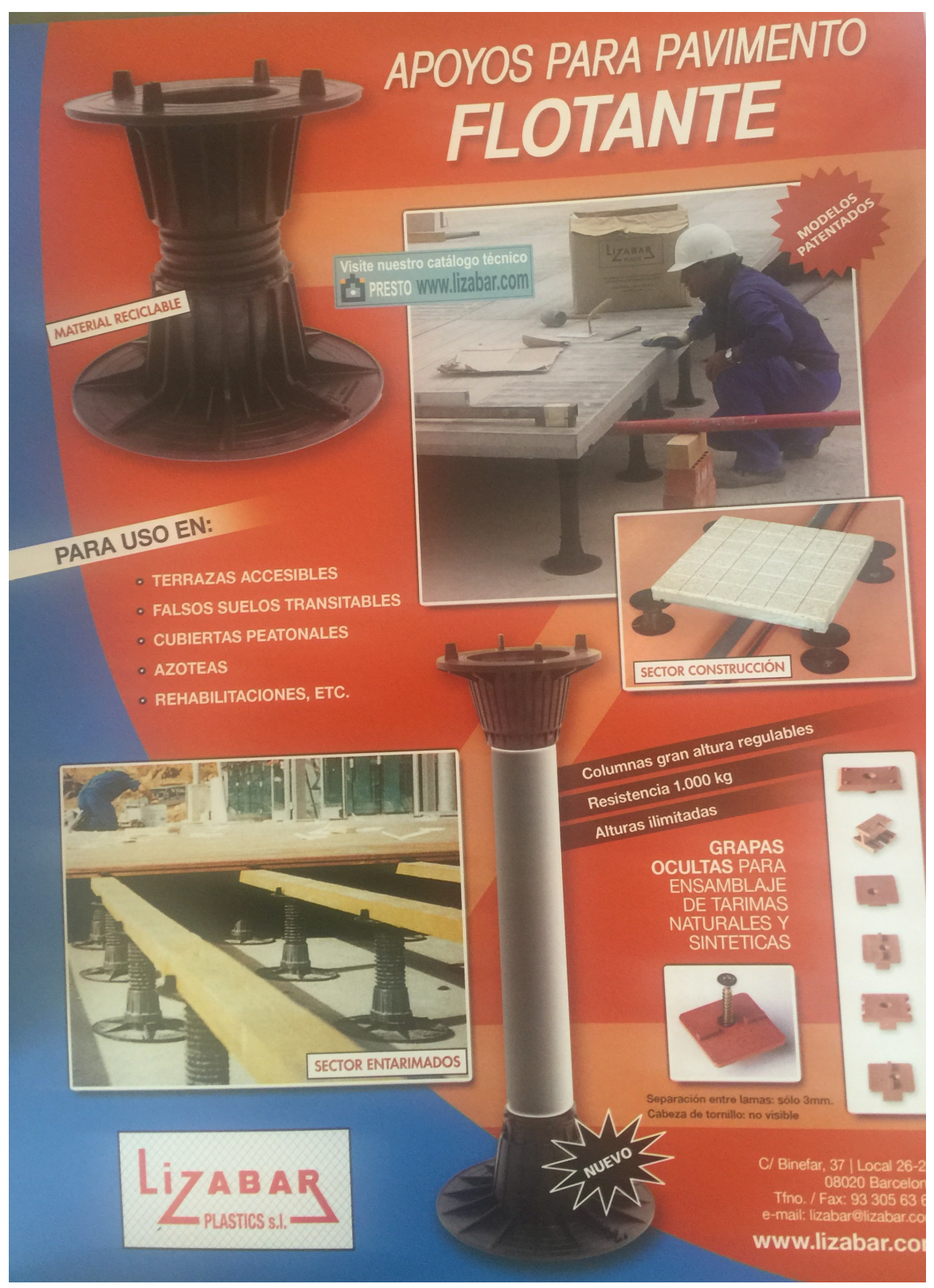

87. Anuncio Varón. Fuente: Arquitectura Viva 163, 2014. 


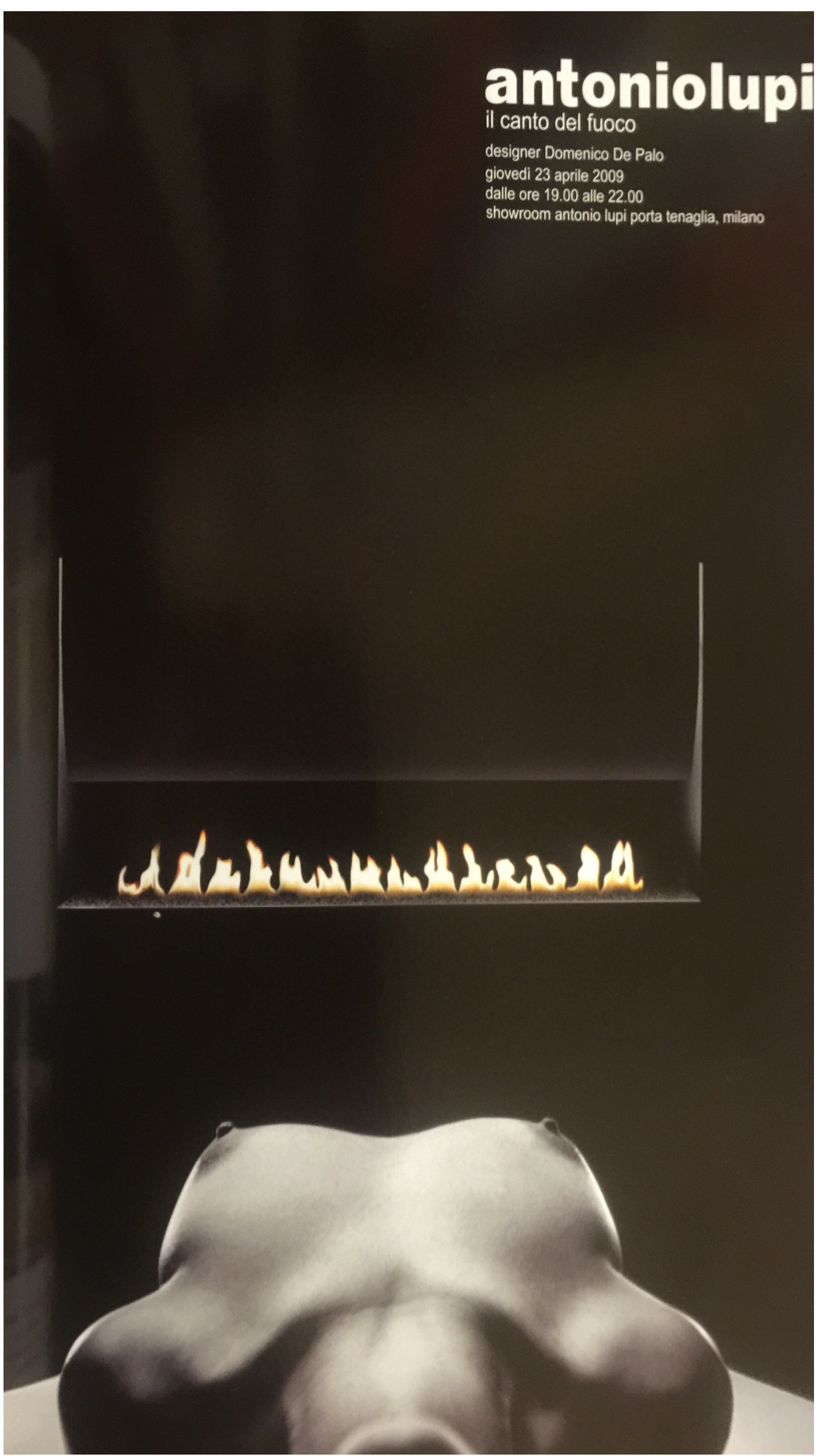

88. Anuncio Mujer. Fuente: Diseño Interior 201, 2009 
Casabella

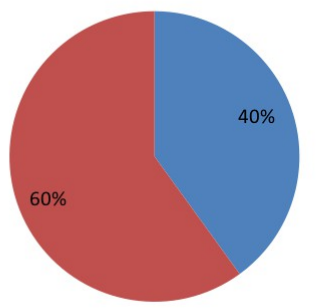

Arquitectura Viva

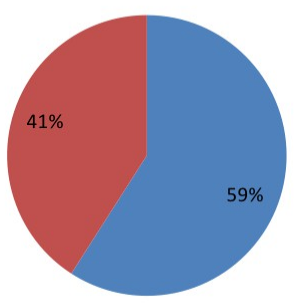

Diseño Interior

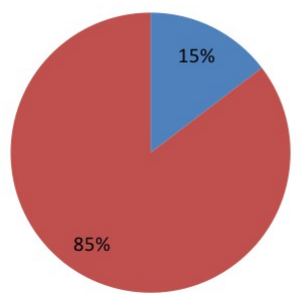

El Croquis

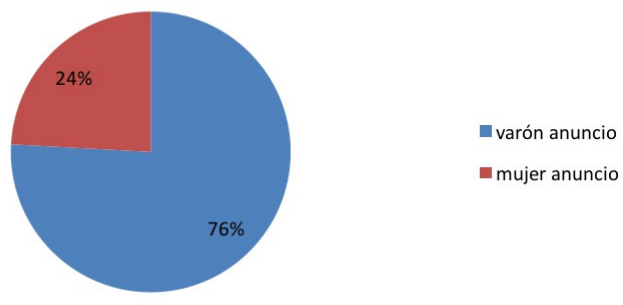

Domus

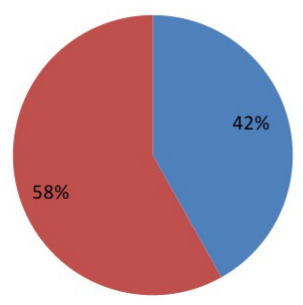

ON Diseño

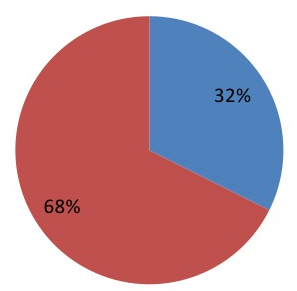

89. Presencia de figura humana distribuída por roles publicitarios en revistas de arquitectura y diseño. Fuente: G.E.P., 2016.

\section{Diseño Interior:}

Tal y como se desprende de los análisis desgranados hasta aquí, partimos de porcentajes muy bajos de imágenes de espacios interiores en los que aparecen figuras humanas. En concreto en Diseño Interior solo el $16 \%$ de las imágenes de espacios interiores publicadas cuentan con personas. Bien, ese $16 \%$ reparte proporcionalmente las situaciones en las que nos expresa quienes desarrollan según qué funciones tal y como hemos visto en la imagen 85 , y el $16 \%$ de ese $16 \%$ hemos visto que se correspondía con personas en espacios interiores en anuncios, por tanto, tan solo un $2,6 \%$ de las figuras humanas que aparecen en estas revistas en espacios interiores suponen imágenes de anuncios en los que aparecen personas bien sean mujeres, bien sean hombres. Anuncios de los 
que también cabe plantear quienes son estadísticamente sus protagonistas. EI $15 \%$ son varones, el resto, $85 \%$, son mujeres, es decir, en un $0,4 \%$ de los casos estamos ante una imagen de espacios interiores con un anuncio protagonizado por un varón, y en un 2,2\% mujeres en anuncios en espacios interiores. Caben más análisis que veremos en la batería de gráficas que todavía quedan por analizar en el presente trabajo de campo de esta investigación.

\section{On Diseño:}

El $90 \%$ de los espacios interiores que nos muestra esta publicación no cuentan con personas que los ocupen. Del $10 \%$ del total de figuras humanas que encontramos en las páginas de On Diseño, veíamos en la imagen 85 como un $28 \%$ lo constituyen los anuncios en los que aparecen hombres o mujeres. El $32 \%$ de las personas que protagonizan dichos anuncios, según la imagen 89 , son varones, el resto, un $68 \%$, son mujeres. También aquí, entre los pequeños porcentajes de presencia humana, es obvia la masiva presencia de la mujer en la publicidad. Las mujeres en anuncios suponen un $1,9 \%$ de las pocas representaciones humanas que hay en esta revista, algo más del doble que los varones, que suponen un $0,89 \%$ en este rol.

\section{Arquitectura Viva:}

A la vista de la gráfica correspondiente a Arquitectura Viva podemos decir que en esta publicación aparecen más varones en los anuncios publicitarios que mujeres. Este dato en sí mismo induciría a pensar en una posible situación de equilibrio, quizá en unas publicaciones aparecen más hombres en los anuncios y en otras son las mujeres quienes prevalecen en este ámbito, y entre unas y otras el espacio de los anuncios queda ajustado de manera igualitaria entre sexos. Pero es imposible no hacer la reflexión sobre el contenido de los propios anuncios. Salir o no en un anuncio no es un dato completo en sí mismo. Estos hombres anuncio van asociados en muchísimas ocasiones a un trabajo considerado, todavía hoy, como de estatus de relevancia, como puede verse en las imágenes que preceden: piloto de carreras de fórmula I, arquitecto.

En este mismo sentido debemos tener muy presente que las mujeres van asociadas en los anuncios al desempeño de papeles en los que, en numerosas 
ocasiones, resultan cosificadas con roles de seducción, o desarrollan tareas domésticas, como podremos verificar en los gráficos de los apartados siguientes.

Tras calcular el porcentaje sobre el total, en esta ocasión los anuncios con varones alcanzan un $1,4 \%$ del total de las figuras humanas que aparecen en los espacios interiores de Arquitectura Viva en anuncios, frente al $0,98 \%$ de mujeres que lo hacen.

\section{El Croquis:}

Hemos visto al analizar la distribución por funciones en cada una de las publicaciones objeto de este trabajo cómo, en concreto en el caso de El Croquis, el porcentaje de páginas dedicadas a anuncios era cuantitativamente hablando, muy bajo, un $6 \%$, y que sobre el porcentaje de imágenes con presencia humana de esta publicación supone un exiguo 1,2\% de esas páginas. A la vista de esta gráfica, podemos hablar de la invisibilización de las mujeres, puesto que su presencia no refleja lo que ocurre en la realidad observable, ni podemos asumir que pretenda tampoco corregir, quizá por discriminación positiva, desequilibrios sociales con voluntad de inducir una mejora. Aquí las mujeres aparecen menos incluso en los anuncios, son la tercera parte que los hombres, las mujeres suponen un $0,28 \%$ de presencia en los anuncios frente al $0,91 \%$ de varones, eso sí, valores que muestran la potencia de la ausencia en estos ejemplares.

Domus:

En valores absolutos Domus enfrenta un $42 \%$ de varones en los anuncios a un $58 \%$ de mujeres en esa misma situación. Cada vez se acercan más los varones al mundo de la publicidad. Necesariamente debemos leer los matices de gráficas que vienen a continuación para no caer en simplificaciones que nos alejarían de la realidad. Estos porcentajes siempre hay que considerarlos en su verdadera dimensión, en valores absolutos, un $0,30 \%$ son varones en anuncios y el $0,42 \%$ mujeres. 


\section{Casabella:}

Se repite la información acerca del emparejamiento de las cifras entre varones y mujeres en los anuncios publicitarios y se impone el análisis de los distintos roles que desempeñan unos y otras en esos anuncios. Sobre el total de las imágenes de espacios interiores analizadas en Casabella, el 1,56\% son mujeres en anuncios y el $1,04 \%$ son varones en este rol publicitario.

\section{Distribución por sexos en espacios virtuales global}

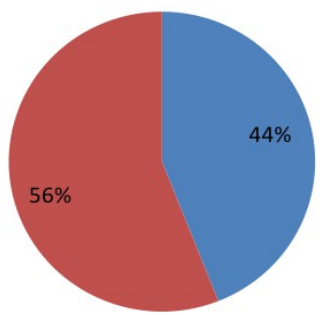

varones

mujeres

90. Presencia de figura humana distribuída según modelos publicitarios por sexos global en revistas de arquitectura y diseño. Fuente: G.E.P., 2016.

¿Qué relación porcentual presentan en las revistas de carácter profesional, con las características que hemos podido leer según sus equipos editoriales, las mujeres y los varones dedicados a la arquitectura y el diseño de interiores?:

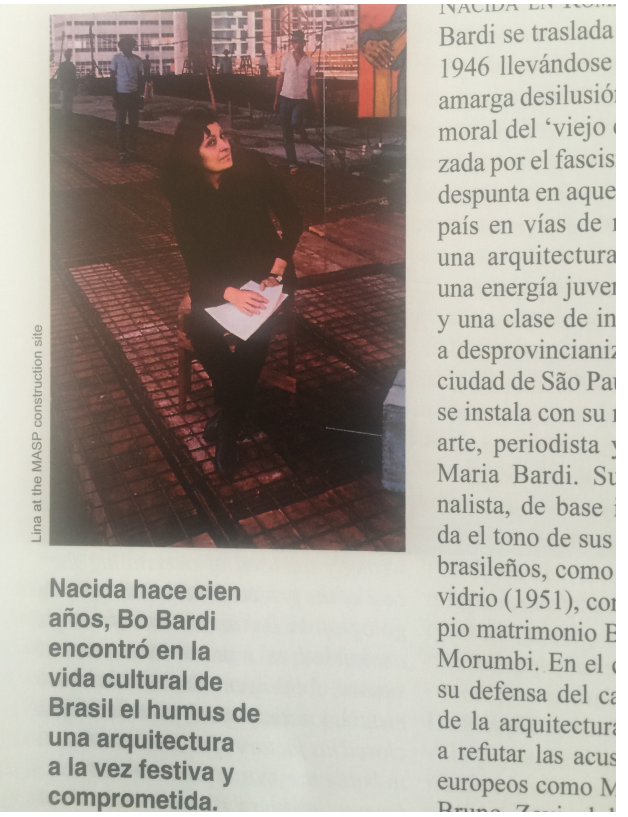

91. Mujer arquitecta. Fuente: Arquitectura Viva 167, 2014. 


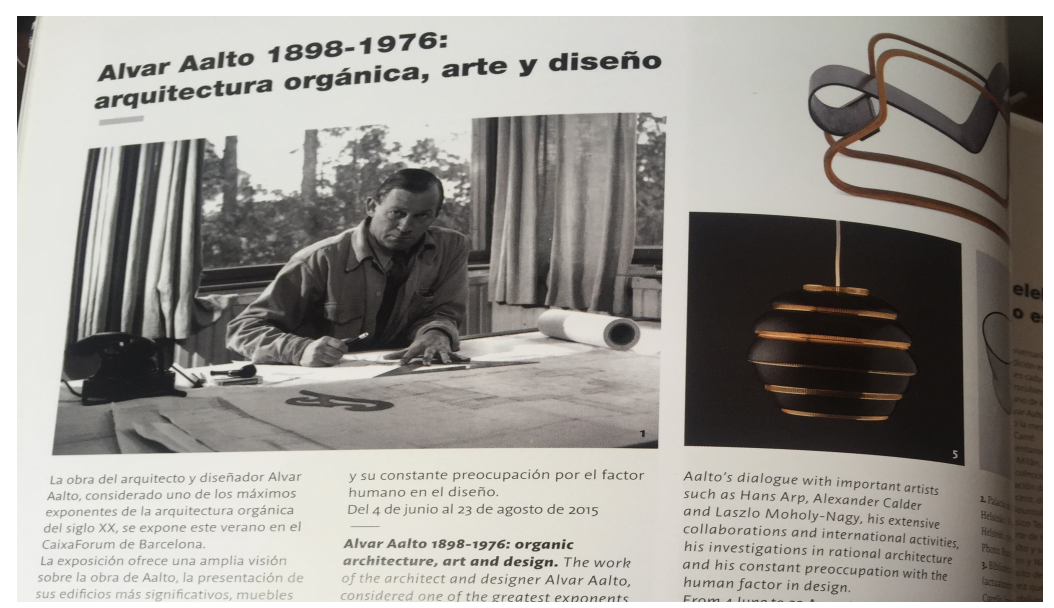

92. Varón arquitecto. Fuente: On Diseño 352, 2015.

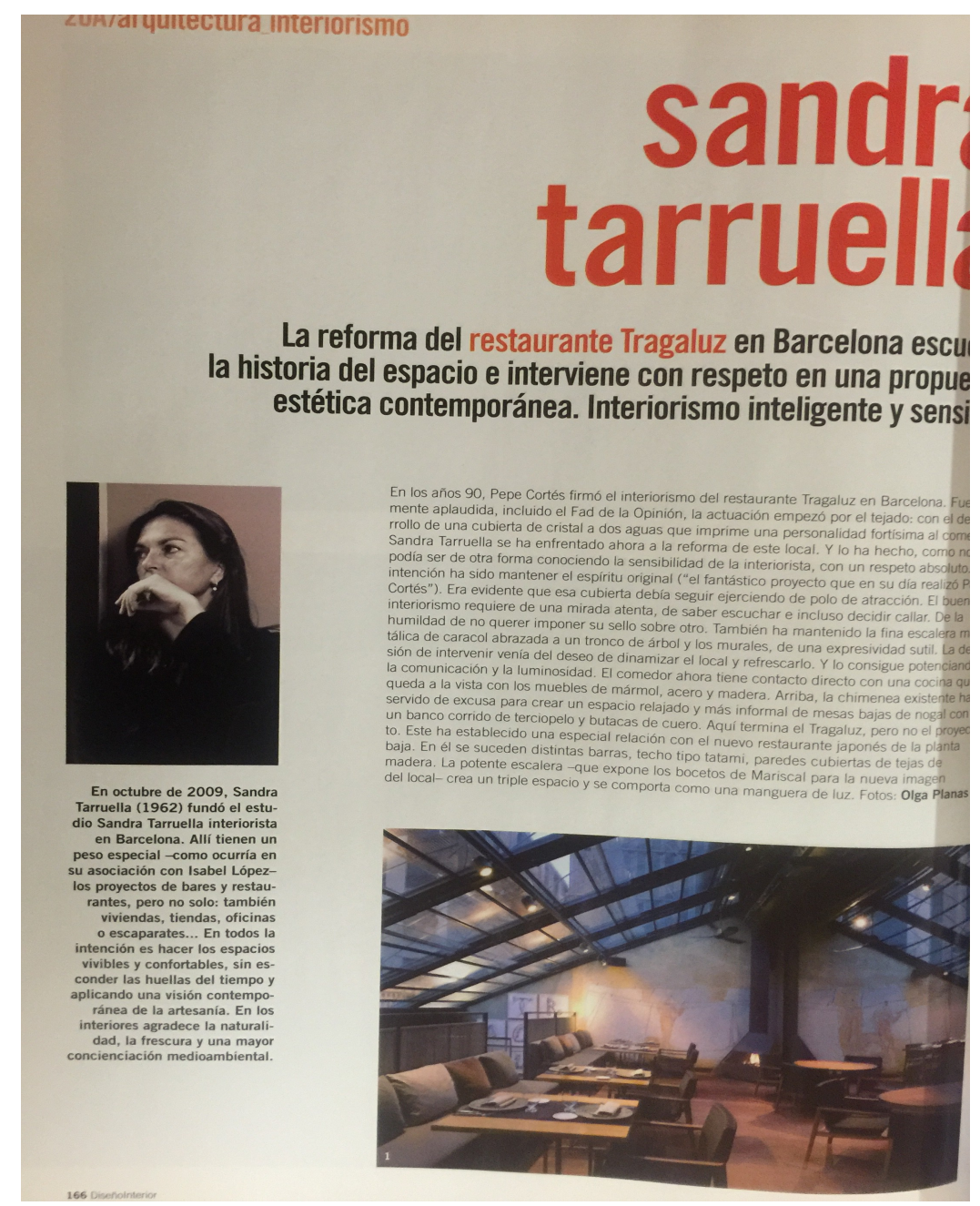

93. Mujer diseñadora de interiores. Fuente: Diseño Interior 227, 2011. 


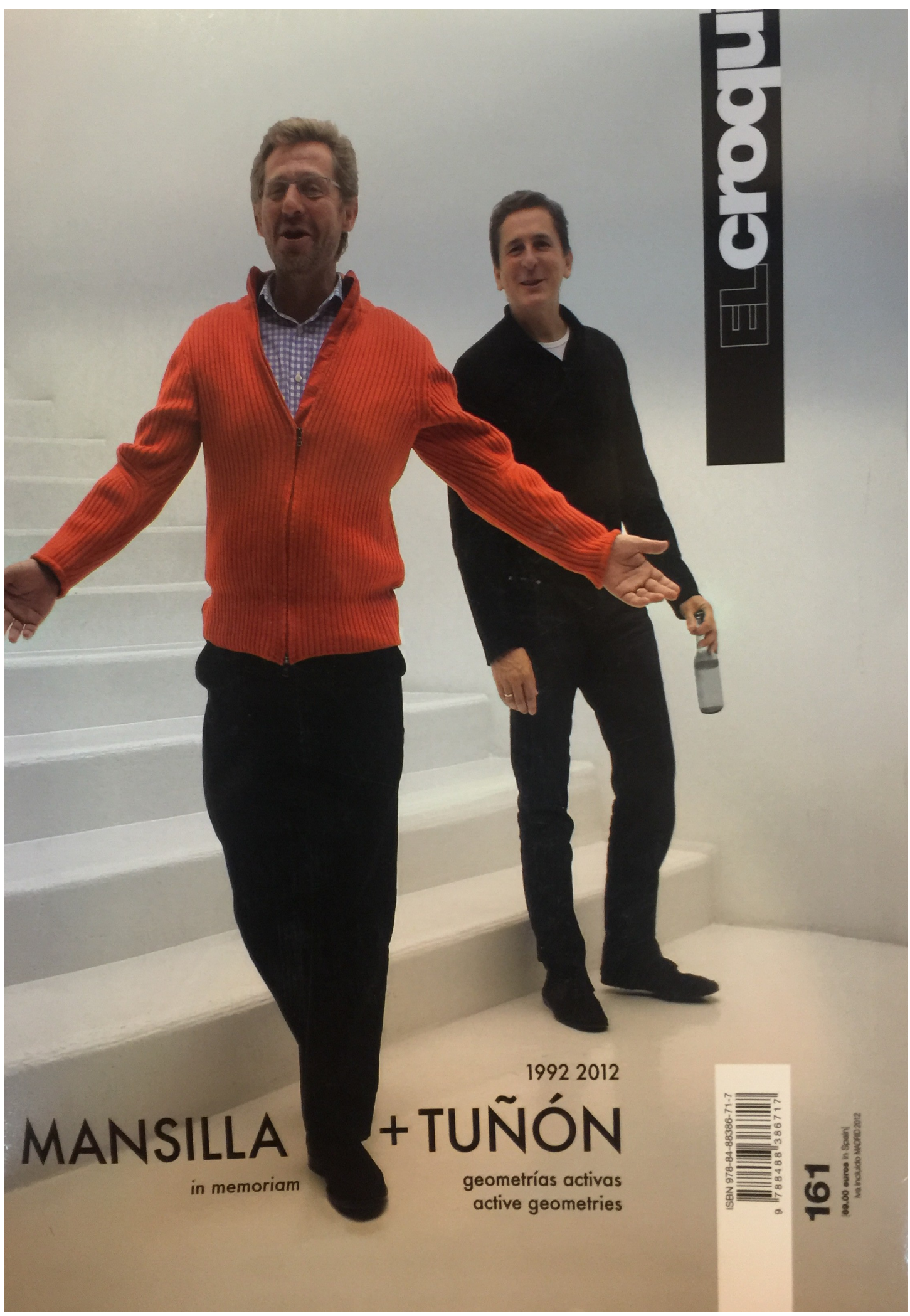

94. Varones arquitectos. Fuente: El Croquis 161, 2012. 


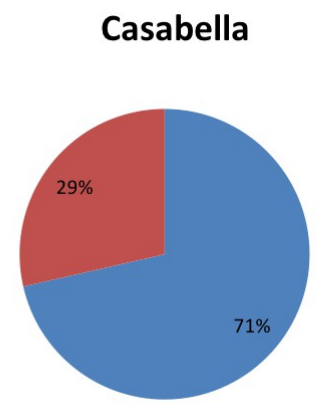

Arquitectura Viva

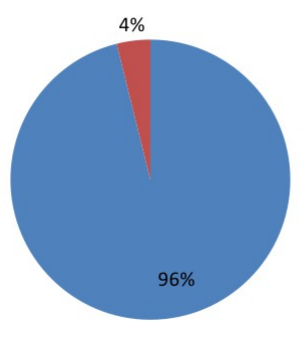

Diseño Interior

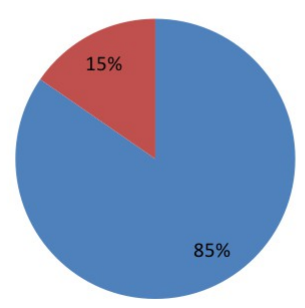

El Croqius

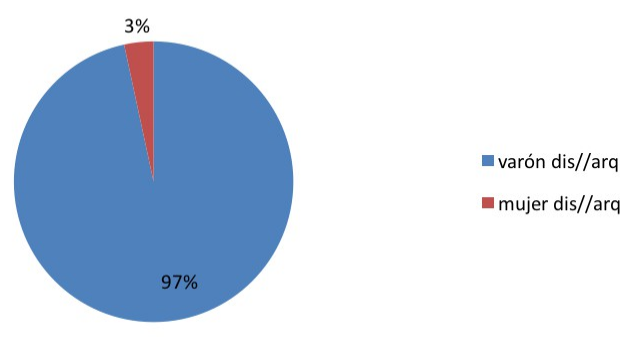

Domus

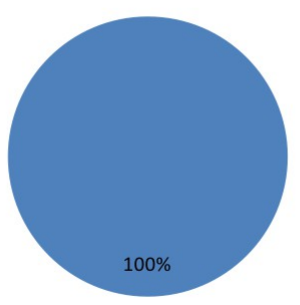

ON Diseño

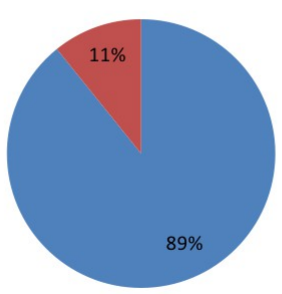

95. Presencia de figura humana que se dedica a la arquitectura o al diseño de interiores distribuída por sexo en revistas de arquitectura y diseño. Fuente: G.E.P., 2016.

Si analizamos publicación por publicación, observamos los datos que paso a describir a continuación.

Diseño Interior:

En el subcapítulo 5.4.1. Criterios establecidos para el tratamiento de los datos, hemos visto, con datos extraídos del sistema educativo español, cómo en las aulas de las escuelas de Artes Plásticas y Diseño, y en la obtención de la titulación correspondiente a Diseño de Interiores, la proporción entre varones y 
mujeres no está ni tan siquiera cercana al equilibrio paritario. No, es aplastante el número de mujeres sobre el de varones que cursan y superan estos estudios. Por otra parte los datos referentes a arquitectura en concreto no son asequibles en cuanto a las fuentes oficiales consultadas, ya que las gráficas enmascaran los porcentajes de mujeres que estudian arquitectura al expresarlas en las mismas gráficas que las de las ingenierías. Aun así, teniendo en cuenta los datos de los que sí disponemos en cuanto a diseño de interiores se refiere y los que en cuanto a arquitectura resultan de relevancia y extrapolables a todo el estado español desde la Comunidad de Galicia, no deja de ser llamativo el reparto que las publicaciones difunden del desempeño de estas profesiones.

\section{Relación colegiadas/colegiados}

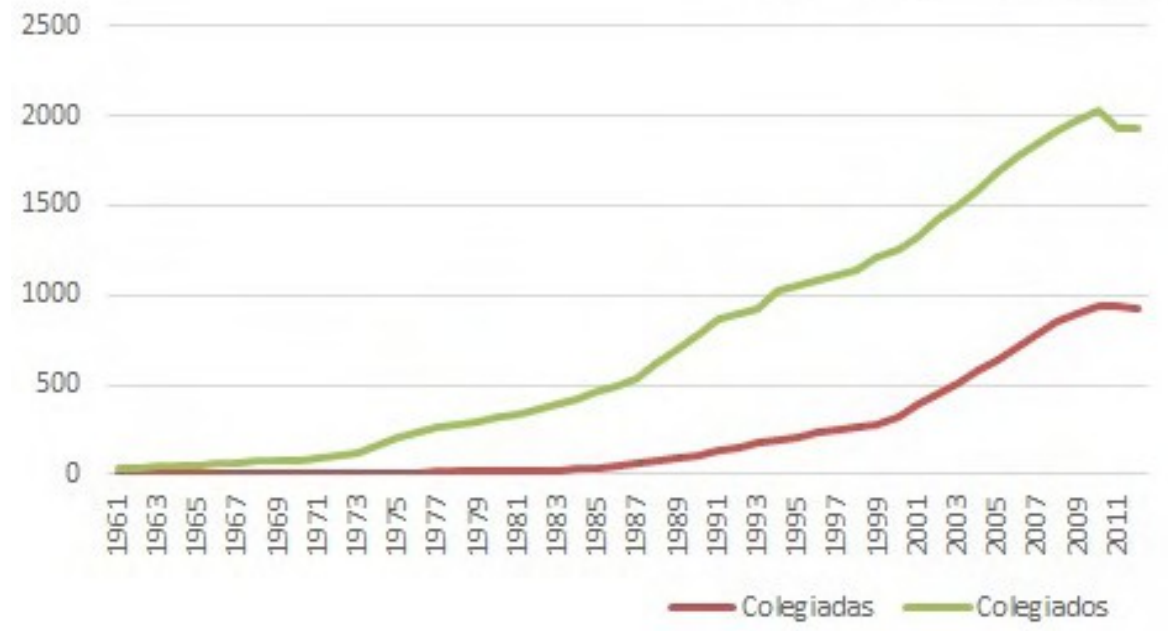

96. Número de arquitectas y arquitectos colegiad@s en Galicia. Fuente: MAGA, 2011.

Cuando el trabajo es específicamente de arquitectura y diseño, la presencia de varones se dispara. Diseño Interior cuenta con un tajante $85 \%$ de varones diseñadores o arquitectos; en el caso de On Diseño la proporción de varones cuya profesión pertenece al mundo del diseño y o la arquitectura llega al 89\%, por tanto y por obvia que resulte la aclaración, únicamente una de cada diez veces en las que nos muestra a una persona del mundo del diseño y la arquitectura esta publicación lo hace escogiendo a una mujer; Arquitectura Viva reduce la presencia femenina entre sus páginas y con la variable que nos ocupa 
como filtro para extraer la información todavía más, un 96\% son varones; cerca, muy cerca del de Arquitectura Viva está el porcentaje que traduce las cifras de presencia femenina y masculina en el mundo del diseño y la arquitectura como profesión en El Croquis, un $97 \%$ son varones, es más, a la vista de los ejemplares analizados, el $73 \%$ de ellos son monográficos dedicados a varones y el $27 \%$ a equipos mixtos dedicados a la arquitectura. El $100 \%$, sin paliativos, el $100 \%$ de la presencia como profesional del mundo del diseño y la arquitectura de los ejemplares que han supuesto la muestra para este estudio, el $100 \%$ repito, en los ejemplares de Domus, son varones. Casabella trae a sus páginas una proporción del $71 \%$, siete de cada diez profesionales de la arquitectura y el diseño escogidos son, en el caso de Casabella, varones.

A nivel global, entre el $0 \%$ de Domus y el $29 \%$ de Casabella, se sitúa la escasa representación de las mujeres en la profesión de diseñadoras y arquitectas.

Tanto Doris Salcedo como Lynne Cohen generan debate, provocan una mirada atenta, sobre la violencia de la invisibilización, que se hace muy necesasaria cuando analizamos todos estos datos extraidos de las páginas de las revistas que nos ocupan. Páginas que constituyen un referente, un indicador para profesionales y personas usuarias. Referente que potencia unos roles e invisibiliza otros, gestiona así las posibilidades, o falta de ellas, que las mujeres tienen para aspirar a según qué futuro.

\section{Distribución por sexos en arquitectura y/o diseño de interiores global}

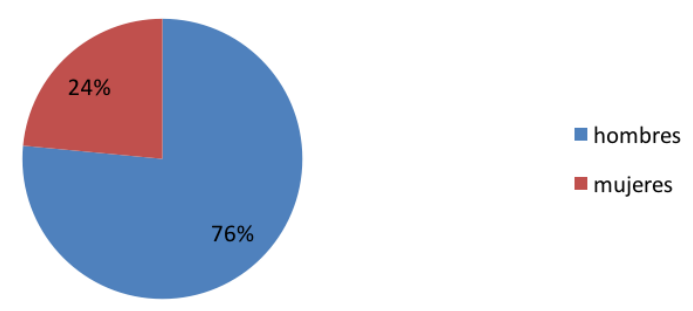

97. Presencia de figura humana distribuída por sexo global en revistas de arquitectura y diseño. Fuente: G.E.P., 2016. 
Las revistas de las que nace la batería de gráficas completa que estamos interpretando traen a nuestro imaginario también trabajos profesionales de distintos tipos, desempeñados por mujeres o varones.

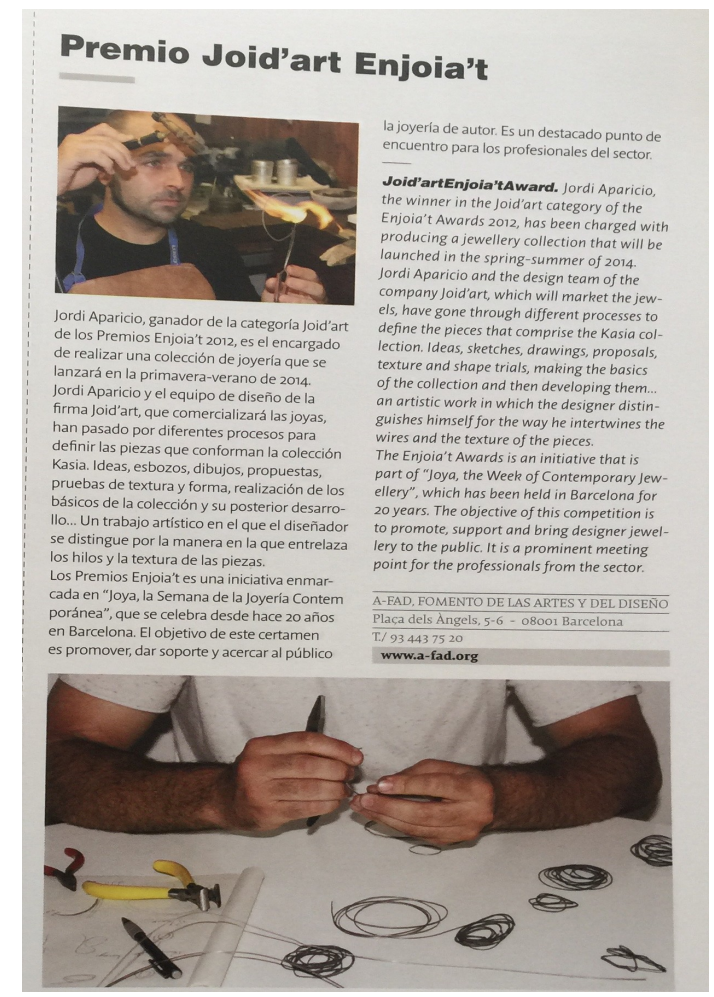

98. Varón profesional. Fuente: On Diseño 338, 2013.

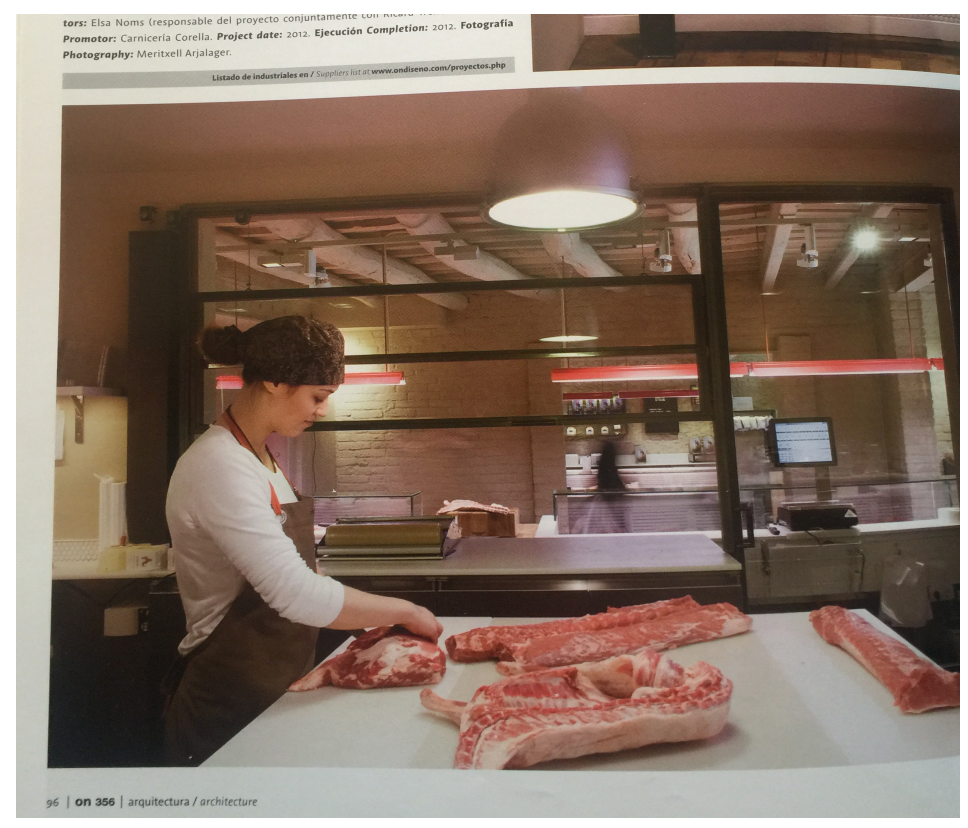

99. Mujer profesional. Fuente: On Diseño 356, 2015. 


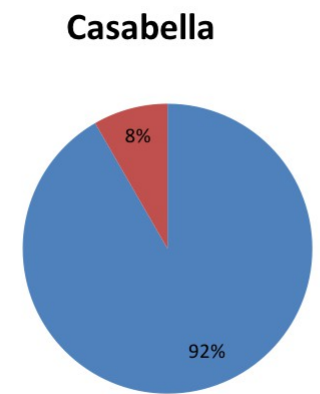

Arquitectura Viva

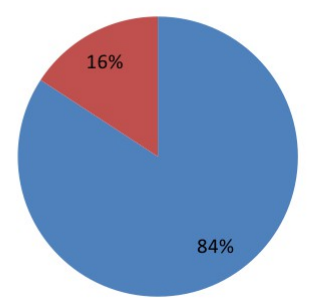

Diseño Interior

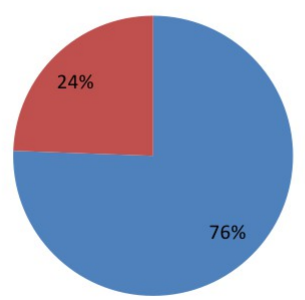

El Croquis

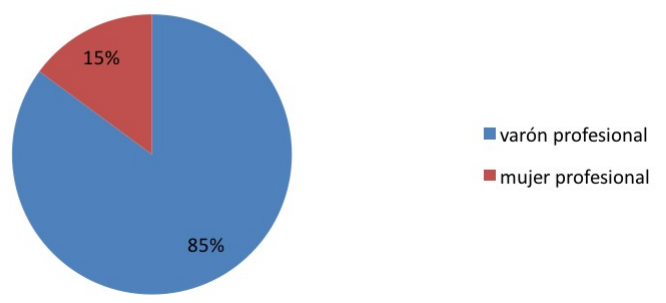

Domus

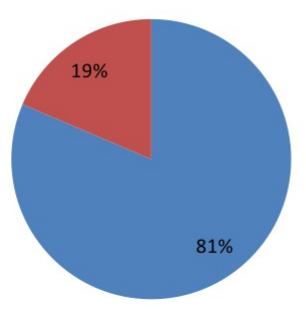

ON Diseño

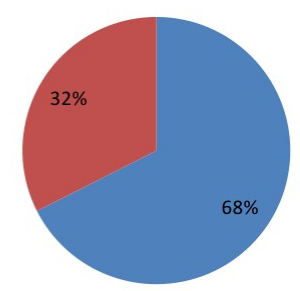

100. Presencia de figura humana distribuída por otros trabajos según sexo en revistas de arquitectura y diseño. Fuente: G.E.P., 2016.

En los ejemplares analizados de Diseño Interior, los trabajos profesionales que nos muestra la revista lo hace mayoritariamente con varones, un $76 \%$ del total en esta publicación. Dentro de ese $76 \%$ se encuentran representados también los trabajos representados por los varones en los anuncios.

En el caso de On Diseño el porcentaje de trabajo profesional asignado a los varones asciende a un $68 \%$, proporción en absoluto irrelevante. Ya hemos acordado en apartados anteriores que las revistas tienen la voluntad de difundir modelos sociales y la capacidad de influir realmente en que estos transformen la sociedad. Ya era este el cometido de las publicaciones en las que aparecía el matrimonio Eames por ejemplo. Por tanto, estos altos porcentajes en roles 
profesionales no son únicamente un dato, suponen una construcción hacia el futuro, desde mi punto de vista harto preocupante. El hecho de que en escuelas de arquitectura y diseño de principios del siglo $X X$ no estuviese permitido matricularse si eras mujer, de que en la propia Bauhaus hubiera talleres cerrados al acceso de ellas en según qué etapas, obligándolas a inscribirse en el de tejidos en lugar de en el de construcción y arquitectura, no dista tanto del efecto que estos porcentajes imbuyen en nuestra sociedad. La falta de referentes femeninos en según qué posiciones merma la aspiracionalidad de aquellas jóvenes que creen, muchas veces sin saberlo, que hay tareas propias de los varones tal y como estos datos arrojan al analizar las publicaciones que nos ocupan. No se trata de un dato inocuo, o simplemente de un reflejo de lo que ocurre, puesto que cabe preguntarse si, en realidad estos porcentajes publicitados son fieles al hecho real respecto de todas y cada una de esas profesiones. Puesto que las tasas ocultan los números, a continuación veremos las tasas de empleo y desempleo y los números referentes a la población activa, con lo que queda clara la tasa y se desvela la falacia de los datos de las imágenes en las revistas estudiadas.

\section{Inserción laboral y mercado de trabajo}

Tasas de empleo y desempleo de la población con educación superior por sexo. 2010 (\%)

\begin{tabular}{|c|c|c|c|c|c|c|c|}
\hline & & \multicolumn{2}{|c|}{ Todos los niveles de educación } & \multicolumn{2}{|c|}{ Universitaria } & \multicolumn{2}{|c|}{ Superior no Universitaria } \\
\hline & & Hombres & Mujeres & Hombres & Mujeres & Hombres & Mujeres \\
\hline \multirow{2}{*}{ España } & Empleo & 71,9 & 57,3 & 84,4 & 78,6 & 80,8 & 70,4 \\
\hline & Desempleo & 17,6 & 18,6 & 8,1 & 9,8 & 12,2 & 15,7 \\
\hline \multirow{2}{*}{ OCDE } & Empleo & 80,0 & 65,0 & 88,3 & 79,3 & 85,5 & 77,2 \\
\hline & Desempleo & 7,3 & 7,2 & 4,4 & 4,7 & 5,8 & 5,6 \\
\hline \multirow{2}{*}{ UE-21 } & Empleo & 77,8 & 65,4 & 88,0 & 81,1 & 83,9 & 77,7 \\
\hline & Desempleo & 8,4 & 8,3 & 4,6 & 4,9 & 6,5 & 6,2 \\
\hline
\end{tabular}

101. Tabla de inserción laboral. Datos y cifras del sistema universitario español Curso 2012-2013.

Fuente: Ministerio de Educación, Cultura y Deporte, 2012-2013. 


\begin{tabular}{|c|c|c|c|c|c|}
\hline \multicolumn{6}{|l|}{ AMBOS SEXOS } \\
\hline Población de 16 años y más & $38.489,6$ & 2,8 & 0,01 & $-33,8$ & $-0,09$ \\
\hline$\overline{\text { Activos }}$ & $22.873,7$ & $-25,8$ & $-0,11$ & $-153,2$ & $-0,67$ \\
\hline - Ocupados & $18.094,2$ & 45,5 & 0,25 & 525,1 & 2,99 \\
\hline - Parados & $4.779,5$ & $-71,3$ & $-1,47$ & $-678,2$ & $-12,43$ \\
\hline Inactivos & $15.615,9$ & 28,7 & 0,18 & 119,4 & 0,77 \\
\hline Tasa de actividad & 59,43 & $-0,07$ & - & $-0,35$ & - \\
\hline Tasa de paro & 20,90 & $-0,29$ & - & $-2,81$ & - \\
\hline Población de 16 a 64 años & $30.120,5$ & $-32,0$ & $-0,11$ & $-147,2$ & $-0,49$ \\
\hline$\overline{\text { Tasa de }}$ actividad (16-64) & 75,38 & $-0,05$ & - & $-0,23$ & - \\
\hline Tasa de paro $(16-64)$ & 21,02 & $-0,28$ & - & $-2,80$ & - \\
\hline Tasa de empleo (16-64) & 59,53 & 0,18 & - & 1,94 & - \\
\hline \multicolumn{6}{|l|}{ HOMBRES } \\
\hline Población de 16 años y más & $18.741,3$ & $-5,9$ & $-0,03$ & $-32,5$ & $-0,17$ \\
\hline$\overline{\text { Activos }}$ & $12.250,9$ & $-104,4$ & $-0,84$ & $-131,1$ & $-1,06$ \\
\hline - Ocupados & $9.863,3$ & $-33,2$ & $-0,34$ & 305,1 & 3,19 \\
\hline - Parados & $2.387,6$ & $-71,2$ & $-2,90$ & $-436,1$ & $-15,44$ \\
\hline Inactivos & $6.490,4$ & 98,5 & 1,54 & 98,6 & 1,54 \\
\hline Tasa de actividad & 65,37 & $-0,54$ & - & $-0,59$ & - \\
\hline Tasa de paro & 19,49 & $-0,41$ & - & $-3,32$ & - \\
\hline Población de 16 a 64 años & $\overline{15.091,8}$ & $-24,3$ & $-0,16$ & $-89,9$ & $-0,59$ \\
\hline$\overline{\text { Tasa de }}$ actividad (16-64) & 80,55 & $-0,63$ & - & $-0,47$ & - \\
\hline Tasa de paro $(16-64)$ & 19,61 & $-0,40$ & - & $-3,31$ & - \\
\hline Tasa de empleo (16-64) & 64,76 & $-0,18$ & - & 2,30 & - \\
\hline \multicolumn{6}{|l|}{ MUJERES } \\
\hline Población de 16 años y más & $19.748,3$ & 8,7 & 0,04 & $-1,3$ & $-0,01$ \\
\hline$\overline{\text { Activas }}$ & $10.622,8$ & 78,6 & 0,74 & $-22,1$ & $-0,21$ \\
\hline - Ocupadas & $8.230,8$ & 78,6 & 0,96 & 220,0 & 2,75 \\
\hline - Paradas & $2.391,9$ & $-0,1$ & 0,00 & $-242,1$ & $-9,19$ \\
\hline Inactivas & $9.125,6$ & $-69,9$ & $-0,76$ & 20,8 & 0,23 \\
\hline Tasa de actividad & 53,79 & 0,37 & - & $-0,11$ & - \\
\hline Tasa de paro & 22,52 & $-0,17$ & - & $-2,23$ & - \\
\hline Población de 16 a 64 años & $15.028,7$ & $-7,7$ & $-0,05$ & $-57,3$ & $-0,38$ \\
\hline Tasa de actividad (16-64) & 70,19 & 0,55 & - & 0,03 & - \\
\hline Tasa de paro $(16-64)$ & 22,65 & $-0,17$ & - & $-2,22$ & - \\
\hline Tasa de empleo (16-64) & 54,29 & 0,54 & - & 1,58 & - \\
\hline
\end{tabular}

102. Encuesta de población activa, $4^{a}$ trimestre 2015. Fuente: INE, 2016.

Arquitectura Viva lleva entre sus páginas un $84 \%$ de representación masculina en lo que respecta a estas otras profesiones que dan lugar a estas gráficas. Un $84 \%$ de varones frente al $16 \%$ de mujeres. ¿Es esto un reflejo de nuestra sociedad? ¿Realmente las tasas de empleo masculino y femenino tienen alguna correlación con estos porcentajes? Preguntas cuya respuesta conocemos, pese a la discriminación que sufren las mujeres en el mundo laboral y que no es objeto de esta tesis. La tasa de empleo femenino asciende a un $57 \%$ si no atendemos a criterios de niveles educativos frente a un $71,8 \%$ en el mismo caso si hablamos de varones, llega a un $70,4 \%$ en al caso de mujeres con estudios superiores no universitarios frente al $80,8 \%$ si son varones, e incluso alcanza el $78,6 \%$ en el caso de mujeres con estudios universitarios que si son 
hombres asciende al $84,4 \%$, todo esto según la tabla de inserción laboral y mercado de trabajo publicada por el Ministerio de Educación, Cultura y Deporte en Datos y Cifras del sistema universitario español respecto al curso 2012-2013, que se corresponde con datos del año 2010. Por tanto, la desviación de 68 puntos porcentuales que vuelcan las revistas analizadas se aleja, con mucho, de los datos comentados, en los que el nivel máximo de desviación entre mujeres y varones en cuanto a empleo se refiere queda en 14,6 puntos porcentuales cuando no diferenciamos niveles educativos, y en el caso de personas universitarias no alcanza los 6 puntos porcentuales.

Casabella arroja un porcentaje de proporciones similares a las de Arquitectura Viva, un $92 \%$ de la variable que hemos convenido en denominar otras profesiones plantea a varones ocupando esos lugares, el resto, valor casi residual del $8 \%$ queda para las mujeres en el desempeño de estas tareas profesionales.

Diseño Interior no dista mucho de lo ya analizado, un $76 \%$ de tareas profesionales lo llevan a cabo los varones en sus páginas, 24 de cada 100 personas que desempeñan estas otras tareas profesionales son aquí mujeres.

El Croquis se mantiene en la misma proporción que el resto de revistas, un 15\% son mujeres desempeñando otras profesiones, y el $85 \%$ del rol profesional en esta ocasión lo desempeñan varones.

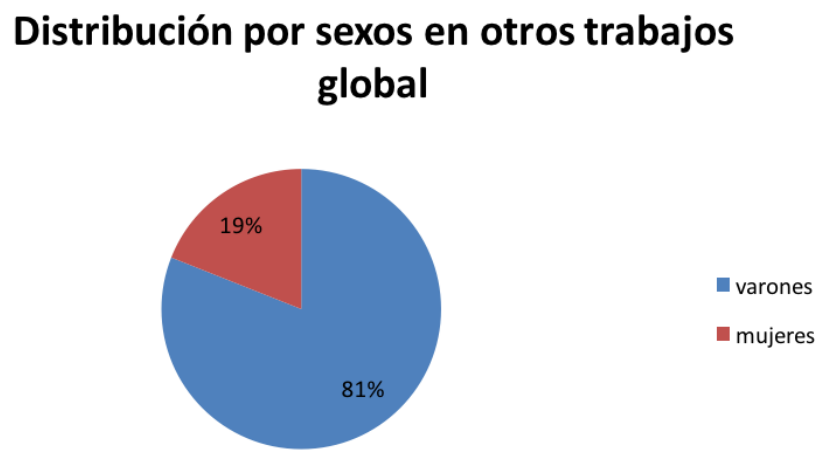

103. Presencia de figura humana distribuída por sexo en otros trabajos global en revistas de arquitectura y diseño, Fuente: G.E.P., 2016. 
Hemos podido observar en gráficas precedentes que el rol doméstico aparece de una manera muy minoritaria en todas y cada una de las publicaciones que dan lugar a este análisis, y como en cada ítem, caben matices.

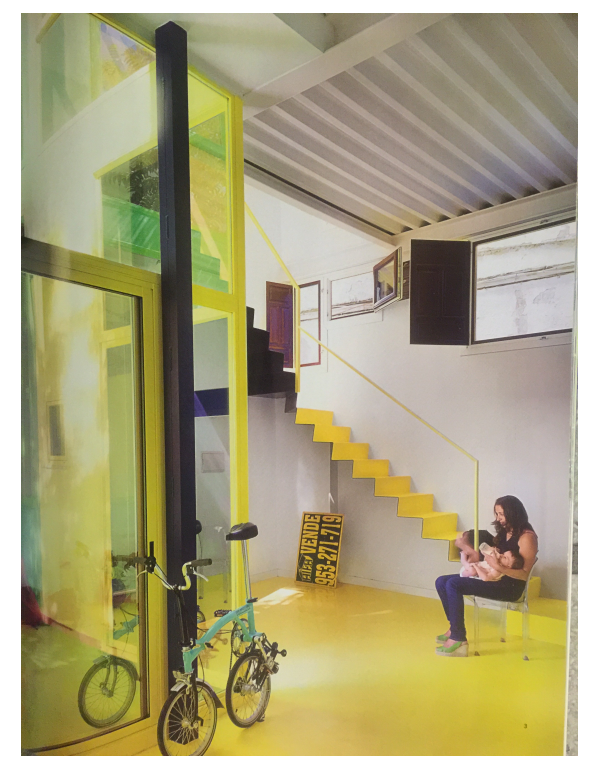

104. Mujer en rol doméstico. Fuente: Diseño Interior 224, 2011.

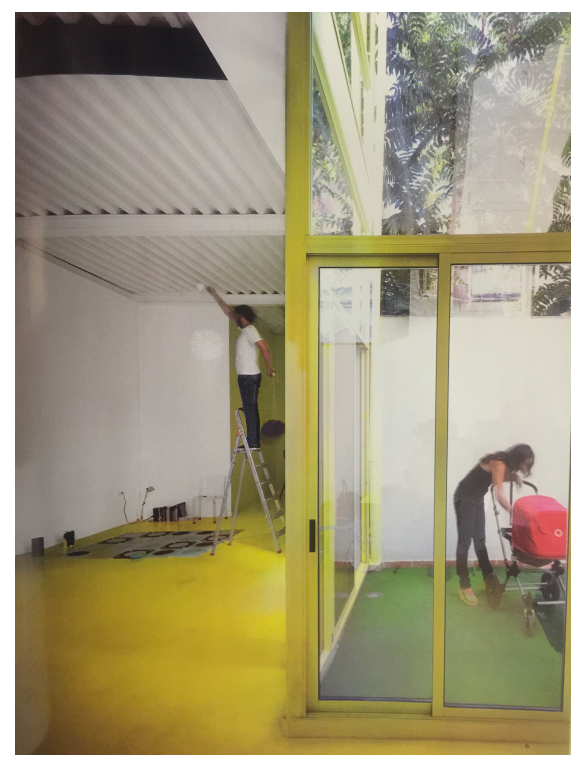

105. Varón en rol doméstico. Fuente: Diseño Interior 224, 2011. 
Casabella

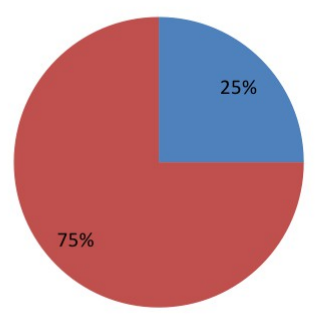

Arquitectura Viva

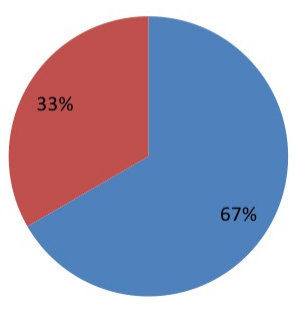

Diseño Interior

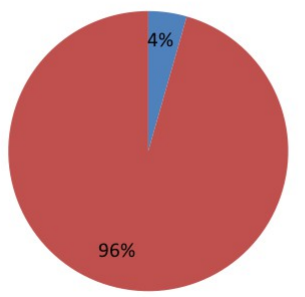

El Croquis

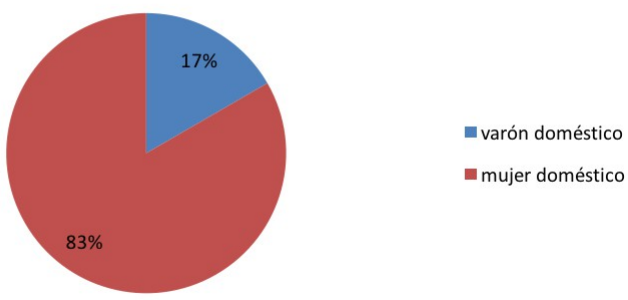

Domus

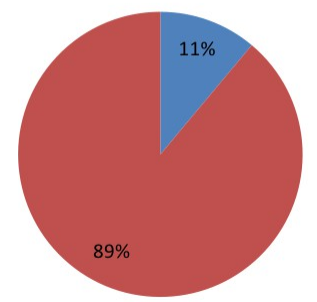

ON Diseño

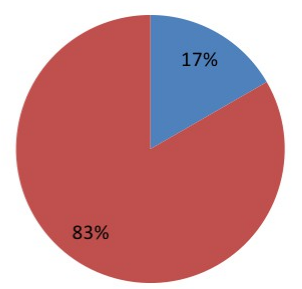

106. Presencia de figura humana distribuída por roles domésticos en revistas de arquitectura y diseño, Fuente: G.E.P., 2016.

Hablamos de una representatividad frente a otras funciones de entre el $1 \%$ en el caso de El Croquis, y el 4\% como índice más alto, en el caso de Diseño Interior, un $1 \%$ en Arquitectura Viva, un $3 \%$ en Domus y Casabella, así como en On Diseño el rol doméstico supone únicamente el $2 \%$ frente al resto de funciones que desempeñan las personas que en ellas aparecen.

Bien, sin perder de vista estos datos, considerando que hablamos de porcentajes muy reducidos destinados al rol doméstico, es pertinente y necesario diferenciar quienes desempeñan dichas tareas cuando aparecen. La teoría de la neurocientífica Susana Martínez-Conde es en este caso significativa. No únicamente en tanto en cuanto solo algunas personas ven algunas partes de una escena, es decir, hay que fijar la atención para ver 
aspectos que, aún estando ahí pueden pasar desapercibidos en función de nuestra base cultural por ejemplo, sino en cuanto a que nuestro cerebro completa la percepción de la realidad. Unos pocos datos, esporádicos si queremos, pueden transformar todo un discurso, por neutro que pueda parecer en principio. Es importante tener esto presente a la vista del material que tenemos entre manos.

Un pequeño porcentaje de figuras humanas aparecen en rol doméstico. De ese pequeño porcentaje veamos en cada publicación qué cifras arroja en cuanto a representación femenina o masculina y analicemos la aportación real de dichas cifras. Estamos ante gráficas con pesos muy significativos en los que el rol doméstico recae sobre las mujeres en cinco de las seis revistas escrutadas, la excepción la constituye Arquitectura Viva, cuyos porcentajes muestran un 67\% de la representación del rol doméstico recayendo sobre los varones. En este caso el peso de la ausencia es tal que no podemos dejar de anotar que ese $67 \%$ se corresponde únicamente con dos varones, dos entre todas las páginas de todas las revistas de Arquitectura Viva escrutadas, y un sola mujer que constituye el 33\% restante. En el improbable caso de que caiga en manos de alguna persona que consulta alguno de estos ejemplares aquel que lleva a alguno de esos varones en rol doméstico, podemos afirmar que esa imagen allí incluida puede estar empezando un camino, el de servir de referente para construir una sociedad más paritaria. El porcentaje de Casabella, 75\% mujeres y $25 \%$ varones nace también del cómputo de tan solo cuatro personas, un varón y tres mujeres. El resultado respecto a Casabella en cuanto a construir un modelo de sociedad u otro, es el mismo, ni Casabella ni Arquitectura Viva hacen un reconocimiento explícito de las tareas domésticas, prácticamente no existen, y en la mayoría de sus ejemplares ni aparecen. La violencia de la invisibilización permanece.

El Croquis y On Diseño muestran los mismos porcentajes en esta combinación de variables, $83 \%$ de mujeres en rol doméstico y $17 \%$ de varones. El Croquis ya hemos comentado que solo plantea un $1 \%$ de los espacios interiores vinculados a tareas domésticas, y esto implica por tanto un número muy bajo de personas representando ese rol, en concreto un varón frente a cinco 
mujeres, que en el caso de On Diseño, con un $2 \%$ de espacios interiores dedicados a esta función, pasa a dos varones frente a diez mujeres. Seguimos frente a niveles de invisibilización muy altos si consideramos el volumen de ejemplares escrutados. En general lo más probable al abrir una revista de estas publicaciones será no encontrar representación de las tareas domésticas.

Diseño Interior trae un $96 \%$ de mujeres en rol doméstico frente a un $4 \%$ de varones, y muy similar el $89 \%$ de mujeres frente al $11 \%$ de varones de Domus. En estas gráficas cabe comentar que en el caso de Domus la invisibilización del rol permanece, un varón y ocho mujeres constituyen el total de personas dedicadas a estas tareas en Domus, sigue siendo por tanto muy llamativa la ausencia de representación de este rol en la mayoría de sus páginas. Diseño Interior obtiene ese disco con un $96 \%$ a $4 \%$ de contabilizar dos varones frente a cuarenta y tres mujeres en rol doméstico, aquí quizá ya no se trata solo de invisibilización, pues el desequilibrio entre sexos es patente y empieza a ser más probable encontrar este rol entre sus páginas. Deseable sería que apareciera en todas las publicaciones un mayor número de espacios en los que se desempeñase el rol que estamos analizando y que se potenciase desde ellas el desarrollo paritario de estas tareas.

Si establecemos la confrontación entre trabajo remunerado y trabajo no remunerado, las tareas domésticas representan el grueso del trabajo no remunerado. Las publicaciones que nos ocupan tratan a las mujeres y el trabajo doméstico de un modo más sesgado, como ya hemos visto, que la propia sociedad.

En lo tocante a trabajo remunerado y no remunerado podemos recurrir a los datos de la Agencia Estatal conocida como Consejo Superior de Investigaciones Científicas, (CSIC), que es el mayor organismo público de investigación de España y el tercero de Europa y que se encuentra adscrita al Ministerio de Economía. 
Según el CSIC:

Tiempo medio dedicado al trabajo remunerado y no remunerado según la EUTE

\begin{tabular}{|l|l|l|l|}
\hline Porcentajes para cada género & mujeres & hombres & total \\
\hline Trabajo remunerado & $26 \%$ & $69,90 \%$ & $44 \%$ \\
\hline Trabajo no remunerado & $74 \%$ & $30,10 \%$ & $56 \%$ \\
\hline Carga total de trabajo & $100 \%$ & $100 \%$ & $100 \%$ \\
\hline
\end{tabular}

Durán: El trabajo no remunerado, datos de la Encuesta CSIC sobre Uso del Tiempo en España, 2003.

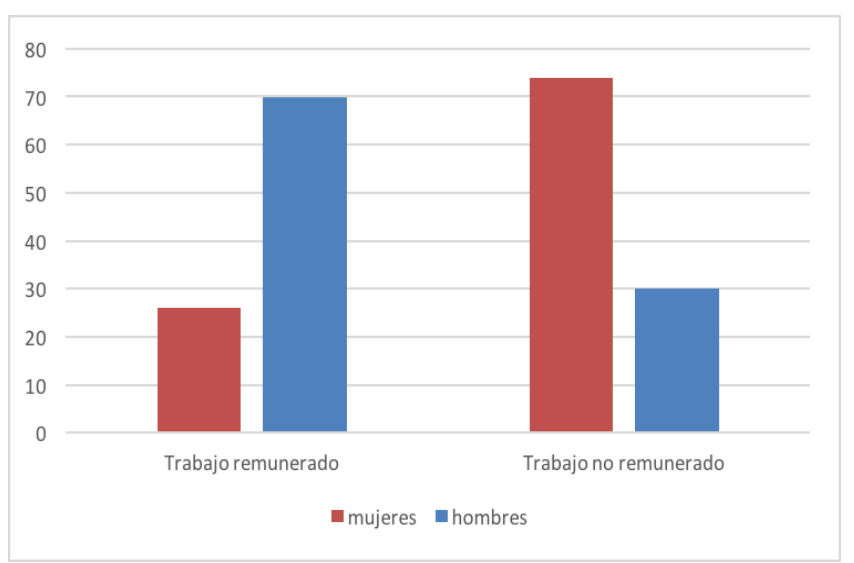

107. Gráfica del trabajo no remunerado, datos Encuesta CSIC sobre Uso del Tiempo en España en 2013, Fuente: G.E.P., 2016.

Ese $56 \%$ de trabajo no remunerado es el trabajo necesario para el sostenimiento de la vida. El remunerado, $44 \%$, sostiene a los mercados, aunque yo me atrevo a plantear que tampoco de forma estricta, porque ese $44 \%$ jamás podría salir adelante sin que el otro $56 \%$ estuviese resuelto. No cabe el tiempo para el trabajo remunerado si no existe la gestión y el sostenimiento de la vida, del trabajo no remunerado. Algo estamos haciendo mal, y los medios de difusión de la arquitectura y el diseño no son inocentes, como vemos, todas las revistas investigadas, arrojan cifras exageradas. 


\section{Distribución por sexos en rol doméstico global}

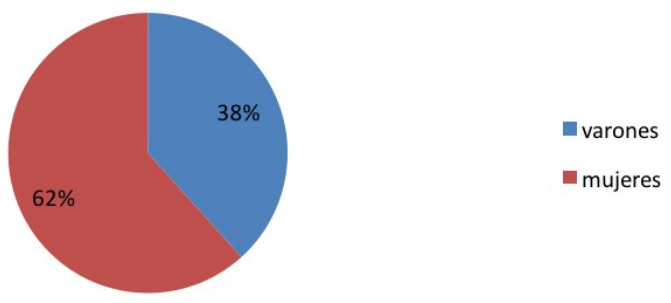

108. Presencia de figura humana distribuída por roles domésticos global en revistas de arquitectura y diseño, Fuente: G.E.P., 2016.

¿Qué proporción de trabajo remunerado frente al no remunerado nos muestran las publicaciones investigadas?:

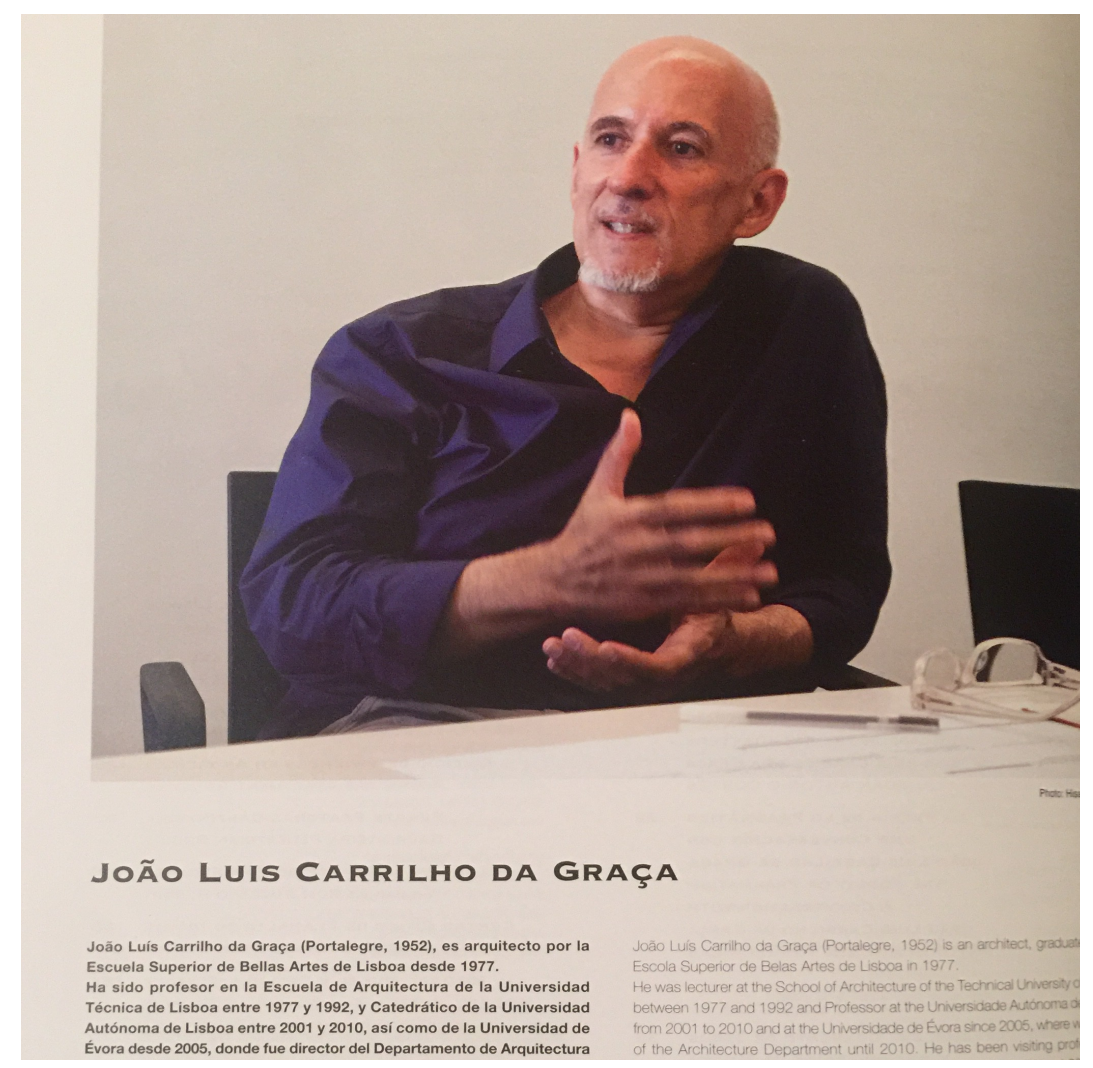

109. Varón trabajo remunerado. Fuente: El Croquis 170, 2014. 


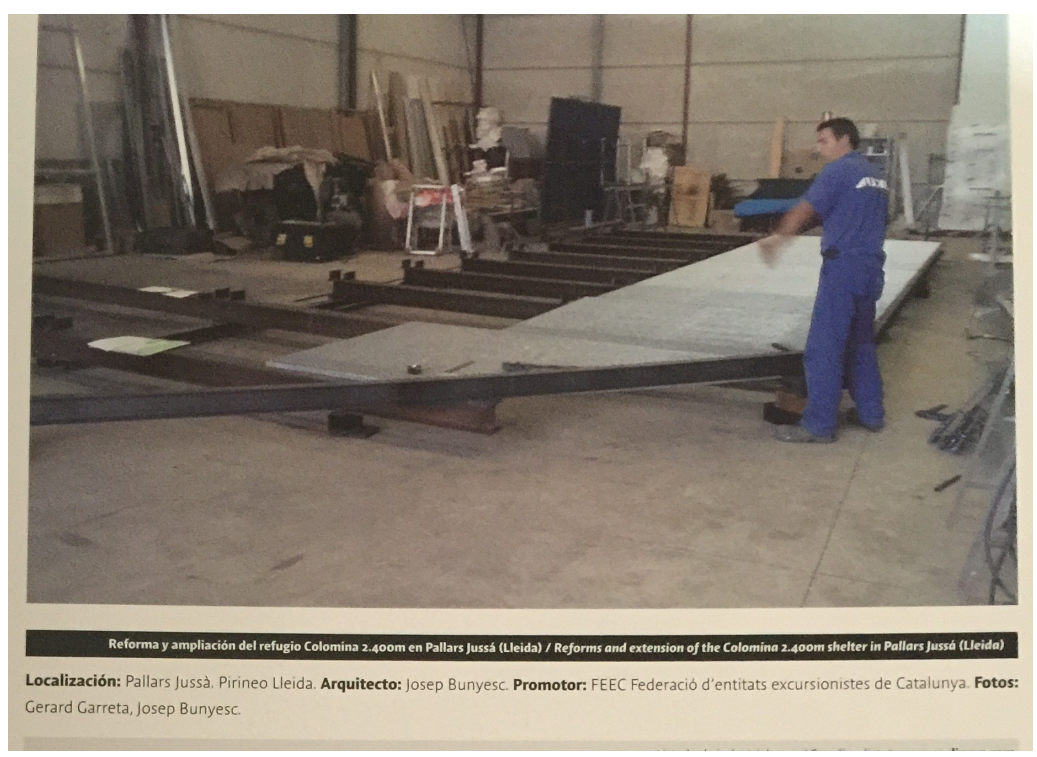

110. Varón trabajo remunerado. Fuente: On Diseño 326, 2012.

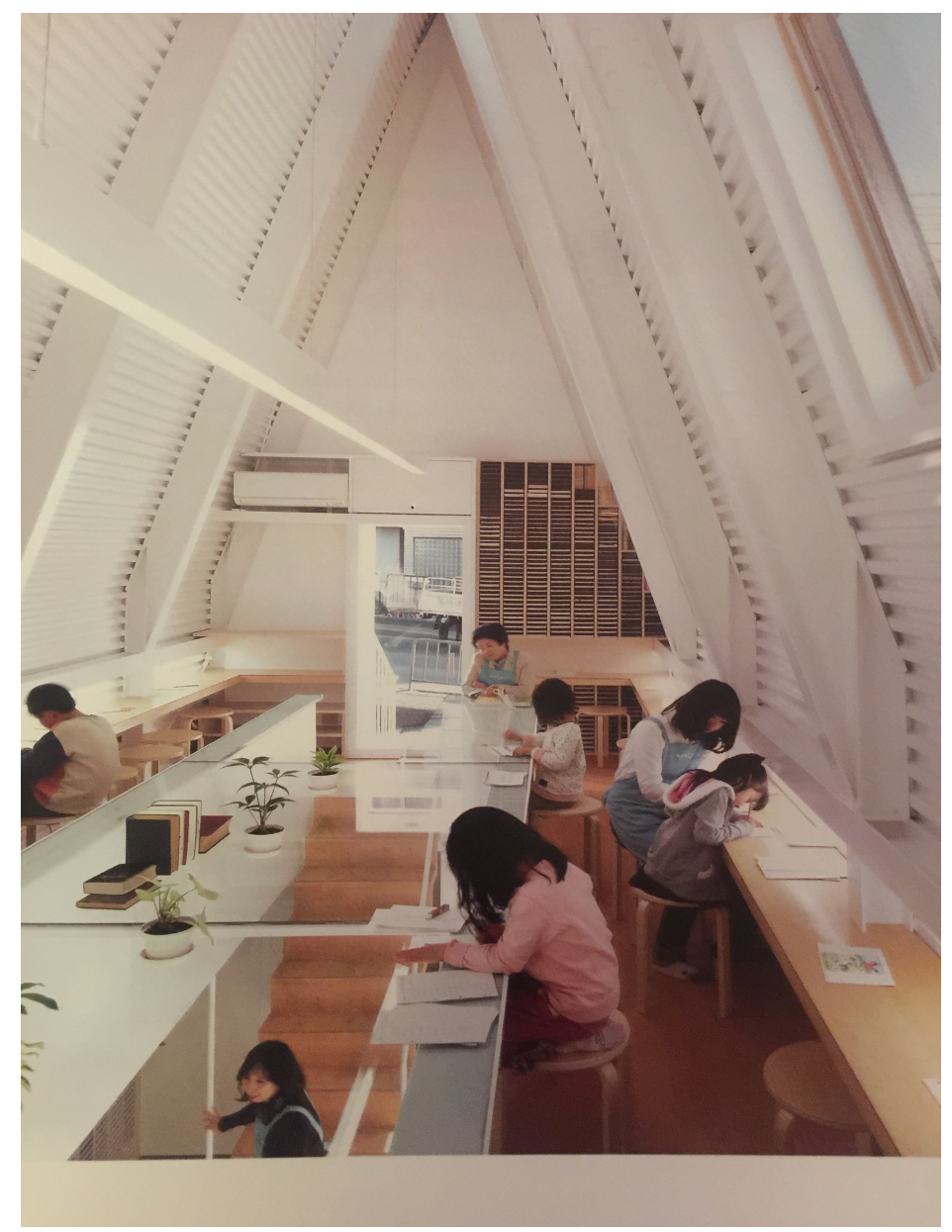

111. Mujer trabajo remunerado. Fuente: Arquitectura Viva 142, 2012. 


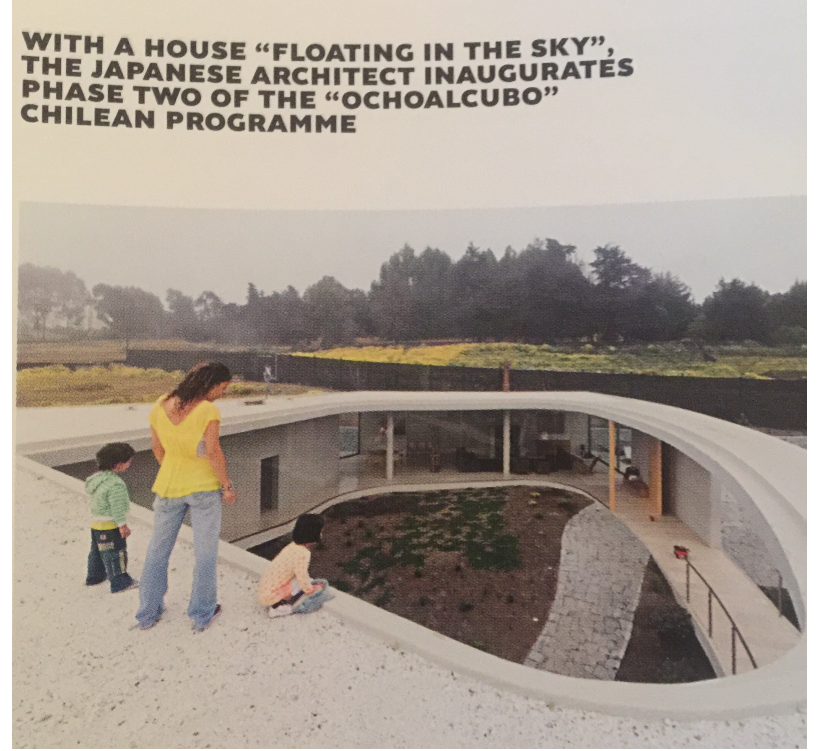

112. Mujer trabajo no remunerado. Fuente: Domus 932, 2010.

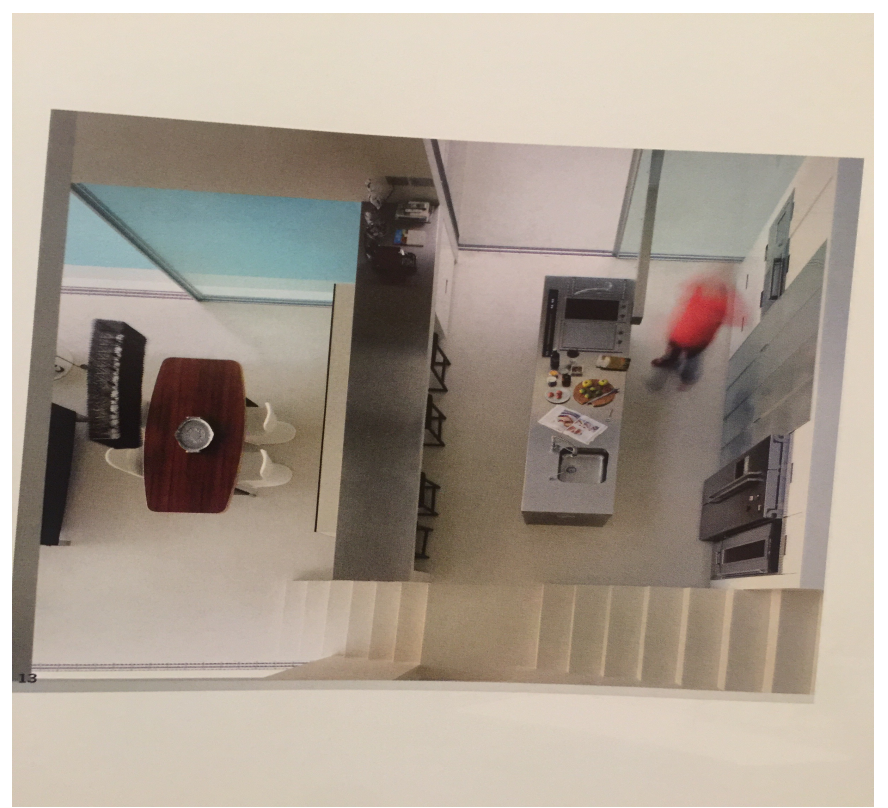

113. Varón trabajo no remunerado. Fuente: Domus 932, 2010. 


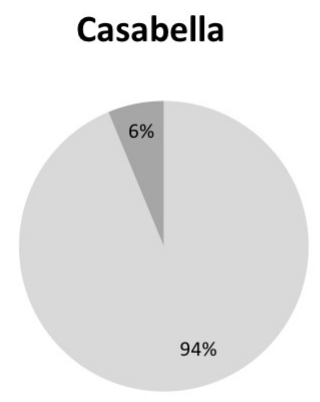

Arquitectura Viva

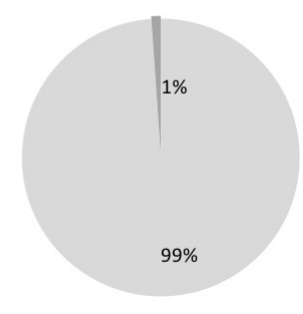

Diseño Interior

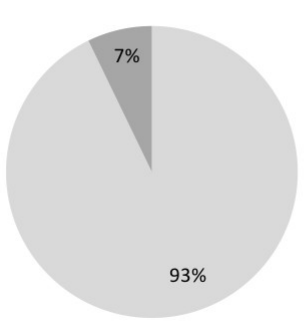

El Croquis

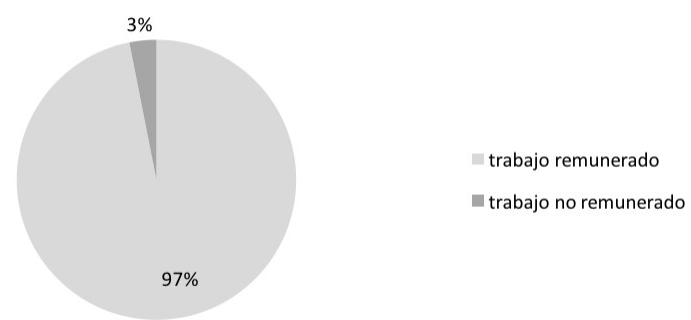

Domus

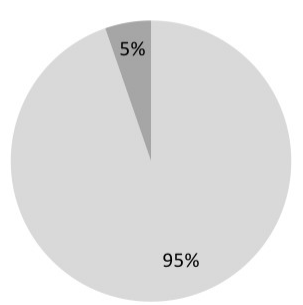

ON Diseño

$4 \%$

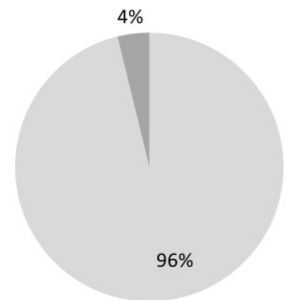

114. Presencia de figura humana distribuída por remuneración en revistas de arquitectura y diseño, Fuente: G.E.P., 2016.

En el segundo capítulo leíamos la diferenciación que establece Soledad Murillo entre trabajo remunerado y trabajo no remunerado y la asignación que el heteropatriarcado hace del reparto de estos trabajos.

En la tabla del CSIC, fruto de datos obtenidos en el año 2003, vemos cómo el trabajo no remunerado suponía en esa fecha el $56 \%$ en la sociedad española. Aun poniendo de manifiesto que las revistas que han servido para mi trabajo de campo no se circunscriben estrictamente a la sociedad española, pues cinco de 
las publicaciones analizadas trasladan proyectos y diseños de ámbito internacional, todas ellas traen en sus páginas información referente al mundo occidental mayoritariamente y cabe la comparativa sin riesgo de grandes desviaciones. No obstante, para mantener el criterio de rigor que conviene a esta tesis, circunscribo la comparativa de manera directa únicamente a On Diseño, revista que dedica su linea editorial a temas proyectuales y desarrollados por profesionales en nuestro país. On Diseño lleva en sus páginas un $4 \%$ de figuras humanas desempeñando un trabajo no remunerado y un $96 \%$ del trabajo que aparece es trabajo remunerado.

En On Diseño el 56\% de trabajo no remunerado que el CSIC detectó en 2003 en la sociedad española, queda reducido a un escaso $4 \%$. Se trata no únicamente de una falta de remuneración monetaria para este tipo de trabajos, sino de una total falta de reconocimiento hacia los mismos. No reciben ni el valor en términos crematísticos, ni el reconocimiento del propio desempeño de las tareas en sí mismas. Como se desprende de la tabla del CSIC esta situación afecta en una proporción de tres es a uno a las mujeres, pues son las mujeres quienes, en un $74 \%$ de los casos desempeñan el trabajo no remunerado.

El $44 \%$ del trabajo remunerado queda magnificado hasta su $96 \%$. De la misma tabla se deduce que esta distorsión de la realidad detectada en estas publicaciones afecta también en el mismo sentido a la población femenina, es decir, se magnifica la representatividad del trabajo remunerado en el que la presencia masculina supone un $70 \%$. Se lleva adelante con esto un empoderamiento del sector privilegiado ya de antemano por la situación del reparto del trabajo en nuestra sociedad.

¿Es esto invisibilización o no? ¿Existe sesgo androcéntrico en estas revistas o no?

La situación en las restantes revistas estudiadas es similar, aunque como ya he citado, la comparativa asume en el resto de casos la similitud en el estado de la cuestión entre países occidentales, debido a que sus contenidos no se limitan al territorio español. 
Veamos una tabla comparativa entre el valor proporcionado por el CSIC y los que se obtienen del vaciado de las revistas estudiadas:

\begin{tabular}{|c|c|}
\hline CSIC & $56 \%$ \\
\hline Diseño Interior & $7 \%$ \\
\hline On Diseño & $4 \%$ \\
\hline Arquitectura Viva & $1 \%$ \\
\hline El Croquis & $3 \%$ \\
\hline Domus & $5 \%$ \\
\hline Casabella & $6 \%$ \\
\hline
\end{tabular}

\section{Trabajo remunerado y no remunerado global}

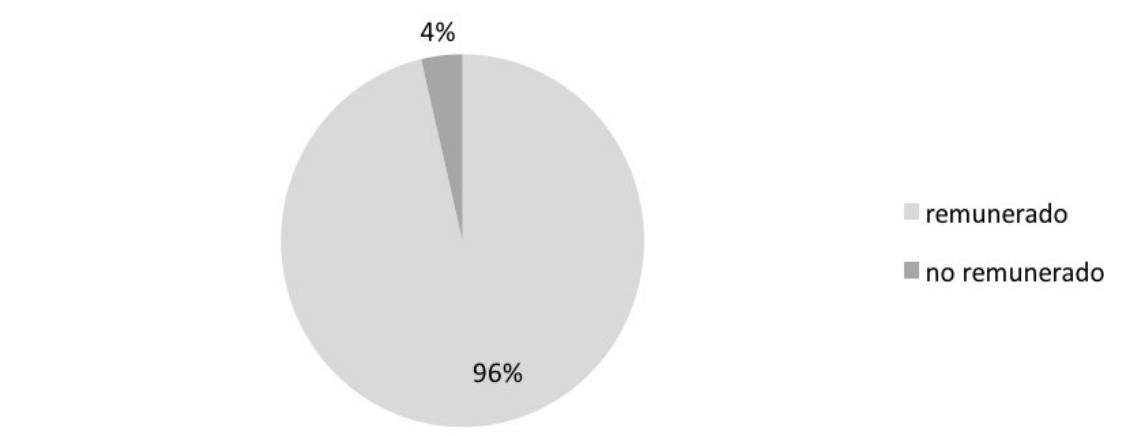

115. Presencia de figura humana distribuída por remuneración global en revistas de arquitectura y diseño. Fuente: G.E.P., 2016.

Otra variable interesante para nuestro estudio es investigar en qué medida las revistas estudiadas ofrecen una imagen cosificada de las personas que nos muestran. ¿Qué proporción entre varones cosificados y mujeres cosificadas arrojan? Podemos también observar que el nivel de cosificación, la violencia de este hecho, se da con intensidades realmente diferentes. Para mostrarlo voy a incluir a continuación, entre otras, una imagen mixta, en la que si bien podríamos analizar que ambos están cosificados, las palabras respecto a la asignación de roles implícitos sobran. 


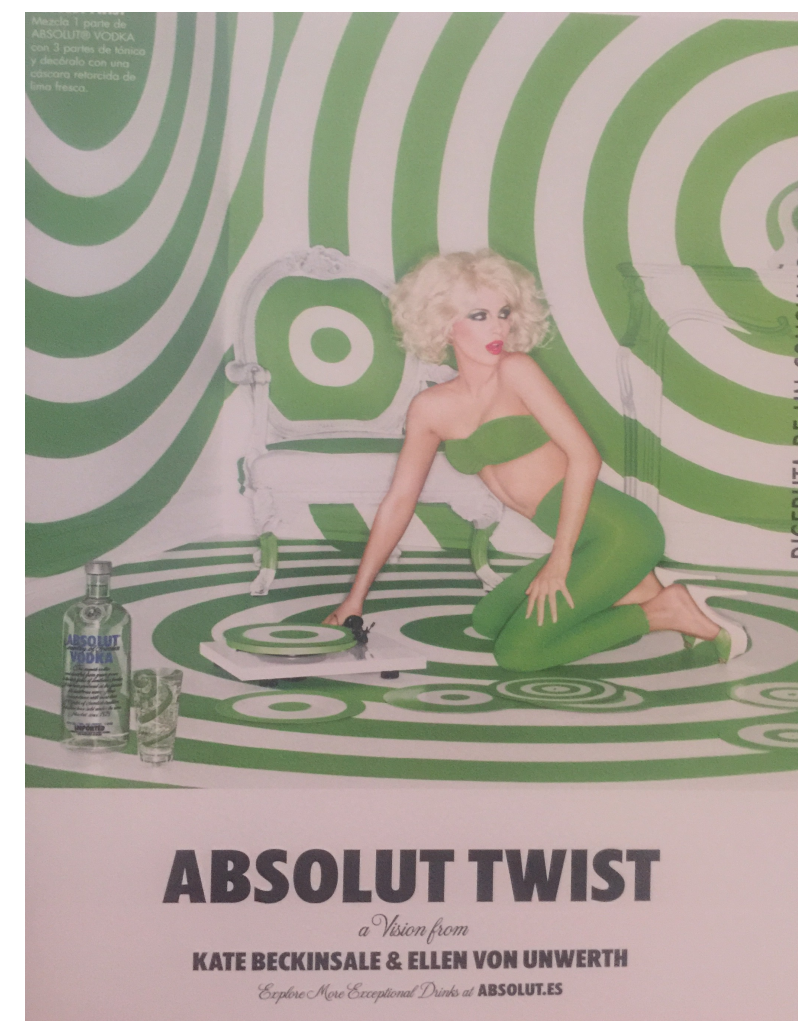

116. Mujer cosificada. Fuente: On Diseño 314-315, 2010.

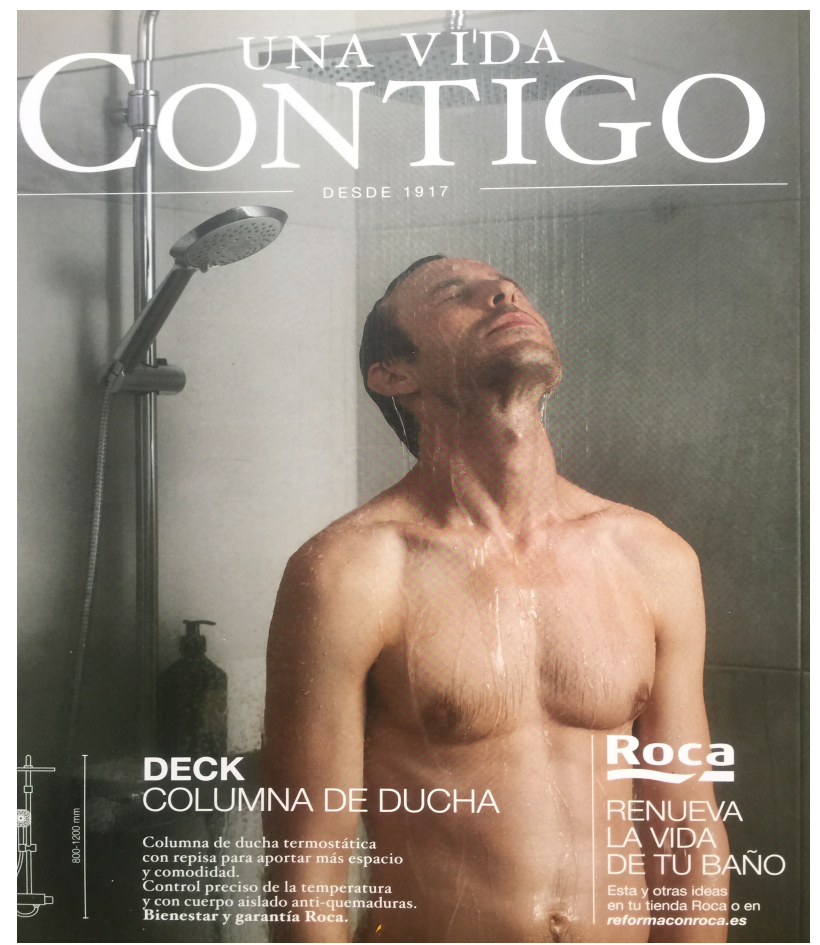

117. Varón cosificado. Fuente: On Diseño 352, 2015. 


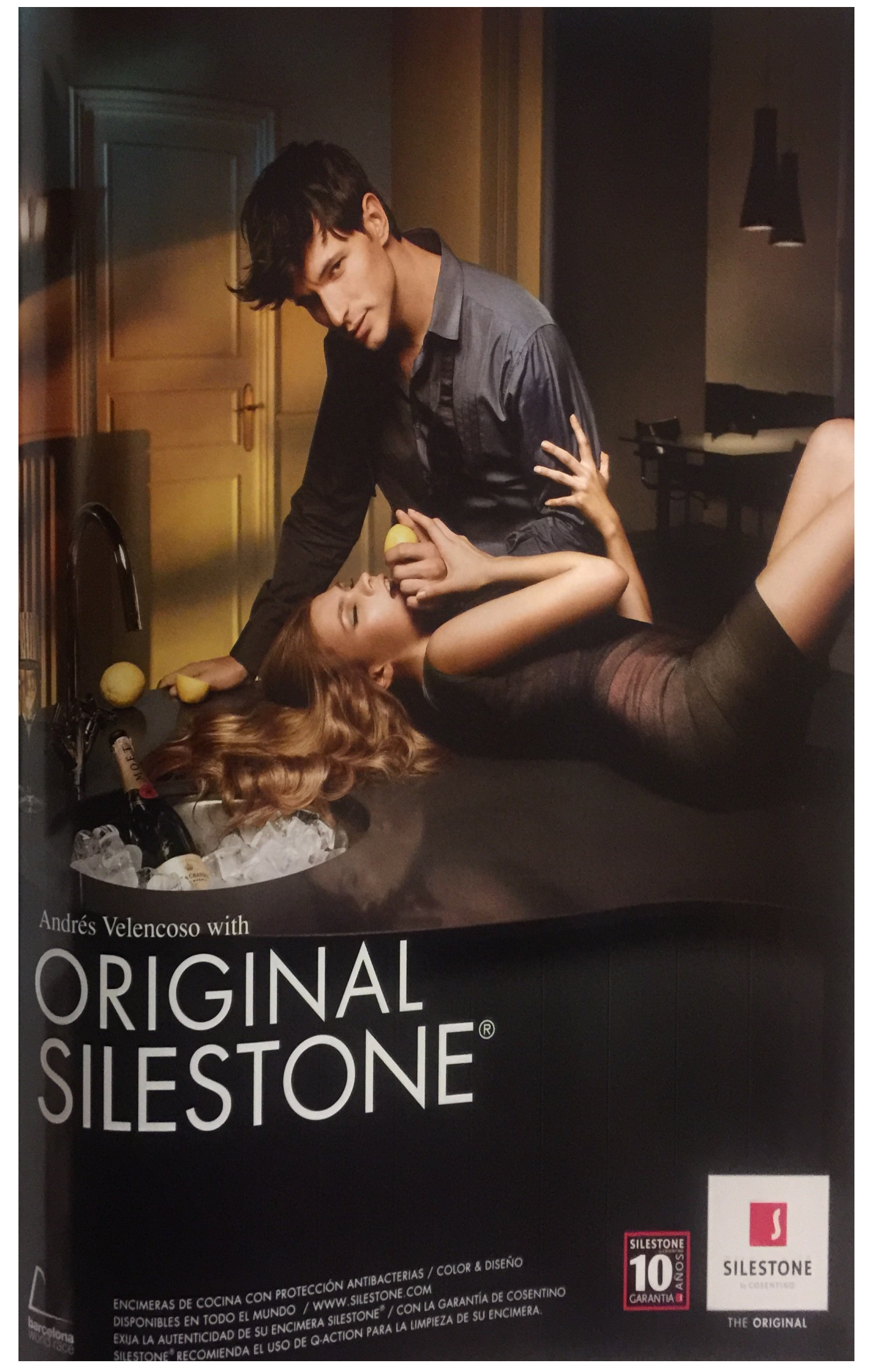

118. Imagen mixta, anuncio. Fuente: Diseño Interior 206, 2009. 


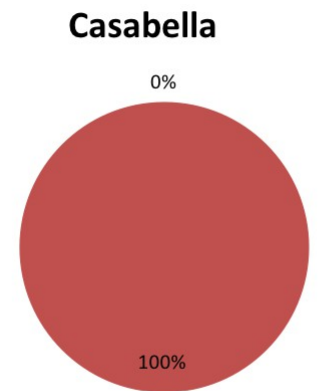

Arquitectura Viva

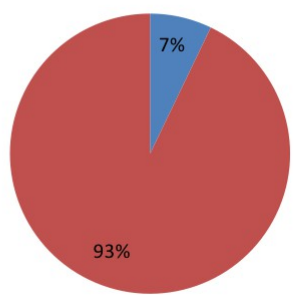

Diseño Interior

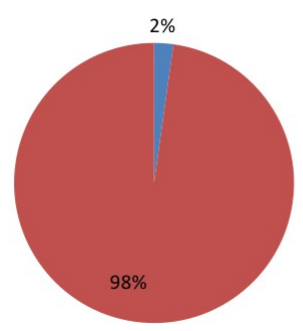

El Croquis

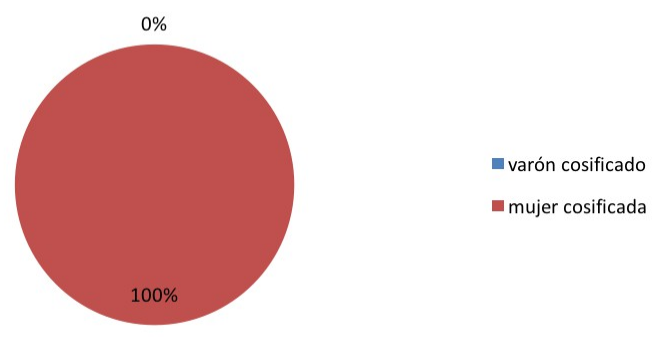

Domus

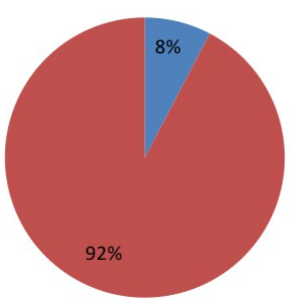

ON Diseño

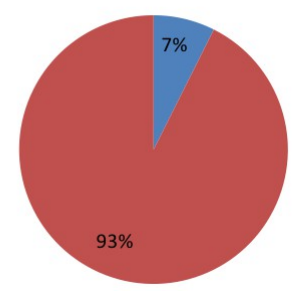

119. Presencia de figura humana distribuída por cosificación en revistas de arquitectura y diseño.

Fuente: G.E.P., 2016.

Los discos de las gráficas que se corresponden con la detección de personas cosificadas reflejan cómo, esos porcentajes de cosificación, que oscilaban en la imagen 85 entre el 1\% en El Croquis y el $8 \%$ en Casabella, como tope superior, o el 3\% en Arquitectura Viva y en Diseño Interior, Domus y On Diseño y el mismo $4 \%$, necesitan su propio análisis de género.

No estamos ante bajos niveles de cosificación frente a otras funciones. Estamos frente a la construcción de identidades futuras que reciben la presión de los medios para ser. Y esa presión es claramente diferenciada según sexos.

Vierto mi opinión al expresar mi repulsa frente a la cosificación de cualquier ser humano, mujer o varón, y vaya por delante esta reflexión. No cabe justificación 
ninguna para cosificar a un varón y utilizarle como objeto de presión sobre el resto de varones. No cabe aquel discurso de pretendida igualdad en el que, en lugar de eliminar la objetualización de la mujer del heteropatriarcado, y devolverles a todas las mujeres, en plural ahora sí, su dignidad, se somete a los varones al mismo tipo de violencia estructural, aunque en una proporción de acciones de rango inferior. No cabe sostener la violencia estructural que supone la cosificación, en ningún caso.

Vuelvo al análisis objetivo de los datos extraídos cuando describo aquello que los discos de las gráficas que analizan este tipo de representación de seres humanos nos aportan. On Diseño, Domus, Arquitectura Viva y Diseño Interior plantean un desequilibrado reparto del sometimiento de seres humanos a la cosificación. Este desequilibrio va desde el 92\% de mujeres cosificadas en Domus, pasando por el 93\% en Arquitectura Viva y On Diseño, el $98 \%$ de mujeres cosificadas frente al $2 \%$ de varones cosificados en Diseño Interior, hasta el $100 \%$ de las personas cosificadas que presentan El Croquis y Casabella son mujeres, no aparecen varones cosificados.

El Croquis y Casabella llevan en sus páginas un 100\% de mujeres ocupando el lugar de las figuras humanas sometidas a cosificación. El androcentrismo quizá pueda comentarse como latente si no ponemos el foco para vislumbrar estos aspectos. Una vez analizados estos datos no podemos quedarnos con el adjetivo latente, sino que el adjetivo sangrante clama por sustituir al primero.

\section{Cosificación de figura humana global}

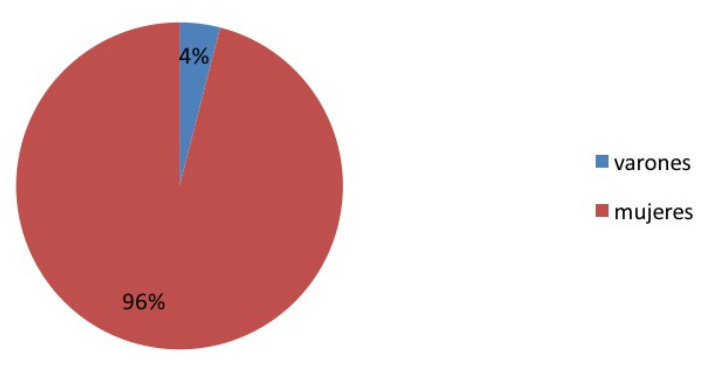

120. Presencia de figura humana distribuída por cosificación global en revistas de arquitectura y diseño. Fuente: G.E.P., 2016. 
Hasta aquí las gráficas han venido a expresar aspectos vinculados con el rol asignado a las figuras humanas que aparecen en las revistas objeto de análisis. Hemos visto los porcentajes de figuras humanas que aparecen en estas publicaciones y qué proporción de ellas son mujeres o varones. También hemos podido extraer la proporción de roles según distintas funciones en las que aparecen mujeres y hombres, la distribución proporcional de las propias funciones antes reseñadas y las gráficas que nos aportan la lectura de la distribución por sexos de: modelos en la publicidad; personas diseñadoras o arquitectas; aquellas que desempeñan otros trabajos; roles domésticos; cosificación; y la distribución de la remuneración de los trabajos reflejada en las páginas investigadas.

Vamos ahora a emprender un último sistema de cribado de los datos a través de las gráficas. Vamos a hacer un análisis del tipo de espacios que nos ofrecen estas publicaciones, para poder, posteriormente, realizar una comparativa entre roles y espacios que nos permita llegar a ciertas conclusiones.

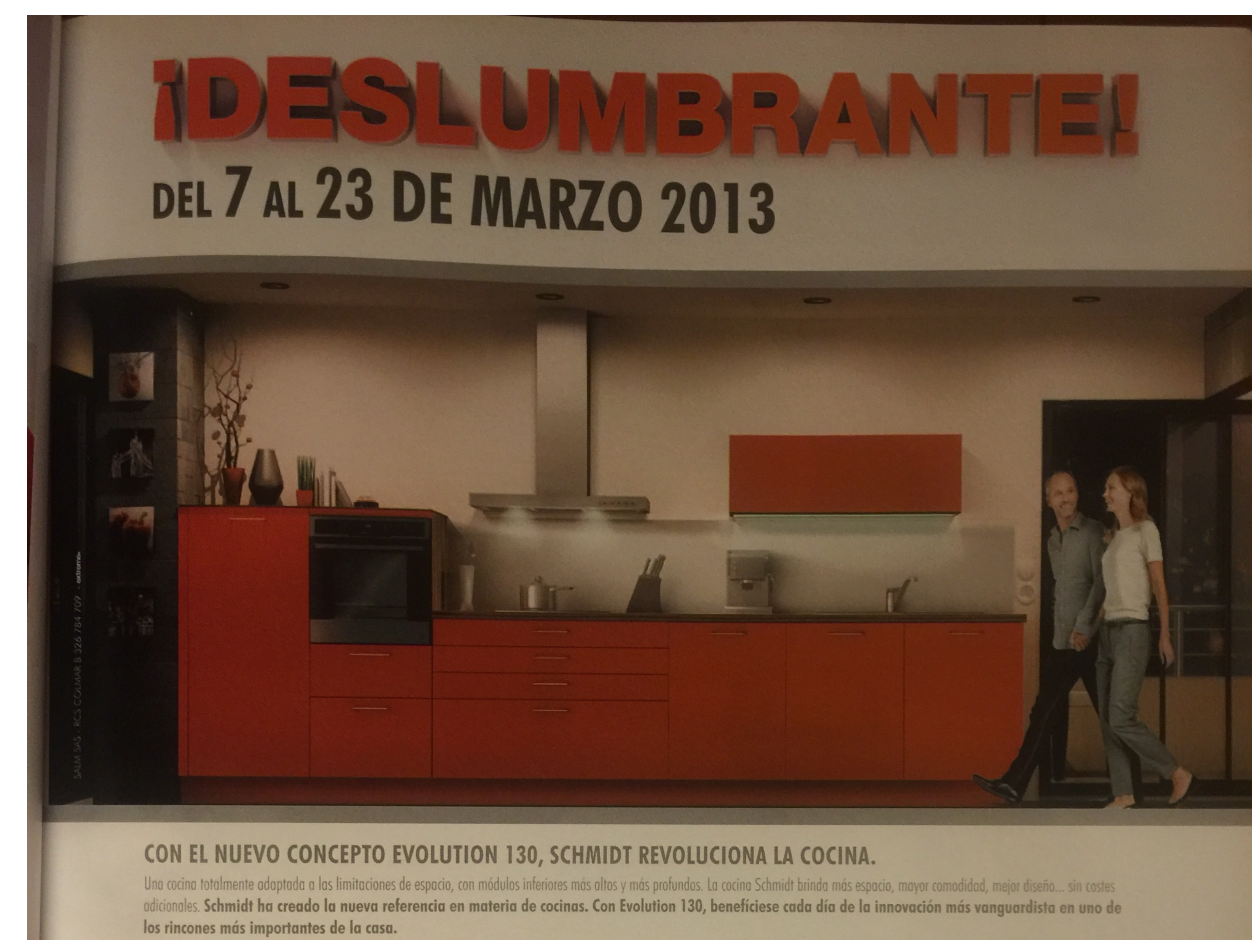

121. Espacio anuncio. Fuente: Diseño Interior 247, 2013. 


\section{El poder de la innovación}

The power of innovation

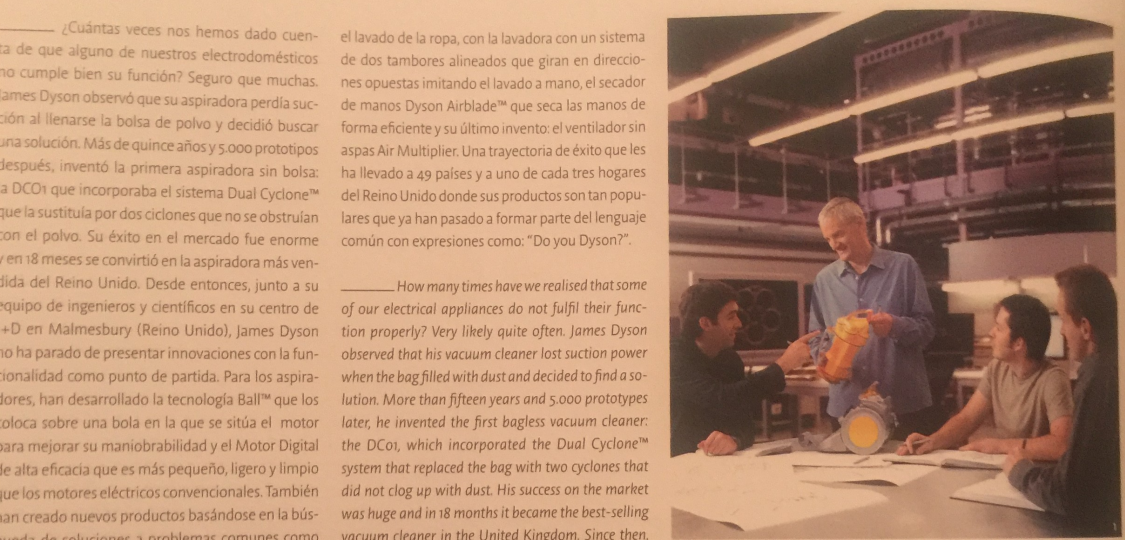

122. Espacio real. Fuente: On Diseño 314-315, 2010.

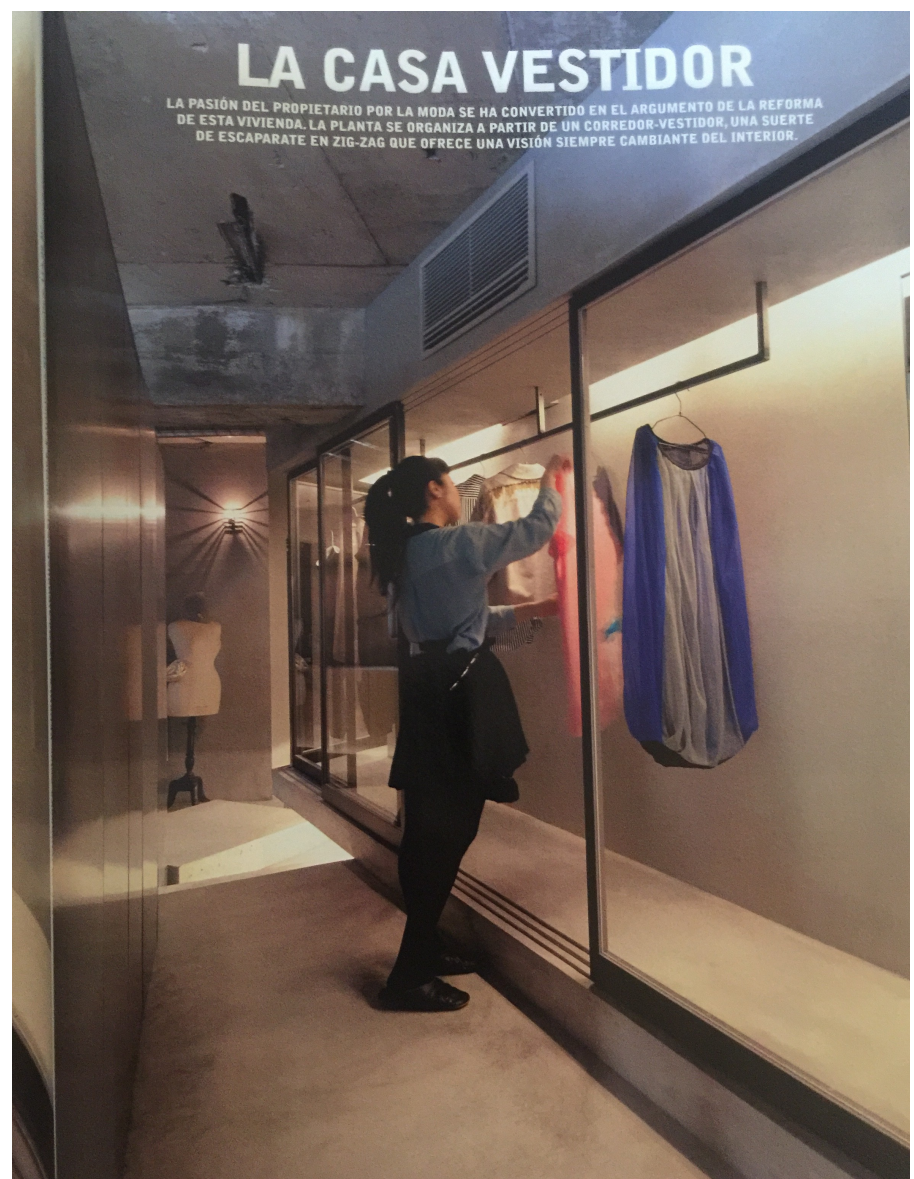

123. Espacio real. Fuente: Diseño Interior 262, 2014. 


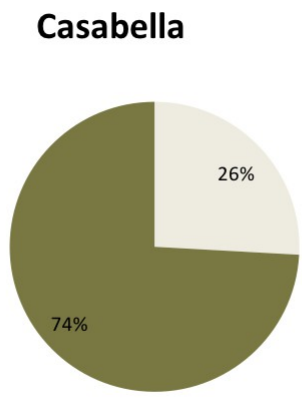

Arquitectura Viva

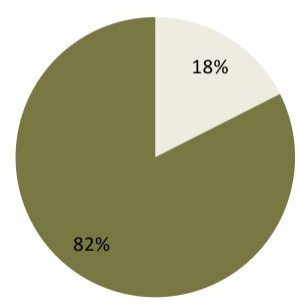

Diseño Interior

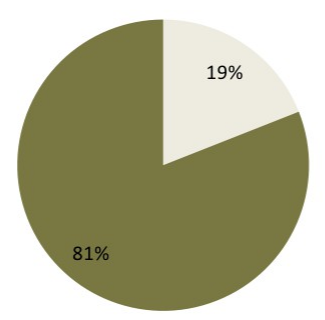

El Croquis

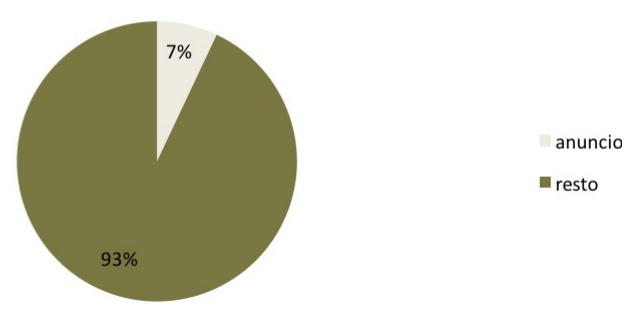

Domus

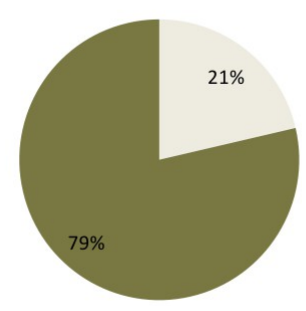

ON Diseño

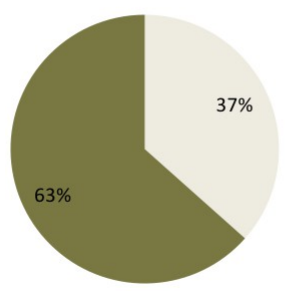

124. Presencia de figura humana distribuída en anuncios en revistas de arquitectura y diseño. Fuente: G.E.P., 2016.

El trabajo remunerado representa en las revistas de Diseño Interior, como hemos visto en la imagen de G.E.P., 114 un porcentaje muy elevado del trabajo que en ellas aparece, desde un 93\% hasta un 99\%. De ese elevado porcentaje de trabajo remunerado que, como ya hemos dicho, más que duplica al que refleja la estadística del CSIC que otorgaba al trabajo remunerado un $44 \%$ del total del trabajo desarrollado en el 2003, la publicidad no ocupa en ninguno de los casos estudiados más del $37 \%$ del total que aparece en sus páginas. Casabella y On Diseño son las dos revistas que más espacio dedican a los anuncios, con un $26 \%$ la primera y un $37 \%$ On Diseño. En Arquitectura Viva la publicidad tiene menos presencia relativa que en otras revistas, con tan sólo un 
$18 \%$, tras Diseño Interior con un $19 \%$ muy próximo al $21 \%$ de contenido en anuncios de Domus. Es la publicación El Croquis la que menos abusa de la publicidad, como lo muestra un reducido $7 \%$ de espacio para anuncios en la gráfica correspondiente.

Estas proporciones de imágenes, estudiadas en el caso concreto de Casabella, por ejemplo, se hallan inmersas en anuncios, de los que hemos visto en la imagen 89 , G.E.P., que el $60 \%$ son de mujeres y el $40 \%$ de varones, con las diferencias a tener en cuenta que se han advertido. Las mujeres son cosificadas o desarrollan tareas domésticas y los hombres aparecen, generalmente, en roles profesionales ligados a la arquitectura o la construcción, hecho trasladable, en la proporción que a cada revista corresponde, en la imagen 89 a todos los casos.

\section{Proporción de espacios virtuales frente a reales global}

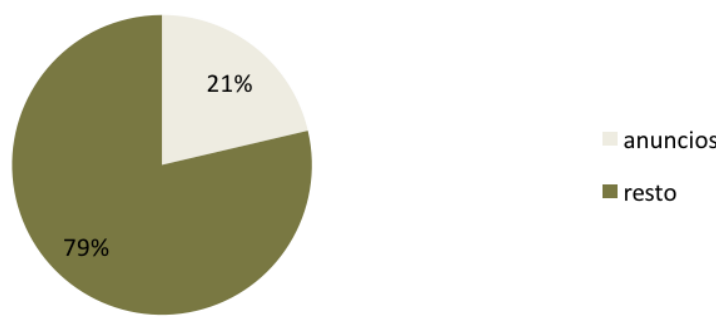

125. Proporción de espacios virtuales frente a reales global en revistas de arquitectura y diseño. Fuente: G.E.P., 2016.

El análisis de roles desempeñados en los espacios interiores, de la posibilidad de construcción de la propia identidad según la imagen percibida en espacios interiores, obliga a la categorización de dichos espacios. Espacios interiores públicos, espacios interiores privados y espacios interiores domésticos son los tres ítems mensurables que dan lugar a los siguientes diagramas y que han sido definidos en las páginas de apartados anteriores de esta tesis. 
Veamos en primer lugar algún ejemplo sustraído de entre los que nos ofrecen las revistas para pasar, a continuación, al análisis de las gráficas que nos muestran la proporción de este tipo de espacios que podemos encontrar en las publicaciones que nos ocupan.

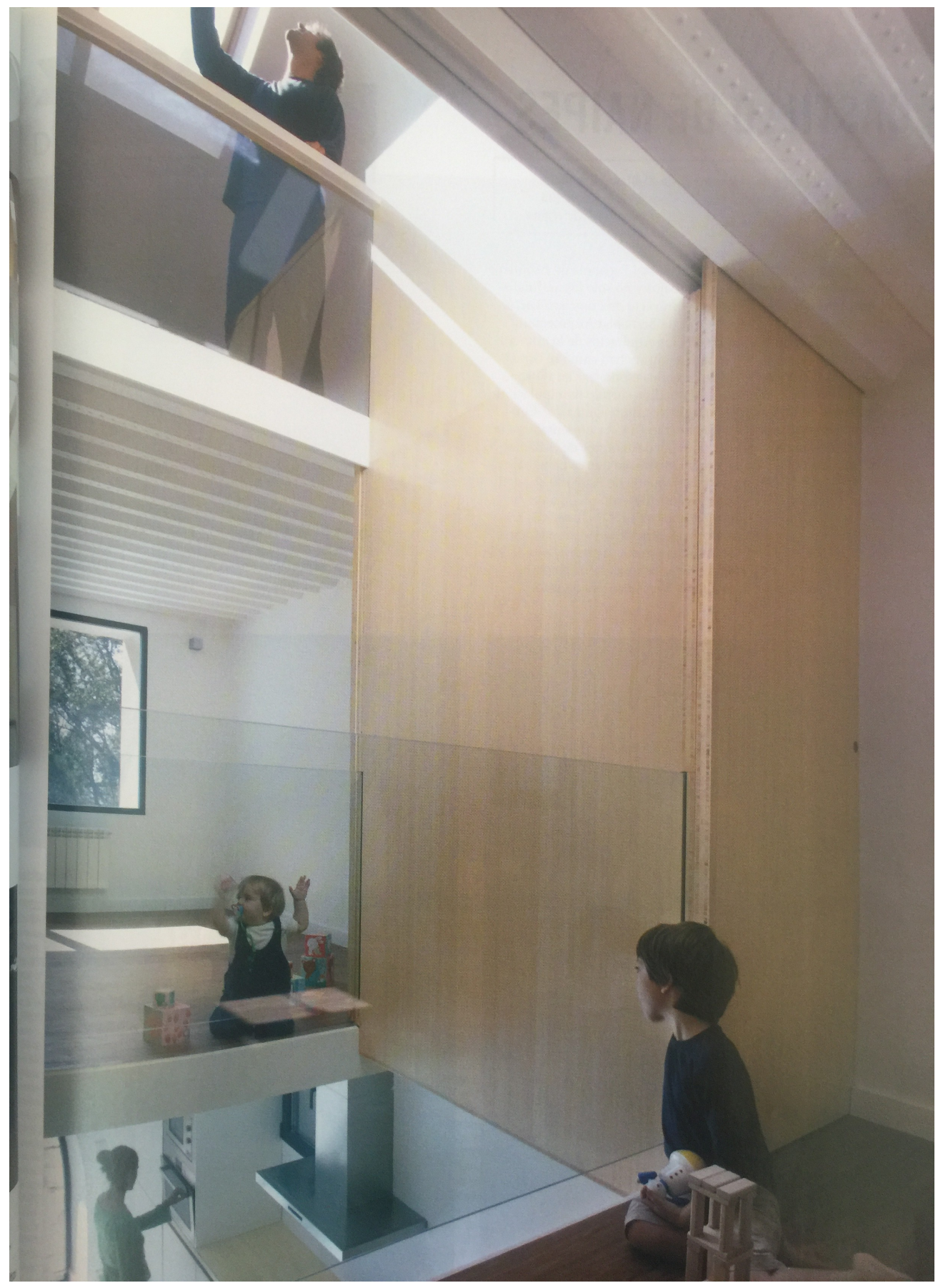

126. Espacio interior doméstico. Fuente: Diseño Interior 237, 2012. 


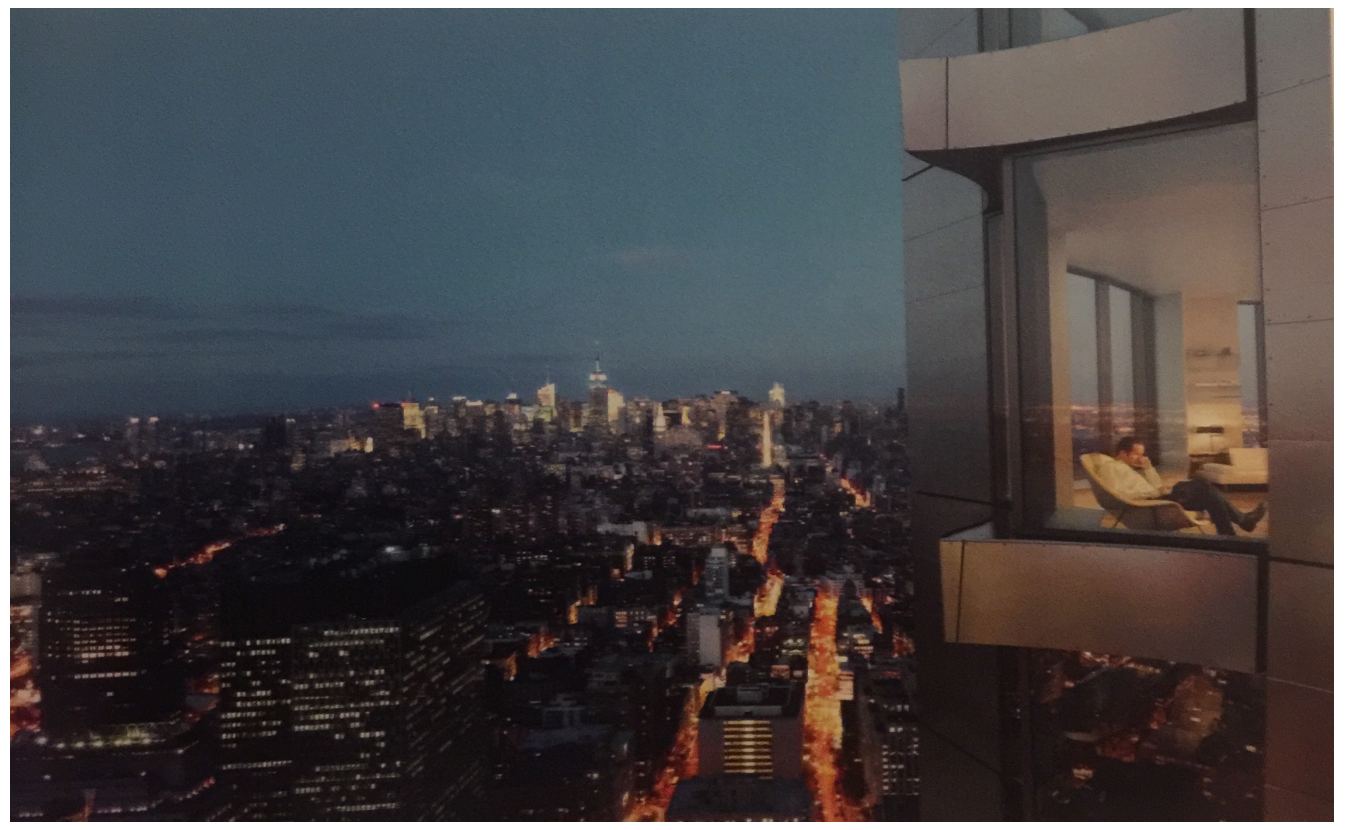

127. Espacio interior privado. Fuente: Arquitectura Viva 146, 2012.

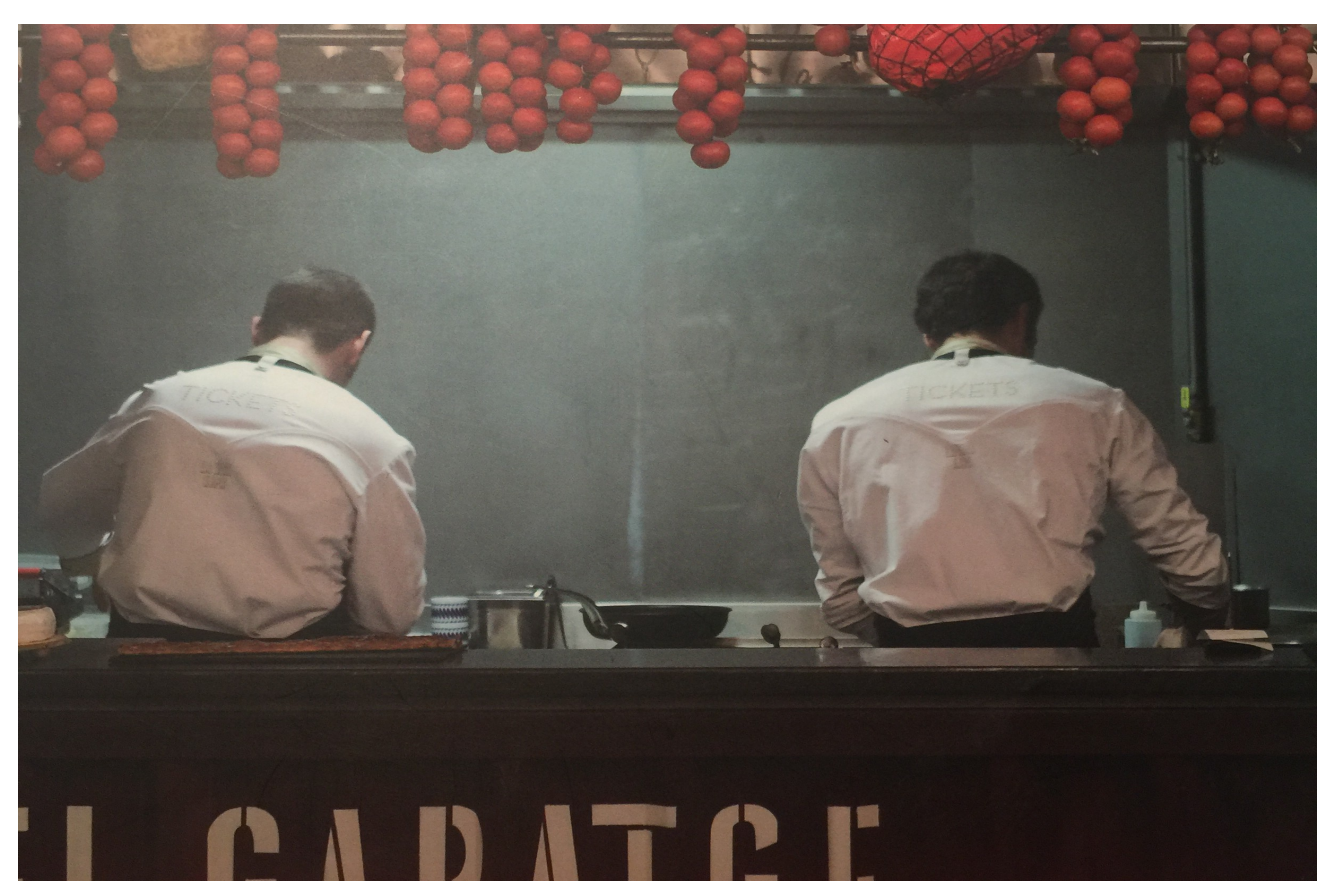

128. Espacio interior público. Fuente: On Diseño 325, 2012. 


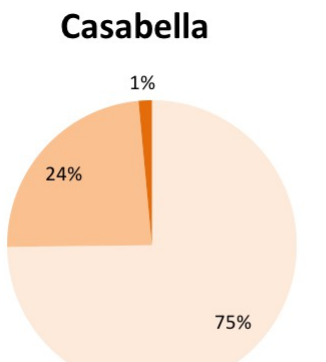

Arquitectura Viva

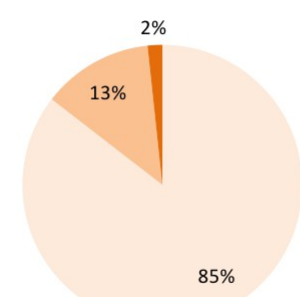

Diseño Interior

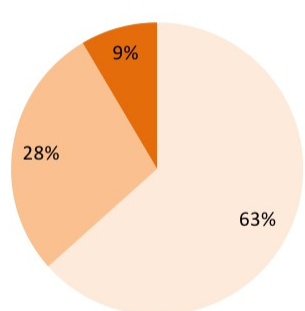

Diseño Interior

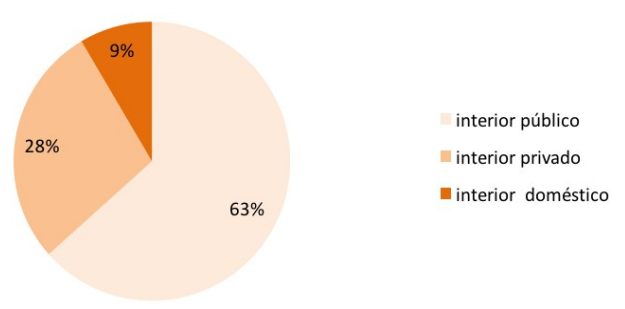

Domus

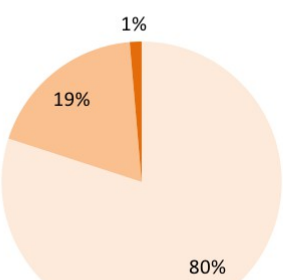

ON Diseño

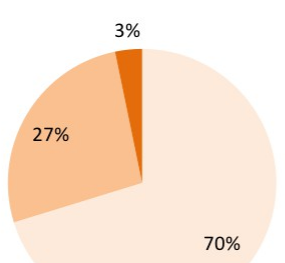

129. Presencia de figura humana distribuída por tipos de espacios interiores en revistas de arquitectura y diseño. Fuente: G.E.P., 2016.

Aparecen en estas revistas distintos tipos de espacios interiores en los que encontramos la figura humana y en los que desarrollamos diferentes funciones. Espacios y funciones, volcados al imaginario de nuestra sociedad por estas y otras publicaciones, y que, recordemos, analizamos aquí con el objetivo de anclar todos estos datos al discurso de la construcción de la propia identidad que cada mujer puede hacer con las herramientas que la sociedad en la que se desarrolla le aporta y los recursos que, en cada caso, sea capaz de adquirir por múltiples caminos.

Los espacios interiores que estas publicaciones muestran, en aplastante mayoría, son aquellos que hemos convenido en definir como espacios públicos. El $85 \%$ de los espacios interiores que aparecen en Arquitectura Viva son espacios públicos, un $13 \%$ corresponde en esta publicación a los interiores privados y el escaso $2 \%$ restante trae a colación interiores domésticos. 
Los espacios públicos suponen un $89 \%, 80 \%$ y un $75 \%$ en El Croquis, Domus y Casabella respectivamente. Es decir, tres cuartas partes de los espacios interiores que aparecen en estas tres revistas, o más, son espacios públicos. Queda poco margen para el espacio interior privado, que en las tres publicaciones oscila desde el $10 \%$ de El Croquis, pasando por el $19 \%$ de Domus, hasta el $24 \%$ de Casabella. El espacio interior doméstico tiene una exigua cabida en El Croquis, Domus o Casabella, donde supone un $1 \%$ de todos los espacios que allí aparecen. Arquitectura Viva eleva los interiores domésticos publicados a un $2 \%$, On Diseño a un 3\% y de manera ¿destacada? Diseño Interior presenta un $9 \%$ de espacios interiores domésticos, según podemos leer en la G.E.P. de la imagen 129.

En El Croquis, Diseño Interior, On Diseño, Arquitectura Viva, Domus y Casabella la masiva presencia de figuras humanas en el espacio público, dentro de la escasa presencia humana de estas revistas, hace que la invisibilización de aquello que ocurre en el espacio doméstico y privado sea coherente con los roles que he tratado anteriormente.

No quiero dejar de señalar el hecho de que sea On Diseño, revista que trae a sus páginas proyectos y personas del ámbito nacional español, la revista que cuenta con uno de los porcentajes de espacios púbicos más bajo. Aunque su $70 \%$ no se preste tampoco a grandes signos de equilibrio, trae en sus páginas también un $27 \%$ de espacios privados. Los espacios interiores domésticos suponen únicamente un $3 \%$ en On Diseño respecto al total de los publicados siendo la segunda revista en el ránquing únicamente detrás de Diseño Interior.

\section{Distribución por tipos de espacios global}

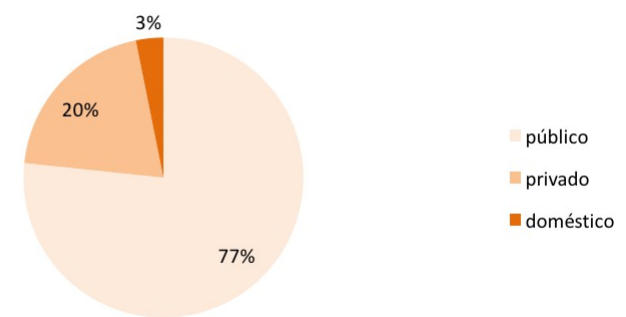

130. Presencia de figura humana distribuída por tipos de espacios interiores global en revistas de arquitectura y diseño. Fuente: G.E.P., 2016. 
¿Qué aspectos diferenciales cabe resaltar en las imágenes que recibimos vinculadas a espacios interiores domésticos? ¿Ofrecen estas revistas matices apreciables en cuanto al desempeño de roles en los espacios interiores domésticos?

Veremos seguidamente que el rol profesional en espacio doméstico lo encontramos, en el caso de los varones, en un anuncio. La imagen de la mujer profesional en espacio doméstico se entiende en tanto en cuanto se puede observar junto a la de rol doméstico, la cual aparece en la misma página de la misma revista. Juntas, ofrecen un contexto completamente diferente al que hubiera aportado cada una por separado.

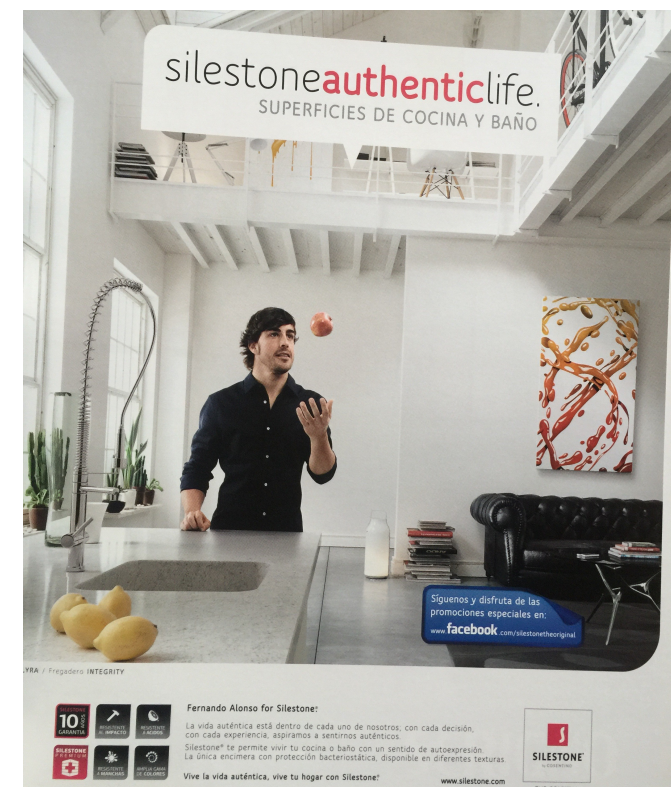

131. Varón profesional. Fuente: On Diseño 323, 2011.

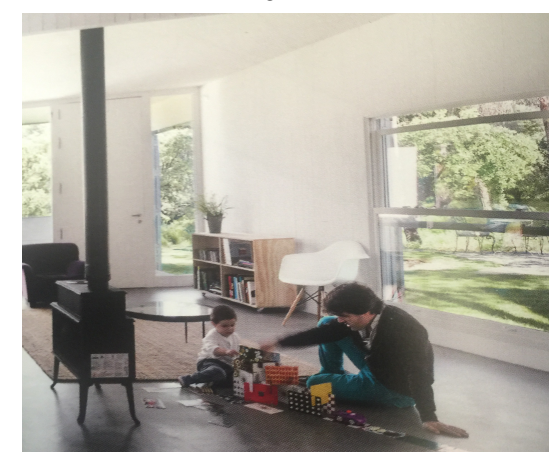

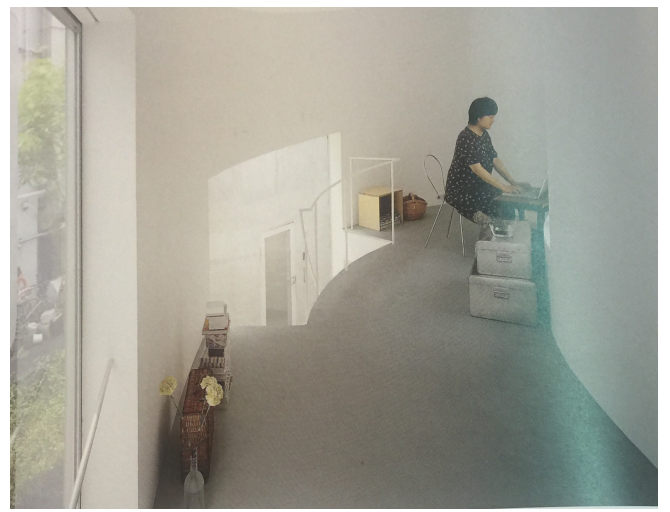

132. Mujer profesional. Fuente: El Croquis 155, 2011.

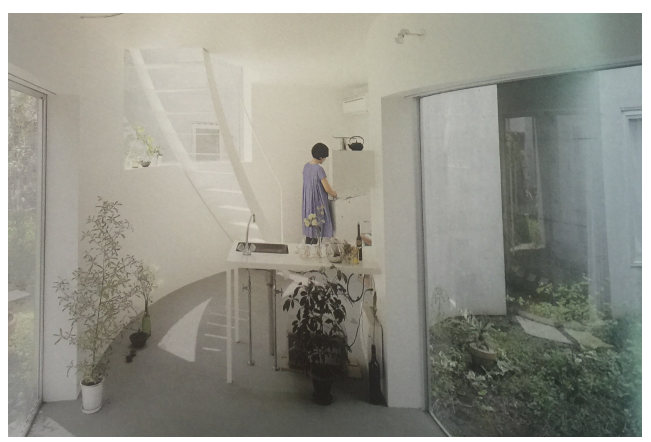

133. Varón rol doméstico. Fuente: On Diseño 351, 134. Mujer rol doméstico. Fuente: El Croquis 155, 2015. 2011. 


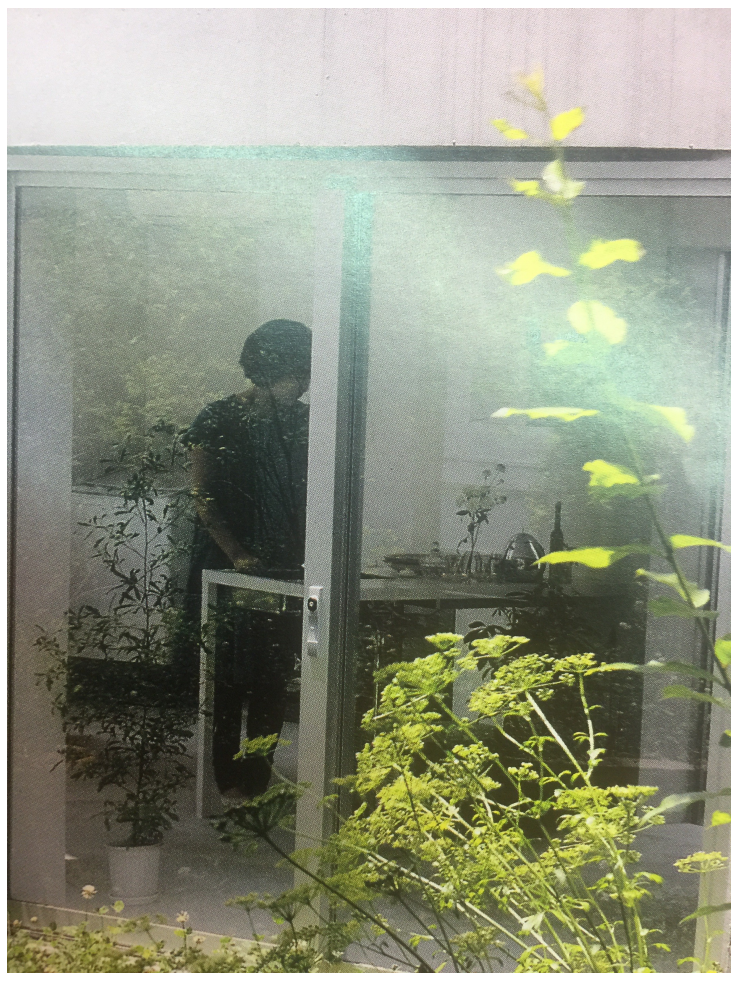

135. Mujer usuaria. Fuente: El Croquis 155, 2011.

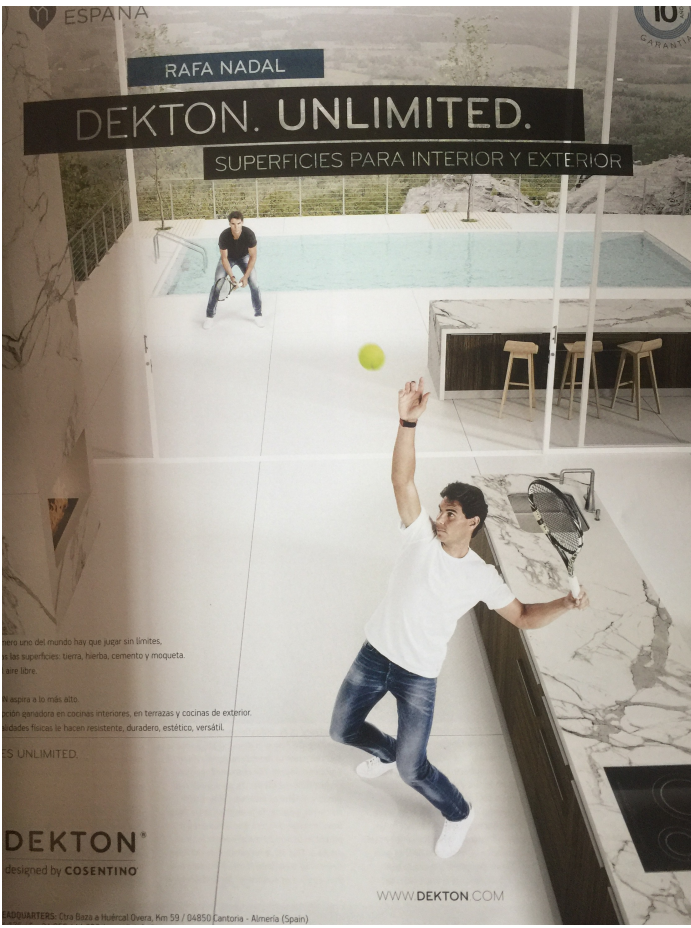

136. Varón usuario. Fuente: On Diseño 352, 2015. 


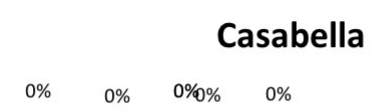

Arquitectura Viva

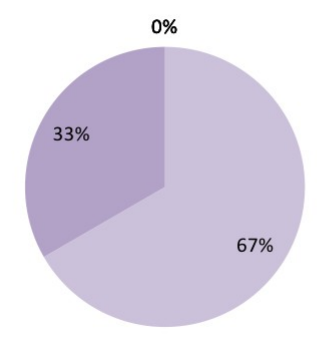

Diseño Interior

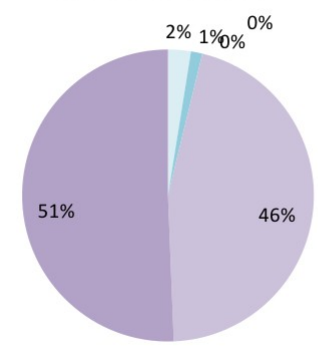

El Croquis

$0 \% \quad 0 \% \quad 0 \%$

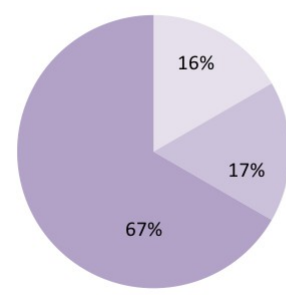

Domus

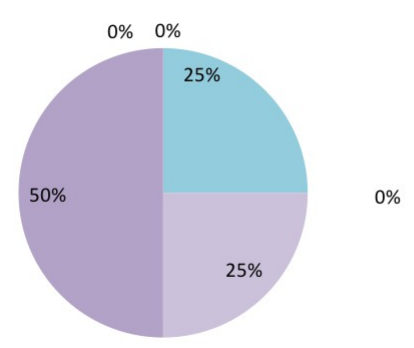

ON Diseño

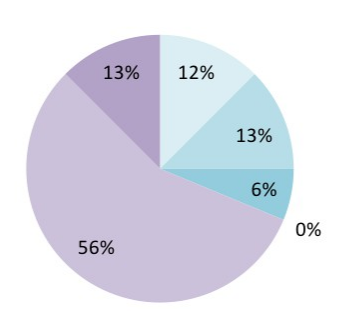

varón profesional

"varón usuario

varón doméstico

mujer profesional

"mujer «usuaria»

mujer doméstico

137. Presencia de figura humana distribuída en el interior doméstico en revistas de arquitectura y diseño. Fuente: G.E.P., 2016.

¿Dónde están las imágenes de mujeres profesionales en el espacio interior doméstico? ¿No existen? ¿En ese espacio, el interior doméstico, no hay espacio propio para el desarrollo profesional de las mujeres? ¿Lo hay pero no ha llegado a estas páginas? De las seis publicaciones que han servido de base para este estudio no encontramos este perfil de mujer dentro del espacio interior doméstico en cinco de ellas y en El Croquis aparece en una proporción del 16\%, que refleja en realidad un $0,032 \%$ del total de los espacios interiores con figura humana que El Croquis nos transmite. Aparecen de manera tan puntual que, aún reflejándose en una gráfica, siguen clamando debido a su ausencia. 
Por otra parte, el $2 \%$ de los espacios interiores domésticos que aparecen en Diseño Interior son espacios en los que nos presentan a un varón desempeñando el rol de profesional en este tipo de espacios, y de manera mucho más llamativa cabe comentar el $12 \%$ de varones profesionales que aparecen dentro de un interior doméstico en On Diseño. Ni Arquitectura Viva, Domus o Casabella traen a sus páginas ningún grupo o persona profesional dentro de los espacios interiores domésticos que publican.

No debemos olvidar el especial caso de Casabella, cuyo disco aparece en un $0 \%$ como consecuencia de la simplificación realizada al inicio de este capítulo para el tratamiento de datos. Según esa simplificación han quedado fuera los grupos de personas mixtos en espacios interiores, por eso Casabella, aun con un $1 \%$ de espacios interiores domésticos no tiene representación en este diagrama en concreto.

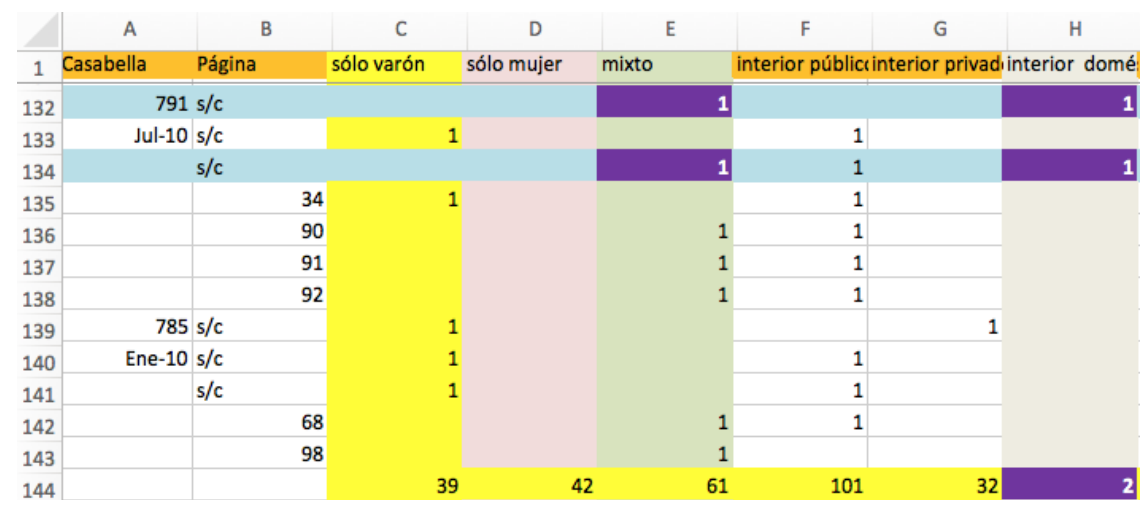

138. Visualización de la causa de los 0\% en Casabella. Fuente: G.E.P., 2016.

El Croquis, como expresa la imagen 129, G.E.P., representa un $1 \%$ de figura humana en el espacio interior doméstico, sobre el $20 \%$ de representación de figura humana que aparece en sus páginas con espacios interiores. Esto implica que un $0,2 \%$ del total de figura humana de El Croquis está en espacios que hemos definido como interiores domésticos, por tanto el disco que vuelca un $16 \%$ de mujeres profesionales en espacio interior doméstico, hay que interpretarlo con rigor, vislumbrando que constituye un $0,032 \%$ de las figuras humanas de esta revista. Un $0,032 \%$ es el volumen de mujeres profesionales de las que estamos hablando. Además de la carga que supone que en el espacio interior doméstico de esta revista únicamente aparezcan mujeres. 
Domus cuenta en sus páginas con un $75 \%$ de personas en rol doméstico en sus espacios interiores domésticos, sumatorio del $50 \%$ de mujeres que aparecen en dicho rol y el $25 \%$ de varones en rol doméstico que muestra la imagen 137 , también cuenta con un $25 \%$ de mujeres «usuarias», mientras que Arquitectura Viva traslada a estos espacios únicamente mujeres, de tal modo que el $33 \%$ de ellas desempeñan rol doméstico y el $67 \%$ son usuarias y/o «usuarias».

Y de nuevo las fisuras alzando la voz: de ese $9 \%$ del espacio interior doméstico en la revista Diseño Interior, que es el más alto de entre las seis revistas estudiadas, según la imagen 129, vemos en la imagen 137 que el $51 \%$ corresponde a mujer en rol doméstico frente a un $1 \%$ de varones desempeñando ese mismo rol. Si tenemos en cuenta que las mujeres usuarias que aparecen, y que suponen un $46 \%$, lo hacen de manera completamente neutra, y que no aparece ninguna mujer en rol profesional, podemos convenir, según la teoría de la neurofisióloga Susana Martínez-Conde que la lectura global de esa revista transmite un $97 \%$ de figuras humanas en espacio interior doméstico que son mujeres, en rol doméstico unas y «usuarias» las otras, frente a un escandalosamente bajo $3 \%$ de varones de los cuales el $2 \%$ lo hacen en rol profesional. "Usuaria», término que en sí mismo ya refleja esa diferencia tan desventajosa para las mujeres entre hacer uso para sí, que es lo que el término usuario viene a referir, y hacer uso del espacio para atender las necesidades de otras personas, sin tiempo propio ni espacio propio real, que es lo que esas comillas de «usuaria» traen a colación.

\section{Roles en interior doméstico global}

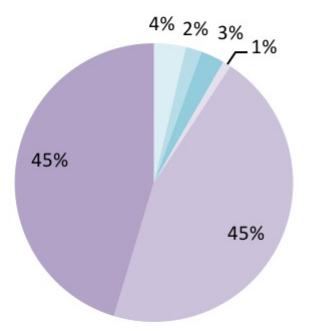

varón profesional

varón usuario

warón doméstico

mujer profesional

mujer «usuaria»

mujer doméstico

139. Presencia de figura humana distribuída en el interior doméstico global en revistas de arquitectura y diseño. Fuente: G.E.P., 2016. 
¿Cabe esperar un nivel de neutralidad superior en los espacios que hemos convenido en denominar privados? ¿en qué proporción son ocupados por varones o mujeres $\mathrm{y}$, qué roles desempeñan unos y otras en estas imágenes?

Es relevante el hecho de que una de las tres únicas mujeres que he encontrado entre las páginas escrutadas, desempeñando un rol profesional, sea la que muestro bajo estas líneas. Es relevante por el titular del artículo en el que se masculiniza a la violinista que posteriormente ocupa sus páginas y para quien va destinado el proyecto de la vivienda. Es para una violinista, y el texto reza en masculino.

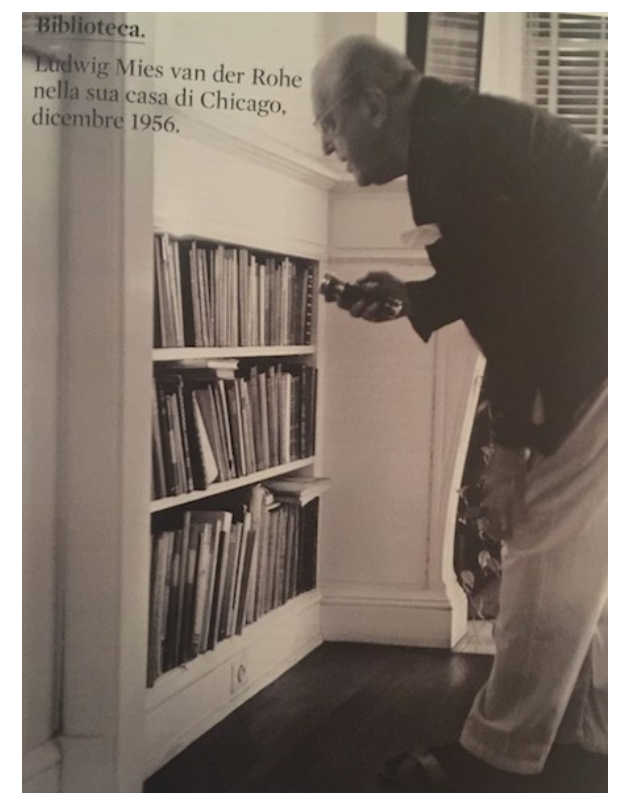

140. Varón profesional. Fuente: Casabella 820, 2012.

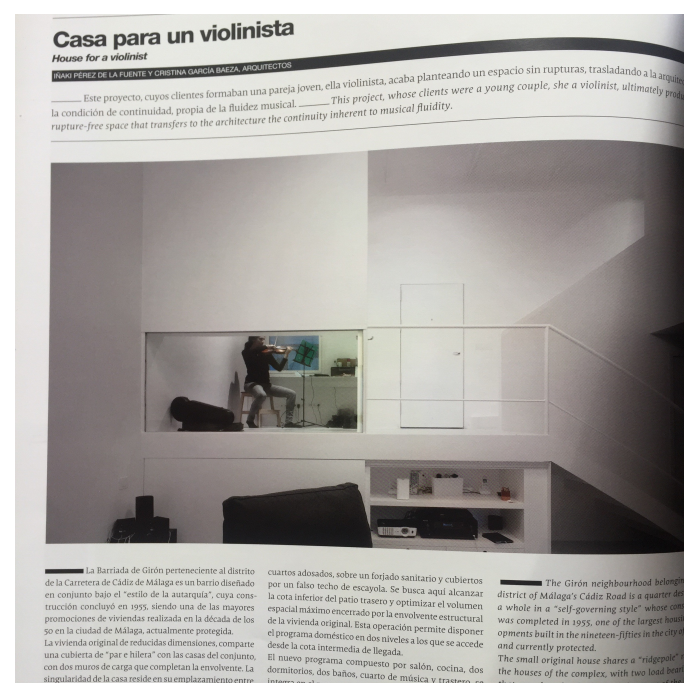

141. Mujer profesional. Fuente: On Diseño 352, 2015. 


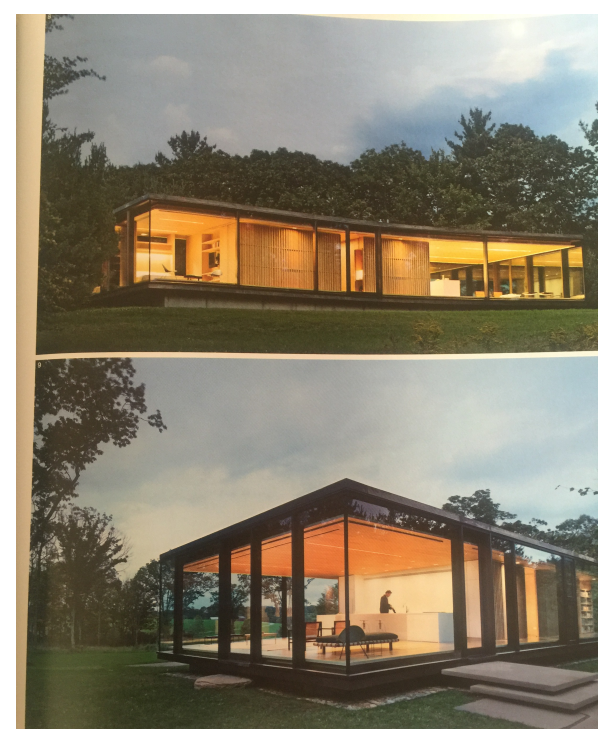

142. Varón en rol doméstico. Fuente: Casabella 839-840, 2014.

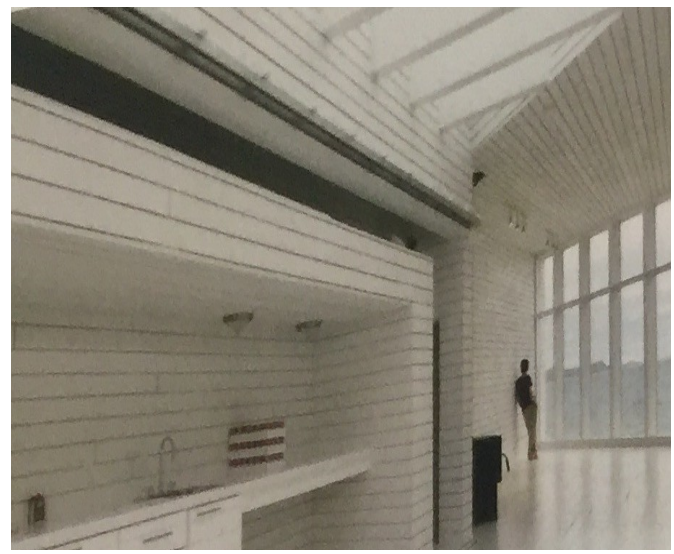

144. Varón en rol usuario. Fuente: Casabella 838, 2014.
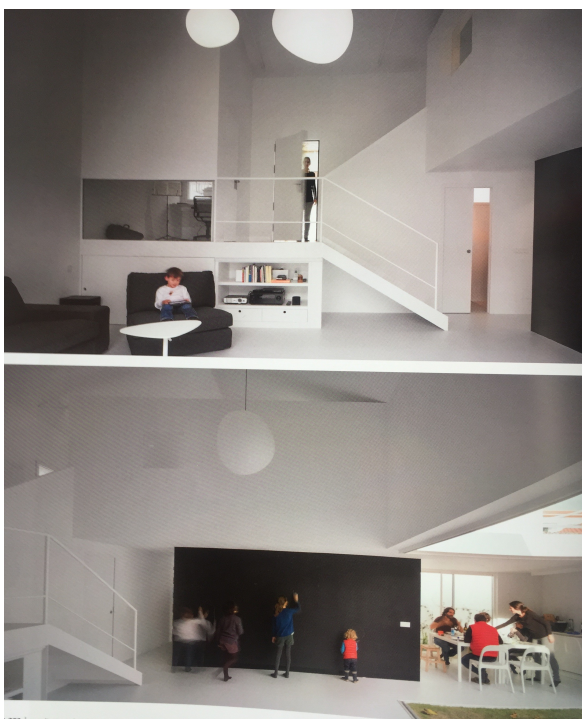

143. Mujer en rol doméstico. Fuente: On Diseño 352, 2015.

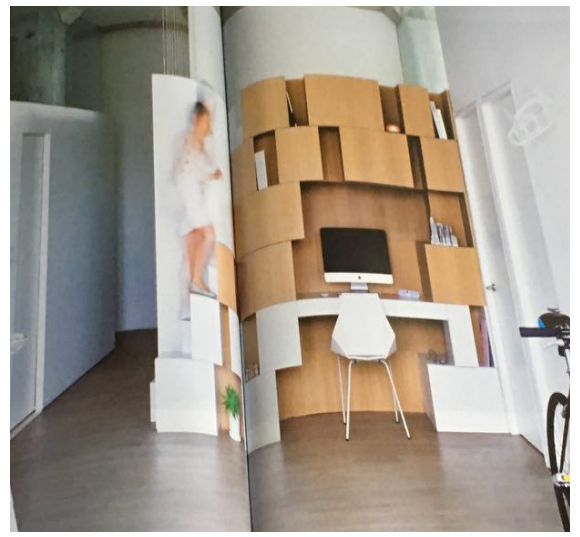

145. Mujer en rol usuaria. Fuente: Diseño Interior $277,2015$. 


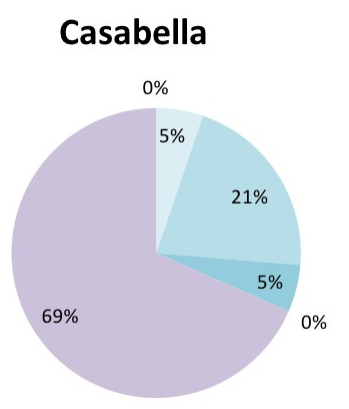

Arquitectura Viva

$0 \%$

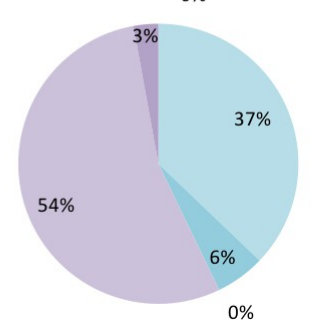

Diseño Interior

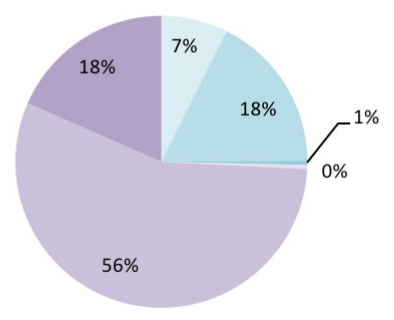

\section{El Croquis}

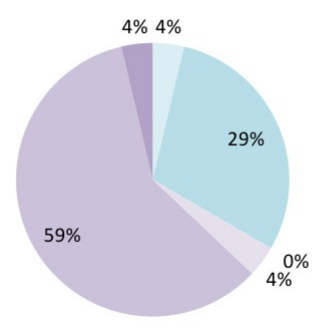

Domus

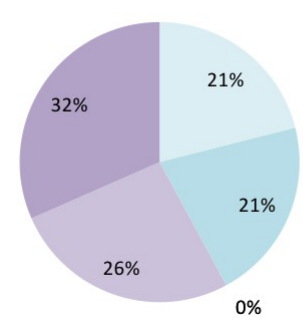

ON Diseño

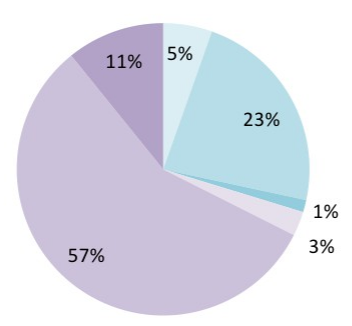

146. Presencia de figura humana distribuída en el interior privado en revistas de arquitectura y diseño.

Fuente: G.E.P., 2016.

Veíamos en la imagen 129, G.E.P. de tipos de espacios interiores, que Diseño Interior comunicaba un $28 \%$, On Diseño un $27 \%$, Casabella un $24 \%$, Domus un $19 \%$, Arquitectura Viva un $13 \%$ y El Croquis un $10 \%$ de espacios interiores privados. Son cifras francamente superiores a las que vuelcan respecto a espacios interiores domésticos. De nuevo es necesario entrar a matizar, observar con espíritu crítico, qué nos están transmitiendo en esas imágenes. ¿Es neutra la capacidad comunicativa de una imagen en el espacio interior privado? ¿Dichos porcentajes traen consigo realmente una proporción de imágenes que van a modelar de manera equitativa el mensaje lanzado a la sociedad desde las páginas de esta revista? 
Si tenemos en cuenta las comillas del término «usuaria», vemos que, realmente, estamos lejos del por mí deseado equilibrio comunicativo. Del $27 \%$ de espacios interiores privados que nos muestra On Diseño, el 11\% corresponde a mujeres en rol doméstico, el $57 \%$ se corresponde con el rol de mujer «usuaria», y un $3 \%$ son mujeres en rol profesional; el $23 \%$ de los interiores privados sí los ocupan varones usuarios de pleno derecho, el $5 \%$ de varones que, en ese interior privado, están desempeñando sus tareas como profesionales, y a todo esto queda sumarle un $1 \%$ de varones en rol doméstico. Podemos por tanto deducir, que pese a la posibilidad de separar por franjas en la gráfica diferentes usos en el espacio interior privado, éste es de uso exclusivo del varón, quizá con la exigua excepción de ese $3 \%$ de mujeres profesionales en esta revista en concreto, todo lo cual refuerza las tesis de Soledad Murillo, respecto a la clasificación de los espacios y su adjudicación por el topo-poder.

La gráfica de El Croquis casi calca el resultado de On Diseño sobre el que acabamos de reflexionar, con el énfasis de que esta publicación no presenta varones en rol doméstico.

Casabella trae a sus páginas únicamente mujeres en el rol de "usuarias», un $69 \%$ de las figuras humanas que publica lo son en este perfil, el resto, varones, un $21 \%$ varones usuarios, un $5 \%$ varones en rol domésico y otro $5 \%$ varones en rol profesional.

En el caso de Arquitectura Viva, el espacio privado usado por el varón es del $37 \%$, pero ese uso no es de servicio a los demás sino el uso que el morador hace de su vivienda. Por tanto el $54 \%$ de espacio interior privado en el que encontramos mujeres "usuarias» y ese $37 \%$ de uso del morador en su propia vivienda, vuelven a construir un $91 \%$ de espacio interior privado para el varón, pues cuando ellas realizan cuidados para el otro, es ese otro quien lo disfruta.

Al observar la gráfica que sale de los datos extraídos de Diseño Interior respecto a los espacios interiores privados, los cuales suponían en la imagen 129 un $28 \%$ del total de los espacios interiores publicados en su páginas, esta publicación presenta un porcentaje de varones haciendo uso de esos espacios privados, en concreto un $26 \%$ sumatorio del $7 \%$ de varones en rol profesional, el $1 \%$ en rol doméstico y el $18 \%$ de usuarios, frente al que el $74 \%$ de mujeres 
haciendo uso de estos espacios privados, que incluso sin asignación de roles, ya resulta llamativo. Ámbito privado vinculado a las mujeres de manera mayoritaria, y sin asignación de rol profesional a ninguna de ellas en esta revista en concreto, con un $7 \%$ de las figuras como varones profesionales volviendo por tanto a la misma encrucijada. Todo el espacio interior privado lo es para los varones, en el sentido de propio, para su disfrute.

A primera vista la gráfica correspondiente a Domus plantea un uso del espacio interior privado diferente. Diferente en tanto en cuanto un $42 \%$ de esos espacios interiores se asignan a varones, un $21 \%$ a varones usuarios y otro $21 \%$ en el desempeño de su tarea profesional. A las mujeres les asigna un $26 \%$ en rol usuaria, y un $32 \%$ en rol doméstico, hecho que conlleva la lectura de ese $26 \%$ como «usuaria», por tanto, una vez más, ellos aparecen haciendo uso y disfrute de los espacios interiores privados, y ellas como personas que prestan servicio a los demás.

\section{Roles en interior privado global}

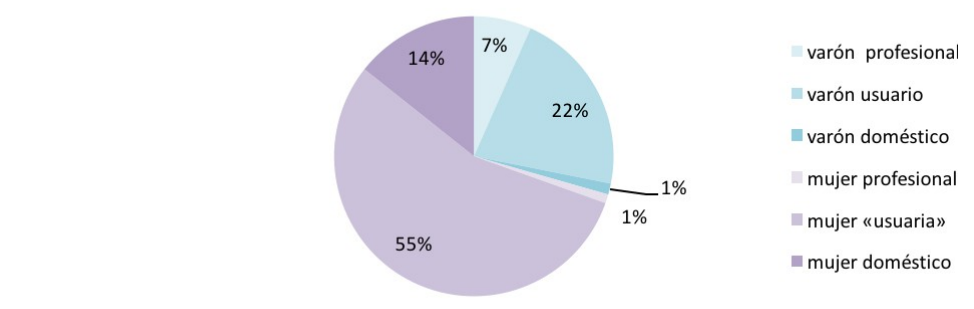

147. Presencia de figura humana distribuída en el interior privado global en revistas de arquitectura y diseño. Fuente: G.E.P., 2016.

La inexistencia de mujeres profesionales en el espacio interior privado, que observamos puede traducirse en que la mujer profesional no dispone de espacios privados para el ejercicio de su profesión.

Hemos visto en las gráficas de la imagen 129 cómo la proporción de espacios interiores públicos que nos muestran las páginas de todas las revistas analizadas es abrumadoramente superior a la de los espacios interiores privados y domésticos, incluso si sumásemos estos dos últimos entre sí. 


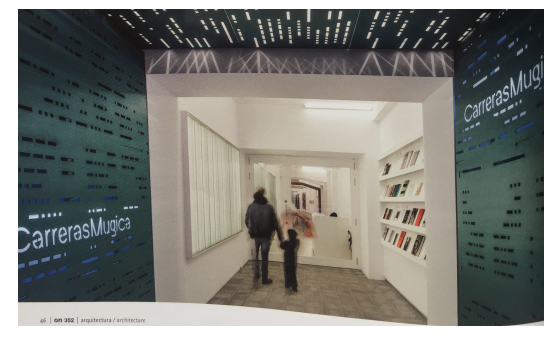

149. Varón rol doméstico. Fuente: On Diseño 352, 2015.

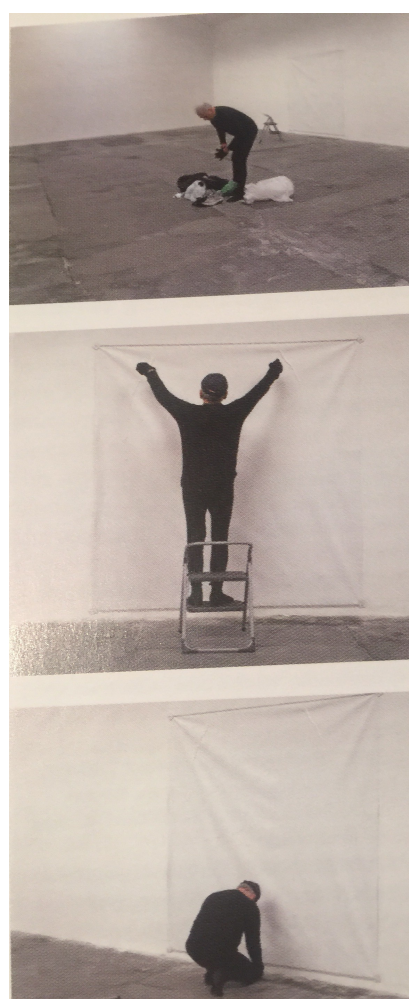

150. Varón en rol profesional. Fuente: Domus 943, 2011.

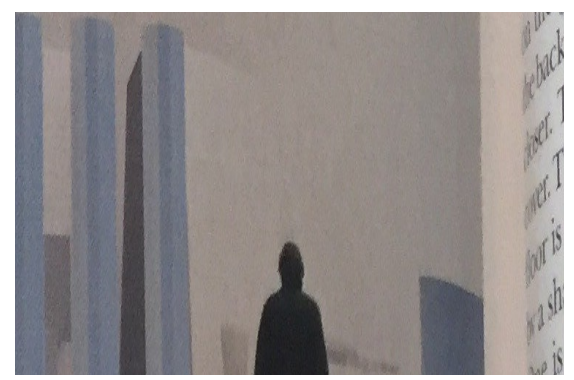

153. Varón en rol usuario. Fuente: Domus 938, 2010.

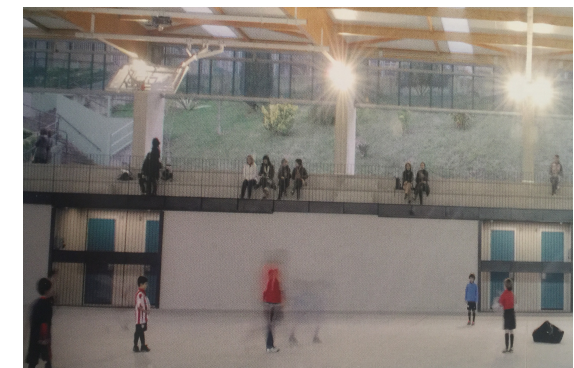

148. Mujer rol doméstico. Fuente: Domus 934, 2010.

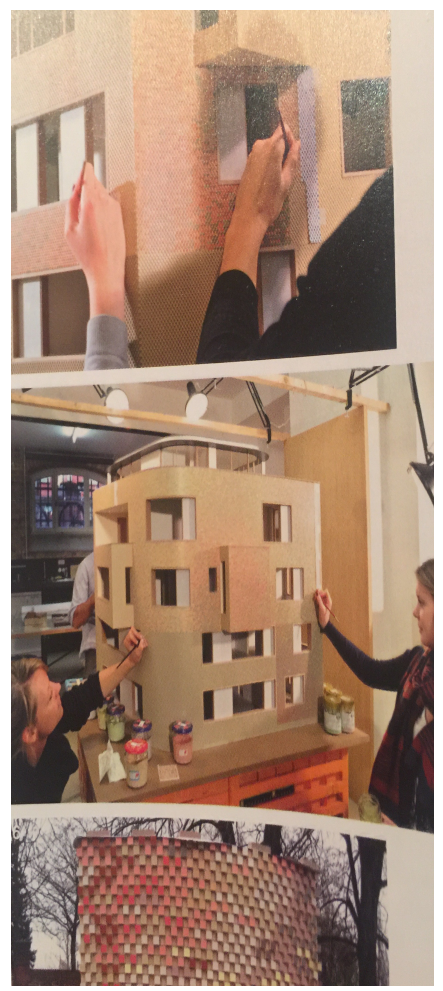

151. Mujer en rol profesional. Fuente: Casabella 848, 2015.

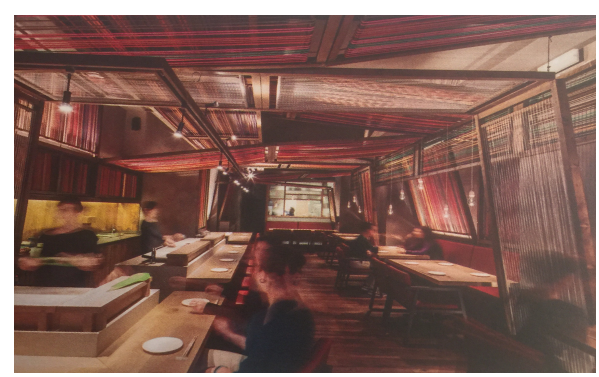

152. Mujer en rol usuaria. Fuente: On Diseño 348, 2014. 

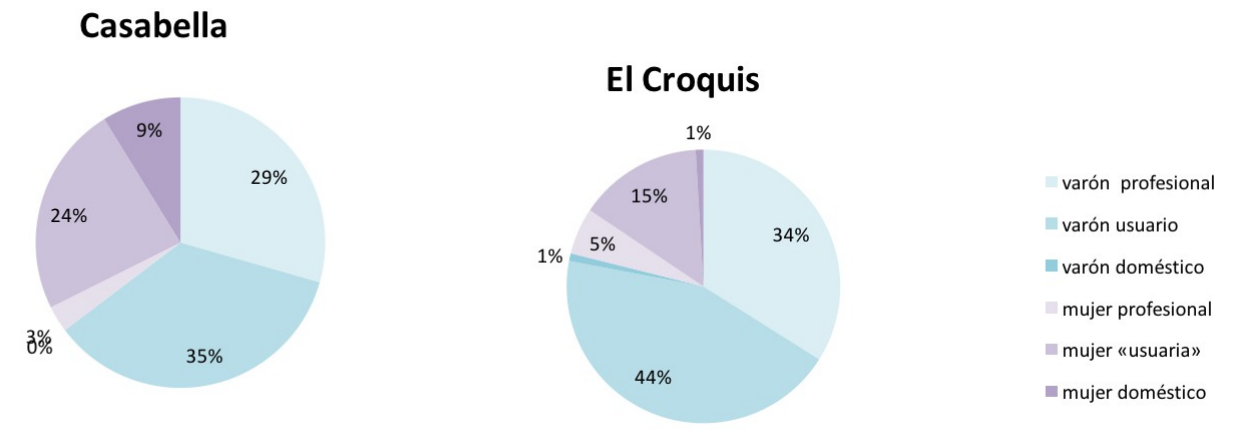

\section{Arquitectura Viva}

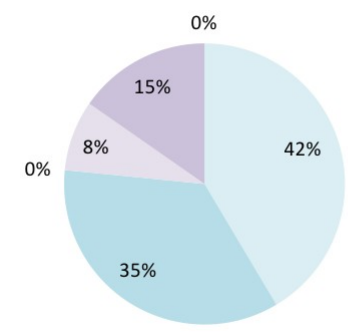

Diseño Interior
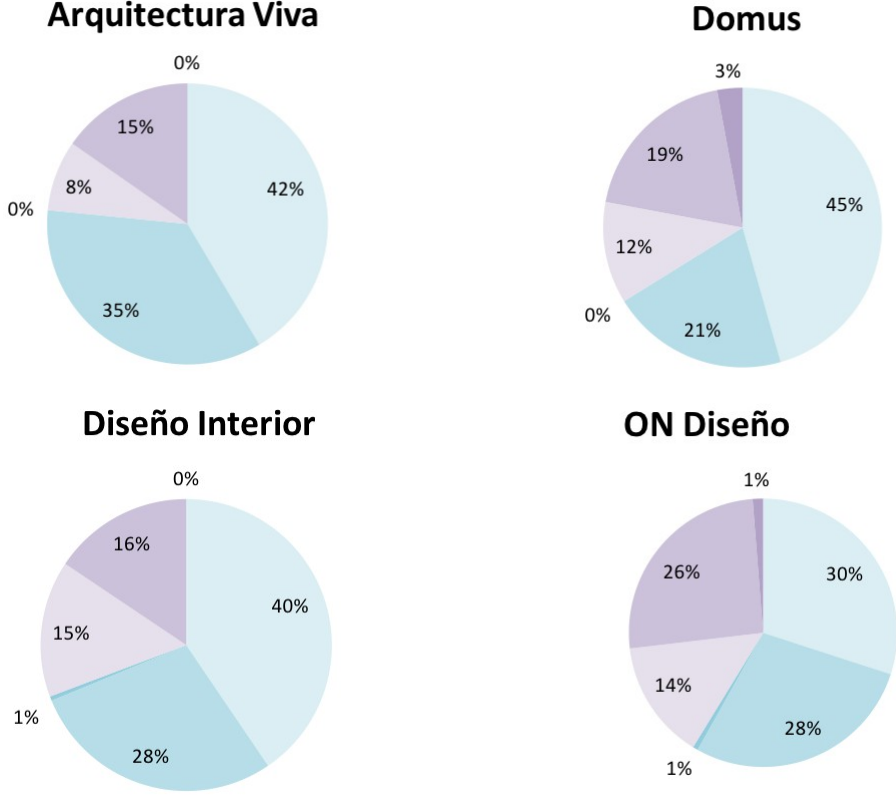

\section{ON Diseño}

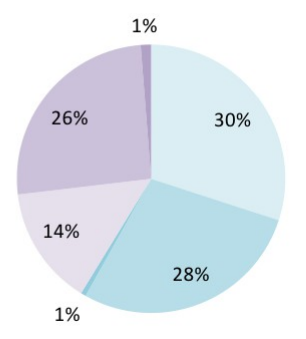

154. Presencia de figura humana distribuída en el interior público en revistas de arquitectura y diseño.

Fuente: G.E.P., 2016.

El interior público: oficinas, talleres, hoteles, restaurantes, museos, es ocupado mayoritariamente por el varón, ya sea profesional, doméstico o usuario:

\begin{tabular}{|c|c|c|c|c|c|c|}
\hline \multirow{2}{*}{ Interior público } & \multicolumn{3}{|c|}{ Varón } & \multicolumn{3}{c|}{ Mujer } \\
\cline { 2 - 7 } & Prof. & Usuario & Suma & Prof. & «Usuaria» & Suma \\
\hline Diseño Interior & 40 & 28 & $68 \%$ & 15 & 16 & $31 \%$ \\
\hline On Diseño & 30 & 28 & $58 \%$ & 14 & 26 & $40 \%$ \\
\hline Arquitectura Viva & 42 & 35 & $77 \%$ & 8 & 15 & $23 \%$ \\
\hline El Croquis & 34 & 44 & $78 \%$ & 5 & 15 & $20 \%$ \\
\hline Domus & 45 & 21 & $66 \%$ & 12 & 19 & $31 \%$ \\
\hline Casabella & 29 & 35 & $64 \%$ & 3 & 24 & $27 \%$ \\
\hline
\end{tabular}


Lo cual es coherente con lo visto en los gráficos de los apartados anteriores. Ocupa el espacio público y el privado y prácticamente no pisa el doméstico. Son datos, no opiniones como las que circulan acerca de que la igualdad ya ha sido conseguida. Si el espacio configura identidades, esa aserción debe ser discutida y denunciada como falaz. El trabajo no está hecho. Sobre todo en los medios de difusión de la arquitectura y el diseño. Aquí, en los espacios públicos sí encontramos a mujeres en el desempeño del rol profesional. Es necesaria una seria reflexión: en las publicaciones que han servido para realizar esta investigación el rol de mujer profesional aparece, en el espacio interior público, en una horquilla que en su valor superior alcanza el 15\% del total, estando en el el $3 \%$ en algún caso, en el caso de estos valores porcentuales en varones, la variación oscila desde el $29 \%$ de Casabella hasta el $45 \%$ de Domus.

Diseño Interior es la publicación que mayor proporción de mujeres en rol profesional lleva en sus páginas. En concreto un $15 \%$ de los espacios públicos de Diseño Interior los ocupan mujeres profesionales. Vuelvo a remitirme a los tiempos de la Bauhaus y el veto a las mujeres de principios de siglo XX para acceder a determinados niveles de estudios, especialmente si estos eran técnicos, cerraban sus puertas a las mujeres que con derecho y capacidad propias, a ellas se dirigían. El proceso en la actualidad se repite. El acceso está cerrado según a qué espacios si eres mujer. El espacio de la difusión profesional en el mundo del diseño y la arquitectura queda denegado y sólo algunas privilegiadas pueden romper ese impedimento, como en su día hicieran las pioneras que empezaron a acceder a las aulas de educación superior de manera muy excepcional, poco a poco.

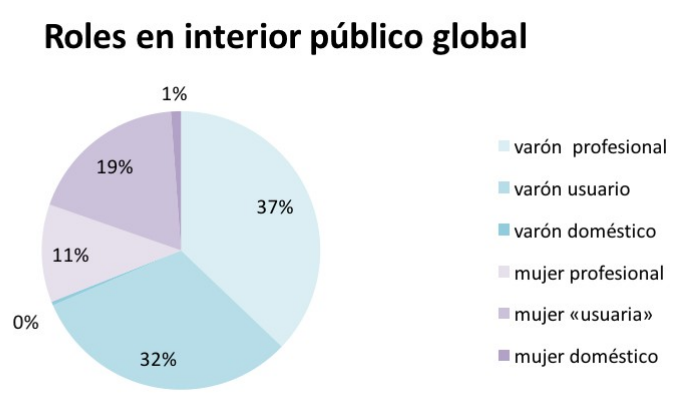

155. Presencia de figura humana en interior público global en revistas de arquitectura y diseño.

Fuente: G.E.P., 2016. 


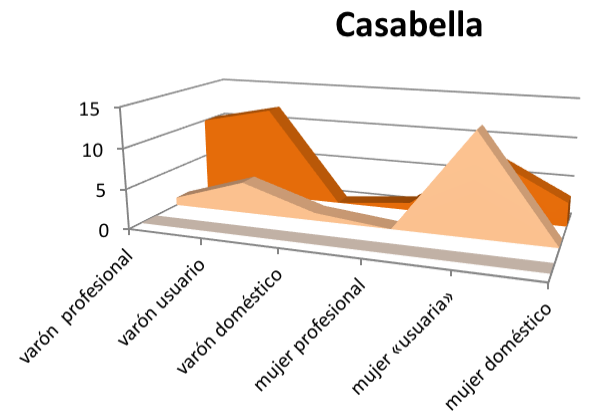

Arquitectura Viva

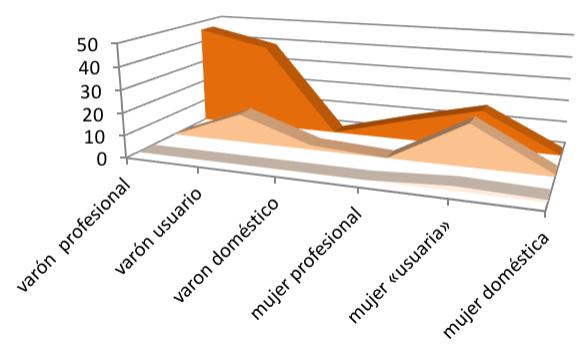

Diseño Interior

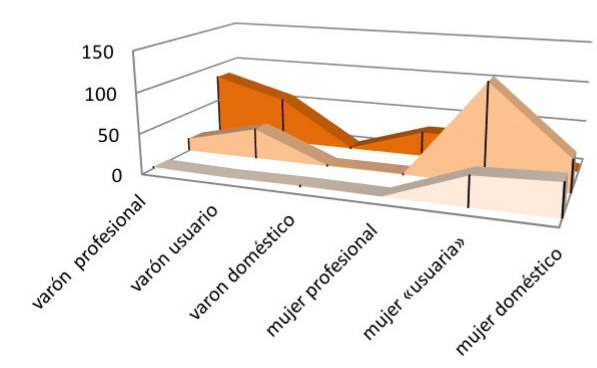

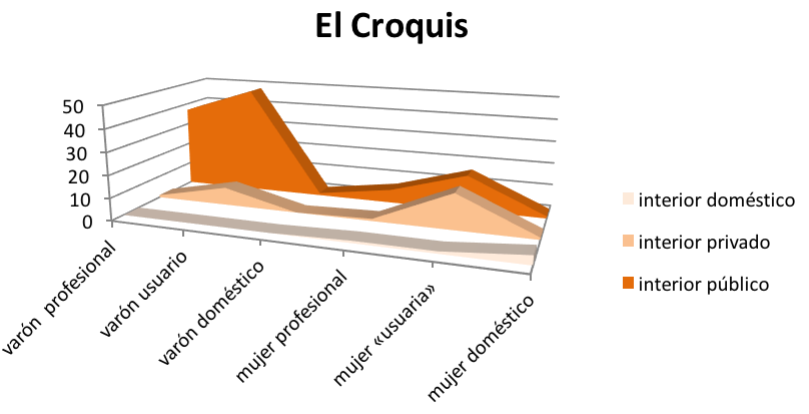

Domus

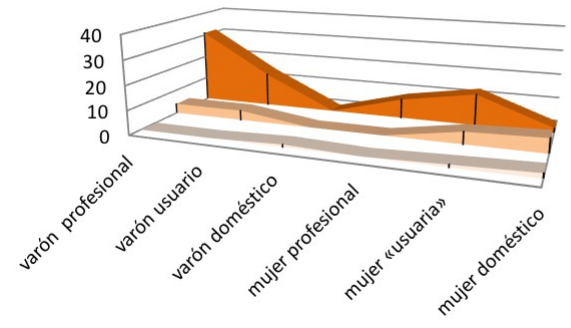

ON Diseño

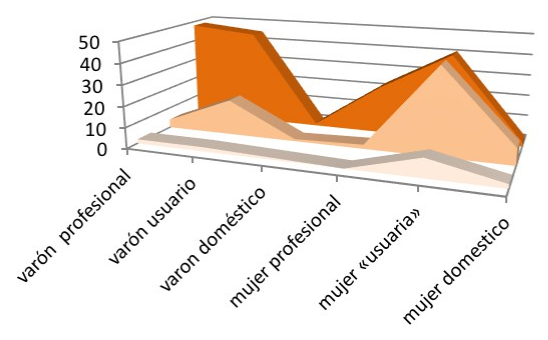

156. Presencia de figura humana estudio comparativo en revistas de arquitectura y diseño. Fuente: G.E.P., 2016.

Los gráficos comparativos de Diseño Interior, On Diseño y Arquitectura Viva refuerzan visualmente la disimetría del uso de los espacios por varones y mujeres, con máximos de varones profesionales en el espacio público y máximos de mujeres «usuarias» en el espacio doméstico. Si trazásemos un eje imaginario en el centro de estas gráficas, a la izquierda podemos observar el lugar que ocupan los varones en estas revistas, y a la derecha el que ocupan las mujeres.

No hay figuras humanas, muchas menos de mujeres, apenas testimoniales, pero el testimonio del androcentrismo de las revistas de Diseño Interior 
estudiadas, es abrumador. En el caso de El Croquis se produce el mismo fenómeno, pero lo más llamativo, sin embargo, es esa cinta casi plana del interior doméstico, inexistente para unos y otras. Se olvidan que quien sostiene la vida, y por tanto el resto de actividades, es precisamente el trabajo que se desarrolla en el interior (y exterior) doméstico. Estas ausencias están en consonancia con la falta de remuneración y prestigio (valoración social) de lo doméstico, que se refleja en los medios de difusión como las revistas estudiadas. También en Domus y Casabella llama la atención esa cinta plana, que también nos habla de un interior doméstico desaparecido para unas y otros, interior doméstico que mantiene la vida y por tanto el resto de producciones, pero que se invisibiliza, se menosprecia, se devalúa.

A excepción de Diseño Interior, en la que la gráfica nos muestra cómo sí aparecen mujeres profesionales, aunque siempre en el espacio interior público, en todos los demás casos, la presencia de las mujeres profesionales es prácticamente inexistente. Aparece un pequeño porcentaje de mujeres profesionales, también en el espacio interior público, en las gráficas de On Diseño, Domus y Casabella, pero tal y como se aprecia en la gráfica comparativa de roles y espacios, en ninguno de los tres casos aludidos se roza ni tan siquiera en $5 \%$ de la presencia de figuras humanas, mujeres, desempeñando el rol profesional en el espacio interior público, que es en el único en el que contamos con dicha presencia.

\section{Comparativa espacios-roles}

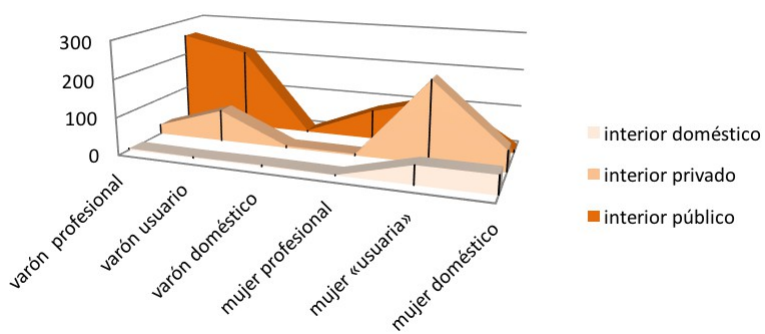

157. Presencia de figura humana estudio comparativo global en revistas de arquitectura y diseño. Fuente: G.E.P., 2016. 


\subsection{Inferencias}

El procesamiento gráfico de la información nos permite ver a golpe de vista la relación entre los resultados de las tablas:

1) Del total de imágenes de estas revistas, una ínfima parte incluyen figuras humanas.

2) La mayor parte de figuras humanas son varones.

3) La mayor parte de varones son profesionales, mayormente relacionados con el diseño, la arquitectura o la construcción.

4) Las mayor parte de mujeres que aparecen lo hacen en ambientes domésticos o en anuncios.

5) Las mujeres que aparecen como profesionales, lo hacen en su mayoría, como modelos publicitarias en los anuncios.

6) Las mujeres que no aparecen como modelos aparecen en actividades domésticas o de cuidados en los espacios interiores, casi siempre, tanto en las fotografías de los espacios interiores como en los anuncios.

7) La mayoría de los espacios interiores mostrados en las publicaciones que hemos estudiado son espacios de uso público.

8) Los espacios interiores domésticos están infrarrepresentados en las publicaciones analizadas.

9) En los interiores domésticos el $90 \%$ de la presencia humana la ocupan mujeres, de ellas la mitad en rol doméstico y la otra mitad en rol «usuarias».

10) Frente a un $45 \%$ de mujeres en rol doméstico, estas seis revistas muestran tan solo un $3 \%$ de varones en ese mismo rol dentro de los espacios interiores domésticos.

11) Los interiores privados son ocupados mayoritariamente por mujeres, en concreto un $70 \%$ de ellos. 
12) La mayor parte de las mujeres que aparecen en los espacios interiores privados lo hacen en rol de «usuarias».

13) Los espacios interiores públicos son ocupados mayoritariamente por varones, el $69 \%$ de estos espacios.

14) El espacio interior público que aparece en las revistas objeto de este apartado de esta tesis está ocupado de manera muy significativa en rol profesional.

15) Las imágenes de mujeres diseñadoras o arquitectas suponen un $13 \%$ de las imágenes de mujeres, tal y como se desprende de la imagen 76, frente al $64 \%$ de varones diseñadores o arquitectos en relación a las imágenes que de ellos arrojan estas revistas, dato que nos proporciona la imagen 81.

El androcentrismo y sexismo que se desprende del análisis de las revistas estudiadas, me permite decir que, en la actualidad, la arquitectura refuerza el modelo de familia burguesa. Modelo que se ha extendido a las clases medias y populares, y que de las dos derivas fundamentales de este modelo: la nueva mujer del feminismo y el nuevo varón del capitalismo, en las revistas de arquitectura va ganando el segundo. Hasta tal punto que el primero, la mujer del feminismo, es inexistente en dichas revistas, tanto las estudiadas en mi investigación como en las revistas estudiadas por Daniela Arias en la suya. Si aparecen mujeres, no lo hacen en contextos ni actitudes de mujeres liberadas de las imposiciones del oculto contrato sexual denunciado por Pateman en su obra homónima, sino en actitudes de servicio doméstico o sexual. Daniela Arias denuncia con contundencia la situación en las revistas de arquitectura en el siguiente párrafo:

El tema de género es el gran ausente en todas las publicaciones. [...]

En efecto un artículo que publica The Architectural Review escrito por Mireille Rodder en marzo de 2013, Feminist Practices, Interdisciplinary Approaches to Women in Architecture explores what it means to employ feminism in design, but can the exposed design 
methods be really considered radical ${ }^{15}$, no se presenta como un desarrollo continuo de un tema instaurado, sino como un artículo acerca de un libro publicado que recoge la perspectiva de género aplicada al diseño de espacios.

El debate en las revistas aquí mencionadas sobre los roles en la profesión que tradicionalmente ha relegado a las mujeres a campos de acción distintos dentro de la disciplina, apenas consta en un par de artículos. [...] Es posible afirmar a este respecto, que la revista, como tantos otros actores sociales de influencia, reproduce y reafirma el modelo dominante que históricamente ha marcado a las sociedades, a las ciudades y a la disciplina. (Arias; 2013: 76)

Las revistas son objetos culturales en los que está presente el diseño gráfico tanto en la composición de la propia revista como en los anuncios que se insertan en ella. Es por ello que, de entrada, ya hay que contar con el uso consciente de las ilusiones ópticas desde la intencionalidad de la persona que las diseña para sugerir, persuadir o convencer, formando parte del mensaje oculto de estos objetos. Todo es estudiado en sus más mínimos detalles. Nada escapa a la planificación del diseño. Por otra parte hay que tener en cuenta que las ilusiones ópticas pueden insertarse en el diseño por acción o por omisión. El segundo caso es el explorado en las revistas analizadas. ¿Quién visibiliza o invisibiliza el trabajo de las mujeres diseñadoras o arquitectas en estas revistas, los equipos editoriales, articulistas de uno u otro sexo? Esta es una pregunta que queda abierta para futuras investigaciones.

15. Las prácticas feministas, los enfoques interdisciplinares relativos a la mujer en Arquitectura, exploran lo que significa emplear el feminismo en diseño, pero los métodos expuestos pueden realmente ser considerados radicales.

(Traducción propia). 
6. EVIDENCIA DEL LUGAR ASIGNADO POR EL TOPO-PODER 


\subsection{La cocina moderna}

Más allá de los tres modelos de mujer presentes en las revistas de arquitectura: la profesional del diseño y de la arquitectura, el ángel del hogar y el cuerpo sexy, dedico esta parte de mi investigación a profundizar en los roles que la arquitectura moderna asigna a la mujer en el ámbito doméstico y de los cuidados.

Cocinar y comer son las funciones básicas de toda vivienda, la cocina, junto con el baño, son dos piezas esenciales y, de ellas, la cocina me parece la más influyente en tanto en cuanto al proceso de construcción de la propia identidad se refiere.

En particular este capítulo se centra en la cocina y en los mandatos patriarcales que se ocultan en ella.

He hecho un recorrido, a través de los modelos estándar que se han impuesto desde el Movimiento Moderno y que, según Ellen Lupton y J. Abbot Miller, se están replanteando en la actualidad:

Aunque el ideal de la cocina continua sigue siendo hoy una norma fundamental, se están replanteando muchos de sus elementos estándar. El uso de una altura estándar para los mostradores y aparatos resulta económico para los constructores y fabricantes, pero crea un entorno hostil para cualquiera que no sea la inquilina idealizada de la cocina moderna: la denominada «mujer media». Las puertas de armario al mismo nivel del borde del mostrador dificultan el trabajar sentada, mientras que las rinconeras crean espacios de almacenaje profundos y difíciles de organizar. La obsesión por crear un banco uniforme de aparatos sitúa parrillas, hornos y lavavajillas en una posición incómoda cerca del suelo, haciéndolos inaccesibles a adultos incapacitados o algo torpes. (Lupton y Abbot; 1992: 41)

Incapacidad y torpeza que, con algo de suerte, experimentaremos todos con el paso de los años. El modelo de cocina moderna tiene su origen en la necesidad y la oportunidad que propició la posguerra de construir viviendas populares económicas, en serie, industrializadas y por tanto imitadoras de otros contextos 
habitacionales que por su naturaleza debían resolver el problema en espacios y tiempos reducidos. Los tiempos se reducían con la prefabricación en serie y el espacio venía marcado por los propios contextos: trenes, barcos, aviones. Pero hoy en día, esas cocinas tipo vagón de tren están en crisis. Según Juan Bravo:

En la actual sociedad del bienestar, la incorporación de la mujer a la vida pública es ya un hecho incuestionable que, hoy por hoy, ha desplazado el debate social más hacia la corresponsabilidad en las tareas domésticas, desde la limpieza, la compra o la cocina hasta la atención infantil. [...] respecto a su futuro como espacio doméstico, la cocina no sólo debería ser el lugar donde compartir buena parte de esas tareas que giran alrededor de la función de cocinar sino también, deseablemente, las relativas a la de comer. Con ello se amplificaría otro de sus papeles fundamentales al definirse como un lugar central en la vivienda para la socialización y educación de las nuevas generaciones, donde de manera natural, éstas puedan aprender el valor y la satisfacción de responsabilizarse y compartir las diferentes tareas domésticas. (Bravo, 2011: 208-209)

O, como dice Otl Aicher

Cocinar es una actividad de varios. En la cocina, el ser humano es un ser social. La cocina es una función de la naturaleza social del hombre. Sólo se cocina con ganas cuando se va a disfrutar de la cocina con otros. $Y$ se cocina con más ganas si se cocina en compañía.

Por muy sociales que hayan sido las preocupaciones de los arquitectos que concibieron la Cocina de Frankfurt, forzar a alguien a cocinar donde sólo cabe una persona, es parecido a una condena (Aicher, 2004: 43)

Esta preocupación ya la tuvo la propia creadora de la Cocina de Frankfurt, pero su modelo estaba pensado para la vivienda destinada a la población obrera, debía ser construída rápidamente y con presupuesto mínimo. Margarete Schütte-Lihotzky había diseñado previamente un modelo que hubiera satisfecho a Bravo y Aicher, pero las alternativas no eran cocina grande o pequeña, sino apta para vivienda popular. 
Tampoco es cierto que hoy todo el mundo pueda optar por cocina grande o pequeña. Ese estado del bienestar al que alude Bravo, se ha convertido en un espejismo y el problema de la vivienda vuelve a plantearse con crudeza, a pesar de los miles de viviendas vacías que ha dejado la burbuja inmobiliaria. Viviendas que son también mínimas, no por la conciencia social con la que se plantearon esas promociones, sino por la especulación. Y en esas viviendas las cocinas siguen siendo las herederas de la famosa cocina Frankfurt y de las de otras pioneras como Charlotte Perriand. Tanto Bravo como Aicher parecen estar pensando en la cocina para la discutida clase media y sus modelos de vivienda burgueses.

La cocina moderna destinada a las clases medias y altas es una cocina amable y acogedora, bien equipada de artefactos, sobre todo electrodomésticos, amplia, bonita y confortable. Con modernos muebles funcionales confeccionados con materiales de radiantes colores y fácil limpieza, en la que el ama de casa reine feliz.

[...] la cocina es descrita como corazón del hogar, ámbito de eficiencia y exactitud, espacio cuya belleza merece la admiración del ama de casa que desde allí, confortablemente, reina sobre el mundo doméstico.

[...] En agosto de 1954, la revista Para ti publicaba un artículo que resume buena parte de los elementos condensados en la nueva cocina propuesta como ideal. Cómoda, bonita, bien equipada, mecanizada y adecuadamente organizada, la cocina moderna garantizaría el bienestar de la familia y la belleza del ama de casa. «La reina de casa no debe ser una esclava» rezaba el título de este artículo, en el que se analizaban las horas invertidas semanalmente por las mujeres en cada una de las tareas domésticas y se detallaban los novedosos artefactos que le permitirían a la dueña de casa ser también «reina de sí misma». [...] Nuevos artefactos (antes), nuevos materiales (después): el plástico, la fórmica, los materiales sintéticos en general introducen colores antes insospechados en la cocina. La consideración estética de este ambiente sufrió un impulso no menor en los años de la difusión de estos materiales. Como nunca antes, se 
publicitan muebles para cocina, ponderados por ser alegres, coloridos, de fácil limpieza, resistentes al uso y baratos. Para pasar de Cenicienta a princesa, a la cocina sólo le hizo falta vestirse de plástico. (Pérez, 2010: 110-123)

Estas cocinas llenan las hojas de las revistas dedicadas al hogar. Son señuelos para incitar a consumir, objetivo prioritario de las modernas cocinas que han cambiado su antigua función de producción para convertirse en centros de consumo.

En mi trabajo como profesional de la arquitectura he defendido siempre la necesidad de construir viviendas mínimas para facilitar el acceso a las clases con menor poder adquisitivo, pero siempre exigiendo unos mínimos dignos. Ha sido una tarea ardua, difícil y, de momento, sin éxito. En este trabajo me interesa profundizar en el modelo de cocina del ama de casa burguesa y la construcción de su identidad, en la medida en que funciona como aspiración de las clases menos favorecidas y en consecuencia produce modelos de imitación. La construcción de la identidad sexy, subsidiaria del modelo Playboy, de camas redondas y cocinas estéticas pero no para cocinar, me interesa por sus consecuencias en la construcción de las identidades de las nuevas generaciones, que tienen ante sí el reto de ser ángeles del hogar y bellas y lánguidas adolescentes sexy.

Sin perder de vista esos dos referentes, me centraré en las características de la cocina moderna estandarizada especialmente para las viviendas populares y su relación con la construcción de la identidad femenina moderna.

Se puede establecer la genealogía de la cocina moderna como hija de la cocina Frankfurt y de la cocina integrada de Perriand que, a su vez, bebieron de la arquitectura moderna de la primera postguerra mundial. Según Juan Bravo, la actual cocina moderna se convirtió en modelo universal bajo el nombre de cocina sueca, debido a la suavización que los diseñadores suecos, Aino y Alvar Aalto, aplicaron al austero modelo de la Cocina Frankfurt (Bravo, 2011: 208).

Establecida esta genealogía, procedo a rastrear, a través de las medidas de las cocinas y de las mujeres, el androcentrismo oculto en la cocina estándar actual, 
como heredero del androcentrismo de los arquitectos y también arquitectas de la vanguardia europea de principios del siglo XX.

En las imágenes de las revistas de arquitectura, que desde sus orígenes en el Movimiento Moderno y en el Estilo Internacional constituyen los órganos de difusión de la arquitectura y el diseño, la figura humana tiene una escasa presencia. Ernts Neufert critica esta situación como hemos visto anteriormente.

De las casas Eames sí que hay fotografías de edificios con seres humanos. Es la pareja quien se fotografía junto a su obra con el fin de publicar las fotografías en las revistas de arquitectura. Para ellos esas fotografías son, a su vez, arquitectura. Según Beatriz Preciado, ellos son el modelo que sigue y supera la arquitectura Playboy.

Sólo cuando se considera que la casa es una máquina y, como tal, necesita un manual de uso, aparecen esquemas con figuras humanas explicando las funciones de cada módulo de la vivienda. ¿Y qué figuras humanas van vinculadas a cada función? Son reveladores los esquemas y secuencias de funcionamiento del bloque Higpoint II de Berthold Lubetkin, reproducidos por Montays y Fuertes en su «Casa Collage» (Montanys y Fuertes, 2010: 131).

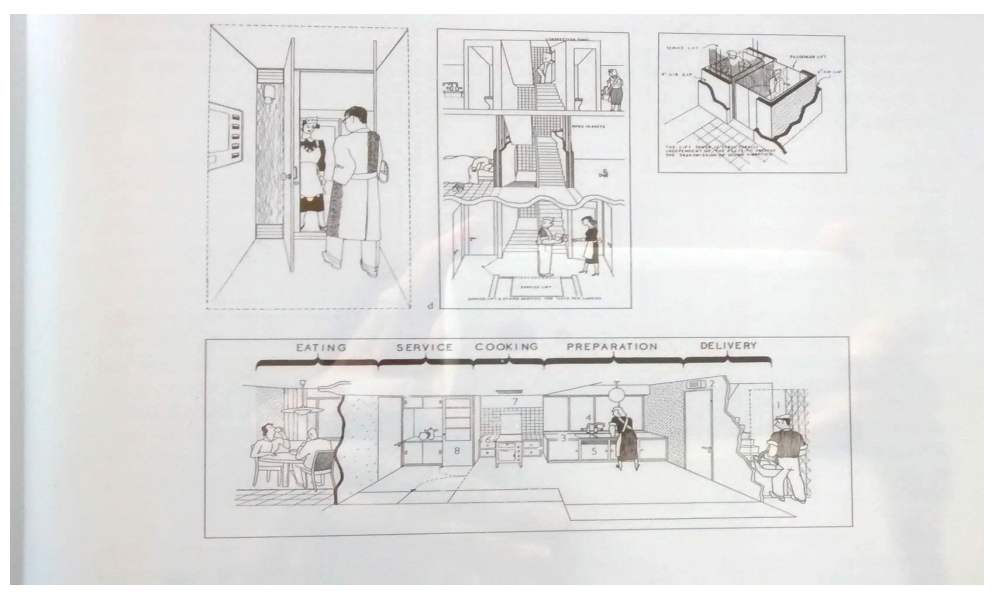

158. Esquemas de funcionamiento de los ascensores y de la cocina del bloque Highpoint II de Bertold Lubetkin. Fuente: Montays y Fuertes, 2001. 
También aparecen figuras humanas desempeñando roles heteropatriarcales en las fotografías publicitarias de la DDU de los folletos de la casa Butler, que tenían el claro objetivo de vender el bidón de grano-barracón militar, como un hogar acogedor, para lo cual había que explicar visualmente el cambio de funciones.

\subsection{Un legado más de Neufert}

Aunque la crítica de Neufert me parece pertinente, sin embargo las figuras humanas que él utiliza profusamente hacen de su texto un elemento ineludible para mi investigación. El texto al que aludo es El arte de proyectar en arquitectura, publicado por Ernst Neufert en 1936, actualizado y reeditado periódicamente hasta hoy. Con sus 41 ediciones en alemán y 16 en castellano, constituye un compendio de medidas y datos técnicos de arquitectura de reconocido valor universal. Su estilo eminentemente visual -propio de la Bauhaus- reduce el texto a su mínima expresión. Sus dibujos son esquemáticos, portadores de las medidas estandarizadas del varón (Zöllner, 2014: 52) y van casi siempre acompañados de figuras humanas que representan la acción ligada a los espacios o elementos arquitectónicos que se ilustran. Es un manual de referencia para las personas profesionales de los ámbitos de la arquitectura superior, la arquitectura técnica, ingeniería superior y técnica, personas dedicadas a la construcción, clientes, docentes y estudiantes en todo el mundo. A lo largo de sus 41 ediciones, actualizando permanentemente sus contenidos técnicos, la asignación de roles estereotipados no ha variado un ápice en los 80 años de su existencia, ninguna de las importantes transiciones ha variado el modelo, ni la $12^{\mathrm{a}}$, ni la $26^{\mathrm{a}}$ ni la $30^{\mathrm{a}}$ ni la $33^{a}$. En alguna de ellas su publicidad afirma que no ha quedado sin modificar ni una sola página. Lamentablemente esas modificaciones no han tenido en cuenta la necesaria revisión de la asignación heteropatriarcal de roles domésticos. 


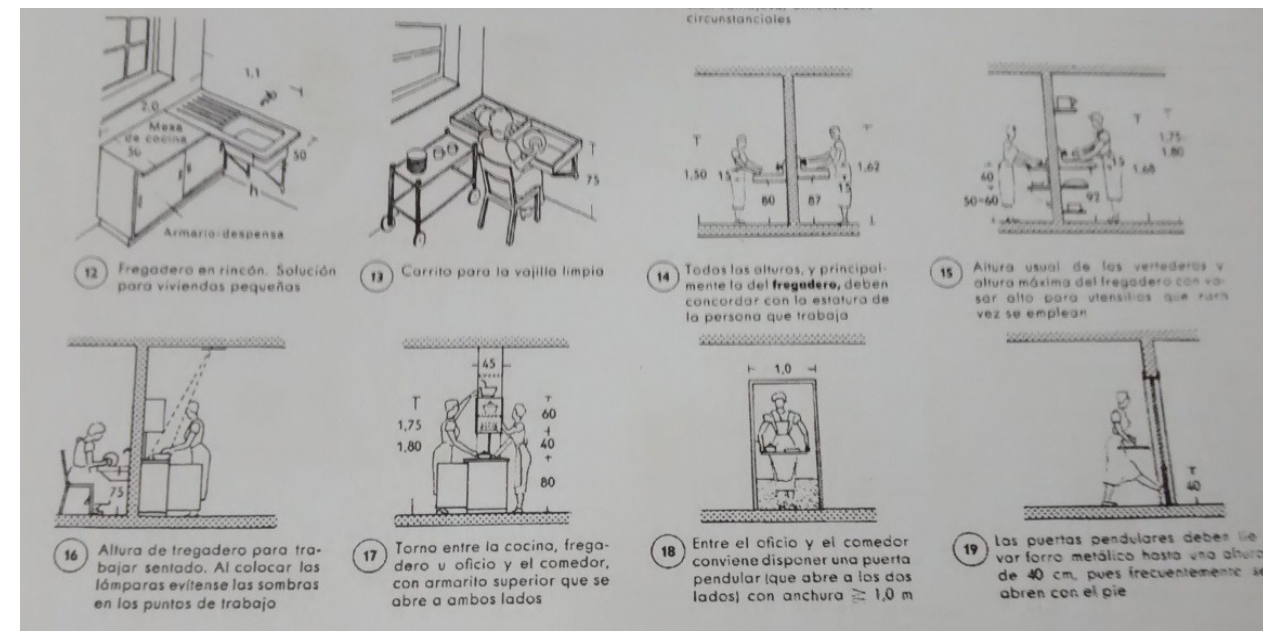

159. Ernst Neufert. Ejemplos de usos y medidas de cocinas estándarizadas, 1942.

La medida de $80 \mathrm{~cm}$ de altura de la tabla de trabajo se mantiene hasta después de la edición $12^{\mathrm{a}}$. En dicha edición se incorpora someramente el Modulor de Le Corbusier como norma antropométrica y se mantienen las recomendaciones del modelo de la cocina Frankfurt para la que Margarete Schüte-Lizhotsky tuvo en cuenta también el mueble de cocinar.

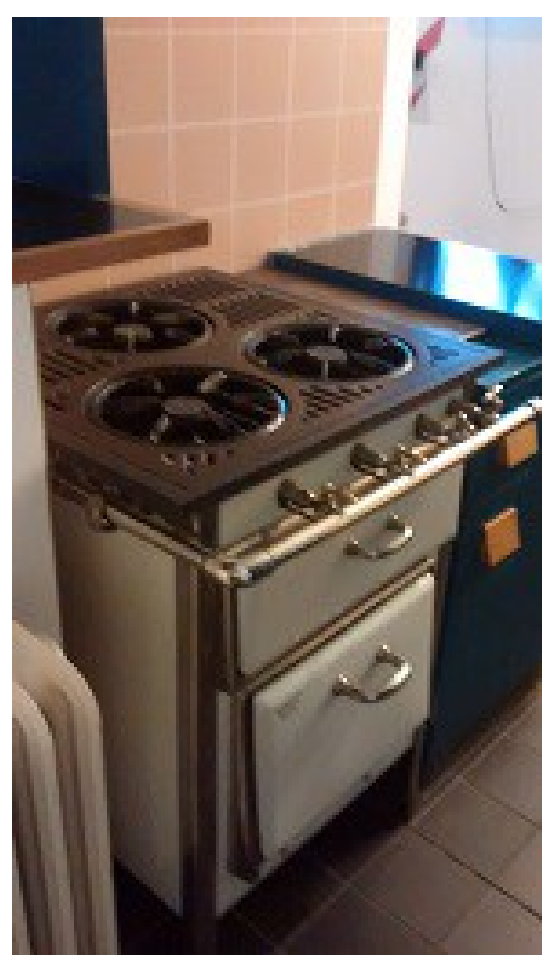

160. Mueble de cocinar en la Frankfurt Küche. Fotografía de la autora, 2015. 
Tras la primera tirada de la décimo segunda edición alemana, aparecida poco después de finalizada la Segunda Guerra Mundial, en 1949, se produjeron multitud de ediciones en un breve espacio de tiempo. De tal modo que, en 1960, se publicó la primera tirada de la vigésimo primera edición alemana, referente para las ediciones españolas de ese periodo, hasta la undécima y para las ediciones $5^{\mathrm{a}}-13^{\mathrm{a}}$ portuguesas de 1977 a 1988. En esta edición sigue el modelo de cocina Frankfurt, la bancada ya mide $85 \mathrm{~cm}$ y el Modulor ya aparece ocupando una página entera, extraída del propio texto de Le Corbusier, publicado en 1950.

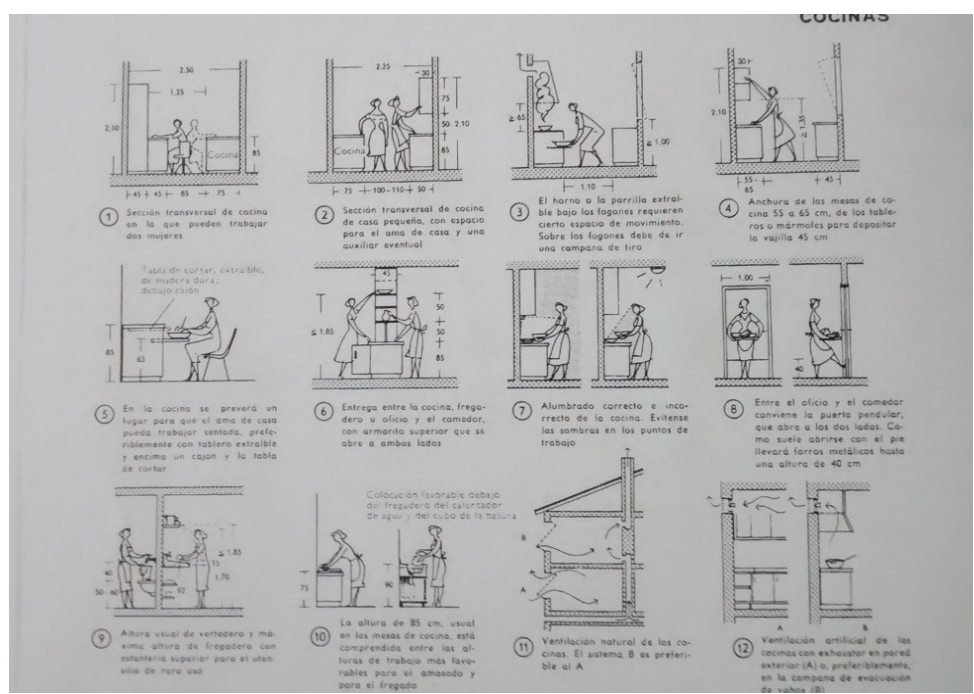

161. Ernst Neufert. El arte de proyectar en la arquitectura. Edición $12^{a}$ española, $21^{a}$ alemana, 1964.

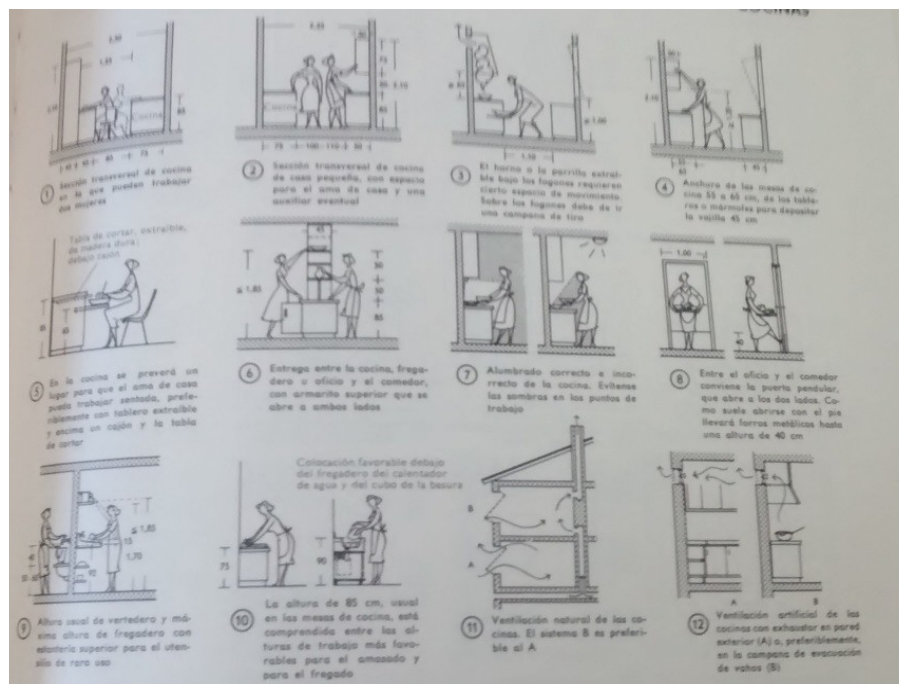

162. Ernst Neufert. Ejemplos de usos y medidas de cocinas estándarizadas. Edición $13^{a}$ española, $30^{a}$ alemana, 1991. 
En la $13^{a}$ edición en español (1991), adaptación de la trigésima en alemán, siguen las mismas ilustraciones, idénticas a las de la primera edición, sólo ha cambiado el estilo de los vestidos y el trazado de los dibujos, aunque ya ha desaparecido la cocina Frankfurt, se mantienen los $85 \mathrm{~cm}$ de bancada y el Modulor permanece como en la vigésimo primera edición alemana.
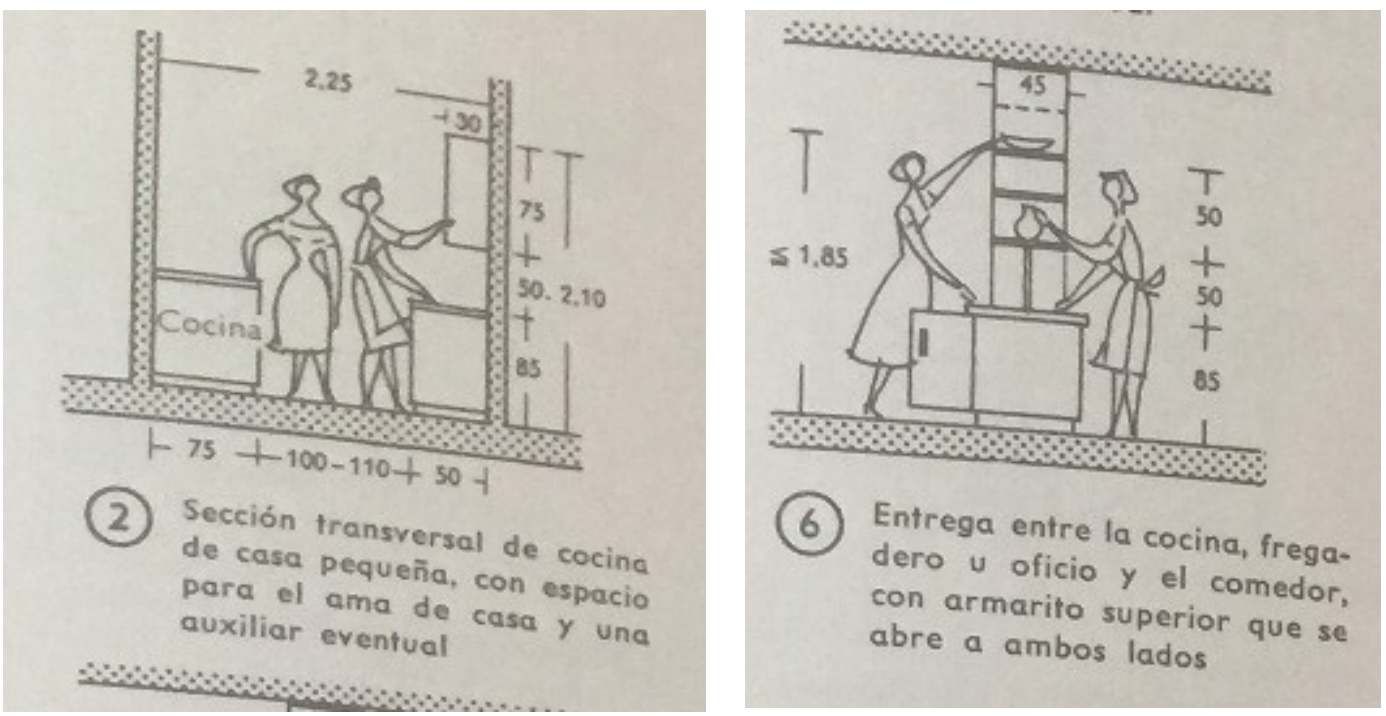

163. Ernst Neufert. Altura de la bancada en la 13ª edición española, 1991.
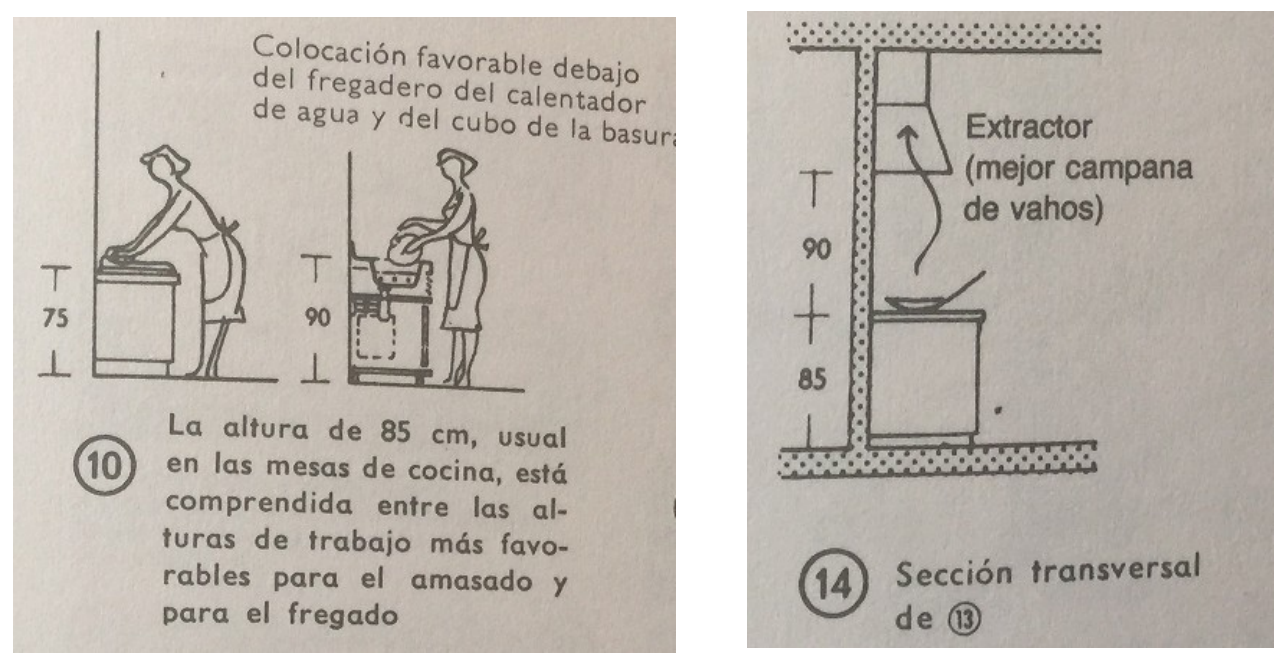

164. Ernst Neufert. Altura fogones y mesa de trabajo según $13^{a}$ edición española, 1991. 
En la $14^{\mathrm{a}}$ edición española podemos ver distintos modelos de muebles-cocina eléctricos o de gas, cuya altura arrastra la medida de $85 \mathrm{~cm}$, vista en las ilustraciones anteriores, pero ya aparece una horquilla para la bancada entre 85 $\mathrm{cm}$ y $90 \mathrm{~cm}$. La cocina Frankfurt ha desaparecido definitivamente.

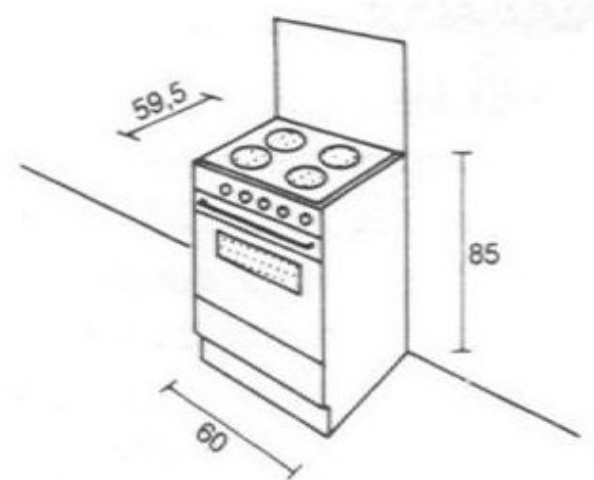

(1) Cocina eléctrica

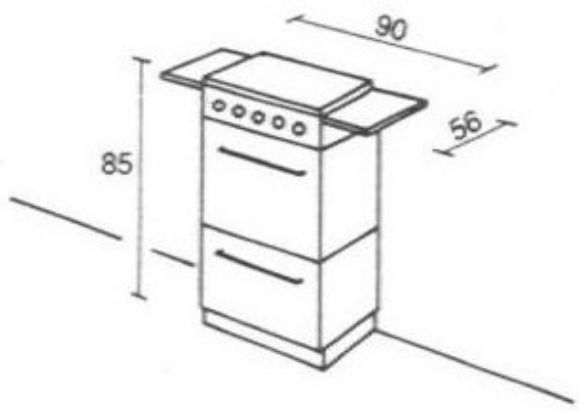

(2) Cocina grande a gas

165. Ernst Neufert. Ejemplos de usos y medidas de muebles cocina estándarizadas, página 212 de la $33^{\mathrm{a}}$ edición en alemán, $14^{\mathrm{a}}$ en castellano, 1995.

La medida de $85 \mathrm{~cm}$ de altura del plano de trabajo que estipula al menos desde 1958, es incontestable y es respetada al pie de la letra por la industria actual.

A continuación expongo una tabla elaborada con datos de distintas ediciones de El arte de proyectar en arquitectura. Unas propias (la décimo tercera edición española, adaptada de la trigésima alemana. Así como la décimo cuarta española, adaptada de la trigésimo tercera alemana, disponible en internet); y otras consultadas en la Biblioteca de Cataluña (la sexta edición alemana de 1940; la primera versión española de 1942, adaptación de la octava alemana; la séptima edición portuguesa, adaptada de la vigésimo primera versión alemana y la duodécima versión española, adaptada de la vigésimo sexta alemana). Entre las versiones consultadas, unas están escritas en castellano y otras en portugués, francés, inglés o alemán. Aunque la tabla no está completa, sí contiene la mayor parte de aquellas ediciones relevantes por las innovaciones 
que introducen, desde la primera en 1936 hasta la cuadragésimo primera de 2016. Considero que son suficientes como para constatar los momentos de transición que me han aportado información relevante como son los incrementos en la altura de la bancada; también podemos constatar en estas ediciones los aspectos fundamentales que nunca han sufrido variaciones, como son los maniquíes femeninos siempre trabajando en la cocina. La décimo segunda edición, la vigésimo primera, la trigésima, la trigésimo tercera y la trigésimo sexta son clave en una parte de mi investigación.

En la siguiente tabla podemos observar la mayor parte de las ediciones alemanas en relación con las españolas y alguna de otro país como Portugal o Gran Bretaña. Las ediciones de este último país son especialmente interesantes por lo que de conciliación llevaba la propuesta del Modulor, entre el sistema de medidas continental (Sistema Métrico Decimal) y el sistema anglosajón.

Para facilitar la comparativa he insertado cuatro columnas, de modo que una de ellas muestra las ediciones alemanas, otra las ediciones españolas, siguen las ediciones portuguesas y por último las ediciones inglesas.

\begin{tabular}{|l|l|l|l|l|l|}
\hline año & alemana & española & portuguesa & inglesa & comentarios \\
\hline 1936 & $\begin{array}{l}\text { primera, } \\
\text { segunda y } \\
\text { tercera }\end{array}$ & & & & Comienzo de la guerra civil española \\
\hline 1937 & cuarta y quinta & & & & \\
\hline 1938 & sexta & & & & \\
\hline 1939 & & & & & Fin de la guerra civil española \\
\hline 1940 & $\begin{array}{l}\text { séptima y } \\
\text { octava }\end{array}$ & & & & Altura plano de trabajo 80 cm \\
\hline 1941 & & & & & $\begin{array}{l}\text { No aparece Le Corbusier, sí la cocina } \\
\text { Frankfurt, altura bancada 80 cm } \\
\text { (adaptada de la 8a alemana) }\end{array}$ \\
\hline 1942 & novena y & primera & & & $\begin{array}{l}\text { (adaptada de la décima edición } \\
\text { alemana) }\end{array}$ \\
\hline 1943 & & & & $\begin{array}{l}\text { Fin Segunda Guerra Mundial } \\
\text { Referencia del Neufert, duodécima } \\
\text { edición alemana al Modulor }\end{array}$ \\
\hline 1944 & undécima & segunda & & & \\
\hline 1945 & & & & & \\
\hline
\end{tabular}




\begin{tabular}{|c|c|c|c|c|c|}
\hline año & alemana & española & portuguesa & inglesa & comentarios \\
\hline \multicolumn{6}{|l|}{1946} \\
\hline \multicolumn{6}{|l|}{1947} \\
\hline 1948 & & & & & $\begin{array}{l}\text { Le Corbusier afirma en el Modulor, } \\
\text { publicado en 1950, que en } 1948 \text { ya lo } \\
\text { tiene terminado }\end{array}$ \\
\hline 1949 & duodécima & & & & \\
\hline 1950 & $\begin{array}{l}\text { duodécima y } \\
\text { décimo tercera }\end{array}$ & & & & $\begin{array}{l}\text { Primera en la que se cita brevemente el } \\
\text { Modulor de Le Corbusier, refiriéndolo a } \\
1945 . \\
\text { En estas ediciones ya introduce la } \\
\text { cocina Frankfurt, cuya altura de la } \\
\text { bancada es de } 80 \mathrm{~cm} \text {, como modelo de } \\
\text { cocina industrializada. }\end{array}$ \\
\hline 1951 & & quinta & & & \\
\hline \multicolumn{6}{|l|}{1952} \\
\hline 1953 & & sexta & & & (adaptada de la décima alemana) \\
\hline 1954 & Décimo quinta & & & & \\
\hline 1955 & Décimo sexta & & & & \\
\hline 1956 & $\begin{array}{l}\text { Décimo } \\
\text { séptima }\end{array}$ & séptima & & & $\begin{array}{l}\text { (adaptada de la décimo primera edición } \\
\text { alemana) }\end{array}$ \\
\hline \multicolumn{6}{|l|}{1957} \\
\hline 1958 & & octava & & & $\begin{array}{l}\text { (adaptada de la décimo segunda } \\
\text { edición alemana) }\end{array}$ \\
\hline 1959 & vigésima & & & & \\
\hline 1960 & $\begin{array}{l}\text { vigésimo } \\
\text { primera }\end{array}$ & & & & $\begin{array}{l}\text { Ya hay una página dedicada al Modulor } \\
\text { y la bancada mide ya } 85 \mathrm{~cm} \text {. } \\
\text { Por otra parte sigue presente la cocina } \\
\text { Frankfurt como modelo de cocina } \\
\text { industrializable. }\end{array}$ \\
\hline 1961 & $\begin{array}{l}\text { vigésimo } \\
\text { segunda }\end{array}$ & & & & \\
\hline 1962 & $\begin{array}{l}\text { vigésimo } \\
\text { segunda y } \\
\text { vigésimo } \\
\text { tercera. }\end{array}$ & $\begin{array}{l}\text { décima } \\
\text { undécima }\end{array}$ & & & $\begin{array}{l}\text { La bancada mide } 85 \mathrm{~cm} \text {. Sigue presente } \\
\text { la cocina Frankfurt como modelo de } \\
\text { cocina industrializable. } \\
\text { (adaptadas de la Vigésimo primera } \\
\text { alemana) }\end{array}$ \\
\hline \multicolumn{6}{|l|}{1963} \\
\hline 1964 & vigésimo sexta & & & & $\begin{array}{l}\text { Sigue una página dedicada al Modulor, } \\
\text { la bancada mide } 85 \mathrm{~cm} \text { y sigue estando } \\
\text { la cocina Frankfurt. }\end{array}$ \\
\hline \multicolumn{6}{|l|}{1965} \\
\hline 1966 & $\begin{array}{l}\text { vigésimo } \\
\text { quinta }\end{array}$ & & & & \\
\hline \multicolumn{6}{|l|}{1967} \\
\hline \multicolumn{6}{|l|}{1968} \\
\hline \multicolumn{6}{|l|}{1969} \\
\hline 1970 & $\begin{array}{l}\text { vigésimo } \\
\text { séptima }\end{array}$ & & & primera & \\
\hline 1971 & & & & & \\
\hline
\end{tabular}




\begin{tabular}{|c|c|c|c|c|c|}
\hline año & alemana & española & portuguesa & inglesa & comentarios \\
\hline \multicolumn{6}{|l|}{1972} \\
\hline 1973 & $\begin{array}{l}\text { vigésimo } \\
\text { novena }\end{array}$ & & & & \\
\hline \multicolumn{6}{|l|}{1974} \\
\hline 1975 & & duodécima & & & \\
\hline 1976 & & & quinta & & $\begin{array}{l}\text { (adaptada de la vigésimo primera } \\
\text { alemana) }\end{array}$ \\
\hline 1977 & & duodécima & & & $\begin{array}{l}\text { (adaptada de la vigésimo sexta } \\
\text { alemana) }\end{array}$ \\
\hline 1978 & trigésima & & & & $\begin{array}{l}\text { Neufert tiene } 78 \text { años, sigue una página } \\
\text { dedicada al Modulor y la bancada sigue } \\
\text { con } 85 \mathrm{~cm} \text {. } \\
\text { No está representada la cocina } \\
\text { Frankfurt. }\end{array}$ \\
\hline 1979 & trigésima & & & & \\
\hline 1980 & & & & segunda & \\
\hline 1981 & & & séptima & & (adaptada de la Vigésimo primera) \\
\hline 1982 & $\begin{array}{l}\text { trigésimo } \\
\text { primera }\end{array}$ & & & & \\
\hline 1983 & & $\begin{array}{l}\text { décimo } \\
\text { tercera }\end{array}$ & & & $\begin{array}{l}\text { Última edición española en vida de } \\
\text { Neufert quien tenía ya } 83 \text { años, } 78 \\
\text { cuando se publicó la Trigésima } \\
\text { alemana de la que esta } 13^{a} \text { española es } \\
\text { adaptación, sigue una página dedicada } \\
\text { al Modulor y la bancada sigue con } 85 \\
\text { cm } \\
\text { No está presente la cocina Frankfurt } \\
\text { (adaptada de la trigésima edición } \\
\text { alemana) }\end{array}$ \\
\hline 1984 & $\begin{array}{l}\text { trigésimo } \\
\text { segunda }\end{array}$ & & & & \\
\hline \multicolumn{6}{|l|}{1985} \\
\hline 1986 & & & & & Muerte de Ernst Neufert a los 86 años. \\
\hline \multicolumn{6}{|l|}{1987} \\
\hline \multicolumn{6}{|l|}{1988} \\
\hline \multicolumn{6}{|l|}{1989} \\
\hline \multicolumn{6}{|l|}{1990} \\
\hline 1991 & $\begin{array}{l}\text { trigésimo } \\
\text { tercera }\end{array}$ & & & & $\begin{array}{l}\text { Primera (y única) edición del hijo de } \\
\text { Neufert. Página entera Modulor. } \\
\text { Bancada 85-90, electrodomésticos } 85 . \\
\text { No está ya la cocina Frankfurt. }\end{array}$ \\
\hline \multicolumn{6}{|l|}{1992} \\
\hline \multicolumn{6}{|l|}{1993} \\
\hline \multicolumn{6}{|l|}{1994} \\
\hline 1995 & & $\begin{array}{l}\text { décimo } \\
\text { cuarta }\end{array}$ & & & $\begin{array}{l}\text { Muerte del hijo de Neufert, Peter } \\
\text { Neufert. } \\
\text { (adaptada de la trigésimo tercera } \\
\text { alemana) }\end{array}$ \\
\hline
\end{tabular}




\begin{tabular}{|c|c|c|c|c|c|}
\hline año & alemana & española & portuguesa & inglesa & comentarios \\
\hline 1996 & $\begin{array}{l}\text { trigésimo } \\
\text { cuarta }\end{array}$ & & & & \\
\hline \multicolumn{6}{|l|}{1997} \\
\hline 1998 & $\begin{array}{l}\text { trigésimo } \\
\text { cuarta } \quad \text { y } \\
\text { trigésimo } \\
\text { quinta } \\
\end{array}$ & & $\begin{array}{l}\text { décimo } \\
\text { tercera }\end{array}$ & & $\begin{array}{l}\text { Modulor págs } 29,44 \\
\text { (adaptada de la } 21 \text { alemana disponible } \\
\text { en pdf) }\end{array}$ \\
\hline \multicolumn{6}{|l|}{1999} \\
\hline 2000 & $\begin{array}{l}\text { trigésimo } \\
\text { sexta }\end{array}$ & & & tercera & $\begin{array}{l}\text { Architechtural data. } \\
\text { Hoja Modulor sí, } \\
\text { Bancada 85-92, } \\
\text { Electrodomésticos } 85 \\
\end{array}$ \\
\hline \multicolumn{6}{|l|}{2001} \\
\hline 2002 & $\begin{array}{l}\text { trigésimo } \\
\text { séptima }\end{array}$ & & & & \\
\hline \multicolumn{6}{|l|}{2003} \\
\hline 2004 & & & $\begin{array}{l}\text { décimo } \\
\text { séptima } \\
\end{array}$ & & \\
\hline \multicolumn{6}{|l|}{2005} \\
\hline \multicolumn{6}{|l|}{2006} \\
\hline \multicolumn{6}{|l|}{2007} \\
\hline \multicolumn{6}{|l|}{2008} \\
\hline 2009 & $\begin{array}{l}\text { trigésimo } \\
\text { novena }\end{array}$ & & & & \\
\hline 2010 & & $\begin{array}{l}\text { décimo } \\
\text { cuarta }\end{array}$ & & & $\begin{array}{l}\text { Versión en español en pdf: } \\
\text { Página entera Modulor. Bancada 85-92, } \\
\text { electrodomésticos } 85 \mathrm{~cm} \\
\text { No está ya la cocina Frankfurt. } \\
\text { (adaptada de la trigésimo tercera } \\
\text { edición, primera del hijo de Neufert) }\end{array}$ \\
\hline \multicolumn{6}{|l|}{2011} \\
\hline 2012 & cuadragésima & & & cuarta & $\begin{array}{l}\text { Adaptada de la trigésimo novena } \\
\text { alemana } \\
\text { Architechtural data. } \\
\text { Hoja Modulor sí, bancada 85-92, } \\
\text { electrodomésticos } 85\end{array}$ \\
\hline 2013 & & $\begin{array}{l}\text { décimo } \\
\text { quinta }\end{array}$ & $\begin{array}{l}\text { décimo } \\
\text { octava }\end{array}$ & & $\begin{array}{l}\text { (adaptada de la trigésimo séptima } \\
\text { versión alemana) }\end{array}$ \\
\hline 2014 & & & $\begin{array}{l}\text { décimo } \\
\text { octava }\end{array}$ & & \\
\hline 2015 & $\begin{array}{l}\text { cuadragésimo } \\
\text { primera }\end{array}$ & décimo sexta & & & (adaptada de la trigésimo novena) \\
\hline
\end{tabular}

Aunque la tabla está incompleta, es interesante conocer las ediciones en las que se advierte de que ha habido una revisión total y comprobar que las ediciones intermedias no contienen diferencias en lo tocante a la asignación de roles domésticos -las de transición tampoco-, ni en lo referente a medidas sólo hay un cambio en la décimo segunda edición alemana- ni en cuanto al modelo antropométrico -sólo cambia en la edición décimo segunda alemana 
que incorpora el Modulor de Le Corbusier. Por tanto, para el cometido de esta tesis, las lagunas no alteran el análisis.

Según opinión de arquitectos de varios países, se trata de un libro que necesita continuas actualizaciones y adaptaciones a la normativa de cada país. Resulta muy útil en Alemania, donde se lo considera la biblia de la arquitectura, porque cada revisión nace con la actualización de la normativa DIN o Normativa Industrial Alemana. Pero aunque sea más seguro en los otros países consultar otras fuentes en lo referente a normativa, el libro es muy útil para orientar en cuanto a medidas. Las medidas que aconseja el libro, como ya he dicho, pueden ser consideradas referentes globales según diversos profesionales de la arquitectura y el diseño:

El libro El Arte de Proyectar en Arquitectura (Bauentwurfslehre. Handbuch für den Baufachmann, Bauherren, Lehrenden und Lernenden; Aprendizaje de Construcción. Manual para Arquitectos, Constructores, Profesores y Estudiantes) de Ernst Neufert (1900 1986) se publicó por primera vez en marzo de 1936. Es un libro de texto básico para el aprendizaje de arquitectura que nació a partir de la documentación recogida para una serie de conferencias por el mismo Neufert en las que recopiló numerosas mediciones, variables métricas y conocimientos adquiridos por el arquitecto a lo largo de su experiencia profesional. Este libro es utilizado como referencia para muchos estudiantes que desean conocer las dimensiones estándar de un espacio. (Renderos et alt., 2015: 3)

El propio Neufert se explica en el prólogo de su libro:

Por un lado nos apoyamos en nuestros antecesores, pero, por otro, todo continúa; somos hijos de nuestro tiempo y tenemos la mirada puesta en el futuro, además, la perspectiva de cada individuo es a menudo muy distinta, debido a las diferencias de educación y a la formación posterior, a la influencia del entorno y a la capacidad y grado de formación propia de cada individuo.(Neufert, 1991, VII)

Para descubrir el androcentrismo en las medidas de los elementos básicos de una cocina estándar, voy a estudiar las medidas de las cocinas estándar disponibles en el mercado y las imágenes asociadas a ellas. Realizo una 
búsqueda de la posible repercusión de las medidas del Neufert y del Modulor de Le Corbusier, en las cocinas más comunes de la actualidad, y su influencia en las representaciones humanas que aparecen en la publicidad de las cocinas, para establecer la cadena de trasmisión del modelo heteropatriarcal de asignación de roles a través del espacio interior central, la cocina.

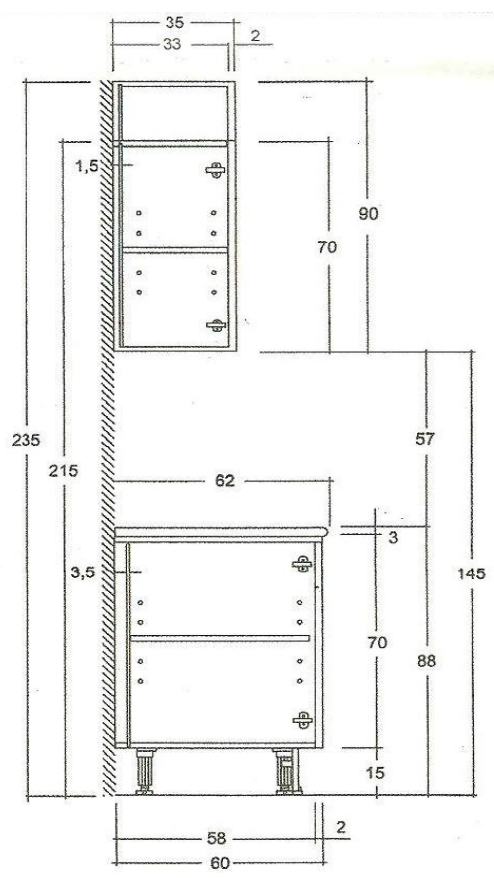

166. Las medidas de los muebles de la cocina. Fuente: Kansei, 2016.

Veamos algunas observaciones sobre la cocina actual:

En la industria del mueble de cocina se mantiene una norma: «La altura de la encimera determina el resto de alturas de la cocina, altura a la que se cuelgan la campana y los muebles altos» (Valcucine, 2016), pero, la altura de la bancada de la cocina estándar depende, a su vez, de los electrodomésticos estándar que se empotran debajo de ella, las lavadoras y lavavajillas se fabrican con una altura estándar de $85 \mathrm{~cm}$, lo cual implica que la industria de electrodomésticos es, en última instancia, quien marca los estándares de las alturas. 


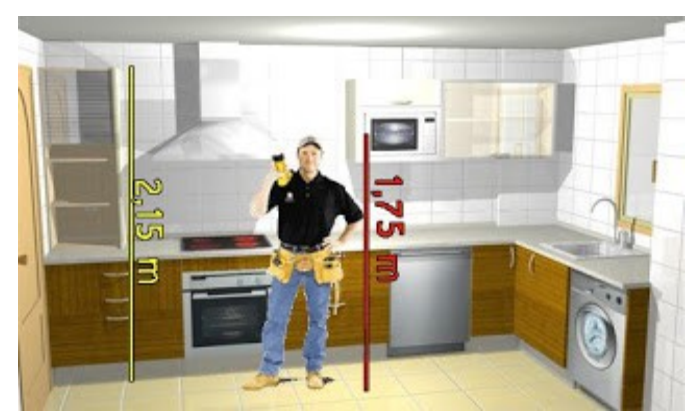

167. Medidas estándar de los módulos de cocinas. Fuente: Hermanos Pérez, 2012.

La altura habitual de un lavavajillas es de $85 \mathrm{~cm}$ pero casi todos los lavavajillas cuentan con una tapa que, al quitarla, hace que la altura descienda a $83 \mathrm{~cm}$. Si el espacio del que dispones es de $83 \mathrm{~cm}$. Asegúrate antes de comprar tu lavavajillas de que la tapa se pueda quitar. (Pérez, 2015: s/c)

Se ve, a su vez, la adhesión de la industria de la construcción respecto a las normas de los grandes maestros de la arquitectura, como podemos ver en estas cocinas mueble extraídas del Arte de proyectar de Neufert. (véase la ilustración 165):

De modo que el último referente de estos estándares no es tampoco la industria, sino los arquitectos de referencia en obras como el Modulor de Le Corbusier o El arte de proyectar de Neufert, -que en su trigésimo tercera edición, donde introduce la horquilla $85-90 \mathrm{~cm}$ para la bancada, mantiene la altura de los electrodomésticos en $85 \mathrm{~cm}$.

Tal como resulta evidente en la ilustración 166, la altura estándar del plano de trabajo en una cocina es la suma del zócalo estándar, $15 \mathrm{~cm}$, el módulo bajo estándar, $70 \mathrm{~cm}$ y la encimera estándar, $3 \mathrm{~cm}$, es decir:

$$
70+15+03 \text { Suman } 88 \mathrm{~cm}
$$

Por tanto, los $88 \mathrm{~cm}$ se perfilan como referencia estándar para las bancadas de cocina de producción industrial en serie. 
Pero esta medida se corresponde con la $3^{\mathrm{a}}$ opción de la ilustración siguiente, donde explícitamente está asignada una mujer. Es decir, la elección predeterminada de los $88 \mathrm{~cm}$ de la industria implica la asignación predeterminada de la mujer a la cocina.

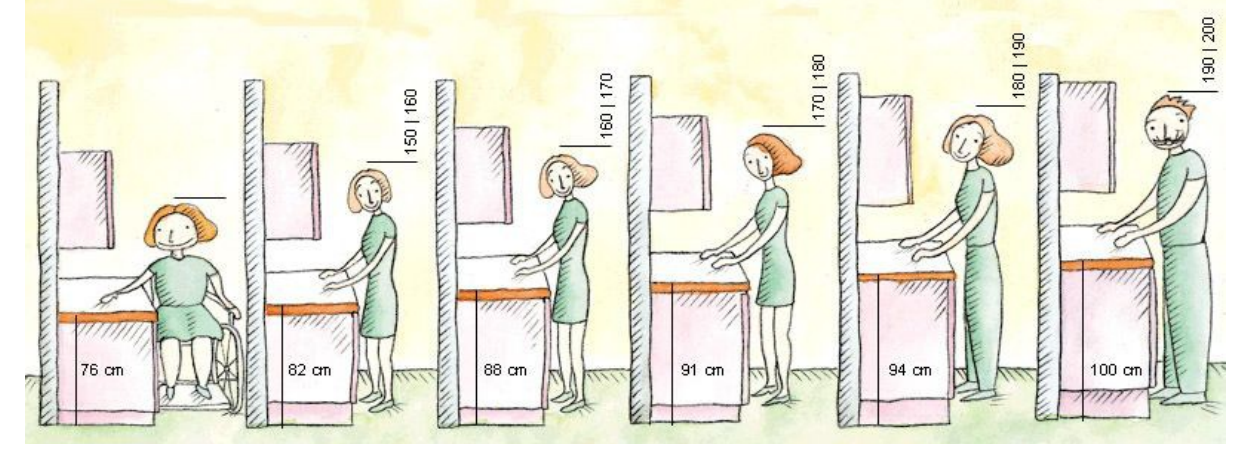

168. Consejos de ergonomía. Fuente: Kansei, 2016.

Nótense el sexo de los maniquíes y las alturas correspondientes. Otra vez, si quitamos los $3 \mathrm{~cm}$ de la encimera, vemos en la tercera figura la propuesta estándar de la industria de la construcción: $88-3=85 \mathrm{~cm}$, coincidente con la recomendación del Neufert hasta la trigésima edición. No olvidemos a lo largo de este trabajo que a esa altura en los catálogos de encimera se asigna una mujer de estatura entre 160 y $170 \mathrm{~cm}$.

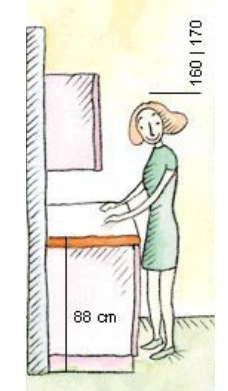

169. Detalle de la figura 112. Consejos de ergonomía. Fuente: Kansei, 2016.

La industria fabrica varias tallas ergonómicas, como indica la ilustración 168, pero no se instalan dos cocinas en una vivienda popular. ¿Cuál se elige? ¿Quién suponen, desde las posiciones de decisión de las promociones de vivienda, constructoras o personal técnico, que va a trabajar en ella? Y una vez instalada, ¿quién la hace funcionar? ¿Quién podrá justificar su ausencia por la 
inadecuación de su talla a las medidas? Ya sé que se me puede decir que hay varones que se ocupan de la cocina, pero son las excepciones, no sirve ese argumento para desmontar el mandato social en vigor.

El poder todavía está ahí, aun cuando en algún caso individual no se utilice. Christine Delphy señala lo mismo: «el individuo varón particular [puede] no jugar un papel en esta opresión general que tiene lugar desde antes que él aparezca en escena, pero recíprocamente, ninguna iniciativa personal de su parte puede superar o mitigar lo que existe desde antes y desde fuera de su entrada».(Pateman, 1995: 220)

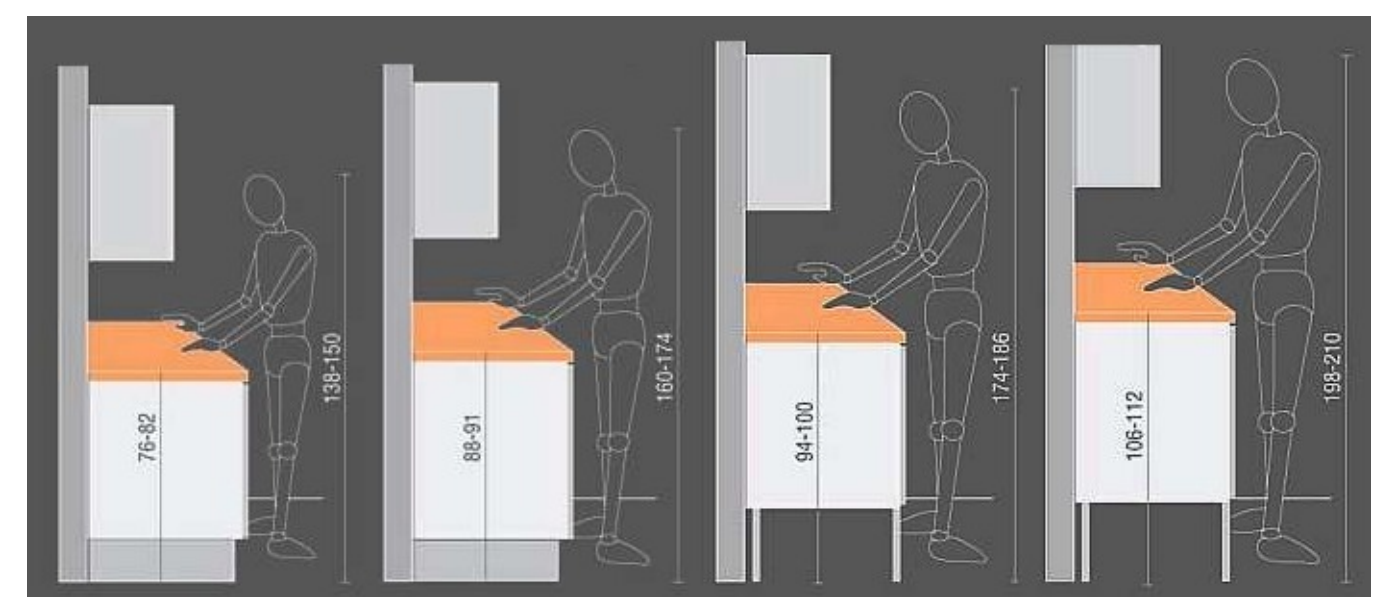

170. Altura encimera cocina. Fuente: Valcucine, 2016.

Valcucine afirma que «cuando la encimera es muy alta la persona pierde visibilidad de lo que cocina. Por el contrario, si es muy baja, hemos de doblar la espalda durante todo nuestro trabajo en este espacio. De esta posición incorrecta se derivan dolores en la espalda y cansancio al realizar las tareas en la cocina.» (Valcucine, 2016: 1).

$\mathrm{Y}$ «Estas medidas ergonómicas ayudan mucho en personas mayores a sentirse seguros en la cocina.», donde hay que notar el género masculino plural utilizado por la marca comercial para dirigirse a su cliente, que seguramente no será el usuario final del producto, pero sí será mayoritariamente varón el negociador de la compra (en la fase de diseño o decisión de inversión será el arquitecto, el constructor o el promotor). 
Qué espalda está en riesgo queda en evidencia en la siguiente figura del Neufert, pero, por si acaso, las figuras anteriores evidencian que si se instala una cocina supuestamente adecuada a la «usuaria» habitual, el usuario medio debe cuidarse de trabajar en ella.

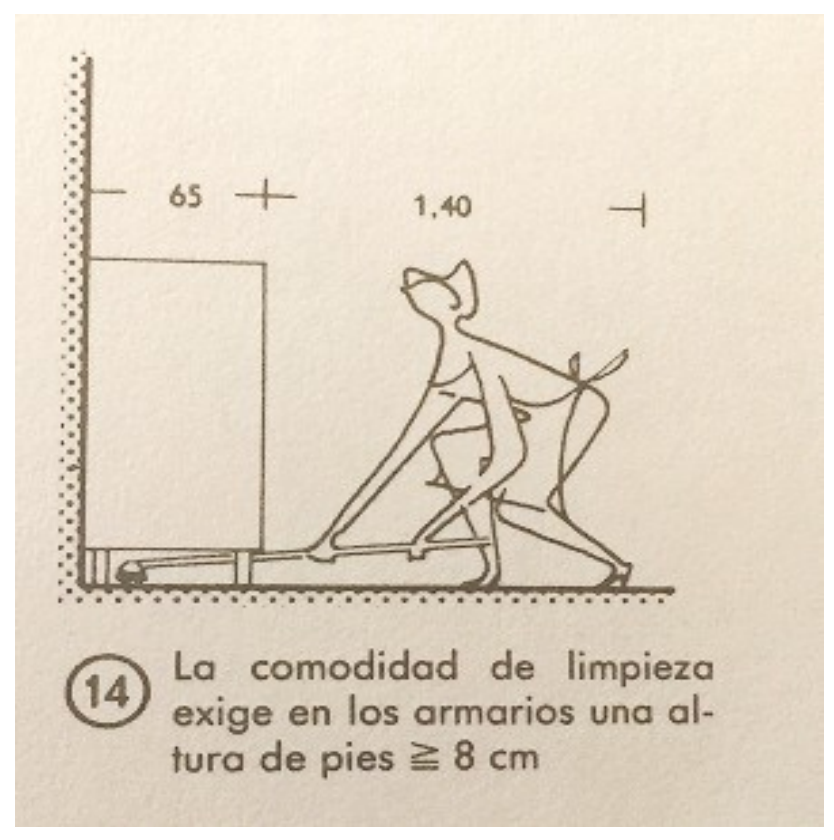

171. Erns Neufert. Estereotipo de género en las tareas domésticas.

Página 205 de la $13^{a}$ edicion en castellano, 1991.

Una firma famosa por la economía y el diseño de sus productos es IKEA. En los módulos bajos de la cocina de IKEA el zócalo más el módulo, suman $86 \mathrm{~cm}$ de altura. Como veremos más adelante esos $86 \mathrm{~cm}$ son los recomendados por el Modulor de Le Corbusier.

Por si los dibujos esquemáticos de Neufert y de la industria no fueran suficientemente explícitos, vamos a ver que las alturas medias de las figuras femeninas que aparecen en el dibujo, correspondientes a esa encimera de 88 $\mathrm{cm}$, se corresponden con la altura media de las mujeres.

La talla media de mujeres es 161,2 y varones 172,1 según los datos de Eurostat de 2001, expuestos por el INE a fecha actual de 2016. 


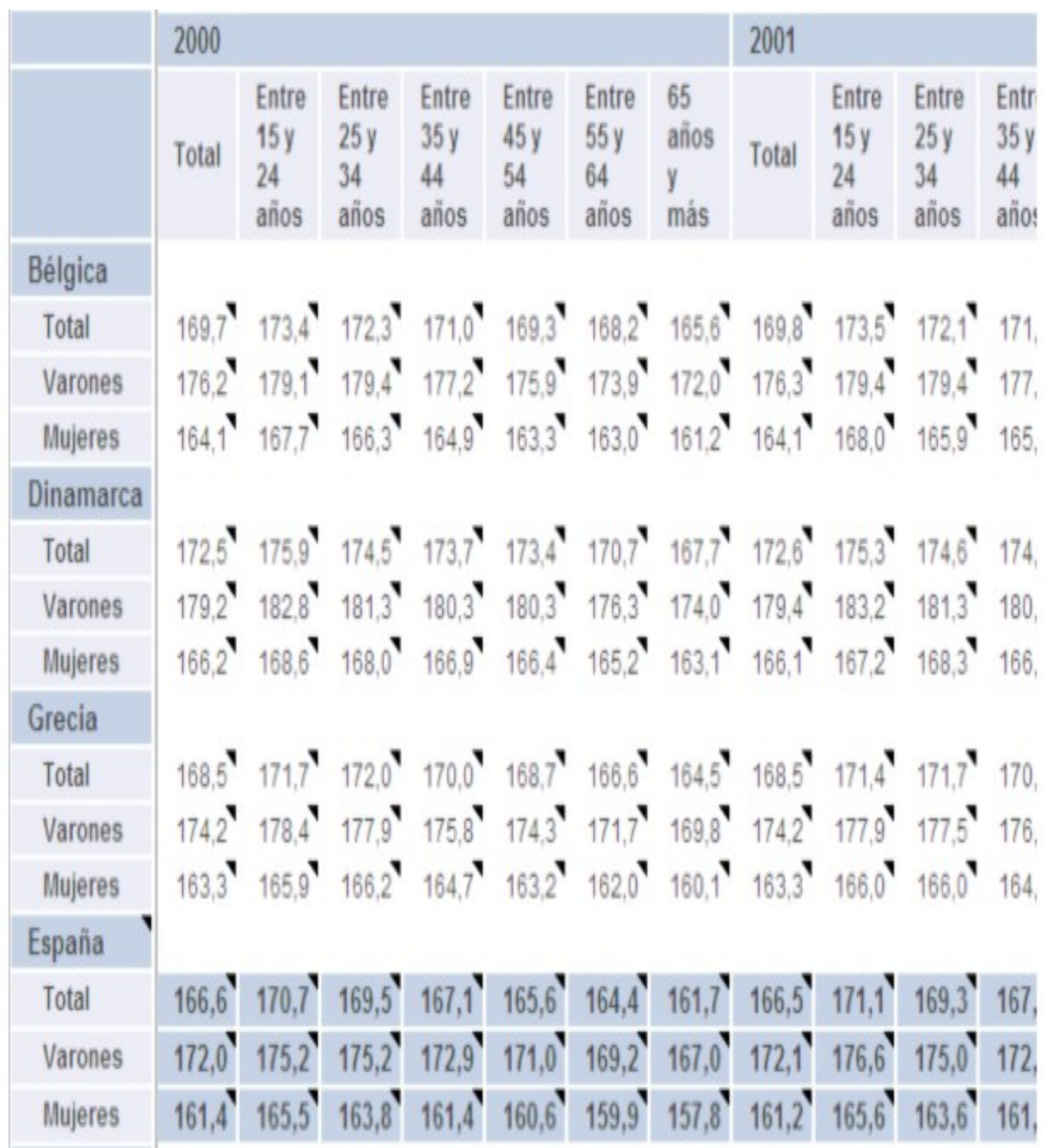

172. Tallas mujeres y hombres. Fuente: EUROSTAT-INE, 2001.

De reciente publicación, el más detallado trabajo hecho hasta la fecha, abarca desde 1914 hasta 2014. Se analizan los datos de 200 paises y más de 18 millones de personas en referencia a sus estaturas. Es un estudio realizado en coordinación con la Organización Mundial de la Salud y una red de 800 personas investigadoras, entre quienes está Fernando Artalejo, científico español de la Universidad Autónoma de Madrid (Elpaís.com, 2016). 
En estas gráficas dejan clara la altura máxima por termino medio de varones y mujeres en los 200 países en los que han realizado el estudio, y más concretamente cuál es la altura media por países y por sexo siendo el de mayor rango Holanda en el caso de los varones, con 182,5 cm de altura media en 2014, y Letonia en el caso de las mujeres con $169,8 \mathrm{~cm}$ de altura media.

\section{ALTURA MEDIA, POR PAÍSES}
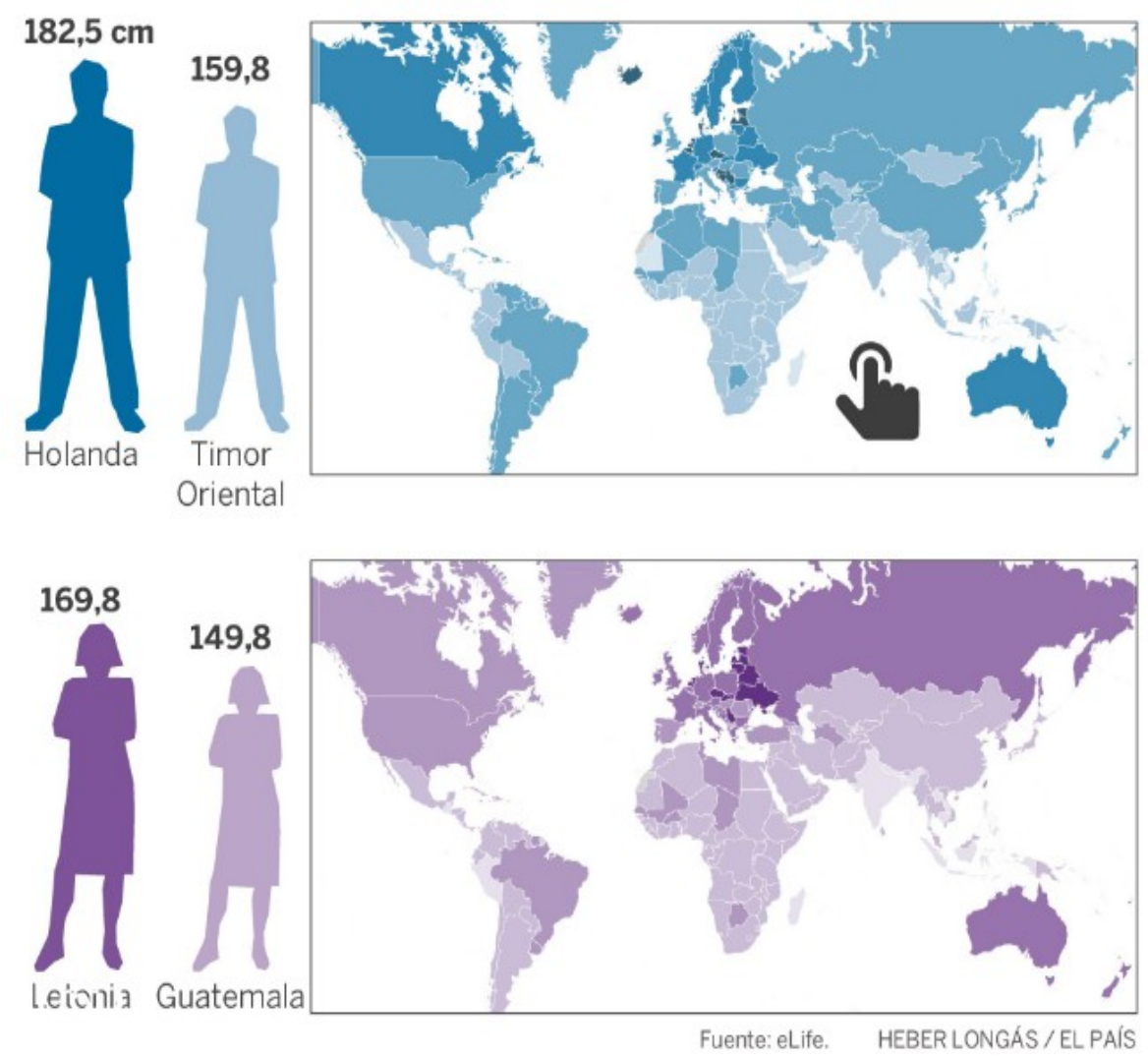

173. El mapa mundial de la estatura. Fuente: El País, 2016.
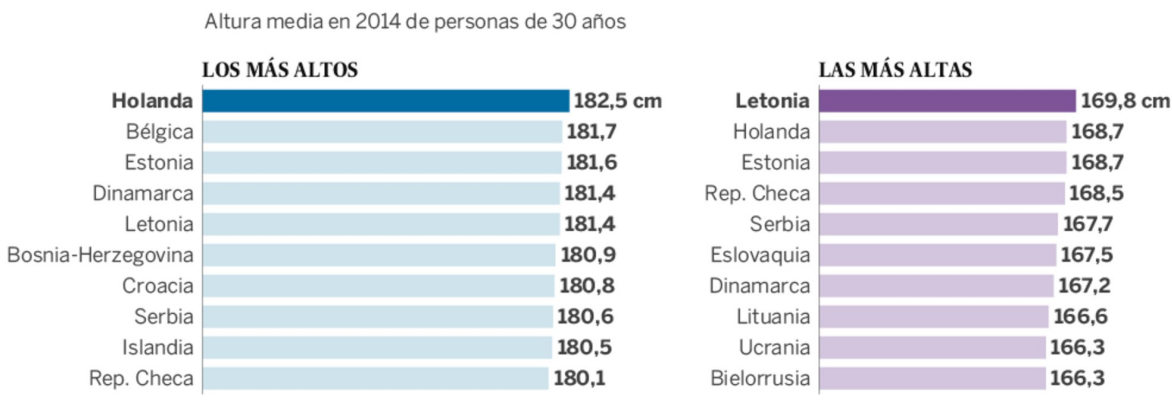

174. El mapa mundial de la estatura. Fuente: El País, 2016. 


\subsection{La cocina y los modulores}

Le Corbusier construyó dos cánones del cuerpo, tarea que han abordado muchos otros artistas a lo largo de la historia. La mayoría de ellos eligieron el cuerpo masculino:

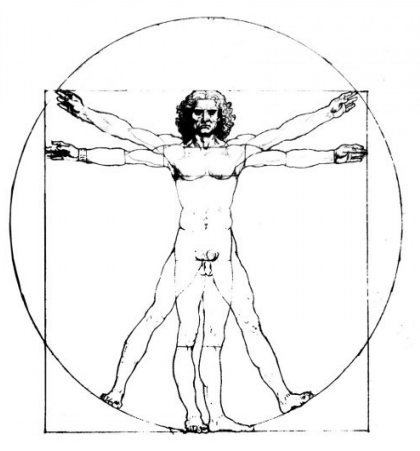

I ennardo Da Vinri

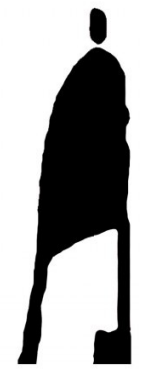

Gilenn Murrutt

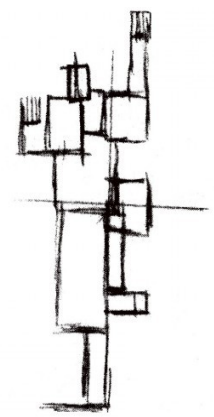

Theo van Doeshura

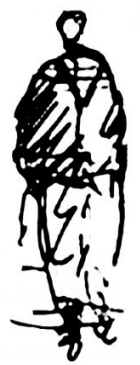

Norman Foster

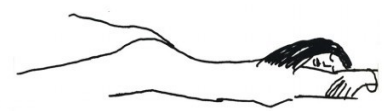

Oscar Niemever

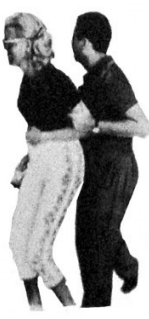

Alison and Peter Smithson

175. Noor Makkiya. Recopilación de escalas humanas de arquitectos famosos. Fuente:

Plataforma de arquitectura, 2016. 

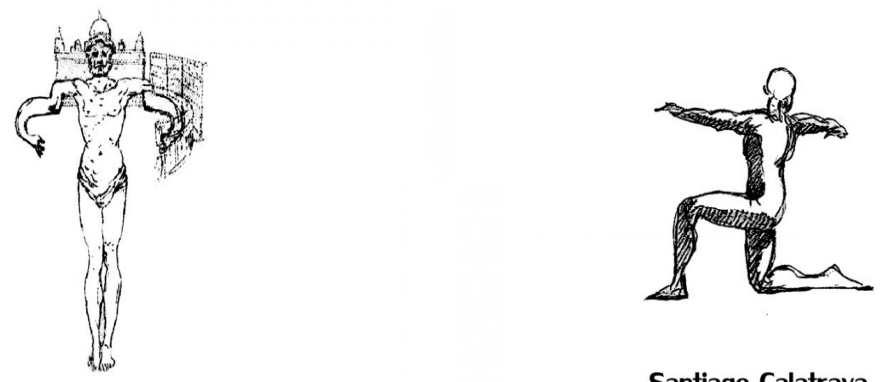

Gian Lorenzo Bernini

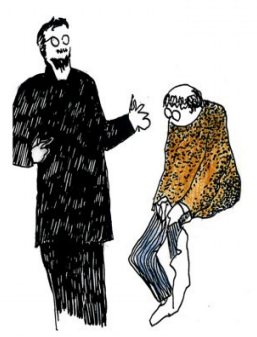

Peter Conk
Santiano Calatrava

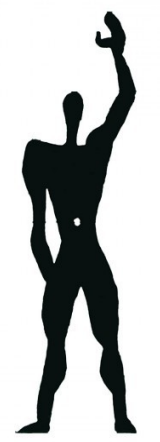

I e Corhu usier

176. Noor Makkiya. Recopilación de escalas humanas de arquitectos famosos. Fuente:

Plataforma de arquitectura, 2016.

Vamos a centrarnos en los dos cánones de Le Corbusier el Modulor I a) y Modulor I b). Ambos se apoyan en el número de oro, cuya comprensión y profundización Matila Ghyka le había facilitado, tras su publicación en 1927 de Estética de las proporciones en la naturaleza y en las artes (Le Corbusier, 1953: 63). No era el primero en intentar un sistema de medidas relacionado con el número de oro, Durero, Zeising, Mössel y Neufert le precedieron. Sí ha sido el último en intentar generalizar un sistema de medidas antropométrico, en plena difusión del sistema métrico decimal. Las actualizaciones del Neufert desde poco después de la duodécima edición alemana, sustituyen el canon de Mössel por el Modulor 1b) de Le Corbusier, lo cual convierte al Modulor en el sistema antropométrico de referencia actual.

Ya en el siglo XIX, fue Zeising quien rescató las virtudes de la proporción áurea, tan querida por los renacentistas, en particular una relacionada con las proporciones del cuerpo humano (del varón). «Zeising, en 1885, efectuó medidas en miles de cuerpos humanos y comprobó estadísticamente que el 
ombligo divide al hombre medio según la extrema y media razón» (Gómez et alt, 2003: 233) o lo que es lo mismo, según la proporción divina, la razón áurea o número de oro, es exactamente igual a

$$
(1+\sqrt{5}) / 2=\Phi
$$

Cuyo valor aproximado es 1,62. (Matila Ghyka, 1983: 24-28)

La construcción geométrica era conocida por los pitagóricos que la utilizaban para construir el símbolo de la escuela, el pentagrama o pentágono regular estrellado.

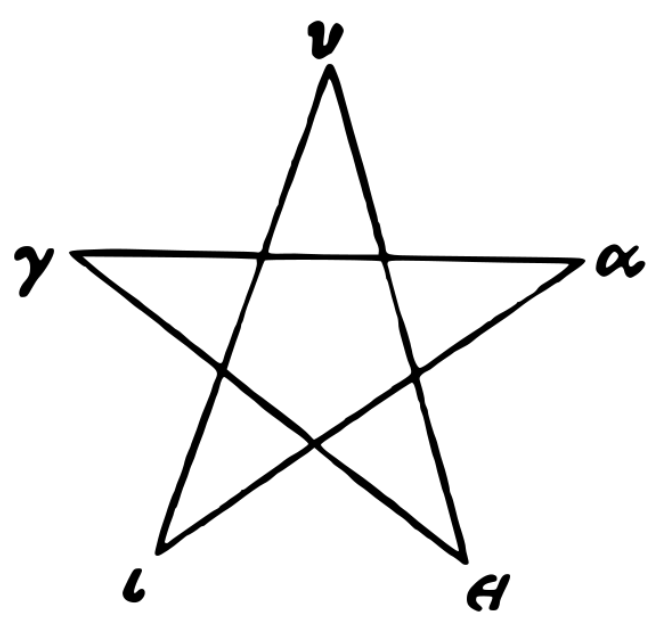

177. Pentagrama místico pitagórico, con la palabra «úyı́ía», Hugieia, es decir, «salud». Fuente: Cátedra de Cultura Científica, 2013.

Euclides retomó el problema de la división de un segmento en su extrema y media razón en Los Elementos, en el libro II, proposición 11 y en el libro VI, proposición 30. La proposición 11 expresa geométricamente la relación definida por la proporción áurea: «Dividir una recta en dos partes de modo que el rectángulo comprendido por la recta entera y por una de sus partes sea equivalente al cuadrado de la otra parte» (Euclides, 1970, 746), es decir:

178. Segmento áureo de un segmento. Fuente: G.E.P., 2016.

$A B / A X=A X / X B$ 
De estas expresiones se deducen construcciones muy visuales como son las ilustraciones siguientes:

Construcción 1:

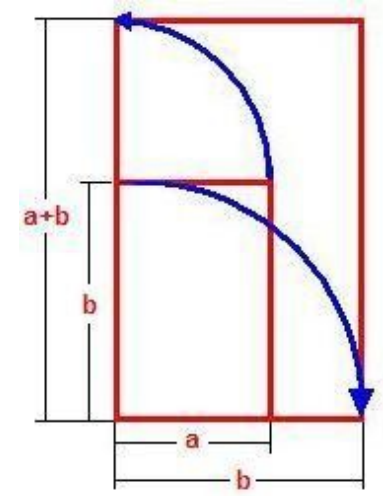

179. Construcción de la sección áurea. Fuente: Piziadas, 2016.

Dibujamos el rectángulo a-b y luego construimos el rectángulo mayor que tiene como lado menor $b$ y como lado mayor $a+b$. La diagonal común a ambos justifica que son semejantes $y$ al escribir la proporcionalidad de sus lados obtenemos la proporción áurea:

$$
\frac{b}{a}=\frac{a+b}{b}
$$

Construcción 2:

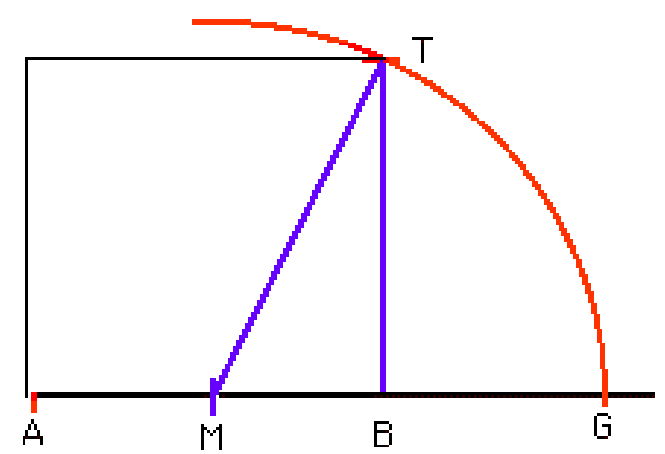

180. Construcción de la sección áurea. Fuente: G.E.P., 2016. 
Dibujamos el segmento $A B$, tomamos su punto medio $M$ y trazamos un arco con centro en $\mathrm{M}$ y radio $\mathrm{MT}$, el arco corta a la prolongación de $\mathrm{AB}$ en el punto $\mathrm{G}$.

Si tomamos el lado del cuadrado como unidad, el segmento AG mide $=\phi$

Todas las ediciones de El arte de proyectar en Arquitectura, de Neufert, incorporan también una construcción del segmento áureo. En la edición decimotercera figura en la página 23.

El descubrimiento de la proporción de oro en el cuerpo humano, realizada por Zeising implicaba que el hombre de Vitrubio, dibujado por Leonardo da Vinci para ilustrar un estudio sobre el canon de Vitrubio, estaba inscrito en un círculo cuyo radio era la sección áurea de la altura total del hombre inscrito en él, puesto que dicho radio era la distancia entre el ombligo y la planta del pie. (ver imagen 1)

El texto manuscrito que rodea a la imagen es una transcripción de las palabras de Vitrubio, la traducción al castellano es de Ángel González García:

Vitruvio arquitecto dice en su obra sobre la arquitectura que las medidas del hombre están, por naturaleza, distribuidas de esta guisa; a saber: que 4 dedos hacen un palmo y 4 palmos hacen un pie; 6 palmos hacen un codo; 4 codos hacen un hombre y que 4 codos hacen un paso y 24 palmos un hombre. Estas medidas están en sus edificios. Si abres tanto las piernas que tu altura mengüe en 1/14 y tanto extiendes y alzas los brazos que con los dedos medios alcances la línea que delimita el extremo superior de la cabeza, has de saber que el centro de los miembros extendidos será el ombligo y que el espacio que comprenden las piernas será un triángulo equilátero. La longitud de los brazos extendidos de un hombre es igual a su altura. (Da Vinci, 1986: s/c ) 
En caso de que esto fuera exacto, el hombre con las piernas abiertas y los brazos en horizontal, dibujarían un pentágono regular y su pentágono estrellado.

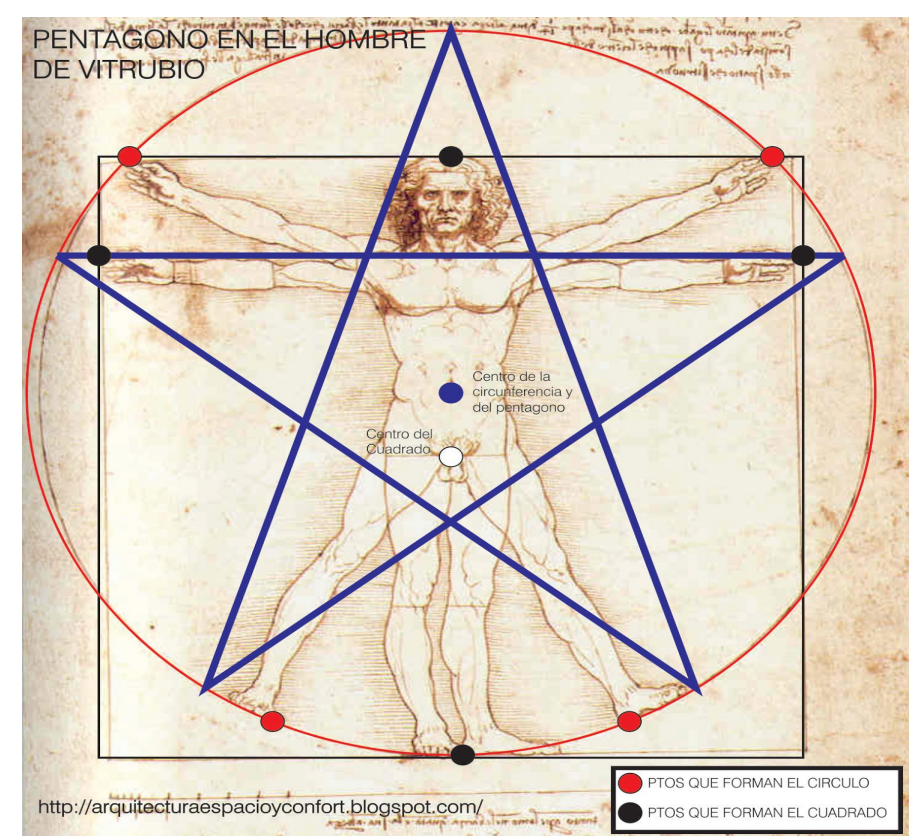

181. Leonardo da Vinci. Cuadrado y pentágono en el hombre de Vitrubio. Fuente:

Berman Araya Lara, 2013.

El módulo a partir del cual es posible dibujar un pentágono regular es el triángulo de oro. Un triángulo isósceles en el que los lados iguales y la base guardan la proporción áurea.

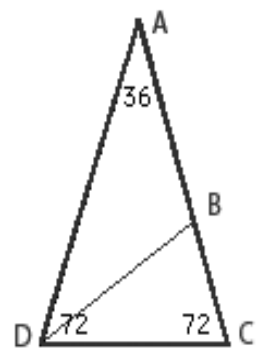

182. Triángulo áureo y construcción del pentágono regular del hombre de Vitrubio ideado por Da Vinci. Fuente: G.E.P., 2016.

En la figura anterior, se observan varios triángulos, denotados por las letras mayúsculas $A, B, C$ y $D$ en sus vértices. Las propiedades de dichos triángulos permiten demostrar la afirmación anterior acerca de la proporción que guardan los lados del triángulo áureo: 
Los triángulos siguientes son semejantes porque tienen los ángulos iguales:

$\mathrm{DCA} \approx \mathrm{CDB}$

Por lo tanto los lados opuestos a ángulos iguales son proporcionales.

Si la base DC de DCA vale 1, teniendo en cuenta que los triángulos DCA, CDB y DBA son isósceles, se cumple que $D C=D B=A B=1$ y podremos escribir:

$A C / D C=D C / B C$, luego $x / 1=1 / x-1$, de donde $x^{2}-x-1=0$, por lo que

$x=\frac{1 \mp \sqrt{1+4}}{2}$ de dónde se deduce que una solución será $x_{1}=$

$\frac{1-\sqrt{5}}{2}$ y la otra $x_{2}=\frac{1+\sqrt{5}}{2}$, que, como hemos visto antes, recibe el

nombre de número de oro y se representa con la letra griega $\Phi$

En 1927, Cook retoma los resultados de Zeising y los aplica al cuerpo femenino. Construye un canon ideal para el cuerpo femenino (Ghyka; 1983: 3941), que cumple la relación de oro. Obsérvense las medidas en la imagen 183.

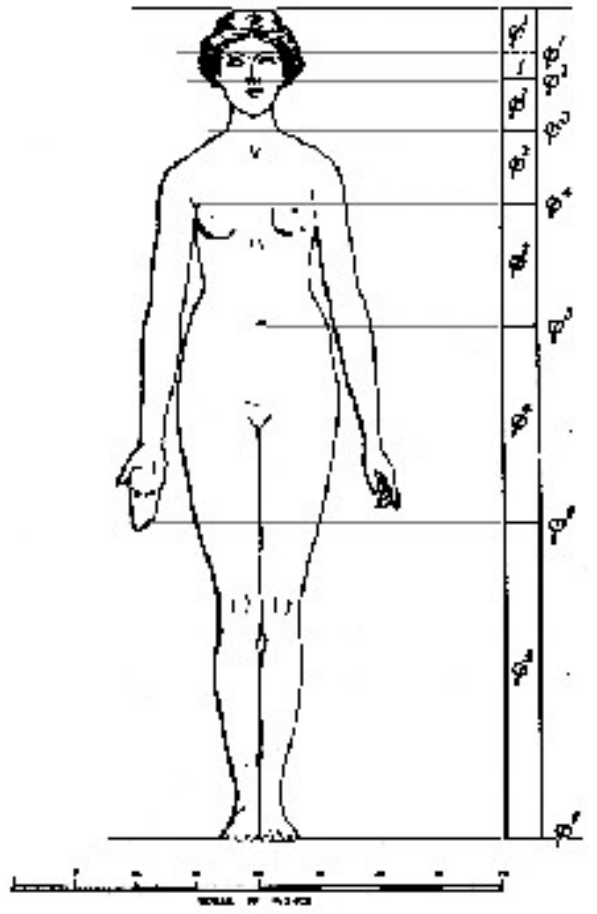

183. Matila GHYKA. Modulora de Cook, 1927. 
En la figura 183, la columna a la derecha del cuerpo femenino es una cinta para medir tomando como referencia el número de oro y sus potencias. Veamos que la relación entre la altura total y la altura del ombligo coincide con la rescatada por Zeising:

$$
\text { altura total/altura ombligo }=\phi 7 / \phi 7-\phi 5=1,62 \sim \phi
$$

Por su parte, Neufert, recopila los cánones del cuerpo humano (siempre varón y simbolizando todo ello con la imagen del hombre de Vitrubio de Da Vinci) para justificar sus elecciones de medidas de edificios, estancias, instalaciones y objetos.

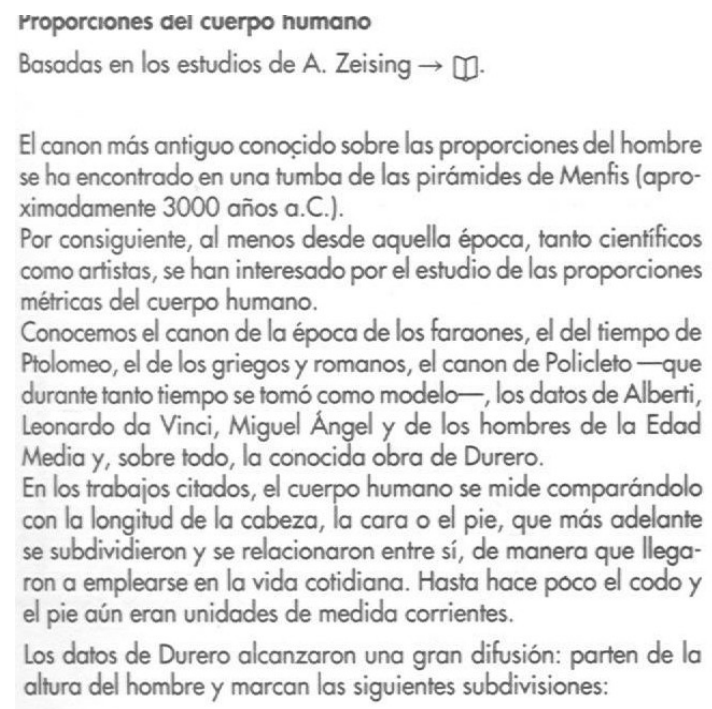

$1 / 2 \mathrm{n}$ = airura ae ia cadeza y ei ronco uesue ia nurcapuaura,

$1 / 4 \mathrm{~h}$ = altura de la pierna desde el tobillo hasta la rodilla y distancia del ombligo al mentón,

$1 / 6 \mathrm{~h}=$ longitud del pie,

$1 / 8 \mathrm{~h}=$ altura de la cabeza desde el canto inferior del mentón y distancia entre las tetillas,

$1 / 10 \mathrm{~h}$ = altura $\mathrm{y}$ anchura de la cara (incluidas las orejas) y distancia entre la muñeca y el extremo del dedo corazón,

$1 / 12 h=$ anchura de la cara a la altura de la base de la nariz y anchura de la pierna encima de la rodilla, etc.

Las subdivisiones llegan hasta $1 / 40 \mathrm{~h}$.

En el siglo pasado, A. Zeising emprendió un amplio estudio de las proporciones del cuerpo humano basándose en la sección áurea. Por desgracia, sus trabajos no recibieron la debida atención hasta hace muy poco tiempo, cuando el conocido investigador en este campo, E. Moessel $\rightarrow \square$, apoyó sus investigaciones en el método elaborado por A. Zeising.

Desde 1945, Le Corbusier empleó, en todos sus proyectos, las proporciones basadas en la sección áurea, agrupándolas en un sistema de medidas que denominó «Le Modulor» $\rightarrow \square$. Sus unidades básicas son la altura del hombre $=1,829 \mathrm{~m}$ y la altura hasta el ombligo $=1,130 \mathrm{~m} . \rightarrow$ p. 37

184. Ernst Neufert. Historia de las proporciones del cuerpo humano,1950.

La incorporación del Modulor de Le Corbusier a las ediciones posteriores a la undécima, ha contribuido a expandir el uso del canon corbuseriano en todo el mundo. 


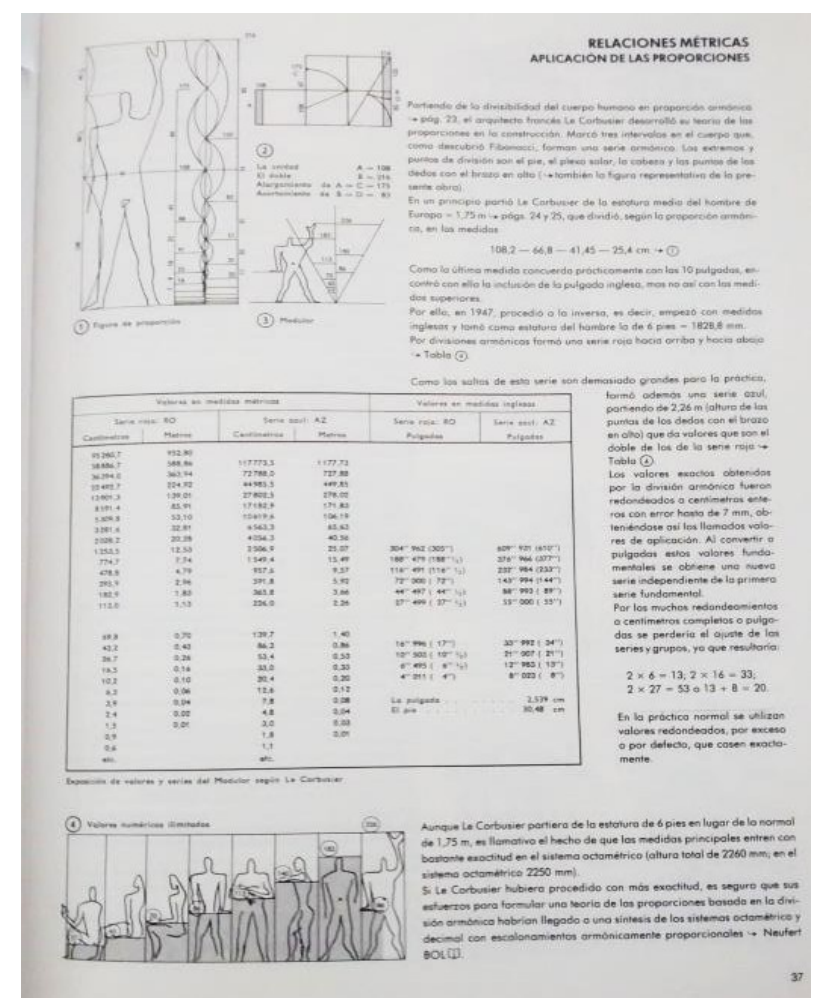

185. El Modulor de Le Corbusier en El arte de proyectar en arquitectura. Fuente: Ernst Neufert, 1950.

Es por ello que procede hablar a continuación del Modulor a partir del texto original de Le Corbusier.

En su libro «Modulon», publicado en 1950, cuya primera edición en castellano es de 1953, Le Corbusier propone dos Modulores.
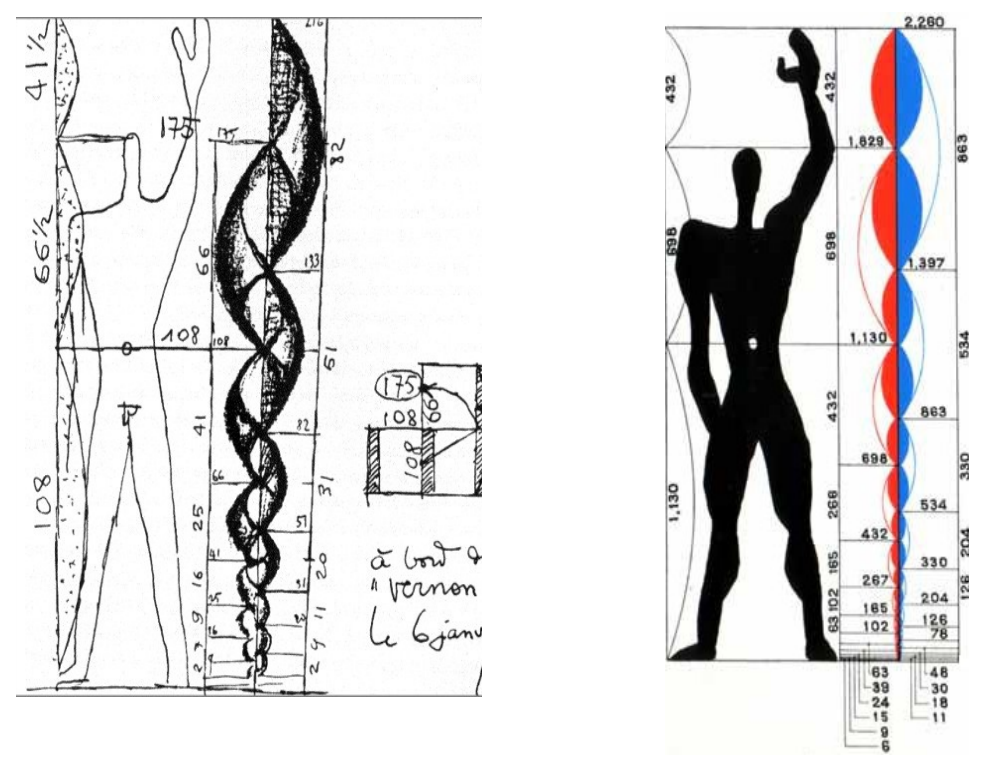

186. Le Corbusier. Izquierda Modulor / a) Derecha Modulor II b) , 1950. 
Para el Modulor I a), (Le Corbusier, 1953: 49), a la izquierda de la imagen 186, el dibujo esquemático no deja lugar a dudas de que es un varón. Su estatura es de $175 \mathrm{~cm}$ y la altura de su ombligo de $108 \mathrm{~cm}$. La imagen de la derecha es la del Modulor I b) (Le Corbusier, 1953: 302), también es un varón y su estatura es de $183 \mathrm{~cm}$, la altura del ombligo es de $113 \mathrm{~cm}$.

Tomando las medidas indicadas en la imagen, el Modulor I a) cumple que $175 / 108 \sim 1,62 \sim \phi \mathrm{cm}$

Para el Modulor I b) también se cumple que 183/113 1.62 $\phi$, (Le Corbusier, 1953: 61) es decir, ambos se aproximan al número de oro.

La altura $183 \mathrm{~cm}$ a su vez equivale a seis pies (Le Corbusier, 1953: 80), lo cual es la talla del hombre de Vitrubio (De Architectura, 1991: 81), a la vez que da cuenta del deseo de Le Corbusier de reconciliar las medidas de longitud anglosajonas con el sistema métrico decimal.

La altura de bancada más frecuente en la industria, $88 \mathrm{~cm}$, se aproxima a la altura de la bancada general del Modulor I b) masculino de le Corbusier, 86 según se observa en las ilustraciones 188 y 189. Los dos centímetros de diferencia se explicarían por el aumento de talla de la población. Ooreka, la marca de cocinas de IKEA, reconoce como referencia los $85 \mathrm{~cm}$ recomendados en los libros de Neufert desde 1958 hasta su muerte en 1986. Difieren de las medidas del Modulor I b) sólo en un $\mathrm{cm}$ y reconocen que la tendencia en la industria de la fabricación de cocinas es el incremento positivo de esta medida, aunque construye sus módulos, como hemos visto, con una altura de $86 \mathrm{~cm}$.

Las grandes firmas de cocinas actualizan su discurso de acuerdo con el argumento de que se produce un aumento de la altura de la población. Aumento que el estudio publicado el 1 de agosto de 2016 en la revista científica de acceso gratuito eLIFE, sobre el mapa mundial de la estatura, matiza según países, y del que se deriva que existe una brecha entre los países más ricos y los más pobres. En los países más pobres la estatura dismunuye, afirma este estudio. 
La hauteur d'un plan de travail de cuisine classique sera de $85 \mathrm{~cm}$. Mais, comme la population grandit, on trouve de plus en plus chez les cuisinistes des plans de travail de $90 \mathrm{~cm}$ de hauteur. (OOREKA, 2015: $1)^{16}$

Además el estudio referido en las imágenes 173 y 174 establece a fecha de 2014 a los hombres holandeses como los más altos del planeta con una estatura media de $182,5 \mathrm{~cm}$, la cual está por debajo del 1,83 que sirvió de base a Le Corbusier.

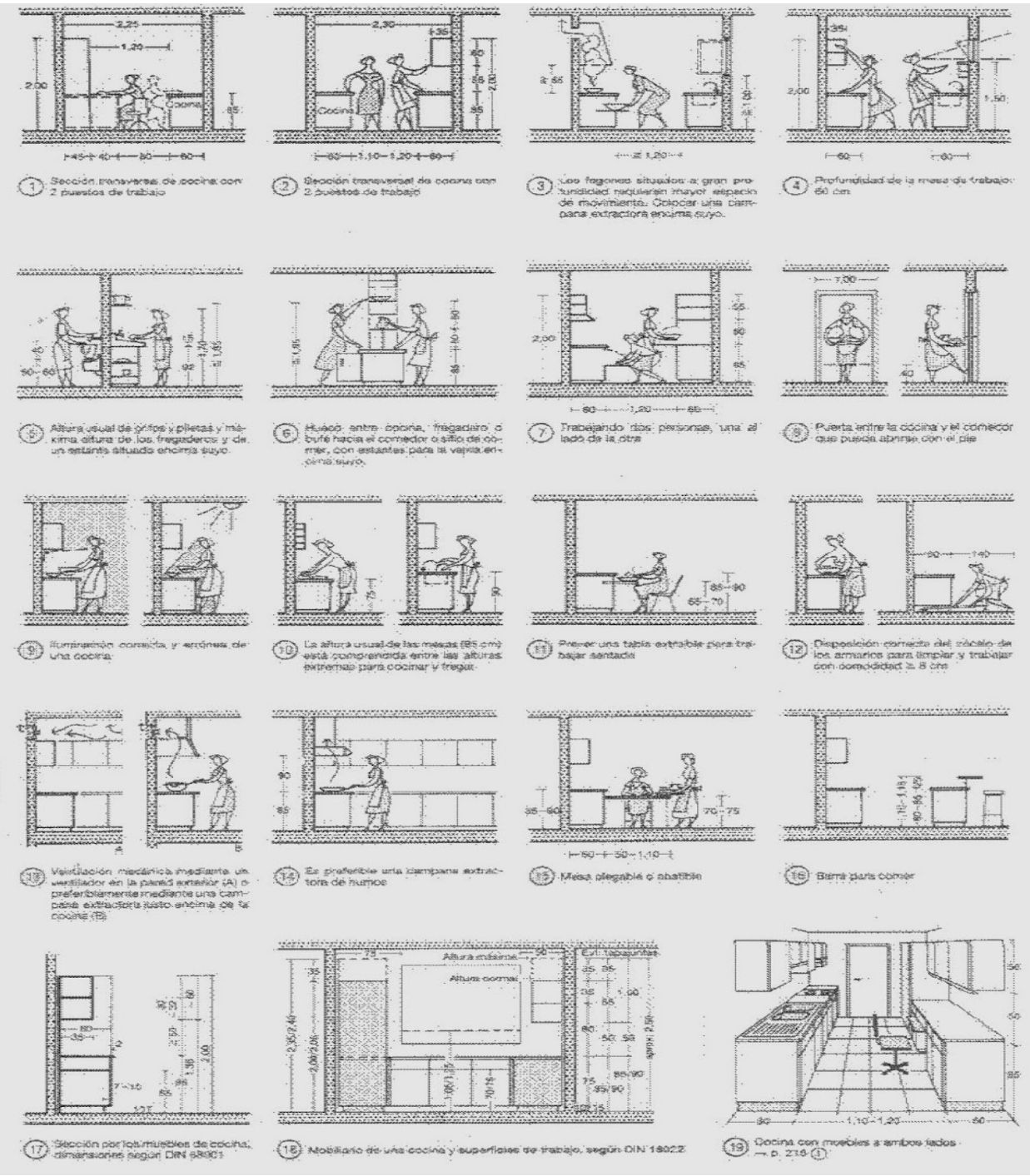

187. Ernst Neufert. Estándares, 1991.

16. La altura de la bancada de la cocina clásica será de $85 \mathrm{~cm}$, Pero como la población gana en estatura, se encuentran en las industrias del mueble de cocina cada vez más bancadas de $90 \mathrm{~cm}$ de altura . (Traducción propia). 
Los $86 \mathrm{~cm}$ del Modulor $1 \mathrm{~b}$ ) de Le Corbusier corresponden al canon masculino clásico de seis pies o sea $183 \mathrm{~cm}$. No tiene nada que ver con el aumento de la talla de la población, lo que aumenta es la talla del hombre medio no del hombre canónico. Ni qué decir tiene la paradoja a la que se ve sometida esta medida, se asigna a la mujer de talla media $162 \mathrm{~cm}$ pero se corresponde con la talla de un varón de $183 \mathrm{~cm}$. Esa encimera, «ergonómicamente», demandaría un usuario varón de talla canónica clásica. No puede deberse a un olvido o despiste, el obviar que el sexo al que el patriarcado y el androcentrismo de la arquitectura asignan las tareas de la cocina sea el femenino.

Los estándares industriales para cocinas, inodoros, muebles, ventanas, puertas, fueron tomados de Le Corbusier directamente de su Modulor 1 b) 0 indirectamente de los Neufert posteriores a la undécima edición alemana. Como podemos ver en multitud de publicaciones comerciales y comprobar, in situ, en las construcciones de vivienda protegida, las bancadas estándar siguen siendo de $88 \mathrm{~cm}$ de altura. En las ilustraciones 188 y 189 se puede observar que la recomendación de Le Corbusier difiere sólo en un par de cm por debajo: $86 \mathrm{~cm}$. Diferencia que las empresas justifican por el incremento de la talla de la población, como hemos dicho antes.

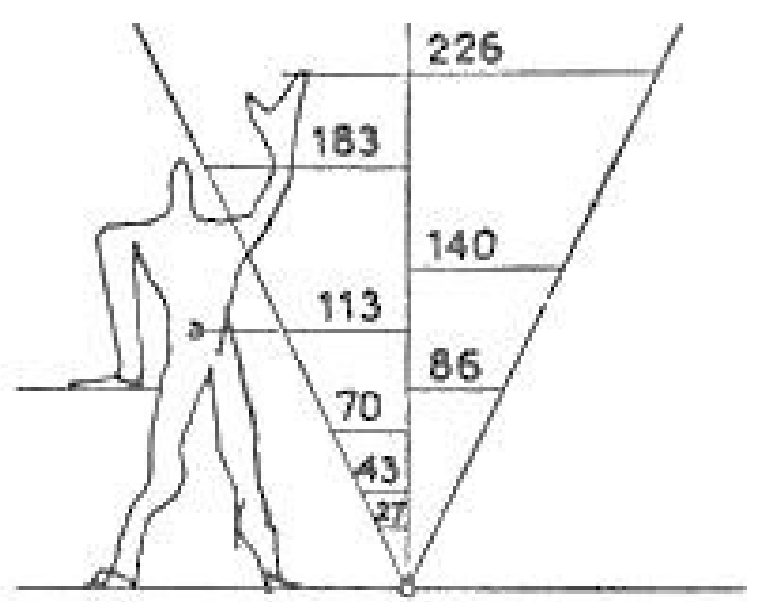

188: Le Corbusier. Modulor, 1950. 


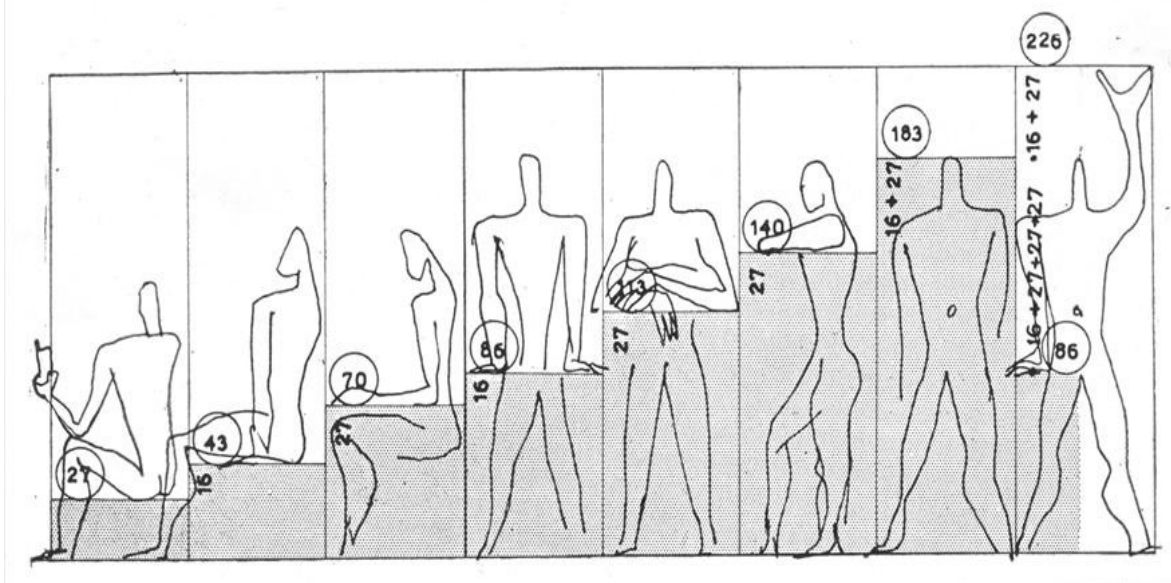

189. Le Corbusier. Modelo de ergonomia del Modulor I b, 1953.

Para cocinas con mayores presupuestos, existen ciertas soluciones que flexibilizan el módulo estándar variando su altura (de forma discreta mediante combinación de zócalos y módulos de distintas alturas e incluso de forma continua mediante motores).

\subsection{La cocina Frankfurt}

Los módulos de cocinas, inodoros, muebles de los actuales apartamentos construidos en serie, tuvieron como precursores los realizados por las pioneras.

En particular, la actual cocina estándar es deudora de la cocina Franckfurt de Margarete Schütte-Lihotzky, no obstante, ella misma tuvo sus antecesoras y posteriores modificadoras del modelo.

Citaré como precursoras de las cocinas a las hermanas estadounidenses Catherine y Harriet Beecher Stowe; la cocina de Benita Otte para la Haus am Horn de la Bauhaus; la cocina de J.P. Oud, diseñada bajo el estricto criterio de Hilde Zimmerman y Erna Meyer, dirigidas por Lilly Reich. Modificadoras del modelo fueron, la cocina integrada de Charlotte Perriand, diseñada para la oficina de Le Corbusier que abrió la cocina al salón comedor, rescatando al ama de casa de su reclusión y aislamiento en la cocina; y, sobre todo, las cocinas suecas que ya he mencionado en otro lugar de esta tesis y que suavizando la austeridad del modelo Frankfurt, consiguieron apropiarse de la 
valoración que supone hacer referencia a la cocina moderna como cocina sueca pues, aquella cocina que recibe el apelativo de cocina moderna, es la que ha impuesto su modelo, de modo que hoy se percibe que quien ha colonizado los hogares del mundo occidental es la cocina sueca, mientras que la cocina Frankfurt es conocida sólo por las personas expertas en la materia.

La evolución de todas ellas fue paralela a las cocinas comunales de los modelos colectivistas desde las cocinas colectivas de los modelos socialistas utópicos de la ilustración, como los falansterios de Fourier, pasando por la producción industrial de los familisterios de Godin de 1865, a las cocinas comunitarias de las urbanizaciones inspiradas en las ciudades jardín de Ebenezer, defendidas por líderes feministas como Melusina Fay Peirce, Mary Livermore, y Charlotte Perkins Gilman que achacaban al aislamiento de la mujer en el hogar su papel secundario en la sociedad -mucho antes de que Betty Friedan descubriera la enfermedad sin nombre- hasta los distintos episodios -espontáneo, planificado y deshumanizado- del colectivismo ruso. Todo ello sucumbió ante el estallido de la Segunda Guerra Mundial.

Tras la guerra, el modelo colectivista no pudo recuperarse, ante el miedo del mundo occidental a la desaparición de la familia tradicional burguesa, y el modelo de Margarete Schütte-Lihotzky, modificado en los países periféricos a la guerra durante la contienda, resurgió suavizado por el diseño sueco de Aino Aalto y enriquecido con el inmenso surtido de electrodomésticos producidos por la industria de EEUU.

Sólo a finales del siglo pasado se retomó la idea de la cocina colectiva, por arquitectas feministas como Dolores Hayden y las austríacas del proyecto Schütte-Lihotzky.

Puesto que la cocina que se ha generalizado es la heredera de aquella de Margarete Schütte-Lihotzky, haré un somero recorrido por aquellas que le precedieron, rastreando, desde la visión de género, los olvidos y los intentos insuficientes para liberar a la mujer de la enfermedad sin nombre. 
Las hermanas Beecher, en 1869 publicaron El hogar de la mujer americana, en el que aparecen algunos bocetos de cocinas inspiradas en las pequeñas y compactas cocinas colectivas de los buques de vapor de la época:

[...] se observa su temprano rechazo a una yuxtaposición de mesas y aparadores independientes para preferir en su lugar la definición de un banco de trabajo continuo -enrasado con el fregadero-, adosado a la pared y bien iluminado bajo las ventanas que en ella se abren. El espacio inferior de dicha superficie de trabajo se ocupa por contenedores para menaje y alimentos mientras que en la parte superior, entre las ventanas, se disponen unas simples estanterías y ganchos que permiten acercar todo tipo de accesorios al alcance de la mano. Por lo que respecta a su organización en planta, es posible observar cómo la autora identifica los tres vértices de lo que hoy se denomina el triángulo funcional de una cocina: el almacenamiento y conservación de alimentos (ocupado en la actualidad por el frigorífico); la limpieza y preparación (fregadero); y el cocinadoservicio (fuego). Debido a su temprana fecha no aparece todavía un dispositivo de conservación en frío sino unos contenedores para alimentos a granel (harina, aceite, azúcar...); como tampoco cuenta con una instalación de fontanería, sino con un rudimentario sistema autónomo de agua corriente ideado por ella misma; a la vez que los fogones se apartan a un compartimento distinto, separado por puertas deslizantes, para reducir los numerosos inconvenientes producidos por un fuego todavía a partir de combustible sólido. (Bravo, 2011: 196)

Benita Otte fue alumna de la Bauhaus. No sólo diseñó la cocina de la Haus am Horn, sino que sorprendió a sus maestros con una espléndida isométrica de la mencionada Casa Modelo, o Casa Experimental, que se expuso en 1923 como parte de los eventos que organizó la escuela para celebrar la graduación de la primera promoción de alumnado de la Bauhaus. Respecto a su cocina, Bravo afirma:

[...] avanza claramente hacia un tipo de cocina compacta e integrada, compuesta por dos clases distintas de armarios -murales y de base- que se disponen adosados a las paredes según una 
configuración en L, para definir una superficie de trabajo continua y sin juntas al mismo nivel que el fregadero y los fogones. Pese a que su altura era adecuada para trabajar de pie, se liberó parte del espacio inferior para las piernas y donde integrar un taburete que permitía sentarse para realizar determinadas tareas con mayor comodidad. Sobre dicha superficie de trabajo se abrió una amplia ventana basculante para procurar un adecuado nivel de iluminación y ventilación natural sin interferir las actividades que se realicen sobre ella. Para facilitar las tareas de limpieza y mantenimiento, los armarios de base carecen de patas que han sido sustituidas por un zócalo continuo, al tiempo que las paredes se han revestido parcialmente mediante piezas cerámicas vidriadas. (Bravo 2011: 189)

Es interesante seguir las características de esta cocina en relación a la de las hermanas Beecher para comprender cómo el modelo actual de cocina ha ido construyéndose con el conocimiento y la experiencia acumulada de mujeres de distintas generaciones. También los siguientes modelos conviene compararlos con éste y el anterior, para discernir qué características se adoptan como irrenunciables y cuáles son innovaciones originales en cada caso.

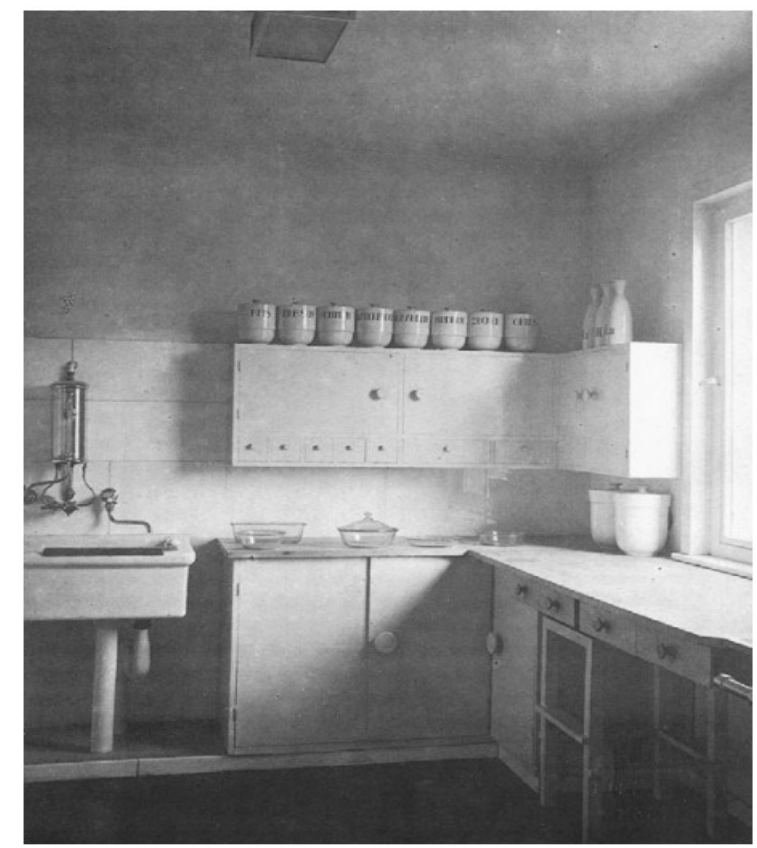

190. Benita Otte y Erns Gebhardt. Cocina de la Haus am Horn de Benita Otte Weimar, 1923. Fuente: Juan Bravo, 2011. 


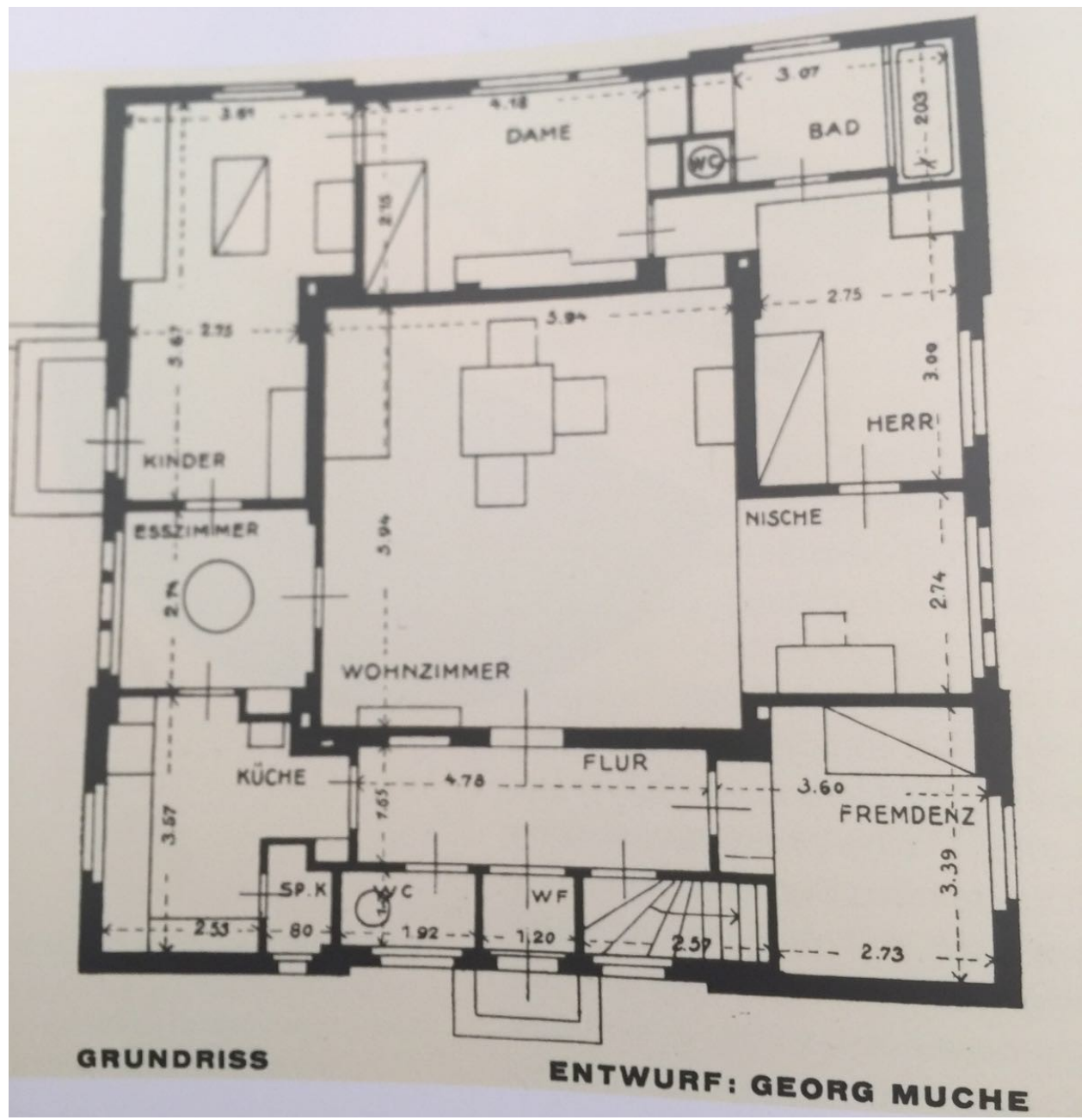

191. Gerge Muche. Planimetría de la Haus am Horm de Meyer y Otte de la exposición Bauhaus, Weimar, 1923. Fuente: Juan Bravo, 2011.

El prototipo de Otte fue retomado por Erna Meyer, para asesorar sobre las condiciones que debían cumplir los proyectos de cocina a quienes querían participar en el concurso Weissenhof de 1927 en Stuttgart. Además incorporó por primera vez criterios ergonómicos aplicables a la altura de trabajo, cuestión que ya hemos visto que es central en esta última parte de mi investigación.

El concurso fue ganado por J. P. Oud:

Éste insistió en una cocina integrada y compacta dispuesta en L, con la superficie de trabajo perfectamente iluminada y ventilada bajo una amplia ventana y liberando parte del espacio inferior para las piernas 
-lo que permite sentarse para trabajar con mayor comodidad-; los armarios murales han sido sustituidos, en esta ocasión, por meros estantes y una barra donde tener a mano parte del menaje y de los accesorios necesarios para las diferentes tareas. Sin embargo, la aportación más interesante de Oud fue quizás la apertura de una ventana interior con carpintería corredera que comunicaba la cocina con el salón-comedor adyacente, estableciendo de esta forma no solo un vínculo directo -a modo de pasaplatos- para facilitar el servicio de la mesa, sino también una comunicación visual y auditiva que suaviza el aislamiento de la cocina -y de la cocinera- como espacio exclusivamente de trabajo. (Bravo, 2011: 193)

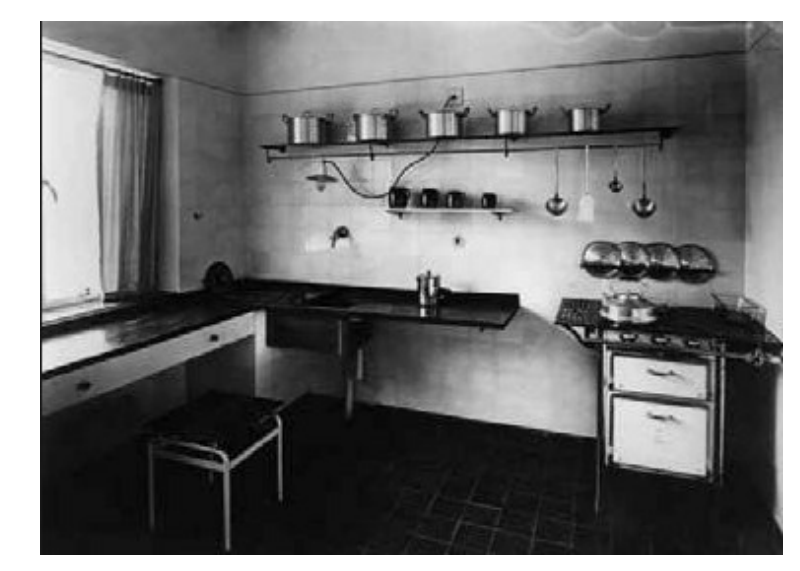

192. J. P. Oud. Cocina Weissenhof, Sttutgard, 1927. Fuente: Pinterest, 2016.

Pero fue el modelo de Schütte-Lihotzky realizado en el año 1926 el que se convirtió en el estándar que siguieron, no sólo Frankfurt, sino también Viena, Berlín o Rotterdam y más allá -durante la Guerra, la cocina Frankfurt siguió expandiendo su influencia, por ejemplo en Suecia y Estados Unidos- seguramente porque con un presupuesto mínimo, la extrema racionalización que su creadora aplicó al proyecto, posibilitó la producción industrial de sus módulos en serie.

En primer lugar, mi trabajo consistió en considerar los principios básicos envueltos en el planteamiento y construcción de viviendas, 
con vistas a racionalizar la organización doméstica. ¿Dónde vivir, cocinar, comer y dormir? Esas son las cuatro funciones básicas que toda vivienda debe cubrir. La función básica, que influye en el diseño de manera decisiva, es cocinar y comer. Mi primera propuesta, construir un salón y combinar una cocina y comedor, fue rechazada bajo el argumento del coste [...] Así que nos decidimos por una sola unidad, compuesta de una cocina compacta e integrada, separada del salón-comedor mediante una amplia puerta corredera. (SchütteLihotzky, cit. en Bravo, 2011: 194)

Hasta hace pocos años, la cocina Frankfurt de Margarete Schütte-Lihotzky, venía incluida en el Neufert como modelo de cocina de referencia.

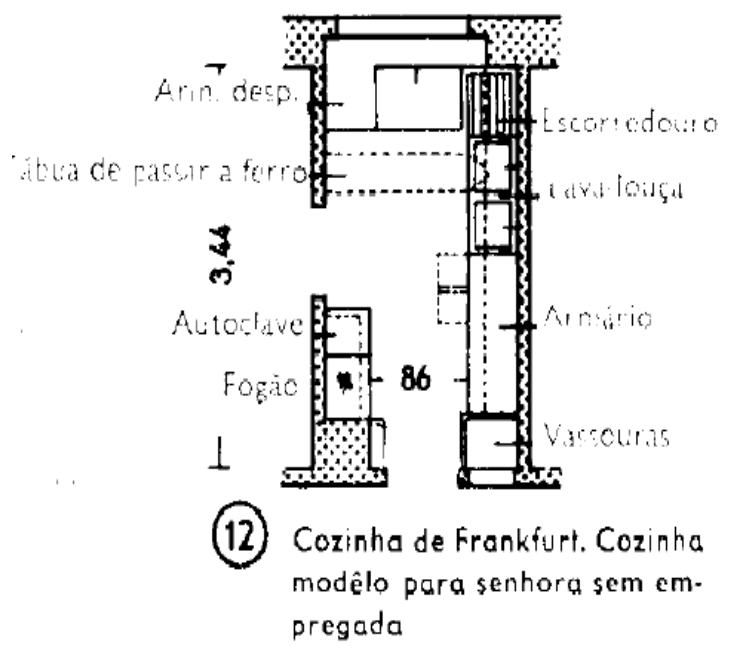

193. Ernst Neufert. Séptima edición portuguesa adaptada de la $21^{a}$ de El arte de proyectar en arquitectura, 1958.

La cocina Frankfurt está presente hasta la trigésima edición alemana, a la que se adapta la décimo tercera española editada por Gustavo Gili en 1983.

Aún hoy, marcas de fabricación de cocinas como Bulthaup, reconocen su deuda con Grete:

En 1966, Bulthaup lanza al mercado su primera cocina modular: el Programa $\mathrm{N}$, basado en la cocina de Frankfurt, su inteligente y compacta distribución de módulos y electrodomésticos facilita enormemente el trabajo en la cocina. El aprovechamiento óptimo del espacio es un requisito básico de los sistemas de equipamiento 
debido a la escasa superficie disponible para las cocinas en las nuevas viviendas de la época. (Bulthaup, 2013: s/c)

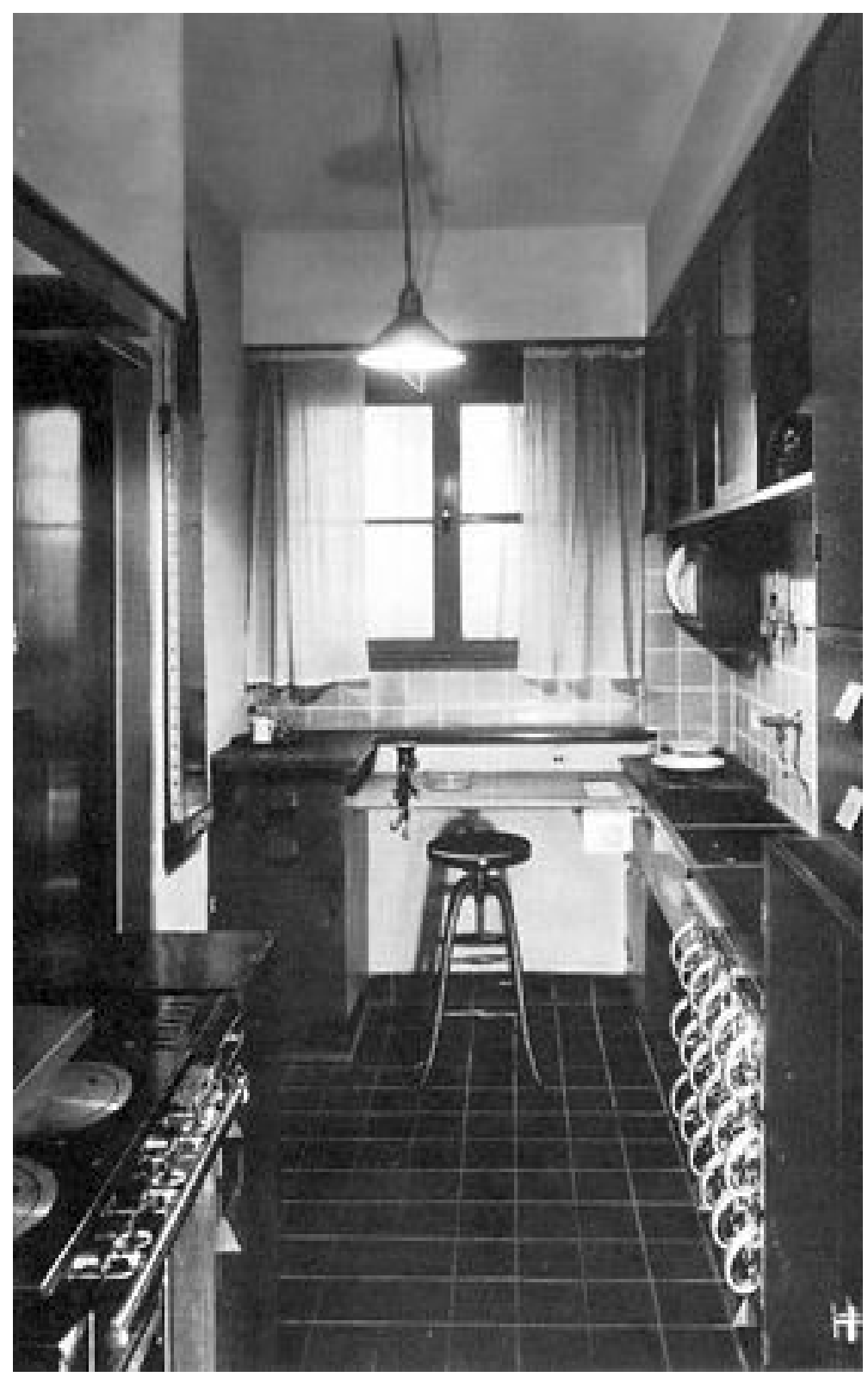

194. Cocina Frankfurt. Fuente: MAK, 1991. 

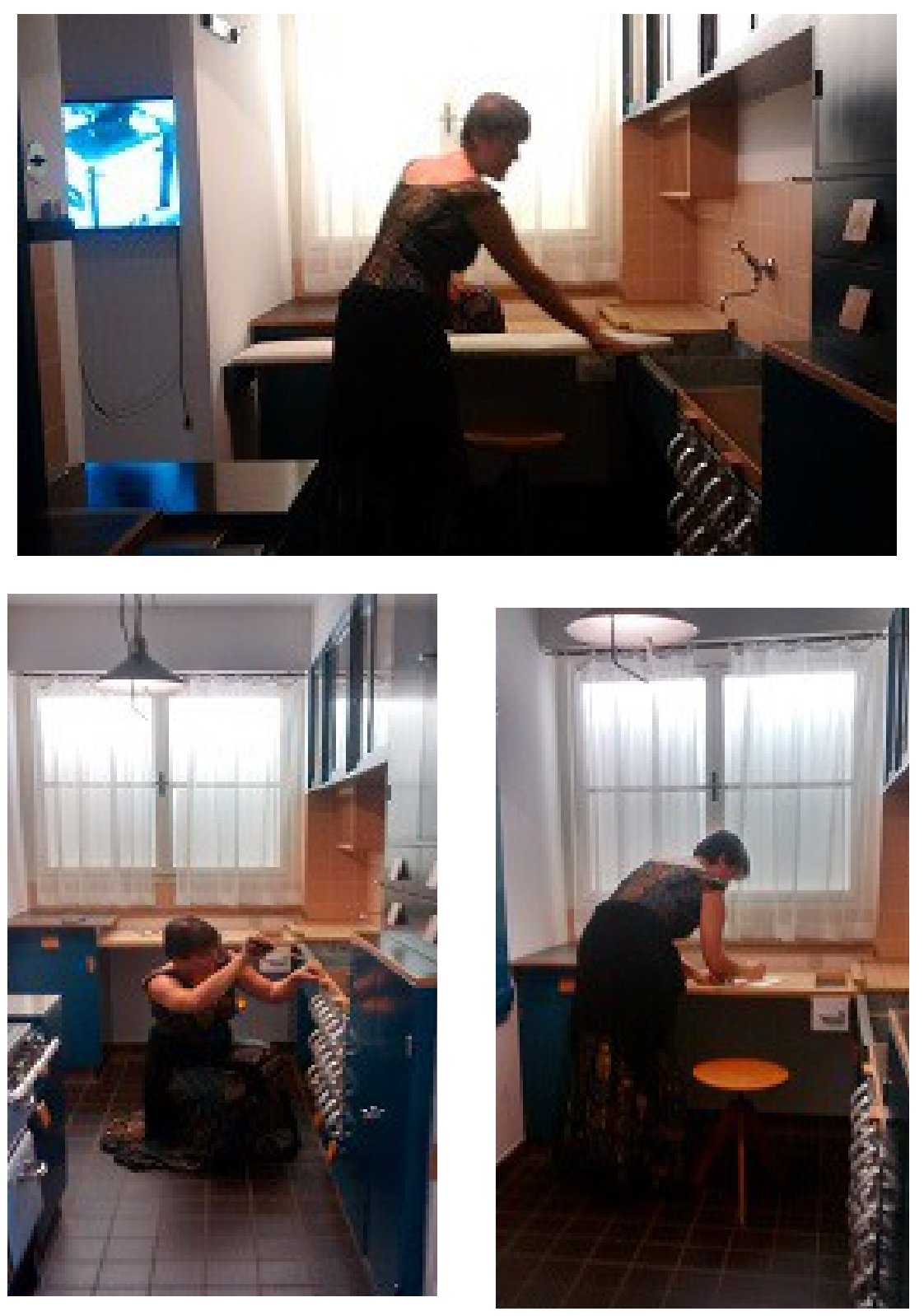

195. Conjunto de fotografías que muestran la toma de datos de los elementos de la cocina Frankfurt en el museo del diseño de Viena. Fotografías de la autora, 2015. 


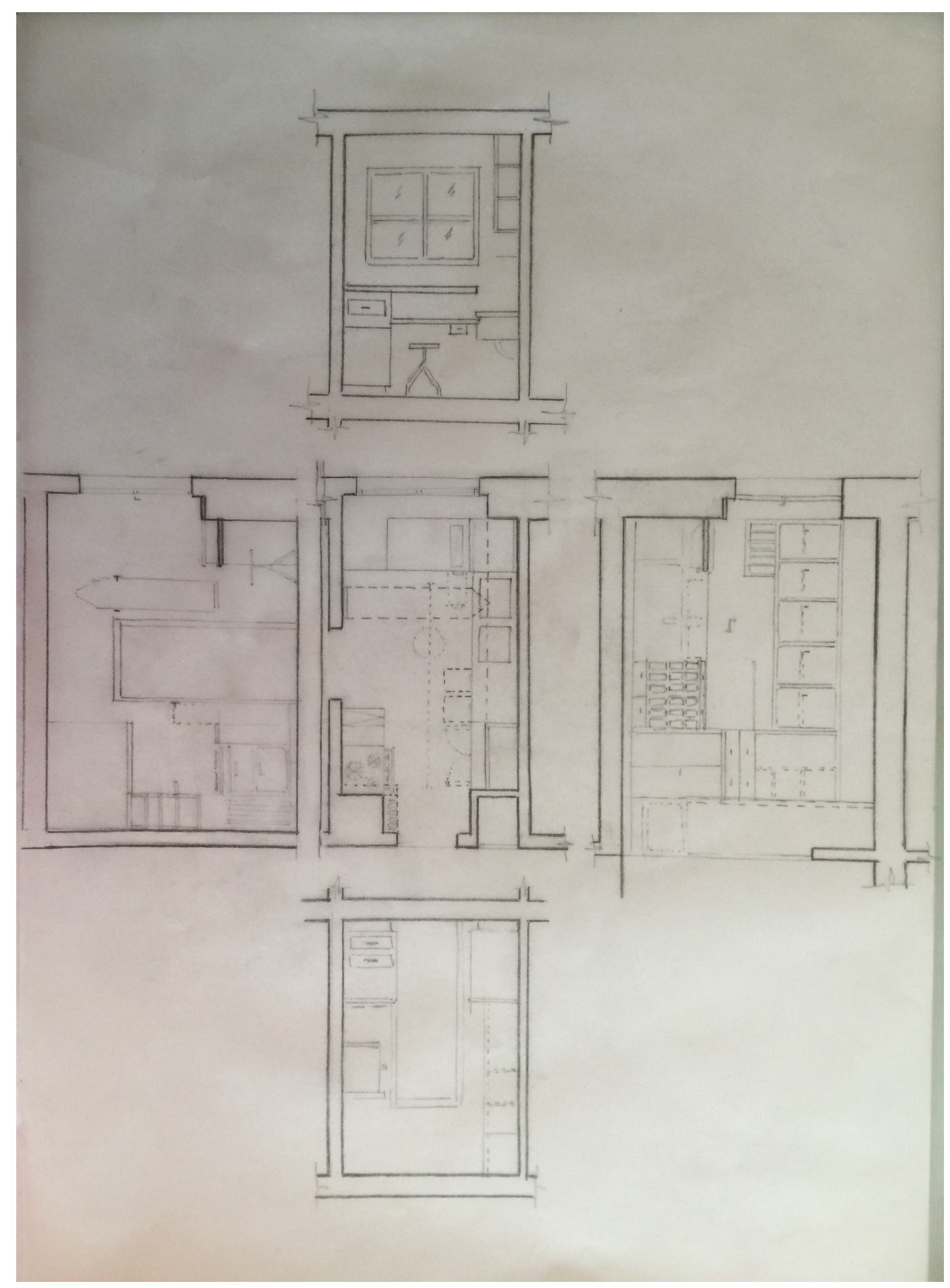

196. Croquis de la distribución de la cocina Frankfurt de Schütte-Lihotzky expuesta en el MAK. Fuente: G.E.P., 2015. 


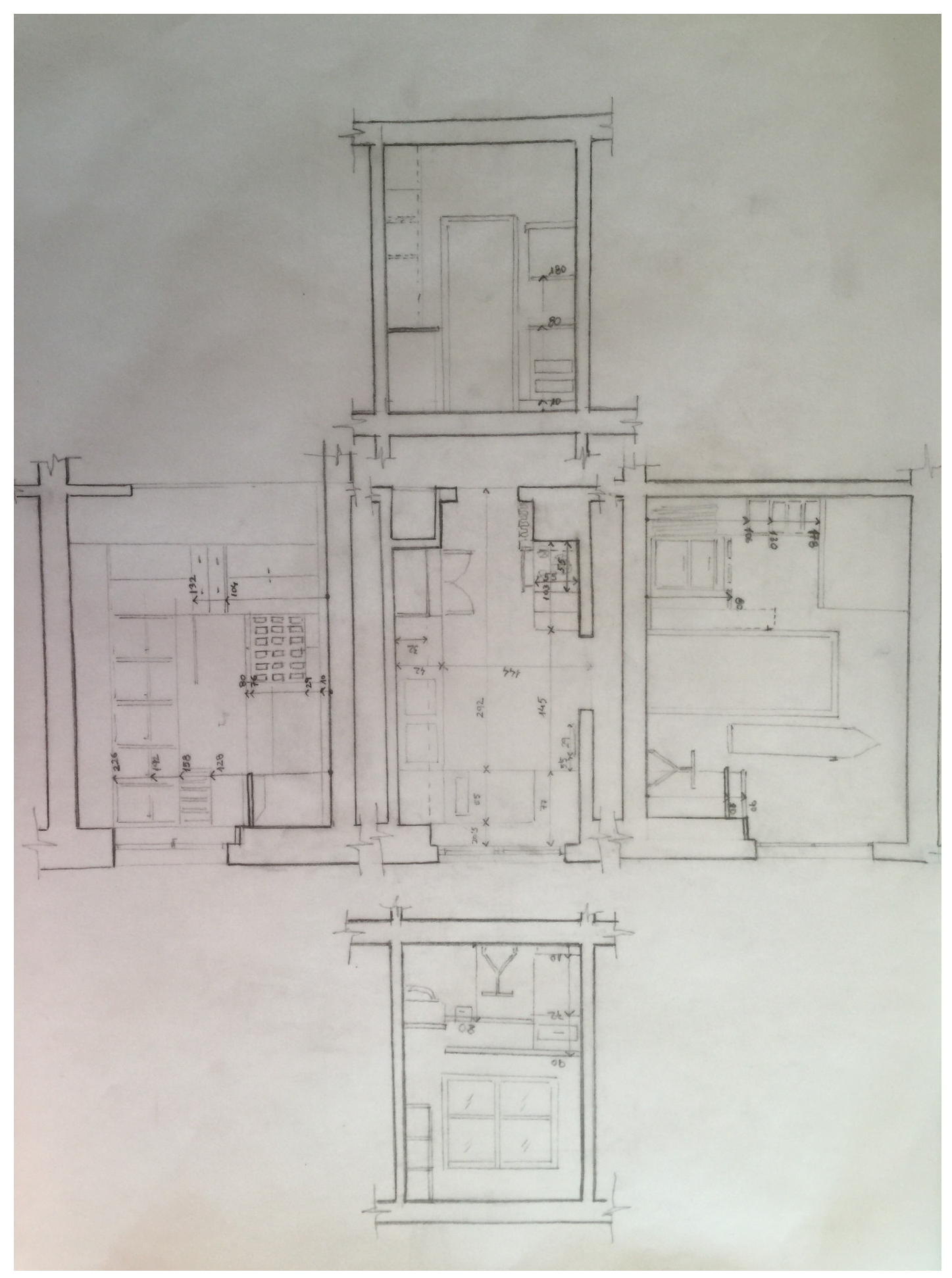

197. Croquis acotado del prototipo de la cocina Frankfurt de Schütte-Lihotzky expuesta en el MAK. Fuente: G.E.P., 2015.

Las medidas tomadas in situ, indican que -bajo el supuesto de que trabajó con el criterio de ergonomía aplicado por sus predecesoras- la cocina fue pensada 
para una mujer menuda. La altura de los módulos de trabajo oscila entre los 76 $\mathrm{cm}$ del fregadero a los $80 \mathrm{~cm}$ de la encimera. El modelo ha sido exportado a todo el mundo, pero sus dimensiones no han sido estandarizadas.

En las primeras ediciones del Neufert sí que se recogía la cocina Frankfurt como referente de distribución y de dimensiones, lo cual supuso una gran difusión de la cocina de Grete. En la edición vigésimo sexta todavía aparece.

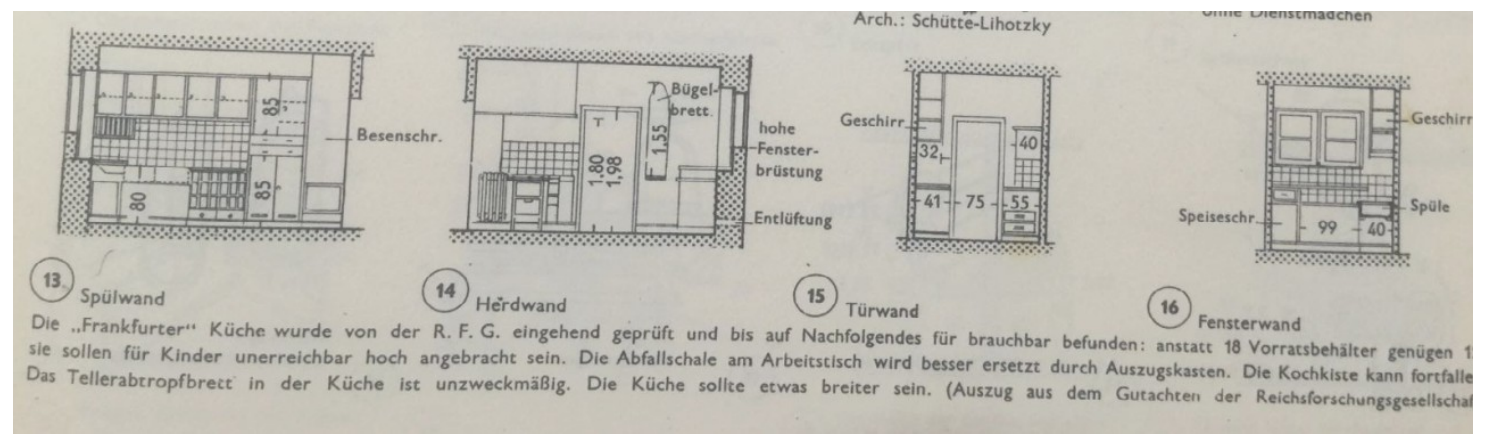

198. Ernst Neufert. La cocina Frankfurt como ejemplo en la duodécima edición alemana de El arte de proyectar en arquitectura, 1949.

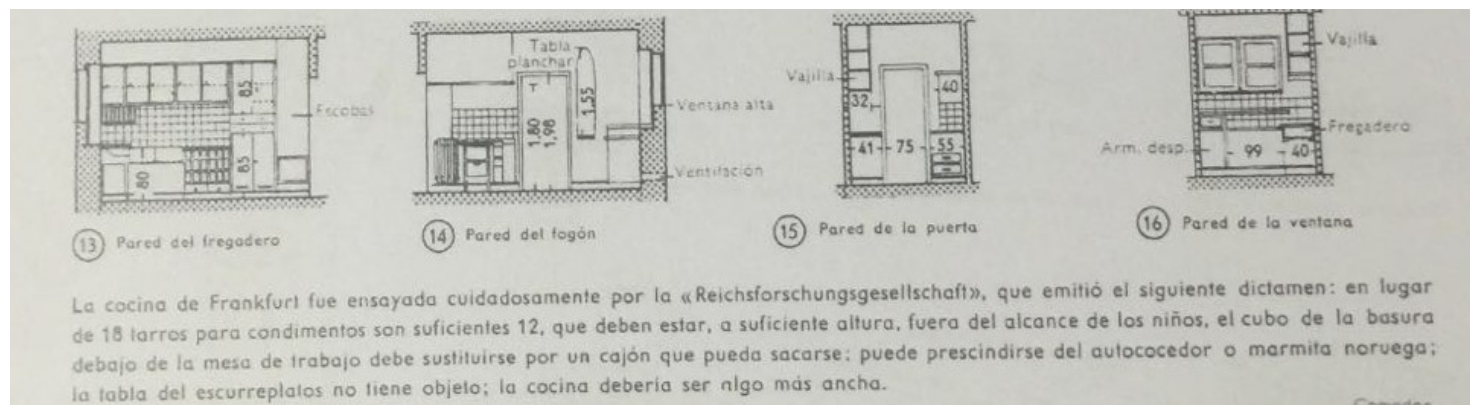

199. Ernst Neufert. La cocina Frankfurt como ejemplo en la décimo segunda edición española, vigésimo sexta de El arte de proyectar en arquitectura, 1977. 
En la trigésima edición ya desaparece el modelo. $Y$, aunque hasta la vigésimo sexta edición sigue apareciendo la cocina Frankfurt con sus dimensiones originales, los alzados de la cocina que el Neufert recomienda como estándar son de $85 \mathrm{~cm}$ de altura para la bancada desde la vigésimo primera edición en 1960.

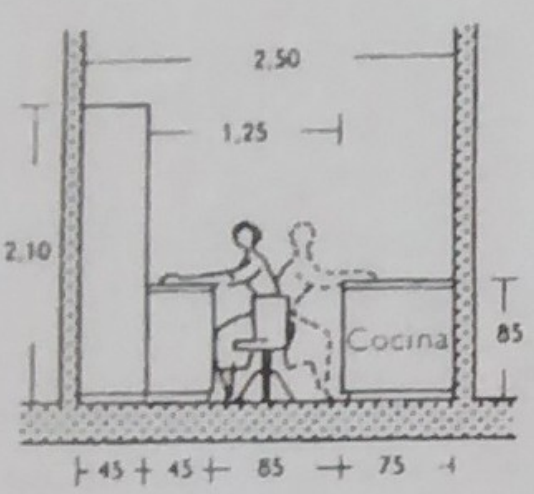

(1) Sección transversal de cacina en la que pueden trabajar dos mujeres

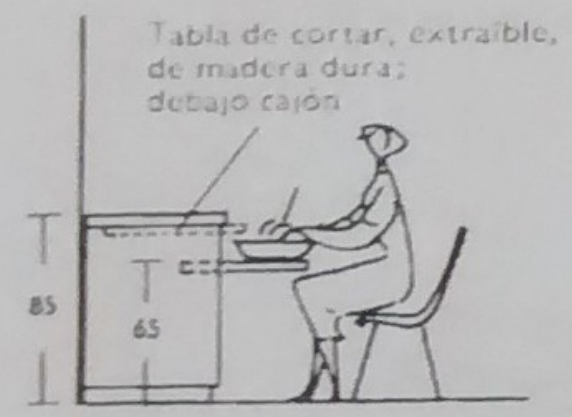

(5)

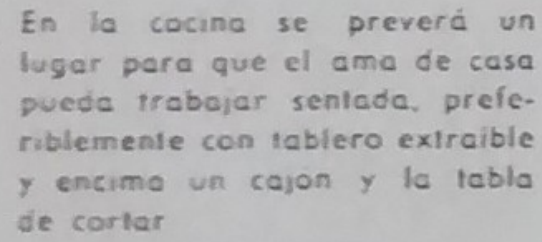
puede trabojar sentada, preferublemente con tablero extrable y encima un cajon y la tabla de corlar

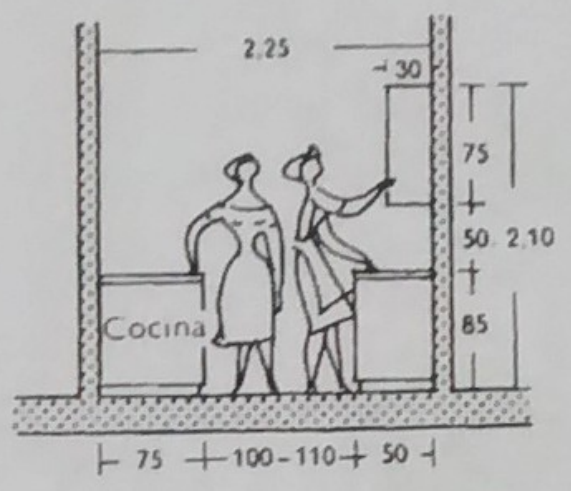

(2) Sección transversal de cocino de casa pequeña, con espacio para el ama de casa y una auxiliar eventual

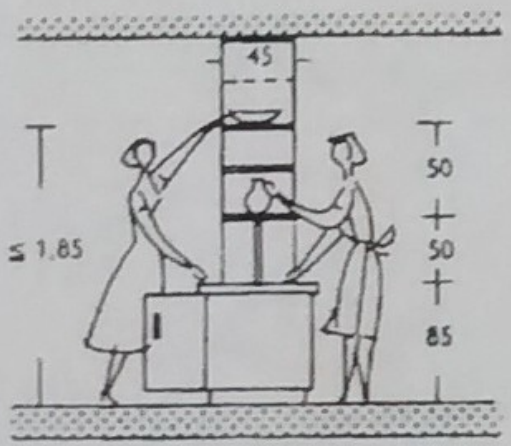

6) Entrega entre ta cocina, fregadero u oficio y el comedor. con armarito superior que se abre a ambos lados

200. Ernst Neufert. Bancada de $85 \mathrm{~cm}$ en la vigésimo primera edición de El arte de proyectar en arquitectura, 1960. 
La $12^{\mathrm{a}}$ edición alemana del Neufert ha sido uno de los últimos materiales conseguidos para esta tesis, antes, la única forma de conocer las dimensiones de esta cocina fue, para mí, el viaje a Viena. Esta última adquisición, confirma las medidas que tomé en el MAK.

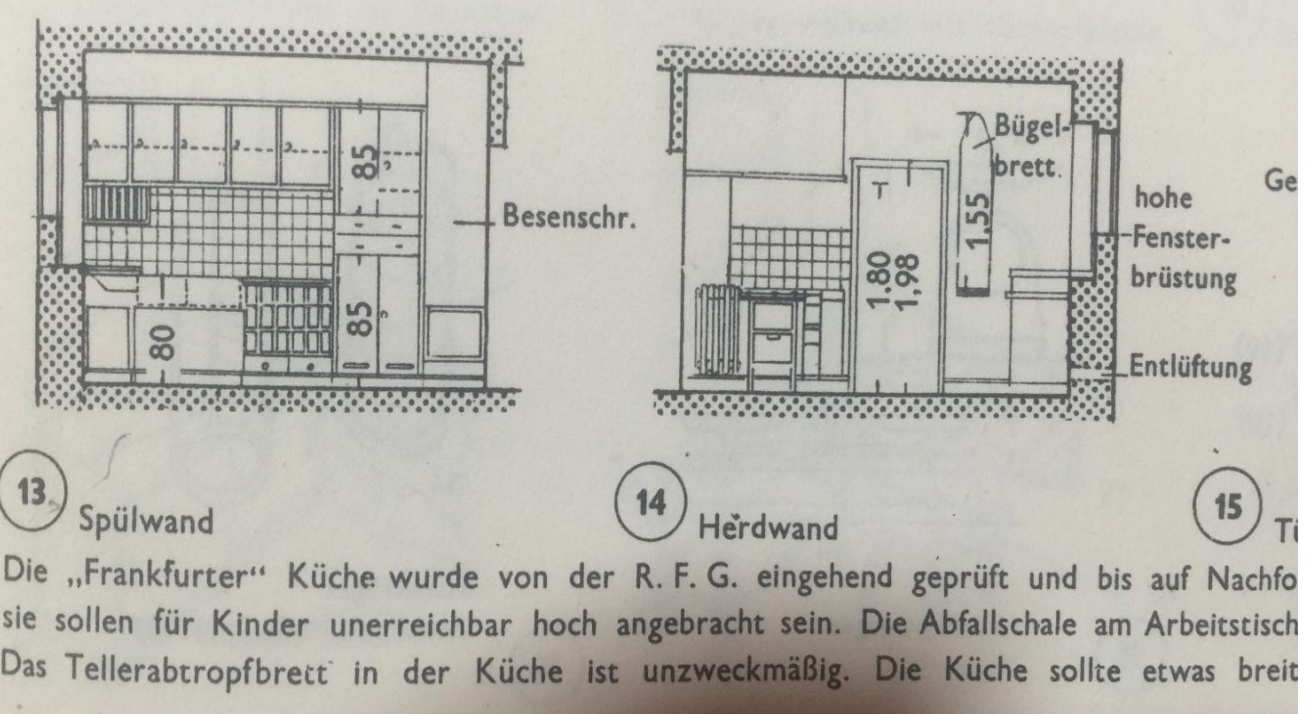

201. Ernst Neufert. Cocina Frankfurt en la $12^{\mathrm{a}}$ edición alemana de El arte de proyectar en arquitectura,

1949.

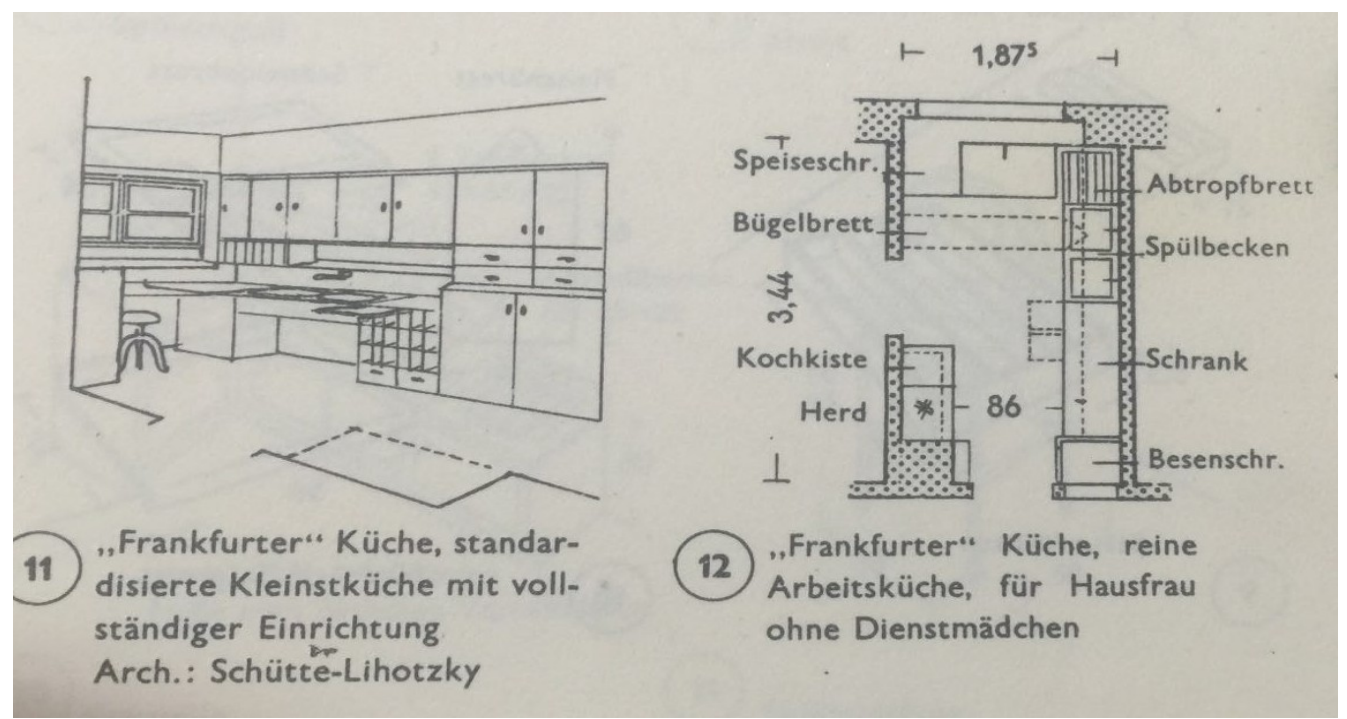

202. Ernst Neufert. Cocina Frankfurt en la $12^{\mathrm{a}}$ edición alemana de El arte de proyectar en arquitectura, 1950. 
En 1948, la cocina de Charlotte Perriand mantiene las características de la cocina de Schütte-Lihotzky, y todas las que ésta última acumula de las anteriores cocinas antes citadas, y aporta el mueble bar que sirve de cerramiento blando y apertura que comunica la cocina con el comedor, al tiempo que mantiene al ama de casa en «su lugar» de servicio, lo hace permitiéndole la comunicación con el resto de la familia a la que sirve.

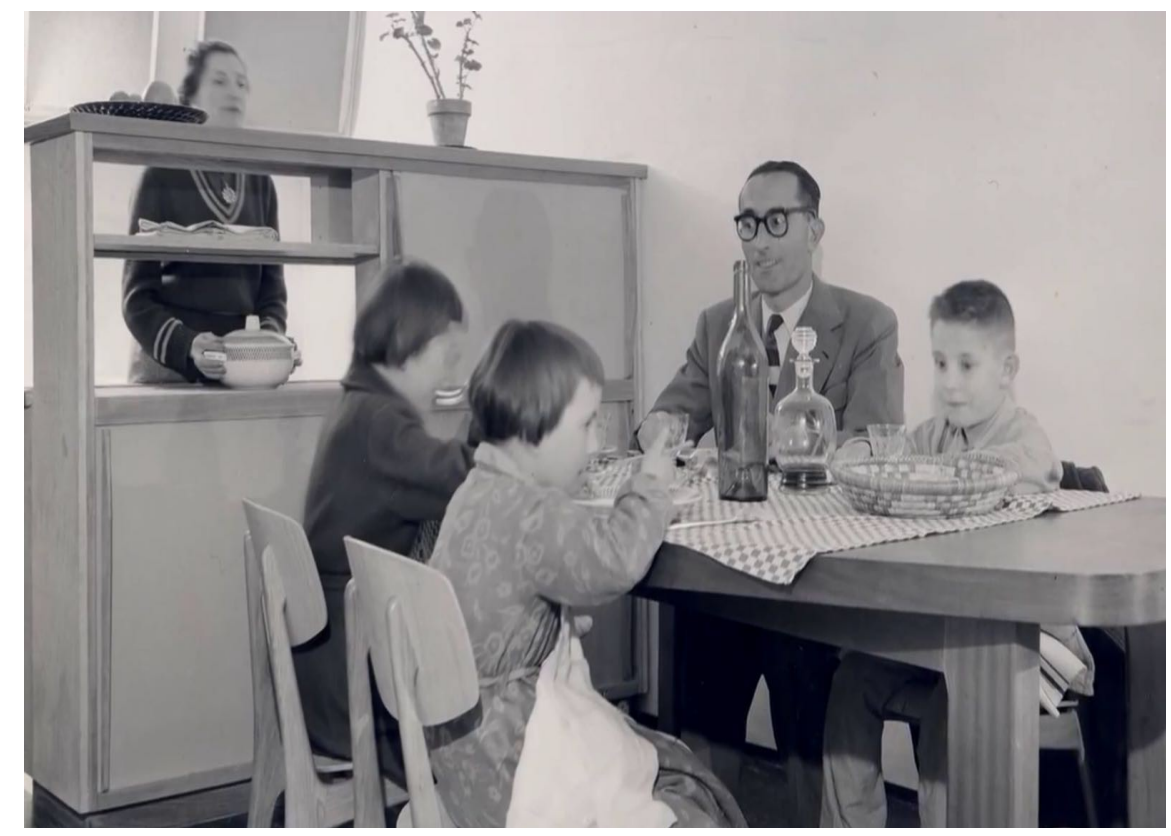

203. La mujer «usuaria» de la cocina sirviendo la comida a los usuarios. Fuente: Roger Griffit, 2015.

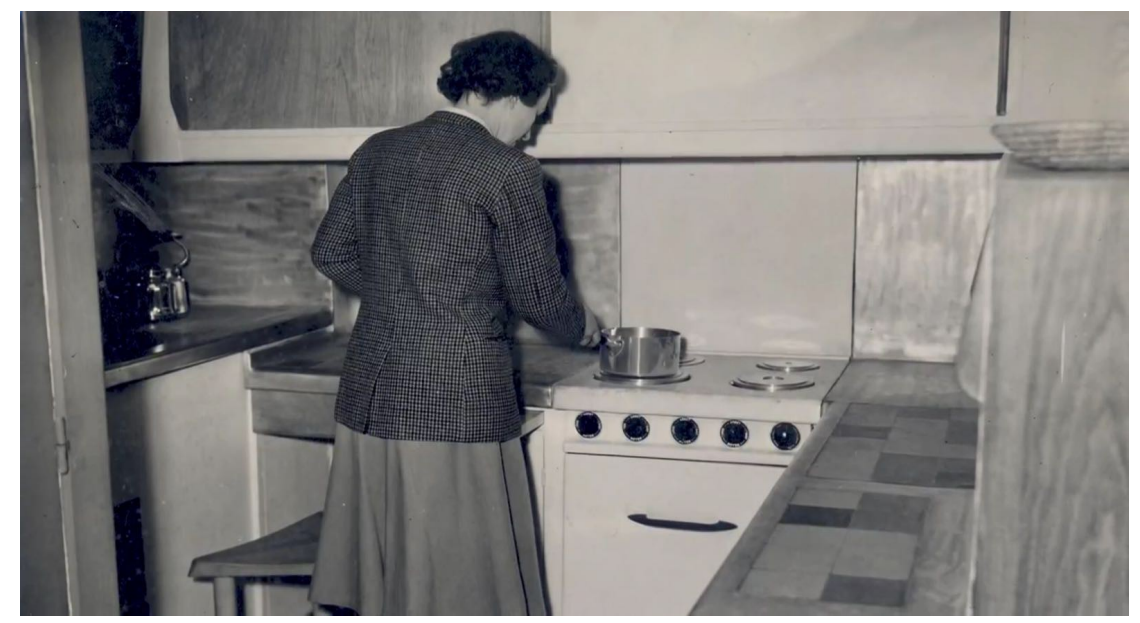

204. La mujer «usuaria» de la cocina de Charlote Perriand, cocinando. Fuente: Roger Griffit, 2015. 
El prototipo de esta cocina fue diseñado por Charlotte Perriand. Inició sus trabajos en 1947 -diez años después de que abandonara el estudio de Le Corbusier por desavenencias profesionales y políticas, 20 años después de su incorporación al taller corbuseriano- y en 1948 fue puesto a punto, con la experiencia adquirida no sólo en la escuela donde estudió y en el taller de Le Corbusier, sino también con la adquirida en Japón, entre 1940 y 1942, a donde emigró cuando se produjo la ocupación nazi de París; y la adquirida en Vietnam donde quedó retenida cuatro años (1943-46) al intentar regresar a Europa tras la entrada de Japón en la guerra. Según Arthur Rüegg, en «Le Corbusier. Meubles et intérieurs», el prototipo puesto a punto por Perriand reunía las siguientes características:

Cocina modular (prototipo): «Cocina taller L.C. tipo I para una Unidad habitacional, interpretación Charlotte Perriand».

Charlotte Perriand con Le Corbusier / ATBAT 1947-1950

Altura aprox. 133 (cara delantera)/226 (altura de la pieza) x ancho 183 (cara delantera) x profundidad aprox. $260 \mathrm{~cm}$.

[...] La cocina puesta a punto en 1948 por Charlotte Perriand, es más sofisticada que la cocina realizada finalmente.

[...] La cocina se compone de tres muebles bajos de altura idéntica, recubiertos de acero inoxidable (fregadero, refrigerador, fogones y plano de trabajo).

[...] Una primera maqueta de muestra de gran talla fue realizada en el taller de Le Corbusier, mientras que una segunda versión simplificada se expuso en julio de 1949 en el piso piloto de Marsella. (Rüegg, 2012: s/c)

Hay que tener en cuenta que la fecha de finalización, 1950, no se refiere tanto a la finalización del proyecto de cocina sino a la exposición que de este proyecto se hizo en ese año.

Los bocetos y planimetrías de la cocina de Perriand fueron expuestos por la plataforma Houzz en un vídeo del que he extraído imágenes clave para este trabajo. 


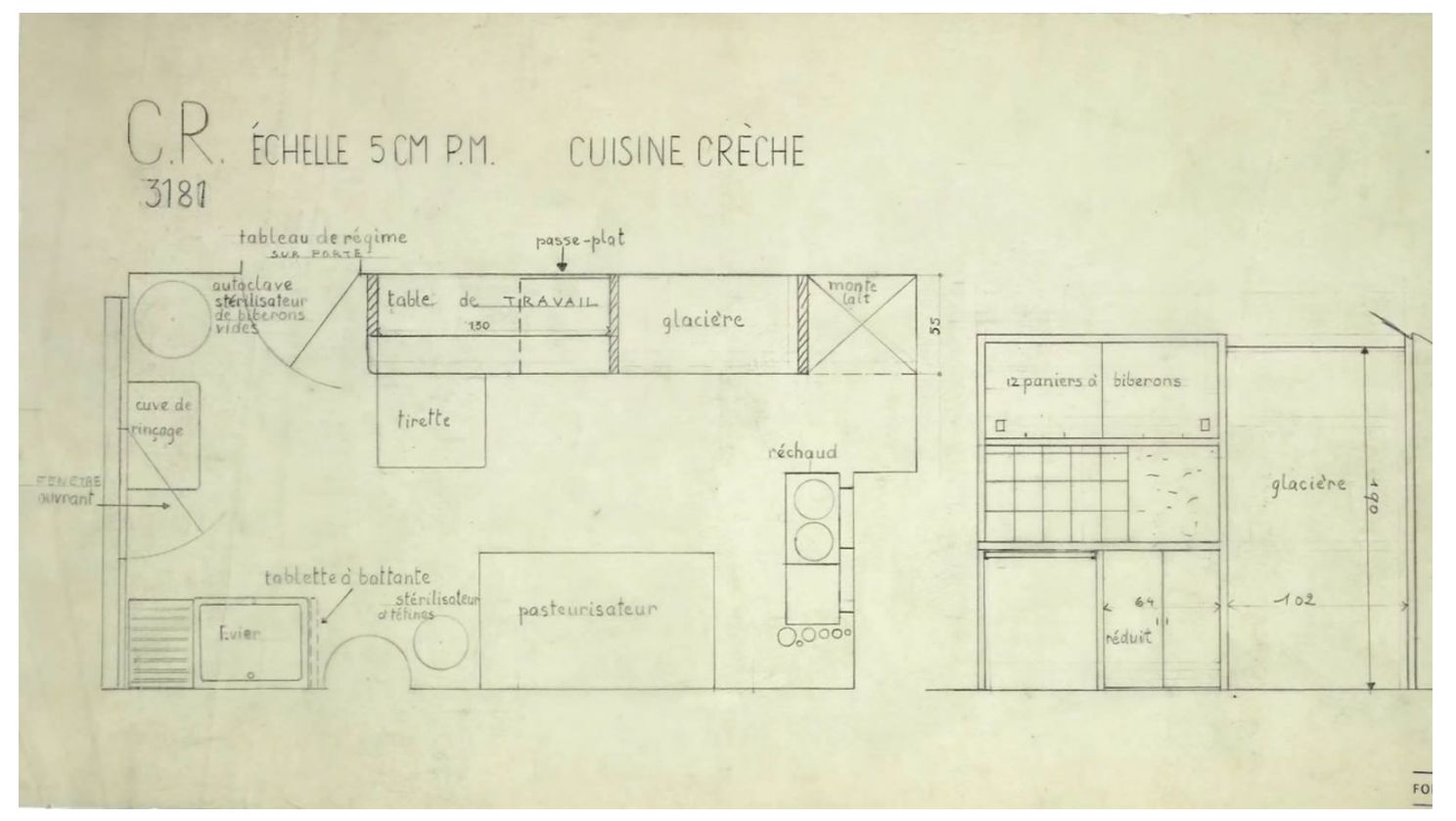

205. Charlotte Perriand. Planimetría de la cocina de Charlotte Perriand, 1948.

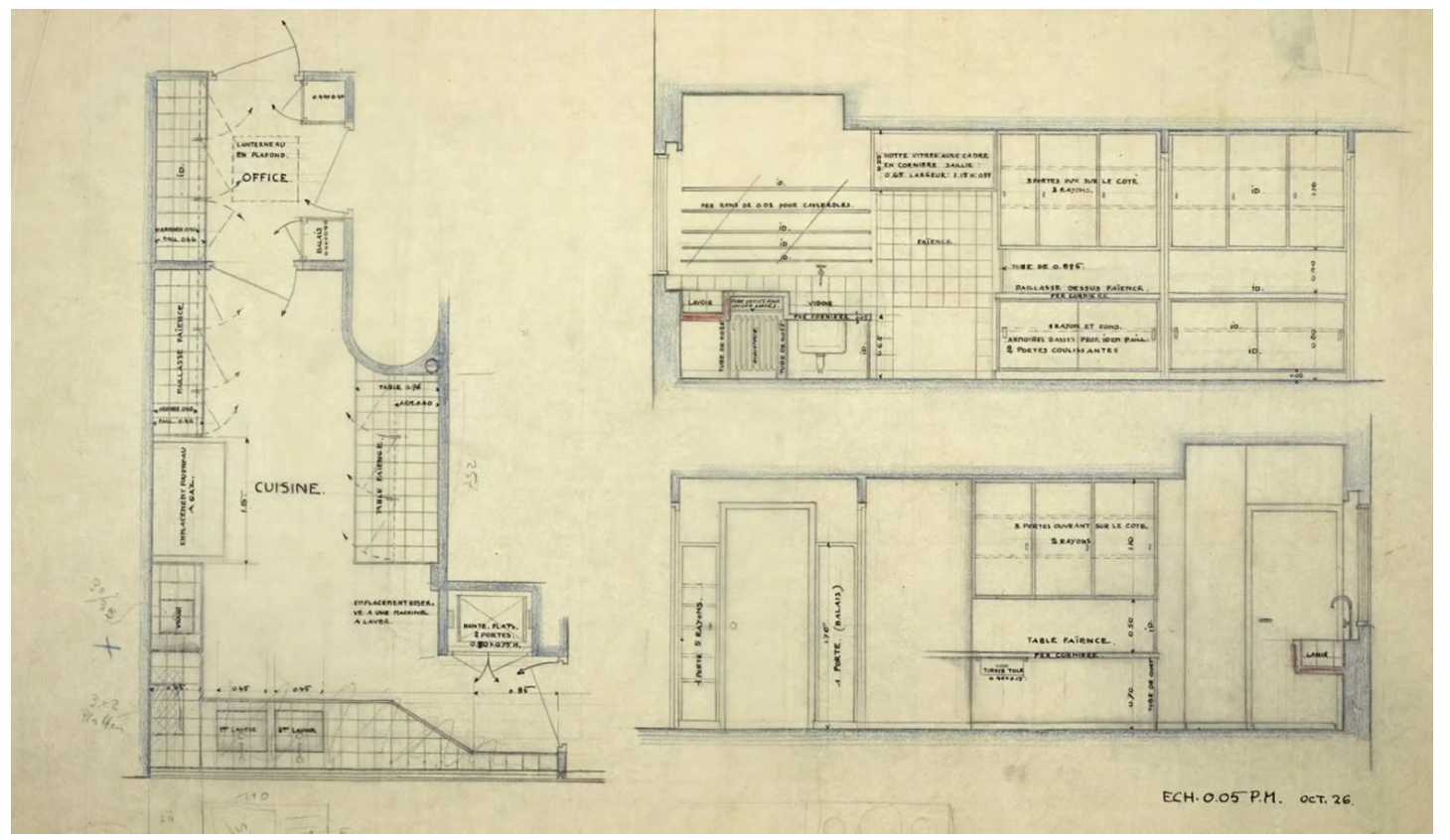

206. Charlotte Perriand. Planimetria de la cocina prototipo de Perriand, 1948. 


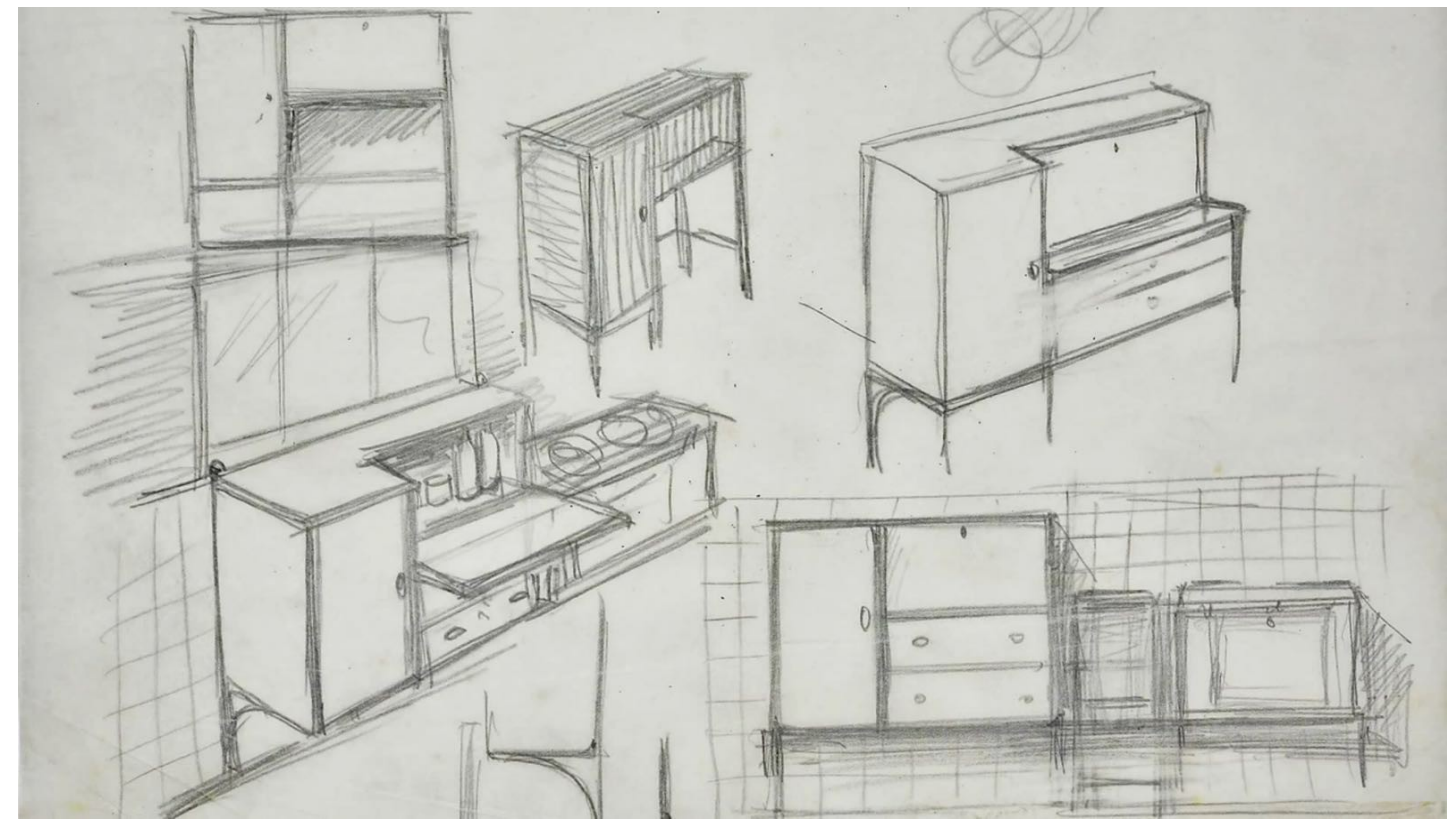

207. Charlotte Perriand. Bocetos del mueble bar de Perriand, 1948.

Nótese en la planimetría la altura del plano de trabajo: $80 \mathrm{~cm}$. Los mismos que hasta esa fecha se consideraban estándar en las versiones aparecidas del Neufert desde 1936, justo dos años después cambiaría el estándar, tras la incorporación de Le Corbusier al Arte de proyectar en arquitectura.

Más tarde, entre 1949 y 1952, el proyecto fue modificado y construido por el taller de Le Corbusier para las cocinas de L'Unité Habitationale de Marsella. Hoy puede visitarse en el Centro Pompidou que ha adquirido un ejemplar. El ejemplar no es completamente original, sino un mosaico fruto de tres cocinas originales. El estudio concienzudo respecto al color de las piezas, mediante microscopio de muestras de reducido tamaño, permite esta afirmación. Sobre esta cocina, Arthur Rüegg, en Le Corbusier. Meubles et intérieurs, registra datos comparativos que ilustran lo antedicho:

Cocina modular

Le Corbusier/ ATBAT, sobre la base de los estudios de Charlotte Perriand

$1949-1952$ 
Altura aprox. 133 (cara delantera)/226 (altura de la pieza) x ancho 188 (cara delantera) x profundidad aprox. $265 \mathrm{~cm}$.

[...] Una primera maqueta de muestra de gran talla fue realizada en el taller de Le Corbusier, mientras que una segunda versión simplificada se expuso en julio de 1949 en el piso piloto de Marsella. (Rüegg, 2012: s/c)

Observamos que la altura de los módulos de trabajo no figura entre las medidas, a pesar de que sí que se mencionan dichos módulos.

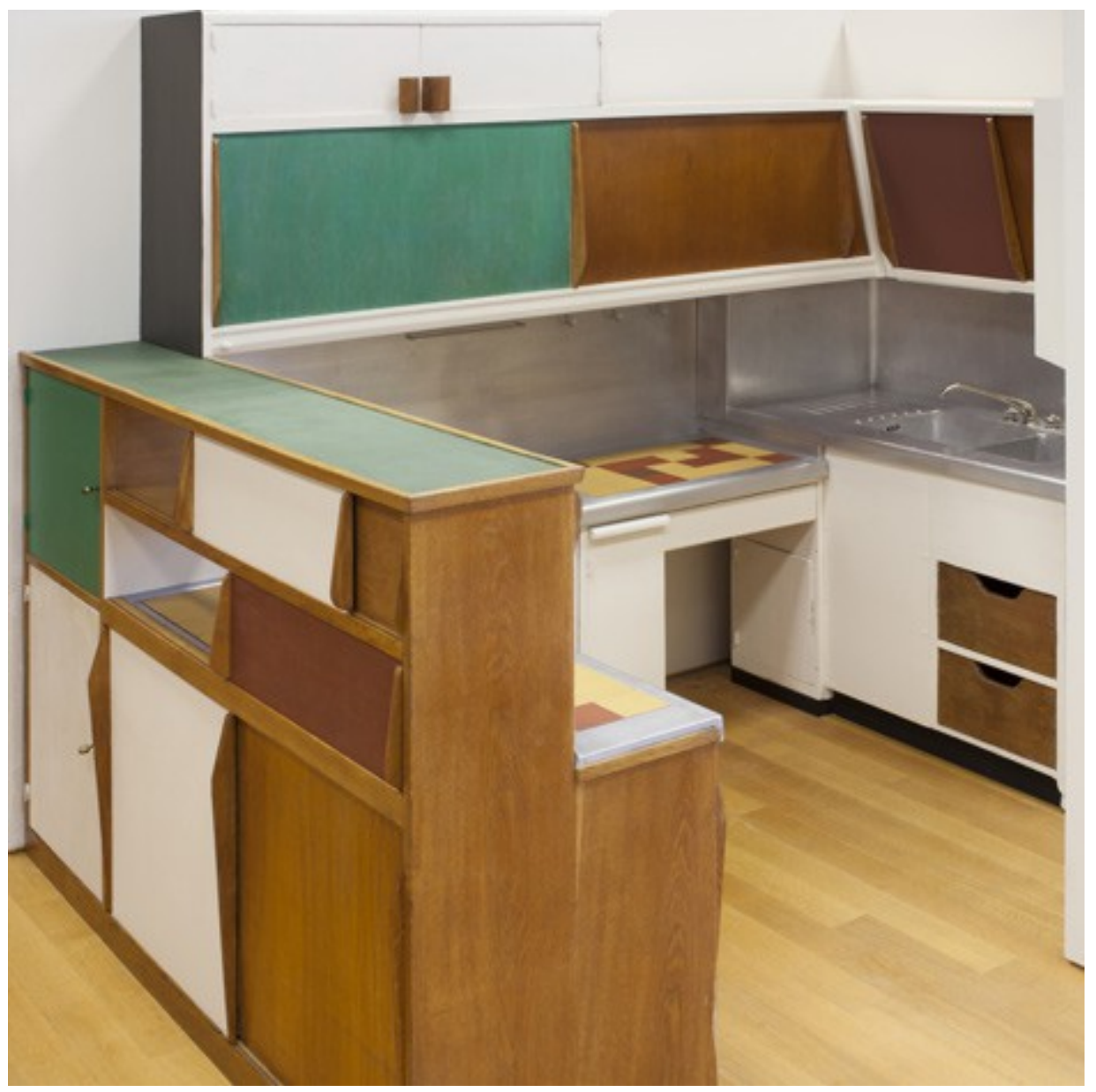

208. Cocina de LHM con el mueble-bar de Charlotte Perriand que la integra en la dinámica social de la casa. Fuente: MOMA, 2014. 


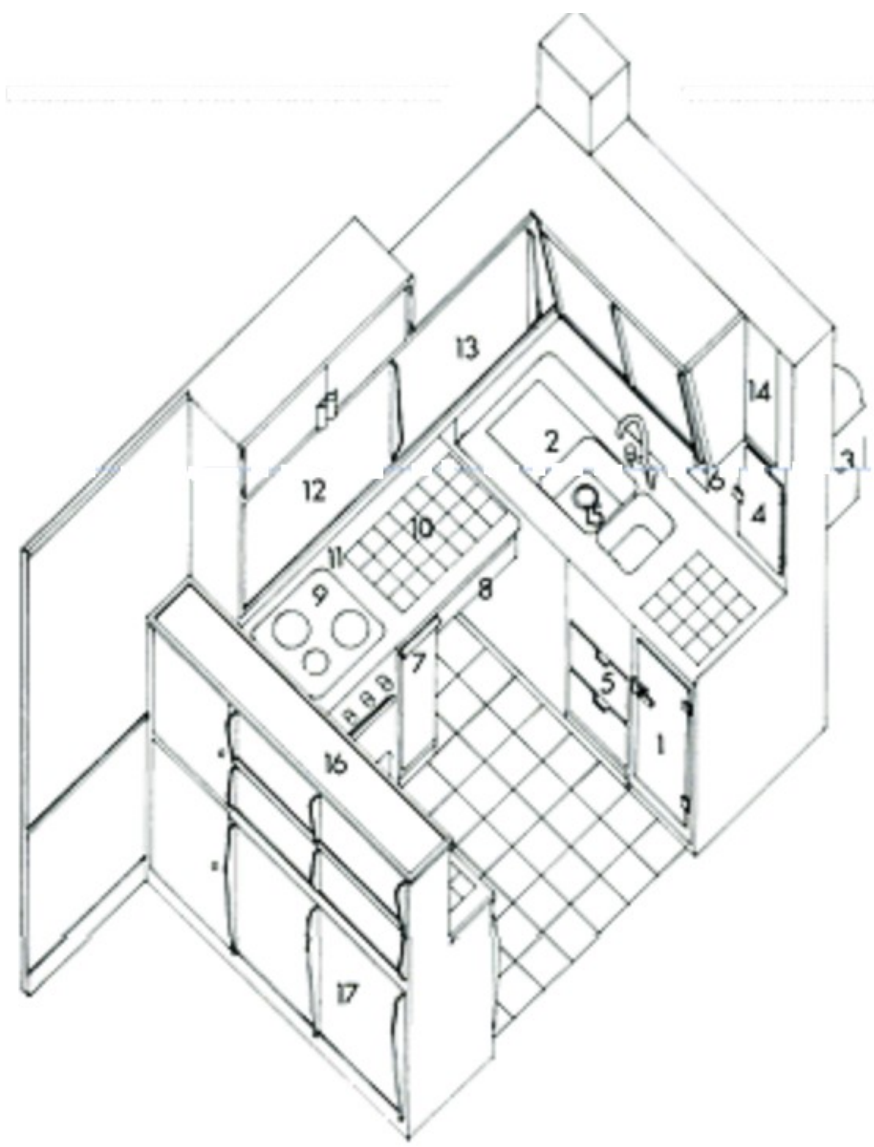

91

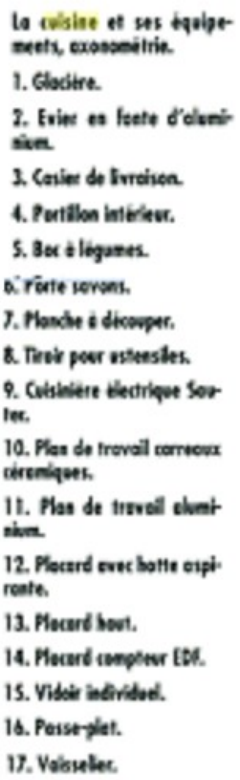

209. Un boceto de la cocina de l'UHM adaptación del prototipo de Charlotte Perriand. Fuente: Jacques Sbriglio, 1992.

Resulta llamativo que ni la altura del módulo de trabajo ni la del fregadero son fáciles de encontrar. Ni en fotografías, ni en textos, bocetos ni planimetrías. Y no es un caso singular el de la cocina de Charlotte Perriand, ocurre exactamente lo mismo con la de Margarete Schütte-Lihotzky. En mi viaje a Viena tomé la medida directamente sobre la cocina expuesta en el Museo de Diseño y Artes Decorativas (MAK).

Para el presente capítulo han sido inestimables los datos proporcionados por Melle Bonino, presidenta de la exposición de L'Unité Habitacionalle de Marsella, y por la arquitecta responsable de la Fundación Le Corbusier de París, Isabelle Godineau: la planimetria de la cocina de Charlotte Perriand y una separata del libro de Arthur Rüegg sobre la cocina de l'UHM. 
La planimetría de la cocina de Charlotte Perriand está firmada por Le Corbusier como arquitecto y proyectada en su taller ATBAT y diseñada por Maisonnier entre marzo y octubre de 1949. Recién publicado el Modulor I y cinco años antes de que se publicara el Modulor II. El Neufert todavía recomendaba $80 \mathrm{~cm}$ como altura estándar del plano de trabajo.

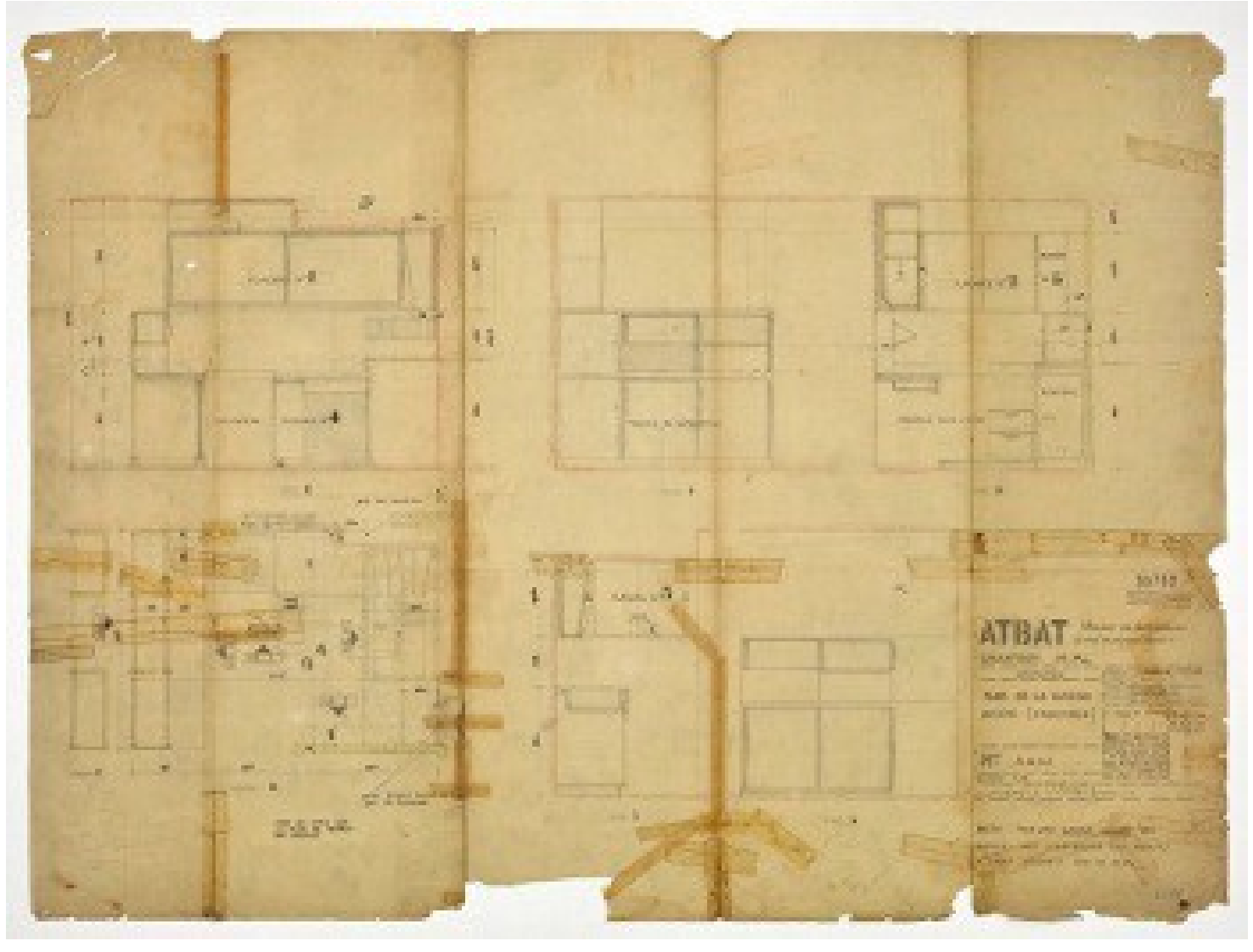

210. Planimetría de la cocina de L'Unité habitationel de Marsella. Fuente: Centro Pompidou, 2016.

Las medidas en altura de los módulos de la cocina, en el taller de Le Corbusier, debían ajustarse a las determinadas por su Modulor I b para los distintos planos de trabajo en general. Como hemos visto, el plano de trabajo que propone es de $86 \mathrm{~cm}$ para un hombre de $183 \mathrm{~cm}$ de altura. 


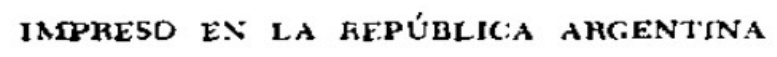

Título del original:

"LE MODUI,OR"

Traducción por:

Rosauio Vira

ESCRTTE EM AEO.194B |P.59|

211. Primera edición en lengua castellana del Modulor I de 1953. Fuente: Gustavo Gili, 1961.

Le Corbusier, en su Modulor I, cuya primera edición francesa data de 1950, recomienda, apoyado en las medidas de las series roja y azul (S.r. y S.a.), que la mesa de trabajo esté a $86 \mathrm{~cm}$ de altura según la serie azul, por lo que los módulos con una altura de $70 \mathrm{~cm}$, tendrían una medida tomada de la serie azul, el zócalo, de 0,16 cm, se encontraría en la serie roja nuevamente.

Cocina: mesa de trabajo, 86---S.a. y 70---S.r. (Le Corbusier, 1953:

La serie roja contiene la altura del ombligo del Modulor lb, 113; y cada término de la serie se obtiene sumando los dos anteriores. La serie azul contiene la altura del hombre con el brazo levantado, del Modulor lb y se construye de igual modo, como en la serie de Fibonacci $(1,1,2,3,5,8,13, \ldots)$.

El cociente de dos términos consecutivos de la serie de Fibonacci tiene por límite el número de oro:

$$
1,2,1.5,1.6, \ldots \rightarrow \phi
$$

Las series roja y azul tienen la misma propiedad, por lo que, a partir de cierto término, se puede conseguir el siguiente, aproximadamente, multiplicando por una aproximación de $\phi$, en torno a 1,6. Así, partiendo de las dos medidas básicas 113 en la serie roja y 226 en la serie azul -doble que la roja-, se obtienen todos los demás términos con suficiente aproximación. Le Corbusier 
quedó prendado de estas series que cumplían tres requisitos: contenían muchas de las medidas que la práctica profesional le había enseñado; estaban relacionadas con el número de oro, por su propia construcción; y la cantidad $183 \mathrm{~cm}$, tomada como altura del varón canónico, devolvía la medida en pies, 6 pies, que permitía establecer las restantes equivalencias entre el sistema anglosajón y el sistema métrico decimal -además de conservar el canon clásico recogido por Vitrubio y rescatado por los arquitectos renacentistas: un varón cuya estatura es igual a seis veces su pie.

\section{DEMOSTRACION: VALORES Y JUEGOS}

Los valores numéricos ilimitados:

VALORES

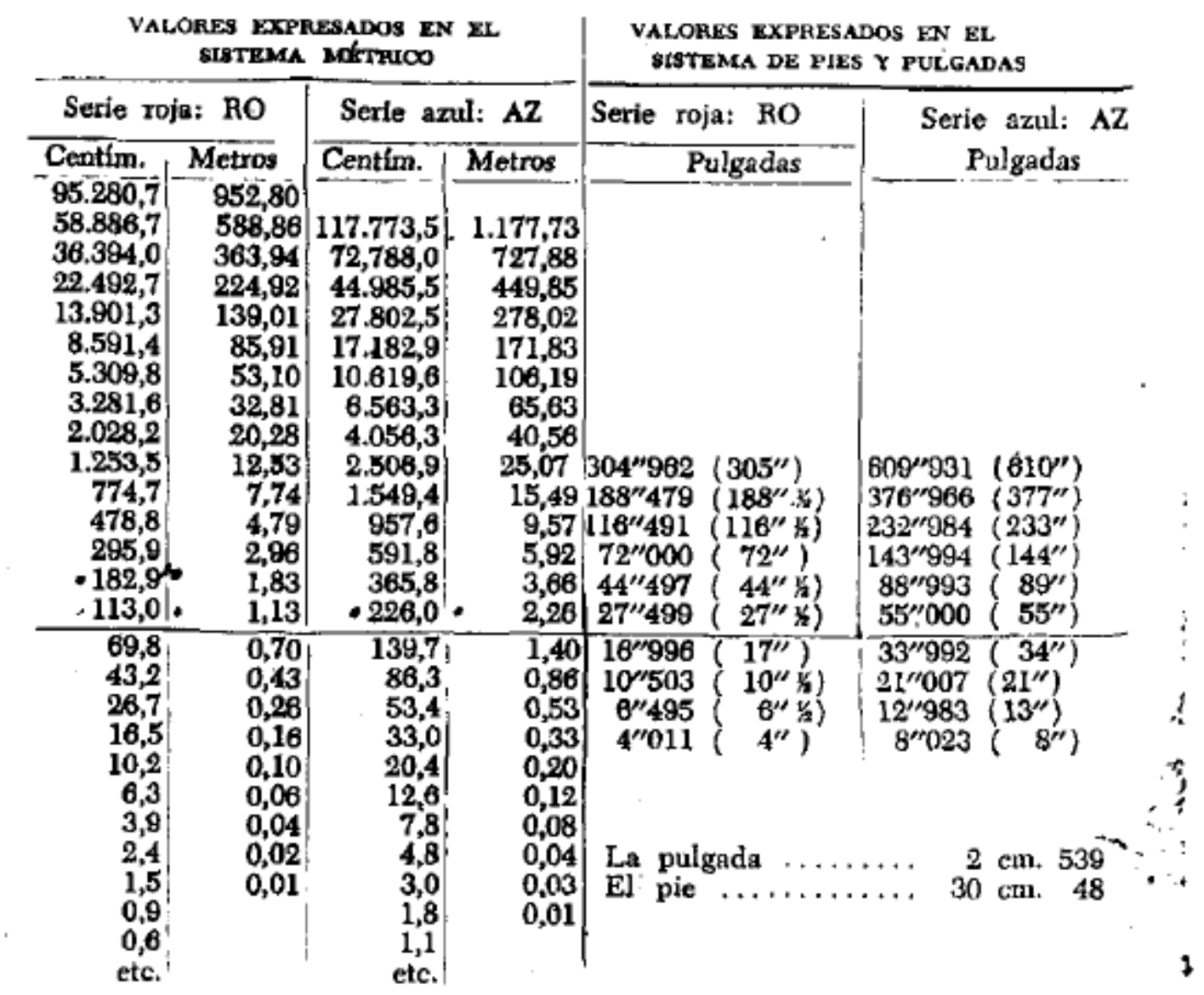


Sin embargo, en el proyecto real, su cocina, la de Charlotte Perriand más bien, determina el fregadero a una altura de $90 \mathrm{~cm}$. ¿Supeditó la altura del fregadero y su bancada a la alineación con el frigorífico más la encimera? (supongo la encimera necesaria para aprovechar la parte superior del frigorífico como área de trabajo).

Él mismo, en la misma página 127 habla de la dificultad de conseguir las medidas exactas del Modulor en los proyectos reales:

Puede afirmarse que, hasta ahora, nunca se han podido aplicar precisiones de esta naturaleza, con tal rigor matemático y armonioso, a la simple disposición de la vida cotidiana: la vivienda. (Le Corbusier, 1953: 127)

Mandaban las máquinas, no la invisible mujer doméstica a la que sí tuvieron en cuenta Grete y Perriand. Incluso en los tiempos en que Le Corbusier no era el referente antropométrico del Neufert, este libro, que declaraba en su primera edición que se inspiraba en la experiencia y la observación de múltiples situaciones, recomendaba esos $80 \mathrm{~cm}$ que fijaban a la mujer en la cocina.

La otra bancada, junto a la cocina, mide $80 \mathrm{~cm}$ de altura, como el mueble de los fogones. Existía el criterio de poner los fogones más bajos, para facilitar la vista de la cocción de los alimentos. Tal vez esas dos alturas hubieran sido ideales para la conciliación familiar, si la asignación del rol doméstico en Le Corbusier, no hubiera sido tan clara y tajante. Recordemos que cuando Charlotte Perriand buscó trabajo en su taller, la primera vez, fue rechazada porque en aquel taller no se bordaban cojines, dijo Le Corbusier. (Gubieda, 2015: 1); y él mismo en su Modulor escribe lo siguiente -especialmente interesante resulta el punto 3- al hablar de las prolongaciones de la casa, en el interior de la construcción:

OBJETO: el equipo doméstico

Objeto que motiva la institución de una auténtica ciencia de la vivienda.

$1^{\circ}$ La casa, piedra angular de una civilización. La casa de la civilización maquinista:

- el programa: 
a) el célibe;

b) la pareja;

c) la familia múltiple;

d) el nómada (hostería),

$2^{\circ}$ las funciones;

- el mobiliario y los utensilios;

- los elementos de composición: la planta; la alzada; y el desarrollo de las paredes.

$3^{\circ}$ Las prolongaciones de la casa:

En el interior de la construcción:

- "los servicios comunes", utillaje de la vida familiar (disminución de las cargas de la mujer: aprovisionamiento, servicio doméstico preparación de platos);

En el exterior de la construcción:

- separación del peatón y del automóvil;

- el deporte al pie de las casas;

- las unidades complementarias (de salud, maternales, casas-cunas, clases primarias, talleres para jóvenes);

- sol, espacio, césped (recuperación del equilibrio nervioso).

EI MEDIO: LA INDUSTRIALIZACIÓN

Disposiciones que preparan la industrialización:

$1^{\circ}$ Acondicionamiento de los locales (ventilación, calefacción, refrigeración).

$2^{\circ}$ Reglamentación municipal: estatuto del terreno.

(Le Corbusier, 1953: 103)

La cocina que estoy describiendo fue ideada por Perriand, firmada por Le Corbusier como arquitecto, construida en su taller ATBAT. Fue presentada al Salón de las Artes del Hogar de 1950 -es el año en que Charlotte Perriand abre su estudio en París, el año en que Le Corbusier publica su primer Modulor, y el 
año en que la actualización del Neufert, en su décimo segunda edición, incorpora como criterio antropométrico el Modulor de Le Corbusier-. La cocina que, tras algunas modificaciones, es la cocina del Taller Le Corbusier, inspirada directamente por la cocina de Charlotte, fue hecha realidad en Marsella, (Rüegg, 2012: s/c).

Pero, aunque Charlotte Perriand resolvió la primera propuesta de Margarete Schütte-Lihotzky, con su módulo bar que abre la cocina al comedor y la delimita, consiguiendo así, según sus propias palabras, situar a «la femme au centre du foyer et non pas reléguée dans un coin à ses tâches ménagères» ${ }^{17}$. (Rüegg, 2012: s/c), el modelo que se convirtió en referencia fue el de la cocina Frankfurt, la segunda propuesta de Schütte-Lihotzky, como hemos leído en sus propias palabras:

Mi primera propuesta, construir un salón y combinar una cocina y comedor, fue rechazada bajo el argumento del coste [...] Así que nos decidimos por una sola unidad, compuesta de una cocina compacta e integrada, separada del salón-comedor mediante una amplia puerta corredera. (Schütte-Lihotzky, 2004: 19)

\subsection{Discusión}

Dado que, como hemos visto, la mujer y el hombre mantienen las mismas proporciones en relación al número de oro, podemos extender dicha proporcionalidad para calcular la altura del plano de trabajo para una mujer de $162+/ 1 \mathrm{~cm}$-dado que las fuentes utilizadas proceden de instituciones y años distintos, he calculado la media de sus medias-, teniendo en cuenta que el Modulor I b) recomienda para el varón la altura de $86 \mathrm{~cm}$ para el fregadero:

$$
\begin{gathered}
86 / 183=x / 162 \\
X=13932 / 183=76 \mathrm{~cm}
\end{gathered}
$$

17. La mujer en el centro del hogar y no relegada a sus tareas domésticas en un rincón. (Traducción propia). 
Ésta sería la medida equivalente para el fregadero a usar por una mujer de 162 $\mathrm{cm}$. Si le sumamos la altura del módulo a los $3 \mathrm{~cm}$ de grosor de la encimera: $76+3=79 \mathrm{~cm}$ daría la altura una vez alineado con la bancada. Exactamente las medidas tomadas por mí en la cocina Frankfurt expuesta en Viena, en el Museo de Diseño y Artes Decorativas (MAK).

La solución de $79 \mathrm{~cm}$ para la bancada, sería el valor para una persona, varón o mujer, de $162 \mathrm{~cm}$ de estatura, no $88 \mathrm{~cm}$ como nos ofrecen las bancadas estándar a las mujeres de $160-170 \mathrm{~cm}$. Como he dicho antes, $88 \mathrm{~cm}$ es la medida del Modulor I b) más dos $\mathrm{cm}(86+2),-(85+3)$ según el Neufert actualizado con Le Corbusier desde la edición $21^{\mathrm{a}}-$, que se suponen por el incremento de 2-3 cm de la talla de la población. Pero esto significaría que la talla $\mathrm{x}$ a quien se dirige esta medida cumpliría la siguiente ecuación

$$
\begin{gathered}
86 / 183=88 / x, \text { es decir } \\
x=187 \mathrm{~cm}
\end{gathered}
$$

\section{KITCHENS}

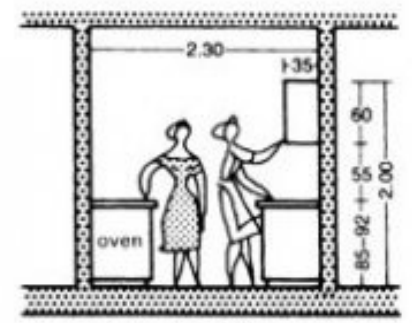

$1-60+1.10-1.20+60-$

(2) Section through kitchen: space for two people

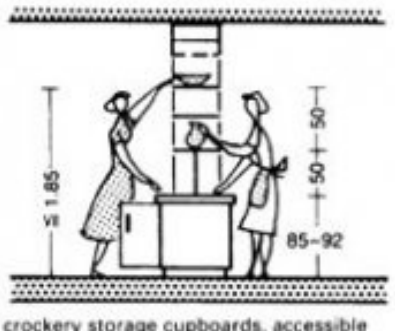

crockery storage cupboards, accessible from both sides

(6) Hatch between kitchen and
dining room

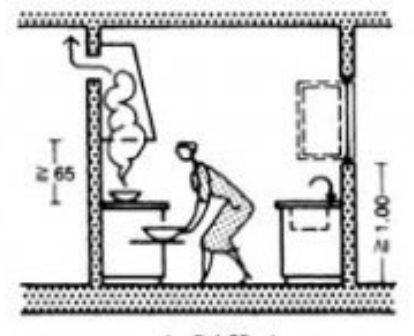

$\mapsto 21.20-$

(3) Low-level oven requires adequate space in front: extracter hood above cooker

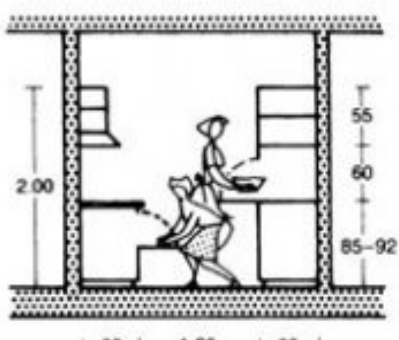

$1-60+-1.20-+60-$

(7)

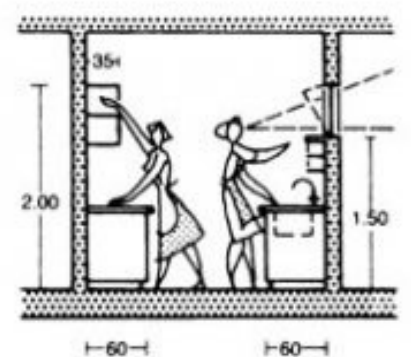

(4) Worktops and storage $60 \mathrm{~cm}$ deep
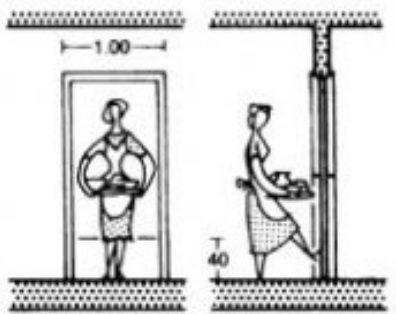

(8) Self-closing doers with kick-plate between pantry and dining room 
Como hemos visto en las imágenes del Neufert y consta en la tabla resumen de sus ediciones, la altura de trabajo oscila entre 85 y 90 . La altura de los personajes es de 1,85 -más dos centímetros por el supuesto crecimiento de la población nos da el 1,87 de los cálculos arriba expuestos- y los personajes representados como habitantes naturales de la cocina son mujeres, contradicción omnipresente en el Neufert. El Modulor de Le Corbusier aparece en las últimas actualizaciones del Neufert en sustitución del módulo de Mössel. A lo largo de décadas, profesionales de la arquitectura e industriales han utilizado tanto El arte de proyectar de Neufert como el Modulor de Le Corbusier. Nadie ha cambiado las referencias a la antropometría del varón ni a las funciones estereotipadas del rol de género de la mujer. Dibujan una mujer de $165 \mathrm{~cm}$ de estatura media pero la altura estándar del plano de trabajo sigue siendo 85 .

La cocina de Margaret Schutte-Lihosky, el prototipo de Charlotte Perriand y las primeras ediciones del Neufert, sí que respetaban las proporciones: $76 \mathrm{~cm}$ para el fregadero y $80 \mathrm{~cm}$ para la bancada. Así pues, $79 \mathrm{~cm}$ con poco más por el incremento de estatura, debería ser el estándar, al menos mientras el topopoder mantenga a las mujeres en ese locus, pues la solución propuesta en este trabajo va más allá: no se trata de mantener a la mujer enjaulada y conseguirle una jaula de oro, de lo que se trata es de que la asignación al servicio doméstico desaparezca como función natural de la mujer.

El trabajo del ama de casa puede ser considerado con más razón una servidumbre doméstica o, con mayor elegancia, servicio doméstico. El trabajo del ama de casa no es «trabajo». El trabajo tiene lugar en el mundo capitalista del hombre y de los espacios de trabajo. El significado de «trabajo» depende de la relación (reprimida) entre la esfera privada y la civil. Un «trabajador» es un esposo, un varón que da sustento/protección a su esposa, que depende económicamente de él (subordinada). Esto quiere decir que un trabajador es alguien que «se gana la vida». La diferencia entre «trabajo» y lo que una esposa hace queda establecido en el lenguaje popular y en las estadísticas oficiales: las tareas del ama de casa no se incluyen en las mediciones oficiales sobre productividad nacional. La construcción del trabajador 
varón como "alguien que se gana la vida» y de su esposa como su «dependiente» puede verse en las clasificaciones del Censo de Gran Bretaña y Australia. En el Censo de 1851 en Gran Bretaña, las mujeres empleadas en el trabajo doméstico no remunerado fueron «ubicadas en una de las clases productivas junto con el trabajo de una clase de pago similar. Esta clasificación cambió después de 1871 y hacia 1911 las amas de casa no remuneradas ya habían sido separadas de la población económicamente activa. (Pateman, 1995: $190,191)$

Dada la situación a principios del siglo $X X$, no podemos negar el mérito a las pioneras, que pelearon por mejorar las condiciones de la mujer en la cocina. Algunas pelearon por cambiar la sociedad.

A pesar del esfuerzo, parte de sus aportaciones se ha perdido: de la cocina de Margarete no han trascendido las dimensiones, como acabamos de ver, ni las distribuciones de la planta de la vivienda, que ella procuró que conectaran la cocina visualmente con el comedor y la sala infantil. Justo recientemente, se está retomando la idea de Perriand que, paralelamente a un deseo de Margarete, diseñó la forma de abrir la cocina para que la mujer tuviera acceso a las conversaciones del salón. Porque la mujer sigue encerrada en la cocina moderna, la heredera de la cocina sueca, heredera a su vez de la cocina de Margarete.

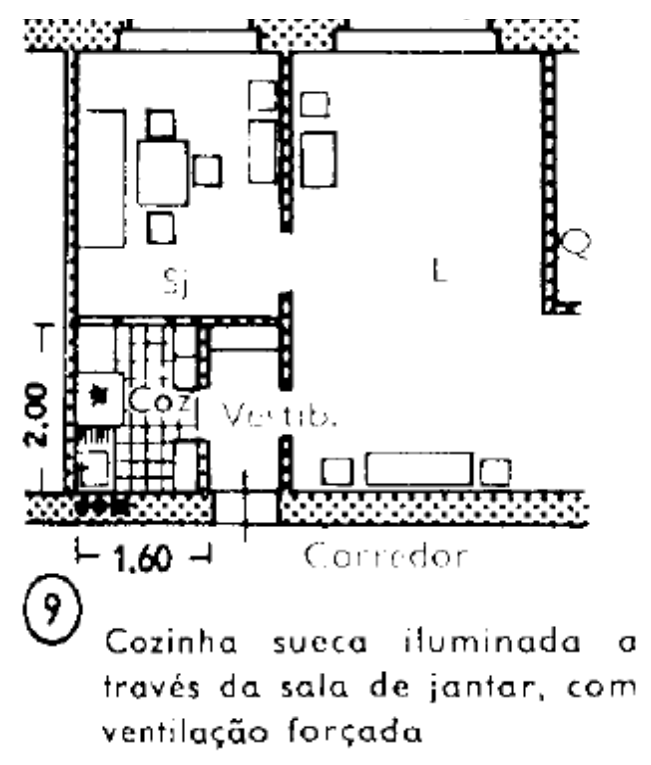

214. Ernst Neufert. Modelo de cocina sueca $7^{a}$ ed. portuguesa, $21^{a}$ alemana en El arte de proyectar en arquitectura, 1958. 
Por otra parte, surge esta cuestión: ¿tan ergonómico es el Modulor? Nada, opina Antonio Bustamante en su Ergonomía, antropometría e indeterminación.

La ignorancia que de la ergonomía tuvieron los maestros del Movimiento Moderno de la Arquitectura y Artes Plásticas y, en particular Le Corbusier, contrasta con su pasión por lo nuevo, las máquinas y lo minimalista. En el portal de Internet de la Académie de Nancy-Metz, alaban al arquitecto suizo en estos términos:

«(Le Corbusier). . . pensaba que el hombre debe adaptarse a la arquitectura, y no a la inversa» (http://www.ac-nancy-metz.fr/). No se puede decir nada más anti-ergonómico. Como ya hicieran los clásicos, Le Corbusier trata de poner en relación las medidas del hombre con las de los objetos construidos mediante su propuesta, denominada Modulor; para el que parte de un hombre que midiera $183 \mathrm{~cm}$. y que tuviera el ombligo a $113 \mathrm{~cm}$. sobre el nivel del suelo; al levantar la mano, este sujeto virtual debería tener la punta del dedo medio 226 $\mathrm{cm}$. por encima del nivel del suelo. A través de una serie de operaciones muy bellas desde el punto de vista aritmético y plástico, deduce unas series de medidas que le sirven para poner orden en los proyectos de construcción, pero que desde el punto de vista de la ergonomía no sirven para nada. Para el Modulor, el usuario es esa sombra que ha de encajar en la red de medidas hechas a imagen del sujeto virtual que inventa Le Corbusier, y así vemos, en la tercera casilla de la imagen de la Figura 3, al hombretón de $183 \mathrm{~cm}$. obligado a escribir en una mesa de $70 \mathrm{~cm}$. de alto. Las lumbalgias que estas medidas han de causar al pobre hombre son evidentes. Para sentar al usuario no parece recomendable forzarlo a cuadricularse para entrar en los números de una serie que proviene de la aritmética y no de la anatomía o la biomecánica. Consideremos, pues, este invento del ruidoso Le Corbusier como algo que, si bien quizá pueda ser un buen ejercicio para los alumnos de arquitectura, es nefasto para la cultura postural del resto de la gente. (Bustamante, 2004: 445)

Para profundizar en este análisis de la falta de ergonomía de las propuestas del Modulor, voy a introducir una notación que me facilite las próximas líneas de la 
discusión: ( $a, b)$ significará que estoy hablando de una cocina, la altura de cuyo fregadero es de b cm y que va a ser utilizado por una persona de a $\mathrm{cm}$ de talla.

Puesto que la ergonomía de las medidas recomendadas en el Modulor, (183, 86), han sido puestas en cuestión, procede preguntarse cuál de las relaciones es más ergonómica: $(183,86)$ para el Modulor masculino, $(162,85)$ para el estándar actual, o $(162,76)$ para el Modulor femenino y la cocina Frankfurt. Frente a estas posibilidades caben distintas conclusiones (bastará sumar $3 \mathrm{~cm}$ a la segunda cifra, referida al fregadero en las tres cocinas, para obtener la altura de la bancada en cada caso).

Si las proporciones del Modulor de Le Corbusier -no olvidemos que determina las indicaciones del Arte de proyectar de Neufert- no son ergonómicas, tampoco lo son las de Grete, por ser proporcional al Modulor aunque tendría la ventaja de haber calculado la proporción en función de la altura de la mujer media que en realidad iba a ser la «usuaria». Tampoco lo es el estándar actual que combina la altura del fregadero que Le Corbusier asigna a un varón de 183 $\mathrm{cm}$ de altura, con la altura de la «usuaria media». Resultado perverso coherente con el pensamiento de Le Corbusier, pues creó un sistema de medidas a partir del varón de $183 \mathrm{~cm}$ de altura pero, como hemos visto, jamás consideró la posibilidad de que en la cocina fuera a trabajar el varón.

$\mathrm{Si}$, en principio, el Modulor de Le Corbusier no es ergonómico, tampoco lo es el de Grete. Sin embargo, entre ambos es preferible la solución de Grete pues, en ese caso, a la falta de ergonomía, Le Corbusier sumaría la perversión antes citada.

¿De dónde sale pues el módulo estándar actual? ¿Se sigue ciegamente al maestro o son los modernos estudios de ergonomía los que lo han determinado? 


\section{La polémica está sobre la mesa, como en el siguiente foro, donde vemos que la sombra del maestro es muy alargada. Veamos a continuación una conversación en dicho foro, donde los participantes se preguntan e informan acerca de las alturas de las mesas de trabajo $^{18}$ :}
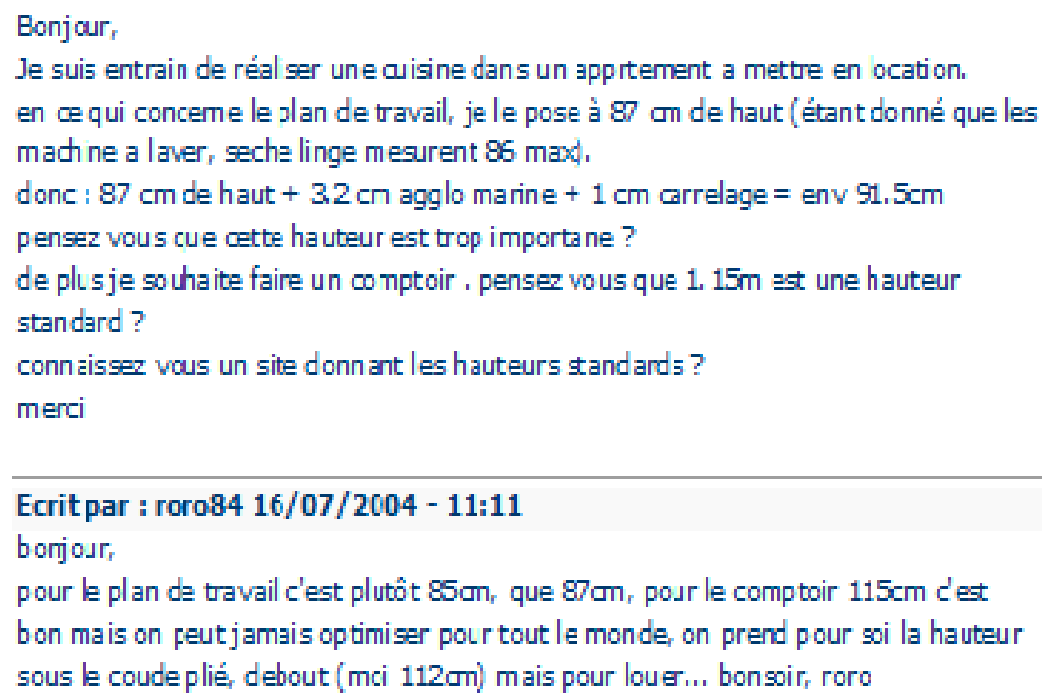

\section{Ecritpar : rene 17/07/2004- 15:24}

tu vas te promener has un marchand de meubles et tu mesures.

87 Cest mieux que $8 \mathrm{~S}$ cr il te faut $\boldsymbol{\&}$ Dessous. et tu psux toujours hatsser pour etre a niveau pas I inverse.

Les catalogues d ameublemen: cest pas mal non plus;

\section{Ecritpar : Charles_F 17/07/2004-22:51}

Bonscir,

Le Corbusier a défini la hauteur d'un p an de travail à 86 an et un comptoir à 113

$\mathrm{cm}$. Vici un lien versles dimensions qui permettent de se sentr bien :

hष्: ://lenombredor, free fr/motulor, htm

Cordialement, Gharles

18. Buenos dias, voy a construir una cocina en un apartamento para alquilar. En lo concerniente al plano de trabajo, he puesto $87 \mathrm{~cm}$ de altura (siendo que las lavadoras y secadoras miden $86 \mathrm{~cm}$ máximo.

¿Pensais que esta altura es demasiada?

Luego me gustaría hacer un mostrador, ¿pensáis que 1,15 m es una altura estándar?

Comocéis alguna página web que dé las alturas estándar.

Gracias.

Buenos dias

para el plano de trabajo es mejor $85 \mathrm{~cm}$ que $87 \mathrm{~cm}$, para el mostrador $115 \mathrm{~cm}$ está bien pero nunca se puede optimizar para todo el mundo, se toma, para uno la altura bajo el codo doblado, d e pie (yo 112) pero para alquilar... buenas tardes, roro.

Date una vuelta por las tiendas de muebles y mide $87 \mathrm{~cm}$ es mejor que 85 porque necesitas 85 debajo y puedes siempre elevarte para estar a nivel, no a la inversa.

Le Corbusier, definió la altura del plano de trabajo a $86 \mathrm{~cm}$ y la del mostrador a $113 \mathrm{~cm}$. Mira un enlace que te da las dimensiones para sentirte bien: http://lenombredor. free.fr/Modulor.htm, Cordialmente. Charles. 


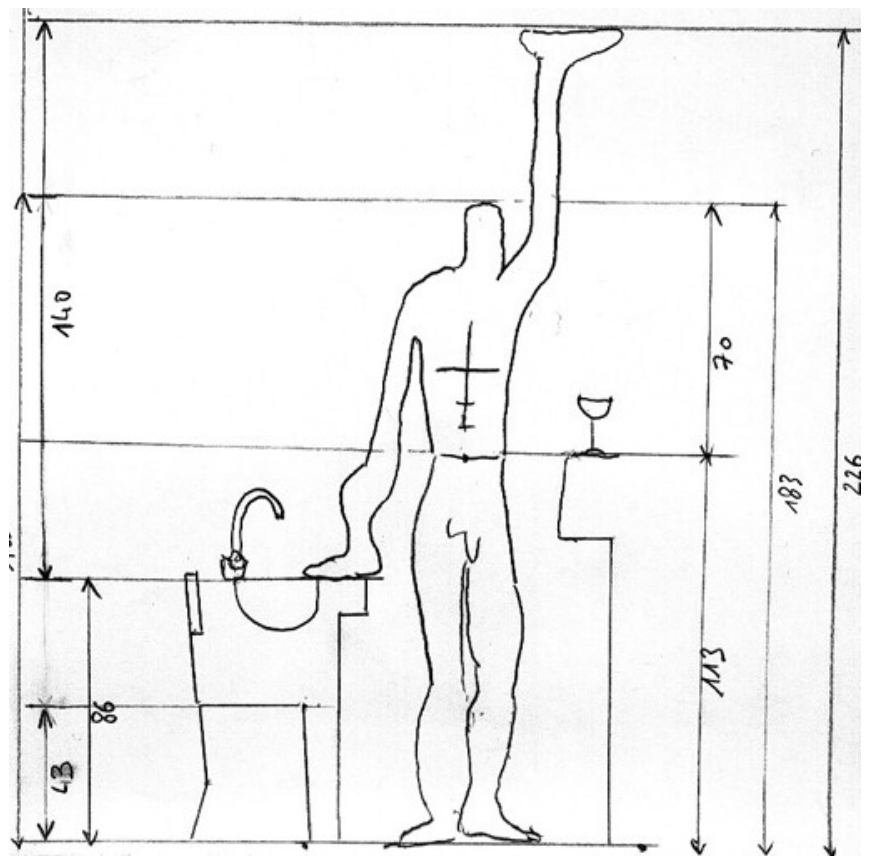

215. No cabe duda alguna de que se destina al propietario de un cuerpo masculino. Fuente: Lenombredor, 2016.

La imagen 215 aparece en el enlace sugerido por Charles en la conversación del foro citado, en ella se ven claramente las medidas recomendadas por el Modulor.

Siguiendo la notación que he sugerido más arriba y las medidas que nos recomiendan los comerciantes o los distintos participantes en la toma de decisiones sobre la altura de la bancada, se nos presentan distintas opciones alternativas: la opción $(162,85)$ tomaría como referencia el 86 del maestro, sin pensar que se lo están asignando a 162, no a 183 y que la «usuaria» con toda probabilidad va a acercarse $162 \mathrm{~cm}$ de estatura. Es decir, a la hora de proyectar se piensa como varón en las medidas pseudoergonómicas para un varón, pero a la hora de cocinar se le adjudica la tarea a una mujer para quien parece que no importa considerar la ergonomía.

Así pues, si aceptamos que el Modulor masculino de Le Corbusier es el referente de los módulos estándar, procede hacerse otra pregunta ¿fue la declaración de maestro en su Modulor I acerca de la bancada de la cocina de la Unidad habitacional de Marsella -que la cocina integrada de Perriand no 
respeta- junto al poder de difusión que poseía la obra del maestro, aumentada desde 1950 con su inclusión en el Neufert, quienes hicieron posible la pervivencia de esta perversión? "Le principe de la cuisine de Marseille será réutilisé dans des Unités plus tardives» ${ }^{19}$. (Rëgg, 2012: s/c)

Antes, en 1924-25 -más de una década anterior al Arte de proyectar de Neufert y dos décadas antes del primer Modulor de Le Corbusier- Rietveld-Schröder, en Utrech (Holanda), construyeron la bancada a $86 \mathrm{~cm}$.

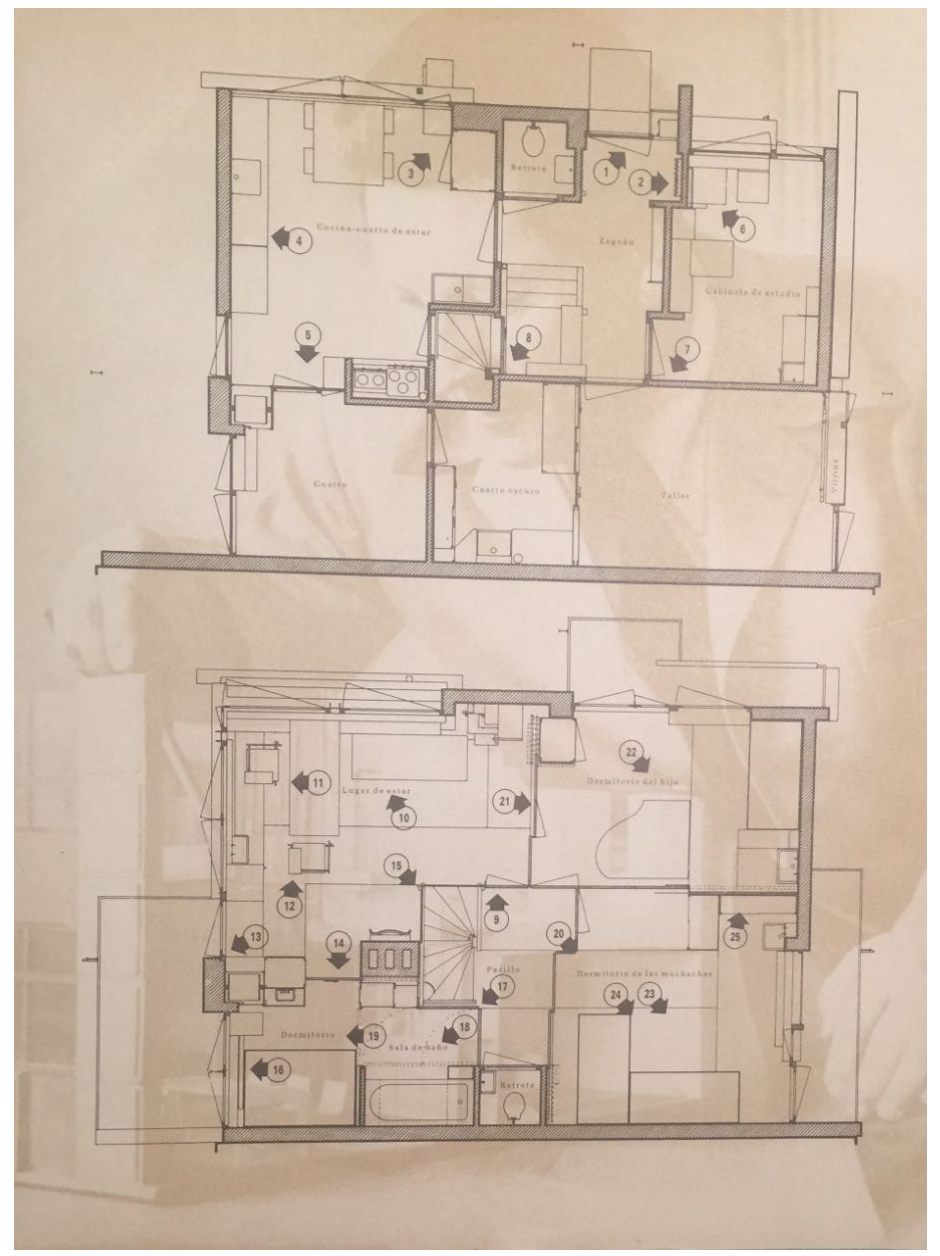

216. Planimetría de la casa Rietveld-Scröder. Fuente: Utrech Central Museum, 1995.

Visité la casa Rietveld-Schröder en 1995, durante mi estancia en La Haya, en el despacho de arquitectura BNA Arcitektenburo Roelevelt-Sykkes. Recientemente la medida de $86 \mathrm{~cm}$ de la bancada he podido tomarla personalmente en la

19. El principio de la cocina de Marsella será reutilizado en Unidades más tardías. 
reproducción de la cocina, expuesta en el IVAM, durante una visita realizada en febrero de 2016.

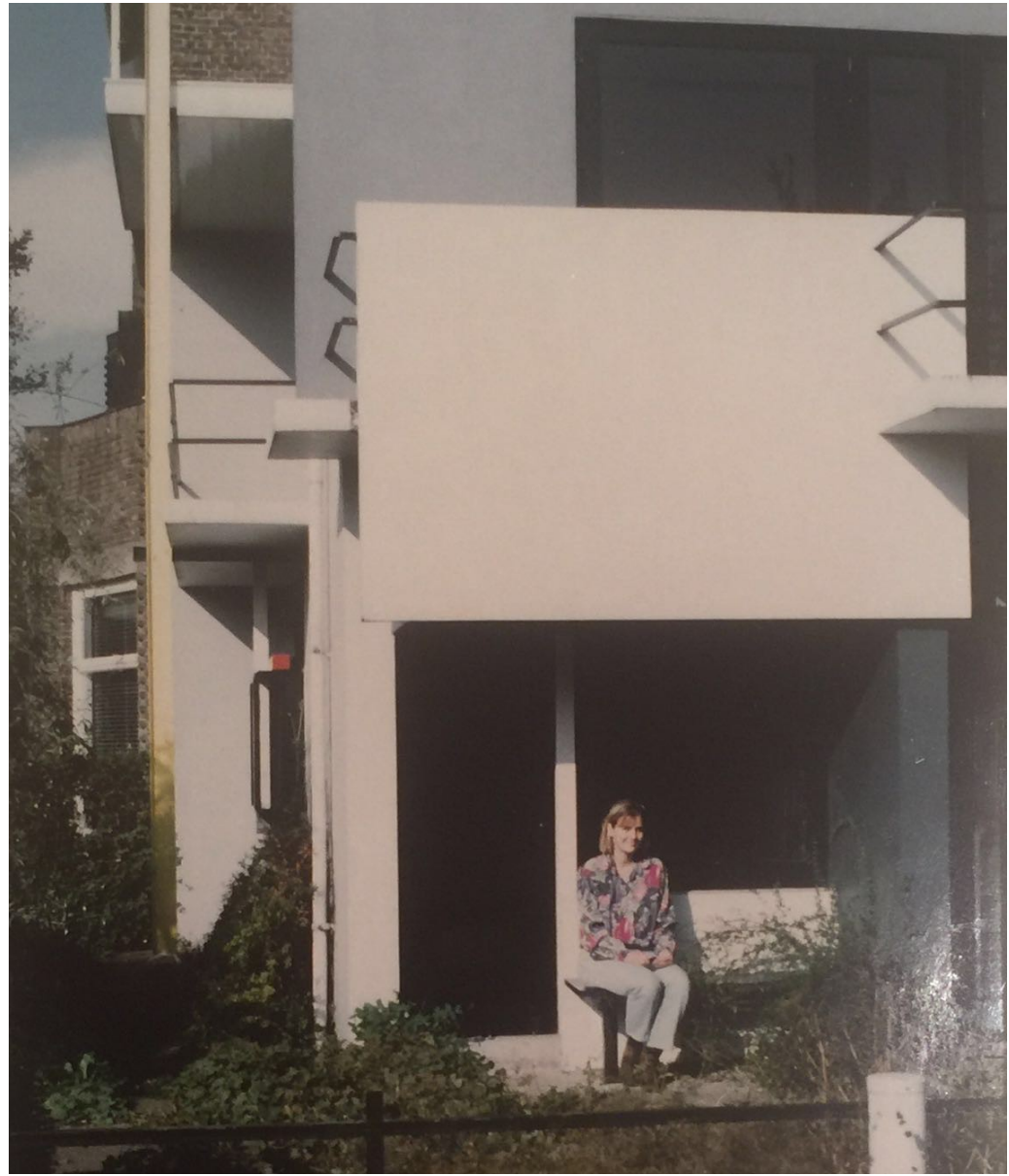

217. Casa Rietveld-Schröder. Fotografía de la autora, 1995.

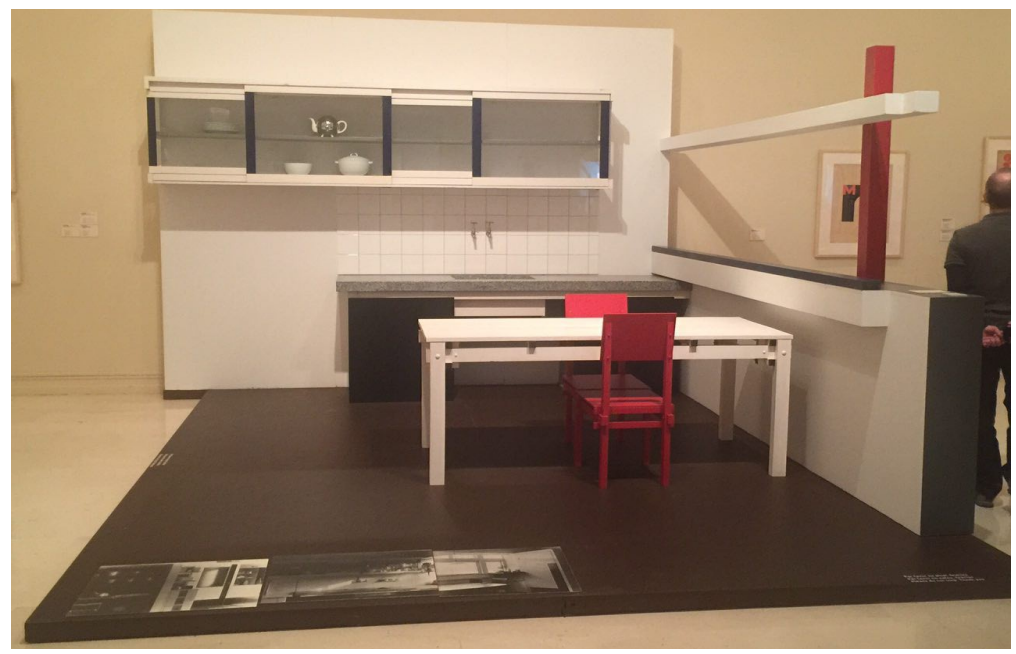

218. Cocina de la casa Rietveld-Schröder en exposición IVAM. Fotografía de la autora, 2016. 
Le Corbusier también visitó la casa, ¿eligió sus $86 \mathrm{~cm}$ para el fregadero alineado con la bancada antes o después de esta visita?

Mantener las proporciones dictadas por los clásicos, perpetuadas por Neufert y popularizadas por el Modulor a partir de la primera medida, $226 \mathrm{~cm}$, no ha resultado ergonómico ni tan siquiera para el varón medio europeo, cuya altura está más acorde con los $175 \mathrm{~cm}$ del primer Modulor.

Determinar una altura piso techo de $226 \mathrm{~cm}$ (tomados de sus múltiples viajes observando y midiendo viviendas de distintas culturas) para que el hombre de $183 \mathrm{~cm}$ (tomado de los clásicos) pudiera entrar y vivir en ella se justifica, pero hacerle la altura de la bancada a él no se justifica. Ni está claro que ese $86 \mathrm{~cm}$ fuera ergonómico para el mismo varón, pero, además, él no la iba a usar, al menos no según el criterio de Le Corbusier. Tampoco, desde luego con la frecuencia suficiente como para que hubiera que priorizar el cuidado de su espalda por encima de la persona que iba a trabajar en ella la mayor parte del tiempo, del tiempo de la cocina y del tiempo de la persona: la mujer.

¿Los $86 \mathrm{~cm}$ de altura del plano de trabajo los ideó o los eligió por su experiencia profesional, como lo hizo con el 226? Porque la casa Rietveld-Schröder, construida entre 1924 y 1925 es muy anterior a su Modulor, incluso a la publicación de Ghyka, que Le Corbusier cita en su Modulor I de 1950 como la fuente de los cálculos matemáticos que relacionan su Modulor con el número de oro para generar las dos series, roja y azul, entre las que podemos hallar sus estimadas medidas: $226,183,113,86$. La primera -226- es una medida clásica, observada por él en sus múltiples viajes, que se ajusta a las series del Modulor. La segunda -183- es una medida teórica procedente del canon clásico, pero también entra en las series del Modulor ¿Ocurre lo mismo con el 86? Podría ser, si nos fijamos en la casa Rietveld-Schröder, pero cabe sospechar que la decidió para ajustar la realidad al Modulor y no el Modulor a la realidad, como nos advertía antes Bustamante.

Hoy día se siguen restaurando casas singulares exactamente según el Modulor (Casa Weston en Altea, por Antonio Maciá): 
El mueble define uno de los seis límites del espacio principal de la vivienda, permitiendo alojar los frentes de una segunda habitación oculta, el acceso al lavadero, el frontal de la cocina, el mobiliario del salón comedor y el de la terraza exterior. El paramento situado enfrente, define el segundo de los límites y sirve de contrapunto al primero siendo totalmente plano y que, construido con otro tipo de madera, contiene varios armarios, el acceso a la habitación principal, los electrodomésticos ocultos de la cocina y el acceso a la vivienda. El suelo y techo forman otros dos importantes límites pues permiten definir las alturas de la vivienda así como los diferentes niveles del mueble. La sección de la vivienda está dimensionada tomando como base el Modulor de Le Corbusier y sus consecuencias a nivel de proporciones y relaciones con el cuerpo humano que, además, establecen una sutil relación con la fotografía de E. Weston. Tomando como altura la medida de $226 \mathrm{~cm}$, el resto de niveles son fracciones del mismo: $86 \mathrm{~cm}$ para las bancadas, $43 \mathrm{~cm}$ para los bancos ó $70 \mathrm{~cm}$ para las mesas. (Maciá, 2013: s/c)

Vemos la impronta de los estándares por los que tanto luchó Le Corbusier, en viviendas singulares que llevan su sello por una cuestión de gusto legítimo, de elección en el diseño desde la voluntad estética. Por otra parte, y sin que deje de ser considerado un lujo a día de hoy encajar las proporciones según el Modulor, estamos hablando de módulos estándar $(162,86)$ y estos módulos van destinados a la industria de la construcción, a la construcción en serie de viviendas de bajo coste, al consumo de masas, con poder adquisitivo reducido, lejos de los refinamientos ergonómicos, por mucho que éstos también adolezcan de indeterminación y en consecuencia tengan una ergonomía limitada, hoy superada por las soluciones personalizadas y, por supuesto, más caras.

Si tenemos en cuenta que casi la mitad de la riqueza mundial está en manos del $1 \%$ de la población, y la otra mitad se reparte entre el $99 \%$ restante, nos volvemos a acercar al otro eje de esta investigación: ¿podemos resolver el problema de la cocina ergonómica para la gran mayoría de la población?, Dentro de este sistema, la altura de la tabla de trabajo determina el resto de alturas, pero los electrodomésticos se fabrican con la medida estándar de 85 
cm de altura, lo cual dificulta soluciones como encimeras de altura móvil, encimeras a medida o encimeras de varias medidas, para resolver por un lado que la altura de la encimera no dañe la espalda de la «usuaria» y por otro que la «usuaria» no sea la «sirvienta» predeterminada en la máquina doméstica. Pero todo esto son cuestiones físicas, queda la cuestión psicológica de la adjudicación social del rol doméstico a la mujer y la aceptación de ésta del mandato social. Ello hace que aun pudiendo encontrar soluciones, lo habitual es que se instalen los módulos estandarizados.

Insistiendo en encontrar soluciones como poco parciales, encontramos graves dificultades: las indeterminaciones se supone que deben ser resueltas por las normas ISO. Pero los principios de estas normas son «los mercados» no «la vida». ¿Entonces, quien vela por los consumidores y las consumidoras? ¿En qué queda la ergonomía? ¿Explica esto la disparidad de criterios en la industria?

Al tratar de la relación geométrica entre el usuario y el objeto, podemos encontrarnos con que la geometría del cuerpo humano presenta dos tipos de indeterminaciones: las de orden físico y las de orden psicológico. Las inexactitudes de una medición pueden ser el resultado de una falta de rigor en su ejecución y por eso, en el presente contexto, es oportuno citar la normativa que atañe a la antropometría, en particular la ISO 7250 y la ISO 11226. (Pueden consultarse también la ISO 6385 sobre Principios ergonómicos de diseño de puestos de trabajo, y la n3v3 4 08-1, sobre antropometría).

La «Organización Internacional de Normalización» (ISO) está formada por institutos de normalización de 130 países, coordinados por una oficina central en Ginebra. En reuniones anuales, los miembros de ISO consensúan especificaciones y criterios de interés en materia de clasificación de materiales, fabricación de productos y prestación de servicios. Las normas publicadas representan un marco de referencia muy útil a fabricantes y consumidores, y facilitan el comercio y la transferencia de tecnología de unos países a otros.

La norma ISO 7250 -que se ocupa de las medidas básicas del cuerpo humano da las definiciones de lo que se considera un «grupo de población» 
aceptable como muestra para las mediciones, y de las medidas de base del cuerpo humano. (Bustamante, 2004: 451)

Las mujeres arquitectas fueron llamadas a colaborar porque eran arquitectas mujeres y «sabían» más de cocinas que los arquitectos varones, quienes les hacían esa concesión por su peculiar saber (Bravo, 2011: 291). Gracias a sus diseños el trabajo en la cocina se hizo más eficiente y las mujeres tuvieron tiempo para salir a trabajar tambien fuera del hogar. Pero no abandonaron la cocina que siguió siendo de su exclusiva responsabilidad.

La liberación hubiera llegado con la colectivización de las tareas domésticas tal como proponía Fourier en su utópico falansterio que, en 1885, el fabricante Godin hizo realidad, en una versión reducida a la que llamó familisterio. (Bravo, 2011: 202). Grete también abordó esta solución, como hemos visto en las imágenes de las casas de la Viena Roja y en sus aportaciones al Primer Plan Quinquenal en la URSS. Pero tanto éstas como el modelo de cocina abierta que Bravo propone para la corresponsabilización familiar, aunque fueron preferidos por Schütte-Lihotzky, hubo que abandonarlos según criterios económicos. Criterios únicamente vinculados a la fase de la inversión inicial, que no a otra que computase conjuntamente. Esa inversión económica es la elegida como criterio de valor, no aquello que supone el trabajo doméstico, que sí repercute en el PIB del país aunque no sea tenido en cuenta.

Por otro lado, cuando el modelo colectivista parecía que iba a triunfar en Occidente, llegó a exportarse incluso a EEUU, la burguesía lo atacó porque ponía en peligro su idea de familia y matrimonio:

Hacia finales del siglo XIX e inspirándose en el movimiento de las Ciudades-Jardín impulsado por Ebenezer Howard (1850-1920), se construyeron en Inglaterra diferentes colonias como el complejo Meadow Way Green (Letchworth, 1914) cuyos inquilinos se encargaban colectivamente de la planificación del menú semanal y del abastecimiento de alimentos, mientras que unas cocineras a sueldo se responsabilizaban de las tareas culinarias, de acuerdo con un sistema que permaneció vigente hasta 1970. [...] tales iniciativas fueron objeto de constantes críticas 
por parte de la burguesía, que las interpretaba como una firme amenaza a la familia y al matrimonio como pilares de la sociedad. (Bravo, 2011: 202)

El final de la Segunda Guerra Mundial y comienzo de la Guerra Fría supuso la victoria del capitalismo, el nacimiento de la sociedad de consumo y se impuso el modelo de viviendas particulares completas.

Hoy, abandonada la idea de la colectivización, los discursos abogan por el reparto equitativo de responsabilidades domésticas pero sin conseguir hacerlo realidad. La división del trabajo por sexos está grabada a fuego en las mentalidades y es mantenida por los mensajes simbólicos de la sociedad y por la permanencia rígida de las distribuciones de espacios en las arquitecturas modernas. Sigue manteniendo a los hombres fuera del hogar jornadas larguísimas; las mujeres son incapaces de liberarse de las responsabilidades domésticas como algo propio, a pesar de haber salido al mundo laboral; en él siguen luchando por superar los obstáculos que encuentran para ser tratadas en igualdad: diferencia de salarios, techo de cristal, invisibilidad de la tarea más difícil de compartir: «el piense», es decir, el control de la gestión de todas las tareas del cuidado, desde la lista de la compra, pasando por la revisión de las tallas de la ropa de niñas y niños si hay en la familia, o simplemente el cambio de indumentaria debido al cambio de temporada, gestiones en centros de salud, hasta la agenda de las citas que permiten el sostén de los vínculos afectivos tanto con la familia extensa como con las amistades. «El piense» es el arraigado sentimiento de a quién corresponde la responsabilidad de tener presentes todas las tareas para que esa máquina doméstica no deje de funcionar a ninguna hora de ningún día. Esto supone una colaboración no de pares sino de apoyo a quien se le sigue asignando la responsabilidad de esas tareas, aunque no necesariamente su ejecución.

¿Cómo construir una identidad no subalterna, distinta de la alteridad absoluta, si en los espacios interiores de la casa, sólo es posible encontrar representaciones espaciales estereotipadas; y en el exterior los techos de cristal actúan como muros disuasorios del deseo de igualdad?

Pareciera que no vemos salida al problema, pero la propia esencia del patriarcado abre las grietas hemorrágicas por las que existe la posibilidad de 
debilitarlo, de provocar una revolución que remueva los centros del poder generando un equilibrio, una sociedad más justa. Celia Amorós (1992) propone la lucha para arrebatarle el monopolio del poder al patriarcado; Almudena Hernando (2002) ve con esperanza el empoderamiento de las mujeres construyéndose identidades independientes, contradictorias porque contienen la componente relacional y la individual, pero poderosas; y Cristina Molina (2003) analiza dicha necesidad, porque no le basta el simulacro, propone discursear al patriarcado, disputarle el poder de nombrar y de asignar lugares. En esa tarea de asignar lugares, hemos visto que la arquitectura y el diseño de interiores, tiene mucho que decir. Hemos desvelado algunos vicios patriarcales ocultos en los espacios que habitamos. Es un primer paso para deconstruir lo establecido por el patriarcado. Sobre sus ruinas podremos construir un nuevo modelo de sociedad... algún día. 


\section{CONCLUSIONES}


A lo largo de esta investigación hemos ido constatando una serie de hechos que corroboran la hipótesis de que el espacio interior contribuye a la construcción de la identidad de cualquier persona, y en particular, de cada mujer.

La construcción de una identidad femenina independiente se enfrenta, como hemos podido comprobar, a la ardua tarea de abandonar la subalteridad. Subalteridad que deviene de la propia necesidad de la identidad individual masculina. El sujeto varón necesita de lo que Almudena Hernando denomina identidad relacional, pero no la atiende. Su subalterna, la mujer del patriarcado, sostiene la vida para él.

Hemos podido reconocer que el espacio es una de nuestras principales referencias dinámicas en lo que concierne a la biografía de nuestra identidad. Es el marco que la contiene. $Y$ desde esa premisa, condiciona el desarrollo de las identidades.

De la revisión de la producción teórica de los hombres a lo largo de la historia en la arquitectura ha quedado constatado que la historia de la Arquitectura desde el Renacimiento hasta el Movimiento Moderno apenas cuenta con referentes femeninos. Cuando la Grecia Clásica y el Renacimiento ponen al hombre en el centro de todas las cosas, no se refieren al hombre como representante del género humano, sino al hombre como varón. Desde Vitrubio, la proporción del cuerpo humano, entendido como cuerpo del varón, será referente en estas cuestiones para toda la arquitectura posterior. También desde Vitrubio, en el siglo I antes de nuestra era, hasta finales del siglo XIX con Loos todavía- se mantiene la idea de que la casa debe ser construida teniendo en cuenta el rango y profesión del varón, pater familias. Vivienda y familia son así conceptos que refuerzan la estructura patriarcal. Con singular potencia, este hecho trasciende lo visible para perpetuar la asignación del lugar de lo doméstico a las mujeres.

En el siglo XV, Leonardo da Vinci resume en el dibujo «el hombre de Vitrubio» el módulo que éste último estableció basado en el varón y que inspirará el Modulor de Le Corbusier, también varón. La historia toma con ello la parte por 
el todo. El hombre, varón, es la parte siendo hoy en día asumida como el todo, la persona, el ser humano, en cuanto a gestión de las dimensiones del espacio se refiere.

Hemos cotejado cómo en el siglo XVII, Plautilla Bricci es la mujer arquitecta que constituye la excepción a la regla general de la ausencia de mujeres en esta disciplina, aunque bajo la sombra de su hermano Basilio Bricci. La historiografía invisibilizará a las mujeres de nuevo hasta finales del siglo XIX. Nos encontramos con una historia de contenido androcéntrico y con un vacío en el reconocimiento al trabajo profesional de las mujeres en el mundo de la arquitectura y el diseño de espacios interiores. No es habitual que trascienda el nombre y la obra de aquellas a quienes llamamos pioneras más allá de ciertos ámbitos ocupados en cuestiones de género.

Tadao Ando, Le Corbusier, Santiago Calatrava. Arquitectos de reconocido prestigio internacional.

Tadao Ando es considerado arquitecto a todos los efectos, aun siendo simple encontrar información respecto a su proceso de formación autodidacta y su falta de titulación en esta materia.

Le Corbusier, nunca cursó los estudios de arquitectura, nunca fue oficialmente arquitecto, y ha devenido en uno de los maestros de la arquitectura. A día de hoy 17 de sus obras han sido reconocidas por la Unesco como patrimonio de la humanidad. Un simple cálculo ya avanza que su primer encargo para una vivienda le llegó con tan solo diecisiete años.

Santiago Calatrava, cuyo currículum es menos claro, pues hay lugares en los que se le presupone arquitecto titulado en 1973, habiendo empezado sus estudios en la Universidad Politécnica de Valencia. Lo cierto es que la Ley General de Educación de 1970 exigía cinco años para la obtención de esta titulación y eso le habría llevado a 1974. Empezó Bellas Artes en Valencia, siguió con unos cursos de arquitectura en la misma ciudad y se tituló en Ingeniería Civil en Zürich. La Universidad Politécnica de Valencia decidió investirle Doctor Honoris Causa en 1993. 
Tres arquitectos. Incuestionable. Reconocimiento profesional sin pudor para ellos tres. Sin embargo, el puritanismo raya lo obsceno en lo tocante a hablar de mujeres dedicadas a esta disciplina. Otorgarles el reconocimiento de arquitectas sigue sonrojando a día de hoy. Pero ¿era arquitecta? En esta misma tesis, al planear sobre la obra del matrimonio Eames explico que Ray era pintora y Charles arquitecto. El pudor -inducido, como Susana MartínezConde nos ha llevado a entender- llega a diferenciar que Ray se ocupó de la piel de la casa Eames; y Charles, el arquitecto, del esqueleto. Aunque el discurso continúa hablando del diseño conjunto, el matiz queda. Ella no lo era. ¿No lo era? ¿Burocrática o realmente? $Y$ es lo mismo con tantas y tantas mujeres que desarrollaron de manera competente esta profesión pero siguen relegadas a un segundo plano en el mejor de los casos. Un argumento ha venido a ser que no estaban tituladas. Ellos no lo necesitan para trascender.

A principios del siglo XX se produce un cambio importante en los objetivos de alojamiento de la población. Hay que realojar a las gentes que han quedado desahuciadas por la guerra. Surgen proyectos de producción de viviendas en serie y proyectos colectivistas. Eran viviendas populares que contemplaban el igualitarismo para la clase obrera, pero no para los géneros.

Por otra parte las viviendas suburbanas de la segunda posguerra, en particular, construyeron el «ángel del hogar». En breve quedaría detectada una de las consecuencias, el conocido como «el malestar sin nombre» que afectaba a tantas mujeres de clase media y alta.

Al emigrar a Rusia, Grete (1930-32) participa en el diseño de viviendas colectivas en las que las cocinas, comedor, lavandería, guardería y otros servicios como el gimnasio eran comunitarios e inducían a asumir el trabajo doméstico colectivamente. Así lo promovía Alexandra Kollontai. Su lucha contribuyó al desarrollo de las propuestas de Grete. La asunción de ese trabajo doméstico recaía en las mujeres como colectivo. Pudiera parecer que se trataba de la misma situación, pero la profesionalización de las tareas anulaba la invisibilización de las mismas. El trabajo doméstico pasaba a otro rango. Existiría un reconocimiento del mismo en tanto en cuanto hubiera que gestionar las horas necesarias para asignárselas a cada grupo de cocineras, lavanderas, 
maestras, tal y como Cevedio ya apunta en Arquitectura y género. Las imágenes de las experiencias colectivistas muestran a mujeres en el desempeño de estos quehaceres, y por tanto en femenino los nombro. Se trata de un reconocimiento, aun con la duda que siempre acecha al poder del lenguaje. No pretendo perpetuar sobre las mujeres la responsabilidad de estas tareas que bien pueden desempeñar los varones si se lo proponen.

Encontramos tics patriarcales de rol subalterno para la mujer en las viviendas del Movimiento Moderno. Le Corbusier escribe: «nuestras necesidades son necesidades de hombre» (1923:19). Este manifiesto, unido a la necesidad de minimizar costes que abarataran la construcción a base de la estandarización y reducción de espacios, dio lugar a cocinas mínimas que aislaron a la mujer en un espacio muy racionalizado pero muy reducido. Las tareas eran más rápidas de desarrollar, pero el aislamiento aumentaba. El tiempo sobrante no era para ir a relajarse a la zona de confort, sino para disponer de tiempo para la jornada laboral remunerada fuera o dentro de casa en la modalidad de trabajo sumergido. El ángel del hogar dejaba paso a la superwoman.

Tanto las políticas de modelos colectivistas de la URSS como las viviendas suburbanas de la posguerra o los tics patriarcales del Movimiento Moderno contribuyen a probar la hipótesis del presente trabajo en lo que respecta a la influencia del espacio interior en la construcción de la identidad de cualquier persona. La idea del sistema social socialista, el ángel del hogar, la superwoman. Todos son modelos que condicionan a las mujeres en una dirección u otra en su desarrollo identitario.

La casa no queda construida hasta que se la apropia quien la habita. Las personas siguen construyéndose en ese proceso de habitación -ya que las representaciones que de sí mismas construyen no se producen en el vacío, sino insertas en los espacios que habitan.

En el siglo XIX había dos modelos para resolver los problemas habitacionales en Norteamérica: la utopía urbana, según la cual se socializaban las tareas domésticas, mucho antes de las primeras experiencias europeas del mismo calado, y la casa modelo. Fue ésta última la que sustituyó a la ciudad ideal como representación espacial de las esperanzas americanas acerca de la vida 
feliz, dando con ello lugar a una opción completamente diferente en el proceso de construcción de identidades respecto a la que promovía la ciudad modelo. Se abandonó la ciudad modelo en favor de la casa de ensueño.

Generalmente, las mujeres carecen de espacio propio en la casa en la que viven. No tienen por tanto espacio privado, aunque lo habiten, aunque sea por entero su espacio doméstico. Esto sigue siendo así para los responsables de las revistas investigadas, tal y como hemos podido observar mediante los gráficos obtenidos. Que sea así en un medio que difunde y promueve modelos para la sociedad es peligroso.

Las élites, arquitectas, arquitectos, tienen la posibilidad de construir sus moradas, morar en ellas y construir sus identidades a un mismo tiempo. Esto permite espejos referenciales poderosos con los que construir identidades dialógicas, no alteridades. Es el plus de poder del que habla Cristina Molina sin el cual no es posible descentrar el género. Estos casos escenifican cómo es posible escapar a la marca de género cuando se tiene el poder de hacerlo, pero el objetivo debe llevar a que cada persona nazca y viva sin marca de género y pueda construir su espacio mientras construye su identidad, para que las alteridades desaparezcan. El problema individual de cada alteridad no puede ser resuelto más que colectivamente, porque quien lo sufre es la persona pero quien provoca el problema es la sociedad. Es la sociedad quien necesita un cambio, y ese cambio no es posible solo con acciones individualizadas o aisladas.

El espacio construido nos envuelve como un todo. Nos contiene, nos limita y nos da forma como afirma Pascuala Campos de Michelena. Andrés Jaque muestra, en la Bienal de Venecia de 2014, que la política, cuando marca directrices en la manipulación del espacio, no es inocente y hace una reflexión sobre el urbanismo radical diseñado para aislar a la población en sectores homogéneos llevado a cabo por Silvio Berlusconi en Milano due.

Tras verificar tanto que las mujeres arquitectas tienen una presencia mínima en los órganos de poder y difusión de la arquitectura, como que las mujeres usuarias de la arquitectura no son tenidas en cuenta en las revistas de arquitectura y diseño de interiores, podemos concluir que desde estos ámbitos 
se construyen entornos que mantienen a las mujeres en lugares subalternos, al servicio doméstico de la familia y sexual de la pareja. Los lugares que se les asignan no tienen en cuenta sus características, ni sus deseos ni sus intereses. Se evidencia que la arquitectura y el diseño de interiores, actualmente, no ayudan a construir una identidad femenina independiente. Las identidades sumisas que la actual arquitectura propicia, mantienen la dependencia relacional masculina, que necesita a las mujeres pero las niega.

El camino para equilibrar la desigualdad que impone el patriarcado pasa por construir identidades femeninas fuertes y establecer actuaciones colectivas.

Las viviendas se construyen actualmente y desde la guerra fría, como centros de consumo, productos de consumo ellas mismas. Consumo que genera deuda y así se controla la protesta.

Las cocinas colectivas fueron una posibilidad de emancipación de la mujer de las tareas domésticas y de obtener verdadera libertad, pero el fracaso del modelo socialista y el recrudecimento del capitalismo se las llevó por delante.

La autocosificación de la mujer, que construye su identidad como esclava doméstica y sexual, roles más que patentes en las revistas de diseño, a través de viviendas que definen los roles domésticos y arquitecturas del espectáculo que promueven el deseo de ser deseadas, según el canon del sujeto patriarcal, el varón, hace que todos los intentos de cambiar desde dentro del sistema sean fagocitados por éste, pasando a engordarle al tiempo que los desactiva como contestación.

No pensar en los efectos que producen los vacíos, las elipsis aquí denunciadas, pertenece, desde el punto de vista de Hanna Arendt, a la ejecución del mal banal. Hablamos del concepto de nocividad no intencional, pero Celia Amorós ya apunta cuando dice, «En este sentido, la ideología patriarcal es precisamente el no-pensamiento acerca de la mujer» (Amorós, 1992: 49), que esa nocividad lleva latente una postura, una ideología. Las elipsis que inegablemente existen en las publicaciones analizadas, como vemos en la muestra representativa y significativa de este tipo de medios de difusión, son fruto de dicha ideología, la ideología patriarcal. Hemos hecho un viaje desde la apariencia de neutralidad 
de las revistas de diseño de interiores y arquitectura, hasta la constatación de la ideología patriarcal que subyace en la elección de proyectos y profesionales traídos a sus páginas.

Después de todas estas verificaciones de omisiones de la historia de las mujeres, tanto como usuarias como como arquitectas o diseñadoras de interiores, mis conclusiones están ligadas a cómo ese no estar interfiere de manera muy dañina en el proceso de construcción de la propia identidad de cada mujer.

La aspiracionalidad es una motivación intrínseca que proporciona a cada ser la fuerza necesaria, no sólo para hacer uso de las herramientas idóneas para su proceso de desarrollo, sino incluso para encontrar dichas herramientas.

En tanto en cuanto permanece el vacío, la violencia del vacío, el proceso de aspiracionalidad se ve truncado en múltiples aspectos. La construcción de la propia identidad se apoya, entre otras cosas, en aquellos referentes externos que aspiramos imitar o incluso superar. Sin esos referentes el alcance de la motivación de una adolescente en concreto difícilmente será el mismo.

Una acción necesaria para contribuir en el desarrollo de una sociedad más equilibrada en la que la construcción de la identidad de las mujeres pueda moverse en todo el rango de posibilidades es la de reescribir la historia. La historia pasada reconociendo a mujeres como las pioneras y sacándolas del ámbito de estudios específicos vinculados a quienes se ocupan de cuestiones de género. Reconociendo a estas mujeres y llevándolas como referentes cuya obra cabe analizar a las aulas en las que se imparten las disciplinas de diseño de interiores y de arquitectura con aquellos con quienes convivieron en el momento histórico en el que desarrollaron sus proyectos. Esto pasa, con toda certeza, porque se las haga presentes en las revistas. Revistas que construyen un modelo social. Revistas que traigan a sus páginas artículos del ayer para las pioneras y con una selección paritaria de proyectos actuales en los que se visibilice el trabajo de tantas mujeres que hoy en día sí están tituladas, colegiadas y en pleno ejercicio de su profesión. 
On Diseño optó en 1978 por una dedicación casi exclusiva a proyectos de nuestro país. Fue una decisión de discriminación positiva. La obra de aquí y de quienes aquí proyectan y diseñan, frente a otras publicaciones con contenido de carácter internacional.

Nosotras diseñamos, moramos, habitamos. Nosotras construimos. Uno de estos dos títulos, o cualquier otro probablemente mejor elegido por un equipo editorial vindicativo sería el nombre adecuado para una revista que seleccionase proyectos de calidad de mujeres profesionales de la arquitectura y el diseño de interiores. Los hay. Muchos. Necesitamos visibilizar esa otra parte que completa la que actualmente y de manera errónea es tomada por el todo. Hemos visto cómo la parte, la perteneciente al hombre varón, ha sido tomada por el todo. Ahora es el momento de enfocar y ver toda la realidad, e insisto de forma paritaria. Todos y cada uno de los equipos editoriales que redactan las publicaciones analizadas en esta tesis pueden dar un vuelco a sus criterios, abandonando estereotipos en el momento de la selección de los proyectos que publican, tomando conciencia de su responsabilidad a la hora de abrir sus espacios de visibilización a las mujeres que están con derecho propio en el desarrollo de estas profesiones. A ellas se les debe un reconocimiento explícito, y a todas y cada una de las mujeres que leen estas revistas se les debe unos contenidos que les permitan reconocer y desarrollar sus propias posibilidades, contenidos que contribuyan al desarrollo de sus diferentes identidades desde referentes sin sesgo androcéntrico.

Si la discriminación nacional en la selección de proyectos es aceptable, que lo es, para dar a conocer buenos proyectos y espacios diseñados aquí. También lo será empezar a abrir espacio sobre el papel, y por tanto, espacio real, a mujeres con trabajos de calidad que ahora no reciben la atención que les corresponde debido al filtro androcéntrico con el que se decide qué se publica y qué no.

El mapa no es el territorio, el mapa de Suiza no es Suiza. Que no estén en las revistas estos trabajos de calidad de las mujeres no significa que no existan.

Ya hemos visto también cómo el trabajo remunerado que aparece en estas publicaciones no se corresponde porcentualmente ni tan siquiera con la realidad. Realidad teñida por el techo de cristal, la falta de posibilidades de 
conciliación familiar, pero, al fin y al cabo, una realidad que ha ido más allá de adonde han llegado, en cuestión de género, estas revistas.

Las gráficas muestran claramente la desviación existente entre la selección de trabajos publicados según la autoría por sexos y la proporción de mujeres matriculadas y tituladas que ejercen las profesiones de diseño que nos ocupan.

Entendiendo como superadas las valoraciones de finales del siglo XIX y principios del XX en las que asumían diferencia de capacidades por cuestión de sexo. Si tenemos alrededor de un $80 \%$ de mujeres tituladas en diseño de interiores, tal y como arrojan las estadísticas del MEC de 1999-2000, o los datos de la Escuela de Arte y Superior de Diseño de Castellón en el curso 2015-2016. Si se ha llegado a un 54\% de titulaciones en Arquitectura Superior obtenidas por mujeres, tras alcanzar, como hemos podido observar, en la imagen 60, en el año 2001 la equiparación entre varones titulados y mujeres tituladas y aunque en la gráfica de la imagen 96 se aprecie que es significativamente mayor la proporción de varones colegiados frente a mujeres colegiadas, estadísticamente es necesario un aumento de los proyectos de esas mujeres publicados para que la proyección de las revistas se corresponda con la realidad. No cabe asumir que estando presentes a nivel profesional, según los datos académicos y de colegiación presentados, la producción de proyectos realizados por mujeres sea de inferior calidad. Aun considerando el desequilibrio de décadas en las que ellas eran un tercio de las personas que obtenían el título de arquitectura superior, las revistas no trasladan datos fieles a esa proporción, no cabe pensar tampoco que los proyectos pertenecen a personas con la carrera profesional consolidada como excusa para tanta ausencia. Como se aprecia en la imagen 69 , o si atendemos a los monográficos de El Croquis analizados en esta tesis, las mujeres diseñadoras y arquitectas no ocupan, como también constata la imagen 95, las páginas de las revistas estudiadas en justa proporción a su presencia en la profesión.

El trabajo de investigación que me lleva a la redacción de estas conclusiones se estructura en tres cuerpos principales. En el primero se ha abordado la construcción de la identidad de las mujeres desde un punto de vista filosófico y antropológico además de desde un posicionamiento de género. En el segundo 
se analiza el papel de las mujeres arquitectas incidiendo en el tratamiento recibido por las pioneras. Ya en el tercero se aborda la construcción de la identidad de las mujeres a través de las imágenes en espacios interiores de las revistas de arquitectura y diseño de interiores. De este último cuerpo deriva el apéndice, a modo de zoom, en el que se desarrolla una investigación sobre las cocinas actuales y que se vincula directamente con la selección de mujeres arquitectas y diseñadoras realizada para el capítulo en el que se aborda el trabajo de las pioneras.

Derivado del objetivo en el que me planteaba el estudio comparativo entre la cocina Frankfurt de Margarete Shütte-Lihotzky y las cocinas actuales, además de considerar la repercusión sobre estos espacios de los modulores de Le Corbusier, encuentro un cúmulo de contradicciones entre el locus asignado a la mujer del heteropatriarcado, y las dimensiones antropométricas que se dan en las cocinas.

Desde Vitubio la proporción del cuerpo humano, entendido como cuerpo del varón, ha sido referente para la arquitectura y el diseño de los espacios que habitamos. Ya escribía en el inicio de estas conclusiones que el hombre, varón, ha sido tomado como el todo, en cuanto a la dimensión de los espacios se refiere.

Ha quedado claro, en el rastreo realizado a través de los textos históricos, quienes eran las personas para las que se diseñaban las cocinas. Incluso en el caso de las pioneras vimos cómo, con la intención de liberar tiempo de las tareas domésticas, entendían que liberaban tiempo para el ama de casa. Ellas, las pioneras, o incluso Christine Frederich en sus estudios sobre las tareas domésticas, tienen en cuenta la ergonomía de esas amas de casa para las que diseñan el espacio de la cocina. Frederich plantea cortar las patas de las mesas de trabajo según la altura que convenga al ama de casa. La cocina Frankfurt de Grete tiene unas dimensiones, en sección, que son adecuadas para una mujer menuda. Sin embargo es tal el poder de la historia androcéntrica, que sin haber modificado el locus, manteniéndose la asignación del trabajo doméstico sobre las mujeres, las dimensiones de las cocinas han transmutado en dimensiones 
adecuadas para los varones. Varones en general, claro, pues cada persona es diferente.

El hombre de Vitrubio, o los modulores, toman la parte por el todo. Es del hombre varón, y no de la persona, de donde salen los cánones a partir de los cuales se han diseñado los electrodomésticos estándar, piezas que, como hemos visto, definen el plano de trabajo. Ese plano de trabajo no se corresponde con las dimensiones que resolverían para una estatura media de las mujeres, sino con la estatura media de los hombres occidentales. $Y$ como ha quedado patente, no se han invertido los roles de desempeño del trabajo doméstico. Esta es una contradicción que queda abierta a futuras investigaciones.

Cabe subrayar el concepto de falacia del hombre medio. Si nos ceñimos a la talla media de la población, ergonómicamente el $50 \%$ de las personas se encontrarán con unas dimensiones de uso inadecuadas. En diseño se pasa al estudio de los percentiles para adaptar realmente el mobiliario y los espacios de uso al $95 \%$ de la población, y si es posible al 98\%. En una vivienda de uso compartido, dos personas adultas pueden fácilmente no responder a este planteamiento. Una cocina preparada para el reparto del trabajo equitativo debería estar diseñada para permitir una colaboración real y simultánea de personas con alturas de diferencia significativa. Es deseable, desde este estudio, que una persona de $1,50 \mathrm{~cm}$ de altura pueda conversar y compartir el trabajo con otra de, por ejemplo $1,93 \mathrm{~cm}$ de altura.

¿Realmente es tan complejo? Los gráficos de las cocinas del Neufert, nada sensibles con las cuestiones de género, por cierto, ya planteaban planos de trabajo ocultos que se utilizarían cuando fuese a desarrollarse el trabajo en posición sentada, como muestra por ejemplo la figura 200 de esta tesis.¿Por qué no continuar desde ahí?

Una de las cartelas de la exposición que visité en el MAK de Viena en agosto de 2015 dice, entre otras cosas:

Cooking, the heating, and preparation of food, is one of mankind's oldest cultural techniques. Through cooking «nature» is transformed into 
«culture,» as the ethnologist Claude Lévi-Strauss explains in his 1964 study The Raw and the Cooked. Whereas in nature raw food becomes rotten, cooked food can be described as an achievement of human culture.

The place where meals are prepared and are often also stored is the kitchen. Most commonly found within people's homes, the kitchen is invariably an expression of housing types and social structures. ${ }^{20}$ (MAK, 2015)

Cita de la que resulta especialmente interesante el hecho de que en un museo, el MAK, quede abiertamente expresado que las cocinas son una expresión de las estructuras sociales. Si así lo interpretamos, es un lugar ideal para plantear modificaciones que puedan trascender al propio espacio interior, modificaciones que deriven en otro tipo de estructuras sociales.

En el viaje a Milán en abril de 2016 me llamó la atención el proyecto EDGE, presentado por la escuela KADK, The Royal Danish Academy of Fine Arts, Institute of Architecture and Design. Me planteaba dudas sobre las variables tenidas en cuenta por el joven equipo de diseño, Mette Vinther Jensen, Aino Michelsen y Damiv Krdzovic, que había proyectado una cocina de calle y desarrollado el prototipo gracias al patrocinio de Hadsten Smede og Maskinverkstad, Designboard and Viroc.

Aunque he tratado de ponerme en contacto con el grupo, el intento no ha resultado fructífero, no obstante puedo transcribir aquello que a pie de Fora Fira, en Milán, me comentaba una de ellas y así consta en los dípticos que repartían para difundir su trabajo. Me interesé por su prototipo de cocina porque ofrecía la opción de varios niveles de plano de trabajo. Le pregunté con qué variables habían trabajado para tomar esta decisión, y me explicó que las diferencias de altura entre generaciones eran significativas en su entorno. Las generaciones

\footnotetext{
20. La cocina, los fogones, y la preparación de los alimentos, suponen una de las técnicas más antiguas de la humanidad. A través de la cocción la «naturaleza» se transforma en «cultura», como el etnólogo Claude Lévi - Strauss explica en su estudio de 1964, Lo crudo y lo cocinado. Mientras que en la naturaleza los alimentos crudos se pudren, los alimentos cocinados se pueden describir como un logro de la cultura humana .

El lugar donde las comidas son preparadas y a veces también se almacenan es la cocina. Se encuentra más comúnmente en los hogares, la cocina es siempre una expresión de tipos de viviendas y estructuras sociales. (Traducción propia).
} 
anteriores son, según esta estudiante, de menor estatura, y esto lo habían considerado para desarrollar su propuesta. El item de género no está, pero una propuesta actual de un tipo de cocina con planos de trabajo de diferentes alturas sí. Falta la concienciación necesaria, pero apunta una posible solución.

Cabe hacer aquí una reflexión acerca de las premisas que establece el Design for All. Establece como objetivo que un buen diseño de un producto, un servicio o un entorno, no debe levantar barreras para las personas usuarias. Se trata de permitir el desarrollo de la actividad humana de manera independiente. Entre otros criterios, para cumplir con los requisitos establecidos para un Diseño para todas las personas, aparece el de que todas tengan la oportunidad de disfrutarlo, debe ser asequible. Si nos centramos en aspectos de funcionalidad, el Universal Design establece que todas las personas puedan desempeñar la función para la que se realizó el diseño, sin problemas ni dificultades. Obviamente, a la luz de lo estudiado, podemos afirmar que en las cocinas generadas desde los estándares de altura marcados por El Modulor de Le Corbusier y difundidos por el libro El arte de proyectar en arquitectura de Ernst Neufert, no se cumplen estos criterios propuestos por el Design for All.

Podemos encontrar prototipos de cocinas con alturas regulables motorizadas, estudiadas para dar respuesta a personas con dificultades de movilidad. Se entienden difíciles de llevar adelante para la mayoría de las viviendas por el coste económico que pudieran suponer. No deja de parecerme paralela a la necesidad de regular distancias en el interior de los automóviles. Incluso el vehículo más económico cuenta con mecanismos que permiten regular la distancia entre asientos así como la posición del volante para ajustarse a las dimensiones de personas diferentes en la conducción. Los mismos, o similares mecanismos, cabrían en el diseño de cocinas más versátiles. No es necesario que varíe toda la bancada simultáneamente, incluso será deseable que no sea así, sino que pueda contarse con planos de trabajo a diferentes alturas en el mismo momento, para poder colaborar de manera equitativa y simultánea, compartiendo. Además, como hemos visto, no siempre existió una bancada continua. 
Tanto en la feria de Cevisama de Valencia, en febrero de 2016, como en el Salone di Mobile de Milán de abril de 2016, los stands de diferentes marcas de reconocido prestigio exponían sus productos con interés por generar negocio como es de esperar en estas ferias. Las firmas presentaban todo tipo de recreaciones de ambientes de cocinas. Mobiliario clásico o contemporáneo, mecanismos para facilitar el almacenaje en espacios de difícil acceso o encimeras motorizadas capaces de ocultar completamente los elementos básicos como el fregadero o los fogones. Un sin fín de novedades con la pretensión de captar la atención de visitantes, profesionales o no. Aparecían planos de alturas diferentes, pero en todo caso eran alternativas de uso, para tomar algo mientras otra persona cocina manteniendo una conversación, una barra con taburetes al otro lado del espacio de trabajo, no eran propuestas de modificación del sistema espacial establecido. Diseñar una cocina con planos de trabajo variables resultaría simple con tantos mecanismos y materiales como se muestran en estas ferias. Plantear una estructura social que genere tareas domésticas colaborativas es posible. Incluso, si la función debe resolverse de manera más económica podríamos rescatar algunos elementos que allí aparecían más por estética que por ética y dotarlos de otro significado, destinándolos para otra función, la adaptación del plano de trabajo a cada persona según su altura. Unos hornillos sutituibles de diferentes alturas variarían la altura de cocción con facilidad, elementos apilables de resistencia suficiente a las tareas que se realizan en las cocinas facilitarían también el alcance de estas nuevas propuestas sociales. Sacar a las mujeres del rol de cocineras pasa por aprovechar los muchos elementos ya mostrados en estas ferias con una finalidad diferente. No recaer en ello nos lleva al concepto de nocividad no intencional, y no pensar en una situación no exime de la responsabilidad que se tiene en ella. En este sentido, rescataría la frase «el desconocimiento de la ley no exime de su cumplimiento», según la cual el sistema jurídico español plantea la responsabilidad individual sin que quepa excusa.

Hemos visto cómo el sistema relacional recae íntegramente sobre las mujeres. El sistema relacional sostiene la vida, y por tanto, con ella, el conocimiento, el 
saber. Especialmente relevante es el hecho de la atribución de los logros de una obra, especialmente si es considerada una gran obra, a una sola persona, que con facilidad resulta ser un varón. Se trata de una invisibilización global de un equipo de trabajo. Equipo, tanto si comparten espacio y tiempo, como si no. Equipo, también en el caso de que cada pequeño avance -porque no suelen ser más que eso, pequeños avances- se le atribuya a una sola persona, dejando silenciadas todas las contribuciones precedentes que han permitido llegar hasta ahí. Pues tal como hemos visto que afirmaba Virginia Woolf:

[...] las obras maestras no son logros aislados y solitarios, son el resultado de muchos años de pensamiento en común, del pensamiento colectivo de muchas personas, de tal suerte que, tras esta voz individual, se encuentra la experiencia de la masa. (Woolf, 2012: 89) 
8. BIBLIOGRAFÍA 


\section{BIBLIOGRAFÍA}

AA.VV., (1993), Margarete Schütte-Lihotzky. Soziale Architektur Zeitzeugin eines Jahrhunderts, Wien, MAK e Wien, Bohlau Verlag.

AA.VV. (2011), Eyleen Grey, Barcelona, Poligrafía.

Adam, Peter (2000), Eileen Gray Architect Designer, London, Thames \& Hudson.

ACANDA, Jorge Luís (2008), «La problemática del sujeto y los desafíos para la teoría de la educación», en Biblioteca Virtual de Filosofía y Pensamiento Cubanos, http://biblioteca.filosofia.cu/, [fecha de consulta 30.03.2016].

ActAs (1993), Curso urbanismo y mujer, nuevas visiones del espacio público y privado, Málaga 1993 - Toledo 1994.

ActAS de (1995), Mujer y Urbanismo. Una recreación del espacio, Madrid, Ministerio de Asuntos Sociales.

Adorno, Theodor y HorkHeimer, Max (1998), Dialéctica de la llustración. Fragmentos filosóficos, Madrid, Trotta.

Agrest, Diana, Conway, Patricia y Wisman, Leslie Kanes (1996), The sex of Architecture, New York, Harry N. Abrams.

Agudo ARRoyo, Yolanda y SÁnchez de Madariaga, Inés (2011), «Construyendo un lugar en la profesión: trayectorias de las arquitectas españolas», en Gutiérrez Mozo, María Elia (coord.), Feminismo/s, núm. 17, págs. 155181, Alicante, Centro de estudios sobre la mujer.

AICHER, Otl (2004), La cocina para cocinar. El final de una doctrina arquitectónica, Barcelona, Gustavo Gili.

AliAgA, Juan Vicente (2007), Androcentrismo y violencia de género en las prácticas artísticas del siglo Xx, Madrid, Akal. 
AlLmAYER-BeCK, Renate (2008), «L'attività di Margarete Schutte-Lihotzky nelle'Ufficio per l'edilizia de Francoforte», en MinoLI, Lorenza, Dalla Cucina alla Citta. Margarete Schütte-Lihotzky, Milano, Franco Angeli.

Amann y Alcocer, Atxu (2005), La mujer y la casa, tesis doctoral dirigida por Javier Seguí de la Riva, Madrid, Universidad Politécnica de Madrid.

Amann y alcocer, Atxu y Borjabad Pastor, Maite (2014), «Espacios diferentes en un mundo desincronizado. La velocidad de las arquitectas en la Universidad - ETSA Madrid», en Álvarez Lombardero, Nuria, (ed.), Arquitectas: Redefiniendo la profesión, págs. 53-64, Sevilla, Universidad de Sevilla.

AmORós BlASCO, Lorena (2005), Abismos de la mirada: Ruptura y muerte con la identidad pasada desde la práctica del autorretrato contemporáneo, Alicante, Instituto de Cultura Juan Gil-Albert, Premios a la Investigación, Tesis Doctoral 2004.

Amorós, Celia. 1987. «Espacio de los iguales, espacio de las idénticas. Notas sobre poder y principio de individuación». Arbor, nº 503-4, págs. 113-127, Madrid, CSIC.

-(1992), «Notas para una teoría nominalista del patriarcado», en Asparkia, Castellón, Universitat Jaume I.

—(1994), «Espacio público, espacio privado y definiciones ideológicas de "lo masculino" y "lo femenino"», en Amorós, Celia, Feminismo, igualdad y diferencia, págs. 23-52, México, Universidad Nacional Autónoma de México,

PUEG, http://www.iidh.ed.cr/comunidades/derechosmujer/docs/dm_enlinea/espa cio\%20publico,\%20espacio\%20privado0173.pdf, [fecha de consulta: 20.07.2014]

Anaut García, Ainhoa (2013), La Arquitectura de la lgualdad, trabajo final de Máster dirigido por Rosalía Torrent Esclapés, Universitat Jaume I de Castelló., Instituto Universitario de Estudios Feministas y de Género 
«Purificación Escribano», Máster Universitario en Investigación Aplicada en Estudios Feministas, de Género y Ciudadanía.

ANDREW, C. (2000), «Resisting boundaries: using safety audits for women», in Miranne, K.B. \& Young, A.H. [coord.] Gendering the City: Women, Boundaries, and Visions of Urban Life, Lanham, Maryland, Rowman and Littlefield.

ANTUNES, Lía (2014), «Reinventar la arquitectura. Hay una mujer justo a tu lado», en Álvarez Lombardero, Nuria (ed.) Arquitectas: Redefiniendo la profesión, págs. 146-164, Sevilla, Universidad de Sevilla.

ARENDT, Hanna (2003), Eichmann en Jerusalen, Un estudio sobre la banalidad del mal, Barcelona, Lumen.

ARIAS LAURIÑO, Daniela (2013), Los paradigmas sociopolíticos emergentes en las revistas de arquitectura contemporánea, Barcelona, Universitat Politècnica de Catalunya.

-(2014), «Mujeres, profesión y medios. La invisibilidad del género femenino en las revistas de arquitectura contemporáneas», en Álvarez Lombardero, Nuria (ed.), Arquitectas: Redefiniendo la profesión, págs. 40-52, Sevilla: Universidad de Sevilla.

Aristóteles (1997), Política, Madrid, Alianza.

ArRedondo zambrano, Celia Esther (2014), «La arquitectura del siglo XX en México. Disciplina, y artefacto de diferenciación de género», en ÁlvAREZ Lombardero, Nuria (ed.) Arquitectas: Redefiniendo la profesión, págs. 130-144, Sevilla, Universidad de Sevilla.

Atwood, Margaret (1986), The Handmaid's Tale, Boston, Houghton Mifflin Harcourt.

Aujame, Roger, Da Costa Meyer, Esther, Mcleod, Mary (ed.), Ockman, Joan, Rüegg, Arthur, Udovicki-Selb, Danilo, Zenno, Yasushi (2003), Charlotte Perriand. An art of living, New York, Harry M. Abrams. 
BAUDOt, Francois (2005), Eileen Gray, Buenos Aires, Kliczkowski.

BAllester, Irene (2013), El cuerpo abierto: representaciones extremas de la mujer en el arte contemporáneo, Gijón, Ediciones Trea.

BANDleR, R., y GRINDER, J., (1988), La estructura de la magia, Santiago de Chile: Editorial Cuatro vientos.

—(1989), De sapos a príncipes, Santiago de Chile: Editorial Cuatro vientos.

Barañano, Kosme de (2011), Materialidad del silencio, Elche, Universidad Miguel Hernández,

https://dialnet.unirioja.es/descarga/articulo/3809086.pdf, [fecha de consulta 16.05.2016]

BARSAC, Jacques (2005) Charlotte Perriand, un art d'habiter 1903-1959, París, Norma.

-2008) Charlotte Perriand et le Japon, París, Norma.

-(2014) Charlotte Perriand, Complete Works. Volume 1: 1903-1940, Zürich, Scheidegger y Spiess.

—(2015) Charlotte Perriand, Complete Works. Volume 2: 1940-1955, Zürich, Scheidegger y Spiess.

BAUeR, U. (1996), «The way forward: Viennese Housing Projects by and for women», in E.M.Komu [coord.] Housing: Question of the Other, pags. 95 105, Ankara, Chamber of Architects of Turkey.

BaumgaRtNer-HaINDL, Susanne 2008), "Ill periodo in Unione Sovietica», en Minolı, Lorenza, Dalla Cucina alla Citta. Margarete Schütte-Lihotzky, Milano, Franco Angeli.

BeAuvolR, Simone (1949a), El segundo sexo. Los hechos y los mitos. Buenos Aires, Siglo Veinte, 1989. 
-(1949b), El segundo sexo. La experiencia vivida. Buenos Aires: Siglo Veinte, 1989.

Benavente, Rocío (2014), En busca de la casa subterránea perdida bajo la ciudad de Nueva York, en el Confidencial, http://www.elconfidencial.com/tecnologia/2014-03-27/en-busca-de-lacasa-subterranea-perdida-bajo-la-ciudad-de-nueva-york_107451/, [fecha de consulta 24.07.2016]

Bennett, C., Booth, C. \& Yeandle, S. (1999), Criteria for the success of a Mainstreaming Approach to Gender Equality: A Case Study Report of the Frauen-Werk-Stadt Model Project, the City of Vienna, Final Report for the 4th action Research Project, Equal Opportunities between men and women.

Bernays, Edward (1928), History is a Weapon. Propaganda, New York, Routledge.

BofiLl LeVI, Anna (2006), «Habitatge i espai comunitari», en Urbanisme $i$ Gènere. Una visió necessària per a tothom, págs. 43-46, Barcelona, Diputació de Barcelona.

-(2012), «Hacia modelos alternativos de ciudad compatibles con una sociedad inclusiva», en GutiérRez ValdiviA, Blanca y Cıocoletto, Adriana (coord.), Estudios urbanos, género y feminismo. Teorías y experiencias, Barcelona, Collectiu Punt 6, págs. 423-434, http://issuu.com/ punt6/docs/publicaciondefi nitivaestudiosurbano, [fecha de consulta: 13.07.2014]

Bоoth, Chris (1998), "Participación de las mujeres en la planificación urbana», en Booth, Chris, Darke, Jane y Yeandle, Susan (coord.), La vida de las mujeres en las ciudades. La ciudad, un espacio para el cambio, Madrid, Narcea, págs.185-201.

-(2002), Infraestructura para la vida cotidiana: el proyecto modelo Frauen-Werk-Stadt, Sheffield, Hallam University. 
BrAVO BRAVO, Juan (2011), «Así en la cocina como en la fábrica», en GutIÉRREZ Mozo, María Elia (coord.), Feminismo/s, núm. 17, págs. 183-211, Alicante, Centro de estudios sobre la mujer.

Bustamante, Antonio (2004), «Ergonomía, antropometría e indeterminación», en Anuario de Psicologia, vol. 35, págs. 439-460, Barcelona, Universitat de Barcelona, http://dialnet.unirioja.es/servlet/articulo?codigo=1119130, [fecha de consulta 19.01.2015]

Bustos, Pilar de y LASAOSA, Ma José (1999), Mujer, Espacio y Arquitectura, Castellón, NOW, UJI.

ButLER, Judith (1990), «Actos performativos y constitución del género. Un ensayo sobre fenomenología y teoría feminista», en Performing feminisms: Feminist Critical Theory and Theatre, págs. 270-282, Johns Hopkins University Press.

—(2006), Filósofa en todo Género, [vídeodocumental], Realizador Paule Zadjermann, París, Arte France, https://www.youtube.com/watch? $v=K k B 8 O 7-j G o M$ [fecha de consulta 19.01.2015]

-(2007), El género en disputa. El feminismo y la subversión de la identidad, Barcelona, Ediciones Paidos Ibérica.

Calvera, Anna (2007), «El cosear de las cosas. Consideraciones rezagadas a partir de Martin Heidegger», en De lo bello de las cosas, Barcelona, Gustavo Gili.

—(2003), Arte ¿? Diseño, Barcelona, Gustavo Gili.

-(2012), «Innovación y mejora educativa en el área de composición arquitectónica» en Composición Innova del Departamento de Composición Arquitectónica, Valencia, Universidad Politécnica de Valencia.

Campos de Michelena, Pascuala (1999), «Identidad y proyecto» en Mujeres, espacio y arquitectura, Castellón, NOW, Universitat Jaume I. 
Carta Europea de las mujeres en la Ciudad (2004), UUEE, http:// habitat.aq.upm.es/boletin/n7/acarta.html, [fecha de consulta 06.07.2014]

Carta de Leipzig sobre las Ciudades Europeas Sostenibles (2007), UUEE, http://www.fomento.gob.es/NR/rdonlyres/9BC567F2-1AD6- 46D1-8A0717EE0BD64269/111500/LeipzigCharte_Es_cle139ba4.pdf, [fecha de consulta 07.07.2014]

Carta Mundial por el Derecho a la Ciudad (2004a), ONU, http://www.onuhabitat.org/index.php?option=com_docman\&task=cat_ view\&gid=93\&ltemid=3, [fecha de consulta 06.07.2014]

Carta Mundial por el Derecho de las Mujeres a la Ciudad (2004b), ONU, www.hic-al.org/documento.cfm?id_documento=1093, [fecha de consulta 06.07.2014]

Casanovas, Roser, Ciocoletto, Adriana, Fonseca Salinas, Marta, Gutiérrez Valdivia, Blanca, Muxí Martínez, Zaida y Ortiz, Sara (2013), Dones Treballant, Guía per al Reconeixement Urbà amb Perspectiva de Gènere, Barcelona, Collectiu Punt 6, http://punt6.fi les.wordpress. com/2011/03/dones-treballant-fi nal-baixa.pdf, [fecha de consulta 07.07.2014]

Centre pompidou (2003), Meuble Cuisine, atelier Le Corbusier, type I, https://www.centrepompidou.fr/cpv/resource/cBLyL4/roXA4p4, [fecha de consulta [28.01.2016]

Cevedio, Mónica (2010), Arquitectura y género, Barcelona, Icaria.

ChíAs navarRo, Pilar (2011), «Estudiantes de arquitectura ¿Un ámbito de igualdad?», en GutiéRREz Mozo, María Elia (coord.), Feminismo/s, núm. 17, págs. 91-103, Alicante, Centro de estudios sobre la mujer.

City of Vienna (2001), Strategy Plan for Vienna: summary, Viena, Urban Planning, Municipal Department 18. 
Сово, María (cur.) (2011), «¿Heroínas o víctimas?», en Exposición Fotomanías 2011, Málaga, Diputación de Málaga.

Colomina, Beatriz (1988), L'ésprit nouveau: Architecture and Publicité, New York, Princeton Architectural Press.

-(1994), Privacidad y Publicidad. La Arquitectura Moderna como Medio de Comunicación de Masas, Murcia, Cendeac, 2010.

—(2006), La domesticidad en guerra, Barcelona, Actar, 2010

-(2010), «With or Without You: The Gosts of Modern Architecture», En Modern Women: Modern Artists at the Museum of Modern Art, New York, MOMA.

Constant, Caroline (2000), Eileen Gray, London, Phaidon Press.

CoRTÉs, José Miguel G. (2004), Hombres de mármol, Barcelona, Egales.

-(2006), Políticas del espacio. Arquitectura, género y control social, Barcelona, Actar.

Cós I RIERA, Pilar (1995), «Arquitectura doméstica o domesticada», en Ciudad y Mujer. Actas del curso urbanismo y mujer. Nuevas versiones del espacio público y privado, Málaga 1993 - Toledo 1994, Madrid, Seminario Permanente Ciudad y Mujer, págs. 247-253.

DARKE, Jane (1998a), «Búsqueda de una vivienda en la ciudad», en Booth, Chris, Darke, Jane y YeAndLE, Susan (coord.), La vida de las mujeres en las ciudades. La ciudad, un espacio para el cambio, págs. 77-95, Madrid, Narcea.

-1998b), «La ciudad modelada por el varón», en BoOtH, Chris, DARKE, Jane y YEANDLE, Susan (coord.), La vida de las mujeres en las ciudades. La ciudad, un espacio para el cambio, págs. 115-130, Madrid, Narcea.

DA VINCI, Leonardo (1986), Tratado de Pintura, Madrid, AKAL.

DAVIS, Ángela (1981), Mujeres, raza y clase, Madrid, AKAL, 2005. 
Debord, Guy (1967), La sociedad del espectáculo, Valencia, Pre-textos, 1999.

DeCLARACIÓN DE Toledo (2010), UUEE, http://ec.europa.eu/regional_policy/archive/newsroom/pdf/201006_toledo _declaration_es.pdf, [fecha de consulta 07.07.2014]

De LA CRUZ, Carmen (2007), «Espacios ciudadanos, violencia de género y seguridad de las mujeres», en Falú, Ana y Segovia, Olga (eds.), Ciudades para convivir: sin violencias hacia las mujeres. Debates para la construcción de propuestas, págs. 203-216, Santiago de Chile, Ediciones Sur.

Del valle, Teresa (1997), Andamios para una nueva ciudad. Lecturas desde la antropología, Madrid, Cátedra.

De OliveIRA, Olivia (2006), Subtle Substances. The Architecture of Lina Bo Bardi, Gustavo Gili, Barcelona.

Descartes, René (1984), Discurso del Método. Tratado de las pasiones del alma, Barcelona, Planeta.

DI GIORGIO, Francesco, (1841), Trattato di architettura civile e militare, Torino, Tipografia Chirio e Mina.

DíAz muÑoz, María Ángeles (1995), «El espacio-tiempo cotidiano», en Ciudad y Mujer. Actas del curso urbanismo y mujer. Nuevas versiones del espacio público y privado. Málaga 1993 - Toledo 1994, págs.107-117, Madrid, Seminario Permanente Ciudad y Mujer.

Díaz PADILLA, Ramón (2016) «Introducción: llusiones ópticas y los escenarios de la representación», en Arte, Magia e Ilusión, Madrid, Consejo Superior de Investigaciones Científicas.

Dıo BleICHMAR, Emilce (2008), «¿Qué han aprendido las adolescentes actuales para evitar las diversas formas de violencia de género?», en El malestar de los jóvenes, Madrid, Díaz de Santos. 
Dos Romero, Manolo (2008), «El silencio como estética cinematográfica. Aki Kaurismäki y La chica de la fábrica de cerillas» en VV.AA., Veintinueve maneras de concebir el silencio, Dos, M. \& FARReLL, M. (eds.), Col.lecció Universitaria, Diputació de Castelló.

-(2009), «Mujer y cine. Voces emergentes y otros silencios», en Máster en Investigación y docencia en estudios feministas, de género y ciudadanía, Castelló, Institut Universitari d'Estudis Feministes i de Gènere, Universitat Jaume I.

-(2013), «¿Cueces o enriqueces? Género, cocina y representación en el cine contemporáneo», en Revista Dossiers, núm. 17, La cultura de las cocinas: género, comida e identidad, págs. 81-98, Seminari d'Investigació Feminista, Universitat Jaume I.

DoveY, Kim (1999), Framing Place: Mediating power in built form, London, Routledge.

DURÁn, María Ángeles (2008), La ciudad compartida. Conocimiento, afecto y uso, Santiago de Chile, Ediciones Sur.

EMOción cocina (2016), Consejos de ergonomía en la cocina, http://emocioncocinas.es/consejos-de-ergonomia-en-la-cocinal, [fecha de consulta 27.06.2016]

ESCRIBANO LóPEZ, Purificación (1996), «La mujer en la sombra de la ciencia»,en Asparkía IV. Dona, dones, art i cultura, núm. 4, págs.19-35, Castellón, Univeristat Jaime I.

Espegel, Carmen (2006), Heroínas del Espacio. Mujeres arquitectos en el Movimiento Moderno, Madrid, Atlántida, 2008.

-(2013), «Arquitectas pioneras en el siglo $X X$ » en Jornadas mujer $y$ arquitectura: experiencia docente, investigadora y profesional, http://oa.upm.es/22820/1/INVE_MEM_2013_154674.pdfhttp://oa.upm.es/ 22820/1/INVE_MEM_2013_154674.pdf, [fecha de consulta 17.05.2016] 
Espegel, Carmen and MovilLA, Daniel (2011), «E.1027. Maison en bord de mer: Theoretical Restoration», en The International Conference Approaches for the 20th Century Architectural Heritage, Madrid, ICOMOS.

EucLides (1970.), «Elementos de Geometría» en Científicos Griegos, Madrid, Aguilar.

Fainstein, Susan S. y Servon, Lisa J. (2005), «The Intersections of Gender and Planning», en Fainstein, Susan S. y Servon, Lisa J. (eds.), Gender and Planning. A reader, New Brunswick, New Jersey and London, Rutgers University Press.

Falu, Ana y Segovia, Olga (2007), «Ciudades para convivir: sin violencias hacia las mujeres», Portal de desarrollo local, Ed. Sur, http://www.dhl.hegoa.ehu.es/ficheros/0000/0072/Ciudades_para_convivir .pdf, [fecha de consulta 19.01.2015]

FASCIOLI, Ana (2010), «Ética del cuidado y ética de la justicia en la teoría moral de Caroll Gilligan», en $\mathrm{n}^{\circ} 12$ de la revista ACTIO, http://actio.fhuce.edu.uy/Textos/12/Fascioli12.pdf, [fecha de consulta 20.04.2016]

FemeníAs, María Luisa (1988). «Mujer y jerarquía natural en Aristóteles», en Hiparquia, vol. I. Universidad de La Plata, http://www.hiparquia.fahce.unlp.edu.ar/numeros/voli/hiparquiav1a1, [fecha de consulta: 18.07.2014].

Fernández Gago, Paula (2012), «Evolución cuantitativa de la presencia de la mujer en la ETSAC», en Grupo de investigación MAGA, Mujeres Arquitectas de Galicia. Jornadas mujer y arquitectura. Experiencia docente, investigadora y profesional, A Coruña: Universidade da Coruña, págs. 65-71, http://ruc. udc.es/dspace/bitstream/2183/9986/6/JMA_26_27_nov12_ruc.pdf, [fecha de consulta: 07.07.2014]. 
Fernández Gago, Paula, Pernas, Inés, Eduardo, Caridad, Carreiro, María, LóPEZ, Cándido y MeSEJo, Mónica (2012), «La presencia de la mujer en la ETSAC», en Mujeres arquitectas de Galicia, La Coruña, Universidad de La Coruña.

-(2013), «Las arquitectas gallegas ante el inicio de la carrera universitaria. Etapa docente e investigadora», en Grupo de investigación MAGA, Arquitectas y otras profesionales: perspectivas transdisciplinares.

Fernández Villalobos, Nieves (2012), Utopías domésticas. La casa del futuro de Peter y Allison Smithson, Barcelona, Fundación Caja de Arquitectos.

- (2014), «¿Microarquitecturas o macrodiseños? Formas mixtas de habitar», en Res Mobilis, Oviedo, University Press.

FILARETE (Antonio Averlino llamado) (1965), Treatisse on Architecture, London, Yale University Press.

-(2003), Trattato di architettura, Biblioteca Italiana, en http://www.bibliotecaitaliana.it/xtf/view?

docld=bibit000307/bibit000307.xml\&chunk.id=d3733e138\&toc.depth $=100$ \&toc.id=d3733e133\&brand=newlook, [fecha de consulta 19.04.2015]

Frampton, Kenneth (1997), Le Corbusier, Colmenar Viejo (Madrid), Akal Arquitectura.

França Rocha, María Elisa (2001), La contribución de las series juveniles de televisión a la formación de la identidad en la adolescencia, Directora: Amparo Huertas, Universidad Autónoma de Barcelona, Departament de Comunicación Audiovisual i de Publicitat, Universitat Autònoma de Barcelona.

Franck, Karen A. (2000), «A Feminist Approach to Architecture: Acknowledging Women's Ways of Knowing», en Borden, lain, Penner, Jane y Rendell, Jane (eds.), Gender Space Architecture: An Interdisciplinary Introduction, London and New York, Routledge, págs. 295-305. 
Franck, Karen. \& Ahtrentzen, Sherry. (1989), «New Households, New Housing», en Infrastructura para la vida cotidiana: el proyecto modelo Frauen-Werk-Stadt, Nueva York, Van Nostrum Reinhold.

FRAUENBURO (1995), The competition paper for the model project "Frauen-WerkStadt" in Vienna, Viena, Frauenburo.

Friedan, Betty (2009), La mística de la feminidad, Madrid, Cátedra/Universitat de València/Instituto de la Mujer.

Galmés Cerezo, Álvaro (2012), "Construir es dejar de habitar» en Verbo Conjugado, Barcelona, Papers, http://upcommons.upc.edu/bitstream/handle/2099/12929/DC\%2324-21GALMES.pdf, [fecha de consulta 13.05.2016] -(2014), Morar, arte y experiencia de la condición doméstica, Madrid, Universidad Europea.

García, Laura (2008), Desbordamientos de una periferia femenina, México, Sociedad Dokins para las nuevas prácticas artísticas, A.C.

García, Rafael (2010), prologuista de Woude, Auque van der en «La vivienda popular en el movimiento moderno», en Cuadernos de notas 7 , http://www.aq.upm.es/Departamentos/Composicion/webcompo/webcnota s/pdfs/CN7_1_Vivienda\%20Popular.pdf, [fecha de consulta 28.06.2015].

GaRner, Philippe (2006), Eileen Gray. Design and arquitecture 1878-1976, Koln, Taschen.

GHYKA, Matila C. (1983), Estética de las proporciones en la naturaleza y en las artes, Barcelona, Poseidón.

GILBERT. M. (2000), «Identity, difference, and the Geographies of Working Poor Women's Survival Strategies», in Miranne, K. B. \& Young, A.H. [coord.] Gendering the City: Women, Boundaries and Visions of Urban Life, Lanham, Maryland, Rowman and Littlefield Publishers. 
GiménEz, Gilberto (1992), «La identidad social o el retorno del sujeto en sociología», en Versión, $n^{\circ}$ 2, abril, págs. 183-205, México, Universidad Nacional Autónoma de México.

-(1997), «Materiales para una teoría de las identidades sociales», en Frontera Norte, Vol. 9, $\mathrm{n}^{\circ}$ 18, julio-octubre, págs. 9-28, México, Universidad Nacional Autónoma de México.

Gómez Gracía, Pedro (2009), Globalización cultural, identidad y sentido de la vida, Granada, Universidad de Granada.

Gómez VAlVerde, Lidia (1996), "La mujer no existe...insiste por existir», en Dona, dones, art i cultura, Asparkia, $\mathrm{n}^{\circ}$ 6, págs. 37-50, Castellón, Universitat Jaume I.

González García, Begoña (2003), "Odiseo o el sujeto libre. El concepto de identidad en Th. W Adorno», en Nómadas, Madrid, Universidad Complutense de Madrid.

Graft-johnson, Ann; Manley, Sandra y Greed, Clara (2003), Why do women leave architecture?, Bristol: University of the West of England, http://www.architecture.com/fi les/ribaprofessionalservices/education/discussionpapers/ whydowomenleavearchitecture.pdf, [fecha de consulta: 12.07.2014]

Gravagnuolo, Benedetto (1991), Historia del Urbanismo en Europa, Madrid, Akal, 2009.

GraY Eileen, BADOVICI, Jean (1929a), «De l'éclectisme au doute», dans n AH de L'Architecture Vivante, Paris, Éditons Albert Morancé.

—(1929b), «E. 1027: Maison en bord de mer», dans L'Architecture Vivante, Marseille, Imbernon, 2006.

GREgORIO GIL, Carmen (2006). «Contribuciones feministas a problemas epistemológicos de la disciplina antropológica: representación y relaciones de poder», en AIBR Revista de Antropología Iberoamericana, 
vol. 1, núm. 1, págs. 22-39. Madrid, Antropólogos Iberoamericanos en red, http://www.redalyc. org/pdf/623/62310104.pdf, [fecha de consulta: 21 mayo 2014].

GRIFFIT, Robert (2015) Charlotte Perriand, https://www.youtube.com/watch? $\mathrm{v}=$ CahrFHbZ53k, [fecha de consulta 24.07.2016].

Gruber, Helmunt (1991) Red Vienna. Experiment in Working-Class Culture 1919-1934, New York, University Press.

GubiedA, Patricia (2015), «Una vida dedicada a la creación», en Houz, http://www.houzz.es/ideabooks/54841223/list/charlotte-perriand-una-vidadedicada-a-la-creacion, [fecha de consulta 28.06.2016].

HABERMAS, Jürgen (2008), El discurso filosófico de la modernidad, Madrid, Katz Conocimiento.

HADID, Zaha (2008), «Si no te comes el miedo, no consigues nada», entrevista realizada por ZABALBEASCOA, Anaxu, en El País, http://elpais.com/diario/2008/01/13/eps/1200209212_850215.html, [fecha de consulta 20.04.2016]

HARDING, Sandra (1998), «¿Existe un método feminista?», en Feminism and Methodology, Bloomington/Indianápolis, Indiana University Press.

Hayden, Dolores (1984), Rediseñando el sueño americano, New York, W.W. Norton, 2002.

-(1988), «La felicidad entre cuatro paredes», en Casa, cuerpo, sueños, Madrid, Arquitectura y Vivienda $\mathrm{n}^{0} 12$.

-(1997), The Power of Place: Urban Landscapes as Public History, USA, The MIT Press.

Hernández PeZzl, Carlos (1995), «Planificación física y usos del suelo: una aproximación desde el género», en Ciudad y Mujer. Actas del curso urbanismo y mujer. Nuevas versiones del espacio público y privado. 
Málaga 1993-Toledo 1994, Madrid, Seminario Permanente Ciudad y Mujer, págs. 403-408.

-(1998), La ciudad compartida. El género de la arquitectura, Madrid, Consejo Superior de los Arquitectos de España.

-(2011), «La visión de género y el espacio inteligente», en GUTIÉRREZ Mozo, María Elia (coord.), Feminismo/s, núm. 17, págs. 65-89, Alicante, Centro de estudios sobre la mujer.

-(2014), «Arquitecturas y mujeres en busca de nombres. Las arquitectas en contra de la doble ocultación», en Arenal. Revista de la historia de las mujeres, núm. 21, págs. 69-95, http://revistaseug.ugr.es/index.php/arenal/article/view/2261, [fecha de consulta 20.04.2016]

Hernando, Almudena (2002), Arqueología de la identidad, Tres Cantos, Akal.

-(2015), «Identidad relacional y orden patriarcal» en Mujeres, hombres, poder. Subjetividades en conflicto, Madrid, Traficantes de sueños.

Hervás y Heras, Josenia (2015), Las mujeres de la Bauhaus: de lo bidimensional al espacio total, Barcelona, Diseño Editorial.

HIRSHON, Nicholas (2012), Is it down there?, entrevista a Lory Walters, en http://narrative.ly/is-it-down-there/ [fecha de consulta, 26.09.2016]

Hoffmann, Julius (1933), L'habitation Minimum, [Edicion facsímil], Zaragoza, Delegación de Zaragoza del Colegio Oficial de Arquitectos de Aragón, 1997.

Horelui, L, Booth, C. \& Gilroy, R (2000) A toolkit for mobilising women in local and regional development, EuroFEM, Helsinki.

Horelul, L. (2000), «Creating the infrastructure of everyday life in the context of European local and reginal development» ponencia del seminario de ESRC, Women and local and regional development: gender equality issues in participation and consultation, Sheffield, Hallam Univerity. 
JACOBS, Jane (1961), Muerte y vida de las grandes ciudades, Madrid, Capitán Swing, 2011.

JAQUE, Andrés (2014a), entrevistado por Roger Salas en Babelia, Madrid, El País, http://cultura.elpais.com/cultura/2014/06/07/actualidad/1402159693_572 343.html, [fecha de consulta 03.07.2016]

-(2014b), Sales Oddity. Milano 2 and the Politics of Direct-to.Home TV Urbanism, Memoria del proyecto, Premio León de Plata de la XIV Bienal de Venecia.

JónASDÓtTIR, Anna G. (1993), El poder del amor. ¿Le importa el sexo a la democracia?, Valencia, Cátedra.

KAIL, E. (1994), «Model Project 'Frauen-Werk-Stadt' An Approach to Urban Development in Vienna oriented on women's needs», ponencia en el congreso de la OCDE, París.

KAISER, Débora y De LEÓN, Valentina (2012), La introducción de las lógicas de la Industria en la Arquitectura doméstica. TFC de la Facultad de Arquitectura, Montevideo, Universidad ORT de Uruguay.

KaUfFmAn, Linda S. (2000), Malas y perversos. Fantasías en la cultura y el arte contemporáneos, Madrid, Cátedra.

KoHAN, Néstor (2014), «Racionalidad, hegemonía y fetichismo en la teoría crítica», en Laberinto, $\mathrm{n}^{\circ} 44$, http://laberinto.uma.es/index.php? option=com_content\&view=article\&id=608:racionalidad-hegemonia-yfetichismo-en-la-teoria-critica\&catid=135:lab41\&ltemid $=54$, [fecha de consulta mayo 2015].

Kollontal, Alexandra (1918), El comunismo y la familia, Archivo Kollontai on line https://www.marxists.org/espanol/kollontai/1918/001.htm, [fecha de consulta, 13.05.2016] 
KoolHASS, Rem (2013), Sobre Fundamentals, Venecia, Bienal 2014, http://www.metalocus.es/es/noticias/fundamentos-rem-koolhaas-anunciael-tema-para-la-bienal-de-venecia-2014, [fecha de consulta, 13.05.2016]

Kuhlmann, Dörte (2013), Gender Studies in Architecture: Space, Power and Difference, London, Routledge.

Lacalle Zalduendo, Rosario, Suárez Villeggas, Juan Carlos y Pérez Tornero, Manuel (2014), II conferencia internacional sobre género y comunicación. Libro de actas. Madrid, Dikinson.

LaUB, Claudia (2007), «Violencia urbana, violencia de género y políticas de seguridad ciudadana», en Falú, Ana y Segovia, Olga (eds.), Ciudades para convivir: sin violencias hacia las mujeres. Debates para la construcción de propuestas, págs. 67-81, Santiago de Chile, Ediciones Sur.

Le Corbusier, Ch.-E. (1923), Hacia una arquitectura, Barcelona, Apóstrofe, $\left(1998, \quad 2^{\mathrm{a}} \quad\right.$ ed) $\quad$ https://www.academia.edu/6468653/Le_Corbusier__Hacia_Una_Arquitectura_PDF, [fecha de consulta 01.06.2014].

-(1953), Le Modulor, Buenos Aires, Poseidón, 1961, http://fauufpa.files.wordpress.com/2013/07/el-Modulor-por-le-corbusier.pdf , [fecha de consulta enero 2014].

—(1955), Le Modulor 2, Buenos Aires, Poseidón, 1962, http://fauufpa.files.wordpress.com/2013/07/el-Modulor-2-por-lecorbusier.pdf, [consulta enero 2014].

—(1957), La Charte d'Athènes, Paris, Editions de Minuit, —(1999), La casa del hombre, Madrid, Apóstrofe.

—(2000), Por uma arquitectura, São Paulo, Perspectiva.

LefF, Enrique y Elizalde, Antonio (2010), «Sujeto, subjetividad, identidad y sustentabilidad», en Polis, http://polis.revues.org/290, [fecha de consulta 10.03.2015] 
LINDNER-Gross, Marion (2008), «Vienna dopo il 1945: Architettura, politica e impegno per le donne», en MinoLI, Lorenza, Dalla Cucina alla Citta. Margarete Schütte-Lihotzky, Milano, Franco Angeli.

LIPOVETSKy, Gilles y SeRRoy, Jean (2010), La cultura-mundo. Respuesta a una sociedad desorientada, Barcelona, Anagrama.

-(2015), La estetización del mundo. Vivir en la época del capitalismo artístico, Barcelona, Anagrama.

Lollobrigida, Consuelo (2013), Plautilla Bricci Architettrice donna e pittrice nel 600, Roma, Etgraphiae Editrice.

LóPEZ de LA CRUZ, Juan José (2012), Proyectos encontrados. Arquitectura de la alteración y el desvelo, Sevilla, Recolectores urbanos editorial.

LÓPEZ DíEZ, Pilar (2004), «La mujer, las mujeres y el sujeto del feminismo en los medios de comunicación», en Manual de información en género, cap. 4, Madrid, IORTV (RTVE) e Instituto de la Mujer.

LóPez Rodero, Myriam (2014), «Mujeres a la sombra: Aino Marsio», en Un día / una arquitecta, https://undiaunaarquitecta.files.wordpress.com/2015/04/congresoarquitectas_myriam-lopez-rodero.pdf, [Fecha de consulta 13.01.2016].

LoseKE, Donileen R. (2013), Methodological thinking. Basic Principles of Research Design, Florida, Sage.

Lupton, Ellen y Miller, J. Abbot (1992), El cuarto de baño, la cocina y la estética de los desperdicios. Procesos de eliminación, Madrid, área de Medio Ambiente del Ayuntamiento de Madrid.

MACIÀ, Antonio (2013), Reforma de una vivienda. Casa Weston, Altea, Alicante, http://antoniomacia.com/projects/casa-weston-altea-hills/, [fecha de consulta 28.06.2016]

MAKKIYA, Noor (2016), «Estas escalas humanas de reconocidos arquitectos nos ofrecen una visión de sus mentes», en Plataforma de arquitectura, 
http://www.plataformaarquitectura.cl/cl/tag/noor-makkiya, [fecha de consulta, 28.06.2016]

Marcos, Carlos L. (2011), "Crítica de Género. E. 1027: Eileen Gray vs Le Corbusier en Cap Martin», en Feminismo/s no 17, págs. 259-295, Universidad de Alicante.

http://rua.ua.es/dspace/bitstream/10045/22344/1/Feminismos \%2017_12.pdf, [fecha de consulta 13.05.2016].

Martínez-Conde, Susana \& Macknick, Stephen (2013), Los engaños de la mente, Madrid, Destino.

MARTínez-Conde, Susana (2014a), «Necesitaríamos un cerebro del tamaño de un edificio para percibir fielmente la realdad» en $A B C$, entrevistada por QUIJADA, Pilar, http://www.abc.es/ciencia/20140405/abci-susana-martinezconde-enganos-201404041804.html, [fecha de consulta 13.05.2016]

-(2014b), «Nuestro cerebro no nos permite ver la realidad» en Materia, entrevistada por MediAVILLA, Daniel, http://esmateria.com/2014/04/04/, [fecha de consulta 13.05.2016]

Martínez López, Cándida y Serrano Estrella, Felipe (2016), Matronazgo y Arquitectura, Granada, Universidad de Granada.

MASSEY, Doreen (1994), Space, place and gender, Minneapolis, University of Minnesota Press.

Matas Fernandez, Rafael y Luque Rodrigo, Laura (2010), «La mujer en el espacio pintado: de la Edad Moderna a la Contemporánea», en Asparkía, núm. 21, págs. 47-64, Castellón, Univeristat Jaime I.

MATESANZ PARelLAdA, Ángela (2014), «Arquitectas precarias. Situación laboral de las arquitectas según la III Encuesta del Sindicato de Arquitectos», en Álvarez Lombardero, Nuria (ed.), Arquitectas: Redefiniendo la profesión, Sevilla, Universidad de Sevilla, págs. 25-39. 
MATRIX (1984), Making space: women and the man made environment, Londres, Pluto Press.

McdoweLL, Linda (2000), Género, identidad y lugar, Madrid, Cátedra.

Melgarejo Belenguer, Maria (2011), La arquitectura desde el interior, 19251937: Lilly Reich y Perriand Charlotte, Barcelona, Fundación Caja de Arquitectos.

Miguel, Ana de (2001), Alejandra Kollontai, Madrid, Ediciones del Orto.

MıNolı, Lorenza (a cura di) (1999), Margarete Schütte Lihotzky Dalla cucina alla città, Milano, F. Angeli.

MolinA PETIT, Cristina (1995), «La metáfora espacial doméstica en la definición de lo femenino». En Ciudad y Mujer. Actas del curso urbanismo y mujer. Nuevas versiones del espacio público y privado. Málaga 1993-Toledo 1994, págs. 339-343, Madrid, Seminario Permanente Ciudad y Mujer.

-(2003), «Género y poder desde sus metáforas. Apuntes para una topografía del patriarcado», en Del sexo al género. Los equívocos de un concepto, págs. 123-160, Madrid, Cátedra.

Monleé, Rosa (2012), «La perspectiva de género en la historia contemporánea. Dos destinos diferentes para las mujeres y los hombres», en TORRENT, Rosalía y REVERTER, Sonia (eds.), Variaciones sobre género. Materiales del Máster en Investigación Aplicada en Estudios Feministas, de Género y Ciudadanía, Castellón, Acen, págs. 85-93.

MontANeR, Josep Maria y Muxí, Zaida (2011), «Ciudad próxima: urbanismo sin género» en Arquitectura y política. Ensayos para mundos alternativos. Barcelona, Gustavo Gili.

Monteys, Xavier y Fuertes, Pere, (2001), Casa collage. Un ensayo sobre la arquitectura de la casa, Barcelona, Gustavo Gili. 
MoRA, Pola (2014), Bienal de Venecia 2014: SALES ODDITY / Andrés Jaque, León de Plata Mejor Proyecto de Investigación, Plataforma de Arquitectura, bienal-de-venecia-2014-sales-oddity-andres-jaque-leon-deplata-mejor-proyecto-de-investigacion, [fecha de consulta 05.04.2016]

MorReL, Helen (1998), "Seguridad de las mujeres en la ciudad», en BоOth, Chris, DaRke, Jane y YeAndLe, Susan (coord.), La vida de las mujeres en las ciudades. La ciudad, un espacio para el cambio, págs.131-145, Madrid, Narcea.

MüLler, Ulrike (2009), Bauhaus Women: art, hadicraft, design, Paris, Flammarion.

Muñoz, Nieves (2010), Los ecos del banquete no escrito, Castelló, Universitat Jaume I.

MURILlo, Soledad (1996), El mito de la vida privada. De la entrega al tiempo propio, Madrid, Siglo XXI editores.

-(1999), «Espacio doméstico. El uso del tiempo», en Jornadas Universidad Carlos III, Madrid, Universidad Carlos III, http://www.soledadmurillo.es/articulo/espacio-domestico-el-uso-deltiempo, [fecha de consulta: 05.04.2016]

-(2007), «El tiempo de trabajo y el tiempo personal: un conflicto de intereses», en Bloque temático 8, Tema 8.0, Formación y acreditación en consultoría para la igualdad de mujeres y hombres, Gobierno Vasco.

MuÑóz PÉrez, Laura (2011), «Singularidad, naturalismo y movimiento. La aportación de Zaha Hadid al contexto arquitectónico actual», en La arquitectura y el urbanismo con perspectiva de género, en Feminismos, $\mathrm{n}^{\circ} 17$, págs 258-297, Alicante, Centro de estudios sobre la mujer de la Universidad de Alicante.

Muxí, Zaida (2009), Recomanacions per a un habitatge no jeràrquic ni androcèntric, Barcelona, Institut Cátala de les Dones, Departament de Mediambient i Habitatge, Generalitat de Catalunya. 
Nbdeportes (2016), Playboy y sus túneles secretos, https://www.nbcdeportes.com/playboy-y-sus-tuneles-secretos, [fecha de consulta 22.07.2016]

NeUfeRt, Ernst (1958), Arte de projetar em arquitetura, San Adrià de Besós, Gustavo Gili , $7^{a}$ ediçao.

-(1998), Arte de projetar em arquitetura, San Adrià de Besós, Gustavo Gili, $13^{\mathrm{a}}$ ediçao.

—(1940), Bauentwurfslehre, Berlin, Druckhaus Tempelhof, 6 ausgave.

—(1950), Bauentwurfslehre, Berlin, Druckhaus Tempelhof, 12 ausgave.

-(1942), El arte de proyectar en arquitectura, Barcelona, Gustavo Gili S.A. $1^{\text {a }}$ edición.

—(1977), El arte de proyectar en arquitectura, Barcelona, Gustavo Gili S.A. $12^{\text {a }}$ edición.

-(1991), El arte de proyectar en arquitectura, Barcelona, Gustavo Gili S.A. $13^{\mathrm{a}}$ edición, $8^{\mathrm{a}}$ tirada.

-(1995), El arte de proyectar en arquitectura, Barcelona, Gustavo Gili S.A. $14^{\text {a }}$ edición.

Neufert, Ernst and Neufert, Peter (2000), Architect's data, New Jersey, WileyBlackwell, 3th edition.

Nordic Council Research Group (1991), The New Everyday Life Perspective, Estocolmo, The Nordic Council.

NovAs, María (2014), Arquitectura y Género. Una reflexión teórica, Trabajo fin de master dirigido por Rosalía Torrent, Castellón, Instituto de estudios feministas y de género «Purificación Escribano», Universitat Jaume I.

OlezA, Juan (1996), «Notas en torno a la crisis del sujeto» extractadas de Joan Oleza: «Luís Álvarez Petreña o la tragicomedia del yo», en Actas I 
Congreso Internacional Max Aub y el Laberinto Español, s/c,Valencia, Ayuntamiento de Valencia.

Orozco, Amaia (2010), «Diágnóstico de la crisis y respuestas desde una economía feminista», en Revista de Economía Crítica, n 9, págs. 131144, Asociación Cultural Economía Crítica.

ORsinI, Marco Antonio (2014), Gray Matters "Teaser", en Vímeo, https://vimeo.com/82442640, [fecha de consulta 09.04.2016]

Oudshoorn, Nelly, Rudinow SaEtan, Ann et LIE, Merete (2009), «Du genre et des réflexions sur une exposition d'objects sexués», dans elles@centrepompidou. Artistes femmes dans la collection du muse d'art moderne. Centre de creation industrielle, págs 304-308, Paris, Centre Pompidou.

Pardo buendía, Mercedes (2000), La participación de las mujeres y la ciudad o el derecho de las mujeres a la ciudad, http://e-archivo. uc3m.es/bitstream/handle/10016/10979/participacion_pardo_2000_wp.pd f?sequence=1, [fecha de consulta: 20 julio 2014].

Pateman, Carole (1988), El Contrato Sexual, Barcelona, Anthropos, 1995.

Patiño Garzón, Luceli y Rojas Betancur, Mauricio (2009), «Subjetividad y subjetivación de las prácticas pedagógicas en la Universidad», en Educación y educadores, vol 12, n 1, págs. 93-105, Curdinamarca (Colombia), Universidad de la Sabana.

PÈREC, Georges (2001), Espèces d'espaces. París, Éditions Galilée.

Perez Gauli, Juan Carlos (2000), El cuerpo en venta: Relación entre arte y publicidad, Barcelona, Cátedra.

PÉrez, Inés (2010), «Corazón de hojalata, hogar de terciopelo. La cocina, epicentro del mundo doméstico. (Mar del Plata - Argentina, 1950-1970)» en Asparkia, $n^{\circ} 21$, págs. 105-128. Castellón, Universitat Jaume I.

Perriand, Charlotte (1998), Une vie de création, Paris, Editions Odile Jacob. 
-(2003), A life of creation. An Autobiography, New York, Monacelli Press.

PerRot, Michelle (1988), «Modos de habitar. La evolución de lo cotidiano en la vivienda moderna», en El espacio privado, Madrid, Arquitectura y Vivienda $\mathrm{n}^{\circ} 14$.

Pisano, Margarita (2003), «Utopías 1970-2003», en Coloquio, Chile, Universidad Arcis, http://www.radiofeminista.net/dic03/notas/esp/nota2.htm, [fecha de consulta 14.04.2014].

—(2014), «Mirar desde el afuera...y ver», en Julia quiero que seas feliz, Santiago de Chile, Surada, http://www.mpisano.cl/?page_id=655, [fecha de consulta 14.04.2014].

Poulain de la BarRe, François (2015), De l' égalité des deus sexes, discours physique et moral, où on voit l'ímportance de se défaire des préjugés, Paris, Chez Antoine Dezallier, 1679, Paris, Gallimard.

-(1674), De l'Éducation des dames pour la conduite de l'esprit dans les sciences et dans les mœurs, entretiens, Paris, Chez Jean du Puis. (De la educación de las damas, Madrid, Cátedra, 1993).

Preciado, Beatriz (2010), Pornotopía: arquitectura y sexualidad en Playboy durante la guerra fría, Barcelona, Anagrama.

Ramirez, Juan Antonio (2003), Corpus solus. Para un mapa del cuerpo en el arte contemporáneo, Siruela, Madrid.

Reeves, Dory (1998), "Las compras en la ciudad», en Booth, Chris, Darke, Jane y YeANDLE, Susan (coord.), La vida de las mujeres en las ciudades. La ciudad, un espacio para el cambio, Madrid, Narcea, págs.147-166.

Rendell, J., Penner, B., \& Borden, I. (2000), Gender space architecture: an interdisciplinary introduction, London, Routledge. 
Renderos, Alex, Grande Carlos, Vázquez, Ivonne (2015), «3. Usuario, ergonomía y antropometría» en Diseño del espacio interior, http://teiiuca.blogspot.com.es/p/blog-page_23.html, [fecha de consulta 24.07.2016].

ReVERTER BAÑón, Sonia (2003), "La perspectiva de género en filosofía», en Feminismos/1, $\mathrm{n}^{\circ} 1$, págs. 33-50, Centro de Estudios de la Mujer, Universidad de Alicante.

—(2004), Valores básicos de la identidad europea, Castellón, Universitat Jaume I.

RibeIRo ToRAL, Raquel (2010), «Prácticas de crianza contemporánea ¿subjetivantes?», en Carta Psicoanalítica, $n^{\circ} \quad 7$, http://www.cartapsi.org/spip.php?article139, [fecha de consulta 30.03.2016].

RICHARDS, Ellen (1900), «Housekeeping in the Twentieth Century», Vol. XII n 6 , Boston, American Kitchen Magazine.

Rivera Garretas, María Milagros (2008), «Ni mujeres privadas ni mujeres públicas: lo personal es político», Duoda, Centro de Investigación de Mujeres. Universidad de Barcelona http://www.ub.edu/duoda/diferencia/html/es/imprimible11.html, [fecha de consulta 27.07.2014]

Rodríguez LoRENZO, Higinio (2011), El movimiento moderno. La arquitectura del siglo XX, http://es.slideshare.net/Ginio/23-movimiento-moderno-en-laarquitectura, [fecha de consulta 26.04.2016].

Rodríguez Magda, Rosa María (1997), El modelo Frankenstein. De la diferencia a la cultura post, Madrid, Tecnos.

Roso, Cristina (2014), «Refugios de diseño para tiempos de guerra», en Unfollow, http://unfollowmagazine.com/tag/cristina-rojo/, [fecha de consulta 20.04.2016] 
Roland Calvo, Jorge (2013), «La Bastida de Totana», en La aventura del saber, Madrid, TVE. https://www.youtube.com/watch?v=KkB8O7-jGoM, [fecha de consulta 23.01.2014 10:29]

Royo naranjo, Lourdes, Pérez Cano, María Teresa y del Espino Hidalgo, Blanca (2014), «Resultados de investigación en arquitectura y género, Jornada de Arquitectura, Arte y Urbanismo con Perspectiva de Género en la Universidad de Sevilla. Experiencias docentes, investigadoras y profesionales», EN Álvarez Lombardero, Nuria (ed.) Arquitectas: Redefiniendo la profesión, págs. 40-52, Sevilla, Universidad de Sevilla.

RüEgG, Arthur (2012), Le Corbusier. Meubles et intérieurs 1905-1965, Zurich, Verlag Scheidegger \& Spiess AG.

-(2004), Charlotte Perriand, livre de bord, 1928-1933, París, Infolio éditions.

RUIZ SÁNCHEZ, Javier (2011), "¿Qué ciudad...? Acerca de la necesidad de reformular la pregunta». En GutiéRRez Mozo, María Elia (coord.), Feminismo/s, núm. 17, págs. 23-43. Alicante: Centro de estudios sobre la mujer.

SAN JOSÉ, Begoña (2004), «De la impotencia de Antígona al empoderamiento de las mujeres en el siglo XXI» en Proyecto Equal, Castellón, UJI.

SÁnCHEZ dE MADARIAGA, Inés (2004), "Infraestructuras para la vida cotidiana y calidad de vida», en Ciudades: Revista del Instituto Universitario de Urbanística de la Universidad de Valladolid, Valladolid, Universidad de Valladolid.

-(2008), «El papel de las mujeres en la arquitectura y el urbanismo, de Matilde Ucelay a la primera generación universitaria en paridad», en LeboreIRo, Marian (ed.), La arquitectura y el urbanismo desde la perspectiva de las Arquitectas, págs. 69-77, Madrid, Ministerio de Vivienda- ETSAM. 
-(2012), «Más allá del star-system en la arquitectura. Género y arquitectura menor», En GutiéRREZ Valdivia, Blanca y Ciocoletto, Adriana (coord.), Estudios urbanos, género y feminismo. Teorías y experiencias, Barcelona, Collectiu Punt 6, págs. 435-443, http://issuu.com/punt6/docs/publicaciondefi nitivaestudiosurbano, [fecha de consulta: 13.07 .2014$]$

Sánchez de madariaga, Inés, Bruquetas Callejo, María y Ruiz Sánchez, Javier (2004), Ciudades para las personas. Género y urbanismo: estado de la cuestión, Madrid, Instituto de la Mujer.

-(2010), «Una agenda de investigación en España sobre género y urbanismo», en Arquitectura y espacios de género, Asparkia, n² 21, pp. 193-197, Castellón, Universitat Jaume I.

SANTOS PEDROSA, Patricia (2014), «Women architects in Portugal, a long and winding road», en Álvarez Lombardero, Nuria (ed.) Arquitectas: Redefiniendo la profesión, Sevilla: Universidad de Sevilla, págs. 99-112.

Sanz, Fina (1990), Psicoerotismo femenino y masculino. Para unas relaciones placenteras, autónomas y justas, Barcelona, Kairós.

SARASOTA, Architectural Fundation (2016), "Gray Matters More than Ever», estreno del documental Gray Matters "Teaser", Florida, SAF, https://safsrq.wordpress.com/2016/02/05/gray-matters-more-than-ever/, [fecha de consulta 09.04.2016]

SARTORIS, Alberto (1930), Intorno alla cucina standarizzata di Francoforte, Milán, Casabella.

Sbriglıo, Jacques (1992), Le Corbusier. Unité d'Habitacion de Marseille, París, Éditions Parenthèses.

SchÜTTE-LIHOTZKY, Margarete (2014), Erinnerungen aus dem Widerstand. Das Kämpferische Leben einer Architektin von 1938-1945, Viena, Promedia. 
—(1997 ), Erinnerungen aus den Widestand, 1938-1945. Hamburg, Ed Chup Friemert, 1985. (Traducción italiana Ricordi della resistenza. La vida combattiva d'una donna architetto dal 1938 al 1945. Firenze, Alinea).

Scott Brown, Denise (1989), «Room at the Top? Sexism and the Star System in Architecture», en Architecture: A Place for Women, Washington, Smithsonian Institution Press.

Segura Soriano, Isabel (2012), Urbanisme i Gènere: La ciutat per a la vida quotidiana, Barcelona, Diversia.

SeYMour, John y O'ConNoR, Joseph (1992), Introducción a la PNL (Programación Neurolingüística), Barcelona, Urano.

SherRY, Ahrentzen y Anthony, Kathryn H. (1993), "Sex, Stars and Studios. Look at Gendered Educational Practices in Architecture», en Journal of Architectural Education, vol. 47, núm. 1, págs. 11-29.

Sindicato de Arquitectos (2013), "La situación actual en el sector de la arquitectura y la competitividad: ¿de verdad es necesaria una LSP?», en SARC, Por un oficio digno y con función social, https://sindicatoarquitectos.wordpress.com/2013/06/07/la-situacionactual-en-el-sector-de-la-arquitectura-y-la-competividad-de-verdad-esnecesaria-una-lsp/ , [fecha consulta 03.07.2016]

SMITHSON, Alison (1966), «And now Dhamas are dying out in Japan», in Eames Cellebration, London, Architectural Design.

Stoller, Robert J. (1968), Sex and Gender: Th e Development of Masculinity and Femininity, New York, Science House.

Stratigakos, Despina (2016), Where Are the Women Architects?, New Jersey, Princeton University Press.

Suárez Villegas, Juan Carlos, Lacalle Zalduendo, Rosario y Pérez Tornero, José Manuel (2014), Actas de la Il conferencia internacional sobre género y comunicación, http://www.casadellibro.com/ebook-ii- 
conferencia-internacional-sobre-genero-y-comunicacion-libro-de-actasebook/9788490850305/2355288, [fecha de consulta 24.07.2016]

TAulÉ, Lucía (2011), Historia del diseño I, Bauhaus-Movimiento Moderno, en http://slideplayer.es/slide/3454309/, [fecha de consulta 26.04.2016]

TEIGE, Karel (2002), L'habitation minimum, Cambridge, MIT Press.

TEYsSOT, Georges (1988), «Lo social contra lo doméstico. La cultura de la casa en los últimos dos siglos», en El espacio privado, Madrid, Arquitectura y vivienda, $\mathrm{n}^{\circ} 14$.

TORRE, Susana (1981), «Space as Matrix». En Making Room: Women in Architecture, Heresies 11, vol. 3, núm. 3, págs. 51-52, http://heresiesfilmproject.org/wp-content/uploads/2011/09/heresies11.pdf, [fecha de consulta 05.07.2014]

TORRENT, Rosalía (1995), «Mujeres y diseño industrial: la escuela de la Bauhaus», en Asparkia V, Investigación Feminista, núm. 5, págs. 57-69, Castellón, Universitat Jaume I.

-(2012), «El silencio como forma de violencia. Historia del arte y de las mujeres», en Arte y políticas de identidad, Murcia, Universidad de Murcia.

Trogal, Kim (2003), Feminine tactics in architecture, Doina Petrescu, Sheffield University, Submission for Master for Architecture.

Tyler May, Elaine (2008), Homeward Bound: American Families in the Cold War Era, Piladelphia, Perseus Group.

Uzcátegul Araujo, Judit (2010), El Imaginario de la casa. Formas y modos de Habitar en cinco artistas: Remedios Varó, Louise Bourgeois, Marjetica Poyrc, Doris Salcedo y Sydia Reyes, [Tesis doctoral dirigida por Carmen Senabre], Valencia, Universidad de Valencia.

VAdILLO-Rodríguez, Marisa (2013), «La Bauhaus y sus "experimentos innecesarios": las arquitectas prófugas», en Arte, Individuo y Sociedad, 
vol. 25, núm. 3, págs. 359-375, Madrid, Servicio de Publicaciones de la Universidad Complutense de Madrid.

VAlCÁrCel, Amelia (1995), «Los modos de conocer. Para una filosofía del espacio y del género», en Ciudad y Mujer. Actas del curso urbanismo y mujer. Nuevas versiones del espacio público y privado. Málaga 1993Toledo 1994, págs.35-39, Madrid, Seminario Permanente Ciudad y Mujer.

—(2008), Feminismo en un mundo global. Madrid: Cátedra.

VÉLEZ, Irene (2013), Historia del boudoir, http://boudoir.irenevelez.es/historiadel-boudoir/, [fecha de consulta 22.07.2016]

VílcheZ Luzón, Javier (2013), Matilde Ucelay: Primera Mujer Arquitecta en España, Tesis de doctorado, Departamento de Historia del Arte, Granada, Universidad de Granada, http://hera.ugr.es/tesisugr/21557019.pdf,. [fecha de consulta 04.07.014]

Vitrubio Polion, Marco (1997), Los diez libros de arquitectura de Vitrubio, Madrid, Alianza Editorial.

Wigley, Mark (1992), «Untitled: The Housing of Gender», en Colomina, Beatriz (ed.), Sexuality \& Space, New York, Princeton Architectural Press.

Woolf, Virginia (2012), Una habitación propia, Madrid, Alianza Editorial.

Woude, Auque van der (2010), «La vivienda popular en el movimiento moderno», en Cuadernos de notas 7, traducido por García Rafael, http://www.aq.upm.es/Departamentos/Composicion/webcompo/webcnota s/pdfs/CN7_1_Vivienda\%20Popular.pdf, [fecha de consulta 28.06.2015].

Zöllner, Frank (2014), Anthropomorphism: From Vitrubus to Neufert, from Human Meausurement to the Module of Fascism, Tübigen, Berlin, Kirsten Wagner and Jasper Cepl editors.3. 


\section{BIBLIOGRAFÍA COMPLEMENTARIA}

BULTHAUP (2013), «Del aparador de cocina a la arquitectura del espacio vital. La historia.», http://www.blogbulthaup.es/del-aparador-de-cocina-a-laarquitectura-del-espacio-vital-la-historia/l, [fecha de consulta 25.09.2016]

Dirección General de tráfico (2013), Censo de conductores por clase, sexo y edad, en Formación Vial, DGT, Ministerio del Interior, http://www.dgt.es/es/seguridad-vial/estadisticas-e-indicadores/censoconductores/por-clase-sexo-y-edad/, [fecha de consulta 16.05.2016].

García, Ángeles (1994), Los espacios en que se mueven las personas, Madrid, El País, 18/02/2014.

Gómez , Jesús, García, Fulgencio, M. Pina, Emilio y Navarro, Jorge (2003), Profesores de Enseñanza Secundaria. Temario para la preparación de oposiciones de Matemáticas. Volumnen II, Murcia, MAD-Eduforma.

Gracia, Pablo y García Román, Joan (2015), «Piedras de papel. Género y trabajo doméstico: ¿Tiende España a la igualdad?», en eldiario.es, http://www.eldiario.es/piedrasdepapel/Genero-domestico-Tiende-Espanaigualdad_6_345125504.html, [fecha de consulta 03.07.2016].

IKEA (2016) Cocinas modulares, serie Finding, http://www.ikea.com/es/es/catalog/categories/departments/kitchen/22957/ . [fecha de consulta 27.06.2016].

KANSel cocinas (2016), Las medidas de los muebles de cocina, http://kanseicocinas.com/2014/07/las-medidas-de-los-muebles-decocina/, [fecha de consulta 27.06.2016].

LínEA 3 cocinas (2016), Altura a la que debe estar la encimera de la cocina, http://www.linea3cocinas.com/blogs/entrada/a-que-altura-debe-estar-laencimera-de-la-cocina, [fecha de consulta 27.06.2016]. 
Gobierno Vasco. Departamento de Vivienda, Obras Públicas y Transporte (2010), Manual de análisis urbano. Género y vida cotidiana, VictoriaGasteiz, Servicio Central de Publicaciones del Gobierno Vasco.

Martinez Belmonte, Luis (1983), "La talla media de los españoles varones crece cada año» en Revista estadística española, n 101, págs. 121-125, Madrid, Instituto Nacional de Estadística.

MediaVILLA, Daniel. (2014), «Nuestro cerebro no nos permite ver la realidad como es», Entrevista a Susana Martínez Conde, Directora del Laboratorio de Neurociencia Visual del Barrow Neurological Institute, en esmateria.com: web de noticias de ciencia, medio ambiente, salud y tecnología, http://esmateria.com/2014/04/04/entrevista-martinez-conde/, [fecha de consulta 14.04.2014].

Mı cocina online (2012), Medidas estándar de los módulos de cocina, http://www.micocinaonline.com/Blog/MEDIDAS-I-MEDIDAS-ESTANDARDE-LOS-MODULOS-DE-COCINA, [fecha de consulta 24.07.2016].

Ministerio de EDUCACIÓn, CULTURA Y DEPORTE (2013), Datos y cifras del sistema universitario español curso 2012-13, http://www.mecd.gob.es/dms/mecd/educacion-mecd/areaseducacion/universidades/estadisticas-informes/estadisticas-informesdocumentum/datos-cifras/2012-2013-datos-y-cifras-sistema-universitarioespanol.pdf, [fecha de consulta 03.07.2016].

OOREKA (2016) Hauteur plan de travail, https://plan-detravail.ooreka.fr/comprendre/hauteur-plan-de-travail, [fecha de consulta 28-06-2016].

PéREZ, Hermanos (2015), Medidas estándar lavavajillas, http://www.hnosperez.com/blog/medidas-de-lavavajillas-estandar/, [fecha de consulta 24.07.2016]. 
VAlCUCINE (2016), Ergonomía en cocina. Altura de encimera, https://rehabitatinteriors.wordpress.com/2011/09/12/ergonomia-en-cocinaalturas-de-encimera/, [fecha consulta 27.06.2016]. 
9. ANEXO DE ESTADÍSTICA 
En este apartado se incluyen dos hojas de cálculo, en soporte digital, que han servido para elaborar el tratamiento de datos analizados en el capítulo cinco de esta tesis.

En el primer archivo, denominado Gráficas, han sido introducidas todas las variables que se han extraído de las publicaciones escogidas para la realización de la parte de la investigación vinculada a las imágenes en los espacios interiores, en relación con las revistas de arquitectura y diseño de interiores seleccionadas para este trabajo. Se trata de un archivo en el que se pueden encontrar seis pestañas, correspondientes, cada una de ellas, a una de las revistas estudiadas: Casabella, El Croquis, Arquitectura Viva, Domus, Diseño Interior y On Diseño; y una séptima pestaña que contiene diagramas con combinaciones generales de las seis revistas por tipos de espacios.

En cada pestaña, dedicada a cada una de las revistas aparecen, los datos que han sido introducidos, con cada ímput localizado por número de página y número de ejemplar analizado. Aparece también la combinación de variables que da como resultado todos y cada uno de los diagramas de sectores de las gráficas de elaboración propia, G.E.P., que se analizan en el capítulo cinco, así como los propios diagramas de sectores fruto de esta hoja de cálculo.

En el archivo Gráficas han sido generadas, además de los diagramas de sectores ya mencionados, unas gráficas que permiten una rápida comparativa, muy intuitiva, por código de color, entre los espacios público, privado y doméstico, tratados en esta tesis, y los roles analizados, tanto en el caso de los varones como en el caso de las mujeres. Encontramos también, en la séptima pestaña del archivo Gráficas, la gráfica correspondiente a las seis revistas de manera conjunta, que refleja el análisis comparativo entre los tipos de espacios y los roles de las personas que aparecen en los espacios interiores que nos ofrecen las revistas con las que se ha desarrollado este trabajo.

Para completar la visión que arrojan los datos analizados se ha generado, por cada combinación de variables, un diagrama de sectores global en el que se tienen en consideración, de manera simultánea, los datos referentes a las seis 
publicaciones analizadas. Estos diagramas, combinación de las seis revistas con las que se ha trabajado se obtienen de la hoja de cálculo denominada Globales. 